\title{
Houston Area Geoarcheology: A Framework for Archeological Investigation, Interpretation, and Cultural Resource Management in the Houston Highway District
}

James T. Abbott

Texas Department of Transportation

Follow this and additional works at: https://scholarworks.sfasu.edu/ita

Part of the American Material Culture Commons, Archaeological Anthropology Commons, Environmental Studies Commons, Other American Studies Commons, Other Arts and Humanities Commons, Other History of Art, Architecture, and Archaeology Commons, and the United States History Commons

Tell us how this article helped you.

This Article is brought to you for free and open access by the Center for Regional Heritage Research at SFA ScholarWorks. It has been accepted for inclusion in Index of Texas Archaeology: Open Access Gray Literature from the Lone Star State by an authorized editor of SFA ScholarWorks. For more information, please contact cdsscholarworks@sfasu.edu. 


\section{Houston Area Geoarcheology: A Framework for Archeological Investigation, Interpretation, and Cultural Resource Management in the Houston Highway District}

\section{Licensing Statement}

This is a work for hire produced for the Texas Department of Transportation (TxDOT), which owns all rights, title, and interest in and to all data and other information developed for this project under its contract with the report producer. The report may be cited and brief passages from this publication may be reproduced without permission provided that credit is given to TxDOT and the firm that produced it. Permission to reprint an entire chapter, section, figures or tables must be obtained in advance from the Supervisor of the Archeological Studies Branch, Environmental Affairs Division, Texas Department of Transportation, 125 East 11th Street, Austin, Texas, 78701 


\section{HOLISTON AREA \\ GEOARCHEOLOGY}

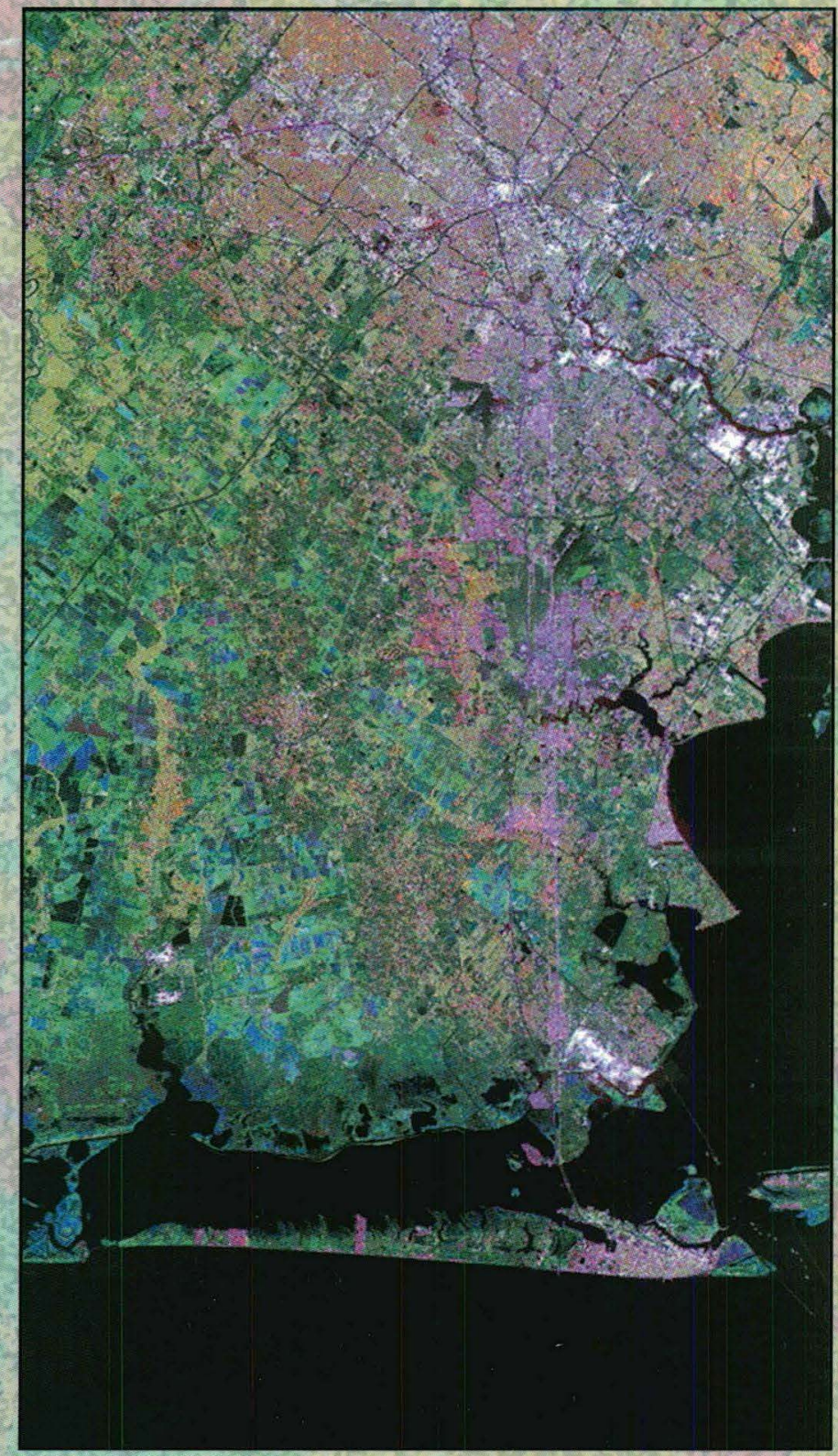

A Framework

for Archeological

Investigation,

Interpretation,

and Cultural

Resource

Management in

the Houston

Highway District

BY JAMIES T. ABBOTT

TEXAS DEPARTMENT OF TRANSPORTATION

Environmental Affairs Division

Archeological Studies Program

Report 27

March 2001 


\section{Houston Area Geoarcheology}

\section{A Framework for Archeological Investigation, Interpretation, and Cultural Resource Management in the Houston Highway District}

by

James T. Abbott

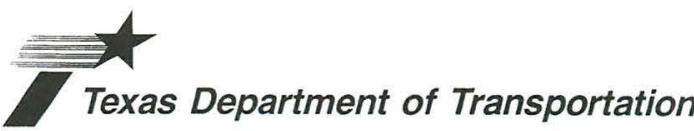

Environmental Affairs Division Archeological Studies Program, Report 27 


\section{Houston Area Geoarcheology: \\ A Framework for Archeological Investigation, Interpretation, and Cultural Resource Management in the Houston Highway District}

Copyright @2001 by the Texas Department of Transportation (TxDOT)

All rights reserved

TxDOT owns all rights, title, and interest in and to all data and other information developed for this project. Brief passages from this publication may be reproduced without permission provided that credit is given to TxDOT and the author. Permission to reprint an entire chapter or section, figures and tables must be obtained in advance from the Supervisor of the Archeological Studies Program,

Environmental Affairs Division, Texas Department of Transportation, 125 East $11^{\text {th }}$ Street,

Austin, Texas, 78701. Copies of this publication have been deposited with the

Texas State Library in compliance with the State Depository requirements.

Printed in the United States of America at

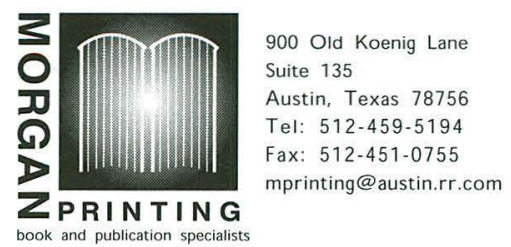

On acid-free, $70 \mathrm{lb}$. paper

March 2001

For further information on this and other TXDOT archeological publications, please contact

Texas Department of Transportation

Environmental Affairs Division

Archeological Studies Program

Nancy A. Kenmotsu, Ph.D., Supervisor

Archeological Studies Program Report No. 27

A. McGraw, Series Editor

Editing and production of this report was directed by

Timothy K. Perttula, Ph.D.

Archeological \& Environmental Consultants

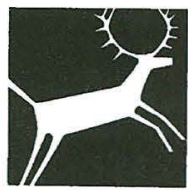

10101 Woodhaven Drive

Austin, Texas $78753-4346$

(512) 873-8131

tkp4747@aol.com

ISBN: 1-930788-05-3

About the cover: This image of the Houston/Galveston area was obtained by SIR-C/X-SAR space-borne radar on board the space shuttle Endeavor on October 10, 1994. Used with permission of NASA-JPL. 


\section{For Ed Garner}

and Saul Aronow 


\section{Table of Contents}

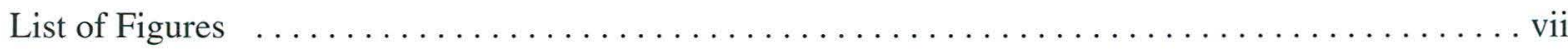

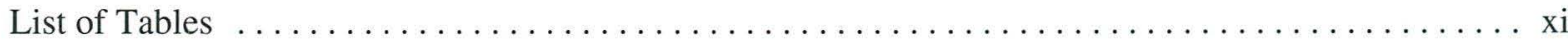

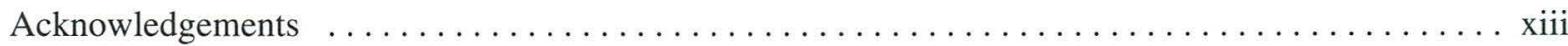

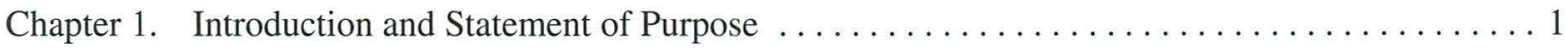

Chapter 2. Late Quaternary Environmental Context of the Houston District $\ldots \ldots \ldots \ldots \ldots \ldots \ldots$

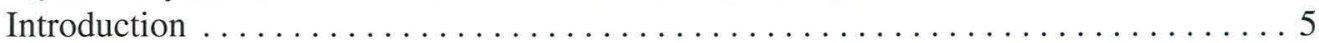

Climate and Hydrology of the Houston District . . . . . . . . . . . . . . . 7

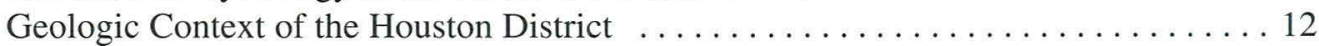

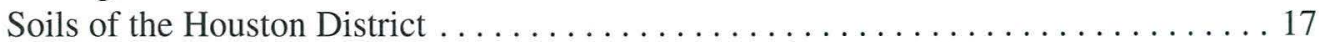

Vegetation and Fauna of the Houston District . . . . . . . . . . . . . . . . . 24

Late Quaternary Paleoenvironments of Southeastern Texas . . . . . . . . . . . 26

Resource Distributions in the Houston District . . . . . . . . . . . . . . . . . . 36

Chapter 3. Physical Processes of Site Formation, Modification, and Destruction

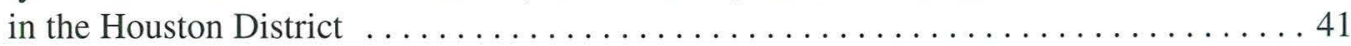

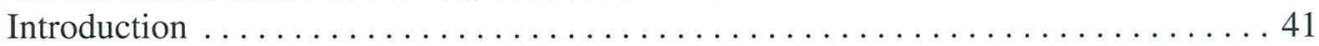

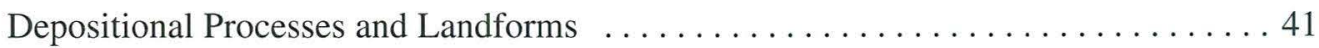

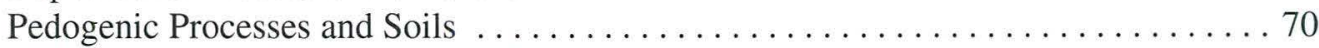

Disturbance Processes . . . . . . . . . . . . . . . . . . . . . . . 80

Chapter 4. Late Quaternary Stratigraphy and Geoarcheology of the Houston District $\ldots \ldots \ldots \ldots 91$

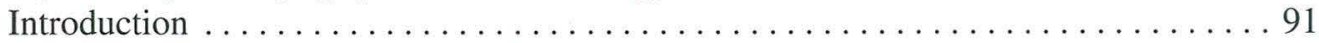

Geoarcheological Issues Associated with Common Site Settings $\ldots \ldots \ldots \ldots \ldots . . \ldots 1$

Discussion and Geoarcheological Significance

of Stratigraphic Models . . . . . . . . . . . . . . . . . . . . . . . . 106

The Houston District as an Evolving Archeological Landscape . . . . . . . . . . . 148

Chapter 5. Potential Archeological Liability Mapping of the Houston District $\ldots \ldots \ldots \ldots \ldots \ldots 153$

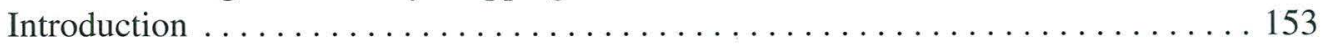

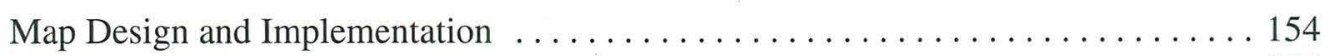

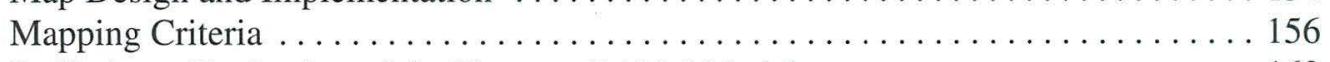

Preliminary Evaluation of the Houston-PALM Model $\ldots \ldots \ldots \ldots \ldots \ldots . \ldots \ldots$

Advantages and Disadvantages of an Integrity-Driven

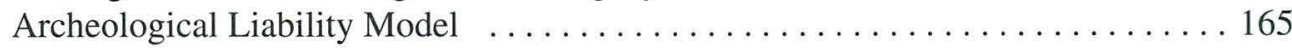


Houston Area Geoarcheology

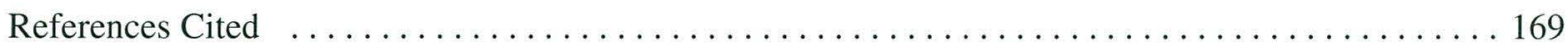

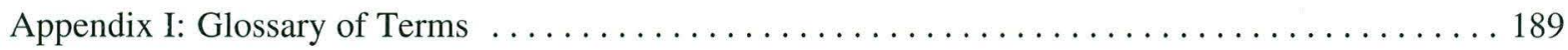

Appendix II: Character of Soil Carbonate Morphology and Implications

of Soil Carbonate Accumulation in the Houston District . . . . . . . . . . . . . . 197

Appendix III: Stable Isotopic Evidence for Late Quaternary

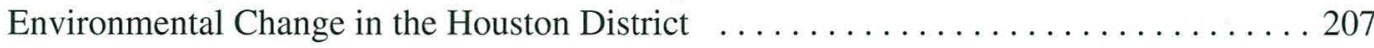

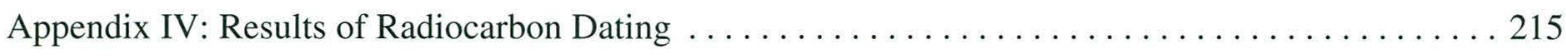

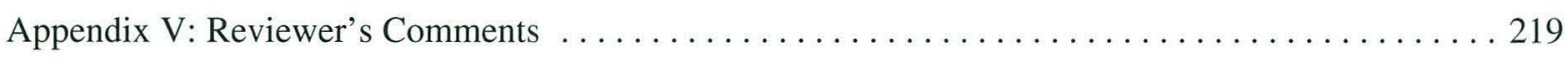

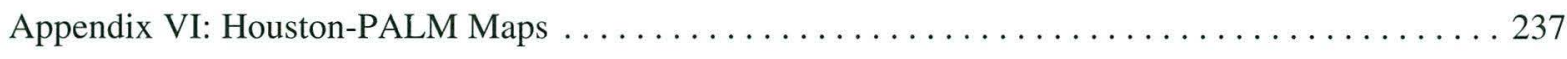




\section{List of Figures}

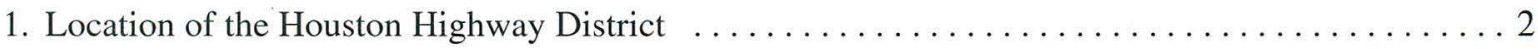

2. Principal drainages and water bodies in the Houston Highway District $\ldots \ldots \ldots \ldots \ldots \ldots \ldots 6$

3. Plot of Natural Regions in the Houston District, after data from the Texas Natural Resource

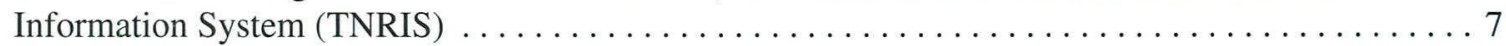

4. Vegetation distribution in the Houston District, after data compiled by the

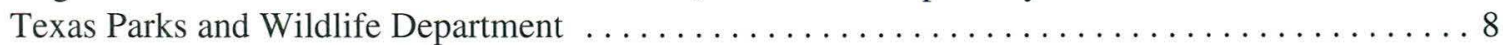

5. Climographs of selected stations in the Houston District $\ldots \ldots \ldots \ldots \ldots \ldots \ldots \ldots \ldots$

6. Climatic variability in Conroe, Montgomery County $\ldots \ldots \ldots \ldots \ldots \ldots \ldots \ldots \ldots \ldots \ldots$

7. Discharge of five Houston area streams of various sizes over forty years of record

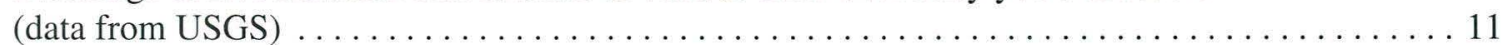

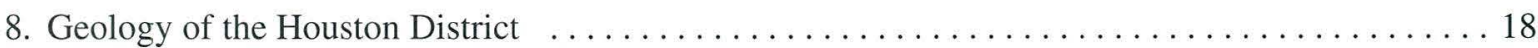

9. General distribution of soils in the Houston District according to

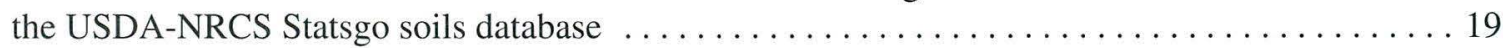

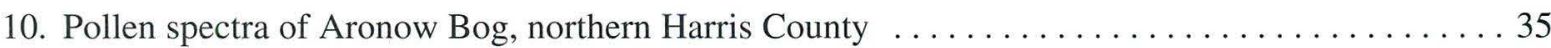

11. Generalized relationship between particle size and velocity in determining fluvial erosion, transport, and deposition

12. Principal environments and facies in a classic meandering stream $\ldots \ldots \ldots \ldots \ldots \ldots \ldots \ldots 44$

13. Morphology and facies assemblages in a chute-modified meandering stream $\ldots \ldots \ldots \ldots \ldots .45$

14. Relationship between wind drag velocity and grain size in eolian erosion, transport, and deposition

15. Schematic illustration of a typical rotational failure. Note that the lower part of the failure has lost integrity and begun to flow 
16. Illustration of slope terminology and loci of erosion, transport, and deposition in a

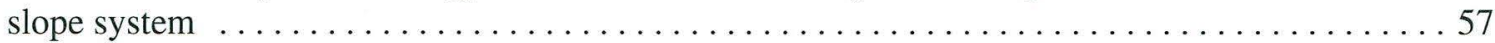

17. Reconstructed sea-level curves from the Texas Gulf coast, from Morton and McGowen (1980) . . 58

18. Cross-section of Galveston Island at 8 Mile Road, illustrating timing of accretion during the

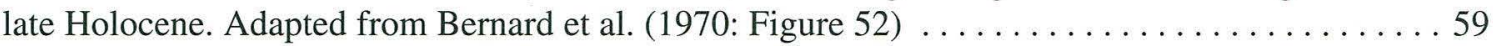

19. Aerial photograph of a moderately-sized washover fan on western Galveston Island $\ldots \ldots \ldots 60$

20. Shoreline changes in the historic Brazos delta between 1933 and 1971. Adapted from Seelig

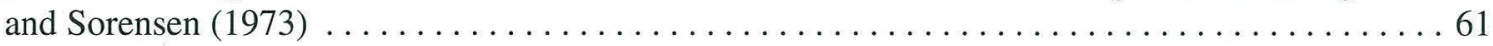

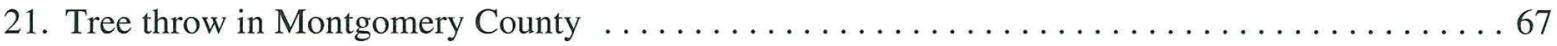

22. Small crayfish chimney, containing less than $1 \mathrm{~kg}$ of sediment $\ldots \ldots \ldots \ldots \ldots \ldots \ldots$

23. Illustration of two different models of gilgai formation. The pedoturbation model is adapted from Gustavson (1975) and Buol et al. (1980). The soil dynamics model is adapted from

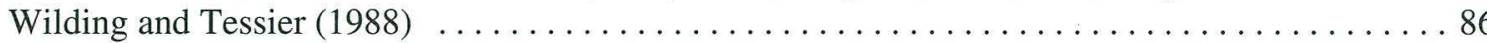

24. Relationship between age and depth for radiocarbon samples less than 12,000 years old obtained

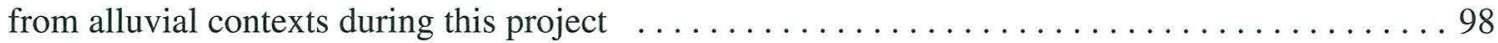

25. Detail of the Algoa, Texas 7.5' topographic quadrangle, illustrating the occupation of an old, high-discharge relict channel pattern by a small modern stream . . . . . . . . . . . . . . 102

26. Generalized architecture of small to moderately-sized Houston-area streams $\ldots \ldots \ldots \ldots \ldots 103$

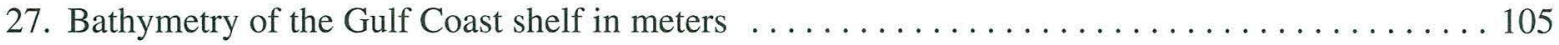

28. Map of the lower Brazos Valley and Brazos Delta $\ldots \ldots \ldots \ldots \ldots \ldots \ldots \ldots \ldots \ldots \ldots \ldots$

29. Generalized stratigraphy of the Brazos River between Hearne and Navasota, after Waters

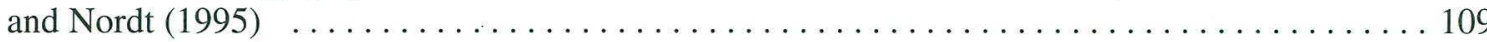

30. Generalized composite cross-section of the Blasdel point bar, adapted from data presented

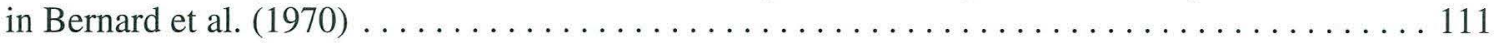

31. Middle to Late Holocene meanderbelts of the Brazos and San Bernard rivers according

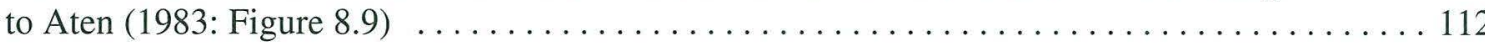

32. Photograph of the Brazos TDCJ Section, Fort Bend County $\ldots \ldots \ldots \ldots \ldots \ldots \ldots \ldots \ldots$

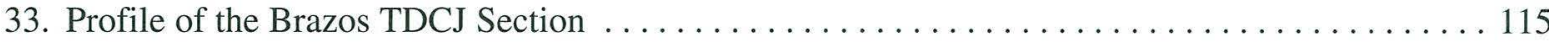

34. Schematic stratigraphy of the Brazos Valley cores, with radiocarbon ages and fill

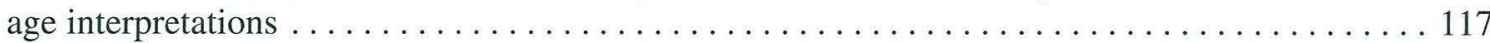

35. Illustration of textural, chemical, and magnetic trends in Core 2 from the lower Brazos valley . . 121 
36. Illustration of textural, chemical, and magnetic trends in Core 6 from the Brazos delta $\ldots \ldots 122$

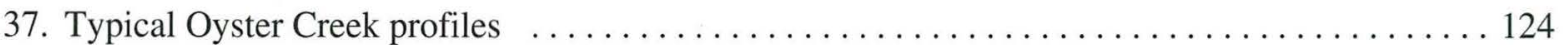

38. Inferred geometry and facies associations, at the crossing of SH $288 \mathrm{~B}$

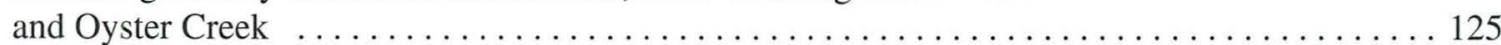

39. Different mapping interpretations of the vicinity of the lower San Bernard River $\ldots \ldots \ldots \ldots 127$

40. Cross-section of the former lower Colorado valley based on a series of 12 cores along FM 521, west of Brazoria, Texas, by Aslan and Blum (1999) . . . . . . . . . . . . . 128

41. Illustration of core logs from the SH 242 crossing of the West Fork of the San Jacinto River

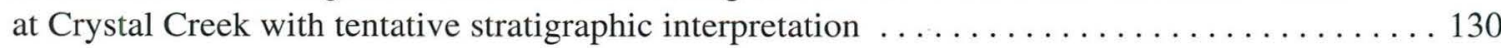

42. Schematic illustration of core logs from the US 59 crossing of the East Fork of the San Jacinto River, in Liberty County, Texas, with tentative interpretation

43. Generalized, schematic cross-section of the West Fork of the San Jacinto River

44. Artificial exposure of thick, slightly loamy fine sands with moderate soil development on a mapped Deweyville terrace of the San Jacinto River near Humble, Texas

45. Relationship between gauge height and discharge for discharge peaks, between 1972 and 1993

46. Profile of BT4 at Greens Bayou and FM 526, illustrating thick historic-age sediments

capping the terrace

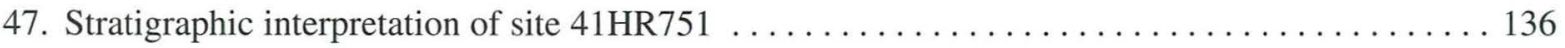

48. Generalized, schematic stratigraphy of Lake Creek and tributary streams, after Mandel (1987) . 138

49. Generalized, schematic cross-section of Spring Creek at Kuykendahl Road,

Harris and Montgomery counties, with interpretations by Aronow

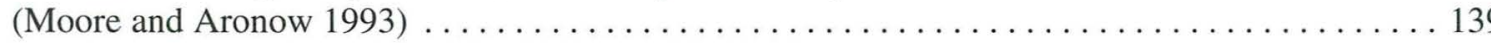

50. Oblique photograph of the profile of Trench 7 at SH 6 and Highland Bayou,

illustrating organic marsh strata separated by probable storm deposits $\ldots \ldots \ldots \ldots \ldots \ldots \ldots 140$

51. Distribution and character of analyzed upland textural samples $\ldots \ldots \ldots \ldots \ldots \ldots \ldots \ldots 142$

52. Illustration of typical textural frequency curves for unimodal and bimodal distributions

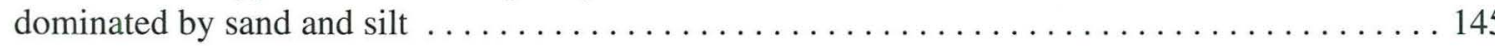

53. Schematic illustration of the Woodlands 1 exposure, illustrating a thin, discontinuous mantle

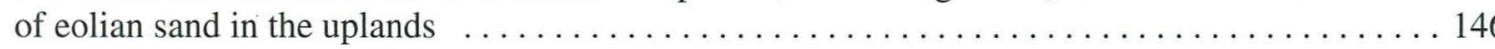

54. Time series of aerial photographs illustrating forest regeneration in the vicinity of Tomball

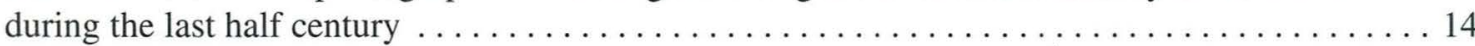


Houston Area Geoarcheology

55. Model of landscape development and site burial proposed by Paine (1987a, 1990) for

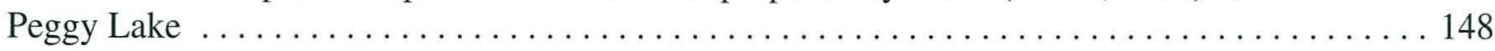

56. Map of Late Pleistocene (Oxygen Isotope Stage 2) incised valleys on the upper Texas paleocoast line, after Abdulah (1995)

57. Flowchart illustrating the mapping protocol for the Houston-PALM $\ldots \ldots \ldots \ldots \ldots \ldots \ldots 158$

58. Distribution of identified site centroids in the Houston District $\ldots \ldots \ldots \ldots \ldots \ldots \ldots \ldots \ldots$

59. Examples of macroscopic morphological variability in cut faces of imprregnated thin section blocks

60. Photomicrographs of thin sections illustrating some of the characteristics and variability of calcite pedofeatures in Pleistocene and Holocene soils on the outer Gulf Coastal Plain

61. Photograph of broken Pleistocene brecciated pedode, illustrating "explosive" internal morphology

62. Results of $\delta^{13} \mathrm{C}$ assays on bulk humate radiocarbon samples vs. radiocarbon age 208

63. Results of $\delta^{13} \mathrm{C}$ assays by Beta Analytic and Coastal Science Laboratories on samples from

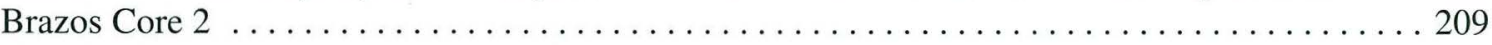

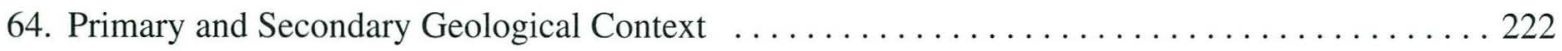

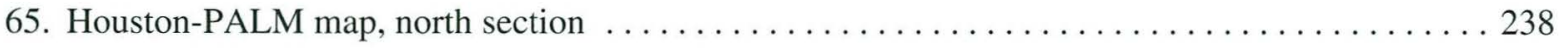

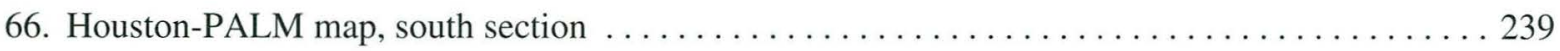




\section{List of Tables}

1. Stratigraphic sequence of Cenozoic rocks in the Houston area $\ldots \ldots \ldots \ldots \ldots \ldots \ldots \ldots \ldots$

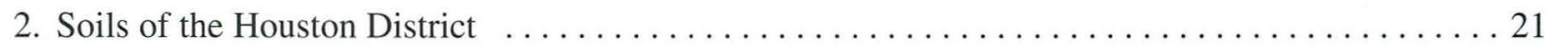

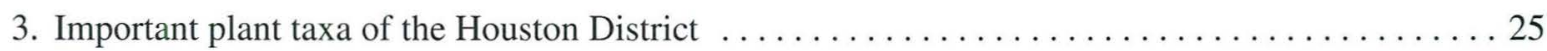

4. Principal depositional facies in a typical meandering stream system $\ldots \ldots \ldots \ldots \ldots \ldots \ldots 46$

5. Characteristics and geoarcheological potential of mass movements $\ldots \ldots \ldots \ldots \ldots \ldots \ldots 5$

6. Stages of secondary carbonate development in gravelly and non-gravelly parent material $\ldots \ldots 75$

7. Generalized relationship between drainage and gleying of soil horizons $\ldots \ldots \ldots \ldots \ldots \ldots 78$

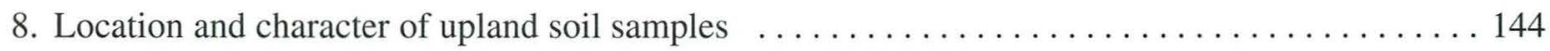

9. Evaluation of geoarcheological potential of Houston District landforms $\ldots \ldots \ldots \ldots \ldots \ldots 157$

10. Comparison of Houston-PALM map units and identified archeological sites $\ldots \ldots \ldots \ldots .6164$

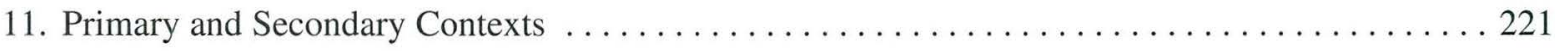




\section{Acknowledgements}

This study involved the input and assistance of a great many people. Nancy Kenmotsu, supervisor of the Archeological Studies Branch, Ann Irwin, supervisor of the Cultural Resources Management Section, and Dianna Noble, director of the Environmental Affairs Division, were instrumental in facilitating all phases of this effort. The archeological staff at TxDOT were also involved to varying degrees, but particular thanks are due to Diane Dismukes, Sterling Hays, Dennis Price, and Lain Ellis for developing and coordinating fieldwork opportunities and for providing valuable feedback. The environmental staff in the Houston District and employees from a variety of area offices within the district also provided technical and logistical support, particularly in furnishing and operating backhoes, arranging access and utility clearance, and generally responding to a variety of requests in a prompt and cheerful manner. Individuals deserving particular mention include Debbie Taylor, Stan Cooper, Robin Sterry, Bob Stelchek, Sandra Williams, Ellen Stephenson, Julie Morse, James Roscher, David Pillar, Charles Machart, Donald Loesch, and Donald Guidry. Mike Bahm of the Houston District materials lab graciously supplied geotechnical core logs of the San Jacinto River.

The GIS component of the project benefited from the participation of TxDOT IR employees Jennifer Gaa, Dee Dee Broberg, and, in particular, Michael Pierce. Digitization of the Houston-PALM was performed by the Mapping and Graphics shop at the Ferguson Unit, Texas Department of Criminal Justice (TDCJ). Thanks are due to Robert Laake, Neil Rayford, and John Katambani of TDCJ for assuring that digitization was completed accurately and within the allocated time and budget.

Core investigations were performed by the Bureau of Economic Geology (BEG), The University of Texas at Austin. This work was coordinated by Ed Garner and performed by a BEG crew headed by Jordan "Cookie" Forman and Andy Graham. Laboratory analyses were coordinated by Ed Garner (BEG) and performed at the Soil Analysis Laboratory, University of Wisconsin (Madison), and the University of Sheffield (UK). Thin sections were documented at the BEG, with the gracious cooperation of Sigrid Clift.

This project also benefited from conversations with geoarcheological specialists familiar with Texas. Foremost among these are the geoarcheological peer reviewers who reviewed the draft document: Britt Bousman (Southwest Texas State University), Charles Frederick (University of Sheffield), and Lee Nordt (Baylor University). While not all of the ideas advanced in this document are endorsed by these reviewers, their comments improved the arguments considerably. Carolyn Murphy (Galveston COE) and Roger Moore (Moore Archeological Consulting) also reviewed the draft. While not trained as geoarcheologists, Murphy and Moore both have considerable knowledge of the Houston archeological record, and used that knowledge to critique the draft from a user's perspective. Roger Moore also supplied me with a copy of his dissertation and a large number of Moore Archeological Consulting reports, which proved very helpful. Other professionals who provided valuable input through conversation and/or access to study areas or unpublished data include Nicola Hubbard and Abbey Beck (Moore Archeological Consulting), Robert Rogers (PBS\&J), Mike Blum (University of Nebraska-Lincoln), Andres Aslan and Ed Garner (BEG), Mike Collins (Texas Archeological Research Laboratory), Myles Miller (Texas Historical Commission), Dennis Sylvia (UT Geology), and Jan Stokes (Galveston COE). 
Thanks are also due to Tim Perttula, Archeological and Environmental Consultants, who provided the technical edit, TxDOT series editor Al McGraw, and the folks at Morgan Printing (especially Terry Sherrell, Blake Mitchell, and Stephen Bright) for their help and their patience with the printing of this volume.

This report is dedicated to two individuals who passed away during its preparation. Ed Garner was a long-time employee of the BEG, and was instrumental in coordinating the coring and analyses conducted during this study. As a BEG employee, he consulted for the archeological program at TxDOT for many years, and authored several geology studies included in TxDOT's archeological report series. Ed was always helpful, knowledgeable, and friendly, and he is missed. Saul Aronow (Professor Emeritus, Lamar University) worked extensively in the Houston area, and authored many important archeological geology reports dealing with the Texas Coastal Plain. He had agreed to review the current document in draft, but passed away before it was completed. The archeological and geological communities along the Gulf Coast will miss his insights.

The author cannot take credit for most of the ideas presented in this document, because it is a synthesis of geological and geoarcheological research in the region. Every attempt has been made to present a balanced treatment and to provide credit where credit is due. Any omissions or errors in this report are solely the author's responsibility. 


\section{Chapter 1}

\section{Introduction and Statement of Purpose}

This report represents an examination of geoarcheological issues affecting a six county area in the vicinity of Houston, Texas. The study area includes Harris, Montgomery, Waller, Fort Bend, Brazoria, and Galveston counties (Figure 1), which collectively make up the Houston District, a regional administrative entity of the Texas Department of Transportation (TxDOT). This study represents the first phase of a district-focused geoarcheological program being implemented at TxDOT, with similar studies of other districts to follow. It is intended to familiarize archeologists working in the region with relevant geoarcheological issues, thus serving as a resource for researchers involved in prospection, assessment, and interpretation of prehistoric archeological sites. Although the focus of investigation is on the six counties making up the Houston District, most of the issues addressed are equally applicable to adjacent areas of the upper Texas Gulf Coastal Plain.

Archeology is the study of human history and prehistory through the examination of artifacts and other types of refuse that are left behind as a result of human behavior. In many cases, these remains are buried within soils or sediments. For this reason, the collaboration between archeologists and geologists, geomorphologists, stratigraphers, pedologists, and other types of earth scientists is natural and has a long history (Butzer 1982:35-36). Nevertheless, the term geoarcheology, and the related term "archeological geology," are used in many different senses by various authors (e.g., Butzer 1975, 1982; Gladfelter 1977, 1981; Rapp et al. 1974; Renfrew 1976). Gladfelter (1981) identifies a number of lines of geoarcheological investigation, including regional and site-specific remote sensing investigations using geophysical or geochemical techniques; documentation and interpretation of site formation processes; examination of site setting and landscape context; paleoenvironmental and paleotopographic reconstruction; and relative or absolute chronological assessment. Similarly, Butzer (1982:38) identifies five basic geoarcheological themes, each of which may be addressed at a variety of scales: (1) landscape context; (2) stratigraphic context; (3) site formation; (4) site modification; and (5) intentional and unintentional landscape modification. Other definitions of geoarcheology and archeological geology (e.g., Rapp et al. 1974; Renfrew 1976) are equally broad.

For this reason, it is appropriate to define the range of geoarcheological issues addressed in this report. The purpose of this report is to (1) outline the broad geologic, geomorphic, and pedologic character of the Houston District; (2) briefly summarize the modern climatic and biotic character and Late Quaternary paleoenvironmental history of the region; (3) summarize relevant depositional agents, depositional processes, and pedogenic processes, and the resulting morphological attributes of sediments laid down by those agents or affected by those processes; (4) summarize relevant disturbance processes and the resulting morphological attributes of affected soils and sediments; and (5) summarize what is known about the Late Quaternary stratigraphy of depositional systems in the region. The database used to address these issues includes extant regional and process literature, as well as new data that are reported here for the first time.

The preceding topics are of importance to archeology for several reasons. First, they provide a context for interpretation of individual sites and broader cultural networks at a variety of scales. Landscapes are dynamic entities, evolving constantly under the influence of physical and biotic influences. Cultural systems are superimposed upon and adapted to extant landscapes, which may bear little 


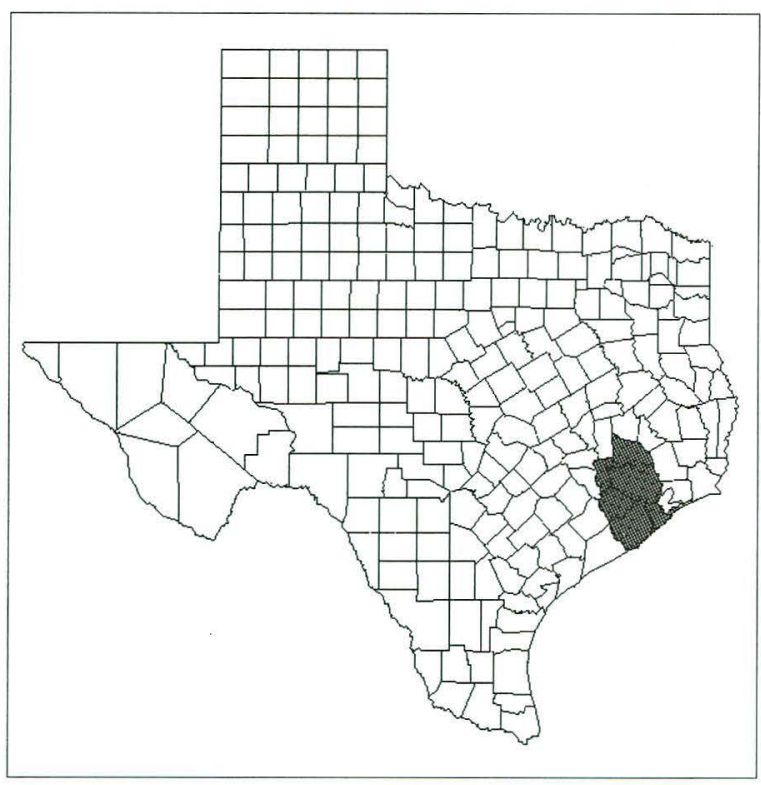

Figure 1. Location of the Houston Highway District.

resemblance to the landscape present when the material remains of that cultural system are exhumed hundreds or thousands of years later. Too often, the dynamic nature of the landscape system is underappreciated, leading to interpretations that are simplistic or erroneous. The classic, apocryphal example is the archeologist who uses survey data to assemble a complex model of settlement patterning in a river basin during a given period, never realizing (or never acknowledging) that large segments of the relevant landscape-and the sites that occupied them-have since been removed by erosion or deeply buried beneath more recent alluvium. While real-world cases are seldom that extreme, there is a very strong tendency for prehistoric sites and site networks to be interpreted using modern environmental characteristics and resource distributions.

Second, geoarcheological data provides a basis for assessing site integrity. In essence, archeology is the study of humans through examination of the debris that they leave behind. Under ideal circumstances, examination of this debris can yield information about behavioral and adaptive traits of the people that left it, including (but not limited to) information on technological adaptations, resource exploitation, settlement organization and patterning on the landscape, and social organization. There are two distinct types of data that are relevant to the archeological interpretation of human material remains (e.g., artifacts, organic residues, and remains). The first of these is the suite of attributes characteristic of an individual artifact or a suite of artifacts. A stone tool, for example, possesses distinct physical characteristics (e.g., length, width, form, flaking pattern, raw material type and provenience, evidence of heat modification, evidence of use wear, etc.) that can be used to interpret its place in the cultural system of interest. However, a second, equally important type of data is the archeological context of the artifact; that is, its spatial and stratigraphic relationships with related materials. Typically, human occupation of a given locality results in the production of a variety of materials through discard, loss, and various biophysical processes. Collectively, these materials make up an occupational assemblage, and are initially arranged in a manner that reflects behavioral patterning (e.g., the spatial arrangement of activities, patterns of discard, and associations between elements of the cultural system). During the uselife of a given artifact, it can be said to be in systemic context (Schiffer 1987), and exhibits a dynamic relationship with other elements of the material culture that is directly contingent on behavior.

However, upon loss or discard, an artifact enters an archeological context, and may be affected by either subsequent cultural processes or by natural processes. In almost every case, the spatial relationships between a given artifact and other elements of a site assemblage continue to evolve under the influence of a variety of mechanisms that Schiffer (1987) terms natural formation processes. Such processes can affect, and ultimately destroy, the original spatial (horizontal) and stratigraphic (vertical) relationships between artifacts. The degree to which these relationships are maintained is frequently termed the integrity of the assemblage. If the behaviorally dictated context of a given assemblage is disrupted to such a degree that inferences about that behavior cannot be made, archeological integrity is lost and the research value of the site is severely diminished. In such instances, the site is normally considered ineligible for consideration under existing Federal and State antiquities laws.

It follows that archeological interpretations can benefit from the careful consideration of the natural formation processes in operation at any given site or in any given region. Natural formation processes include a vast suite of interacting geomorphic, pedologic, and biotic processes that serve to alter and transform archeological sediments and cultural deposits (Butzer 1982; Schiffer 1987). While it is 
impractical to perform an intensive review and synthesis of information on the suite of natural processes relevant to a given area in conjunction with most individual projects, preparation of a single document as a resource for subsequent investigations can provide tremendous benefits for archeological interpretation and cultural resource management (CRM) in the region. This document represents such a synthesis, and it is intended as a resource to familiarize TxDOT archeologists, archeological contractors, area transportation planners, regulatory agencies, and other interested parties, with relevant geologic, geomorphic, and pedologic issues, as well as familiarizing geomorphological consultants with aspects of the Late Quaternary record of particular importance to archeology.

This document consists of four main parts, and is supplemented by a series of appendices. Chapter 2 presents a summary of the environmental context of the Houston District based upon a literature review. The content is similar to the environmental summaries in project-specific archeological reports, albeit here in relatively more detail than is typical. The goal of Chapter 2 is to summarize and synthesize existing climatic, geological, soils, biotic, and paleoclimatic data. Chapter 3 approaches the record from a process-oriented perspective. It summarizes relevant physical processes responsible for the preservation and destruction of archeological assemblages in the Houston District. Chapter 4 outlines what is known about the geomorphic/ stratigraphic context and the geoarcheological potential of a variety of specific environments. All primary fieldwork conducted during this study is reported here or in the appendices. Chapter 5 describes the rationale, methodology, and legal basis for the design and implementation of a management/ planning tool termed the Houston District Potential Archeological Liability Map (Houston-PALM).

Several abbreviations are used throughout this document that may not be familiar to all readers. These include: ka (thousand years ago), ma (million years ago), rybp (radiocarbon years before present), and bgs (below ground surface). A Glossary of Terms is also included (Appendix I) to provide the reader with definitions of unfamiliar terms used in the document. Other appendices include discussions of carbonate development (Appendix II) and the climatic implications of carbon isotopes (Appendix III) in the district, a table of radiocarbon ages obtained during the study (Appendix IV), reviewer's comments and discussion (Appendix V), and the Houston-PALM map (Appendix VI).

Finally, it should be explained that the frequent discussions of "geoarcheological potential" throughout this document refer to the likelihood that Clovisage (roughly $12.5 \mathrm{ka}$ ) or later materials could be preserved with reasonable integrity in a given setting. While TxDOT acknowledges that a growing body of evidence suggests that people may have been present in the New World long before the advent of the Clovis culture (e.g., Dillehay 1997; Meltzer et al. 1997), the paucity of convincing evidence for such remains in the south central United States does not currently justify the systematic search for pre-Clovis remains in the context of TxDOT's CRM program. 


\section{Chapter 2}

\section{Late Quaternary Environmental Context of the Houston District}

\section{INTRODUCTION}

The six county (TxDOT) Houston District encompasses an area of approximately $5,977 \mathrm{mi}^{2}$ (1,548,070 ha) (Kingston 1986), and varies in elevation from sea level to approximately $100 \mathrm{~m}(0$ to $330 \mathrm{ft}$ ), ramping gently up from the Gulf coast to the maximum elevation in northern Montgomery County. With the exception of a few small hillocks representing near-surface salt domes, the southern part of the area is a low lying and monotonously level grassland/open woodland with interspersed saline and freshwater marshes and occasional riparian corridors, while the northern part of the area is gently rolling and typically heavily forested. High water tables and seasonally standing surface water are common throughout the district. The western part of the area is dominated by the alluvial valley and delta of the Brazos River, which merges to the southwest with the delta of the former Colorado River (the pre-avulsion channel of which is now occupied by Caney Creek). The northeastern part of the study area is dominated by smaller, low gradient streams, including the San Jacinto River and its tributaries and Buffalo Bayou, which bisects the city of Houston. The Gulf Coast, including the Holocene barrier of Galveston Island and the estuarine environment of Galveston Bay, bounds the district to the southeast (Figure 2).

The district is dominated by the sprawling metropolis of greater Houston, which occupies a large percentage of the total acreage, particularly in Harris and Galveston counties. According to the Harris County soil survey (Wheeler 1976), 40\% of the county is occupied by urban land. However, this figure is now more than 20 years out of date, and the urban expansion has continued apace. Galveston, Montgomery, Fort Bend, and Brazoria counties are also experiencing significant growth, particularly in areas surrounding Houston, Galveston, Conroe, Sugar Land, and Clute/Lake Jackson.

The entire Houston District is contained within the Western Gulf subdivision of the Atlantic and Gulf Coast physiographic province (Aronow 1988; Walker and Coleman 1987). However, the region exhibits considerable environmental diversity. Four of the 11 principal Natural Regions of Texas recognized by the Texas Natural Resource Information System (TNRIS) occur in the district. These are: (1) the Gulf Coast Prairies and Marshes Region, (2) the Piney Woods Region, (3) the Blackland Prairie Region, and (4) the Oak Woods and Prairies Region. The Gulf Coast Prairies and Marshes Region is dominant, occupying almost $1,146,000$ ha $(73 \%$ of the district). It is subdivided into three subregions, including (1) the Upland Prairies and Woods (approximately 1,116,000 ha, 71\%), (2) the Estuarine Zone (approximately 16,500 ha, 1\%), and (3) the Dunes and Barriers (approximately 12,500 ha, $0.8 \%$ ). The Piney Woods Region is represented by the Mixed Pine-Hardwood subregion, which occupies approximately 376,000 ha $(24 \%)$. The Blackland Prairie and Oak Woods and Prairies regions are distinctly secondary in areal importance, occupying approximately 48,000 ha (3\%) and 500 ha $(0.03 \%)$, respectively, near the northern boundary of the district in Waller and Montgomery counties (Figure 3 ).

Biotic diversity is indicated by the eight broad vegetation communities mapped by the Texas Parks and Wildlife Department (McMahan et al. 1984). These include Cropland, Bluestem Grassland, Marsh/Barrier Island, Other Native or Introduced Grasses, Pecan-Elm Forest, Pine-Hardwood Forest, Young Forest/Grassland, and Urban Areas (Figure 4). The distribution of these communities is 


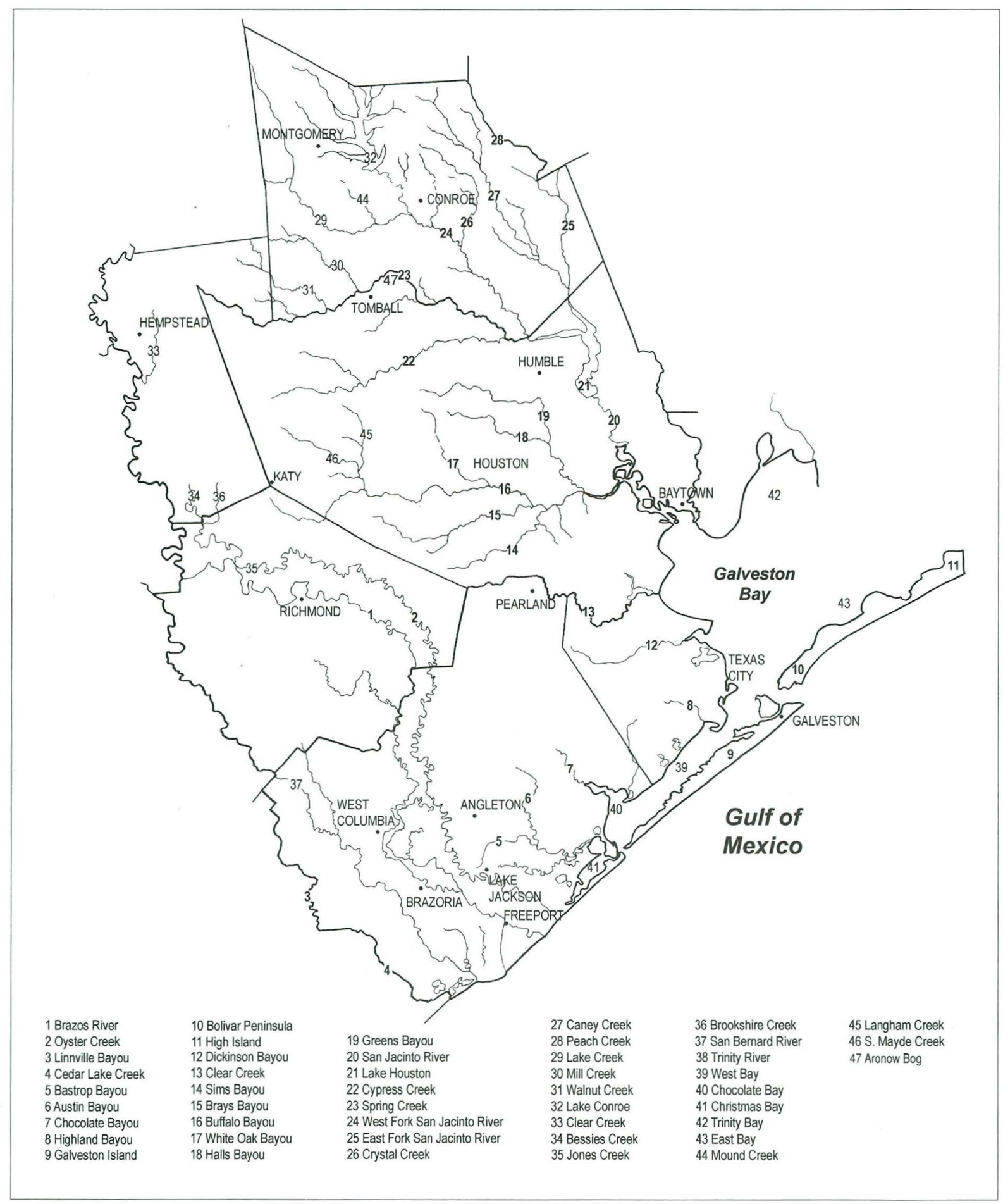

Figure 2. Principal drainages and water bodies in the Houston District.

a combined result of distance from the coast, a generalized precipitation gradient that declines from east to west, anthropic influences and controls, and vegetative responses to pedologic and geologic variability of the substrate.
The Houston District encompasses a diverse landscape that provided many resource opportunities, and presented many environmental constraints, to prehistoric inhabitants of the region. The following summary outlines the climatic, 


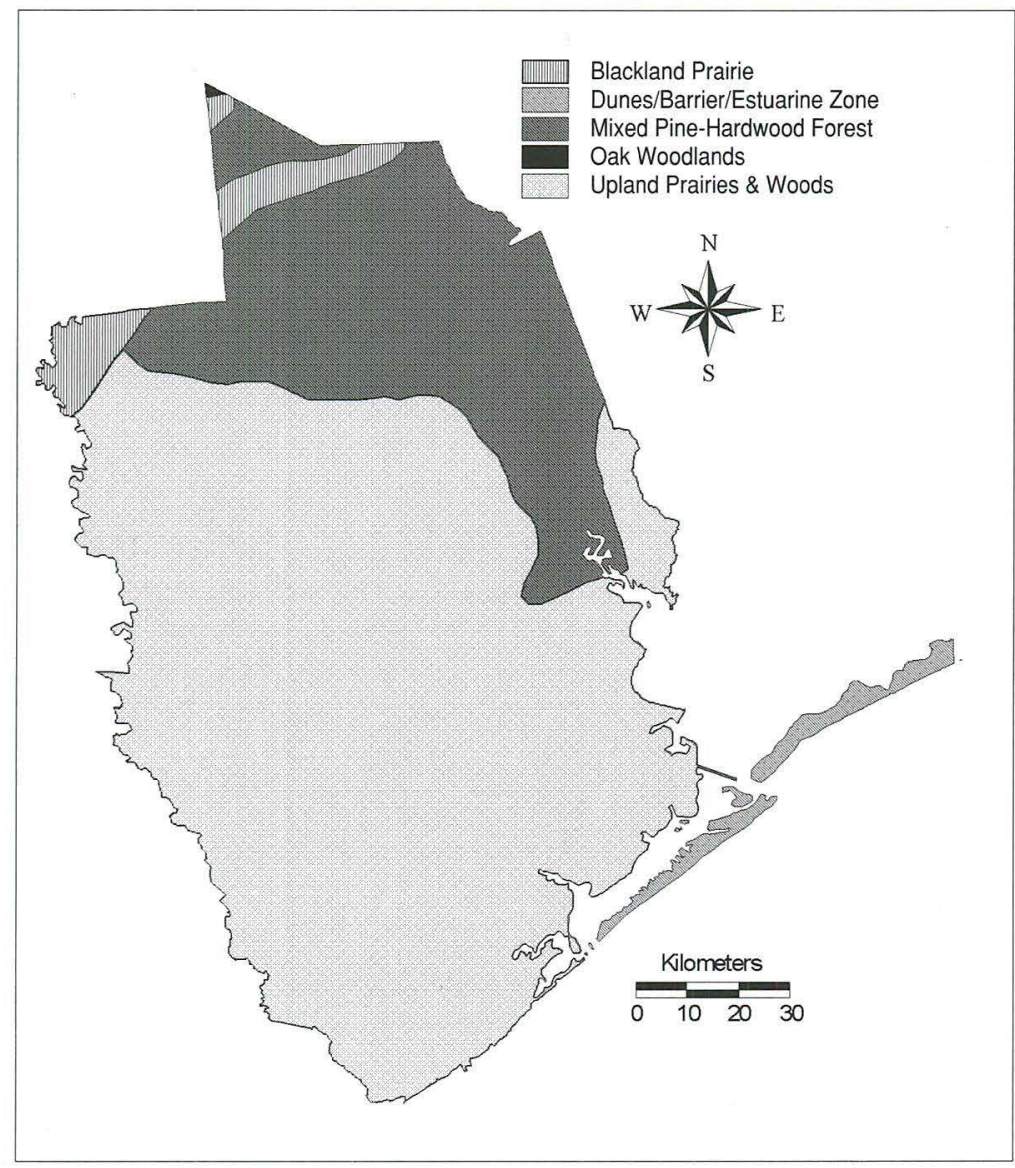

Figure 3. Plot of Natural Regions in the Houston District, after data from the Texas Natural Resource Information System (TNRIS).

geologic, pedologic, and biotic context of the region; reviews evidence for shifts in environmental variables that may have occurred through the culturally relevant past; and briefly discusses the character and distribution of resources important to prehistoric inhabitants of the region.

\section{CLIMATE AND HYDROLOGY OF THE HOUSTON DISTRICT}

The climate of the upper Texas Coast, including all of the Houston District, is classified as Subtropical Humid (Larkin and Bomar 1983), and it is transitional between the humid southeastern United States and the semi-arid to arid west. The climate reflects the influence of latitude, low elevation, and proximity to the Gulf of Mexico. These factors combine with the urban heat island formed by the tremendous concentration of asphalt and concrete to give Houston a notorious modern climate that is oppressively warm and moist throughout much of the year. Although still hot and muggy, the climate of surrounding rural areas is typically slightly less oppressive, while the dominance of land-sea breezes in the coastal areas makes localities like Galveston Island seem pleasant by comparison.

From a regional perspective, there are two precipitation peaks throughout the year, one of which occurs in late spring (May-June) due to the passage of infrequent cold fronts that spawn chains of powerful frontal thunderstorms, and a second in late summer/early autumn (August-September) due to the incidence of tropical storms and hurricanes from the Atlantic and, occasionally, Pacific (Bomar 1995). Winter and early spring, in contrast, are relatively dry, and high summer rainfall is dominated by convectional thunderstorms that are relatively brief and localized, albeit frequently intense. Although frontal passages are stronger and more frequent during winter and early spring, they tend to produce relatively little rainfall because they occur in such quick succession that moist, unstable air masses are seldom established over the region, while the more infrequent late spring fronts do allow such air masses to develop. Average annual precipitation in the Houston District varies from a low of approximately 40 inches $(100 \mathrm{~cm})$ in northwestern Waller County to a high of more than 52 inches $(132 \mathrm{~cm})$ in central Brazoria County. Average monthly precipitation across the district varies from a low of less than 2-3 inches $(5-8 \mathrm{~cm})$ in March to a high of more than 7.5 inches $(19 \mathrm{~cm})$ occurring locally on the coast during September. Almost all of the measurable precipitation falls as rain-snowfall is extremely rare, occurring in measurable amounts only about one year in 10 .

As a result of proximity to the Gulf and the abundance of surface water, humidity in the early morning can approach $100 \%$ even on cloudless summer days, while it often exceeds $50 \%$ even on the 


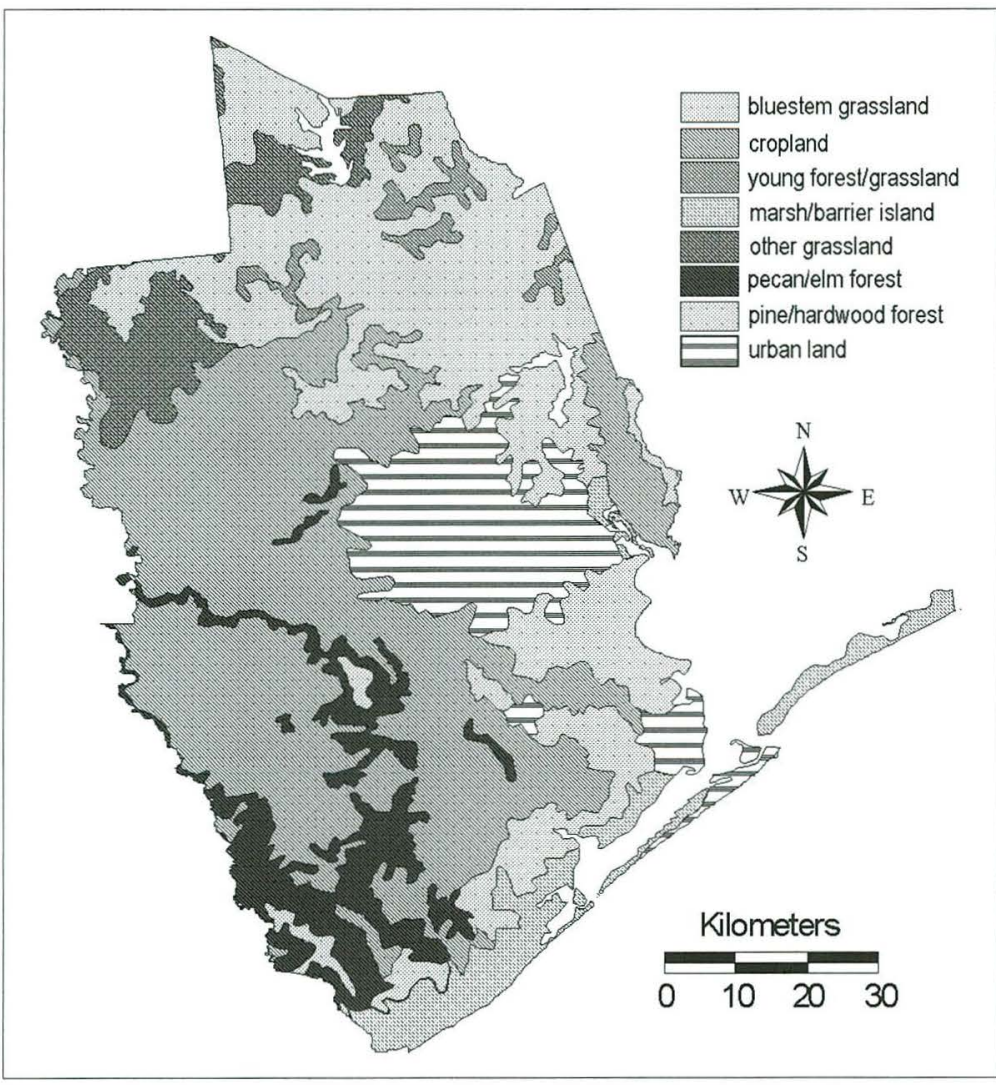

Figure 4. Vegetation distribution in the Houston District, after data compiled by the Texas Parks and Wildlife Department.

warmest afternoons. Potential evapotranspiration is limited by the relatively high moisture content of the air, and the total evaporation rate is similar to the precipitation total. Nevertheless, moisture availability and evaporation potential does vary considerably throughout the year, and there are periods, particularly during summer, when plants may experience significant moisture stress. Unsurprisingly, the rate of potential evaporation increases east to west in a relatively direct reciprocal relationship with the decline in precipitation. Average gross lake surface evaporation rates vary from a low of approximately 2.25-2.5 inches $(5.7-6.4 \mathrm{~cm})$ during January-March to a high of approximately 5.75-7 inches (14.6-17.8 cm) in July and August, with the yearly total ranging from approximately 50 to 55 inches $(127-140 \mathrm{~cm}$ ) across the district (Larkin and Bomar 1983).

Largely as a consequence of the relatively high humidity characteristic of the region, temperature patterns in the district exhibit a moderate annual range and a modest diurnal range that increases slightly to the west and with distance from the coast.
Average monthly high temperature ranges from a low of $59-63^{\circ} \mathrm{F}(17-$ $19^{\circ} \mathrm{C}$ ) in January to a high of 89$96^{\circ} \mathrm{F}\left(38-40^{\circ} \mathrm{C}\right)$ in August, while average monthly lows range from $38-47^{\circ} \mathrm{F}\left(4-9^{\circ} \mathrm{C}\right)$ in January to $72-$ $79^{\circ} \mathrm{F}\left(25-29^{\circ} \mathrm{C}\right)$ in July and August. On an annual basis, average low temperatures range between 56 and $65^{\circ} \mathrm{F}\left(15-21^{\circ} \mathrm{C}\right)$, and average high temperatures range between 75 and $79^{\circ} \mathrm{F}(27$ $29^{\circ} \mathrm{C}$ ) (Larkin and Bomar 1983).

Given these regional generalities, it is instructive to examine the spatial variability in climate through the district. Figure 5 presents climographs of four stations in the Houston District, illustrating variability in mean monthly precipitation and mean maximum and minimum daily temperature. Two aspects of climatic variability within the district are immediately apparent from these graphs. First, the daily temperature range exhibits a clear tendency to increase with distance from the coast (compare the separation between maximum and minimum temperatures at Galveston and at Conroe), yet maintains a relatively consistent range at any one station throughout the year. Second, the importance of the spring and fall rainy seasons varies considerably among stations. The fall tropical storm season is clearly more important at the coastal station at Galveston, while the spring frontal thunderstorm season is more prevalent at Conroe, some 83 miles inland. In Brazoria County, the influence of both seasons is apparent, but in none of the locations is there a marked dry season. Precipitation in Houston, in particular, exhibits a remarkably even distribution, dipping only slightly during late winter and early spring.

Information about climatic extremes is equally informative as the climatic averages in understanding the character of the climate of the Houston District. Figure 6 illustrates variability of the climate in Conroe, near the northern, inland limit of the study area. The upper graph illustrates the extremes of recorded temperature on a monthly basis. Although the highest temperatures predictably occur 


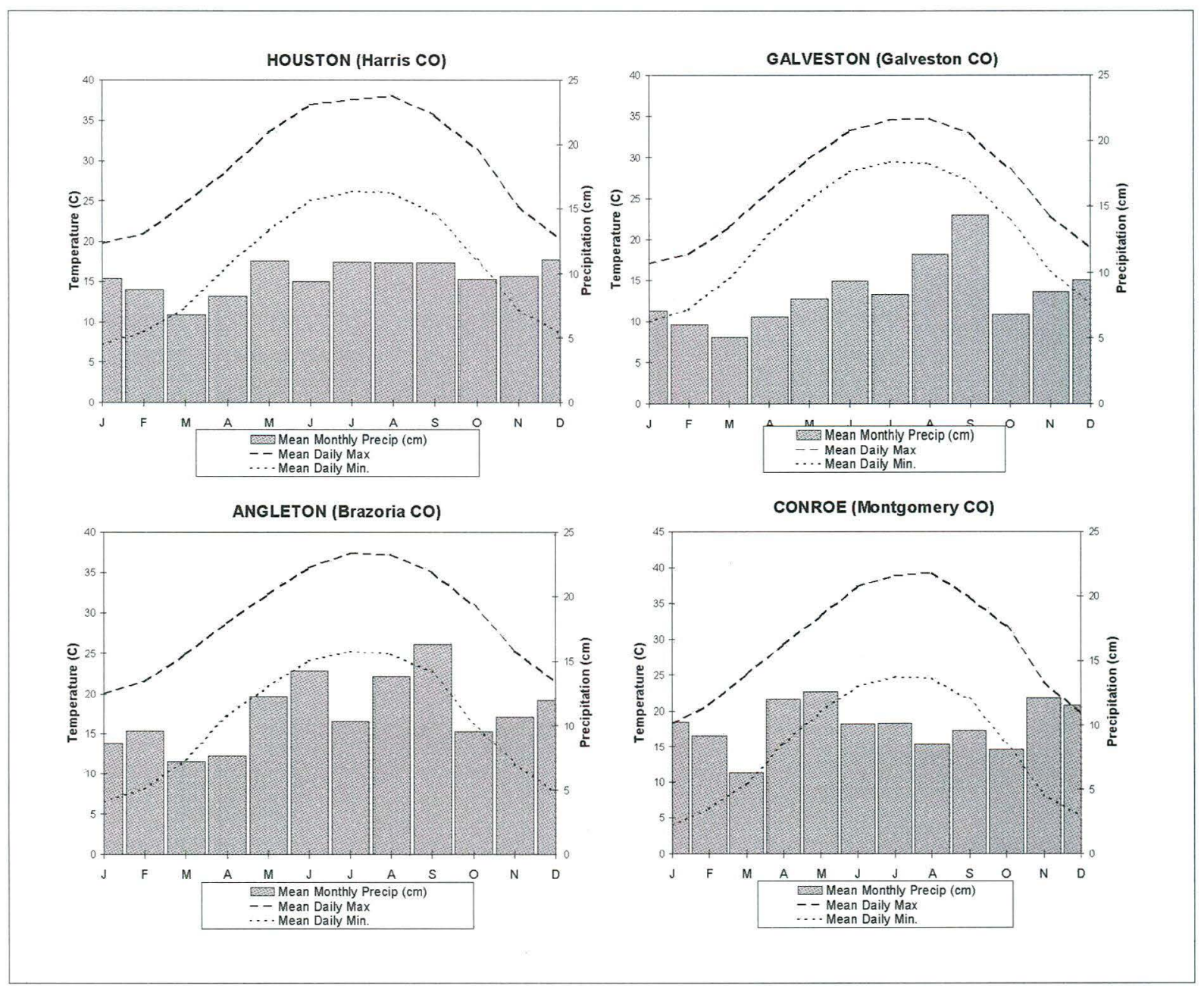

Figure 5. Climographs of selected stations in the Houston District.

during late summer, the range of possible temperatures is much greater during the low sun season; while possible summer temperatures vary by approximately $45-50^{\circ} \mathrm{F}\left(30-35^{\circ} \mathrm{C}\right)$, in winter temperatures can range more than $80^{\circ} \mathrm{F}\left(50^{\circ} \mathrm{C}\right)$. Moreover, temperatures approaching these extremes can occur within a span of a few days, as temperatures hovering near $90^{\circ} \mathrm{F}$ give way to subfreezing temperatures with the passage of a strong cold front. Such changes can have severe consequences for potential food availability if plants blossoming in response to a "false spring" are subjected to a severe late season freeze.

Precipitation extremes at Conroe during the period of record (1934-1963) are indicated by the lower graph in Figure 6. The shaded portion of the graph indicates the variability of precipitation that can be expected to occur in eight of every 10 years on a month to month basis, while the upper and lower limits indicate maximum and minimum thresholds that are exceeded approximately one year in 10. Thus, the height of the bar presents an approximation of the variability inherent in monthly precipitation. Examination of the graph reveals that low rainfall $(<5 \mathrm{~cm})$ can be expected to occur in every month throughout the year, but that high rainfall $(>15 \mathrm{~cm})$ is most common in spring through early summer and again in autumn. These peaks reflect the influence of the frontal thunderstorm and hurricane seasons, respectively. The two months with the lowest variability are February and August. Highest variability is associated with the frontal/convectional storms of April through July and, particularly, the hurricane season in September through November. The month of October is particularly striking; one year in 10 can be expected to yield only a trace of precipitation, while one year in 10 can be expected to yield more 


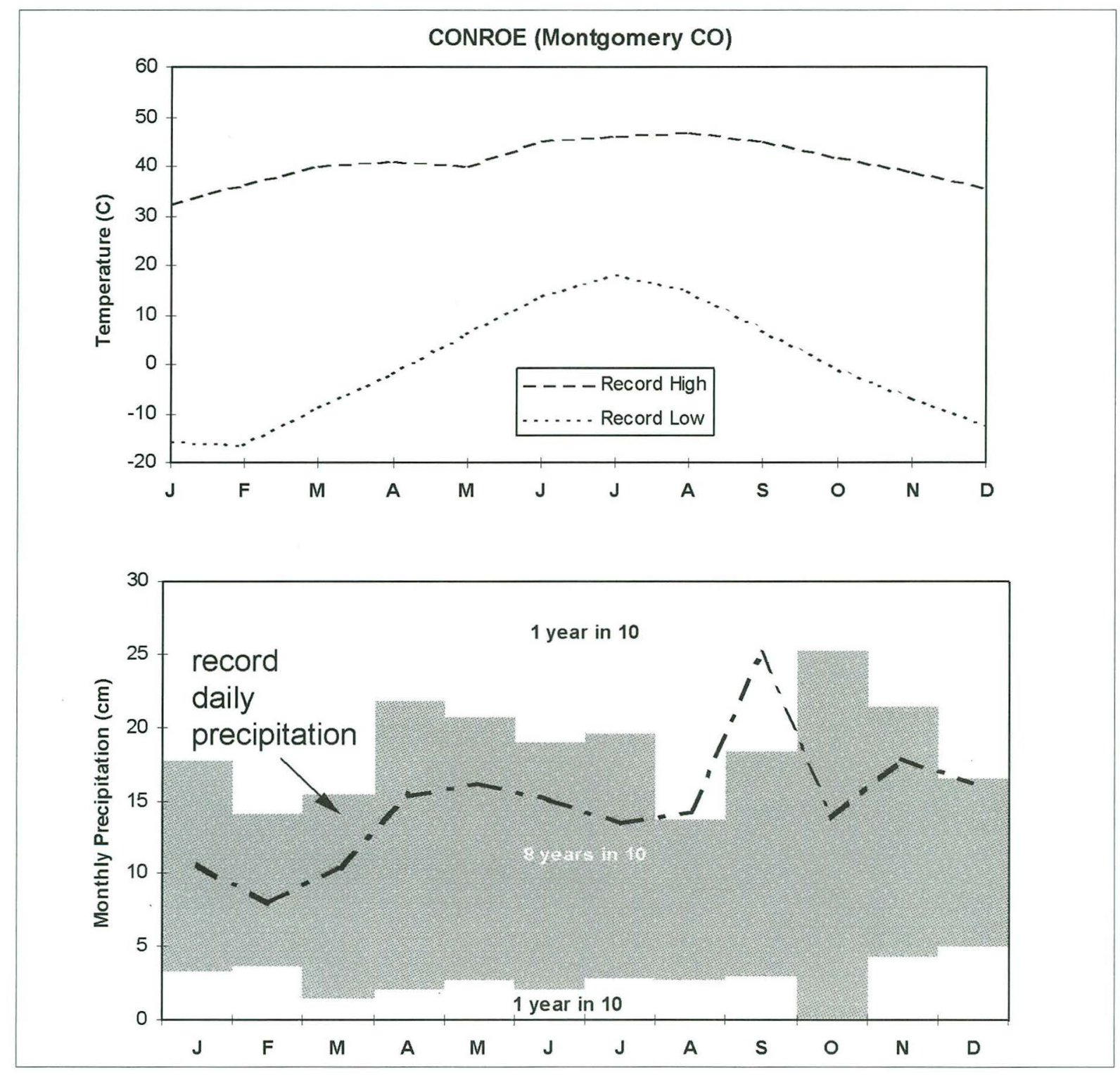

Figure 6. Climatic variability in Conroe, Montgomery County.

than $25 \mathrm{~cm}$ (10 inches), depending on the incidence of late season hurricanes.

The line in the lower graph provides a measure of the record amount of precipitation for each month that has been received during a single day. This graph clearly indicates that while strong storms may occur at any time of year-even in February, more than $8 \mathrm{~cm}$ ( 3 inches) of precipitation has been recorded in a 24 hour period - the highest potential is associated with hurricanes making landfall, which have yielded up to $25 \mathrm{~cm}$ (10 inches) in a single day. The fact that the record daily totals are of the same magnitude as the norms for the entire month illustrates the importance that individual storm sys- tems can have in influencing the monthly total. This is important because storms of this magnitude far outstrip the ability of the soil to take up the moisture, and can lead to devastating flooding. However, these totals pale in comparison to the periodic events along the Balcones escarpment, which has experienced some of the highest hourly and daily rainfall totals in the world in association with tropical storms (Kingston 1986; Bomar 1995).

The flow of five streams of different size in the Houston area over 40 years of record is illustrated in Figure 7. Although the scale is markedly different, and all of the systems presented have been modified to some extent over the past 40 years, several aspects 


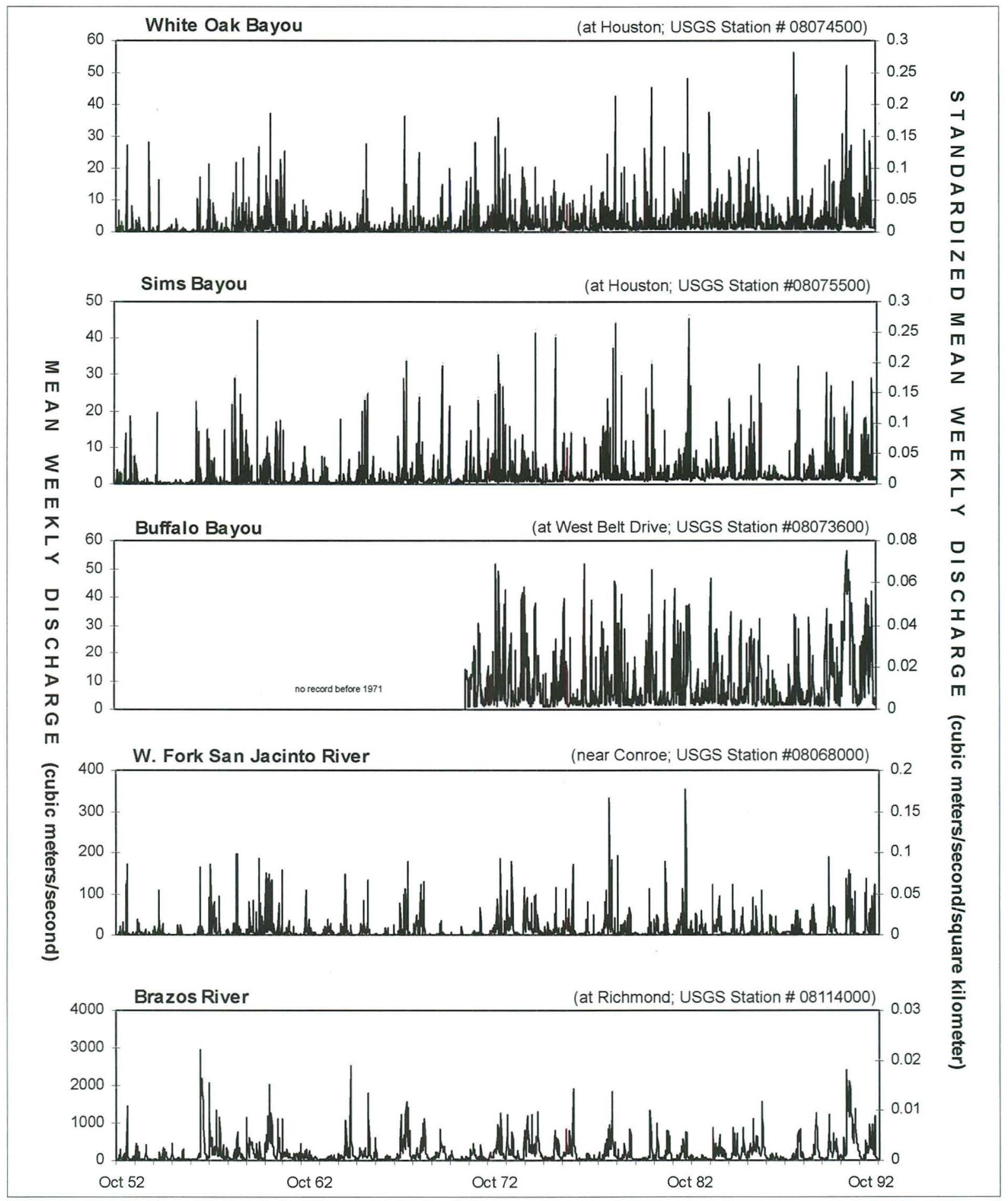

Figure 7. Discharge of five Houston area streams of various sizes over 40 years of record (data from USGS).

of the regional hydrology are apparent. First, flow is strongly governed by precipitation events, and is therefore aperiodic and strongly variable. Base flow on all streams in the region is no more than a few cubic meters/second $\left(\mathrm{m}^{3} / \mathrm{s}\right)$, but peak flow varies from approximately $40-60 \mathrm{~m}^{3} / \mathrm{s}$ in the smaller streams to approximately $3,000 \mathrm{~m}^{3} / \mathrm{s}$ (>100,000 cfs) in the Brazos drainage. There is also a noticeable increase in base flow in the small Houston bayous since about 1970, which probably reflects ongoing 
construction of water retention structures in the basins. Second, as comparison of the location of peak flows on the various plots suggests, flow is also strongly dependent on the geographic distribution of strong, localized rains; many of the high magnitude events apparent in the White Oak Bayou record, for example, are not mirrored in the Sims Bayou and upper Buffalo Bayou records, even though all three gauging stations are located within metropolitan Houston.

When standardized to drainage basin area (see Figure 7), peak flows in the small $\left(<250 \mathrm{~km}^{2}\right)$ White Oak Bayou and Sims Bayou drainages range between 0.6 and $0.8 \mathrm{~m}^{3} / \mathrm{s} / \mathrm{km}^{2}$ of drainage area. Most peaks in the somewhat larger West Fork of the San Jacinto drainage basin $\left(2150 \mathrm{~km}^{2}\right)$ range between 0.2 and $0.3 \mathrm{~m}^{3} / \mathrm{s} / \mathrm{km}^{2}$, although two peaks in excess of $0.4 \mathrm{~m}^{3} / \mathrm{s} / \mathrm{km}^{2}$ are apparent. While absolute peak discharge of the Brazos is from one to several orders of magnitude greater than the smaller streams, its drainage basin is also significantly larger. Therefore, even very large individual storms only involve a fraction of the drainage basin, and peak flows do not exceed $0.08 \mathrm{~m}^{3} / \mathrm{s} / \mathrm{km}^{2}$ of drainage area.

\section{GEOLOGIC CONTEXT OF THE HOUSTON DISTRICT}

The Houston area is underlain by rocks and unconsolidated sediments that are quite young in a geological sense, ranging from modern to Miocene in age (Barnes 1968a, 1968b, 1974a, 1974b, 1975, 1982, 1992; Morton and Nummendal 1982; Van Siclen 1991; DuBar et al. 1991). For the most part, these rocks represent a series of coalescent fluviodeltaic bodies arranged in an offlapped sequence, with interdigitated and capping eolian, littoral, and estuarine facies making up a relatively minor component of the lithology. Major bounding disconformities between these formations are generally interpreted to represent depositional hiatuses that occurred during periods of sea level low stand. Although the basic depositional architecture of the Late Quaternary sequence has been understood for some time (e.g., Barton 1930; Plummer 1932; Price 1933; Doering 1935; Fisk 1938, 1940; Bernard et al. 1962), much controversy remains regarding the particulars, and the terminology applied is in a relatively constant state of flux (Morton 1988; DuBar et al. 1991; Van Siclen 1991).
The Gulf of Mexico represents a structural basin formed by the deformation of lithosphere. The Texas Coastal Plain, which extends as far north as the Ouachita uplift in southern Oklahoma and westward to the Balcones escarpment, consists of seaward-dipping bodies of sedimentary rock, most of which are of terrigenous clastic origin, that reflect gradual infilling of the basin from its margins. The oldest rocks in this fill are of Late Cretaceous age. As a result of the geometry of basin filling, successively younger rock units crop out in subparallel bands as one moves from the basin margin toward the modern coastline.

The basic architectural relationships of Late Tertiary and Quaternary depositional bodies in the upper Texas Gulf Coast reflect the response of fluvial systems to glacioeustatic sea level change and variations in the rate of sediment delivery, conditioned by isostatic adjustment. Eustatic sea level change is a global phenomenon which is caused by changes in ocean volume, primarily as a result of the expansion and contraction of continental glaciers. As glaciers advanced, the buildup of ice on the land surface created imbalances between the amount of water lost to evaporation and the amount returning to the sea as river discharge, and sea level dropped by $130 \mathrm{~m}$ or more (Bradley 1985). This drop in sea level exposed broad areas of the continental shelf in the Gulf region to subaerial weathering and soil formation (and to potential human occupation; see Stright [1990, 1995]), and caused rivers to entrench deep valleys in their lower reaches as they adjusted their gradients to the new base level. Retreat of the glaciers returned the water to the oceans, and sea level rose, flooding the entrenched river valleys and forming estuaries. Gradually, aggrading deltaic sediments filled these estuaries and prograded seaward, merging laterally into coast-parallel expanses of new coastal plain that overlay the distal part of the weathered surface of the previous low stand, until the next glacial cycle caused another episode of entrenchment and subaerial weathering. As the coastline accreted during sea-level high stands, alluvial activity inland of the active deltas resulted in deposition of floodplain deposits that were subsequently abandoned as the rivers entrenched, forming inland fluvial terraces that are genetically related to the broad, strikeoriented coastal terraces.

It has been generally agreed for at least 50 years that long-term repetition of this basic sequence 
of events resulted in the offlapping architecture of the coastal deposits and the morphostratigraphic sequence of coast-parallel, strike-oriented alluvial surfaces forming the Quaternary part of the Coastal Plain (Fisk 1938, 1940; Bernard 1950; Doering 1935, 1956). Nevertheless, many specifics of the geologic record remain far from clear, and uncertainty and controversy concerning the number of stratigraphic units present, the age of the deposits, the terminology applied to the various deposits, and correlations between surfaces on the coastal plain and genetically related fluvial terraces inland, is still apparent in relatively recent literature. Table 1 outlines the stratigraphic sequence as interpreted by various authors.

Until recently, interpretation of Gulf Coast Quaternary stratigraphy was based on the traditional four-fold division of the Pleistocene (into the Wisconsin, Illinoian, Kansan, and Nebraskan glaciations), a model developed by Fisk $(1938,1940)$ for the Red River in Louisiana. Fisk's argument, which was elegant and persuasive, was that the coastal terraces and genetically related stream terraces formed during sea-level highstands in the recognized interglacial periods (Aftonian, Yarmouthian, Sangamonian, and Middle Wisconsinan). Because effective dating of the coastwise-terrace stratigraphy is exceedingly difficult, age estimation and correlation has historically relied almost exclusively on correlation of deposits and surfaces within an interpretive framework based on control exercised by four presumed glacial/interglacial cycles.

Unfortunately, reality is not so simple. Subsequent research, particularly in the marine environments (e.g., Shackleton and Opdyke 1973; van Donk 1976), has demonstrated that the four-fold subdivision of the Pleistocene is not valid; there appear to have been at least 21 significant glacial-interglacial cycles that would have exercised strong eustatic control on coastal sedimentation during the Quaternary period. Most Quaternary scientists have now abandoned the four-fold subdivision of the Pleistocene, retaining only the most recent (Wisconsinan) subdivision-and occasionally the preceding Sangamonian interglacial—as useful units. This revision undermines temporal underpinnings of all but the most recent studies.

Another problem is presented by the fact that the commonly recognized units are nominally defined on morphostratigraphic grounds. Morphostratigraphy consists of the subdivision of rock units on the basis of observable topographic differences in outcrop (Bates and Jackson 1984), and is not recognized by the current Stratigraphic Code (North American Commission on Stratigraphic Nomenclature 1983). In reality, subdivision of the rock units in the Houston area reflects a combination of morphostratigraphic, pedostratigraphic, and lithostratigraphic criteria, and correlations with subsurface lithostratigraphic units is tentative at best (Winkler 1991). Moreover, recent and fairly convincing research by Blum (1992; Blum and Valastro 1994) illustrates that morphostratigraphic correlation between coastal terraces and inland fluvial terraces (Looney and Baker 1977; Baker and Penteado-Orellana 1977) resulted in drastic overestimation of the age of Late Quaternary terraces in the Colorado River basin, suggesting that similar correlations elsewhere (e.g., Fisk 1938, 1940; Gagliano and Thom 1967) may also be in need of revision. Fortunately, recent advances in techniques for detailed, synoptic examination of unit outcrops (e.g., various forms of satellite imagery), and for dating of sediments in the time span represented by the coastwise terraces (e.g., thermal- and optically stimulated luminescence), provide considerable potential for refinement of the sequence.

In many cases, interpretation within the Fisk framework has caused deposits to be forced into the framework with relatively little evidence other than correlation of surfaces on the basis of lithology, soil development, and regional gradient, resulting in what subsequent radiometric dating suggests are some rather poor fits. For example, the Waddel Bluff exposure on the Red River in Louisiana was initially interpreted as representing the Montgomery Terrace (Fisk 1938), while subsequent researchers attributed it to the higher of two Prairie surfaces (Smith and Russ 1974; Russ 1975). Subsequently, radiocarbon data from buried tree stumps at the locality produced ages ranging from $22,860 \mathrm{BP}$ to 30,370 BP (Alford et al. 1985), which is in the age range (late Wisconsinan) most researchers attribute to deposition of the inset Deweyville terrace fills. However, Alford et al. (1985) note that the surface at Waddel Bluff lacks large channel scars characteristic of the Deweyville while an adjacent lower surface possesses them, and they argue that the locality does indeed represent the Prairie terrace, but a Prairie terrace that is of Farmdalian to Woodfordian (middle-late Wisconsinan) rather than Sangamonian age (implying a latest Pleistocene or Early Holocene age for the adjacent "Deweyville" 


\section{Houston Area Geoarcheology}

Table 1. Stratigraphic sequence of Cenozoic rocks in the Houston area.

\begin{tabular}{|c|c|c|c|c|c|c|c|c|}
\hline \multicolumn{2}{|c|}{$\begin{array}{c}\text { Geological } \\
\text { Age }\end{array}$} & $\begin{array}{c}\text { Hays \& Kennedy } \\
1903\end{array}$ & Deussen 1924 & Doering 1935 & Fisk 1938,1940 & Doering 1956 & Bernard 1950 & $\begin{array}{c}\text { Bernard \& LeBlanc } \\
1965\end{array}$ \\
\hline & & E TEXAS & TEXAS & SE TEXAS & LOUISIANA & GENERALIZED & ETEXAS & ETEXAS \\
\hline \multirow{2}{*}{\multicolumn{2}{|c|}{$\begin{array}{c}\text { Recent } \\
\text { (Holocene } \\
\text { or latest } \\
\text { Pleistocene/ } \\
\text { Holocene) }\end{array}$}} & \multirow{2}{*}{\multicolumn{2}{|c|}{ 一 }} & $\begin{array}{l}\text { floodplain and } \\
\text { beach deposì's }\end{array}$ & \multirow[t]{2}{*}{ recent } & $\begin{array}{l}\text { floodplain and } \\
\text { beach deposits }\end{array}$ & & \\
\hline & & & & post-Beaumont terrace & & Sicily Island & Deweyville & Deweyville \\
\hline \multirow{6}{*}{$\begin{array}{l}\frac{0}{0} \\
0 \\
0 \\
0 \\
\frac{0}{0} \\
\frac{0}{0} \\
\square\end{array}$} & \multirow{2}{*}{$\stackrel{9}{+}$} & \multirow[b]{2}{*}{ Beaumont } & \multirow[b]{2}{*}{ Beaumont } & \multirow{4}{*}{ Beaumont } & \multirow[b]{2}{*}{ Prairie } & Hollow ay Prairie & \multirow[b]{2}{*}{ Prairie } & \multirow{2}{*}{$\begin{array}{l}\text { Prairie } \\
\text { or } \\
\text { Beaumont }\end{array}$} \\
\hline & & & & & & Eunice & & \\
\hline & \multirow{2}{*}{$\frac{0}{\frac{0}{0}}$} & \multirow{3}{*}{ Columbia } & \multirow{3}{*}{ Lissie } & & Montgomery & Oberlin & Montgomery & $\begin{array}{l}\text { Montgomery } \\
\text { or } \\
\text { Upper Lissie }\end{array}$ \\
\hline & & & & & \multirow{2}{*}{ Bentley } & \multirow[t]{2}{*}{ Lissie } & Bentley & $\begin{array}{c}\text { Bentley } \\
\text { or } \\
\text { Lower Lissie }\end{array}$ \\
\hline & \multirow{2}{*}{$\begin{array}{l}\text { 즈 } \\
\text { ত̃ } \\
\text { ய }\end{array}$} & & & \multirow[t]{2}{*}{ Lissie } & & & \multirow{3}{*}{ Williana } & \multirow{3}{*}{ Williana } \\
\hline & & Lafayette & Reynosa & & \multirow{2}{*}{ Williana } & Citronelle & & \\
\hline \multirow{2}{*}{\multicolumn{2}{|c|}{ Pliocene }} & & & Willis & & \multirow{2}{*}{ Goliad } & & \\
\hline & & & & Goliad & & & & \\
\hline Miocer & & & & Fleming & & Fleming & & \\
\hline
\end{tabular}

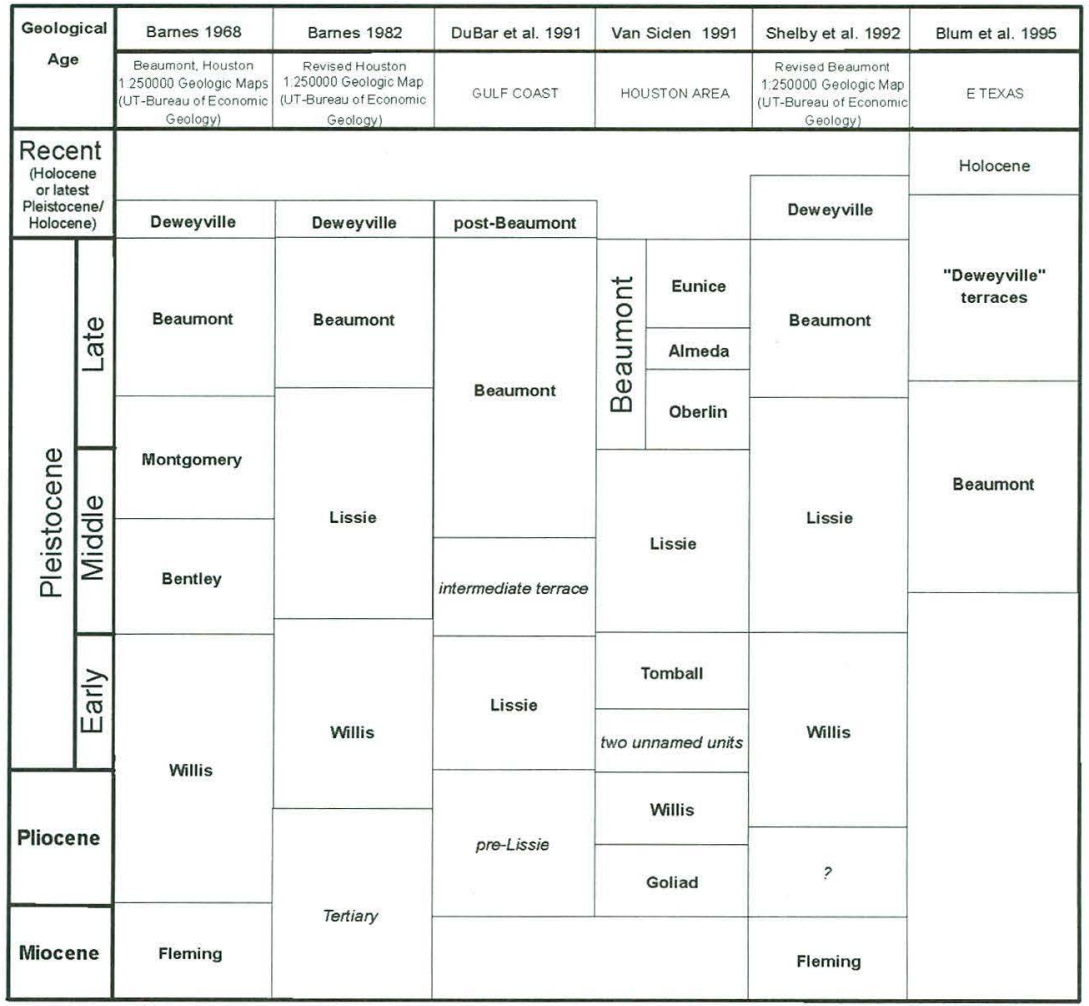


surface). In contrast, basing their findings on luminescence dating of Beaumont sediments and offshore biostratigraphic and seismic data, Blum et al. (1995; Blum and Price 1994) present a convincing argument that "Deweyville" surfaces in Texas span oxygen-isotope stages 2-4 (e.g., the classical Wisconsinan), and that the Beaumont surface actually represents a series of cross-cutting major valley fills that may represent a period as long as 500 ka prior to the Wisconsinan period. In short, much work remains to be done before we gain a firm understanding of what increasingly appears to be a complex sequence of PlioPleistocene rocks on the outer Texas Coastal Plain.

The oldest subaerially exposed rocks in the Houston district represent the Fleming Formation (Barnes 1968b) or Fleming Group (Sellards et al. 1932), which consists primarily of clay with some silt and sand, and is of probable Middle Miocene age (approximately 11-18 ma). These rocks are exposed in the northern part of the district, where they are overlain by rocks of the Willis Formation. In general, the outcrop of the Fleming Formation underlies the Blackland Prairie Natural Region in the Houston District, and represents a comparatively minor component of the landscape. Nevertheless, Fleming Rocks are thick (390-450 m) in comparison with subsequent units, and underlie much of the district at depth.

The next younger commonly recognized unit is the Willis Formation, which correlates with the Williana Formation further east in Louisiana. This unit, or series of units, is also occasionally referred to as pre-Lissie, and units in the same approximate stratigraphic context have been termed Citronelle (based on correlations with Gulf Coast units farther east) and Goliad (see Table 1). In mapping the regional geology, The University of Texas Bureau of Economic Geology (Barnes 1982, 1992) subdivides the Willis Formation into two spatially discrete informal members (designated Qwl and Qwc) that differ in the degree of weathering and may represent deposits of different age. The older, less highly weathered Qwl member is relatively strongly dissected, consisting primarily of large, discrete upland remnants surrounded by outcrops of the Fleming Formation. The more strongly weathered member, Qwc, is preserved as a relatively continuous outcrop belt and typically forms a prominent cuesta scarp on the landward side. Lithologically, the Willis Formation consists of diverse fluvial deposits with clay, silt, sand, and siliceous gravel. This lithology is overprinted with moderate (in the case of Qwl) to intense (Qwc) lateritic weathering. The Qwc in particular is characterized by iron concentrations and large ferric concretions. Thickness in the study area is on the order of 100 feet $(30 \mathrm{~m})$. In South Texas and northeastern Mexico, a roughly equivalent unit is strongly calichified, and forms the locally prominent Reynosa Escarpment (Price 1958; DuBar et al. 1991). The Willis, and the other correlative units, are at present undated. Based on stratigraphic criteria, the Willis/Williana/Citronelle complex has traditionally been considered lower Pleistocene in age, although it is likely that at least some of the "unit" represent Pliocene deposition.

The coastwise Lissie terrace extends relatively continuously from Alabama to southern Texas. Together with the Beaumont/Prairie terrace, the Lissie is the most laterally continuous major geomorphic surface in the region, and is interrupted only by the more recent, cross-cutting valley fills. The Lissie has frequently been subdivided into two distinct units, the lower Bentley terrace and the upper Montgomery terrace (e.g., Bernard 1950; Barnes 1968a, 1968b), but this subdivision is largely an artifact of imposing the four-stage Fisk framework and is gradually being abandoned (e.g., Barnes 1982, 1992; DuBar et al. 1991; Van Siclen 1991). Lissie deposits consist of clay, silt, sand, with occasional very fine gravel that is slightly more common in the lower part. Lissie deposits are sometimes characterized as somewhat loamier than the subsequent Beaumont Formation, but the distinction is minor, if it exists at all. Lissie deposits show considerable diagenic (or pedogenic) alteration, including large carbonate concretions and iron or iron-manganese rhizoliths, concretions, and amorphous segregations. The presence of both substantial ferric and calcic segregations, frequently in the same profile, implies that pedogenic trajectories in the Lissie deposits are complex. The surface is typically level to gently rolling and is frequently marked with shallow ponded depressions and pimple mounds. Thickness is on the order of $60 \mathrm{~m}$ in the study area.

The Beaumont, or Prairie, terrace is the youngest continuous coastwise terrace fronting the modern Gulf. The Beaumont Formation consists of clay, silt, and fine sand arranged in spatial patterns that reflect the distribution of fluvial (channel, point bar, levee, and backswamp) and mudflat/coastal marsh 
facies (Van Siclen 1985). Sandy deposits associated with littoral facies (e.g., the Ingleside barrier system) are also frequently considered part of the Beaumont. Barnes (1982) maps three distinct lithostratigraphic units in the Beaumont: (1) deposits that are "dominantly clay and mud of low permeability, high water holding capacity, high compressibility, high to very high shrink-swell potential, poor drainage, level to depressed relief, low shear strength, and high plasticity" that represent floodbasin, backswamp, and abandoned channel-fill muds; (2) deposits that are "dominantly clayey sand and silt of moderate permeability and drainage, low to moderate compressibility and shrink-swell potential, level relief with local mounds and ridges, and high shear strength" that represent channel, levee, crevasse splay, and distributary sands; and (3) "fine grained sand normally without shell material" that exhibits "high to very high permeability, low water holding capacity, low compressibility, low shrink-swell potential, good drainage, low ridge and depressed relief, high shear strength, and low plasticity" that represent barrier island and/or strandplain facies. Many investigators (e.g., Fisk 1938, 1940; DuBar et al. 1991) have correlated the Beaumont terrace with the Sangamon Interglacial (roughly 130-75 ka), although age estimates range from Middle Wisconsinan (Alford and Holmes 1985) to 100-600 ka (Blum and Price 1994). The sandy deposits of the "Ingleside" system crop out as a discontinuous, sandy strip from western Louisiana to the South Texas sand sheet, with correlates present east of the Mississippi River to Florida and on the Atlantic Coast (Otvos 1972; Wilkinson et al. 1975). These deposits appear related to a Late Pleistocene sea level highstand of probable Middle Wisconsinan age; however, there is controversy about whether the Ingleside system is contemporaneous with the Beaumont or postBeaumont (e.g., Price 1955; Wilkinson et al. 1975; Otvos 1991; DuBar et al. 1991). Another controversy surrounding the Ingleside system is whether it represents a Pleistocene barrier island that was separated from the mainland by a lagoon (DuBar et al. 1991; Otvos 1991), or simply a sandy strandplain/ beach assemblage unconformably overlying the Beaumont (Wilkinson et al 1975).

While the debates concerning correlations between, and temporal affiliations of, the deposits underlying the major coastwise terraces remain active, they are of little direct geoarcheological relevance because virtually all investigators agree that these deposits considerably predate the range of demonstrated human occupation in North America. However, the same is not true of the series of presumably related fluvial terraces, commonly designated by the informal term "Deweyville," that fit stratigraphically between the youngest ("Beaumont") coastwise terrace and the Recent deposits of the outer coastal plain, deltas, and stream valleys. As mentioned previously, the age of "Deweyville" deposits has been estimated between 3-4 ka and 100 ka by various investigators, with most assuming a Middle to Late Wisconsinan age (Bernard 1950; Delcourt and Delcourt 1977; Otvos 1980; Alford et al. 1985; Mossa et al. 1989; DuBar et al. 1991; Blum et al. 1995). Deweyville deposits consist of up to three inset fluvial terraces that lie stratigraphically between the Holocene floodplains and the lowest coastwise (i.e., Beaumont/Prairie) terrace. The principal distinguishing factor of these terraces in Texas is that they retain large, looping meander scars that clearly indicate discharge regimes considerably greater than exhibited by the equivalent modern streams. Although extant "Deweyville" terraces are absent in the lower reaches of several of the larger streams in the coastal zone, including the Brazos River, investigators from Bernard (1950) to Blum et al. (1995) have recognized the presence of outsized arcuate scallops on the valleys walls that appear to represent "Deweyville"-scale terraces covered with a veneer of Holocene overbank deposits.

This author is of the opinion that the stratigraphic position occupied by the Deweyville terraces, and the hydrologic implications of the preserved meander scars that occupy the surfaces, provide strong support that the deposits making up the terrace cores predate the Holocene. However, it is likely that these features still exhibit archeological potential. The best potential is probably associated with those "Deweyville" terraces that have been buried by Holocene aggradation, particularly in the Brazos drainage. Such terraces would have been relatively dry, elevated surfaces in the valleys until they were finally overtopped by the aggrading overbank deposits, and thus may have been attractive sites for occupation throughout much of the Holocene. Similar settings, albeit on a much smaller scale, have been demonstrated to be prime localities for site preservation at areas farther inland within the outcrop belt of Eocene sands (Abbott 1996). Even in cases where aggradation has not 
been sufficient to bury the terraces below the level of the extant floodplain, it is possible that many "Deweyville" surfaces could exhibit a culturally relevant veneer of post-12 ka alluvial overbank deposits laid down during high magnitude flooding, which could help explain the presence of buried cultural material beneath these surfaces (e.g., Alford and Holmes 1985). However, in those cases where meander scrolls are still visible, such a veneer would necessarily be relatively thin, and may have been subject to historic disturbance, while all such surfaces have the potential to contain palimpsest deposits from many different periods.

Post-"Deweyville" deposits on the coastal plain include the diverse alluvial deposits associated with extant stream floodplains, deltas of the streams debouching into the Gulf or into back-barrier lagoons, marsh deposits, strandplain deposits, lagoonal deposits, eolian deposits overlying older sedimentary units, and the modern barrier island complexes. They represent the suite of deposits with potential to contain stratified archeological components. Most geological mapping (e.g., Barnes 1968a, 1982) provides minimal discrimination between these diverse sediments, although different environments are mapped in considerable detail in the Geologic Atlas of the Coastal Zone (Fisher et al. 1972; McGowen et al. 1976). With the exception of the sandy barrier island deposits, which have few analogs in the record (the Ingleside system being the main exception), this suite of deposits is directly analogous to facies present in the Pleistocene formations.

Figure 8 illustrates the distribution of principal geologic units in the Houston District. The map is based on the most recent Geologic Atlas of Texas mapping by The University of Texas Bureau of Economic Geology.

\section{SOILS OF THE HOUSTON DISTRICT}

In general, soil properties reflect the interaction of five soil-forming factors: (1) climate; (2) organisms; (3) relief; (4) parent material; and (5) time (Jenny 1941; see Chapter 3). The spatial variability of soils in the Houston District is primarily a function of the texture and chemical properties of the parent material and the length of the soil forming interval, tempered by factors such as vegetation type, degree of bioturbation, depth to water table, surface drainage characteristics, influx of saline water, historic and modern land use, and relief. Although changes in climate over the long term have strongly influenced the trajectory of pedogenesis, so that very old soils exhibit starkly different properties than are currently developing, the spatial influence of climate is minor because the area is too small and too close to the moderating influence of the Gulf of Mexico to exhibit strong climatic gradients. Similarly, while toposequence variability is apparent, particularly in the northern part of the district, relief is also of relatively minor importance in comparison to areas of similar size elsewhere because most of the Houston area is relatively smooth and level.

In the United States, soils are typically classified according to the official USDA Soil Taxonomy (Soil Survey Staff 1975, 1999) classification system. Soil Taxonomy is a complex, hierarchical system based on interrelationships between soil properties. Although Soil Taxonomy is not a genetic classification per se, the relationship between soil properties and pedogenic processes is such that the classification of a soil has strong implications for its origin and history. Twelve soil orders (Alfisols, Andisols, Aridisols, Entisols, Histosols, Gelisols, Inceptisols, Mollisols, Oxisols, Spodosols, Ultisols, and Vertisols) are recognized in the most recent version of the system (Soil Survey Staff 1999), but only six are represented in the Houston District. Soil orders are subdivided successively into Suborders, Great Groups, Subgroups, Families, and Soil Series, with each class representing soils grouped on more narrowly focused criteria than its parent class. The dynamic nature of the Soil Taxonomy is illustrated by increases in the total number of classifications at each level of the hierarchy between the 1975 and 1999 editions; for example, the 1975 edition recognized 185 Great Groups and approximately 10,500 Series, while the 1999 edition recognizes more than 300 Great Groups and 19,000 Series (Soil Survey Staff 1975, 1999).

Figure 9 illustrates the generalized distribution of soils in the Houston District. This distribution is extracted from the USDA Natural Resource Conservation Service STATSGO database. Thirty-five general soil associations are mapped in the six county area. Table 2 lists the 105 soil series identified in the USDA-SCS county soil surveys from the district (Mowery et al. 1960; McClintock et al. 


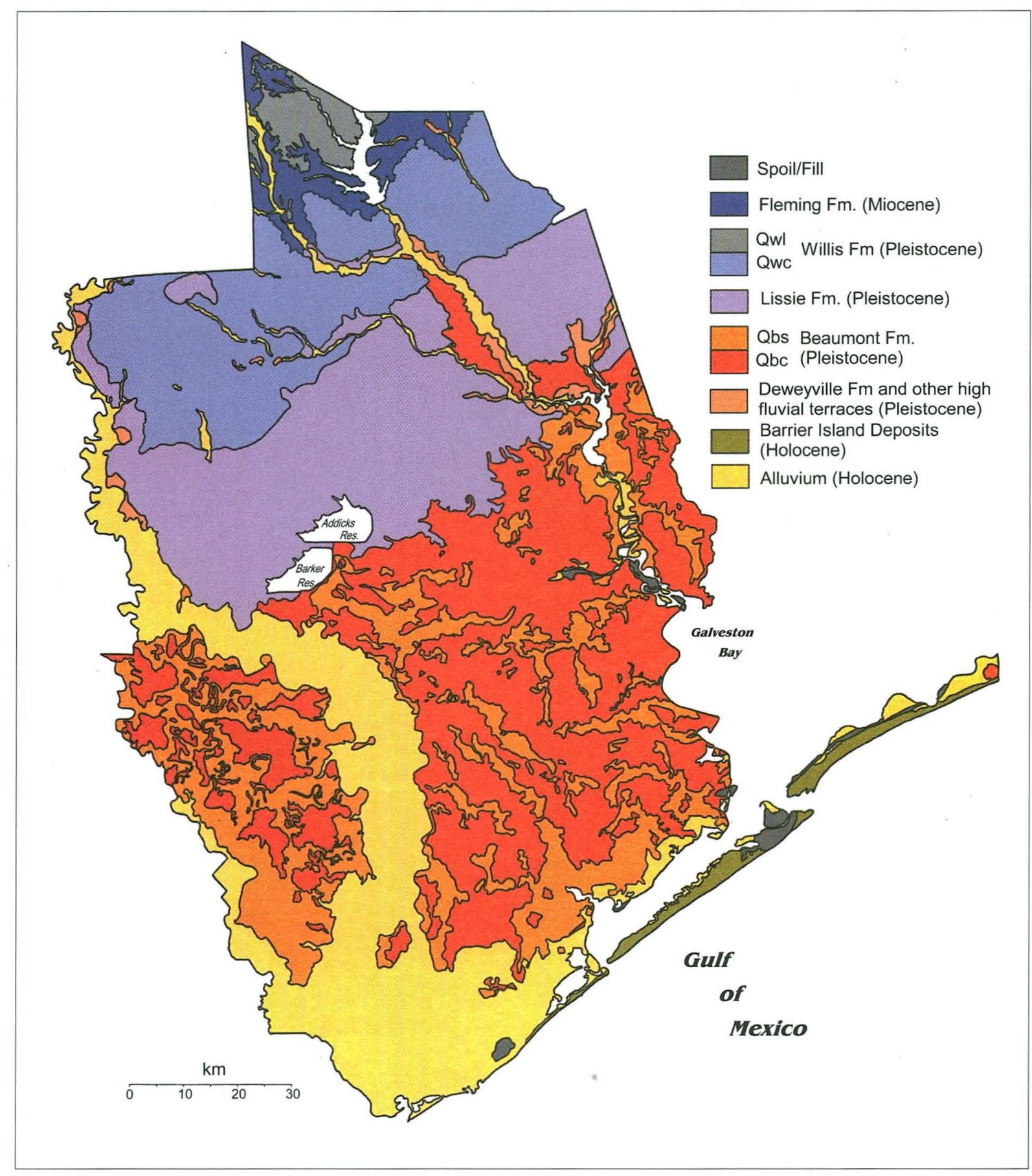

Figure 8. Geology of the Houston District. Adapted from the Geologic Atlas of Texas (Austin, Seguin, Houston, Beaumont, and Beeville-Bay City sheets) by the Bureau of Economic Geology, University of Texas at Austin.

1972; Wheeler 1976; Crenwelge et al. 1981; Chervenka and Daniel 1983; Greenwade 1984; Crenwelge et al. 1988). In the process of mapping, these soils were grouped into general associations on a county-by-county basis in every county but Fort Bend County, which was mapped before this practice was initiated. While the number of general soil associations defined in the individual counties ranges from eight in Harris and Montgomery counties to 15 in Waller County, this difference reflects more on the amount of detail employed in defining the broad associations than any real difference in the range of soils present in the various counties. The STATSGO database represents a redefinition 


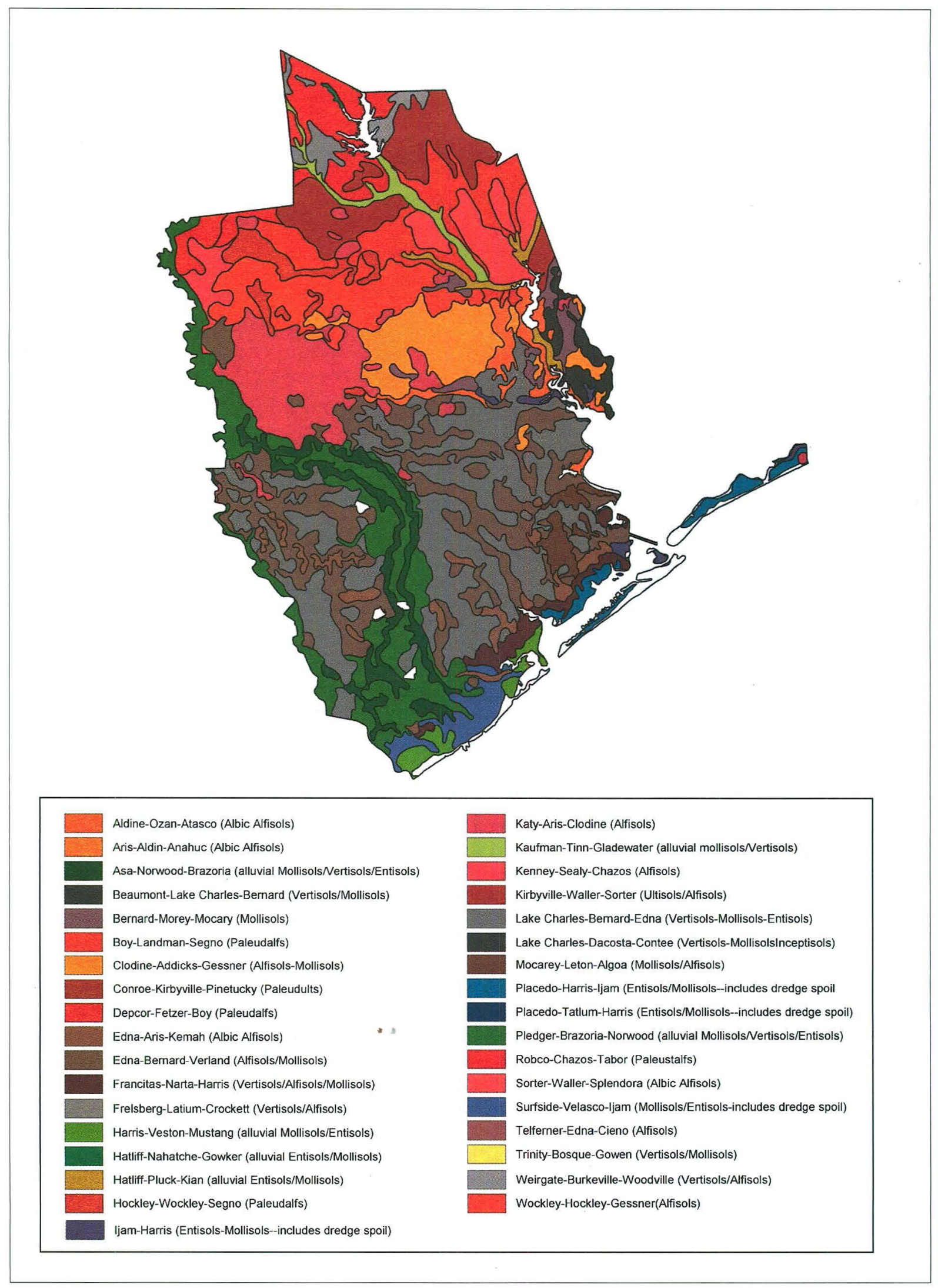

Figure 9. General distribution of soils in the Houston District according to the USDA-NRCS Statsgo soils database. 
of these general associations into categories that are useful for statewide classification. Consequently, the named associations include many soil series that are not mapped in the individual county soil surveys.

Comparison of the distribution of soils illustrated in Figure 9, and the geology of the district illustrated in Figure 8, illustrates the very strong control that lithology and age of parent material exercise over soil characteristics and distribution. One of the most striking examples of this control is apparent in the patterning of soils on the Beaumont surface, which reflects the distribution of channel (relatively sandy) and floodbasin (relatively clayey) facies of the Pleistocene deltaic systems. In many cases, the former channel traces form low, broad linear mounds that can rise up to a meter above the surrounding surface. No similar pattern is observable on the Lissie surface, indicating that facies variation is not as pronounced. It is debatable whether this difference is due to gradual destruction of what was originally a similar pattern of facies variation by a variety of modifying processes, or a reflection of real differences in the patterns of primary depositional activity. Geological controls are also apparent in the northern part of the district, where older (pre-Lissie) deposits support relatively distinctive soil associations; in the larger modern stream valleys (particularly the Brazos); and on the barrier islands. Finally, a distinctive suite of seasonally to semi-permanently wet, saline soils are typical of the low coastal areas.

Table 2 lists pertinent data for each soil series reported in the district, including counties where it is present, characteristic topographic position and parent material, typical profile, approximate solum thickness, and specific comments. Of the 105 soil series listed, 103 are classified by the USDA soil taxonomy and two (Iuka and Roebuck) are defunct series. The classified soils represent six soil orders: Entisols (23\%), Mollisols (16\%), Vertisols (11\%), Alfisols (35\%), Ultisols (11\%), and Inceptisols (1\%). In general, the Ultisols and the Alfisols are typical of the ancient, strongly developed soils on the Beaumont and older units, while the Entisols and Inceptisols represent soils developed on dredge spoil and on natural Holocene sediments in the stream systems and deltas, barrier islands, and outer coastal plain. While these orders primarily reflect the duration of the soil forming interval, the distribution of Vertisols is more dependent on parent lithology (i.e., presence of smectitic clays) than time. Vertisols and other soils with strong shrinkswell properties are also common on the older surfaces, particularly on the grasslands of the Beaumont outcrop, but also may occur on relatively clayey facies in Holocene deposits. Although only 12 of the soil series are classified as Vertisols, strong vertic properties are also characteristic of eight Alfisol series and five Mollisol series.

On the basis of the information in Table 2 and examination of the distribution of the soils, an initial assessment of geoarcheological potential, or likelihood that the soil could contain buried cultural material in reasonable context, was developed for each soil series. Two series, both of which are relatively recent alluvial soils characterized by buried paleosols, are judged to have very high potential. Seventeen soil series, including 10 Entisols, three Mollisols, one Inceptisol, and one Alfisol, are judged to have high geoarcheological potential. Almost all of these series are developed in thick, stratified deposits of recent, loamy alluvium, although two are typical of weak soils developed on eolian deposits on the barrier islands. Nine series are judged to have moderate to high potential. These soils consist of those formed in relatively clayey recent alluvium or channel/point bar sands, and are dominated by Mollisols, Vertisols, and sandy Entisols. These soils are judged to have slightly lower potential than the loamier alluvium because they were probably less attractive localities for prehistoric occupation and are more likely to have experienced shrink-swell disturbance. The 39 soil series judged to have low-moderate potential consist of those developed on high alluvial terraces that may possibly contain a veneer of more recent sediment based on the published description, coastal marsh soils, and upland soils that may include an eolian or colluvial veneer based on the published description or classification. Soil series judged to have low potential consist of strongly developed upland soils. These soils comprise approximately one-third of the mapped soil series in the district. Finally, two soil series characteristic of dredge spoil deposits were judged to have no prehistoric archeological potential.

Although the areal coverage of these soils is not equal, it is still telling that 75 of the 105 soil series in the Houston District (71\%) are judged to have low-moderate or poorer archeological potential. Most of these soils are the product of prolonged pedogenesis, and the sediments are simply 


\begin{tabular}{|c|c|c|c|c|c|c|c|c|c|c|c|c|}
\hline Soil Series(subfamily) & $\frac{\bar{\omega}}{\bar{\sigma}}$ & 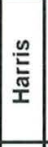 & 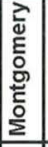 & 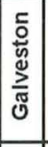 & 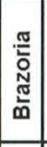 & 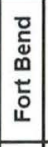 & Topographic Position & Parent Material & Typical Profile & 至总 & Comments & Georcheological Potential \\
\hline $\begin{array}{l}\text { Clemville(Typic Udifluvents) } \\
\text { Miller(Vertic Haplustolls) }\end{array}$ & $\mathrm{x}$ & & & & $\mathrm{x}$ & $x$ & $\begin{array}{l}\text { floodplain } \\
\text { floodplain }\end{array}$ & $\begin{array}{c}\text { loamy recent alluvium } \\
\text { clayey recent alluvium of the } \\
\text { Brazos River }\end{array}$ & $\begin{array}{c}\text { Ap-A12-C1-Ab } \\
\text { Ap-A11-A12-A13-B21-B22b }\end{array}$ & $\begin{array}{l}>60 \\
>46\end{array}$ & $\begin{array}{l}\text { buried paleosols common } \\
\text { buried paleosols common; } \\
\text { soil cracks }\end{array}$ & $\begin{array}{l}\text { very high } \\
\text { very high }\end{array}$ \\
\hline Asa(Fluventic Haplustolls) & & & & & $x$ & $x$ & floodplain & loamy recent alluvium & $A 1-B 21-B 22-C$ & $30-60$ & stratified parent material & high \\
\hline Bibb(Typic Haplaquents) & & & $x$ & & & $x$ & floodplain & loamy recent alluvium & A-Cg1-Cg2 & 12 & & high \\
\hline Bruno(Typic Udifluvents) & & & $\mathrm{x}$ & & & & floodplain/levee & sandy recent alluvium & A-C1-C2-C3-C4 & $7-22$ & stratified parent material & high \\
\hline Hatliff(Aquic Udifluvents) & & $x$ & & & & & forested floodplain & loamy recent alluvium & Ap-A1-C1-C2-C3-C4 & 10 & stratified parent material & high \\
\hline luka*(not classified-defunct) & & & & & & $x$ & floodplain & loamy recent alluvium & $A-A C-C$ & 30 & $\begin{array}{c}\text { typical of San Bernard River } \\
\text { floodplain }\end{array}$ & high \\
\hline Kosse(Fluventic Haplaquolls) & & & $x$ & & & & floodplain & loamy recent alluvium & $\mathrm{A} 1-\mathrm{B}-\mathrm{Cg}$ & $17-46$ & stratified parent material & high \\
\hline Mustang(Typic Psammaquents) & & & & $x$ & $x$ & & $\begin{array}{c}\text { littoral/barrier island/coastal } \\
\text { dunes }\end{array}$ & sandy littoral/eolian deposits & A-Cg1-Cg2 & $<5$ & marine shell fragments & high \\
\hline Nahatche(Aeric Fluvaquents) & $x$ & $x$ & & & & & floodplain & loamy recent alluvium & $A 1-C 1 g-C 2 g$ & $<10$ & stratified parent material & high \\
\hline Norwood(Typic Udifluvents) & $x$ & & & & $x$ & $x$ & floodplain & loamy recent alluvium & Ap-A12-C1-\|C2-\|C3-IIC4 & $15-40$ & weak stage I carbonate & high \\
\hline Oklared(Typic Udifluvents) & $x$ & & & & & & floodplain & $\begin{array}{l}\text { loamy recent alluvium of the } \\
\text { Brazos River }\end{array}$ & $\mathrm{A} 1-\mathrm{C} 1-\mathrm{C} 2$ & $<10$ & stratified parent material & high \\
\hline Tuckerman(Typic Ochraqualfs) & & & $x$ & & & & floodplain/low terrace & loamy recent alluvium & A1-A2g-B21g-B22g-Cg & $50-76$ & & high \\
\hline Tuscumbia(Vertic Haplaquepts) & & & $x$ & & & & floodplain & clayey recent alluvium & $A-B 21 g-B 22 g-B 3 g-C g$ & 50 & soil cracks & high \\
\hline Voss(Aquic Udipsamments) & & $x$ & & & & & floodplain & sandy recent alluvium & A1-C1-C2 & $<10$ & stratified parent material & high \\
\hline Yahola(Typic Ustifluvents) & & & & & & $\mathrm{x}$ & floodplain & $\begin{array}{c}\text { sandy recent alluvium of the } \\
\text { Brazos River }\end{array}$ & $A-A C-C$ & 28 & stratified parent material & high \\
\hline Brazoria(Typic Chromuderts) & $x$ & & & & $x$ & & floodplain & clayey recent alluvium & Ap-A12-B21-B22-B23 & $40-60+$ & gilgai; soil cracks & moderate-high \\
\hline Chipley(Aquic Quartzipsamments) & & & $x$ & & & & floodplains/low terraces & sandy recent alluvium & A-C1-C2-C3 & $>72$ & high bioturbation potential & moderate-high \\
\hline Crevasse(Typic Udipsamments) & & & $x$ & & & & stream channels & sandy recent alluvium & A-C1-C2 & $6-12$ & & moderate-high \\
\hline Kaman(Vertic Haplaquolls) & & $x$ & & & & & floodplain & clayey recent alluvium & A11-A12-A13-Bg-Cg & 52 & soil cracks & moderate-high \\
\hline Kaufman(Vertic Haplaquolls) & & & $\mathrm{x}$ & & & $x$ & floodplain & clayey recent alluvium & A11-A12-A13-C & $40-100$ & soil cracks & moderate-high \\
\hline Navasota(Aeric Endoaquerts) & & & & & & $x$ & floodplain & clayey recent alluvium & $A-A C-C$ & 44 & soil cracks & moderate-high \\
\hline Ozan (Typic Glossaqualfs) & & $x$ & & & & & floodplain/upland depressions & loamy recent alluvium & $\mathrm{A} 1-\mathrm{A} 21 \mathrm{~g}-\mathrm{A} 22 \mathrm{~g}-\mathrm{B} 21 \mathrm{tg} \& \mathrm{~A} 22 \mathrm{~g}$ & $>65$ & $\begin{array}{c}\text { common burrows; description } \\
\text { suggests Holocene veneer } \\
\text { over older sediment }\end{array}$ & moderate-high \\
\hline Pledger(Vertic Hapludolls) & & & & & $x$ & $x$ & floodplain & clayey recent alluvium & A1-B21-C & $30-70$ & soil cracks & moderate-high \\
\hline Sumpf(Cumulic Haplaquolls) & $x$ & & & & $x$ & & $\begin{array}{l}\text { floodplain (abandoned } \\
\text { channels) }\end{array}$ & clayey recent alluvium & A11-A12-IIC-IIIC & $40-60$ & & moderate-high \\
\hline Trinity(Typic Pelluderts) & $x$ & & $x$ & & & & floodplain & clayey recent alluvium & A11-A12-A13s & 36 & gilgai; soil cracks & moderate-high \\
\hline Axtell(Udertic Paleustalfs) & $x$ & & & & & & stream terrace & loamy ancient alluvium & $A 1-A 2-B 21 t-B 22 t-B 23 t g-B 3$ & $>60$ & soil cracks & low moderate \\
\hline Burleson(Udic Pellusterts) & $x$ & & $x$ & & & & ancient stream terraces & clayey ancient alluvium & A11-A12-AC-C & 40-100 & gilgai; soil cracks & low-moderare: \\
\hline Clodine(Typic Ochraqualfs) & & $x$ & & & & $x$ & upland & loamy ancient alluvium & Ap-A12-B21tg-B22tg-B23tg & $>72$ & stage $|-| l$ carbonate & low moderate \\
\hline Crowley(Typic Albaqualfs) & & & $x$ & & & & ancient stream terraces & loamy ancient alluvium & Ap-B21tg-B22tg-B31tg-B32tg? & $48-60$ & & \\
\hline Eufala(Psammentic Paleustalfs) & $x$ & & & & & & ancient stream terraces & sandy ancient alluvium & A1-A21-A22\&B21t & $>80$ & reddish clay lamellae & low-moderate \\
\hline
\end{tabular}




\begin{tabular}{|c|c|c|c|c|c|c|c|c|c|c|c|c|c|}
\hline Soil Series(subfamily) & $\frac{\bar{\omega}}{\bar{\omega}}$ & 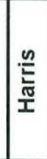 & 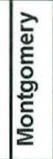 & 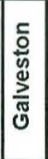 & 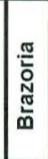 & 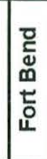 & Topographic Position & Parent Material & Typical Profile & 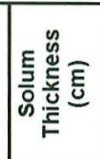 & Comments & Georcheological Potential & $\begin{array}{l}\overrightarrow{0} \\
\stackrel{0}{\sigma} \\
\stackrel{\tilde{N}}{\sigma}\end{array}$ \\
\hline Follet(Typic Haplaquents) & & & & $\mathrm{x}$ & $x$ & & coastal marsh & $\begin{array}{c}\text { loamy recent alluvium/marsh } \\
\text { sediment }\end{array}$ & $\mathrm{Ag}-\mathrm{Cg} 1-\mathrm{Cg} 2$ & $8-16$ & $\begin{array}{c}\text { common peaty surface } \\
\text { horizon }\end{array}$ & low-moderate & 离. \\
\hline Fulshear*(Typic Hapludalfs) & & & & & & $x$ & upland & $\begin{array}{c}\text { sandy ancient alluvium/littoral } \\
\text { deposits }\end{array}$ & $A 1-A B-B 2-B 3-C$ & 38 & stage I-II carbonate & low-moderate & ฉี \\
\hline Gessner(Typic Glossaqualfs) & & $x$ & & & & & upland depressions & loamy ancient alluvium & $A p-A 2 g-B g \& A g-B 21 t g-B 22 t g$ & $>84$ & & low-moderate & \\
\hline Harris(Typic Haplaquolls) & & $x$ & & $x$ & $x$ & & coastal marsh & $\begin{array}{c}\text { clayey recent alluvium/marsh } \\
\text { sediment }\end{array}$ & $A 11 g-A 12 g-A 13 g-B 21 g-B 22 g-C g$ & $40-60+$ & & low-moderate & \\
\hline Karankawa(Typic Haplaquents) & & & & $x$ & & & coastal marsh & $\begin{array}{c}\text { loamy recent alluvium/marsh } \\
\text { sediment }\end{array}$ & Ag1-Ag2-Cg1-Cg2-Cg3-Cg4 & 18 & & low-moderate & \\
\hline Leton(Typic Glossaqualfs) & & & & $x$ & $x$ & & upland depressions & loamy ancient alluvium & A-Eg-B/E-Btg & $40-60$ & & low-moderate & \\
\hline Narta(Typic Natraqualis) & & & & $x$ & $\mathrm{x}$ & & $\begin{array}{l}\text { low uplands near coastal } \\
\text { marsh }\end{array}$ & $\begin{array}{l}\text { loamy or clayey ancient } \\
\text { alluvium }\end{array}$ & A-Btg1-Btg2-Bkg & $30-60$ & & low-moderate & \\
\hline Nass(Typic Haplaquents) & & & & $x$ & & & coastal marsh & $\begin{array}{c}\text { loamy recent alluvium/marsh } \\
\text { sediment }\end{array}$ & A-Cg1-Cg2-Cg3 & 27 & marine shell fragments & low-moderate & \\
\hline Osier(Typic Psammaquents) & & & $\mathrm{x}$ & & & & toeslope/floodplain & $\begin{array}{c}\text { sandy ancient alluvium and } \\
\text { colluvium }\end{array}$ & $\mathrm{A} 1-\mathrm{C} 1-\mathrm{C} 2$ & $<10$ & & low-moderate & \\
\hline Placedo(Typic Fluvaquents) & & & & $x$ & & & coastal marsh & $\begin{array}{c}\text { clayey recent alluvium/marsh } \\
\text { sediment }\end{array}$ & Ag1-Ag2-Cg1-Cg2 & 28 & & low-moderate & \\
\hline Surfside(Vertic Haplaquolls) & & & & & $x$ & & coastal marsh & $\begin{array}{c}\text { clayey recent alluvium/marsh } \\
\text { sediment }\end{array}$ & $A 11 g-A 12 g-B 2 g$ & $40-60+$ & soil cracks & low-moderate & \\
\hline Tatlum(Typic Hydraquents) & & & & $x$ & $x$ & & coastal marsh & $\begin{array}{c}\text { loamy recent alluvium/marsh } \\
\text { sediment }\end{array}$ & Ag-Cg1-Cg2 & $12-20$ & $\begin{array}{l}\text { common peaty surface } \\
\text { horizon }\end{array}$ & low-moderate & \\
\hline Tracosa(Typic Haplaquents) & & & & $x$ & $\mathrm{x}$ & & coastal marsh & $\begin{array}{c}\text { clayey recent alluvium/marsh } \\
\text { sediment }\end{array}$ & A-Cg1-Cg2-Cg3 & $14-20$ & $\begin{array}{c}\text { common peaty surface } \\
\text { horizon }\end{array}$ & low-moderate & \\
\hline Velasco(Cumulic Haplaquolls) & & & & & $x$ & & coastal marsh & $\begin{array}{c}\text { clayey recent alluvium/marsh } \\
\text { sediment }\end{array}$ & $A 11 g-A 12 g-A C g$ & $40-60+$ & & low-moderate & \\
\hline Veston(Typic Fluvaquents) & & & & $x$ & $x$ & & coastal marsh & $\begin{array}{c}\text { loamy recent alluvium/marsh } \\
\text { sediment }\end{array}$ & A-Cg1-Cg2-2Cg & $30-60+$ & & low-moderate & \\
\hline (Waller(Typic Glossaqualfs) & $x$ & & $\mathrm{x}$ & & & $\mathrm{x}$ & upland depressions & loamy ancient alluvium & $A 1-A 2 g-B 21 \operatorname{tg} \& A 2-B 22 \operatorname{tg} \& A 2$ & $60-100+$ & & low-moderate & \\
\hline Addicks(Typic Argiaquolls) & & $x$ & & & & & upland & loamy ancient alluvium & A-B21t-B22tca-B23t & $>80$ & & low & \\
\hline $\begin{array}{l}\text { Albany(Grossarenic Paleudults) } \\
\text { Aldine(Aeric Glossaqualfs) }\end{array}$ & & $x$ & $\mathrm{x}$ & & & & $\begin{array}{l}\text { low terraces } \\
\text { upland }\end{array}$ & $\begin{array}{l}\text { loamy ancient alluvium } \\
\text { loamy ancient alluvium }\end{array}$ & $\begin{array}{l}A 1-A 21-A 22-B 21 t-B 22 t \\
A 1-A 2-B \& A-B 21 t a-B 22 t a-B 3 C\end{array}$ & $60-100$ & & low & \\
\hline Algoa(Aeric Calciaquolls) & & & & $\mathrm{x}$ & & & $\begin{array}{l}\text { upland } \\
\text { upland }\end{array}$ & $\begin{array}{l}\text { loamy ancient alluvium } \\
\text { loamy ancient alluvium or } \\
\text { eolian depsits }\end{array}$ & $\begin{array}{l}\text { A1-A2-B\&A-B21tg-B22tg-B3g } \\
\text { A-Bkg1-Bkg2-Bkg3-2Cg }\end{array}$ & $\begin{array}{c}>60 \\
40-60+\end{array}$ & & $\begin{array}{l}\text { low } \\
\text { low }\end{array}$ & \\
\hline Angie(Aquic Paleudults) & & & $\mathrm{x}$ & & & & $\begin{array}{l}\text { upland ridges and stream } \\
\text { terraces }\end{array}$ & $\begin{array}{l}\text { loamy to clayey ancient } \\
\text { alluvium }\end{array}$ & $A 1-A 2-B 1 t-B 21 t-B 22 t$ & $>60$ & & low & \\
\hline Aris(Typic Glossaqualfs) & $x$ & $x$ & & $x$ & $x$ & & upland & $\begin{array}{l}\text { loamy to clayey ancient } \\
\text { alluvium }\end{array}$ & Ap-Bg\&Ag-B21tg-B22tg & $>70$ & & low & \\
\hline Atasco(Aquic Glossudalfs) & & $\mathrm{x}$ & & & & & upland & loamy ancient alluvium & Ap-A\&B-B\&A-B21t-B22tg-B23tg & $>60$ & & low & \\
\hline Bacliff(Entic Pelluderts) & & & & $\mathrm{x}$ & & & upland & loamy clayey alluvium & $A-A g-B g 1-B g 2$ & $>60$ & gilgai; soil cracks & low & \\
\hline Beaumont(Entic Pelluderts) & & $\mathrm{x}$ & & & $\mathrm{x}$ & $x$ & upland & loamy clayey alluvium & A11-A12-AC1g-AC2g-Cg & $>60$ & gilgai; soil cracks & low & \\
\hline Bernard(Vertic Argiaquolls) & & $x$ & & $x$ & $x$ & $x$ & upland & loamy ancient alluvium & Ap-B1g-B21tg-B22tg-B3g & $50-70+$ & soil cracks & low & \\
\hline Bissonnet(Aeric Glossaqualfs) & & $\mathrm{x}$ & & & & & upland & loamy ancient alluvium & A1-A21-A22-B\&A-B21tg-B22tg & $>70$ & & low & \\
\hline Blanton(Grossarenic Paleudults) & & & $\mathrm{x}$ & & & & upland & sandy ancient alluvium & A1-A21-A22-A23-A24\&B1t-A25\&B2t & $>80$ & & low & \\
\hline Boy(Grossarenic Plinthic Paleudalfs) & $x$ & $\mathrm{x}$ & $x$ & & & & upland & sandy ancient alluvium & A1-A21-A22-B21tg-B22tg & 60-100+ & plinthite & low & \\
\hline Chazos(Aquic Paleustalfs) & $x$ & & & & & & ancient stream terraces & sandy ancient alluvium & Ap-A2-B21t-B22t-B23t-C & $45-80$ & & low & \\
\hline Conroe(Arenic Plinthic Paleudults) & $x$ & & $\mathrm{x}$ & & & & upland & $\begin{array}{l}\text { loamy to sandy ancient } \\
\text { alluvium }\end{array}$ & A1-A2-B21t-B22t-B23t-B3 & 60-100+ & plinthite & low & \\
\hline
\end{tabular}




\begin{tabular}{|c|c|c|c|c|c|c|c|c|c|c|c|c|}
\hline Soil Series(subfamily) & $\frac{2}{\bar{\omega}}$ & 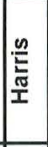 & 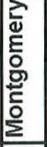 & 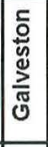 & 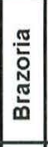 & 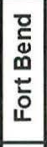 & Topographic Position & Parent Material & Typical Profile & 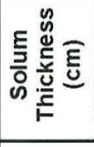 & Comments & Georcheological Potential \\
\hline Crockett(Udertic Paleustalfs) & $x$ & & & & & & upland & loamy ancient alluvium & Ap-B21t-B22t-B23t-B31-C & $40-60+$ & $\begin{array}{l}\text { stage II carbonate; soil } \\
\text { cracks }\end{array}$ & low \\
\hline Edna(Vertic Albaqualfs) & $x$ & $x$ & $x$ & $x$ & $x$ & $x$ & upland & loamy ancient alluvium & $?$ & $50-100$ & $\begin{array}{l}\text { soil cracks; stage II } \\
\text { carbonate }\end{array}$ & low \\
\hline Eustis(Psammentic Paleudults) & & & $x$ & & & & upland/ancient stream terrace & sandy ancient alluvium & Ap-A2-B2t & $>60$ & & low \\
\hline Ferris(Udorthentic Chromusterts) & & & $x$ & & & & upland/ancient stream terrace & clayey ancient alluvium & Ap-AC-C & $40-65$ & gilgai; soil cracks & low \\
\hline Francitas(Typic Pelluderts) & & & & $\mathrm{x}$ & $x$ & & coastal marsh & $\begin{array}{c}\text { clayey recent alluvium/marsh } \\
\text { sediment }\end{array}$ & A1-A2-Bg1-Bg2-Bg3 & $40-80+$ & gilgai; soil cracks & low \\
\hline Fuquay(Arenic Plinthic Paleudults) & & & $x$ & & & & upland/ancient stream terrace & loamy ancient alluvium & $A 1-A 2-B 21 t-B 22 t-B 23 t-B 3 t$ & $60-100$ & plinthite & low \\
\hline Garner(Entic Pelluderts) & & & $x$ & & & & upland/ancient stream terrace & clayey ancient alluvium & Ap-A12-AC-C & $40-60$ & gilgai; soil cracks & low \\
\hline Gunter(Grossarenic Plinthic Paleudults) & & & $x$ & & & & upland & loamy ancient alluvium & $A 1-A 21-A 22-B 1 t-B 2 t$ & $60-100+$ & plinthite & low \\
\hline Hockley(Plinthic Paleudalfs) & $x$ & $x$ & $x$ & & & $x$ & upland & loamy ancient alluvium & Ap-A2-B21t-B22t-B23t & $70-120$ & plinthite & low \\
\hline Houston Black(Udic Pellusterts) & & & $x$ & & & & upland/ancient terrace & clayey ancient alluvium & $\begin{array}{c}\text { A1p-A12-A13-AC } \\
\text { A1p-A12-AC1-AC2-C }\end{array}$ & $40-70$ & gilgai; soil cracks & low \\
\hline |jam(Vertic Fluvaquents) & & $\mathrm{x}$ & & $\mathrm{x}$ & $\mathrm{x}$ & & coastal areas & dredging spoil & $\mathrm{A} 1-\mathrm{Cg}$ & $<10$ & soil cracks & none \\
\hline Katy(Aquic Paleudalfs) & $x$ & $\mathrm{x}$ & $\mathrm{x}$ & & & $x$ & upland & loamy ancient alluvium & Ap-A12-A2-B21t-B22t-B23t-B24t & $>50$ & & low \\
\hline Kemah(Typic Albaqualfs) & & & & $x$ & & & upland & loamy ancient alluvium & A-E-Btg1-Btg2-Btg3 & $>50$ & & low \\
\hline Kenney(Grossarenic Paleudalfs) & $x$ & $\mathrm{x}$ & & & $x$ & $x$ & upland & sandy ancient alluvium & A1-A21-A22-B21t-B22t & $65-80+$ & & low \\
\hline Kipling(Vertic Hapludalfs) & & & $\mathrm{x}$ & & & & upland & clayey ancient alluvium & Ap-B21t-B22t-B23t-C & 40 & soil cracks & low \\
\hline Lake Charles(Typic Pelluderts) & $x$ & $\mathrm{x}$ & & $\mathrm{x}$ & $\mathrm{x}$ & $x$ & upland & clayey ancient alluvium & Ap-A11-A12-ACg-C & $50-80$ & gilgai; soil cracks & low \\
\hline Leefield(Arenic Plinthaquic Paleudults) & & & $x$ & & & & upland & loamy ancient alluvium & A1-A2-B1t-B2t & $>60$ & plinthite & low \\
\hline Lucy(Arenic Paleudults) & & & $\mathrm{x}$ & & & & upland/ancient terraces & loamy ancient alluvium & A1-A2-B21t-B22t-C & $>60$ & & low \\
\hline Lufkin(Vertic Albaqualfs) & $x$ & & & & & & upland & loamy ancient alluvium & Ap-B21tg-B22tg- $-\| \mathrm{Cg}$ & $35-60$ & soil cracks & low \\
\hline Midland(Typic Ochraqualfs) & $x$ & $\mathrm{x}$ & & & & & upland & loamy ancient alluvium & Ap-B21tg-B22tg-B23tg-B3tg-C & $>72$ & stage $|-| \mid$ carbonate & low \\
\hline Mocarey(Typic Haplaquolls) & & & & $\mathrm{x}$ & & & upland & loamy ancient alluvium & $A-B W-B k 1-B k 2-2 C$ & $36-60$ & stage II carbonate & low \\
\hline Morey(Typic Argiaquolls) & & & & $x$ & $\mathrm{x}$ & & upland & loamy ancient alluvium & A-BA-Btg1-Btg2-Btg3 & $60-80+$ & & low \\
\hline Oktibbeha(Vertic Hapludalfs) & & & $x$ & & & & upland/ancient terraces & loamy ancient alluvium & $A p-B 21 t-B 22 t-B 23 t-C$ & $>40$ & soil cracks & low \\
\hline Rader(Aquic Paleustalfs) & $x$ & & & & & & ancient stream terraces & loamy ancient alluvium & A1-A2-B\&A-B21t-B22t & 60-100+ & & low \\
\hline Robertsdale(Plinthaquic Fragiudults) & & & $x$ & & & & upland (drainage heads) & loamy ancient alluvium & ? & $60-100+$ & plinthite & low \\
\hline Segno(Plinthic Paleudalfs) & $x$ & $\mathrm{x}$ & $x$ & & & & upland & loamy ancient alluvium & A11-A12-A2-B21t-B22t-B23t-B24t & $60-100+$ & plinthite & low \\
\hline Sievers(Typic Fluvaquents) & & & & $x$ & & & coastal marsh & dredge spoil & A-C1-C2-Cg1-Cg2-Cg3 & 12 & & none \\
\hline Sorter(Typic Ochraqualfs) & & & $\mathrm{x}$ & & & & upland & silty ancient alluvium & A1-A2-B2tg-B3g-C1g-C2g & 60-100+ & & low \\
\hline Splendora(Fragic Glossudalf) & $x$ & & $\mathrm{x}$ & & & & upland & loamy ancient alluvium & A1-A2-A2g\&B21t-B22tg-B23tg & $60-100+$ & fragipan & low \\
\hline Stowell(Typic Argialbolls) & & & & $x$ & & & upland & sandy ancient alluvium & A-E-Btg-Btg2-Btg3 & $50-80+$ & & low \\
\hline Straber(Aquic Paleustalfs) & $\mathrm{x}$ & & & & & & upland & sandy ancient alluvium & A1-A2-B21t-B22t-B23t-B24t & $40-70$ & & low \\
\hline Styx(Arenic Paleustalfs) & $x$ & & & & & & ancient stream terraces & sandy ancient alluvium & Ap-A2-B21t-B22t-B23t-B3t & $>80$ & & low \\
\hline Sunsweet(Plinthic Paleudults) & & & $\mathrm{x}$ & & & & upland & loamy ancient alluvium & $A-B 21 t-B 22 t-B 23 t-B 24 t-B 3 t$ & $60-80+$ & plinthite & low \\
\hline Susquehanna(Vertic Paleudalfs) & & & $\mathrm{x}$ & & & & upland & loamy ancient alluvium & A1-A2-B21t-B22t-B23t-B24t-B3t-C & $>60$ & soil cracks & low \\
\hline Vamont(Aquentic Chromuderts) & & $\mathrm{x}$ & & $x$ & & & upland & clayey ancient alluvium & A1-AC1-AC2-AC3-C & 70-100+ & gilgai; soil cracks & low \\
\hline Verland(Vertic Ochraqualfs) & & & & $\mathrm{x}$ & & & upland & loamy ancient alluvium & A-Btg1-Btg2-Btg3 & $50+$ & soil cracks & low \\
\hline Wicksburg(Arenic Paleudults) & & & $\mathrm{x}$ & & & & upland & loamy ancient alluvium & A-A21-A22-B21t-B22t-B23t-B3t & $>60$ & & low \\
\hline Wockley(Plinthaquic Paleudalfs) & $x$ & $x$ & & & & & upland & loamy ancient alluvium & $A p-A 2-B 21 t-B 22 t-B 23 t$ & $>60$ & plinthite & low \\
\hline
\end{tabular}


too old to contain archeological materials in good context. However, in some cases there is a possibility of burial through slopewash, eolian sedimentation, or biogenic sedimentation (e.g., earthworms, slaking of crayfish chimneys) in the soils judged to have low potential, while in other cases materials may be worked into such soils through shrink-swell cracking or bioturbation. In contrast, the soils judged to have moderate-high potential or better represent pedogenic alteration of relatively recent alluvial, colluvial, and eolian sediments. While these soils are also subject to turbation disturbance and the emplacement of more recent sediment veneers, they have higher geoarcheological potential because the sediment bodies in which the soils formed usually accreted during the period of demonstrable human occupation in the region.

\section{VEGETATION AND FAUNA OF THE HOUSTON DISTRICT}

Modern vegetation and fauna in the Houston District reflects the transition from the humid east to the semi-arid west, tempered by the distribution of urban and agricultural areas, surface water, and patterns of artificial clearing and replanting during the historic period (Blair 1950). While the boundary between the relatively heavily forested east and the grasslands to the south and west is gradual, and the extent and character of forest in the entire area has been heavily modified during the modern era, the general transition between forested lands and grasslands clearly predates Euro-American settlement.

Vegetation in the Houston District varies tremendously, and it is beyond the scope of this report to provide more than a brief summary of vegetative assemblages in the district. Nevertheless, it is important to summarize some of the most important taxa typical of various environments in the district. Important taxa and the communities that they are characteristic of are presented in Table 3. For purposes of discussion, it is appropriate to identify a suite of vegetative communities that represent the range of natural environments in the district, discounting the agricultural and urban classes presented in Figure 4. In general terms, four broad communities can be identified (McMahan et al. 1984).

(1) Coastal Marsh/Barrier Island. This category includes well-drained sandy coastal environments and saline and freshwater wetlands in the coastal zone. Marsh vegetation is typical of areas that are seasonally wet, and have substrates that are dominated by sands and silts, clays, or organic decomposition products. The character of the vegetative assemblage is strongly controlled by texture, salinity, frequency and duration of inundation, and depth of the seasonal water table. Sandy, relatively well-drained freshwater environments are typically dominated by little bluestem, switchgrass, Florida paspalum, and brownseed paspalum. Wetter environments are often dominated by marshhay cordgrass, seashore saltgrass, saggitaria, bulrushes, smooth cordgrass, seashore paspalum, seashore dropseed, olney bulrush, saltmarsh bulrush, saltmarsh aster, longtom, sprangletop, burhead, arrowhead, coastal waterhyssop, needlegrass rush, and other sedges and rushes. Slightly higher, better-drained environments are characterized by taxa like seashore saltgrass, seashore paspalum, gulfdune paspalum, shoregrass, gulf cordgrass, red lovegrass, bushy sea-oxeye, and glasswort. A variety of fauna are characteristic of the shore zone. Important larger taxa include raccoon, nutria, alligators, turtles, swamp rabbit, and many birds, including ducks, geese, heron, and many smaller species. Aquatic taxa, including a wealth of fish and shellfish adapted to brackish to hypersaline conditions, are also important in the coastal zone.

(2) Coastal Prairie. This community consists primarily of grasses with minor amounts of forbs and woody plants, and is characteristic of upland areas in the southern and eastern part of the district that are not saturated on a seasonal basis. It grades gradually into the Pine-Hardwood Forest to the north and east, and into the Coastal Marsh/Barrier Island to the south. A wide number of grasses are characteristic of prairie environments, but principal taxa include big bluestem, little bluestem, indiangrass, eastern grama, switchgrass, brownseed paspalum, sideoats grama, silver bluestem, buffalograss, threeawn, and Texas wintergrass. Common forbs include Maximilian sunflower, Engelman daisy, blacksalmon, penstemon, dotted gayfeather, bundleflower, yellow neptunia, snoutbean, prairie clover, tickclover, wildbean, western indigo, paintbrush, bluebonnet, ragweed, croton, milkweed, vetch, verbena, and winecup. Woody plants occurring in the Coastal Prairie include mesquite, honey locust, huisache, eastern 
Table 3. Important plant taxa of the Houston District.

\begin{tabular}{|c|c|c|c|c|c|c|}
\hline & & Beach/Barrier & Marsh & Grassland & Riparian Forest & $\begin{array}{c}\text { Mixed Pinel } \\
\text { Hardwood Forest }\end{array}$ \\
\hline Acacia famesiana & huisache & & & & & \\
\hline Andropogon gerardii & big bluestem & & & & & \\
\hline Andropogon littoralis & bluestem & & & & & \\
\hline Andropogon temarius & spitbeard bluestem & & & & & \\
\hline Axonopus spp. & carpetgrass & & & & & \\
\hline Batis maritima & maritime saltwort & & & & & \\
\hline Bignonia sp. & trumpet creeper & & & & & \\
\hline Borrichia frutescens & sea oxeye & & & & & \\
\hline Carya illinoiensis & pecan & & & & & \\
\hline Carya spp. & hickory & & & & & \\
\hline Celtis spp. & hackberry & & & & & \\
\hline Cenchrus incertus & coastal sandbur & & & & & \\
\hline Crataegus viburnifola & red haw & & & & & \\
\hline Cynadon dactylon & bermudagrass & & & & & \\
\hline Dicanthelium sphaerocarpum & roundseed dicanthelium & & & & & \\
\hline Distichilis spicata & saltgrass & & & & & \\
\hline Fraxinus spp. & ash & & & & & \\
\hline Galactia sp. & milkpea & & & & & \\
\hline Hymenocallis caroliniana & spider lily & & & & & \\
\hline Ilex vomitoria & yaupon & & & & & \\
\hline Iva ciliata var. annua & sumpweed & & & & & \\
\hline Juncus spp. & rushes & & & & & \\
\hline Liquidambar styraciflua & sweetgum & & & & & \\
\hline Maclura pomifera & bois d'arc & & & & & \\
\hline Magnolia spp. & magnolia & & & & & \\
\hline Muhlen bergia fililpes & gulf muhly & & & & & \\
\hline Paspalum monostachyum & Gulf dune paspalum & & & & & \\
\hline Paspalum plicatulum & brownseed paspalum & & & & & \\
\hline Pinus echinata & shortleaf pine & & & & & \\
\hline Pinus elliotti & slash pine & & & & & \\
\hline Pinus palustris & Iongleaf pine & & & & & \\
\hline Pinus taeda & loblolly pine & & & & & \\
\hline Prosposis spp. & mesquite & & & & & \\
\hline Quercus marilandica & blackjack oak & & & & & \\
\hline Quercus nigra & water oak & & & & & \\
\hline Quercus phellos & willow oak & & & & & \\
\hline Quercus virginiana & live oak & & & & & \\
\hline Rubus trivialus & dewberry & & & & & \\
\hline Salicornia bigelovii & glasswort & & & & & \\
\hline Salicornia perennis & glasswort & & & & & \\
\hline Schizachyrium scoprium var. frequens & little bluestem & & & & & \\
\hline Schizachyrium tenerum & slender bluestem & & & & & \\
\hline Scirpus spp. & bullirush & & & & & \\
\hline Scleria ciliata & fringed nutbush & & & & & \\
\hline Senecio spp. & groundsel & & & & & \\
\hline Smilax spp. & greenbriar & & & & & \\
\hline Sorghastrum spp. & indiangrass & & & & & \\
\hline Sorghum halepense & Johnson grass & & & & & \\
\hline Spartina altiflora & cordgrass & & & & & \\
\hline Spartina cynosuroides & big cordgrass & & & & & \\
\hline Spartina patens & marsh hay cordgrass & & & & & \\
\hline Spartina pectinata & sloughgrass & & & & & \\
\hline Spartina spartinae & coastal sacahuista & & & & & \\
\hline Suaeda spp. & seepweed & & & & & \\
\hline Taxodium distichum & bald cypress & & & & & \\
\hline Tillandsia usneoides & spanish moss & & & & & \\
\hline Toxicodendron radicans & poison ivy & & & & & \\
\hline Tripsacum dactyloides & eastern gammagrass & & & & & \\
\hline Typha latifolia & cattail & & & & & \\
\hline UImus spp. & elm & & & & & \\
\hline Uniola paniculata & sea oats & & & & & \\
\hline Vitis spp. & grape & & & & & \\
\hline
\end{tabular}


baccharis, sesbania, live oak, elm, hackberry, bumelia, and coralberry. The frequency of trees increases dramatically as the coastal prairie grades into the Pine-Hardwood Forest, forming an open woodland environment with common stands of hardwood trees and occasional pines. The coastal prairie is home to a diverse fauna including coyote, whitetailed deer, skunks, cottontail rabbit, many small rodents, amphibians and reptiles, and a variety of permanent and migratory birds. Bison and pronghorn were also present at various times in the past.

(3) Coastal Gallery Forest. This community consists of diverse, principally deciduous, trees and associated understory which occupy the floodplains of streams traversing the outer coastal plain. Important taxa include water oak, pecan, poplar, American elm, cedar elm, sugarberry, pecan, ash, loblolly pine, water oak, post oak, cherrybark oak, mulberry, swamp chestnut oak, willow oak, sweetgum, hawthorn, dogwood, hickory, bois d'arc, sassafras cypress, willow, cottonwood, and sumac. Shrubs and vines such as mustang grape, greenbriar, yaupon, coralberry, possumhaw, elderberry, honeysuckle, dewberry, and blackberry are common in the understory, as are grasses little bluestem, big bluestem, and indiangrass. The fauna of the galley forest includes white-tailed deer, opossum, raccoon, squirrel, turkey, a variety of small mammals and rodents, turtles, snakes, and many birds. Black bear was also present at various times in the past, and a number of fish and a few varieties of shellfish are present in the streams.

(4) Pine-Hardwood Forest. This community is typical of northern and eastern parts of the study area, and grades into the coastal prairie to the south and west. It is characterized by a mix of coniferous and deciduous trees, including longleaf pine, shortleaf pine, loblolly pine, post oak, red oak, white oak, blackjack oak, willow oak, and live oak. Riparian environments often support larger deciduous trees like pecan, cottonwood, hickory, beech, and American elm. Understory vegetation varies from relatively open to quite dense, and consists of shrubs, vines, forbs, and young trees. Common shrubs include acacia, yaupon, mayhaw, wild persimmon, myrtle, greenbriar, Virginia creeper, blackberry, dewberry, trumpet vine, gourd, and poison ivy. A variety of fauna are also present, including white-tailed deer, opossum, raccoon, squirrel, rabbit, mink, skunk, various small rodents, turtles, reptiles, and many different birds. Black bear was also present at times in the past, and bison and pronghorn were occasionally present in the transition zone to the Coastal Prairie environment.

\section{LATE QUATERNARY PALEOENVIRONMENTS OF SOUTHEASTERN TEXAS}

\section{The Nature of the Evidence}

Reconstruction of environmental conditions that held sway in the past requires one to examine a number of lines of evidence. Despite a long history of archeological investigations, the paleoenvironmental history of the Houston District, and indeed all of the upper Texas Coastal Plain, remains poorly known. In essence, there is only minimal Holocene paleoenvironmental data reported from the Houston District, and very little from anywhere else on the Quaternary coastal plain of Texas. For this reason, any discussion of paleoenvironment must draw on data from outside the immediate region.

With a few exceptions (e.g., some types of isotopic evidence), paleoclimatic data do not provide direct evidence of former climatic conditions at any given locality. Rather, these data provide information on other environmental parameters (e.g., fauna, flora, rates and trajectories of geomorphic change, or soil development) that can be related to climate using modern analogs. Such lines of evidence are referred to as proxy data (Lowe and Walker 1984; Bradley 1985; Smiley et al. 1991; Caran 1998). Although necessary, interpretation of paleoclimatic conditions using modern analogs is problematic for several reasons (Ellis et al. 1995; Caran 1998). First, there is characteristically a lag period between a change in climate and the environmental response that varies in length among different proxies. To cite a simplistic example, there may be a lag of hundreds of years between an increase in precipitation that makes a former grassland habitat capable of supporting trees and establishment of a forest, but elements of the new environment (e.g., annuals, microfauna) will begin to replace or supplement existing taxa in a much shorter period of time. Second, many types of proxy data will not respond to climatic changes unless that change exceeds a systemic threshold, and the 
value of that threshold (or tolerance) will vary among proxies. Thus, some elements of the overall biotic assemblage may respond to a given climatic shift, while others may not. Third, interpretation of paleoclimate from the former distribution of various taxa assumes that the modern range of those taxa is in equilibrium with modern climatic conditions, which is frequently an erroneous assumption. The distribution of an organism is conditioned not only by climate, but also by edaphic factors, competition between species, degree of tolerance to fluctuations in climate, the trajectory and rate of environmental change, and the previous distribution of the organism. Thus, while interpretation assumes that the modern proxy biota and the fossil taxa were in equilibrium with the environment, these assumptions may not be valid.

Caran (1998) provides an excellent summary of the complexities and potential pitfalls of paleoenvironmental reconstruction from proxy data. He identifies a number of potential problems, including inadequate contextual control (e.g., stratigraphic problems, unrecognized intrusive or reworked materials), inadequate chronological control, inadequate paleoenvironmental control (e.g., mixed assemblages, inappropriate environmental comparisons), inappropriate or overly simplistic proxy functions/models, and inherent biases (e.g., differential preservation, atypical backgrounds, cultural/taphonomic biases in assemblages). He also stresses that interpretation of proxy indicators requires abstraction, and that the degree of abstraction necessary differs markedly between different types of proxy data. As interpretation becomes increasingly separated from the data, the confidence in the interpretation declines.

While they must be investigated and interpreted carefully and critically, proxy data provide the only evidence of paleoclimatic and paleoenvironmental conditions in the past. The most important lines of information about past climatic conditions in eastern and Central Texas include pollen data from bogs on the inner coastal plain, micro-faunal data from caves in the Texas Hill Country, tree-ring data from eastern Texas, Oklahoma, and Arkansas, and isotopic data from a variety of localities in Texas. While all of these lines of evidence provide crucial information, none is particularly straight-forward to interpret.

Much of the available paleoclimatic information is derived from pollen data extracted from a limited series of bogs that roughly parallel the
Balcones fault system on the inner coastal plain (e.g., Weakly Bog, Boriak Bog, etc.); with the exception of an ongoing study from the Houston area (Aronow Bog) that the researcher has graciously allowed to be previewed in this document, pollen data from East Texas is essentially nonexistent (Bryant and Holloway 1985). Pollen consists of tiny reproductive cells of seed-bearing plants and exhibit complex structures that are diagnostic of the parent taxa. Pollen is typically produced in vast quantities and dispersed through the environment, where it falls as "pollen rain" and is preserved as a component of the sedimentary record in conducive localities. In paleoenvironmental studies, this pollen is recovered by stratigraphic sampling of suitable deposits, the sediment samples are processed to concentrate the pollen, and a slide is prepared for counting of different taxa using an optical microscope. The presence and proportion of various taxa represented by pollen grains on the slide is used to infer the character of the past biotic assemblage. However, this process of interpretation is complex, and there are a number of factors that must be taken into account. First, the volume of pollen released by various plants varies considerably, so that the proportion of pollen grains in pollen rain is not directly reflective of the proportion of plants on the landscape. Second, dispersion methods differplants that are primarily pollinated by insects (as opposed to simple aerosolic dispersion) are typically not represented or drastically underrepresented in the pollen rain. Third, the dispersion patterns of aerosolic grains are dramatically different depending on the size and buoyancy of pollen grains from different taxa; some types of aerosolic pollen will only be dispersed locally, while others may travel hundreds of miles. Fourth, the resistance to corrosion/environmental degradation of different taxa also varies considerably, so that the relative frequency of different taxa in a fossil assemblage may be quite different than that of the original pollen rain. Finally, this differential resistance to corrosion can also affect preservation of different taxa during the rigorous processing that pollen samples undergo in the laboratory. Interpretation of pollen data must consider all of these factors.

Faunal data are another very valuable type of paleoenvironmental data that have seen considerable application in Texas. While some macro-faunal information is informative, by far the richest source of information is the rich micro-faunal record 
recovered from Central Texas caves (Lundelius 1967; Graham 1987; Toomey 1993). In general, micro-fauna (and particularly micro-mammals like mice and voles) are much more environmentally sensitive than larger fauna, in that they generally tolerate a narrower range of environmental conditions. Considered in aggregate, assemblages of penecontemporaneous species (faunules) provide powerful evidence of prevailing environmental conditions. However, faunal records are also subject to a number of factors that complicate interpretation. As in pollen analysis, it is necessary to assume that the modern baseline data and the fossil faunule was in equilibrium with environmental constraints, and such an assumption may not always be valid. As with plants, the distribution of animals on a landscape is conditioned not only by environmental constraints, but also by interspecies competition, historical trends, and varying response times to environmental stimuli among different taxa. In many cases, older fossil assemblages include suites of taxa that inhabit differing environments today (disharmonious assemblages), and thus represent an environment with no modern analog. These instances require more abstraction (and thus decreased confidence) in interpretation. In addition to mammalian fauna, insect fauna can also reveal a great deal about former environments (e.g., Elias and Van Devender 1990), but they have yet to be examined on the Coastal Plain.

Tree-ring data provide an extremely sensitive, precise proxy record of climate. The annual growth rings of many tree taxa reflect environmental factors influencing growth. Analysis of tree rings is used for dating by counting the rings back from a known date of cutting, and for paleoclimatic inference by examining the width of the rings, which is related to the supply of moisture during the growth period (as well as other climatic variables and a host of other factors, such as tree species, tree age, soil type, soil depth, nutrient availability, slope inclination, and slope aspect) (Bradley 1985). Other climatically sensitive characteristics, such as frost damage, false rings, and the density and isotopic composition of the wood, can also be informative. The major limitation of dendrochronology is the lack of time depth; individual trees typically live only a few hundred years or less (although there are exceptions). With intensive study, fossil trees with overlapping lifespans can be correlated to create a master regional chronology. Such a tool has been extended back nearly 2,000 years in the Southwestern United States, but no such record exists for Southeast Texas. Nevertheless, the temporal resolution offered by tree ring analysis is unparalleled among lines of paleoenvironmental data, and the promise afforded by some types of long-lived trees remains to be fully exploited.

Isotopic analysis of biotic remains and abiotic materials is another powerful technique of paleoenvironmental reconstruction (van der Mewe 1982; Cerling 1984; De Niro 1987; Cerling et al. 1989; Hertz 1990; Nordt et al. 1994; Humphrey and Ferring 1994; Attendorn and Bowen 1997). Several types of isotopic evidence of paleoenvironmental conditions exist. The most common isotopes examined are carbon $\left({ }^{12} \mathrm{C} /{ }^{13} \mathrm{C}\right)$, oxygen $\left({ }^{16} \mathrm{O} /{ }^{18} \mathrm{O}\right)$, and nitrogen $\left({ }^{14} \mathrm{~N} /{ }^{15} \mathrm{~N}\right)$. Stable carbon isotope analysis is based on metabolic fractionation of ${ }^{12} \mathrm{C}$ and ${ }^{13} \mathrm{C}$ by organisms. Three different metabolic pathways exist in modern plants: the Calvin-Benson pathway (CAL or $\mathrm{C}_{3}$ ), which is typical of most plants; the Hatch-Slack pathway ( $\mathrm{HS}$ or $\mathrm{C}_{4}$ pathway), which is typical of tropical grasses; and the CAM (crassulacean acid metabolism) pathway, which is typical of succulents like cactus. Each of these pathways results in fractionation of the relative ${ }^{13} \mathrm{C}$ content of carbon fixed by organisms relative to the established standard (the Pee-Dee Belemnite standard, which is the same standard used for correcting fractionation effects in radiocarbon dating). Because plants fix the most abundant isotope of carbon $\left({ }^{12} \mathrm{C}\right)$ more readily than its other isotopes $\left({ }^{13} \mathrm{C}\right.$ and $\left.{ }^{14} \mathrm{C}\right)$, all terrestrial biological materials tend to be isotopically light. The relative concentration of the stable carbon isotope ${ }^{13} \mathrm{C}$, and indeed all stable isotopes, is typically expressed as parts per thousand (parts per mil or \%o). $\mathrm{C}_{3}$ pathway plants exhibit typical fractionation values between $-22 \%$ and $-33 \%$ (usually $-25 \%$ o to $-27 \%$ o), while $\mathrm{C}_{4}$ plants typically range between $-9 \%$ and $-16 \%$ (usually $-12 \%$ o to $-14 \%$ o) and CAM plants typically exhibit intermediate values. The isotopic character of consumer organisms is a function of the isotopic character of elements of the diet, additional fractionation effects by the organism, and trophic level (van der Mewe 1982; De Niro 1987).

The primary paleoclimatic information derived from the study of carbon isotopes is related to climate-driven variations in the relative proportion of $\mathrm{C}_{3}$ (woody plants, forbs, and temperate grasses) and $\mathrm{C}_{4}$ plants (primarily warm-season grasses) 
through the Late Quaternary. As climate warms, warm season grasses expand at the expense of temperate grasses, only to be gradually replaced in response to cooling trends. The isotopic value of bulk sediments and paleosols, soil carbonates, animal and human skeletal material, and gastropod shell has been used to infer the relative proportion of $\mathrm{C}_{3}$ and $\mathrm{C}_{4}$ plants in the surrounding environment (e.g., Amundson et al. 1988; Nordt et al. 1994; Humphrey and Ferring 1994; Fredlund and Tieszen 1997, 1998; Goodfriend and Ellis 2000) and the relative contribution of $\mathrm{C}_{3}$ and $\mathrm{C}_{4}$ plants, terrestrial animals, and marine resources in the diet of animals and humans (e.g., Huebner and Boutton 1990; Huebner 1991; Huebner and Comuzzie 1992). However, the use of bulk humates for estimating regional proportions of $\mathrm{C}_{3}$ and $\mathrm{C}_{4}$ plants from isotopic values is not a particularly straight-forward procedure, because there are several specific problems that complicate interpretation. First, the isotopic composition of $\mathrm{C}_{3}$ and $\mathrm{C}_{4}$ plants is somewhat variable due to differences in local environmental conditions (Buchmann et al. 1996). This variability is not extreme (no more than 1-2\%o) and therefore does not preclude reconstruction of the relative percentage of $\mathrm{C}_{3}$ and $\mathrm{C}_{4}$ plants in general terms; however, it does caution against overly precise conclusions about the ratio between $\mathrm{C}_{3}$ and $\mathrm{C}_{4}$ plants. A second and potentially more severe problem is related to spatial variability in stable carbon isotopes in the soil system. In grassland settings, some researchers (e.g., Bird and Pousai 1997) have found differences in average $\delta^{13} \mathrm{C}$ values of up to $6.6 \%$ in the span of a few meters, while others have found negligible variability (Nordt, personal communication, 2000).

Because paleoenvironmental stable isotope studies typically assume that the measured ratio is representative of the regional vegetation (e.g., Cerling 1984; Cerling et al. 1989; Quade et al. 1989; Nordt et al. 1994; Monger et al. 1998), this variability has the potential to bias the data; in other words, the isotopic character of local vegetation may sometimes override the regional signal (Fredlund and Tieszen 1998). This is particularly true in depositional settings like river floodplains, which often support a local flora markedly different than that inhabiting the surrounding uplands. It is likely that the heterogeneity of isotopic carbon in soil is relatively pronounced in some settings and negligible in others, but the degree of heterogeneity in all settings is likely to be enhanced during periods of vegetative response to environmental change, because the soil carbon will be influenced by previous conditions (Boutton et al. 1998). Finally, alluvial and lacustrine sediments often contain carbon fixed hundreds or thousands of years previously (Goh and Molloy 1978) and introduced by the erosion of soils in the catchment. This bias has been demonstrated repeatedly in radiocarbon studies of bulk humates in alluvium, which are often found to date considerably older than associated charcoal samples (e.g., Nordt 1992; Abbott 1994). It follows that the stable carbon isotope signature of such sediments is also influenced by the influx of old carbon.

While carbon isotopes represent fractionation by organisms, isotopes of oxygen $\left({ }^{16} \mathrm{O}\right.$ and $\left.{ }^{18} \mathrm{O}\right)$ are fractionated by physical processes, and should be indicative of paleotemperatures. This fractionation occurs because the vapor pressure of $\mathrm{H}_{2}{ }^{16} \mathrm{O}$ is higher than that of $\mathrm{H}_{2}{ }^{18} \mathrm{O}$. For this reason, water containing the lighter isotope will be preferentially evaporated from a given body of water. The water vapor derived from evaporation will be depleted in ${ }^{18} \mathrm{O}$ relative to the source, and will be progressively depleted as the air mass moves over land and preferential condensation of ${ }^{18} \mathrm{O}$ proceeds through successive rainfall events. The degree of fractionation is also a function of temperature, for colder air is increasingly less able to support ${ }^{18} \mathrm{O}$. Isotopic composition is measured against either the Standard Mean Ocean Water (SMOW) standard (for ice and water) or the Pee Dee Belemnite (PDB) standard (for carbonate).

Long-term oxygen isotope records from deepsea sediments record interglacial cycles created as isotopically light water was bound in the continental glaciers, progressively enriching the oceans in ${ }^{18} \mathrm{O}$. However, isotopic composition of meteoric water also varies because evaporation favors the isotopically light ${ }^{16} \mathrm{O}$, while condensation favors ${ }^{18} \mathrm{O}$. Thus, the isotopic content of water vapor evaporated off a body of water is immediately enriched in ${ }^{16} \mathrm{O}$ relative to the source, and this enrichment increases with distance from the source and elevation as ${ }^{18} \mathrm{O}$ preferentially condenses. Thus, examination of the oxygen isotope record is potentially a valuable proxy of trends in temperature, precipitation seasonality, and the source of precipitation-producing air masses through the Holocene period. Terrestrial oxygen isotope data is available from a variety of sources, including soil carbonates, molluscan shells, wood, and travertine. 
However, the interpretation of temperature from isotope data is very complex, because the signature is a function of the temperature and isotopic composition of the moisture source (which varies not only between sources, but in response to largescale oceanic circulation patterns, seasonality, and freshwater/meltwater influx), the seasonality of precipitation, latitude, distance from the moisture source, and the elevation at which condensation occurs. The complexities introduced by these factors are many, and few meaningful temperature/ precipitation records have yet to emerge from terrestrial data. However, ongoing speleothem research in Central Texas caves by a team headed by Jay Banner, UT Geology Department, has the potential to contribute valuable data related to past climates.

Compared to carbon and oxygen, nitrogen isotopes are of relatively limited utility for paleoenvironmental studies, although they have proven extremely valuable in dietary analyses. However, nitrogen isotopes contained in paleosols, sediments, and bone do have the potential to provide proxy evidence of the abundance of nitrogen-fixing plants such as mesquite and acacia in the environment at different times in the past.

A number of other potential lines of evidence are also available, but have been little exploited. Phytoliths are tiny (silt-sized) siliceous grains that form inside certain plant cells. These siliceous grains have characteristic shapes that reflect the shape of the cell and are thus broadly diagnostic of plants with relatively simple structures. Phytoliths have proven particularly valuable for distinguishing between different families of grasses (e.g., Brown 1984; Piperno 1988), but the taxonomy is extremely complex and is far from fully understood. Phytolith work in Texas has been reported by Robinson (1982) and Fredlund (1998). Diatoms are unicellular algae that secrete diagnostic siliceous structures called frustules. Because different diatoms inhabit a wide range of environments (ranging from dry soil to water of specific salinity, temperature, turbidity, depth, and velocity), they are valuable indicators of local environmental conditions, and can be extremely valuable in site-specific studies (Lowe and Walker 1984). Although the potential for substantial contribution is clearly there, extant diatom analyses in Texas (e.g., Winsborough 1995, 1998) are also relatively limited. Similarly, ostracodes are tiny aquatic bivalves that inhabit fresh to hypersaline environments, and are quite sensitive to local environmental conditions (Lowe and Walker 1984), but their use in the investigation of paleoenvironments in Texas (e.g., Henry et al. 1998) is rare to this point. Foraminifera are protozoans that produce a distinctive calcareous shell. Like ostracodes, they are sensitive to shifts in temperature and salinity, but are largely limited to brackish to hypersaline marine environments. Macrobotanical remains also provide direct evidence that a plant was present in the surrounding environment, and they have proven quite valuable in studies in relatively arid locales such as the Chihuahuan Desert (e.g., Van Devender 1990). However, such records are subject to behavioral and taphonomic biases, and macrobotanical preservation is limited in the moist environment of the Houston District. Fossil insect records (e.g., Elias and Van Devender 1990) also have some potential to inform on aspects of the paleoenvironment, but are likewise subject to severe preservation biases in the moist Houston climate. However, there is potential for preservation of insect and macrobotanical remains in wet environments such as bogs and marshes.

A final line of paleoenvironmental inquiry involves examination of the mechanisms of environmental change. Global Circulation Models (GCM's) are mathematic models of large scale circulation systems, which provide the driving mechanism of climate. GCM's such as CLIMAP and COHMAP (CLIMAP Project Members 1981; COHMAP Members 1988) provide insights into shifting patterns of global atmospheric circulation resulting from changes in insolation and surface ice volume. They are based on relatively coarse-grained cells, however, and as yet do not provide data that are suitable for anything but heuristic analysis. When coupled with multiple lines of proxy data, however, they do provide a powerful, albeit generalized, explanatory framework.

As the following summary indicates, these data only allow for a generalized reconstruction of the evolution of the environment, and more data are desperately needed. Nevertheless, it is possible to outline broad trends in environmental change through the Late Quaternary. The following synopsis is based on a wide range of data, but owes a great deal to previous summaries of paleoenvironments on the Coastal Plain and surrounding areas (e.g., Bryant and Shafer 1977; Bryant and Holloway 1985; Smiley et al. 1991; Ferring 1995; Bousman 1998). 


\section{Late Pleistocene Climates and Biota}

Most evidence suggests that the Late Pleistocene period (roughly 16-12 ka) was relatively cool and moist in Southeast and south central Texas. While pollen data from the Houston area are absent, most Central Texas pollen records from the Full Glacial period (roughly $18 \mathrm{ka}$ ) exhibit a wide range of cold-tolerant deciduous and evergreen arboreal taxa, including Picea (spruce), Populus (poplar), Betula (birch), Fraxinus (ash), Acer (maple), Cornus (dogwood), Carya (hickory), Tilia (linden), Quercus (oak), Alnus (alder) and Pinus (pine) (Bryant and Holloway 1985). However, recent work that includes pollen data from Friesenhahn Cave in Bexar County concluded that the Southern High Plains and Edwards Plateau were dominated by grassland assemblages with no good modern analog during the last Full Glacial (Hall and Valastro 1995). Arboreal assemblages are apparent in the southeastern U.S., where the Full Glacial period pollen record exhibits evidence of substantial populations of cold-tolerant taxa, particularly Picea and Abies (Delcourt and Delcourt 1985). Faunal evidence from Central Texas also suggests that Full Glacial conditions were relatively cool and moist, but that both grassland and forested habitats were present (Graham 1987). Small mammal data also indicates a degree of warming from 15-13 ka (Toomey et al. 1993).

Based on detailed re-analysis of pollen data from several of the east central Texas bogs, Bousman (1998) notes that while woodland communities with many boreal taxa are strongly represented, an apparent increase in grassland communities occurred about $16.5 \mathrm{ka}$ and again around $12.5 \mathrm{ka}$. Bousman also notes that the percentage of oak pollen and pine pollen tends to increase in tandem with grass pollen during the Late Pleistocene, while no such relationship is apparent in the Holocene record, and he proposes that the structure of Late Pleistocene communities has no modern analog. On the basis of faunal, pollen, and soils evidence, Graham (1987) suggests that the Late Pleistocene environment east of the Balcones escarpment consisted of gallery forests that extended west from closed forests in the eastern part of the state, while the upland interfluves were open parklands or grasslands. Stratigraphic/geomorphic investigation of a number of Texas streams suggests that most large systems were characterized by a relatively coarse-grained load, large meandering channels, and broad, low constructional floodplains dominated by lateral accretion deposits (e.g., Epps 1973; Nordt 1992; Ferring 1994; Blum and Valastro 1994; Waters and Nordt 1995).

According to Haynes (1991), the Late Glacial period (roughly 14-12 ka) appears to represent a shift to drier conditions, although the climate apparently remained relatively cold. Based on stratigraphic data, he identifies a period of drought during Clovis times, followed by a return to somewhat cooler, moister conditions during the subsequent Folsom period. Basing his interpretation on investigations of the Mississippi and St. Lawrence systems (e.g., Broecker et al. 1989: Overpeck et al. 1989; Fullerton 1986), Bousman (1998) presents a compelling model for the influence of glacial meltwater on the temperature of water in the Gulf of Mexico, and thus on terrestrial climate in the Gulf of Mexico region. According to Bousman's model, as glacial meltwater from the Laurentide glacier began to flow down the Mississippi River in significant volumes by around $15 \mathrm{ka}$, the Gulf cooled and became a less efficient source for evaporative moisture and energy. This discharge reached a peak between 13-12 ka, but was sharply curtailed as the Laurentide icefront withdrew across the St. Lawrence valley and meltwater was diverted to the North Atlantic. However, the Laurentide glacier re-advanced during a cold phase (the Valders or Younger Dryas event, which may have been stimulated by the influx of meltwater into the North Atlantic), and glacial meltwater was again routed down the Mississippi from approximately $10 \mathrm{ka}$ to $9 \mathrm{ka}$. Bousman believes that these two meltwater surges (and the earlier one in particular) promoted relatively cool, dry conditions along the Gulf coast, while the intervening period was moister and more temperate. Similarly, Toomey et al. (1993) identify a shift to drier conditions beginning around $14 \mathrm{ka}$, followed by a return to somewhat moister conditions by $10.5 \mathrm{ka}$.

Faunal evidence from the Pleistocene-Holocene transition suggests that temperatures were probably cooler than at present, particularly in summer, but that very cold winters were probably not common (Graham 1987). In the southeastern United States, the latest Pleistocene witnessed a gradual shift from forest dominated by boreal elements (e.g., spruce, fir, and Diploxylon Pinus) to cool temperate deciduous elements (Delcourt and Delcourt 1985). The Late Pleistocene alluvial record in Central Texas and on the inner coastal plain indicates that there was a shift from a phase of bedload-dominated 
aggradation during the full glacial to an interval of valley entrenchment during the Late Glacial (Blum 1989; Nordt 1992; Blum and Valastro 1992, 1994), although this entrenchment was not apparent in north central Texas (Ferring 1994, 2000). One of the most significant remaining questions concerns the position of the transitional zone from the relatively closed southeastern forest to the parklands and grasslands of the lower coastal plain. At present, this zone cuts across the district diagonally from Waller County to Harris County, but it is likely that the forested area extended further west, and perhaps further south, during the Late Pleistocene. Although largely inferential, this conclusion is partially supported by the distribution of reddish, acid to neutral Paleustalf soils in areas that now support grassland (Sorenson et al. 1976). Such soils frequently form in association with trees, which produce relatively acidic ground litter, while grasslands typically produce relatively dark, baserich soils like Mollisols. Also, as one reviewer of the draft of this document noted, much of the shift to grasslands in these settings may have occurred relatively recently as a result of clearing associated with Euro-American settlement of the region.

\section{Early Holocene Climates and Biota}

Most lines of evidence suggest that the Early Holocene (roughly $12 \mathrm{ka}-8 \mathrm{ka}$ ) witnessed warming and, at least in Central Texas, drying. However, some investigators have interpreted this transition as a relatively smooth trend, while others see relatively rapid changes and/or a great deal of fluctuation apparent in the record. Pollen profiles from a variety of Central Texas bogs exhibit marked declines in most types of arboreal pollen (Quercus is an exception) and concomitant increases in grass and herbaceous pollen during the Early Holocene. Bryant and Holloway (1985:56) emphasize a steady, gradual warming and drying trend that resulted in incremental changes that "only can be visualized when the entire time period is viewed in relationship to the previous Late-glacial period." Isotopic evidence from Fort Hood in Central Texas (Nordt et al. 1994) also indicates gradual warming and drying through a transition from approximately 45 $50 \%$ warm season grasses in the Late Pleistocene to $50-60 \%$ in the Early Holocene, while soil isotope data from the Wilson Leonard site (Fredlund and Tieszen 1998) remains $C_{3}$-dominated throughout the entire record (this contrasts strongly with phytolith data from the same site; see below). While Bousman's (1998) reanalysis of the pollen data also supports warming and drying during the Early Holocene, he sees evidence for marked fluctuations in canopy cover, including a short-term transition from woodland to grassland around $9 \mathrm{ka}$. Similarly, Holliday (2000) uses stratigraphic and isotopic evidence to argue that while the period from 10.9 $\mathrm{ka}$ to $8 \mathrm{ka}$ was a period of overall drying on the Southern Plains, it witnessed relatively pronounced, short-term fluctuations between moist and very dry conditions. In contrast to the above studies, Humphrey and Ferring (1994) report increasing importance of $\mathrm{C}_{3}$ grasses in the Early Holocene (roughly 11-7.5 ka) in North Texas, which they interpret as a return to somewhat moister conditions following Haynes' Clovis-age drought. Fredlund (1998) uses phytolith data to suggest that woodlands surrounding the Wilson-Leonard site in Central Texas were more closed, and that the species composition of interdigitated grasses was substantially different than modern conditions from approximately 10 to $9.5 \mathrm{ka}$.

One of the most striking aspects of the Late Pleistocene/Holocene transition is the relatively abrupt extinction of the megafauna. There is still no firm consensus on the relative importance of climate change and human predation in this process, but there is little doubt that the changing character of the environment did have an impact on the megafauna. Smaller animals were somewhat slower to adjust, with rodent taxa now found well to the north and/or east such as the eastern chipmunk (Tamius striatus) and the southern bog lemming (Synaptomys cooperi) persisting on the Edwards Plateau until at least $9 \mathrm{ka}$ (Graham 1987).

Alluvial records from Texas show many of the same trends during the latest Pleistocene and Early Holocene, but differ somewhat in the details. On Fort Hood, Nordt $(1992,1994)$ identifies an alluvial unit (the Georgetown alluvium) that spans the period from approximately 11 to $8 \mathrm{ka}$. This fill, which occupies the bedrock incised valley formed by entrenchment during the Late Glacial, is buried by subsequent deposits and capped by a relatively prominent paleosol. Nordt believes that this fill was abandoned by a relatively brief episode of alluvial incision around 8-7 ka, which removed much of the fill and truncated the soil on most of the preserved remnants, but did not incise appreciably into the 
bedrock. Blum (1989; Blum and Valastro 1989) identifies an alluvial unit (Unit E) in a similar stratigraphic setting in the Pedernales River, but interprets the age range represented as roughly $11 \mathrm{ka}$ to $6.5 \mathrm{ka}$, which overlaps Nordt's subsequent unit on Fort Hood (the Fort Hood alluvium) (Nordt 1992). Blum's work on the Colorado River in west central Texas (Blum and Valastro 1992) also identified a unit in a comparable stratigraphic position (variously termed the "early Holocene alluvium" or "Early-Middle Holocene fill"), but dating suggests that it spanned the period from 10 to $5 \mathrm{ka}$. In the upper Trinity basin, Ferring $(1994,2000)$ identifies a period of rapid valley aggradation that dates to roughly $11-7.5 \mathrm{ka}$.

\section{Middle Holocene Climates and Biota}

The Middle Holocene (roughly 8-4 ka) witnessed continuation of the warming and drying trend begun in the Early Holocene. However, opinion is divided on the severity of this trend relative to modern conditions; some authors see evidence of one or two pronounced periods where climate was significantly warmer and drier than at present (the so-called Altithermal or Hypsithermal periods), while others do not. Delcourt and Delcourt (1985) suggest that the prairie/forest boundary shifted eastward significantly in the period between 8,500 to 4,000 BP, while Bryant and Holloway (1985) see little evidence of a pronounced drought in Texas pollen records. However, in his re-analysis of the same pollen data, Bousman (1998) notes a rapid shift from forest to grassland between approximately 8 and $7 \mathrm{ka}$, followed by a brief return to greater arboreal cover (and, by implication, more effective precipitation) around $6 \mathrm{ka}$, then a shift to the driest conditions of the Holocene between approximately 5.5 and $4.5 \mathrm{ka}$. One of the most important changes in the southeastern evergreen forest was a shift from oak and hickory to southern pine dominance (Delcourt and Delcourt 1985). Bryant and Holloway (1985) suggest that an essentially modern oak savanna was established in parts of Central Texas by the Middle Holocene, while other areas may have continued as oak woodlands until as late as 1,500 BP; Bousman (1998), in contrast, suggests that grasslands dominated throughout much of the Middle Holocene, and that oak woodlands were not established until the Late Holocene. Phytolith data (Fredlund 1998) suggests that arboreal cover was declining and arid-adapted short grasses were expanding from 8.7 to $6 \mathrm{ka}$.

On the basis of faunal evidence, Graham (1987) concludes that the Early-Middle Holocene was warmer and drier than the previous period but still relatively mesic compared to modern conditions, while the latter Middle Holocene continued the trend toward aridity. Lundelius (1967) also interprets the faunal record as indicating a gradual, smooth trend towards increasing aridity through the entire Holocene period, while Toomey (1993) interprets faunal and sedimentological data from Hall's Cave (southern Edwards Plateau) as indicating a longterm drying trend interrupted by brief, relatively mesic intervals at 10,400 to $9,000 \mathrm{BP}$ and 2,500 to 1,000 BP. In contrast, Dillehay (1974) interprets apparent periods of bison absence as indicative of pronounced dry periods between 7,500 and 4,500 $\mathrm{BP}$ and 1,500 to $750 \mathrm{BP}$.

Carbon isotopic data from North Texas (Humphrey and Ferring 1994) suggests that the period from approximately 7,500 BP through 5,000 BP was drier than at present, while Nordt et al. (1994) interpret carbon isotope data from Central Texas as indicating substantially warmer and drier conditions (85-95\% $\mathrm{C}_{4}$ grasses, compared to a modern ratio of $65-70 \% \mathrm{C}_{4}$ ) from approximately 6,000 to $4,000 \mathrm{BP}$. In contrast, Goodfriend and Ellis (2000) use stable carbon isotope data from Hinds Cave (southwest Texas) snail shells to postulate that the peak expression of $\mathrm{C}_{4}$ plants in snail diets occurred somewhat later (approximately $3.5 \mathrm{ka}$ ), and that Middle Holocene conditions were considerably more mesic.

Geomorphic data suggests that the Early to Middle Holocene may have experienced significant stripping of thick, reddish Pleistocene soils developed on the Cretaceous limestones of the Edwards Plateau, which is also interpreted as evidence of increasing aridity (Nordt 1992; Toomey et al. 1993). Roughly coincident with this stripping, a series of relatively fine-grained fills accumulated in the stream valleys in Central Texas, followed by a renewed period of incision between approximately 6,500 and 4,500 BP (Blum 1989, 1992, 1994; Nordt 1992; Thoms and Mandel 1992). East of the Balcones escarpment in the Eocene Sand belt, Bousman (1991) documents a series of stacked alluvial units on Buffalo Creek and its tributaries, in Freestone and Leon counties. Here again, a depositional hiatus and/or pronounced erosional event appears to have occurred between approximately 6,000 
and 4,000 BP. In contrast, Waters and Nordt (1994) identify a period of alluvial aggradation on the lower Brazos River that spans the period from approximately 8,000 to 4,000 BP; however, they argue that this aggradation is largely the result of increasing sediment yield (i.e., erosion) during a Middle Holocene warm period in the large Brazos basin.

\section{Late Holocene Climates and Biota}

The Late Holocene pollen record is limited because many of the Central Texas bogs either lack sediments or pollen representing the last few thousand years (in some cases, as a result of mining of the upper part of the peat deposits). Nevertheless, data from Weakley Bog indicate that while oak was present for the entire period of record represented in the column (approximately the last 2,500 years), a transition from an oak woodland to a more open oak savanna occurred approximately 1,500 BP (Bryant and Holloway 1985). In the Houston District, pollen data from a small bog in northern Harris County has recently been analyzed by Abbey Beck of Moore Archeological Consulting (Abbey Beck, personal communication 1999; Figure 10). According to Beck, the $120+\mathrm{cm}$ column yielded three relatively discrete periods. The earliest phase, represented by sediments below $90 \mathrm{cmbs}$, is dominated by pollen from grasses and weeds (e.g., Artemesia) with very low representation of arboreal taxa. The second period $(85-45 \mathrm{cmbs})$ is marked by increasing oak pollen, continued high grass pollen, and an increasing incidence of finely divided charcoal fragments. The final period $(40-15 \mathrm{cmbs})$ indicates increasing arboreal taxa (pine, elm, sweetgum, etc.) and dramatically decreased grass pollen and charcoal. Two radiocarbon ages have been obtained from this recently analyzed column. The first age $(1010 \pm 40 \mathrm{BP})$ is from the approximate transition between the first and second periods, indicating that it occurred in roughly the last millennium during the relatively densely populated Late Prehistoric period. While the record may well represent a climatic signal, the possibility that artificial clearing and intense fuel use strongly affected its character is a likely possibility. The second age $(170 \pm 60 \mathrm{BP}$ ) was obtained from $40-45 \mathrm{cmbs}$, near the boundary between the second and third periods identified in the pollen record. Although radiocarbon ages from this period always have a large error range due to the Suess effect (Bradley 1985), the timing of this shift appears broadly consistent with European settlement of the region.

Faunal data from the Coastal Plain is somewhat equivocal, but in general it continues the previous trend towards increasing aridity (Lundelius 1967; Graham 1987). Isotope and geomorphic data, in contrast, generally indicate more variable climatic conditions. Both Humphrey and Ferring (1994) and Nordt et al. (1994) interpret MiddleLate to Late Holocene carbon isotope data (on soil carbonate and soil/sediment humates, respectively) as indicating a pronounced shift towards more effective moisture (i.e., moister, cooler, or both) following the Middle Holocene dry interval. According to Humphrey and Ferring (1994), this moist interval was punctuated by a 1,000 year shift toward aridity between roughly 2,000 and 1,000 BP. Nordt et al. (1994) also see evidence of a brief shift towards drier and possibly warmer conditions, but this shift occurs slightly earlier (roughly 2,500-1,800 BP). In contrast, Goodfriend and Ellis (2000) see a peak abundance of $\mathrm{C}_{4}$ around $3.5 \mathrm{ka}$, with increasingly depleted samples afterwards.

Geomorphic data also generally indicate the presence of fluctuating climate during the Late Holocene. Major alluvial fills spanning all or part of the period between approximately $4.5 \mathrm{ka}$ and $1.5 \mathrm{ka}$ are documented at several localities throughout Texas (Hall 1988; Blum and Valastro 1989, 1992; Blum 1992; Nordt 1992; Ferring 1994, 2000; Waters and Nordt 1995). In many localities, aggradation appears to have slowed in the second millennium BP, allowing a widespread soil to form. Elsewhere, aggradation of a comparable Late Holocene unit appears to have terminated by approximately $3 \mathrm{ka}$ (Thoms and Mandel 1992). Approximately $1 \mathrm{ka}$, there was another regional episode of stream incision (Hall 1990), followed by aggradation of another unit in the last 1,000 years or so (Blum 1992; Nordt 1992). This episode is also apparent in areas east of the Balcones escarpment. At Jewett Mine in Freestone County, examination of floodplain deposits suggests that the fill in tributaries to Buffalo Creek was extensively eroded at approximately $1 \mathrm{ka}$, and that almost all deposits in the tributary valleys postdate this stripping (Abbott 1996).

As the preceding summary demonstrates, while the broad trends in the paleoenvironment of Texas are relatively consistent, there are many subtle differences among different records of environmental change in Texas throughout the Late 


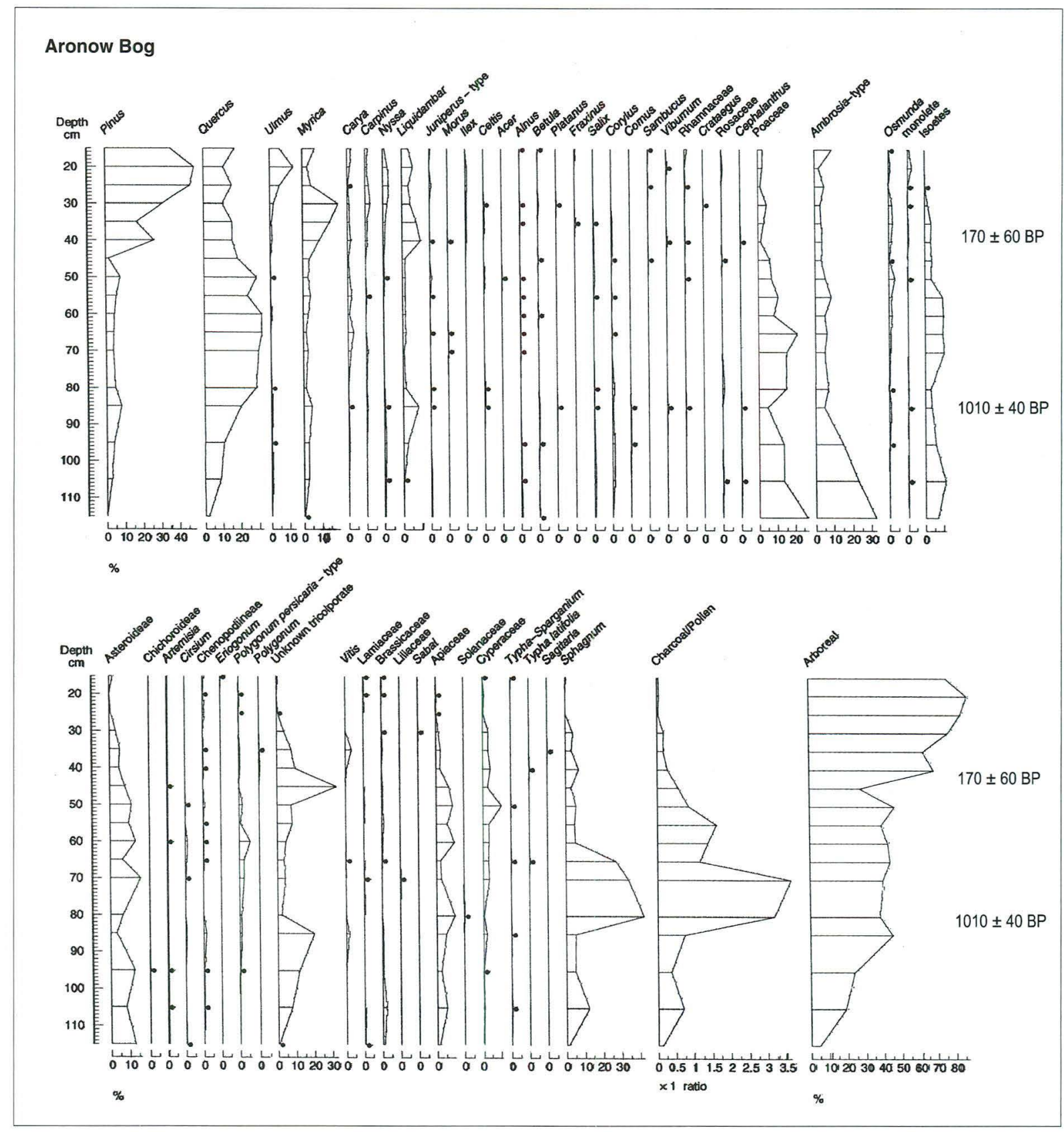

Figure 10. Pollen spectra of Aronow Bog, northern Harris County. Unpublished data presented courtesy of Abbie Beck, Moore Archeological Consulting, Inc.

Quaternary. Importantly, while results should be reviewed and integrated carefully and critically, there is little reason to expect different environmental/climatic proxies to correspond precisely. The various physical and biological components of ecosystems vary in spatially complex ways, and respond to climatic/environmental changes (if at all) according to differing thresholds and lag times. Characterization of the resources available to, and environmental constraints faced by, prehistoric peoples in a given area requires an appreciation of spatial and temporal variability in Texas paleoenvironments, which remain poorly understood indeed. Much more data, of as many different types and from as many different contexts as possible, are needed to characterize the spatiotemporal environment through time in Texas, and particularly in the Houston District. 


\section{RESOURCE DISTRIBUTIONS IN THE HOUSTON DISTRICT}

The spatio-temporal distribution of resources in the Houston District certainly had a marked impact on the activity of prehistoric people, and therefore is of considerable interest to archeology. Unfortunately, as outlined above, the character of resource distributions is obscure, and can be outlined in only the most general of terms. This section presents a brief summary of the types of relevant resources, but more work clearly remains to be done in this regard. For more comprehensive reviews of the structure and distribution of resources in adjacent areas, the reader is referred to summaries by Ricklis (1996) and Tomka et al. (n.d.).

\section{Plant Resources}

The character of plant resources available for exploitation clearly varied across the Houston District. Several basic, functional classes of plant exploitation can be identified: use as a food resource, use as a fuel resource, use as a medicinal resource, and use as a construction/fabrication resource. In addition, plants were almost certainly collected and processed for ritual purposes, and the structure of extant vegetation was utilized to passive, ambient advantage for shade and protection from the wind. No extant publication provides an indepth accounting of prehistorically important plant taxa, and our understanding of the uses of plants by Native Americans in Texas could be considerably enhanced by such an ethnobotanical study. Nevertheless, even under ideal circumstances such a study would provide an incomplete picture of the breadth and details of prehistoric plant use because our ability to approach such a subject archeologically or deductively is constrained by a paucity of evidence, while ethnographic descriptions are limited in availability and scope, and at best apply to the Protohistoric and Historic periods.

Food is the most obvious, and probably the most critical, use of plants by prehistoric residents of the Houston District. The edible portion of a plant is typically a root structure (tubers and bulbs), a reproductive structure (fruits, nuts, or seeds), or foliage (greens), although other parts may also be edible (e.g., cactus pads, sotol hearts). In almost all cases, the availability of these resources varies on a seasonal basis. However, individual plant taxa some- times yield different edible structures at different times of the year. It is difficult to state with certainty how many edible plant taxa are present, or were present at some point in the Holocene, in the Houston District. Stahl (1995) lists the most important food-source plants that were prevalent in the Houston District during the Late Prehistoric period, including cattail, bulrush, American lotus, water lily, arrow-head, river cane, greenbriar tubers, dewberries, blackberries, persimmon, mulberries, pecan, black hickory, black walnut, acorns, grapes, grasses, docks, pokeweed, thistles, nettles, ground cherries, sunflowers, and elderberries. However, Tomka et al. (n.d.) identify more than 250 edible taxa in the central Coastal Plain and Rio Grande Plain, and many of these taxa can be expected to occur, or to have occurred at one time or another during the Holocene, in the coastal grasslands of the Houston District. At the same time, other taxa endemic to the Austroriparian Province are almost certain to be present in the wooded parts of the Houston District, so it would not be unreasonable to assume that more than 300 edible taxa were present during the Holocene in the district as a whole. Of course, it is unlikely that all edible taxa were ever exploited.

Despite the considerable uncertainty that remains about the structure of edible plant resources, it is possible to outline their character and distribution in broad terms. The coastal grasslands in the southern and western parts of the district are characterized by primarily non-woody grasses and forbs that would yield greens, roots, and seeds, while the woodlands and forests to the north and east are characterized by woody plants, and probably yielded nuts and fruits in greater abundance. Overall, the productivity of the mixed pine-hardwood woodland was probably higher than in the forested areas dominated by pine, but lower than the riparian forests. The gallery forests lining the floodplains of streams in the grassland were probably particularly rich, concentrated sources of floral resources, especially in late summer and autumn when the production of fruits and nuts peaked. In terms of seasonality, spring and early summer represents the production peak for greens and many bulbs and tubers, while fruit, nut, and seed production peaks in late summer and autumn. Because winter is the season of lowest productivity, it may have seen comparatively intense exploitation of root resources, not because it represents the optimal time for them, but because other plant foods were relatively unavailable. 
Fuel is another fundamental requirement for people, who use it to feed fire that keeps them warm and cooks their food. In terms of fuel resources, there is a clear dichotomy between the coastal grassland, where firewood would have been a relatively scarce and precious commodity, and the woodlands and forests, where fuel was relatively abundant. Of course, there is the possibility that non-woody fuel sources such as dried dung were routinely exploited in the grassland environment. Nevertheless, it is likely that the need to procure wood for fuel was a much more important consideration in the decision to locate activities in the coastal prairies and marshes than it was in the woodlands to the north and east.

Our knowledge of medicinal and ritual plants in the district is limited, but generalized ethnographic data on hunter/gatherer bands suggests that they were clearly an important resource. Wild plants were potentially used as astringents, tonics, diuretics, emetics, analgesics, stimulants, and as poultices for wound dressings, and there are a variety of native plants that could have fulfilled these functions (Kirk 1970). Although more information is necessary to assess the distribution of such resources, it is likely that those areas characterized by relatively diverse flora, such as the dense riparian corridors, were relatively important sources because they contained a diverse, concentrated assemblage of available taxa.

Plants were also important as a source of raw materials for construction and fabrication. Although many types of plant resources were clearly used to manufacture implements and structures, the most notable include wood and grasses for construction and tool manufacture, and fiber for binding, fish nets, and basketry. While a variety of these resources were available, there were probably clear preferences of specific woods and fibers for specific uses, such as the use of bois d'arc wood for bow manufacture. The distribution of woods clearly favored the more heavily forested areas, although the riparian corridors probably contained a much more diverse set of useful woods than the more uniform upland forests and woodlands. Fibers would have been available from a variety of locales, but the heavy grasses of the coastal marshes were probably a particularly important source. Other construction/ fabrication uses include gourds for containers, a variety of plants for pigments and dyes, sap for binding agents, sources of tannin for curing hides, and sources of soap for cleaning.

\section{Terrestrial Faunal Resources}

In large part, the suite of available faunal resources reflects the character of the habitat; while there was considerable overlap, the available fauna in the coastal grassland were different than those in the pine forest. Although use as a food resource was probably paramount in the exploitation of most types of fauna, other animal parts-skin, bones, sinews, stomach, horns, etc.-were used extensively in the manufacture of tools, clothing, and shelter. However, unlike plants, which include taxa that were exploited for specific properties that were probably often not food-related, it is unlikely that animals were procured for purposes other than consumption. Rather, uses were found for the inedible portions of game, which served to make the process of acquiring the animal more efficient.

While large game were probably preferred because of their yield, it is likely that small game were relatively more important at many times due to their greater abundance. The largest animal in the district through the Holocene was bison (Bison bison), but it is unlikely that it was continuously present. Moreover, bison would have been restricted to the coastal grassland and open woodland, and would not have been available in the northeastern part of the district. The most persistent and reliable taxon of large game occurring through the entire area is white-tailed deer (Odocoileus virginianus), which were widely available but did not occur in the concentrations typical of bison. However, faunal remains from sites in the region typically include a wide range of smaller terrestrial taxa, including small mammals, reptiles, birds, and amphibians. Other large game that may have been important locally at different times include pronghorn (Antilocapra americanus) and American alligator (Alligator mississippiensis).

\section{Lagoonal, Marine, and Freshwater Aquatic Faunal Resources}

In the coastal area, the role of marine resources appears to have been extremely important. The most common type of coastal site consists of middens of shellfish remains, primarily the brackish water clam Rangia cuneata, but also including other, more saline-tolerant shellfish taxa such as the eastern oyster (Crassostrea virginica), lightning whelk (Busycon perversum), giant Atlantic cockle (Dinocardium robustum), quahog (Mercenaria campechensis), sun 
ray venus (Macrocallista nimbosa), shark's eye (Polinices duplicatus), and Carolina marsh clam (Polymesoda caroliniana). In most cases, shell middens in the Houston area are overwhelmingly dominated by Rangia (Aten 1983), Most shellfish middens also contain considerable quantities of fish bone, including such species as black drum (Pogonais cromis), redfish (Sciaenops ocellata), various sea trout (Cynoscion spp.), sea catfish (Aurius felis), sheepshead (Archosargus probatocephalus), mullet (Mugil cephalus), silver perch (Bairdiella chrysura), and Atlantic croaker (Micropogonius undulatus). Inland sites have yielded both freshwater mussels (e.g., Amblema spp., Lampsilis spp.) and freshwater fish such as gar (Lepisosteus spp.) and channel catfish (Ictalurus punctatus).

Because the modern barrier island systems and the protected back-barrier lagoons did not develop until sea level stabilized in the Middle Holocene, the availability of marine resources was probably not constant through the prehistoric period. Ricklis (1993; Ricklis and Blum 1997) presents a convincing argument that Holocene sea level rise was episodic, with relative stillstands separated by periods of relatively rapid rise from approximately 7-6 ka and 4-3 ka, and that this episodic adjustment profoundly affected organic productivity in the coastal zone. Ricklis demonstrates gaps in the suite of radiocarbon dates from archeological sites in the Corpus Christi area corresponding to these periods of apparent rising sea level, and argues that the rich marine ecosystems of the bays and lagoons broke down during periods of rapid sea level rise, leading to much more limited utilization by coastal groups.

\section{Fresh Water}

Water for drinking and cooking is essential for humans, and is always a major consideration in the location of activity loci. Although the availability of water is not strongly restricted in the Houston District because almost all streams in the region flow perennially, there are areas where it could be a concern. One area where water availability is limited is the broad Beaumont surface, where drainage is poorly developed and streams are often far apart. This shortage would have been alleviated for short periods following rains, when shallow pools are prone to develop on depressions in the clayey substrate. Another area where freshwater can be hard to procure is the coastal zone. Although the bays, estuaries, and marshes along the coast afford the greatest frequency of surface water, most of it is brackish or saline and thus not potable. In fact, brackish water can penetrate well inland along the low gradient streams, making freshwater difficult to obtain for miles inland.

In summary, while the availability of water in the Houston District is not a particularly pressing issue as it is in areas to the west, it still probably played a significant role in logistical and settlement choices made by prehistoric inhabitants in the Houston district, particularly in the otherwise resource-rich coastal zone.

\section{Lithic Resources}

The availability of suitable lithic resources is one of the major limiting factors on the outer coastal plain. Lithic raw materials of appreciable size are essentially absent in the district (Aten 1983), although tremendous quantities are available in Central Texas and, to a lesser extent, in upland gravel formations (e.g., the Uvalde Gravel) and stream bedload on the inner Coastal Plain. Some lithic-grade petrified wood is also available in Eocene formations on the inner Coastal Plain, and in the bedload of streams cutting through these formations. However, by the time that these streams reach the outer coastal plain, the gradient is so low that gravel transport is minimal, and gravel bars in the stream beds are practically nonexistent. Therefore, it is likely that raw material procurement required either long-distance logistical expeditions, trade with inland groups, or both.

\section{Other Resources}

Clays for ceramic use became an important resource during the Late Prehistoric period. While the ubiquity of clay deposits and clay soils in the Houston area would seem to suggest that acquisition of suitable clay was not particularly difficult for prehistoric people to accomplish, the mineralogical requirements for a suitable ceramic clay may have been difficult to satisfy. The majority of clays in the district are at least partly smectitic, and shrink considerably on drying. As a result, vessels made from them probably fare poorly in curing and firing. Another significant problem is posed by the considerable content of 
carbonate and other soluble salts in most area clays, which also present severe problems in ceramic manufacture. In addition, clays were often used to make fired clay balls, a widespread type of artifact in coastal prehistoric sites (Patterson 1995). While their function remains debatable, one possibility is that they substituted for hot rocks used elsewhere in cooking (e.g., roasting or stone-boiling).

Asphaltum is a naturally occurring hydrocarbon compound that was used extensively as a binding agent for hafting stone tools and as a coating/ waterproofing for basketry. During the Late Prehistoric, asphaltum was also used as a decorative medium and repair cement on ceramics, particularly Rockport wares (Suhm and Jelks 1962). Asphaltum currently washes up in abundance on Texas beaches, and although some of this material is a result of offshore drilling, it also is derived from offshore oil seeps and thus was probably available during the prehistoric period. On the other hand, as Tomka et al. (n.d.) note, asphaltum is also available locally in terrestrial settings, and ethnohistorical documents suggest that it may have been traded towards the coast from inland areas.

Salt is an essential dietary supplement for humans, and is extremely valuable for curing food to preserve it for long periods. Although this author knows of no prehistoric salt processing sites identified in the district, salt in solution is readily available from the Gulf, and precipitate rinds are common in dry depressions in coastal areas.

The availability of inorganic pigments, and particularly iron oxides (e.g., hematite, limonite) was also not particularly limited in the district. Iron oxide concretions are common in soils developed on the Pleistocene formations, and ironstone hardpans occur in some soils developed on pre-Lissie sediments. Manganese concretions (a source of brown to black pigments) are also common in soils. 


\section{Chapter 3}

\section{Physical Processes of Site Formation, Modification, and Destruction in the Houston District}

\section{INTRODUCTION}

This chapter addresses preservation of the archeological record in the Houston District from a theoretical, process-oriented perspective. The emphasis here is not on behavioral aspects of site location and formation, but rather on the suite of physical and biotic processes responsible for the preservation or destruction of archeological sites. Examination of process provides the basis for interpretation of deposits. Archeological site matrices represent sediments introduced by one or more depositional processes and typically modified by one or more pedogenic and/or disturbance processes. Understanding of the character of these processes and the transformations that they can introduce to the archeological record is a crucial step in interpretation of archeological distributions. The following sections describe the principal suites of physical processes in operation in the Houston District, and the character of deposits resulting from or affected by those processes.

\section{DEPOSITIONAL PROCESSES AND LANDFORMS}

Depositional processes consist of those natural mechanisms capable of introducing sediment into any given setting, and are thus responsible for the burial and preservation of archeological sites. While there are a limited number of basic processes, each subsumes a large number of permutations dictated by variations in the character of sediments and the strength and periodicity of depositional energy. Deposition of sediment can only occur when sediments have been previously mobilized, or entrained, and transported to the site of deposition. Thus, any discussion must also address questions of source, mechanisms of sediment entrainment, and mechanisms of transport.

There are three basic classes of deposited sediments. Clastic sediments represent solid particlesclasts-derived from weathering of a parent rock. Such clasts may be of any size, ranging from submicroscopic (clays) to massive (boulders). Organic sediments represent remains of organisms and decomposition products derived from them. They also include inorganic remains such as calcareous or siliceous deposits derived from the shells of organisms. Such remains can also be considered clastic if they are moved from the location of the organism's death by natural processes. Chemical sediments represent deposits precipitated from solution, such as gypsum and halite. They are relatively unimportant in archeological settings, although they do occur as secondary components precipitated in site sediments.

The mechanisms of sediment transport are also readily divided into three classes: fluid transport, gravity transport, and biological transport. A fluid transport medium may be liquid (e.g., fluvial, littoral, lacustrine, estuarine, and benthic processes), gaseous (e.g., eolian processes), or a plastic solid (e.g., glacial processes). The most pervasive and efficient mechanism of sediment transport involves the action of fluid transport medium. This discussion focuses on processes typical of the Houston area. Although they may be very important elsewhere, processes that are not significant to geoarcheological questions in the Houston area (such as glacial transport, lacustrine processes, and deep-sea processes) are not addressed except where needed to place the discussion in theoretical context.

In addition to fluid transport, sediment transport is also accomplished under the primary influence of gravity, and as a result of intentional or incidental 
movement by organisms. In practice, the separation between these three basic classes of transport is far from clear cut; fluid movement is itself strongly influenced by gravity, most gravity movements are facilitated at least in part by fluid media, and deposits resulting from biotic transport are often syn-depositionally and post-depositionally modified by fluid- and/or gravity-driven processes. Nevertheless, the processes themselves are quite distinct, and affect archeological materials in different ways.

\section{Fluvial Processes, Fluvial Deposits, and Fluvial Landforms}

Rivers are extremely efficient sediment conduits, and are the primary mechanism responsible for transporting the material weathered through subaerial exposure to the sea. No other physical process, save the action of continental-scale ice sheets, is as effective in moving large quantities of sediments of a variety of sizes over extremely long distances. In fact, the bedrock underlying the Houston District is made up almost entirely of fluvial and fluviodeltaic deposits laid down along the coast over approximately the last 20 million years. The following summary is drawn and simplified from a number of sources, but key references include Leopold et al. (1963), Schumm (1977), Reineck and Singh (1980), Howard (1992), and Brown and Keough (1992).

Fluvial transport is accomplished because flowing water exerts a tractive force on sediments in the bed and on the banks of the channel. Entrainment of clasts occurs when this force exceeds the resistance to movement imparted by friction and inter-particular attraction. The magnitude of the tractive force is primarily a function of velocity, but is also affected by the degree of turbulence, water depth, bed roughness, and fluid density (which is affected in turn by temperature and the amount of sediment in suspension). The inherent erodability of alluvial sediments is related to particle size. In general, sand-sized grains are the most readily eroded. Larger clasts (gravels) are more resistant to erosion due to their greater mass and interparticular friction, while smaller particles (silts and clays) are increasingly resistant to erosion due to electrostatic bonding between particles. However, once entrained, gravels and coarse sands will rapidly settle out with minor decreases in flow competence, while turbulence will keep finer sands and coarse silts entrained even after flow competence drops dramatically, and entrained fine silts and clays will remain suspended for a period even after the velocity of flow drops off completely (Figure 11).

The amount of sediment carried by a stream is referred to as its sediment load. Fluvial processes transport sediment in a number of different ways, and the relative importance of these different modes of transport depend on a number of different factors, including stream size and gradient, character of the source rock, and flow conditions at any particular time. There are three different modes of sediment transport typically recognized: traction, suspension, and solution. Traction is responsible for moving larger clasts, either in the bed load, which rolls or slides along the bed of the stream, or in the saltation load, where clasts are lifted off the bed and quickly settle as they move downstream, essentially bouncing along in the water column. Bed load transport may involve clasts of any size, while saltation tends to affect sand-sized and, in conditions of extremely powerful flow, small gravelsized clasts. Finer materials are also frequently transported in traction as aggregates, which behave as comparably sized individual clasts. Suspended load transport primarily involves silts and clays, although high velocity flow may involve very fine sands. Clasts in suspension are held in the water column by turbulence, and only settle out gradually as the water slows and loses competence. Collectively, the traction and suspension loads are termed the solid load. In contrast, dissolved load sediments are those that travel in solution in the water, and are typically not held in storage along the stream in any quantity, but instead pass directly to the sea. Finally, organic materials often are transported at the water surface as the floating load.

Alluvial deposits are composed primarily of traction and suspended load sediments laid down in a variety of channel and floodplain environments. The characteristics of a given stream are largely a function of the spatial structure of these specific depositional environments, which is controlled by a number of interrelated factors, including mean and variability of discharge, volume and character of the sediment load, gradient, structure and resistence of bedrock, degree of valley incision, valley size, and character and density of vegetation on the floodplain and in the basin. While many different types of natural channel pattern can be recognized (Chorley 1969), most can be subsumed under five basic types: meandering channels, 


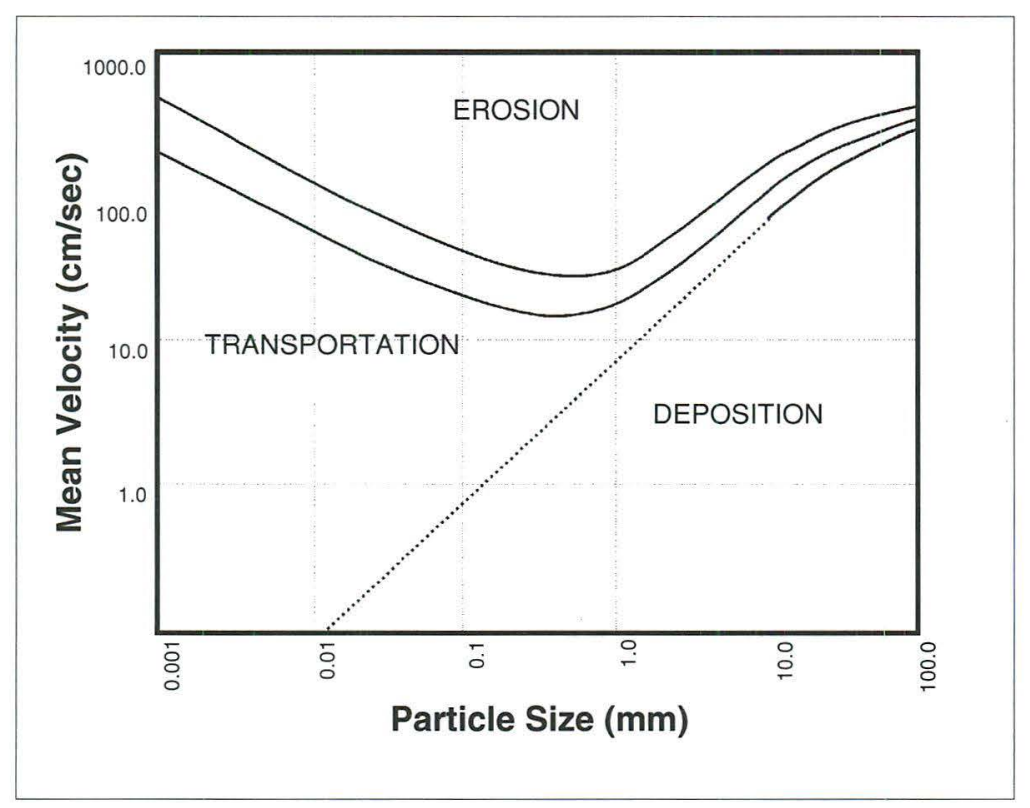

Figure 11. Generalized relationship between particle size and velocity in determining fluvial erosion, transport, and deposition. through repeated avulsion of a single, active channel.

The vast majority of streams in the Houston area exhibit a meandering channel pattern. Meandering streams are characterized by a single, sinuous channel that migrates laterally, eroding sediments on the concave exterior banks and depositing them on the convex interior banks. Actively meandering systems are typical of fine-grained to mixed-load systems that have low to moderate gradients, and are characterized by channels with sequences of well-defined pools and bars separated by relatively shallow riffles. The character of meandering stream deposits varies depending on many factors, including the size and gradient of the stream, the textural character

anastamosing channels, distributary channels, braided channels, and straight channels. Meandering channels, distributary channels, and anastamosing channels are typical of fine-grained and low gradient situations. In contrast, straight and braided channels are typical of environments that are coarser-grained and higher gradient than occur in the study area, and will not be discussed further here.

Anastamosing streams are relatively rare, and have not been studied with the intensity of the much more common braided and meandering forms. Anastamosing streams are multiple thalweg systems characterized by stable, anabranching channels that diverge and converge along the valley system. No significant anastamosing systems are present in the modern Houston area, but it is possible that they existed in the culturally relevant past, and thus they will be only briefly addressed here. Meandering channels are dominant in the Houston area, and are the focus of this discussion. Although anastamosing and distributary channels are also characteristic of fine-grained, low-gradient systems, there are no significant, extant examples in the Houston area. Distributary channels are characteristic of the deltaic environment, and will be addressed in somewhat more detail. However, there is little evidence that a large distributary network was ever active on the Holocene deltas of the Houston District. Rather, the Houston area deltas seem to have accreted of the sediment load, the magnitude and variability of stream discharge resulting from precipitation events and groundwater discharge, the position of the water table, and the degree of bedrock confinement. Meandering streams have been studied extensively (Harms et al. 1963; Leopold et al. 1963; McGowan and Garner 1970; Reineck and Singh 1980), and exhibit a variety of depositional facies that are characteristic of specific sub-environments within the overall system (Reineck and Singh 1980; Walker and Cant 1980). Figure 12 illustrates the characteristic distribution of major depositional facies within a classic meandering stream. These facies can be divided into three classes characterized by increasingly fine-grained deposits: channel lag deposits, which are laid down in the bottom and on the sides of the channel; point bar deposits, which accrete as a series of off-lapping wedges on the streamward margin of a migrating point bar; and overbank deposits, which are deposited across the floodplain during flood stage. Overbank deposits can be divided into natural levee deposits, which are typically sandy or silty strata deposited on the margin of the channel as the stream overtops its bank and velocity drops off; flood basin deposits, which are typically muddy strata deposited on the floodplain from short-term standing water as the flood recedes; backswamp deposits, which are typically fine-grained, organic-rich strata laid down in 
semi-permanent ponds on the floodplain; crevasse splay deposits, which are wedges of sandy sediment laid down in the flood basin when natural levees are breached during flood stage; and channel plug (oxbow lake) deposits, which infill abandoned channels. Although natural levees can exhibit considerable relief in some fluvial systems, those in the Houston District are typically quite low and subtle.

Active meandering streams are not particularly stable, although some are more stable than others, and most are much slower to exhibit changes in channel pattern than braided systems. In addition to lateral migration of the channel, meandering streams often undergo two different forms of sudden shifts in channel position. The more common type is meander cutoff, which results when the channel shifts to occupy a chute or swale on the point bar (chute cut-off), or a meander develops to such an extent that a flood is able to breach the neck of the meander, abandoning a single loop of the sinuous channel (neck cut-off). When such a cut-off event occurs, the ends of the old channel are quickly filled with sediment and an oxbow lake develops along the old channel course. Gradually, the oxbow lake fills with overbank muds, finally resulting in a gentle swale on the floodplain underlain by a channel plug. Occasionally, aggradation of the channel can raise the stream bed to within a few feet of the floodplain surface. When this occurs, the principal axis of flow can break out of the channel during a flood event and establish an entirely new channel elsewhere in the valley in a process termed avulsion. Avulsion events are more common in large streams with broad floodplains, and Late Quaternary avulsions have been identified in the lower Brazos and Colorado River systems. In some cases, channels abandoned by avulsion can quickly infill, while in others they may persist as smaller drainages. Oyster Creek, in the lower Brazos drainage, and Caney Creek, in the lower Colorado drainage, are examples of smaller streams occupying pre-avulsion channels of their respective parent streams.

The characteristics of principal facies associated with a meandering stream are illustrated in Table 4. However, this generalized model should be viewed only as representative of a typical meandering stream, as it does not fully capture the potential for variability of meandering stream deposits. As Brown (1997) points out, it is difficult to generalize about the character of meandering systems because the sedimentology and architecture of streams reflects both the character of the myriad factors affecting their current behavior and influences imposed by their long-term history. In particular, the relative importance of channel, point bar, and overbank facies within a given valley segment varies considerably from stream to stream. In relatively small streams, channel migration frequently involves the entire floodplain surface, so that longterm storage of valley sediments is limited. In many larger systems, lateral migration is limited to one or more relatively well-defined meander belts within

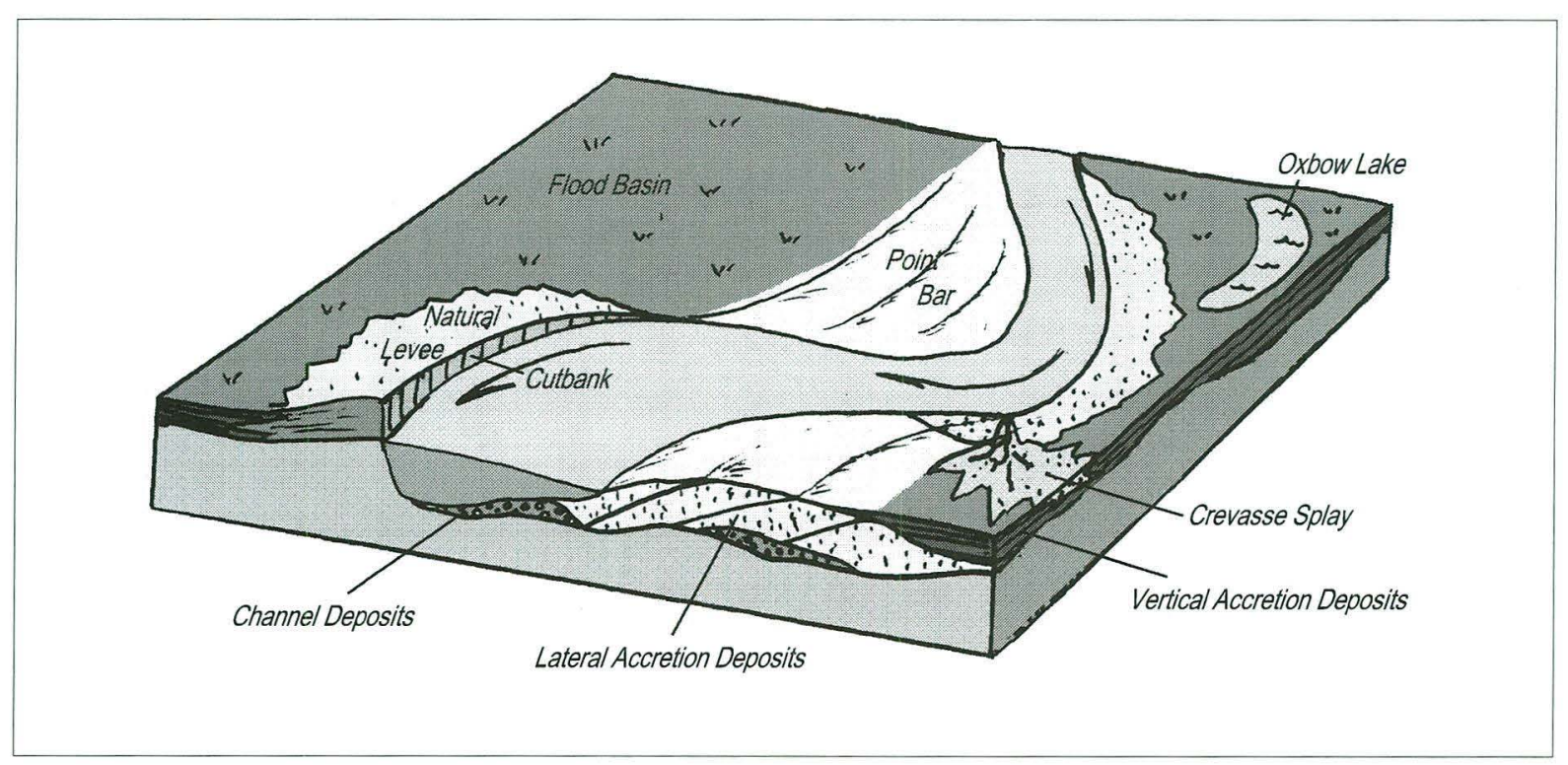

Figure 12. Principal environments and facies in a classic meandering stream. 
the alluvial valley, and overbank deposits can frequently be preserved for long periods in other parts of the valley. Tectonic influences and base level adjustments can also strongly affect the relative proportions of channel, point bar, and overbank facies, while differences in discharge and sediment load can also profoundly affect the configuration of the system. In all cases, however, the character and configuration of fluvial deposits reflects the environment of deposition, and the deposits can thus provide a record of environmental change.

One variant of the classic system common in Central Texas and on portions of the inner coastal plain is illustrated in Figure 13. The most obvious difference between this configuration and the "classic" model illustrated in Figure 12 is the presence of linear swales, or chutes, that cut across the point bars, and of associated, coarse-grained chute bars that develop at the outlets of these chutes on the downstream side of the meanders. These features are the result of high magnitude flows that result from the occasional intense rains in Central Texas, and can grow to considerable size in large systems. In addition, such rains can cause streams to rise $10 \mathrm{~m}$ or more, overtopping terrace landforms that are normally well above the level of flooding, and spreading thin accumulations of overbank sediments across the surface. Because they are occasionally flooded, such surfaces are often termed flood terraces.

Distributary channels consist of thalwegs that bifurcate repeatedly in a downstream direction, creating more channels with distance from the source. They are characteristic of segments of a stream where the gradient is abruptly reduced (e.g., alluvial fans) or approaches zero (e.g., deltas). Although some small, fine-grained fans may be present (albeit buried) beneath many of the floodplains, the deltaic environment is much more important in the Houston District. As a stream flows into a standing body of water, such as a lake or the ocean, it constructs a delta. The most imposing delta environment in the Houston District is the large Holocene delta of the Brazos River. It merges laterally with the equally imposing delta of the Colorado River system, and forms a considerable part of Brazoria County. The only other significant Holocene delta in the study area is the small, confined estuarine delta of the San Jacinto River.

Delta growth occurs as water velocity falls off, reducing competence and causing the solid load carried by the stream to be dropped. The morphology of a marine delta is determined by the morphology of the feeder stream, the quantity and character of the sediment load, the character of the continental shelf, and the character of, and energy imparted by, shoreline processes (Wright 1977). In systems where the fluvial processes are dominant because the quantity of delivered sediment exceeds the erosional potential of shoreline processes, deltas are constructional, and will tend to grow seaward, while streams with lower sediment yield have deltas that tend to be stable or destructional, growing

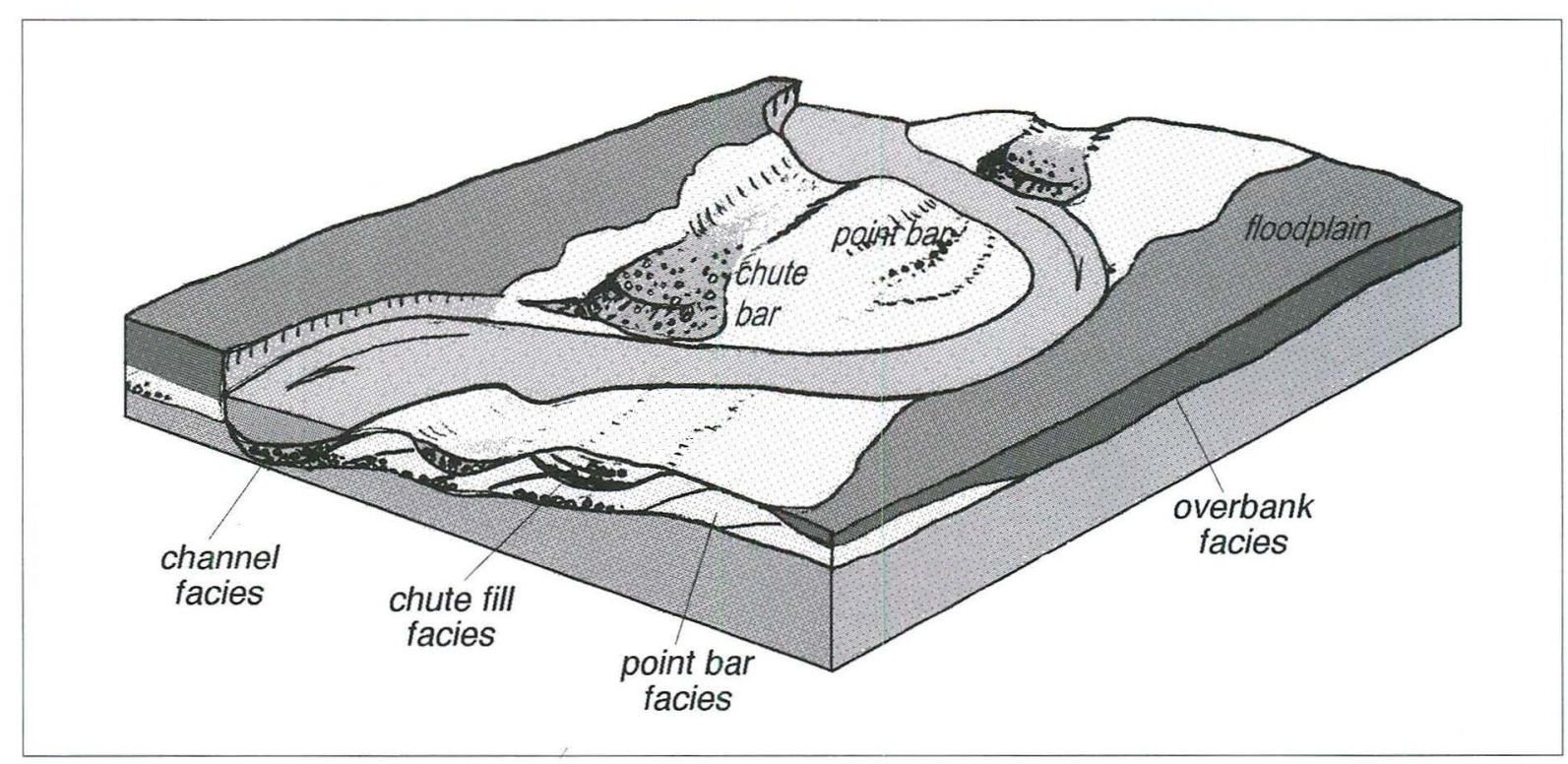

Figure 13. Morphology and facies assemblages in a chute-modified meandering stream. 
Table 4. Principal depositional facies in a typical meandering stream system.

\begin{tabular}{|c|c|c|c|}
\hline Depositional Facies & Lithofacies & Sedimentary Structures & Comments \\
\hline Channel Lag & $\begin{array}{l}\text { Gravels and occasionally } \\
\text { sands; moderately sorted; } \\
\text { may contain lagged detritus } \\
\text { such as tree trunks and } \\
\text { blocks of sediment calved off } \\
\text { the bank }\end{array}$ & $\begin{array}{l}\text { typically massive or horizontally } \\
\text { bedded; may be discontinuous; } \\
\text { scour surfaces common }\end{array}$ & $\begin{array}{l}\text { Contain the coarsest material in the } \\
\text { system }\end{array}$ \\
\hline Point Bar & $\begin{array}{l}\text { Gravels to silts; well sorted } \\
\text { to relatively poorly sorted; } \\
\text { may be muddy in exclusively } \\
\text { fine-grained systems }\end{array}$ & $\begin{array}{l}\text { Typically large-scale bedding near } \\
\text { the base, grading up into smaller } \\
\text { crossbeds and ripple laminations } \\
\text { with interspersed horizontal bedding; } \\
\text { large-scale lateral accretion surfaces } \\
\text { can frequently be discerned }\end{array}$ & $\begin{array}{l}\text { Texture tends to fine upward; larger } \\
\text { streams can develop scrolled topography } \\
\text { that traps lenticular deposits of fines. }\end{array}$ \\
\hline Chute Bar & $\begin{array}{l}\text { Gravels to sands; well sorted } \\
\text { to moderately sorted }\end{array}$ & $\begin{array}{l}\text { horizontal bottomset beds; large- } \\
\text { scale foreset crossbeds; trough-fill } \\
\text { crossbeds; and thin, parallel } \\
\text { laminated to wavy laminated topset } \\
\text { beds }\end{array}$ & $\begin{array}{l}\text { lobate bars formed on the downstream } \\
\text { side of chutes; formed during peak flow } \\
\text { conditions }\end{array}$ \\
\hline Chute Fill & $\begin{array}{l}\text { Gravels to muds; primarily } \\
\text { sand and mud; may be well- } \\
\text { sorted locally but grades } \\
\text { from coarse to fine rapidly }\end{array}$ & $\begin{array}{l}\text { Primarily stacked couplets of rippled } \\
\text { sand grading to mud representing } \\
\text { individual flood events }\end{array}$ & $\begin{array}{l}\text { Most deposits appear to represent } \\
\text { waning flow; Gravel is only common at } \\
\text { the base; muds may exhibit dessication } \\
\text { cracks, root traces and other types of } \\
\text { pedogenic modification }\end{array}$ \\
\hline Natural Levee & $\begin{array}{l}\text { Fine sands and silts; } \\
\text { occasional lenses of coarser } \\
\text { sand and mud }\end{array}$ & $\begin{array}{l}\text { small ripple crossbeds, climbing } \\
\text { ripples; horizontal lamination; } \\
\text { parallel laminated muds; root traces } \\
\text { common; muds can exhibit } \\
\text { desiccation cracks }\end{array}$ & $\begin{array}{l}\text { somewhat finer than corresponding point } \\
\text { bar; commonly grades into upper point } \\
\text { bar on convex banks; typically distinct on } \\
\text { concave banks }\end{array}$ \\
\hline Crevasse Splay & $\begin{array}{l}\text { Sands and silts; typically } \\
\text { somewhat coarser than } \\
\text { natural leveee sediments }\end{array}$ & $\begin{array}{l}\text { small scale ripples, climbing ripples, } \\
\text { and horizontal laminae; typically } \\
\text { interbedded in muds }\end{array}$ & $\begin{array}{l}\text { lobate in planiform; small distributary } \\
\text { channels can frequently be discerned }\end{array}$ \\
\hline Flood Basin & $\begin{array}{l}\text { Sandy loams and muds; } \\
\text { distinctly finer than } \\
\text { associated point bar } \\
\text { deposits }\end{array}$ & $\begin{array}{l}\text { typically massive; ripple lamination, } \\
\text { horizontal lamination, and convolute } \\
\text { bedding may occur; common } \\
\text { pedogenic and phreatic overprinting; } \\
\text { bioturbation very common }\end{array}$ & $\begin{array}{l}\text { may fine upward gradually; weak cumulic } \\
\text { paleosols may occur }\end{array}$ \\
\hline Channel Plug & Dominantly muds & $\begin{array}{l}\text { Typically laminated or thin-bedded; } \\
\text { pedogenic modification and } \\
\text { desiccation cracking common; } \\
\text { gleying common }\end{array}$ & $\begin{array}{l}\text { may contain thin sandy lenses } \\
\text { representing flood events }\end{array}$ \\
\hline
\end{tabular}

slowly and episodically at times and retreating at others. Very high sediment yields, particularly in streams dominated by fine-grained sediment, tend to create bird's-foot deltas like that of the Mississippi River. In bird's-foot deltas, distributary channels construct elevated channel and levee systems that extend offshore, while much of the suspended sediment is released into large sediment clouds that gradually settle to the sea bed over hundreds of square miles. The Brazos and Colorado deltas, in contrast, represent lobate deltas that accreted a segment at a time, forming channel/ levee and associated floodbasin facies that are subaerially exposed. Rather than true distributary systems, where multiple channels are active simultaneously, the Brazos and Colorado deltas 
represent landforms that developed primarily through the action of a single channel that periodically avulsed, abandoning one delta lobe and beginning to construct another in an offlapping sequence. The overall shape of these deltas are also strongly conditioned by the action of waves and the longshore drift along the coast.

The San Jacinto delta, and the neighboring Trinity delta in Chambers County, are considerably different in character from the Brazos and Colorado deltas. Here, the volume of sediment delivery has been outpaced by sediment removal. Despite the fact that tidal fluctuation in the Gulf of Mexico, and particularly in Galveston Bay, is extremely low, these deltas consists of a network of channels, ponds, marshes, and low, swampy floodplains that most closely resemble the tideinfluenced delta type (Chorley et al. 1984). While the implications of this morphology will be more thoroughly explored below in the discussion of the estuarine system, it can be stated that the removal of these sediments, and thus the long-term maintenance of the small deltas and the estuarine system, are probably related to periodic high-magnitude events rather than day-to-day processes.

Within a given delta, the character and distribution of facies is similar to those in the classic meandering stream model, although point bar facies are generally less important, while levee and overbank accretion are more important. Nevertheless, deltaic sediments are typified by spatial patchworks of relatively sandy channel-proximal deposits and muddy floodbasin deposits. Such a pattern is well-expressed in the distribution of sandy and clayey facies of the Beaumont Formation on the geologic map of the district (see Figure 7), revealing its fluviodeltaic origin. As indicated above, avulsion is an extremely important component of delta growth. In addition to aggradation of the active channel, delta avulsion is facilitated by compaction, dewatering, and subsidence of inactive lobes. As a result of this lobate growth mechanism, chronostratigraphic relationships between various parts of a delta are more complex than they may first appear. While strongly wavemodified deltas may exhibit regular patterns (i.e., increasing sediment age with distance from the coast), the age of deposits does not increase steadily with depth or with distance from the coast in most delta environments. Rather, deposits associated with individual lobes are liable to be quite thick and localized, yet represent a limited span of time.
Thus far, the discussion has focused primarily on the suite of contemporary deposits and landforms formed by fluvial processes. Most of these deposits are in temporary storage, and are destined to be re-entrained and moved further toward the sea by the stream. Occasionally, intrinsic adjustments or extrinsic factors can cause a stream to cut down, abandoning former floodplain surfaces and decreasing the probability that the sediments will be reentrained by the stream. Landforms created by such incision are termed alluvial terraces. However, the relationship between terrace surfaces and the number of discrete alluvial fills present is not particularly straight-forward because (1) incision or the influence of more than one flow regime can result in the development of more than one terrace surface in a single fill, and (2) overtopping of an older fill by a subsequent one can create a single surface underlain by multiple fills. Occasionally, multiple episodes of valley incision can create flat benches carved from bedrock termed bedrock straths. Strath surfaces underlain by alluvium (alluvial straths) can also be created by multiple episodes of incision. In the study area, alluvial terrace development is extremely limited. The only significant extant terrace surfaces in the major valleys are of Late Pleistocene age (i.e., surfaces developed on the Deweyville and Beaumont fills). There is clear evidence that even these old surfaces are buried by more recent alluvium in places, particularly in the Brazos valley. While it is possible that Holocene terrace surfaces were once present, any such surfaces are now buried at a variety of depths in the Holocene valley fills. The primary reason for the lack of Holocene terraces is the influence of sea level rise on alluvial activity in the outer coastal plain.

The role played by eustatic base-level control in the morphology of the modern systems is extremely important. As sea water was bound in the continental ice sheets during the Pleistocene, mean sea level fell more than $100 \mathrm{~m}$. As a result, the shoreline shifted seaward and streams in the coastal reaches entrenched into bedrock as their gradients adjusted to the lower base level. In the case of the Brazos and San Jacinto rivers, lateral migration during this episode of downcutting carved out relatively broad valleys. However, in the case of many of the smaller streams and bayous in the district, this downcutting fossilized what was originally a freely meandering system into one in which lateral migration was highly constrained. Many of the 
smaller streams in the district are entrenched in narrow "bedrock" valleys that exhibit a relatively low-amplitude meandering pattern reflecting the Late Pleistocene hydrologic regime.

As sea level rose through the Early and Middle Holocene, it stimulated backfilling of the incised valleys. Alluvial and deltaic deposits in the lower valleys were overridden by marine and estuarine deposits (Aten 1983; Kibler et al. 1996), while those inland were successively buried by younger deposits as sea level rose. Although the rate of sea-level rise was not constant, and there were probably limited periods of stability and minor regressions during the Holocene, the dominant trend of rapidly rising base level suggests that Late PleistoceneLate Holocene valley fill sediments should exhibit stacked architecture. This is broadly consistent with the stratigraphic relationships that have been recognized in alluvial deposits in the region (Chapter 4).

The potential for alluvial deposits to preserve archeological materials is dependent on a number of factors, including: (1) character and depositional energy represented by the deposits, (2) rate of burial, (3) the chemical and biotic environment, and (4) susceptibility to post-depositional disturbance. Relatively high energy fluvial deposits, including channel lag, lower point bar, and chute bar deposits in meandering stream systems, have relatively low potential to contain cultural materials in good context. This is true because the energy conditions that prevailed during deposition were generally high enough that cultural material would have been reworked, and the depositional environments represented are not particularly attractive for occupation. Thus, sites are unlikely to have formed in these environments in the first place, and any that did form would probably not have survived burial in reasonable context. In addition to high energy deposits, which are characteristically coarse-grained, care should be exercised to identify truncation surfaces resulting from erosion during high magnitude flow. In many cases, such scour surfaces may not be associated with coarse clastic deposits, but the context of any archeological materials resting on such surfaces must still be considered highly suspect.

Moderate energy environments, in contrast, can provide the best potential for site preservation in meandering stream settings. These environments, including upper point bar, levee, crevasse splay, and some proximal flood basin settings, represent relatively well-drained, stream proximal settings that were frequently attractive localities for prehistoric peoples. They are also characterized by deposits that were often laid down under fairly energetic conditions, and archeological materials stratified in such deposits can often exhibit moderate to severe taphonomic modifications that alter or disrupt their spatial integrity (e.g., size sorting, removal of small and light materials, reworking of heavier materials through limited transport). In other cases, energy conditions were not as extreme and such biases do not occur or are not particularly pronounced. Moreover, in many cases high rates of sediment supply in these settings can quickly bury occupations, minimizing the potential for destructive reworking during burial. Thus, evaluation of such settings requires detailed investigations of each site, with particular focus on the character of its matrix.

Certain bedforms, particularly climbing ripple laminations, are indicative of high rates of sediment delivery, but in many (if not most) cases, such bedforms are poorly preserved due to post-depositional modification. Patterning in the distribution of archeological materials is frequently taken as evidence of integrity, but care must be exercised as transport of artifacts on vegetated surfaces can result in deposition of diverse materials in the lee of flow restrictions such as trees and clumps of grass, and size sorting is not always apparent, particularly if the materials are being exhumed by flood-induced erosion upstream (and thus released into the bedload incrementally) (Lintz et al. 1992).

From the perspective of burial energy, environments away from the channel, including distal flood basins and channel plugs, represent the settings where the original spatial relationships between artifacts are least likely to be altered. However, because burial occurs so slowly, and because the rates of pedogenic and biotic alteration of the deposits are correspondingly higher (sometimes dramatically so), the overall preservation potential of such deposits is frequently lower than it is in moderate energy settings. Moreover, in many systems, such settings are distinctly less attractive for habitation because they are often wet and muddy. On the other hand, fine-grained matrices (particularly dense clay) can frequently enhance preservation of fragile or chemically susceptible artifacts like bone and other organic materials. Therefore, while these settings have somewhat lower potential than the stream-proximal settings, they do have substantial 
archeological potential and should not be ignored during site prospection.

In general, alluvial deposits have very high potential to contain archeological sites in good, interpretable context. However, finding and investigating sites in such settings requires a considerable investment of time and resources. While exceptions can be cited, surface survey and shovel testing is generally not an effective mechanism to locate sites in such settings. Rather, identification of buried alluvial sites requires detailed cutbank examination and an intensive program of machine-aided subsurface prospection. Such a program is best accomplished if the investigator possesses a good working understanding of the architecture and stratigraphy of deposits underlying the floodplain and terraces in the particular system of interest. While much work remains to be done, Chapter 4 outlines preliminary stratigraphic models for a variety of the streams in the Houston District.

\section{Eolian Processes and Landforms}

Eolian processes involve the action of wind as an agent of transport. Wind primarily affects clasts ranging from coarse sand-sized to clay-sized; gravels (and gravel-sized clasts such as artifacts) are not entrained, but may be concentrated as a residual lag as fines are removed. As with water transport, eolian clasts are transported in the bed load (termed surface creep in eolian processes), saltation load, and suspended load. Many authors (e.g., Pye 1987; Lancaster 1995) draw a distinction between the load in short-term suspension, which is held in the air column by turbulence at low altitude and may travel tens or hundreds of meters, and the load in longterm suspension, which is lofted high in the air column and can be held in suspension for hundreds or thousands of kilometers. The size grades comprising the suspended, saltating, and surface creep fractions are finer and narrower than in fluvial processes due to the lower density of the transport medium, and sorting of eolian deposits is typically much better than it is in even well-sorted alluvial deposits. One distinction between eolian and fluvial processes is that there is no dissolved load associated with eolian transport. Another key difference between eolian processes and fluvial processes is that while flow vectors in a stream are highly constrained by gravity and topography, wind direction (and thus the vector of eolian sediment transport) can and commonly does change radically in a short span of time. Consequently, while alluvium is either moving towards the sediment sink at the stream's mouth or in temporary storage, eolian deposits can move across the landscape in a variety of directions, often changing direction radically or reversing course. This is important because it means that eolian sediments, unlike alluvial sediments, can move perpendicular to or against the prevailing slope. As a result of multiple vectors of transport, eolian deposits frequently develop complex internal architecture and a wide variety of cross-cutting strata.

Eolian deposits can be conveniently divided into those dominated by sands, which are formed primarily by localized transport of the traction load and often develop distinctive bedforms, and those dominated by silts, which are formed by long-distance transport of the suspended load and typically settle out of the air column gradually, forming massive, uniform blankets across the landscape. In both cases, eolian transport and deposition requires two key variables: (1) winds of sufficient power to entrain and transport sediment; and (2) a source of erodable sediment to entrain. Of these, the latter is the primary limiting factor for eolian activity in the Houston District.

Eolian entrainment occurs because wind exerts a tractive force on the ground surface, much as moving water exerts a tractive force on the bed of a stream. This force has two components: a lateral (translational) force and a vertical (lifting) force. The magnitude of this lifting force is a function of wind velocity, air density, and the degree of surface roughness. No matter what the ambient wind velocity, wind speed falls off to zero at some small height above the surface due to friction effects. Bagnold (1941) demonstrated that this height is approximately $1 / 30$ th of the mean diameter of the largest particles resting on that surface. Vegetation also disrupts wind in the nearsurface layer, breaking the vector of flow into a series of eddies and vortexes and diminishing the shearing and lifting forces necessary for entrainment. Thus, continuous vegetative cover effectively eliminates the potential for eolian entrainment, and surfaces mantled with a discontinuous cover of large clasts or discontinuous clumps of vegetation can still be effectively armored against eolian deflation. On the other hand, partial vegetative cover is no guarantee that eolian transport will not occur; Wasson and Nanninga (1986) demonstrate that eolian entrainment and transport can occur in areas with up to $45 \%$ ground cover. 
In addition to an absence of ground cover, soil moisture conditions must be low for transport to be initiated. Eolian deflation requires that the exposed sediments are dry, or nearly so. Because of the attractive force imparted by surface tension, moisture content increases interparticular attraction considerably. For example, medium sands with a moisture content of $0.6 \%$ require winds of twice the velocity to be entrained as dry sands of the same size, while sands with a moisture content of more than 5\% are essentially immune to entrainment by natural winds (Lancaster 1995). Therefore, in order for appreciable eolian activity to occur, the landscape must include a significant number of patches of bare, dry ground. However, even if soil moisture is abundant, sustained wind across a bare surface will tend to desiccate and erode the upper few millimeters of the surface.

Sand transport by wind is dominated by saltation, which accounts for more than $80 \%$ of sediment movement in a sandy system. Surface creep, including grains moved directly by the wind and grains moving by reptation (impacts imparted by saltating grains), accounts for less than $20 \%$ of movement. As with fluvial processes, grains in the very fine sand range are the most readily entrained by eolian processes. As grain size increases, increased mass and friction require increasing wind speed for entrainment, until the resistance of the grains exceeds the force imparted by natural winds in the fine gravel size range. As grain size decreases, the cohesive properties of the sediments make entrainment increasingly difficult. However, because saltating grains impart considerable energy as they return to the surface, abrasion by saltating sand grains is one of the most important mechanisms for breaking down and entraining eolian dust. In fact, it is difficult to entrain silts and clays at all unless sand-size clasts (or aggregates) are also present at the source to break the cohesive bonds through abrasion (Paton et al. 1995). The energy imparted by saltating grains is also commonly transferred to other sand grains, causing them to saltate or reptate in turn. For this reason, the threshold velocity necessary to initiate eolian transport (the fluid threshold) is greater than the velocity necessary to maintain transport once it has begun (the impact threshold) (Figure 14).

At present, appreciable eolian sand transport in the Houston District is limited to the coastal zone,

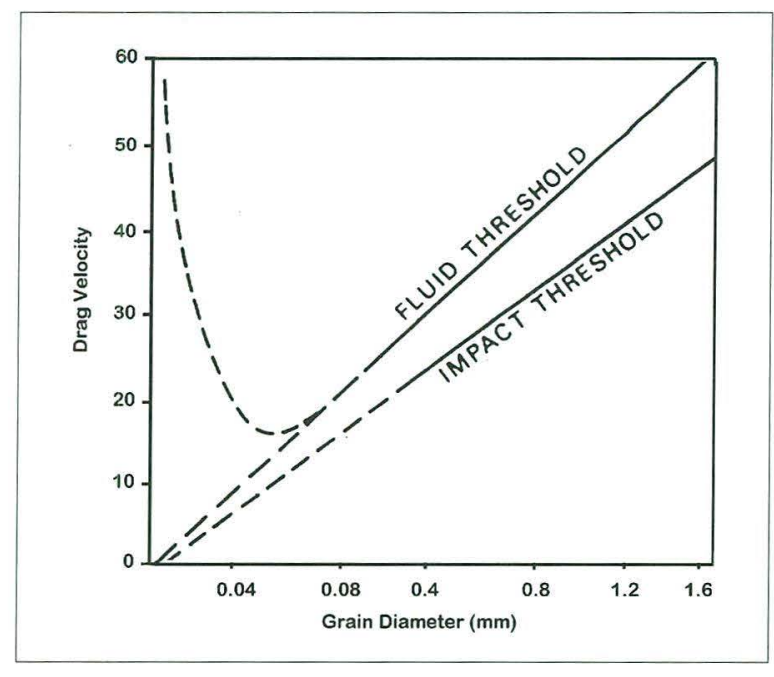

Figure 14. Relationship between wind drag velocity and grain size in eolian erosion, transport, and deposition. The fluid threshold is the velocity necessary to initiate transport, while the impact threshold is the velocity necessary to maintain transport.

where it primarily represents reworking of littoral sediments deposited on the beaches of Galveston Island, the Bolivar Peninsula, and the Brazos Delta. Unlike areas farther down the coast like Mustang Island and Padre Island, large sand dunes are rare on Galveston Island and the Bolivar Peninsula. Because the conditions are similar, the lack of established dunes on Galveston Island probably represents periodic destruction of incipient dunes by overwash and other storm processes, although historic period human modification probably also played a role (Morton and McGowen 1980).

Observations made in other parts of the district suggest that sand movement and dune formation has occurred elsewhere at various times in the past. Probable eolian sand deposits, now completely vegetated and lacking in surface expression, are present locally on the high terraces of the San Jacinto River, and have been noted on upland margins of several streams (e.g., Heinrich 1986a, 1993; Mandel 1987; Aronow 1991; Waters and Nordt 1996; Roger Moore, personal communication, 1997). Because the floodplains are normally wellvegetated, these deposits probably formed during periods of rapid floodplain aggradation when unvegetated alluvial flats served as sediment sources. The author has also observed localized thin sandy mantles in several upland locations inland of the Beaumont Formation. The source of these 
sands is less clear, but may relate to either longerdistance transport of sands from alluvial systems or local devegetation, perhaps resulting from fires, that exposed relatively sandy upland soils to erosion. It is also possible that some of these eolian sediments represent historic mobilization resulting from logging clearance, particularly in Montgomery County where outcrops of the Willis Formation provide a ready source of sand. Also, Aronow (1994) has noted the presence of hundreds of broad depressions, often flanked with low ridges, on detailed ( $1 \mathrm{ft}$ contour), early 20th century maps of terrain underlain by the Lissie Formation. Although he notes that almost all of these features have since been destroyed by agriculture, Aronow interprets these depressions and adjacent rims as eolian blowouts and associated flanking dunes.

Although they are probably relatively localized, eolian sand deposits should usually be readily recognizable because they differ so strongly from most deposits in the Houston District. However, largely because of the very strong emphasis on pedogenic processes over external controls typical of the USDA-SCS methodology, many of these possible eolian mantles are mapped simply as soils with thick E-horizons, and have only recently been recognized as unconformable mantles (Aronow 1992; Heinrich 1993; Waters and Nordt 1996). A more elusive and potentially more archeologically important question relates to the presence, extent, and thickness of finer-grained eolian mantles on the upland landscape. Because the uplands in the Houston District predate the Holocene, they are generally assumed to represent relatively stable surfaces that have witnessed little deposition during the culturally relevant period. If this is true, then the potential for archeological integrity in such settings is limited. However, some authors (e.g., Frederick 1991; Heinrich 1993) have suggested that remnants of a relatively extensive, fine-grained eolian mantle may be preserved in the Houston area. If so, and if the age of this mantle is Holocene, then the potential for preservation of sites predating and contemporaneous with deposition of the eolian cover is considerably enhanced. This possibility is addressed in Chapter 4.

The most obvious sources for high volumes of fine sandy to silty eolian deposits are the coastline, the broad valley of the Brazos River, and the Holocene Brazos delta. Although the Brazos system is currently heavily vegetated, it may have been an important source of eolian sediment at various times in the past. This is particularly true of those periods when sea level was rapidly rising, and thus causing the Pleistocene valley to backfill rapidly. With its broad valleys and expansive delta, such a rapidly aggrading system could have supplied ample amounts of sparsely vegetated sediment for eolian entrainment, as could the Colorado River valley to the west. However, contemporary data on wind speed and direction from Houston (Larkin and Bomar 1983) suggest that westerly and southwesterly winds above 10 knots, which would be required to entrain and distribute eolian sediments from the Brazos across the district as a whole, are extremely rare in all seasons. The coast, which is the other obvious potential source, does experience frequent south winds that could move sediment inland. However, it is largely isolated from the mainland by the back-barrier lagoons, which would trap migrating eolian sands before they could reach the mainland. The coastal beaches may have been a more effective source of sediment in periods when sea level was rising rapidly and the barrier islands and backing lagoons were poorly developed, in the period prior to about $4,000 \mathrm{BP}$, and the lagoon shore also supports small beaches that could yield sand. Finally, if the climate became arid enough to result in a reduction in overall vegetative cover, the Quaternary bedrock formations themselves (and particularly the relatively coarse Willis and Lissie units) could have served as effective eolian sediment sources through localized deflation (Aronow 1994). Large, intense wildfires could have had the same effect locally, allowing eolian processes to operate on the exposed substrate for short periods before the burned areas were re-vegetated.

Because they represent a relatively weak transport medium, sandy eolian deposits have strong potential to contain archeological sites in reasonably good context. Reworking of artifacts occurs primarily through erosion of the surrounding matrix, leaving the relatively large and heavy cultural material to settle. Although this deflation can result in changes to the planimetric distribution of artifacts, these changes are relatively minor compared to the movements that can occur with even relatively gentle flows of water. The primary problem with eolian deflation is that it destroys stratigraphic relations between artifacts. Therefore, a single component site that has been severely deflated and then reburied still has considerable archeological 
potential, but a stratified multi-component site that is deflated can contain commingled artifacts of several different periods on a single paleosurface. Such mixed assemblages can often be very difficult to identify, particularly if the frequency of timediagnostic artifacts is low, and almost impossible to interpret unless the questions asked refer to the entire prehistoric period.

One approach to the assessment of site integrity in sandy eolian settings is to pay attention to the hierarchy of bounding surfaces (Kocurek 1981) in the matrix, if evidence of such surfaces is preserved. Eolian deposition results in the formation of laminae and beds through three primary mechanisms: (1) climbing translatent strata, which are relatively lowangle laminae formed on the stoss (windward) face as sand migrates up a dune or in areas where dunes do not develop; (2) grainfall laminae, which are more steeply inclined and form as sand is deposited on the lee of a dune; and (3) grainflow cross-strata, which form as the lee face of a dune oversteepens and avalanching occurs (Lancaster 1995). Individual eolian beds are composed of packets of subparallel laminae that form during relatively constant conditions. Third order bounding surfaces are reactivation surfaces representing relatively minor discontinuities in depositional conditions (e.g., shortterm changes in wind strength or direction), and define the boundary between bedding sets. Second order bounding surfaces represent more protracted periods of local erosion and renewed deposition within an accreting bedform, and mark the boundary between bedding cosets. First order bounding surfaces are major discontinuities that represent the passage of migrating bedforms; they tend to be relatively parallel to the ground surface and are often overlain by interdune deposits (Kocurek 1981). Because the hierarchy of bounding surfaces reflect varying intervals of time, it follows that archeological materials contained within sets or resting on thirdorder and second-order bounding surfaces have a very high potential to represent materials in primary or semi-primary context, while materials resting on first-order bounding surfaces are likely to represent redeposited lag material, and should be carefully examined for evidence of assemblage mixing. Unfortunately, the preservation of eolian bedding appears to be rare in the district except in recent deposits along the coast. This paucity of preserved bedding strongly suggests that post-depositional disturbance, and particularly bioturbation, is a prevalent problem in eolian environments, and thus presents considerable complication to the interpretation of sites in eolian settings.

In conclusion, while thick eolian deposits appear relatively rare in the district, the extent and preservation of widespread eolian mantles is somewhat controversial. Moreover, even if proven to exist, the geoarcheological potential of such deposits is dependent on their age and on the degree of post-depositional disturbance that they have experienced. Because the potential for site burial decreases, and the potential for extensive turbation increases, with sediments of increasing age, the potential of thin mantles more than a few thousand years old is probably limited. In contrast, the potential of relatively thick eolian deposits, particularly along the coast and on the margins of many of the local streams, is relatively good.

\section{Colluvial and Mass Movement Processes and Landforms}

Mass movement processes encompass those physical mechanisms where sediment is moved downslope under the primary influence of gravity. These processes can be differentiated on the basis of speed of movement, integrity of the moving mass, and degree of lubrication involved. Table 5 lists the major categories of mass movements, their integrity, speed, and lubrication characteristics, a generalized assessment of the potential for the preservation of archeological integrity within resultant deposits, and the potential relevance of the process to the Houston area.

Slope failures such as rockfall, block topple, block glide, spreading, and cambering are typical of consolidated bedrock slopes, particularly where inclined bedding is present, and are relatively unimportant in the Houston area. Debris topple is similar to block topple, in that a block of cohesive material detaches from the face of a steep slope and cants slowly outward until a sudden, catastrophic failure occurs. However, the material involved in a debris topple is unconsolidated sediment that has typically been undercut, as in alluvium on the outside of a meander bend. Rotational failures or slumps are extremely common mass movements that occur at a variety of scales in unconsolidated sediments and, occasionally, in weakly lithified and poorly bedded rock. They involve one or more failures along a 
Table 5. Characteristics and geoarcheological potential of mass movements.

\begin{tabular}{|c|c|c|c|c|c|c|}
\hline \multicolumn{2}{|c|}{ Type of Failure } & Speed & Lubrication & $\begin{array}{l}\text { Integrity of } \\
\text { moving } \\
\text { mass }\end{array}$ & $\begin{array}{c}\text { Geoarcheological } \\
\text { Potential of } \\
\text { Deposits }\end{array}$ & $\begin{array}{l}\text { Applicability to } \\
\text { the Houston Area }\end{array}$ \\
\hline \multicolumn{2}{|l|}{ rock fall } & very rapid & none & high & none & low \\
\hline \multicolumn{2}{|l|}{ block topple } & very rapid & none & high & none & low \\
\hline \multicolumn{2}{|l|}{ block glide } & $\begin{array}{l}\text { moderately } \\
\text { slow to rapid }\end{array}$ & $\begin{array}{c}\text { frequently none; } \\
\text { facilitated by } \\
\text { water }\end{array}$ & high & low & low \\
\hline \multicolumn{2}{|c|}{ spreading, cambering, sacktung } & slow & $\begin{array}{c}\text { frequently none; } \\
\text { facilitated by } \\
\text { water }\end{array}$ & high & none & low \\
\hline \multicolumn{2}{|l|}{ debris topple } & $\begin{array}{l}\text { rapid to very } \\
\text { rapid }\end{array}$ & none & high & low & $\begin{array}{l}\text { moderate } \\
\text { (localized) }\end{array}$ \\
\hline \multicolumn{2}{|l|}{$\begin{array}{l}\text { rotational } \\
\text { failure } \\
\text { (slump) }\end{array}$} & $\begin{array}{l}\text { moderately } \\
\text { slow to } \\
\text { moderately } \\
\text { rapid }\end{array}$ & $\begin{array}{c}\text { frequently } \\
\text { facilitated by } \\
\text { water }\end{array}$ & $\begin{array}{l}\text { moderately } \\
\text { high to high }\end{array}$ & low to moderate & moderately high \\
\hline \multicolumn{2}{|l|}{ landslide } & $\begin{array}{l}\text { rapid to very } \\
\text { rapid }\end{array}$ & air cushion & low & low & moderate \\
\hline \multicolumn{2}{|l|}{ mudslide } & $\begin{array}{l}\text { rapid to very } \\
\text { rapid }\end{array}$ & some water & low & low & moderate \\
\hline \multicolumn{2}{|c|}{ rock avalanche } & slow & ice & high & low & none \\
\hline \multicolumn{2}{|l|}{ earthflow } & $\begin{array}{l}\text { moderately } \\
\text { rapid to rapid }\end{array}$ & some water & very low & low & moderate \\
\hline \multicolumn{2}{|l|}{ mudflow } & $\begin{array}{l}\text { moderately } \\
\text { rapid to rapid }\end{array}$ & water & very low & low & moderate \\
\hline \multicolumn{2}{|l|}{ debris flow } & $\begin{array}{l}\text { moderately } \\
\text { rapid to rapid }\end{array}$ & water & very low & low & moderately low \\
\hline \multirow{4}{*}{ soil creep } & shrink/swell & very slow & water & moderate & low to moderate & high \\
\hline & rainsplash & very slow & $\begin{array}{l}\text { water; raindrop } \\
\text { impacts }\end{array}$ & low & high & high \\
\hline & bioturbation & very slow & $\begin{array}{c}\text { none; may be } \\
\text { reworked by } \\
\text { other processes }\end{array}$ & low & $\begin{array}{l}\text { moderately high to } \\
\text { high }\end{array}$ & high \\
\hline & viscous flow & $\begin{array}{l}\text { very slow to } \\
\text { slow }\end{array}$ & some water & $\begin{array}{c}\text { moderate to } \\
\text { high }\end{array}$ & $\begin{array}{c}\text { moderate to } \\
\text { moderately high }\end{array}$ & moderate to high \\
\hline \multicolumn{2}{|l|}{ solifluction } & slow & $\begin{array}{c}\text { saturated soil } \\
\text { over permafrost }\end{array}$ & moderate & low & none \\
\hline
\end{tabular}

curved cleavage plane, causing the upper surface to tilt down and back away from the scarp, while the lower part rotates out and up. Frequently, the lower part of a rotational failure loses integrity and converts to a slide or flow (Figure 15).

Speed is one characteristic by which mass movements are frequently classified. Movement is typically divided into those processes that are readily observable by a person watching and those that occur over protracted periods and are thus imperceptible. Rapid mass movements may be instantaneous (e.g., a vertical rock fall) or occur over periods of a few minutes to a few hours (e.g., landslides, debris flows, rotational failures). Incremental processes (e.g., soil creep, solifluction) may occur relatively continuously or discontinuously, but require long periods before 


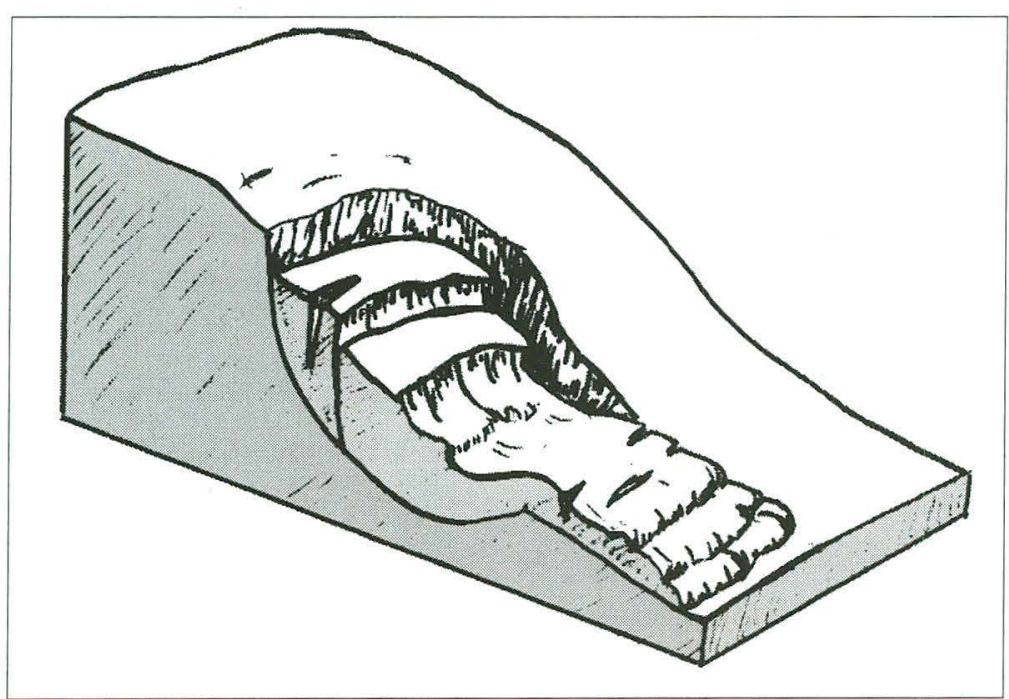

Figure 15. Schematic illustration of a typical rotational failure. Note that the lower part of the failure has lost integrity and begun to flow. particularly in block topples and rotational failures, but this integrity tends to break down as the failure progresses. Mass movements that behave like plastic solids (some flows, solifluction, some types of soil creep) have somewhat less integrity, but are far surpassed by mass movements that act as viscous liquids (e.g., debris and mud flows) or as collections of independently moving solids (e.g., landslides, creep by individual particles on slopes).

The type and degree of lubrication involved also serves to differentiate types of mass movement. The most common lubricating agent is water, which is why

the effects can be noticed. In some cases, rapid mass movements can be preceded by protracted periods of incremental movement that gradually shift the mass to a point where catastrophic failure occurs. One well-documented example is the gradual movement of Threatening Rock, which collapsed onto Pueblo Bonito in Chaco Canyon National Monument in January 1941. Concerned that the rock would fall and damage the monument, the park caretaker collected data that demonstrated an exponential increase in the rate of movement for eight years before the rock fell. Significantly, the rock was perceived as a threat and braced by the original inhabitants approximately 1,000 years ago, suggesting that the fall of threatening rock was preceded by at least 2,000 years of slow movement as it gradually detached from the cliff face and canted outward (Chorley et al. 1984). While this type of spectacular rock fall is not characteristic of the Houston area, other types of catastrophic slope failure that are characteristic of the types of bedrock and soils in the area are also frequently proceeded by incremental movements, particularly bulging of slopes before rotational failures and flows (Selby 1993).

Integrity of the moving mass is another key variable that differentiates various types of mass movement. At one extreme, failure and detachment of individual rock masses in rock fall, block glides, and similar events represent movements with a high degree of internal integrity. Unconsolidated sediments can also move as integrated masses, so many mass failures occur during or after heavy storms. Water permeating into a sediment or along fissures and bedding planes in a rock tends to create hydrostatic pressure that decreases the frictional resistance to movement (the shear strength). At the same time, water also imparts considerable weight to a sediment, increasing the impetus for movement (the shear stress). If the content of water is high, then frictional resistance tends to break down entirely and the movement behaves as a flow (albeit with somewhat higher viscosity than pure water). Although water is the most common lubricant, some mass movements (e.g., rock glaciers) are facilitated by the presence of ice, while other rapid mass movements (e.g., landslides) may be buoyed by a cushion of air, decreasing frictional resistence and increasing their speed considerably (Selby 1993). However, in the Houston area, water is clearly the most important lubricating agent facilitating mass movements.

Although geomorphic texts often focus on the more awe-inspiring rapid mass movements (e.g., rockfall, landslide), in most cases the slow, incremental processes play a more important role on the evolution of the overall landscape and in the preservation and destruction of most archeological sites. These processes occur gradually over periods that are too long to be directly observed, but tend to affect much broader portions of the landscape. While the effect of rapid processes on archeological sites can clearly be considerable, it tends to be highly 
localized, while almost all sites are affected to one degree or another by incremental processes.

Incremental mass movement processes affecting unconsolidated sediment are generally subsumed under the rubric of soil creep. Soil creep, in turn, can be divided into processes that affect individual grains, and those that affect the soil mass as a unit (Paton et al. 1995). The mechanisms and impact of those processes that affect individual particles are relatively well-established. Rainsplash, for example, is a very important process on exposed slopes. Falling raindrops can impart considerable energy, particularly if they are large, and are capable of detaching particles and splashing them into the air. In fact, rainsplash erosion can move considerable amounts of sediment on susceptible slopes; Chorley et al. (1984) report a maximum rate of $2.6 \mathrm{~cm}^{3}$ per $\mathrm{cm}^{-1}$ year ${ }^{-1}$ in the American Southwest. The evidence of rainsplash erosion is often easy to see, both in the form of mineral particles adhering to plants, rocks, or buildings well above the ground surface (Paton et al. [1995] report observing such particles up to half a meter above the ground surface following a rain), and in the formation of small "pillars" of sediment capped by resistant clasts. Rainsplash results in net downslope movement because detached particles follow a parabolic arc returning to earth, and those moving downslope tend to travel farther than those moving upslope. Mosley (1973) performed experiments that showed that on a $5^{\circ}$ slope, $60 \%$ of the material moved by raindrop impact traveled downslope. Therefore, over time, raindrop impacts alone can have a considerable cumulative effect. However, raindrop impacts do not occur in isolation, because at least some of the incident water is quickly converted to runoff (unconfined surface wash). As discussed above, overland flow can also lead to substantial erosion. Chorley et al. (1984) argue that because overland flow alone quickly loses effectiveness as the loose surface particles are removed, raindrop impacts play a major role in detaching grains and making them available for transport.

Another process responsible for soil creep is heave, which can operate either on individual grains or on consolidated masses of sediment. Heave is the result of small-scale expansion/contraction processes resulting from freeze/thaw cycles or hydration and dehydration of expansive clays (Ritter 1978). In the expansion phase, particles are lifted roughly perpendicular with the surface, while in contraction they settle more or less vertically. If the surface is inclined, this process results in a small net movement downslope. The effectiveness of heave remains somewhat controversial, largely because it is difficult to isolate from the effects of granular creep and bioturbation so that meaningful observations and measurements can be made. Still, the contribution of heave processes to overall soil creep will clearly vary with climate (the frequency of freeze-thaw cycles) and with the mineralogical composition (i.e., the amount and type of expansive clay minerals) of the soil.

A final and even more controversial component of soil creep is slow downslope movement of the entire soil mass, sometimes termed continuous creep (Ritter 1978). Early investigators (e.g., Sharpe 1938) argued that evidence of continuous creep was abundant (e.g., displaced and curved trees, displaced posts, downslope bending of bedded rock, etc.), but alternative explanations have since been proposed for almost all of these phenomena (Finlayson 1985). Continuous creep is typically ascribed to slow plastic deformation resulting from loading pressures (i.e., weight of overburden), and some authors have argued that it does not truly reflect a form of gravitydriven mass movement (Paton et al. 1995). Nevertheless, these processes do result in plastic deformation within the soil, and can affect the spatial and stratigraphic relationships between artifacts.

Mass movements, and particularly the various forms of soil creep, are very important geoarcheological considerations because they affect most parts of the landscape, albeit at often imperceptible rates. Although the energy available for mass movement is imparted by the gradient of the slope, colluvial processes are not limited to steep parts of the landscape. Creep processes, in particular, can affect surfaces with very minor inclinations, such as the nearly level uplands in the Houston District. However, the rates of such processes are so slow that the potential for such deposits to contain archeological materials in reasonable context is negligible. In contrast, areas characterized by steeper slopes, such as the margins of the upland surfaces and in the more rolling topography inland in the district, are characterized by rates of mass movement that may affect archeological preservation and produce deposits that incorporate archeological materials.

Colluvium is the generalized term for slope deposits produced by mass movement processes, 
although in practice more specific terms are frequently used when deposits related to specific types of mass movement, and particularly to individual events, are recognized (e.g., landslide deposits). The potential for preservation by colluvial processes varies depending upon the position of the archeological site on the slope. Slopes have characteristic forms, and different segments (or facets) of a slope have varying preservation potential. Figure 16 illustrates common terminology used to describe slopes. As the figure indicates, the upper portion of slopes are predominantly erosional, midslopes are characterized by sediment transport, and the footslope and toeslope is characterized by sediment accumulation. Colluvial deposits tend to accrete on the lower portion of slopes as a wedge that thickens towards the base of the slope and then thins away from it. The geometry of these wedges varies with the geometry of the slope break, the angle of the slope, the textural characteristics of the colluvial deposits, and the character of vegetation. Although the term colluvium is generally equated with mass movement, in reality it is impossible to separate the contribution of gravity-driven processes and slope wash processes to colluvial deposits.

The preservation potential of colluvial deposits depends upon the original position of archeological materials on the slope, the type of mass movement (and relative influence of wash processes) involved, the age of mass movement events relative to the age of the archeological materials, and the degree of post-depositional alteration. In some situations, artifacts originally deposited on the slope are transported downslope as individual clasts and incorporated into colluvium at the toeslope. In these cases, the artifacts are in secondary context and have relatively low research potential in most cases. However, it is also possible for artifacts to be displaced downslope by mass movements with relative integrity, such as a rotational failure, so that the spatial arrangement between a suite of artifacts and features is preserved, albeit at a position on the slope other than where they were originally deposited. In these cases, the research potential of such deposits may remain relatively high, even though they have been subjected to significant displacement. Although such situations are rare, it is important to recognize that any such strata are likely to be inclined rather than level and design an excavation strategy accordingly.
Artifacts deposited at the base of a slope may be covered with colluvium laid down at a later point in time, incorporated into penecontemporaneous deposits, or rest on older colluvial deposits. The integrity of such archeological materials depends upon the rate of colluviation; very rapid mass movements impart considerable energy and are likely to disrupt cultural patterning severely, while very slow colluviation allows an artifact assemblage to remain exposed and subject to disturbance for a long time. Thus, the highest potential for preservation exists in areas where the rate of colluvial deposition is moderate.

After burial, colluvial deposits are subject to the same types of post-depositional alteration that affect other deposits. For this reason, and because the style of colluviation affects the potential for preservation, it is important to assess that context carefully and critically. Therefore, while colluvial deposits have good potential to contain archeological materials in reasonable context, archeological materials contained therein must be carefully evaluated to assure that the integrity of deposits is adequate to support any conclusions that are drawn.

\section{Shoreline Processes and Landforms}

A wide variety of processes are responsible for the creation and modification of coastal deposits. Construction and modification of the beaches and barrier islands is primarily the result of littoral processes, which operate along the shoreline, and neritic processes, which operate between the low tide line and the shelf margin (up to about $200 \mathrm{~m}$ depth). Important processes include longshore transport of sand in the swash zone and immediately offshore, eolian processes in the supratidal zone, tidal deltaic deposition created by water exchange between the Gulf and the lagoon, bioturbation by organisms, and storm processes. Eolian processes have been addressed previously in this chapter, while tidal deltaic sedimentation and bioturbation will be addressed later in the sections on lagoons and estuaries and disturbance processes. This section focuses on the remaining coastal processes.

The long-term development of any particular coastline is a function of a number of factors: trends in eustatic sea-level change, local isostatic adjustments along a coastline, the amount and character of sediment delivery, autocompaction of 


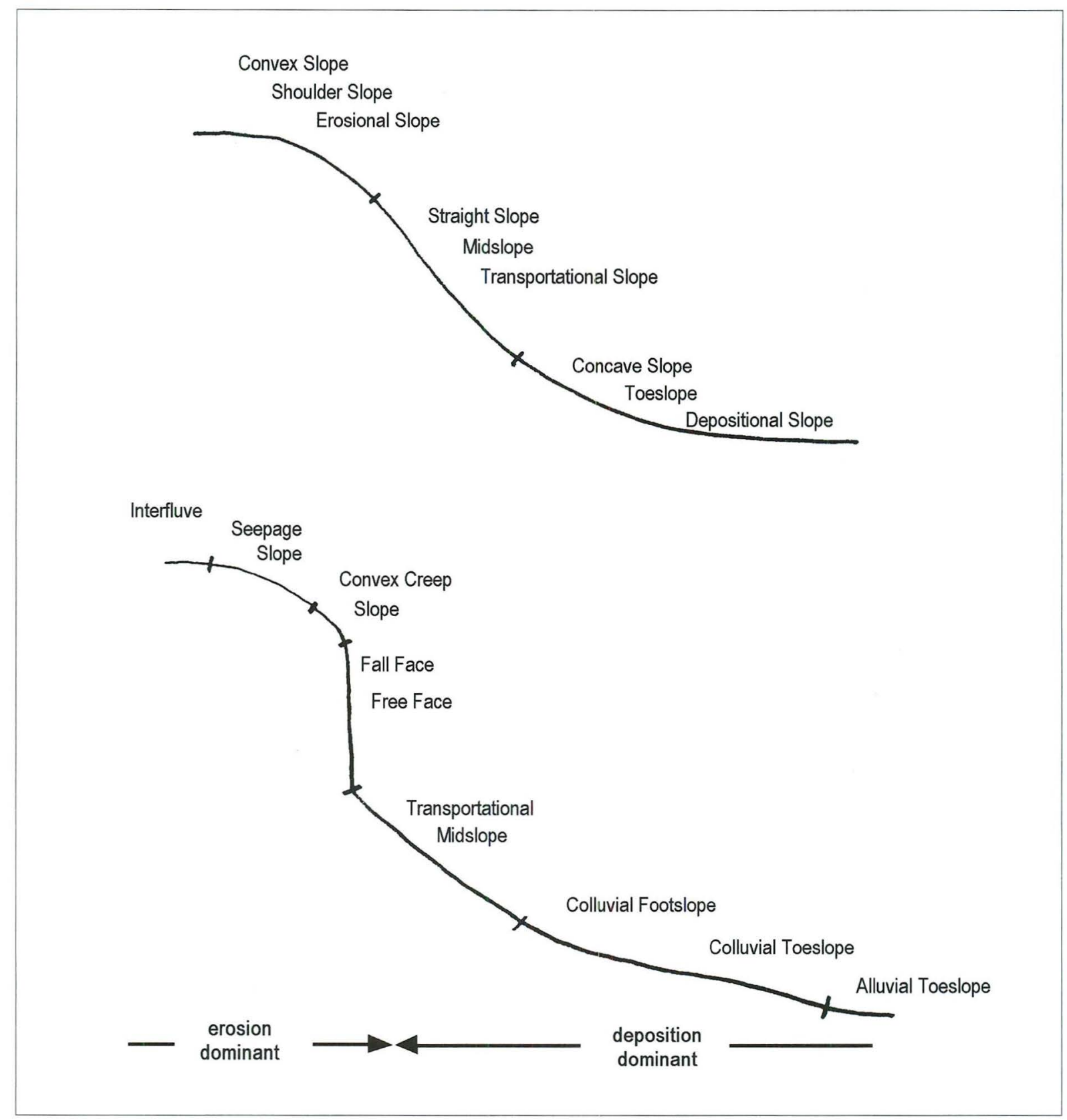

Figure 16. Illustration of slope terminology and loci of erosion, transport, and deposition in a slope system.

coastal sediments, tectonic uplift or subsidence, the character and resistance of coastal bedrock, character and direction of wave energy, frequency and intensity of storms, and the existing morphology of the coast and continental shelf. Over an intermediate scale $\left(10^{3}\right.$ to $10^{4}$ years), coastlines may be either stable (stationary), transgressive (migrating landward), or regressive (migrating seaward). The development of the Texas Gulf Coast, with its characteristic string of long barrier islands, reflects the influence of a number of factors, including a broad, shallow shelf, variable sediment input from the different streams feeding into the Gulf along the Texas coast, the extremely high rates of sediment influx delivered by the Mississippi River, and the trends in Late Pleistocene/Holocene sea level rise (LeBlanc and Hodgeson 1959). Of these, the most important single factor is the character of sea level rise. Figure 17 illustrates trends in sea level along the Gulf coast as reconstructed by three different 


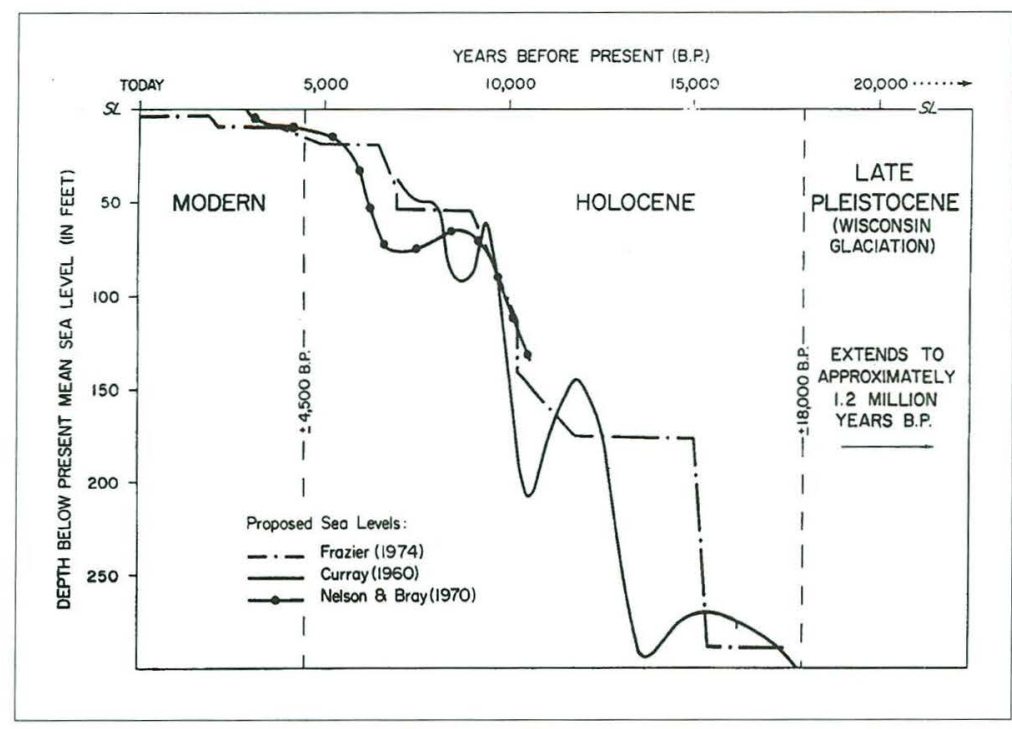

Figure 17. Reconstructed sea-level curves from the Texas Gulf coast, from Morton and McGowen (1980).

researchers. While there are differences in the details, all three reconstructions agree that sea level rose rapidly from the last Full Glacial (roughly 18,000 BP) to the Middle Holocene (roughly 5,000 $\mathrm{BP})$, then slowed markedly during the last five millennia. As sea level rose rapidly in the Late Pleistocene and Early Holocene, the coastline advanced rapidly inland, drowning the lower valleys of rivers feeding into the Gulf, and transgressive bars developed along the coastline. At the same time, estuarine deltas developed at the mouths of the rivers feeding into the Gulf, and larger streams such as the Brazos and Colorado began to prograde, infilling their estuaries. As sea level began to stabilize about 5,000-6,000 years ago, the transgressive bars stabilized and began to grow upward and outward, creating the modern barrier islands. In contrast to the models presented in Figure 17, several other investigators working farther down the Texas coast have identified evidence indicating that sea level may have risen as much as $2 \mathrm{~m}$ above its current elevation during the Middle to Late Holocene (Paine 1987b; Aronow et al. 1994; Michael Blum, personal communication, 1999). If true, this highstand would have affected the character of the coastal habitat, and should be reflected in the location of sites from the interval.

The coastline of the Houston District is dominated by the barrier islands of Galveston Island and the Bolivar Peninsula (which is welded to the mainland, but formed in the same manner as the other Texas barrier islands), and the coastal part of the Brazos alluvial delta. The following summary of barrier island morphology and dynamics is derived primarily from Hayes (1967), Scott et al. (1969), Andrews (1970), Leatherman (1979), Morton and McGowen (1980), Morton (1988), Suter et al. (1989), and Morton (1994). The barrier island complexes of the Texas coast are composed primarily of medium to fine sand with interbedded lenses of marine shell overlying interbedded sand, silt, and clay deposits laid down in the former lagoon during the period of rapid transgression prior to $6,000 \mathrm{BP}$. In most stable to regressive barrier islands, including Galveston Island and the Bolivar Peninsula, phases of growth are marked by a series of subparallel accretional ridges. Coring and radiocarbon dating of Galveston Island by the Bureau of Economic Geology at The University of Texas at Austin (Bernard et al. 1970) suggests that the island has accreted incrementally seaward over the past 6,000 odd years (Figure 18).

The dominant mode of barrier island growth is accretion of the beach and shoreface, which occurs as sediment is introduced by longshore drift and welded to the shoreface. At the same time, barrier islands also tend to grow in the direction of the longshore drift by spit accretion. The prevailing longshore drift in the Houston area is from the east, and some of the sand making up the barriers is ultimately attributable to the Mississippi River. However, most sand originates from the local river systems. In fact, the majority of sand movement in a barrier island system is cyclic and relatively localized; the barriers tend to build slowly upward and seaward during normal conditions, while storms tend to erode the shoreline and distribute the sand landward (into the lagoon) and seaward (across the inner shelf). Much of the sand that is washed across the barrier into the lagoon is also returned to the shelf by strong ebb tidal flow through the barrier inlets. Following storms, this shelf sand is gradually moved back into the shoreface by normal wave energy, reestablishing the beach. Coupled with sediment delivery by the streams and longshore 


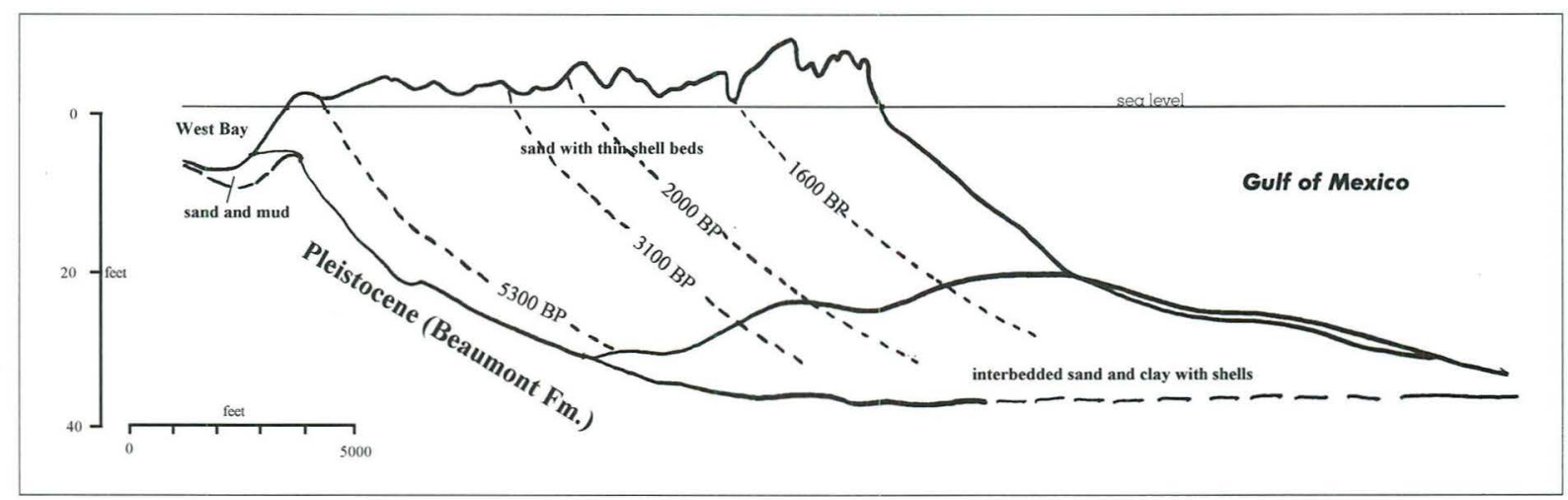

Figure 18. Cross-section of Galveston Island at 8 Mile Road, illustrating timing of accretion during the Late Holocene. Adapted from Bernard et al. (1970: Figure 52).

drift, this mechanism of beach accretion is responsible for the development of the series of sub-parallel accretion ridges that typify barrier island morphology.

Where dunes are developed, their best expression is typically immediately inland of the storm berm at the top of the beach, which represents the actively accreting ridge. Because the barriers are building up as well as out, this location is usually the highest point on the island, which dips gently back toward the lagoon behind the foredunes. While remnants of older accretionary ridges are usually apparent, the parts of a barrier island between the foredune ridge and the lagoon are typically modified by a variety of subsequent erosional and depositional processes.

Major depositional environments here include the barrier flats, wind tidal flats, and washover fans. Barrier flats are gently sloping, ramp-like surfaces that rise in elevation from the lagoon to the foredunes and storm berm. Most barrier flats have a corrugated texture due to the presence of the subparallel accretion ridges and swales, and are relatively densely vegetated. There may be marshy conditions and standing water in the swales, where aquatic plant taxa are common. The sediment matrix underlying most barrier flats on the Texas barrier islands consists of massive fine sands with root traces, rodent burrows, and thin shell lenses, suggesting that bioturbation is ubiquitous in the supratidal zone.

Wind tidal flats are also relatively flat surfaces, and are characteristic of the lagoonal side of the barrier island (as well as the landward side of the lagoon). These low-lying areas are poorly vegetated to barren and are inundated on a regular, cyclical basis by rainwater and wind-driven bay water. Be- tween episodes of wetting, they tend to desiccate and crack, and are subject to eolian reworking. Vegetation is poorly developed primarily because most plants cannot tolerate the moisture and salinity extremes characteristic of the sub-environment. Most wind-tidal surfaces are colonized by blue-green algal mats that are interbedded with thin sheets of sand and shell (derived from the barrier during storms), mud (derived from the lagoon during periods of offshore winds), and chemical precipitates such as carbonate. Biogenic gases produced by decaying algae and desiccation cracking frequently produce contorted bedding, while interbedded storm deposits tend to be thinly laminated and sandy.

Washover fans are unique features formed rapidly during individual storm events, although they are frequently reactivated and modified during subsequent storms. A washover fan forms when water piled up on the beach by an approaching storm breaches the storm berm and foredune chain (if one is present) and transfers sand to the back part of the island (Leatherman 1981). Washover breaches in the "crown" of the island (i.e., the highest elevation on the barrier, whether that be the highest storm berm or the foredune chain) tend to be relatively narrow, erosional channels, termed throats. Once the island crown is breached, sand carried through the washover throat by storm swash splays out across the barrier flat, forming a lobate sandy deposit that frequently contains a number of distributary channels termed sluiceways. In an established washover feature, these sluiceways generally lie at the approximate level of the water table and contain dense vegetation. If vegetation is sparse and overwash activation is frequent or intense, deeper (subaqueous) channels termed guts can result. Occasionally, 
a large washover fan will prograde completely across the island into the lagoon, forming a washover delta. If flow across the fan is directed by well-developed distributary network of sluiceways or guts, progradation into the bay may take the form of a series of overlapping, lobate washover deltas (Leatherman 1981). Figure 19 illustrates a relatively well-defined washover fan on Galveston Island.

Washover deposits were considered by Andrews (1970), who examined a relatively large $\left(7 \mathrm{~km}^{2}\right)$ feature on St. Joseph Island on the central Texas coast. This fan is composed of several superimposed fan deposits, each representing a single storm and consisting of an erosional unconformity mantled by a shell-rich layer that

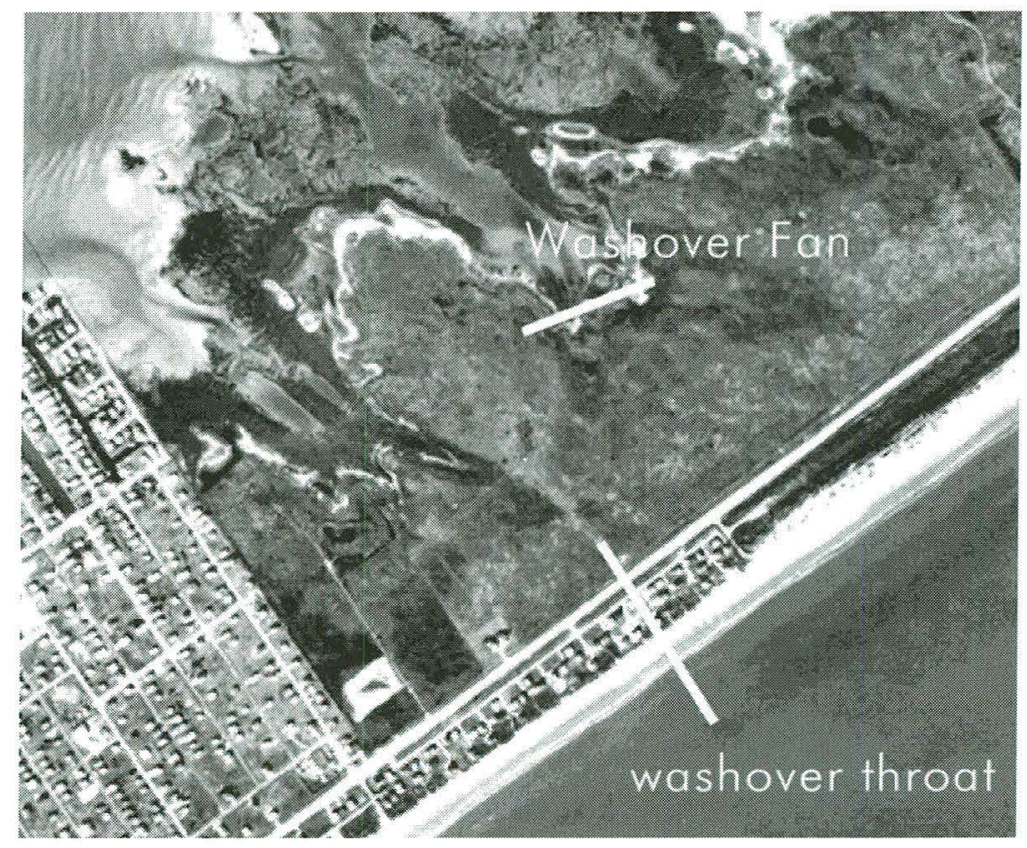

Figure 19. Aerial photograph of a moderately-sized washover fan on western Galveston Island. grades up into laminated sands.

The total thickness of the multi-generation fan was $125 \mathrm{~cm}$ at the center, grading to approximately 75 $\mathrm{cm}$ near the margins.

In contrast to the transgressive to stable barrier islands, the coastline along the Brazos/Colorado river delta has been markedly regressive during the postglacial period, filling the drowned valleys and prograding more than $25 \mathrm{~km}$ seaward since the Pleistocene low-stand. Nevertheless, the planiform shape of the Brazos delta is governed primarily by marine processes that rework the sediments delivered by the fluvial system, spreading them out along the coast. Consequently, the Brazos delta coast has a relatively smooth, convex outline that contrasts markedly with the fluvially dominated bird's-foot delta of the Mississippi River. This delta type is termed "high-destructive, wave-dominated" by Scott and Fisher (1969; Morton and McGowen 1980). Core studies of the modern Brazos delta lobe, which began forming in 1929 after the river was diverted from a previous course that emerged into the Gulf near Surfside, indicate that the delta exhibits a coarsening upward sequence that represents the transition from prodelta muds to reworked fluvial deposits (Bernard et al. 1970). Figure 20 illustrates changes in the modern Brazos delta front from 1933 to 1971. This figure illustrates how dynamic an environment the delta front is, and implies that the potential for preservation of archeological sites situated near the outlet is probably relatively poor because spurts of delta growth are rapidly attenuated by wave action. Away from the river mouth, the potential for preservation is better, but there is little evidence that the beach deposits on the margin of the delta are preserved with any predictability because of the constant reworking of the shoreface. The best potential for site preservation in this environment is in the overbank fluvial deposits laid down atop the delta as it progrades. Naturally, such sites are likely to be increasingly old with distance from the modern delta front.

Examination of Figure 18 reveals that there are also clear geoarcheological implications related to the barrier island deposits. Because the barriers did not stabilize and begin to prograde before about 5,000 to $6,000 \mathrm{BP}$, there is little to no potential for Paleoindian and Early Archaic sites in these environments, while the potential for older (i.e., Middle to Late Archaic) sites to occur should increase with distance from the modern shoreline. Moreover, because the dominant style of barrier island growth is through shoreface accretion, there is little potential for archeological preservation in most barrier island deposits. In contrast, there is moderate to good potential for archeological materials to be contained in the supratidal deposits 


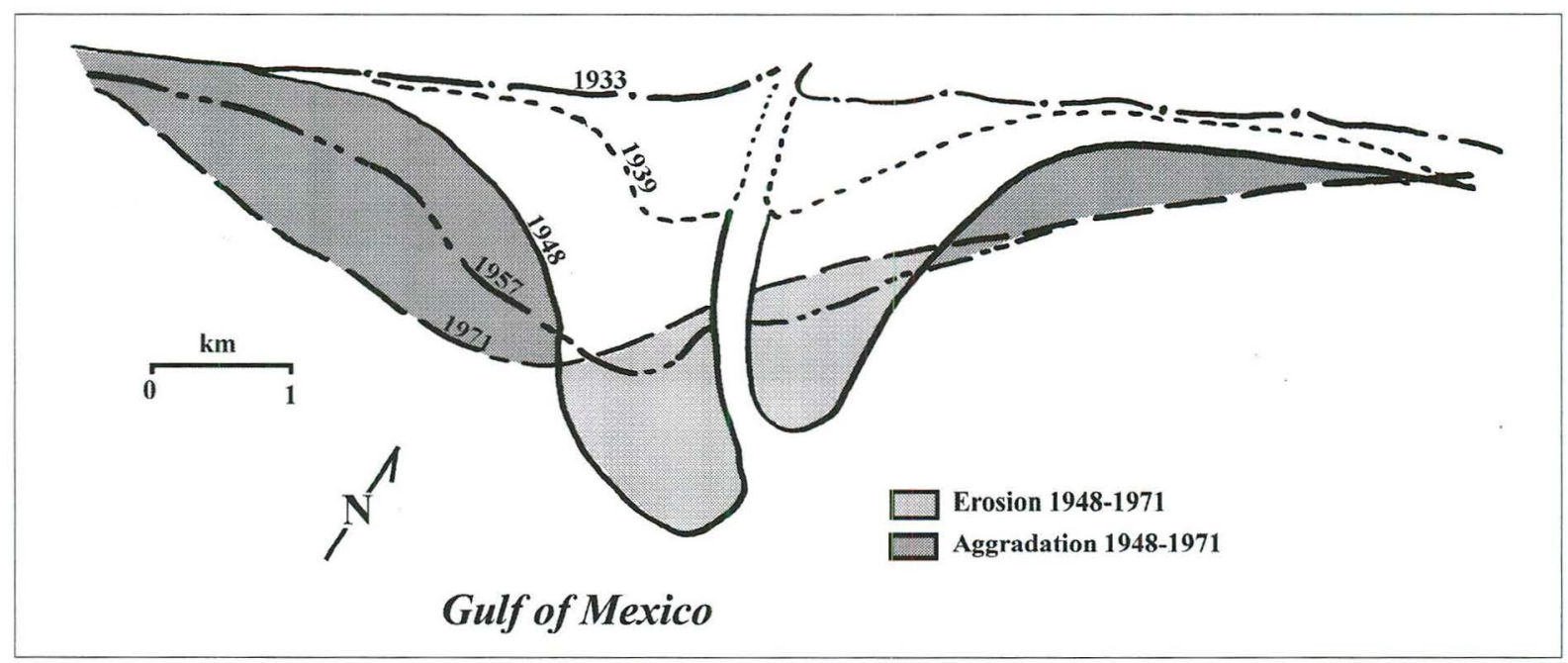

Figure 20. Shoreline changes in the historic Brazos delta between 1933 and 1971. Adapted from Seelig and Sorensen (1973).

that are developed by reworking of the barrier sands, particularly eolian deposits and washover fan deposits. However, considerable care should be exercised in evaluating the context of materials contained in eolian deposits because of the strong potential for reworking in the dynamic barrier island environment. Because deposits associated with washover events form rapidly during extreme events, the potential for materials to be contained within a single graded washover fan bed is negligible. Rather, cultural materials should be contained in the lower, coarse-grained part of a washover couplet and at the basal erosional contact. The potential for such materials to be in reasonable spatial context is highly dependent on the location of the materials relative to the fan; those positioned behind the washover throat (i.e., in the center of the fan) are almost certain to be heavily reworked by the tremendous erosive energy of the flow, while those positioned near the lateral and distal margins are much more likely to retain vestiges of the preceding spatial pattern. Finally, because sea level has remained relatively stable (within approximately $2 \mathrm{~m}$ of modern levels) through the sequence of barrier island growth, the potential for deep site burial is limited on the barriers, and all sites should be contained in the upper few meters of deposits.

\section{Estuarine and Lagoonal Processes and Landforms}

Another important sedimentary system in the Houston District is the estuarine and lagoonal system developed in the drowned valleys of the Trinity and San Jacinto rivers (i.e., Galveston Bay, Trinity Bay) and behind the flanking barriers (i.e., West Bay, East Bay). The estuarine systems were created as sea level rose during the latest Pleistocene and Early Holocene, flooding the lower river valleys with sea water. Similar systems were probably created in the lower Brazos and Colorado River valleys, but the high sediment yield produced by these large rivers quickly infilled the estuaries and began constructing the large Holocene Brazos/ Colorado delta (the Colorado experienced a pronounced avulsion in the recent past and is currently constructing a new delta into eastern Matagorda Bay). Because most of these features are largely isolated from open circulation with the Gulf by the highly developed barrier island chains, some authors (e.g., Morton and McGowen 1980) have argued that they should properly be termed bays rather than estuaries. Clearly, portions of the Houston District systems are drowned river valleys (Galveston Bay, Trinity Bay, Chocolate Bay) and do represent a form of estuary, while flanking portions represent coastwise impoundment by the barrier chain and are not truly estuarine (e.g., West Bay, East Bay, Christmas Bay). Nevertheless, the processes responsible for the evolution of these features clearly represent part of the continuum of estuarine processes.

Archeological sites potentially associated with the estuarine/lagoonal system include Late Pleistocene/Early Holocene terrestrial riverine sites, which would now be subaqueous (Aten 1983; Kibler et al. 
1996), and Middle to Late Holocene sites on the margin of the lagoons and estuaries, which typically represent exploitation of the rich estuarine ecosystem. Many of the sites in the coastal region are characterized by dense middens of shellfish remains, particularly the brackish water bivalve Rangia cuneata. These sites may be situated on Pleistocene surfaces surrounding the bays, on Holocene marsh deposits that have prograded into the coastal lagoons, or on Holocene deltaic deposits of the feeding streams.

The majority of sedimentation in an estuarine system takes place in the subaqueous environment, and represents material introduced by the feeding stream systems, and (usually to a lesser extent) longshore drift, eolian processes, and the hard parts of organisms dying in the system (Stickney 1984). In addition, erosion of Pleistocene-age sediments on the bay margins, clastic sediments introduced from the shelf and barrier islands during storms, and inorganic carbonate precipitation may contribute to the fill of the bay systems. Patterns of sediment distribution on estuarine bottoms reflect the characteristic energy conditions. Sands will typically predominate at river mouths and on either side of tidal inlets through the barrier islands, sandy muds will occur landward of the barrier systems, and muds will predominate in most other parts of the system. Sandy materials may be laminated, ripple-bedded, interbedded with muds to create flaser bedding, or occasionally trough crossbedded at energetic river mouths and tidal passes; most show strong biotic disruption. Muds are typically massive and exhibit considerable evidence of bioturbation (Reineck and Singh 1980; Stickney 1984). Most lagoonal muds are black to gray, reflecting prevailing anaerobic conditions and organic accumulation. They also frequently have a distinct odor due to the generation of hydrogen sulfide, methane, and other gases by decomposition. The salinity of lagoonal systems reflects the volume of river discharge feeding into the system and the degree to which it is connected to the open water. In the Houston area, discharge into the lagoons is relatively high and several areas of effective water exchange are present (e.g., Bolivar Roads, San Luis Pass); consequently, water in the Galveston Bay varies from mildly brackish to nearly normal Gulf salinity depending on the position in the bay and the time of year (Fisher et al. 1972). Farther down the Texas coast, more isolated bays with lower freshwater influx (e.g., Laguna Madre, Baffin Bay) are more saline and can frequently become hypersaline, particularly in summer.

Most estuarine systems, including those of the Houston District, are dominated by muddy sediments. In contrast to freshwater systems, where fine-grained sediments tend to move farther once they are entrained, during normal conditions sediments moving offshore on the continental shelf tend to be relatively coarse-grained. This is because the salinity of estuarine water and sea water promotes flocculation of fine-grained particles, causing them to clump together and settle out (Stickney 1984). Nevertheless, the density of such muds is typically low. While compaction of buried sediments by the weight of the overburden reduces water content, the upper meter of lagoonal muds may be composed of up to $90 \%$ water. Consequently, they are relatively non-cohesive and easy to re-entrain when energy conditions increase markedly with the passage of a storm. Another reason for the preponderance of muds in the Galveston Bay system is the character of the sediment load in the Trinity, San Jacinto, and other small local streams feeding the bay systems, which is dominated by fine-grained, suspended sediment.

Normal exchange of water between the bay systems and the open Gulf is driven largely by the cycle of astronomical tides, which is minimal (mean of 45 to $60 \mathrm{~cm}$ ) in the Gulf of Mexico (Morton and McGowen 1980). At high tide, water from the elevated Gulf flows into the bay systems through the tidal passes, bringing in sediment that accumulates on the inland side of the passes as a subaqueous flood tide delta. Occasionally, portions of flood tidal deltas may become emergent, such as Mud Island and Bird Island, which represent the emergent part of the San Luis Pass flood-tide delta. At low tide, water flows out of the bays, forming an $e b b$ tide delta on the seaward side of the passes. Storms, and particularly hurricanes, can greatly accentuate this process through the approach and retreat of a storm surge. Both ebb-tidal and flood-tidal deltas are predominantly sandy, but flood tidal deltas frequently exhibit trough crossbedding, graded bedding, and thick shell lags, while ebb-tidal deltas are typically laminated sand and shell. Many of the high-energy bedding structures in flood-tidal delta deposits appear to represent rapid evolution of the subaqueous delta during storm passages.

Most investigators consider all estuarine systems to be limited-life sediment traps, destined to 
eventually fill with prograding deltaic sediments. The Trinity Delta, for example, appears to have advanced up to $10 \mathrm{~km}$ in the last millennium after several thousand years of adjusting its inland gradient to the new base level that was achieved around 3,000 BP (Aten 1983). Given this rate of growth, Trinity Bay would appear to have a limited lifespan. However, provided that the influx of sediment is not too great, it is possible that other mechanisms are at work that can maintain estuarine systems indefinitely. Mud-dominated estuarine deltas like the Trinity Delta represent low, marshy extensions of the fluvial system that are built out over thick pro-delta sediments laid down beyond the river mouth. In other words, before the delta can effectively prograde, the estuarine floor must be built up by the deposition of muds and/or sands laid down in the pro-delta environment. Under normal conditions, sediments deposited on estuarine bottoms are relatively stable, suffering primarily from dewatering and autocompaction as they are successively buried by fresh mud. However, recent research is suggesting that estuarine sediments are subject to periodic, catastrophic stripping by storms of the proper configuration. In some cases, such stripping may be able to counteract the cumulative effect of incremental sedimentation by the stream.

Research by W. C. Isphording and his colleagues (e.g., Isphording et al. 1984; Isphording and Isphording 1991; Isphording 1994) on a series of bays in the northern Gulf of Mexico suggests that the impact of a hurricane making landfall on bay bottom sediments can be either minimal or quite pronounced, depending on the characteristics of a particular storm. As a hurricane approaches landfall, it drives with it an accumulation of water termed a storm surge that piles up against the shoreline, raising sea level up to $3 \mathrm{~m}$ or more if it coincides with the high astronomical tide, and accounting for the bulk of the destructive impact of the storm. As the storm center passes inland, the winds and reduced barometric pressures responsible for this surge abate, and the accumulated water flows back seaward. It has long been recognized that the strong wind-induced currents associated with hurricanes can resuspend estuarine sediments, which can be swept to sea with the ebbing surge (Morton and McGowen 1980). However, the research of Isphording and his colleagues illustrates the magnitude of work that this process can attain in a storm where conditions (e.g., wind speed, duration, angle of approach) are favorable is far greater than had been previously recognized. Two examples of significant erosion are documented. The first is the impact of Hurricane Frederick on Mobile Bay, Alabama, in 1979. This storm resulted in the mobilization and removal of approximately 290 million tons of sediment from the bay, deepening it by an average of 1.5 feet $(46 \mathrm{~cm})$. This amount of sediment is approximately equivalent to the load delivered to the mouth of the Mississippi River in a year, and represents 116 years of normal sedimentation in Mobile Bay. A similar phenomenon was recorded at Apalachicola Bay, Florida, in association with the passage of Hurricane Elena in 1985. Here, over 80 million tons of sediment were removed, and the bay bottom was deepened by an average of 1.6 feet $(49 \mathrm{~cm})$. In contrast, many other storms have been documented that had minor or negligible effects on estuarine sediment volume. Nevertheless, it is clear that estuaries fed by small, relatively sediment-poor streams can be maintained for long periods by infrequent tropical cyclones.

To this point, this discussion has included the tacit assumption that all Texas coastal streams developed estuarine systems as sea level rose rapidly, but that those streams with high sediment load quickly filled their estuaries as eustatic sea level rise slowed. In fact, there is some disagreement concerning the degree to which some of the larger Texas streams, such as the Brazos, Colorado, and Rio Grande, were ever embayed. For example, Aten (1983) argues that the Brazos River maintained such a high sediment yield that it was able to maintain a shoreline delta as sea level rose and therefore never developed a significant estuary. While it is clear that the lower Brazos, like other streams on the Gulf Coast, incised a deep valley during the Late Pleistocene low stand (Wilkinson and Basse 1978; Blum 1990), the Brazos was a large, competent bed load stream during the Late Pleistocene (Waters and Nordt 1995), and the rate of backfilling may well have kept pace with sea level rise. While testing this idea would require extensive coring on the delta and offshore, it is a distinct possibility. Even if an estuary did develop, it is likely that it was relatively small, and may have been situated entirely seaward of the present shoreline.

Although it is almost certain that formerly terrestrial archeological sites are preserved offshore on the continental shelf and in the bay system (Aten 1983; Stright 1990, 1995; Kibler et al 1996), the 
following discussion of the geoarcheological potential of the estuarine systems is restricted to those sites that are associated with the modern terrestrial environment; namely, the margins of the bays and estuaries. Here, there are three basic environments where archeological sites may be preserved: (1) the estuarine deltas feeding into the bays; (2) Holocene marshes prograding into the bay systems from the shore; and (3) the top and flanks of Pleistocene surfaces that represent the margins of the drowned and extant river valleys. Mechanisms of sedimentation on the estuarine deltas are dominated by the suite of fluviodeltaic processes discussed previously. Most deltaic sediment deposited by the Trinity consists of churned delta front sands overlying estuarine muds and intedigitated with levee, channel, point bar, backswamp, marsh, lake, and bay margin facies (Lankford and Rogers 1969). Although the Trinity Delta has advanced rapidly in the last millennium, the San Jacinto has no appreciable delta (Lankford and Rehkemper 1969), and environments preserved inland of the modern bay in its valley are almost exclusively fluvial. Both the progradational/ aggradational Trinity River fluviodeltaic deposits and the aggradational San Jacinto fluvial deposits in the vicinity of Galveston Bay are quite young. There is some potential for older deposits to be preserved at depth (i.e., considerably below modern sea level) in both valley systems; such deposits would be overlain by estuarine muds and fluviodeltaic sediments in the Trinity valley and by younger fluvial deposits in the San Jacinto valley. In addition, several of the smaller streams entering the bay have small, single lobed and mostly subaqueous sandy fan-deltas that appear to be active only when storms produce episodes of high discharge. While these deltaic deposits have negligible archeological potential, the small floodplains of these incised minor streams have clearly aggraded and do have the potential to contain cultural material in reasonable context. In addition to such extant floodplains, there is the potential for similar settings to have been buried offshore as sea level rose.

The second significant depositional environment associated with the margins of the bays are Holocene marsh deposits on the margins of the bays and estuaries. These environments have a permanently high water table, are usually situated at elevations less than $1.5 \mathrm{~m}$ above sea level, and are typically flooded on a regular basis. They can be subdivided into inland marshes, which are freshwater features associated with stream valleys and low coastal reaches, fresh to brackish coastal marshes, which usually occur some small distance from the shoreline, and salt marshes, which typically front the extant shoreline. Freshwater marshes are dominated by surface runoff that floods in on a periodic basis, while saltwater marshes are typically inundated by sea water on a daily basis. Brackish marshes, which are gradational between the coastal saltwater and inland freshwater marshes, vary considerably in salinity depending on which source predominates at any particular time. There are also some areas of swamp in the inland valleys, where the vegetation assemblage is dominated by trees (e.g., bald cypress) and other types of woody vegetation as well as grasses.

Environmental mapping by the Bureau of Economic Geology (McGowen et al. 1976; Fisher et al. 1972 ) indicates that areas of brackish and saltwater marsh are abundant along the coastline fronting East Bay, West Bay, and the Brazos delta, and absent along the reentrant formed by Galveston/ Trinity Bay except where streams debouch along the coast. In other words, marshes are common in the district where the shore abuts the gently dipping surface of the Holocene deltas and the Pleistocene Beaumont Formation, and rare where the shore abuts the more steeply dipping margins of the incised Pleistocene valleys.

Coastal marshes grow upward (aggrade) and seaward (prograde) as a result of incremental trapping of fine-grained sediment by salt-tolerant grasses and forbs and by the accretion of dead plant matter in an anaerobic environment. Inorganic marsh sediments may be introduced by inland (freshwater) discharge or be derived from lagoonal muds introduced with the tides (Chorley et al. 1986) or storms (Nyman et al. 1993). Sedimentation associated with storms moving onshore may be relatively pronounced, while marked erosion through the cutting of channels during ebb flow can also occur (Coch 1994). Most marshes consist of complex networks of small, sinuous anabranching channels that cut through a network of low, vegetated islands. In general, the water table is drawn down adjacent to channels by effluence into the channel. Geomorphic examinations (Collins et al. 1987) suggest that channel networks evolve through a complex series of processes; widening of 
channels may occur by erosive flow during spring and ebb tides and storm swash and backwash, while channel narrowing and closure may result from sediments being trapped on lushly vegetated channel banks. In some cases, closure of a surface channel by roots and sediment trapping can allow the lower part of the channel to remain an open, buried conduit for the circulation of water in the marsh system. The relative abundance of organic and inorganic sediment can also exhibit complex patterns. In California, Collins et al. (1987) found that the ratio of organic to inorganic sediment varies markedly with distance from extant channels. Due to a rapid decline in the influx of clastic sediment, peat increased from $10 \%$ to $45 \%$ of total soil weight in a distance of $15 \mathrm{~m}$ from the active channel. Coupled with the frequently rapid evolution of marsh systems by the headward cutting erosion of new channels and closure of old channels, this difference in the ratio between organic and inorganic sedimentation can result in complex spatial patterning of deposits in a marsh system.

Because they are permanently wet, marshes are poor environments for generalized human habitation. However, they are likely loci for specific activities, particularly the procurement of food resources like bivalves, fish, crabs, and crayfish. Recognizable sites are likely to represent loci for the processing of such resources, like the abundant Rangia middens known from the margins of Galveston Bay. Moreover, the anaerobic environment typical of marsh sediments is conducive to the preservation of organic remains. In addition, because coastal marshes moved transgressively over the coast as sea level rose, marsh deposits may be preserved offshore beneath the lagoonal muds, while older sites could be preserved at the contact between extant marsh sediments or older marsh deposits buried offshore and the underlying terrestrial strata.

The third type of environment associated with the estuaries are the slopes and upland margins developed on Pleistocene deposits. These environments are typical of the margins of the true estuaries (e.g., Galveston Bay, Trinity Bay), and represent the upper slopes of the stream valleys cut during the Late Pleistocene low stand. In contrast to the other environments associated with the estuarine system, this sub-environment may exhibit moderate to relatively pronounced relief, with slopes rising relatively abruptly to elevations 4-7 $\mathrm{m}$ above sea level. It includes the shoulder and slopes of the Pleistocene valleys; the slopes, floodplains and fan-deltas of small, headward cutting streams dissecting the estuarine margin; and variably preserved concave deposits at the toeslopes. Although the principal substrate associated with these environments consists of the Pleistocene Beaumont Formation, they are commonly veneered with a thin deposit of Holocene colluvial sediments that frequently contain archeological sites (particularly Rangia middens).

Paine (1987a, 1990) provides a detailed examination of the upland margin in the vicinity of Peggy Lake disposal area, situated near the San Jacinto Monument a few kilometers upstream from Galveston Bay. Here, a veneer of colluvial/ slopewash sediments mantles the valley wall, which is lightly dissected by two headward-cutting gullies. The colluvial sediments consist of dark brown to black, organic-rich clays and vary from approximately $30 \mathrm{~cm}$ thick on the upper slopes and shoulders to $60 \mathrm{~cm}$ thick on the lower slopes and toeslopes. The underlying Beaumont Formation deposits support a thick (up to $3 \mathrm{~m}$ ) soil profile that is laterally truncated by the stream valley slopes. No conformable soil development is apparent on the beveled Pleistocene surface beneath the colluvial mantle; rather, these surfaces expose unmodified horizons of the thick upland soil. This indicates that the soil that would have developed on the Pleistocene valley walls during the extended Late Pleistocene low stand was removed by lateral erosion prior to emplacement of the colluvial sequence. Because no archeological sites older than about 4,000 years are preserved, Paine interprets this episode to be a result of lateral erosion by the San Jacinto River during the Early-Middle Holocene.

Although Paine attributes most sedimentation on the valley slopes to slow, incremental colluvial reworking of the Beaumont Formation soils, it is likely that the valley walls surrounding Galveston Bay have also been strongly affected by extreme events on a periodic basis. Documented storm surges have elevated bay levels by almost $4.5 \mathrm{~m}$ (U. S. Army Corps of Engineers 1961), while a Category 5 hurricane (winds in excess of $155 \mathrm{mph}$ ) could be expected to result in a storm surge greater than $6 \mathrm{~m}$. The combination of wave attack and storm surge resulting from a large hurricane impacts the slopes and marshes fronting on the estuaries through wave erosion, reworking existing sediments through swash and backwash of breaking waves, and (minor) deposition of suspended sediment (Nummendal 
1982; Nyman et al. 1993). Although subsidence due to fluid withdrawal in the Galveston Bay area has been pronounced in the last century (more than $2 \mathrm{~m}$ in many locations; Gabrysch 1984), thus decreasing the height of the slopes and increasing their susceptibility to attack by moderate storms, wave attack and storm surge associated with an intense hurricane could easily affect all portions of a slope up to 8-9 $\mathrm{m}$ above sea level. The impact on sites in this setting would probably be primarily erosional, but disturbance and burial of materials may also occur in conducive settings, particularly on the lower portions of the slopes as the storms abate and the surge ebbs.

As in the barrier island environment, archeological sites in lagoonal and estuarine margin settings probably reflect a focus on the exploitation of the marine/estuarine environment. Farther down the coast, Ricklis (1993; Ricklis and Blum 1997) has advanced a persuasive model that relates temporal variation in coastal site frequency with shifts in the productivity of coastal ecosystems resulting from episodes of rapid and slow sea level rise. This argument appears sound, and fits with the archeological record in the vicinity of Corpus Christi Bay. Although not yet verified by detailed examination of the Galveston Bay site inventory, the controls on estuarine productivity are the same in the Houston District, and a similar behavioral periodicity in site occurrence is likely to occur in the vicinity of Galveston Bay. However, physical processes operating in the vicinity of the estuarine system also exercise controls on the archeological record. The preceding review of processes in operation suggests that (1) site preservation should exhibit a strong bias towards Late Holocene components, and (2) all depositional environments in the vicinity of the estuarine/bay systems are subject to periodic disruption, particularly by short-lived, energetic storm processes. Sites in the vicinity therefore need to be carefully evaluated for erosional reworking and mixing of unrelated components.

\section{Biotic Sedimentation Processes}

Organisms have two distinct roles in the accumulation of sediments making up the matrix of a site. One role that is widely recognized is the broad suite of processes responsible for altering or disturbing site sediments, which are collectively termed bioturbation processes. This section discusses the other major role; namely, the introduction of sediments, or biotic sedimentation. Bioturbation is addressed later in this chapter.

There are a number of types of biotic sedimentation of strong potential relevance to archeology. The most obvious form of biotic sedimentation is the contribution made by organisms as they die and decompose. Although animals do add some material to the system, the contribution of plants is far more important. This phenomenon is all too familiar to any archeologist who has attempted to perform surface survey in a forested area, where a cover of leaf litter and mull (partially decomposed organic matter) commonly obscures the ground surface. As discussed in more detail later, organic decay results in a wide number of early-stage, intermediate-stage, and late-stage products. The rate of accumulation of these products in the soil is a function of the rate of organic production versus the rate of physical and microbial decomposition. While the rate of production increases in the tropics, the rate of microbial decomposition has a concomitantly greater increase, so that organic matter does not tend to accumulate. In the subtropical zone, organic production is somewhat lower, but the rate of decomposition is markedly lower, and organic accumulation is much more rapid. These organics represent a type of sediment, and are capable of progressively burying archeological materials. However, with the exception of permanently wet locations like peat bogs and marshes, where anaerobic conditions tend to limit bacterial action, the accumulation of the organically dominated $\mathrm{O}$ horizon is limited because a variety of pedogenic processes tend to gradually break down and mix accumulated organics into the underlying, mineral-dominated A horizon.

In addition to providing organic sediments through their death and decay, organisms are also capable of introducing mineral sediments which can bury occupation surfaces. This is most common in animals, which result in sedimentation through a variety of behavioral mechanisms (Butler 1995). The role of plants is distinctly secondary, because the only effective mechanism is tree throw, where soil trapped in the root system of an uprooted tree (Lutz and Griswold 1939) is lifted up and out of a hole in the soil en masse (Figure 21) and gradually distributed across the ground surface by rain wash and root decay. Tree throw is a relatively common occurrence, and leads to a characteristic pit and mound 


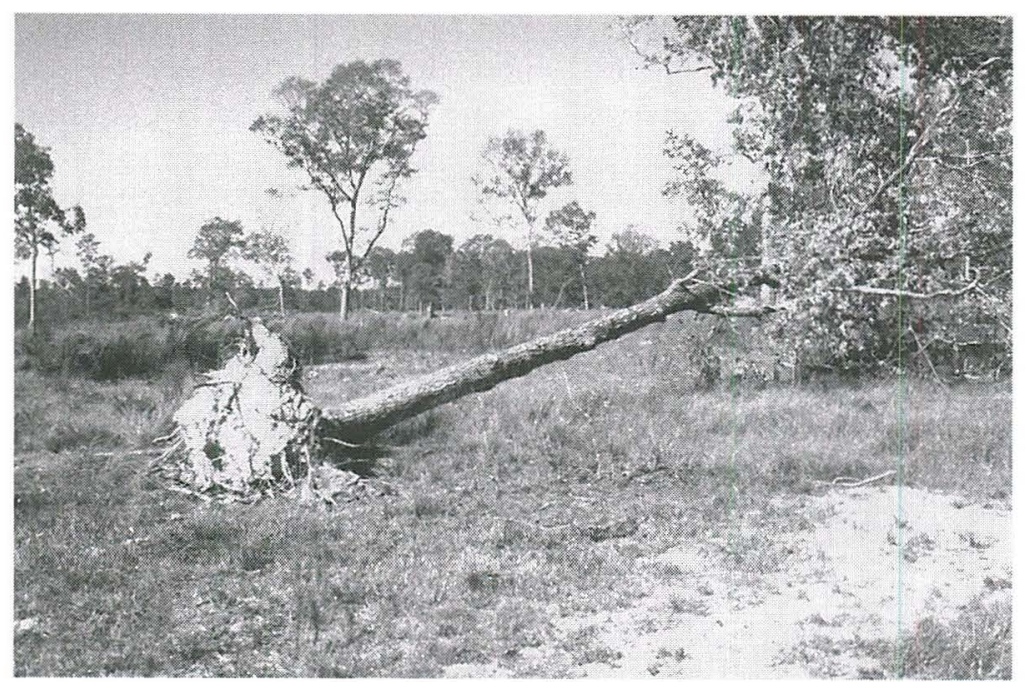

Figure 21. Tree throw in Montgomery County. Note mass of sediment adhering to roots, which will be gradually distributed across the surface by rain wash and decomposition of the binding root structure, potentially burying surficial archeological materials in the vicinity.

topography in areas where it is the dominant process over relatively long periods of time (Paton et al. 1995). Large tree throws can uproot hundreds of kilograms of sediment, leaving a hole several meters in diameter and up to a meter deep. However, the amount of sediment affected by an individual tree throw depends on the size of the tree, the density and morphology of the root system, characteristics of the soil and substrate, and whether the tree is alive or not at the time of uprooting. Moreover, the expression and persistence of pit and mound topography resulting from tree throws is dependent on the characteristics of the soil, the size of the throws, the effectiveness of other processes acting on the surface, and the direction that the tree falls. If the tree falls upslope, the bulk of the soil will tend to wash back into the hole, whereas trees that fall downslope tend to distribute the sediment in a thin wedge downslope.

There are many mechanisms of terrestrial sedimentation by animals, including digging for burrowing prey, rooting for buried vegetal foods, transport of sediment matted or caked on the hide and in the fur; concentration and decay of the remains of prey in a den; the concentration of grasses, leaves, or other vegetal matter for bedding in a den; routine defecation in a limited area such as a den or a corral; and ejection of sediment on the surface in association with burrowing. Of these, burrowing behavior is the most important mechanism of mineral sedimentation in the context of the overall landscape, although other mechanisms may be much more important at individual localities. In the process of excavating a burrow, many animals eject subsurface sediment around the entry point, where it is then reworked by a number of mechanisms, including raindrop impact, overland flow, flooding, and eolian processes. In most instances, reworking of this material results in some sediment re-entering the burrow (where it may again be ejected if the burrow is still occupied) and some being dispersed across the ground surface surrounding the burrow. The volume of sediment affected by any individual animal is a function of its size, life span, and the intensity of its burrowing behavior, while the overall effect of burrowing on any given landscape segment is a function of the type of burrowing animals involved, their population density, and the longevity of surface occupation.

The most important classes of burrowing animals in the Houston District include insects, annelids, crayfish, and small burrowing mammals. The role that each of these classes of organisms play in soil disturbance is addressed below, but because they are all capable of surficial sedimentation, it is appropriate to discuss them here also. Although there are many types of burrowing insects (and other burrowing invertebrates, such as arachnids), appreciable surface modification is primarily limited to social insects like ants and termites, who can collectively result in significant subsurface alterations and surface modifications in a brief span of time. The ability of ant colonies to move sediment is readily apparent to anyone who has dealt with fire ant (Solenopsis spp.) colonies in the Houston area, which can riddle open fields with closely spaced mounds that can reach heights greater than 2 feet. Although the fire ant is a recent immigrant from South America (it was introduced through the port at Mobile, Alabama, in the 1920s), other mound-building species like the western harvester ant (Pogonomyrmex occidentails) and various species of the genus Formica were probably common in the prehistoric past (Mandel and Sorensen 1982; Paton et al. 1995). Many of these 
ants, as well as a variety of other invertebrate and vertebrate species (including, mercifully, ticks and chiggers), are suffering before the onslaught of the fire ant invasion, and non-fire ant mounds are observed less frequently today.

The amount of sediment ejected from an ant burrow represents only a fraction of the volume affected, because much more sediment is reworked in the subsurface. Nevertheless, the amount of sediment brought to the surface by ants can be considerable. In a review of literature on ant mounding, Paton et al. (1995) found reported rates worldwide range from a low of less than $0.003 \mathrm{t} \mathrm{ha}^{-1} \mathrm{yr}^{-1}$ to a high of approximately $10 \mathrm{tha}^{-1} \mathrm{yr}^{-1}$, with the higher rates occurring in relatively moist subtropical and temperate environments. As a result, burial of the surface can occur relatively quickly where rates of mound construction are high. For example, in a study in southwestern Wisconsin, Baxter and Hole (1967) estimated that approximately 700 years would be required before the entire study area surface would have been occupied with mounds formed by Formica cinerea montana.

The distribution, size, and density of ant mounds clearly exercises considerable control on patterns of surface sedimentation. Because they are cooperative social animals, ant mounds develop as a series of sediment point sources that are readily identifiable when active. Patterns of surface sedimentation as a mound breaks down and is dispersed are controlled by a number of factors, including the size and shape of the mound, slope inclination and microtopography surrounding the mound, character of surface vegetation, and the character of mound sediment. The size and shape of the mound reflects a combination of behavioral and physical variables, while the character of mound sediment is constrained by the character of underlying soils and sediments, supplemented by behavioral sorting. Some mounds (such as the prominent fire ant mounds common in the modern Houston area landscape) are relatively tall and irregular with a relatively small base. Such mounds are inherently unstable, and thus highly subject to rapid dispersal by natural processes such as intense rains or flooding. Other mounds, such as those formed by the western harvester ant, are low, broadbased cones with much lower potential to be rapidly redistributed. Coupled with the textural characteristics and friability of the sediments and the character of erosive energy, the slope, vegetation assemblage, and microtopography of the landscape surrounding an ant mound control the vectors and distances of dispersive transport. In some cases, the presence of a surface armor can inhibit breakdown and dispersion of mound sediments. Some ant species, including the western harvester ant, construct mounds characterized by a surface armor of relatively large granules that serve to protect finer-grained sediments below. While in some cases this armor may represent a lag produced by winnowing of fine particles, some species clearly collect coarse clasts (including bits of glass and other items) from the surrounding surface to intentionally armor the mound against erosion (Cowan et al. 1985).

Although the effect of ants can be considerable, it pales in comparison to the potential for soil turnover and surface sedimentation caused by annelids (earthworms). While ants and other burrowing insects (e.g., ground wasps, cicadas, beetles) do so primarily for shelter, earthworms burrow for sustenance, ingesting soil and sediment to extract their nutritive requirements and excreting the residua. Unlike ants, termites, and other organized social insects, earthworms operate individually, riddling the subsurface with a constantly changing network of pathways. The production of surface sediment by earthworms was first described better than a century ago by Charles Darwin (1881), who attributed the development of fine-grained "vegetable mould" in the upper part of soils to the action of earthworms. Since that time, a number of researchers have quantified the rate of surface casting by earthworms, with values ranging from less than 0.06 tons per hectare per year to more than $250 \mathrm{t} \mathrm{ha}^{-1} \mathrm{yr}^{-1}$ (Paton et al. 1995). In Central Texas, Frederick (1996) found that earthworm casting can bury a pre-existing surface with up to $6.3 \mathrm{~cm}$ of fresh sediment in a span of 40 years. As a result, archeological assemblages may be gradually buried in a few decades, sometimes without pronounced internal disruption (Van Nest 1998).

Insects and earthworms typically occupy freely drained soils, and do not tolerate saturated soil conditions well. However, such soils are colonized by crayfish, which build pronounced burrow entries termed chimneys that also represent large quantities of sediment brought to the surface (Figure 22). The rate of surface sedimentation by crayfish has not been studied in a manner similar to the action of ants and earthworms, but some observations suggest that it too may be considerable in certain settings. 


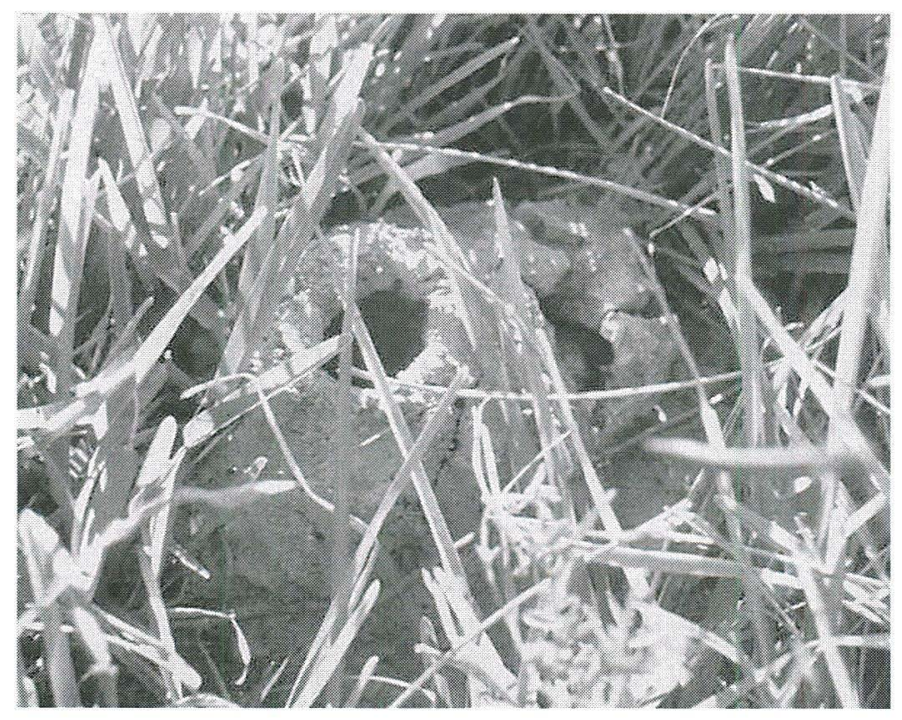

Figure 22. Small crayfish chimney, containing less than $1 \mathrm{~kg}$ of sediment. While such small features are very common, much larger chimneys also occur in places in the Houston District. Over the long term, the breakdown and dispersal of sediment in a succession of these chimneys can bury surficial archeological materials.

For example, Hobbs and Whiteman (1991) report crayfish chimneys averaging $11-25 \mathrm{~kg}$ of sediment occurring in densities of up to 62,500 per ha. Assuming that such burrows have a maximum life span of 2-3 years, this equates to surface deposition of between 379 and $574 \mathrm{t} \mathrm{ha}^{-1} \mathrm{yr}^{-1}$. Of course, in most cases the rate of surface deposition from crayfish burrowing is clearly several orders of magnitude lower, yet even this rate would result in significant surface sedimentation over the long term.

Vertebrate burrowing species also can result in the accumulation of significant quantities of surficial sediments (Johnson 1989, 1990; Johnson and Watson-Stegner 1990). Mammals are probably the most common class of burrowing vertebrates, although some species of reptiles, amphibians, and birds may also burrow. Burrowing mammals include those that burrow for shelter but feed at the surface (e.g., pocket gophers, prairie dogs), and true fossorial mammals that live and feed underground (e.g., moles, shrews). Many burrowing taxa, particularly pocket gophers (Geomys spp. and Thomomys spp.) occupy, or have occupied in the prehistoric past, environments in the Houston area. While studies of the earth moving ability of small vertebrates are not as common as those of invertebrates, several studies have demonstrated that considerable quantities of earth can be exhumed as a result of their behavior. For example, Buechner
(1942) estimated rates of surficial mounding by pocket gophers in Texas between 0.81 and $15.87 \mathrm{t} \mathrm{ha}^{-1} \mathrm{yr}^{-1}$, while Thorn (1978) estimated rates of mounding by a different taxon of pocket gophers in the Colorado Rockies at 3.9 to $5.8 \mathrm{t} \mathrm{ha}^{-1} \mathrm{yr}^{-1}$. Notably, the action of burrowing mammals is one of the mechanisms cited for the formation of pimple mounds (Cox 1984), which remain one of the more enigmatic landforms in the Houston area (see Chapter 4). While insects and annelids will generally not move subsurface artifacts because of their small body size, crayfish may move small artifacts, and burrowing vertebrates may affect artifacts up to 7-8 $\mathrm{cm}$ in size. Even where the artifacts themselves are not moved, removal of the surrounding matrix can result in the concentration of larger stones and artifacts into discrete (and archeologically misleading) subsurface stone lines (Johnson 1990).

In summary, cultural materials may be shallowly buried by biotic sedimentation processes in virtually every environment in the Houston area. However, most of these sedimentation processes also may strongly effect the archeological integrity of materials through direct movement and removal of the surrounding matrix, and the context of such deposits must be carefully and critically evaluated. Although this discussion has focused on "natural" biotic agents of sedimentation, it is important to remember that prehistoric humans were also capable of producing pronounced sediment accumulation either intentionally (e.g., through the construction of mounds, agricultural terraces, and raised platforms) or as a byproduct of other activities (e.g., through shell or burned rock midden accumulation, dumping of spoil from various excavations, or concentration of organic remains). In fact, artifacts themselves represent clasts in a sense, and humans are thus both depositional agents and geomorphic agents (e.g., Nir 1983). Although prehistoric humans frequently did cause significant sedimentation in localized areas, in the historic era, and particularly in the 20th century, the explosion in the human population and the advent of earthmoving machinery has led to disturbance, excavation, and burial of natural surfaces on an unprecedented scale. 


\section{PEDOGENIC PROCESSES AND SOILS}

\section{Soil Morphology and Soil Forming Factors}

The term "soil" is often equated with any matrix containing and enveloping the artifacts at an archeological site. However, in earth science terms, the definition of soil is much more restricted. For purposes of this discussion, soil is defined as a naturally occurring thin layer at the earth's surface that has been acted on by the soil forming factors to produce a material that differs from its parent material. In other words, soils are dynamic entities produced by the action of a number of interrelated processes on a parent sediment (deposited by one or more of the mechanisms outlined in the previous section) or on weathered bedrock. By definition, sedimentary deposits are not soils unless soil forming processes have acted to transform them from their original character in some manner. By the same token, the soil horizons developed through the action of these processes are not strata because they represent differences that developed after deposition of the sediment.

Pedogenesis refers to the action of a suite of processes on a parent material, and serves to convert that parent material into a soil. The character of any given soil is conditioned by the interaction of five soil forming factors. The five soil forming factors are: climate, organisms, relief, parent material, and time (Jenny 1941). Climate refers to the sum total of ambient environmental factors acting on a sediment, including trends in temperature, solar radiation, precipitation, and groundwater. Organisms refers to the cumulative effect of biological activity, including animals, plants, and bacteria on a soil, and is itself strongly conditioned by ambient environmental factors. The influence of these two factors is regulated by relief (primarily slope and aspect), which controls the incidence of radiation and the potential for moisture to penetrate, and the character of the parent material, which controls the chemical and physical nature of the raw material and thus limits the range of potential processes affecting the soil. Finally, time exercises control by dictating the duration of pedogenesis, and thus the potential for progressive pedogenic alteration of the parent material. Collectively, these factors affect not only soils but the archeological record contained within them (Schiffer 1987; Holliday 1990, 1994).
All pedogenic processes are time-dependent to some degree, but the rate of different suites of processes varies considerably. Some processes, like the accumulation of organic matter or soluble salts in specific horizons of a soil, can occur relatively quickly (e.g., $10^{-1}$ to $10^{3}$ years), while other processes-accumulation of secondary clays and dissolution and leaching of siliceous mineralsoccur over much longer periods ( $10^{4}$ to $10^{7}$ years). If conditions remain constant, all pedogenic processes will eventually reach a state of equilibrium where change is not apparent, but the time required for differing processes to achieve equilibrium varies by several orders of magnitude (Birkeland 1984). Moreover, because the physical environment is in a constant state of flux, true equilibrium conditions are rarely if ever achieved.

Nevertheless, the morphology of a given soil is frequently indicative of the cumulative effect of changing pedogenic factors over time. The terminology used to describe such soils is complex and contradictory, and little consensus has been reached, particularly regarding the thresholds necessary to merit use of a given term (Fenwick 1985; Holliday and Goldberg 1992; Johnson and Hole 1994). The issue of threshold is very relevant, because the physical environment is not static, and all soils exhibit the influence of former environments to some degree. However, it is unclear whether such an identification would be useful in broadly applicable terms, and application of terminology continues to be governed by qualitative assessment.

One important construct is the distinction drawn between soils developed under a single, stable soilforming regime (monogenetic soils) or a succession of different regimes, typically as a consequence of climate change (polygenetic soils) (Bryan and Albritton 1943). Polygenetic soils exhibit juxtaposition or overprinting of morphological features or other characteristics that suggest a significant change in pedogenic pathways during its development. Such soils have also been termed relict soils, but the normal usage of that term has changed somewhat in recent years (Johnson and Hole 1994; see below). Another related term is fossil soil, which has also been used in a number of different ways, but typically refers to a soil that does not reflect the modern pedologic environment, usually because it was buried and pedogenesis was arrested (Butzer 1971).

Probably the most commonly used term is paleosol, which has also been defined in a number 
of different ways (see Holliday and Goldberg 1992; Johnson and Hole 1994). While there are a number of subtle distinctions between definitions, the most significant difference is that some authors restrict the term paleosol to buried soils (e.g., Thorp 1949; Fenwick 1985), while others encompass both buried soils and extant soils that exhibit morphological properties related to previous (and typically very different) environments (e.g., Hunt and Sokoloff 1950; Morrison 1967; Butzer 1971). In geoarcheological usage, the term paleosol is usually used as a synonym for a buried soil. If a soil is buried by a thick packet of fresh sediment, pedogenesis will be arrested, preserving the results of soil formation over a specific period of time in the past (Fenwick 1985). However, if the depth of burial is insufficient to take the soil out of the zone of pedogenic alteration, then the buried soil may exhibit properties or overprinted features characteristic of different parts of an intact profile (e.g., a buried A horizon that also contains more recent illuvial material such as secondary carbonate). Such a soil is also generally considered a paleosol, but is less representative of the past character of pedogenesis (i.e., a true fossil soil) because soil processes continued to progressively modify the soil after burial. If such a soil is subsequently exposed through erosion, it can be termed an exhumed soil (Ruhe and Daniels 1958). If an extant surface soil exhibits properties characteristic of a significantly different pedogenic trajectory than currently exists, and it can be demonstrated that the soil was not buried and isolated, then that soil can be termed a relict soil (Ruhe 1965). Note that while the definition differs in emphasis from the polygenetic context used above, it is difficult to envision a relict soil that is not polygenetic to some degree.

Several basic processes affect a wide variety of soil components. The term eluviation refers to the removal of soil components in suspension or solution by infiltrating soil water, and is typical of the upper horizons (A and $\mathrm{E}$ horizons) of a soil. Illuviation refers to the accumulation of material derived from higher in the profile by precipitation from soil water solution or movement of finely divided particles, and is typical of lower soil horizons (B, C, and $\mathrm{K}$ ). The process of downward movement of these constituents through a soil is termed translocation. If the constituents enter the water table and are removed from the pedon, they are said to be leached. Mineralization refers to the conversion of soil constituents from organic forms to inorganic forms through microbial decomposition. Humification refers to the process of recombination of soluble acids produced in the soil during decomposition, and produces a suite of black or dark brown substances collectively termed humus. Chelation refers to a chemical process where metal ions (e.g., iron, aluminum) combine with organic molecules to form a complex that is much more soluble than the metals are alone, and is primarily responsible for eluviation of such metallic compounds in a soil. Melanization refers to the darkening of a soil A horizon, usually due to organic matter accumulation and humification. Oxidation is a chemical process where soil constituents combine with oxygen to produce oxides, which typically exhibit reddish, orange, yellowish and/or brown coloration. Rubifaction (or rubification) refers to the gradual reddening of a soil B horizon through oxidation of in situ constituents and illuviation of oxidized constituents. Gleyzation (or reduction) refers to the reduction of free iron in a soil through intermittent or prolonged saturation by anaerobic waters, and produces bluish, greenish, and gray colors. In intermittently saturated soils, mottling is frequently produced by the interdigitation of oxidized and reduced zones. Mottling (variegation) of soil color may also be produced by other processes, including infilling of burrows produced by vertebrates and insects (krotovina), infiltration of material into soil cracks, root decay, and differential weathering of parent material; however, many investigators prefer to reserve the term mottling for redox phenomena (see Soil Survey Staff 1975:49).

In most cases, the result of pedogenesis acting on a uniform parent material is development of a series of soil zones, or horizons, that are subparallel to the ground surface and exhibit differing properties, although in some cases pedogenic processes may lead to homogenization of a lithologically diverse profile (Johnson et al. 1987). Principal master soil horizons include the $\mathrm{O}$ horizon, $\mathrm{A}$ horizon, E horizon, B horizon, C horizon, R horizon (Soil Survey Staff 1990), and K horizon (Gile et al. 1965; Birkeland 1984). Lowercase suffixes are used to clarify horizon properties; for example, the designation $\mathrm{Bt}$ denotes a B horizon enriched in illuvial clay and the designation $\mathrm{Bk}$ denotes one enriched in secondary (i.e., pedogenic) calcium carbonate. Transitional horizons are designated by combining horizon 
designations, with the dominant characteristics determining the order of listing (e.g., an $\mathrm{AB}$ horizon represents a lower A horizon with clear subordinate properties of the underlying $\mathrm{B}$, while a BA horizon represents an upper B horizon with clear subordinate properties of the overlying A). In some cases, a transitional horizon may have distinct parts that are clearly related to underlying and overlying horizons. In these cases, the dominant horizon is listed first, and a vigule $(/)$ is used to separate the horizon designations (e.g., an A/R horizon) (Soil Survey Staff 1990).

The $\mathrm{O}$ horizon is a surficial horizon dominated by partially decomposed or undecomposed organic matter, and is frequently absent, particularly in semiarid to arid settings. The A horizon is a dominantly mineral surface horizon characterized by the accumulation of organic matter and the loss of organic matter, clay, iron, calcium carbonate, and other soil constituents by leaching and translocation. It occurs below the $\mathrm{O}$ horizon in profiles where both are present. The $\mathrm{E}$ horizon is a mineral horizon that occurs beneath the A in some profiles and is characterized by the loss of organic matter, iron, aluminum, and silicate clay, resulting in the residual concentration of siliceous sand and/or silts. The B horizon occurs beneath the $\mathrm{A}$ or $\mathrm{E}$ and is characterized by the illuvial concentration of soil constituents such as clay, iron, aluminum, humus, carbonate, gypsum, or silica alone or in combination. Although not recognized by the Soil Conservation Service (now Natural Resource Conservation Service), many investigators (Gile et al. 1965; Birkeland 1984) prefer the term $\mathrm{K}$ horizon for a soil zone dominated by, and at least partially plugged by, illuvial accumulation of carbonate. The $\mathrm{C}$ horizon and the $\mathrm{R}$ horizon represent horizons formed in unconsolidated parent material and bedrock, respectively, that are little modified by pedogenesis.

\section{Organic Matter}

The accumulation of organic matter in the surficial horizons of a soil is one of the most conspicuous aspects of soil formation. Organic matter accumulates as plants and animals living on the surface or colonizing the soil die, decompose, and are incorporated into the soil matrix. The archeological implications of organic matter accumulation in soil have rarely been addressed in detail (although there are exceptions, e.g., Carr
[1976]; Stein [1992]), which is unfortunate because the accumulation of organic debris is one of the most important physical consequences of cultural occupation at any given locality. However, spatial and stratigraphic patterning in soil chemistry produced by the decomposition of cultural organics has proven to be a valuable line of archeological evidence in certain settings (e.g., Eidt 1977, 1984).

The process of organic decay is complex, and produces a number of substances and compounds with differing levels of stability. Typically, organic matter accumulated in soils include a wide range of decay products, as organic matter is simultaneously accumulating through the death of organisms and being removed through progressive decay and leaching. Common decomposition products include finely divided plant and animal tissue; proteins, carbohydrates, tannins, fats, lignins, and other complex organic compounds; organic acids such as humin, humic acid, and fulvic acid; and molecular and elemental constituents such as carbon, nitrogen, phosphate, and calcium complexes. Undecomposed and partially decomposed organic matter forms the principal component of soil $\mathrm{O}$ horizons and is the principal minor constituent of most soil A horizons. As organic matter accumulates, the surface horizon darkens in a process termed melanization, which is frequently the first macroscopic indication of incipient pedogenic alteration.

During the early stages of pedogenesis, organic matter tends to accumulate relatively rapidly in the upper horizons of a soil profile. As soil development progresses, the rate of accumulation slows as older organic material is broken down and translocated or lost through leaching. Provided that ambient conditions do not change, eventually the rate of organic loss reaches rough equilibrium with the rate of organic addition. Although the climatic regime exerts strong controls on the time necessary to achieve a steady-state, and much longer periods sometimes may be required, particularly in soils formed under strongly arid regimes (Wang et al. 1996), this quasi-equilibrium is typically reached in a few hundred to a few thousand years (Birkeland 1984). Consequently, radiocarbon determinations on bulk organic matter in active A horizons tend to yield ages no greater than a few thousand years regardless of the true age of the soil. Such ages reflect the equilibrium between organic gains and losses, 
termed the apparent mean-residence time (AMRT) of the soil (Wang et al. 1996). Because more stable (and, hence, older) organic compounds are more common at depth in an active soil, the AMRT tends to increase with depth in most soils. In all moderately to strongly developed soils, the oldest ages obtained are generally still younger than the true age of the soil, although it is possible to increase the precision of the estimate by dating only the most stable fractions (e.g., pretreated charcoal, humin) (Goh and Moloy 1978; Matthews 1985).

When renewed deposition buries a soil, forming a buried paleosol, most active organic accumulation ceases. In these cases, the youngest ages generally provide the best estimate for termination of pedogenesis. However, if the depth of burial is not particularly great, the former A horizon may not be removed from the zone of active pedogenesis, and soluble organic acids (e.g., fulvic acid) and organic solids may continue to accumulate through turbation, eluviation of the active A horizon developing in the new sediment packet, and deep rooting. Consequently, buried soils often produce ages younger than the true age of burial unless thorough pre-treatment procedures are performed.

In addition to in situ accumulation, organic matter may also be introduced into a soil environment from elsewhere as a component of the sediment load. In cases where appreciable organic matter is introduced both as sediment and through the decomposition of animals and plants that died locally (so-called cumulic soils), radiocarbon ages on bulk organics may be either younger or older than the true age of deposition. The results of such assays depend on the ratio between authigenic organic production and allogenic organic delivery, the true age of the soil, and the rate of microbial decomposition through time. Thick alluvial soils intercalated in terrace deposits are particularly likely to exhibit cumulic properties, and dates from them must be interpreted cautiously.

In addition to the importance of organic accumulation on soil character, the decomposition products produced by the decay of organic matter play important roles in the weathering and translocation of mineral components of the soil. Organic acids, and fulvic acid in particular, are capable of combining with metallic ions to form chelating complexes that are soluble in $\mathrm{pH}$ ranges wider than the metal ions alone. These complexes are commonly interpreted as a principal mechanism of iron and aluminum translocation in soils, particularly in the process known as podsolization, where iron, aluminum, and organic matter accumulate in the $\mathrm{B}$ horizon below an $\mathrm{E}$ horizon dominated by residual silica (Birkeland 1984). Maintenance of organic matter in a soil is also largely a function of various types of chemical bonding with mineral constituents, particularly clays, although other mechanisms (particularly nutrient cycling and resynthesis) also play important roles.

\section{Calcification}

In common usage, the term calcification refers to a soil-forming regime typified by the accumulation of carbonate minerals in a soil under the influence of pedogenic processes (Birkeland 1984; Strahler and Strahler 1992). Soil carbonates are dominated by calcium carbonate $\left(\mathrm{CaCO}_{3}\right)$, but may also include magnesian calcites with up to $20 \% \mathrm{MgCO}_{3}$ and dolomite $\left(\mathrm{CaMg}\left(\mathrm{CO}_{3}\right)_{2}\right)$ (Rowell 1994). Calcification is typical of subhumid to arid settings, where precipitation influx is insufficient to leach these soluble minerals completely out of the soil. Rather, the calcification process represents incomplete leaching of carbonates, which are translocated from the upper soil horizons to the lower horizons, where they precipitate as secondary carbonates with distinctive morphologic characteristics.

While this general concept is a valuable heuristic device that allows for the development of basic, generalized linkages between climate and soil dynamics, it is too restrictive to encompass all mechanisms of carbonate precipitation and enrichment that occur in soils. For purposes of this discussion, calcification is defined here as the suite of processes that result in the accumulation of secondary carbonate in soils. The key difference in this definition is that the notion of a requisite climatic regime is removed, for various forms of carbonate can accumulate under a wide range of environmental conditions. In fact, four different mechanisms exist that can account for the occurrence of carbonate in soils, whether alone or in combination. These mechanisms are:

(1) carbonate accumulation attributable to the classic, semi-arid to arid zone model of development described above;

(2) carbonate accumulation under the influence of intermittent saturation or capillary rise from the water table; 
(3) carbonate accumulation as a result of relatively continuous saturation with groundwater; and

(4) carbonate occurrence in the form of residual parent material.

While all soil scientists and Quaternary scientists would accept the first mechanism listed above as a pedogenic process, some would exclude the second and/or third mechanisms, and no one would accept the fourth mechanism as pedogenic unless the material has been dissolved and reprecipitated (Birkeland 1984:144). The distinction drawn here is rarely made in process literature, particularly in North America, but is extremely important if one is to understand the occurrence of soil carbonates in the vicinity of Houston. While papers and other treatments dealing with the arid/semi-arid model of carbonate accumulation are extremely common (e.g., Bretz and Horberg 1949; Brown 1956; Gile et al. 1966; Rightmire 1967; Reeves 1970; Goudie 1973; Bachman and Machette 1977; Gile et al. 1981; McFadden 1982; Goudie 1983; Birkeland 1984; Machette 1985; McFadden and Tinsley 1985; Harden et al. 1991; Dixon 1994), discussion of soil carbonate resulting from fluctuating vadose/phreatic conditions (e.g., Freytat and Plaziat 1982), phreatic influx (Netterberg 1978; Mann and Horwitz 1979), and parent material (West et al. 1988) is relatively limited. In large part, the concentration on the semiarid/arid zone model is a function of differences in the scope of the definition of pedogenic processes; those mechanisms that are not considered pedogenic processes per se (such as phreatic cementation) are rarely addressed except to outline morphological distinctions between pedogenic and non-pedogenic forms. To quote Birkeland, "it is important to be able to differentiate between pedogenic carbonate and groundwater carbonate when working with buried soils because it is obvious that the latter is of little pedogenic or geomorphic importance" (Birkeland 1984:144). Here, it is important to outline all processes that may be responsible for carbonate accumulations apparent in soils, whether or not the genesis of that carbonate was a vadose-zone process.

All carbonate accumulation is a function of equilibrium reactions between carbonate and bicarbonate, as shown by the following reversible reactions:

$$
\underset{\text { (gas) }}{\mathrm{CO}_{2}}+\underset{\text { (liquid) }}{\mathrm{H}_{2} \mathrm{O}} \rightleftarrows \underset{\text { (aqueous) }}{\mathrm{H}_{2} \mathrm{CO}_{3}}
$$

and

$$
\underset{\text { (solid) }}{\mathrm{CaCO}_{3}}+\underset{\text { (aqueous) (aqueous) }}{\mathrm{H}_{2} \mathrm{CO}_{3}} \underset{\mathrm{Ca}^{2}}{\stackrel{2}{2} \mathrm{HCO}_{3}}
$$

In normal equilibrium conditions, water in equilibrium with calcite and the soil atmosphere has a $\mathrm{pH}$ of 8.4 , although the solubility of soil carbonate (and thus $\mathrm{pH}$ ) is affected by coatings and impurities and generally has a lower $\mathrm{pH}$. A decrease in $\mathrm{pH}$, an increase in $\mathrm{CO}_{2}$ content in soil, or an increase in soil moisture will drive the reaction in equation (2) to the right, dissolving carbonate to yield aqueous calcium and bicarbonate ions. Precipitation is promoted by increased $\mathrm{pH}$, decreased soil $\mathrm{CO}_{2}$, evapotranspiration of water, or saturation of the soil water by calcium or bicarbonate ions. In addition, bacterial metabolic processes can promote the precipitation of calcite in settings where it would otherwise not be conducive, and accelerate it in others (Berner 1971).

The most widely recognized mechanism of carbonate enrichment in soils is translocation and precipitation of carbonate in percolating soil water. Detrital calcium carbonate in the upper profile, aerosolic carbonate dust in the atmosphere, and calcium ions dissolved in rainwater are all gradually translocated through the profile, precipitating at depth and eventually forming a Bk horizon. The latter processes appear particularly important in relatively dry regimes, where the accumulation of pedogenic carbonate in the lower profile can greatly exceed the amount of detrital carbonate parent material that could have been present in overlying horizons (Yaalon and Ganor 1973; Bachman and Machette 1977; Gile et al. 1981; Birkeland 1984). In arid settings, the depth of the calcic horizon in an untruncated and unburied soil is a function of the average depth of wetting during formation of the horizon. However, precipitation of carbonate can be stimulated by any mechanism that serves to slow percolation, such as the presence of a textural boundary or a zone of saturation.

As secondary carbonate accumulates in a soil, it typically goes through a series of morphologic stages. Progressions of four (Gile et al. 1966) to six (Machette 1985) stages of pedogenic carbonate accumulation are recognized in soils, with differences evident in soils of relatively coarse and relatively fine texture during early stages of accumulation (Table 6). Early stages of carbonate accumulation, which occur over Holocene time scales, consist of 
filamental (mycellial or pseudomycellial) carbonate accumulation that typically represent carbonate precipitation in the vicinity of fine roots (Stage I), followed by formation of small masses that are typically termed nodules (Stage II). In gravelly parent materials, early stages are represented by the formation of thin carbonate pendants on the undersides of the gravelly clasts (Stage I), which thicken and begin to engulf the matrix (Stage II). It is frequently useful to further characterize Stage I and Stage II as "early" or "late" to describe the thickness and density of filaments and films and the size and frequency of nodules. Over longer (Pleistocene scale) time periods, the amount of carbonate in the matrix increases to the point that it becomes increasingly plugged (impermeable) (Stage III), and a laminar cap develops and thickens (Stage IV-V). These latter stages represent true calcretes, and merit the master soil horizon designation of a $\mathrm{K}$ horizon (Birkeland 1984). Occasionally, a well developed calcrete will be exposed to increased attack and fracture, typically as a result of a shift towards a moister climate or erosion of overlying horizons. Such a horizon, if recemented, forms a thick, brecciated calcrete termed Stage VI.

Most secondary carbonate accumulations in Texas have traditionally been interpreted in terms of the model outlined above. Correlation between deposits of known age of the morphology of secondary carbonates in the soils they support (e.g., Blum and Valastro 1989; Abbott 1990, 1994; Blum 1992; Nordt 1992, 1994; Frederick 1993) has demonstrated that carbonate development is a valuable diagnostic feature for estimating the age of alluvial paleosols and alluvial deposits in Texas. However, a series of observations made over the past few years have called the universal applicability of the model into question in the mind of this author (Abbott 1997a, 1998). While the model probably works well for west central and western Texas, its applicability to many settings in the Houston area is less clear (see Appendix II).

The morphology of secondary carbonate segregations in soil is variable and reflects the mode of accretion. Similar complexity is apparent in concretions and masses formed in other environment, such as pelagic and benthic marine settings (SellésMartínez 1996). The reasons for the complexity and genesis of secondary carbonate segregations is also far from fully understood, and the terminology used to describe such segregations is often used inconsistently. Nevertheless, eight classes of secondary carbonate accumulation can be recognized: filaments, films, crystallaria, nodules, concretions, septaria, rhizoconcretions, and matrix accumulations.

Filaments (also termed mycellial or pseudomycellial carbonate), are typically the first stage of pedogenic carbonate accumulation in fine-grained sediments. They consist of subvertically oriented dendritic threads of fine calcite that are typically concentrated on ped faces in soils with marked pedality and distributed through the matrix in apedal soils. The number of filaments, and the thickness of individual threads, tends to increase with time, although thick filaments may develop relatively rapidly in particularly conducive situations. In most cases, carbonate filaments appear to be associated with fine roots, and frequently appear as

Table 6. Stages of secondary carbonate development in gravelly and non-gravelly parent material, after Machette (1985).

\begin{tabular}{lll}
\hline & Gravelly Parent Material & Non-Gravelly Parent Material \\
\hline Stage I & thin, discontinuous carbonate pendants & films and thin filaments on ped faces and in matrix \\
Stage II & $\begin{array}{l}\text { Thicker, more continuous carbonate pendants } \\
\text { and localized matrix enrichment }\end{array}$ & Thick filaments and/or nodules or other masses \\
Stage III & $\begin{array}{l}\text { Continuous pebble pendants and interclast } \\
\text { matrix cementation }\end{array}$ & coalesced nodules and matrix cementation \\
\hline Stage IV & Plugged matrix; incipient laminar cap & \\
Stage V & Thick laminar cap, strongly cemented \\
Stage VI & Massive, strongly cemented, multilaminar, brecciated with pisoliths \\
\hline
\end{tabular}


accumulations of fine-sparry to micritic calcite surrounding fine open channels (i.e., root traces) in thin section. The mechanism of filament formation is poorly understood. Carbonate solubility is strongly affected by the partial pressure of atmospheric $\mathrm{CO}_{2}$, which can be 10 to 100 times the concentration in soil air as in the surrounding atmosphere due to root and microbial respiration (Birkeland 1984). In $\mathrm{CO}_{2}$-rich conditions, carbonate solubility is dramatically elevated. For this reason, carbonate precipitation is normally inhibited in the shallow root zone, where the high partial pressure of $\mathrm{CO}_{2}$ promotes solubility (Birkeland 1984). However, the formation of filaments in association with roots is somewhat problematic, because solubility should be particularly high in direct proximity to respiring roots. The precipitation of carbonates in association with roots suggests that this tendency is probably counterbalanced by withdrawal of water by transpiration, which elevates the local concentration of solute calcium and bicarbonate ions sufficiently to promote precipitation, forming the characteristic filaments and, ultimately, calcic rhizoconcretions.

Films (calcans) are also common in the early stages of carbonate accumulation in fine-grained soils with developed pedality. Films are thin, discontinuous, two-dimensional coats of fine calcite on ped faces and fissures in the soil matrix. In some cases, such films may form through the infiltration and subsequent evaporation of water along voids between peds, but most probably represent precipitation of carbonate from solute calcium and bicarbonate ions in the matrix due to preferential evaporation at ped faces. Films may also be composed of sparry or micritic calcite, sometimes interdigitated with more soluble salts (e.g., gypsum, halite).

Crystallaria are isolated crystalline aggregates or similar bodies formed in association with other secondary carbonate masses in the soil. They may exhibit radial, concentric, or irregular crystalline patterns, and the size of crystals commonly increases or decreases from the center to the periphery. Crystallaria probably form most commonly where crystalline calcite develops around the margins of a void (growing inward) or around a skeletal clast (growing outward).

Nodules consist of soft to relatively hard microcrystalline calcite (micrite and/or microspar) masses that lack a concentric internal fabric. Elementary carbonate nodules generally range in size from less than 100 microns to several millimeters. However, larger complex nodules also occur frequently; these generally represent fusion of elementary nodules and may exhibit irregular, knobby shapes. The fabric of complex nodules is rarely homogeneous, and may exhibit internal joints, curved contact planes, and ferruginous inclusions. The character of nodules varies from relatively porous, chalky calcite that is typically white or light brown to denser, gray calcite. Sparry calcite (crystallaria) is often associated with nodular development, where it may occur at the core of nodules or along planes and fissures in complex nodules. In advanced development, nodular zones may coalesce to the extent that drainage is restricted, forming a $\mathrm{K}$ (or Bkm) horizon.

Concretions have a concentric internal laminar fabric indicating that they accreted in stages. They may also be relatively small and simple or exhibit complex internal structure. Patches of sparry calcite, ferruginous concretions, and internal cracks and voids may occur. In some cases, nodules and concretions may develop a concentric system of radial cracks intersected with a second system of cracks parallel to the surface of the mass. Often, these features (septaria) have open or sparry calcite-filled voids associated with radial or concentric structures in the nodules. The origin of septaria is poorly understood, but it appears related to shrinking and swelling (usually of the surrounding matrix, although some septaria may engulf and incorporate expandable clays) associated with variations in moisture content of the soil.

One relatively common form of nodule or concretion is a vertically elongate concentric cement that presumably forms around roots. These features, which may be quite thin or large and massive, are termed subcutanic features or rhizoconcretions. In some cases, concentric structure is very apparent, while in others coalescent nodules are clearly indicated. Fractures and cracking structures also frequently develop in rhizoconcretions. Vertically oriented axial canals, either open or filled with dissimilar sediment or sparry calcite, are typically present. In many cases, the character of calcite morphology varies systematically through the crosssection, with dense, crystalline calcite in the interior and more porous, chalky calcite on the outer portion of the rhizolith.

Matrix accumulations represent diffuse-edged zones of micrite or, more rarely, sparry calcite that 
forms in association with other soil constituents. As such, they do not represent calcite-dominated segregations in a soil, but rather zones where precipitated calcite remains a subdominant constituent but is noticeably concentrated in relation to other parts of the matrix. Macroscopically, matrix accumulations tend to result in relatively large (typically 2-10 cm), diffuse "clouds" that whiten (i.e., reduce the chroma and increase the value) soil zones in comparison to the surrounding matrix. Sometimes, matrix accumulations are associated with specific strata in a stratified profile, suggesting that they may sometimes be related to preferential zones of throughflow. They also sometimes occur as low-value "halos" around nodular accumulations. Matrix accumulations are typical of loamy soils that have abundant pore space, and appear to represent precipitation of substantial quantities of dispersed microcrystalline calcite in existing voids, usually without significant displacement of existing constituents or disruption of primary fabric. They are less commonly observed in dense clayey matrices.

\section{Iron and Manganese Mobility}

Iron and manganese pedofeatures are also common in Houston District soils. They reflect chemical transformations and movement of iron and manganese compounds in the soil profile, particularly under the influence of a seasonally or permanently high water table. In some cases, iron has been mobilized and translocated down through the profile, while in other cases it probably represents local reorganization within peds or introduction of solutes by throughflow or groundwater. The morphology of ferric pedofeatures observed in the field is similar to the range of calcic pedofeatures, including concretions, rhizoliths, pore coatings, filaments and films on ped faces, and ferric hardpans. The redox state of iron in the system also influences matrix color. The presence of reduced iron (gley) is indicated by bluish-gray or greenish-gray sediments, while neutral gray colors often indicate that iron has been mobilized and depleted. Intermittent saturation tends to produce sediments with mottled coloring, where gleyed colors and oxidized colors (browns, oranges, yellows, blacks, and reds) interdigitate in complex arrangements within a horizon. Patterns of oxidation and gleying in a profile are indicative of soil drainage conditions (Table 7), and oxidized, reduced, and mottled sediments and soils are commonly patterned on the landscape in complex ways that reflect spatial patterns of soil water and groundwater delivery, retention, and throughflow.

Iron mobility and pedogenic accumulation is facilitated by anaerobic water and relatively acidic $\mathrm{pH}$. There are two principal, distinct soil forming regimes that result in iron enrichment in soil zones: podsolization and laterization. As described above, podsolization is a soil forming regime typical of relatively humid, temperate environments, particularly those under coniferous or mixed deciduous/ coniferous vegetation. True podsols (or spodosols of the USDA Soil Taxonomy [1975]) are typically characterized by a thin, peaty A horizon underlain by a relatively thick $E$ horizon of residual silica and a $B$ horizon characterized by significant enrichment in iron, aluminum, and organic matter. Podsols represent soils where most soil constituents, including iron, aluminum, organic matter, and silicate clays have been eluviated from beneath the active $\mathrm{A}$ in the upper profile and deposited in the B horizon, forming a residual $\mathrm{E}$ horizon of siliceous sand and/or silt and an underlying spodic (Bs, Bh, or Bhs) or Bt (argillic) horizon. Such soils form only where the climate is relatively cool and moist, and no true podsols are present in the Houston District (McLintock et al. 1972; Wheeler 1976; Crenwelge et al. 1981; Greenwade 1984; Crenwelge et al. 1988). However, many soils probably reflect the influence of the podsolization process, particularly in the coniferous landscape of the northeastern District.

Laterization, in contrast, is a soil-forming regime typical of a moist tropical climate. In such environments, the solubility of silica is enhanced and the weathering and leaching of siliceous minerals is pronounced. The end result of laterization is the formation of a thick, rubified oxic horizon composed primarily of residual iron, aluminum, and clay minerals. Silica, soluble cations, and organic matter are nearly absent due to intense weathering, leaching, and microbial activity. Distinctive horizons resulting from laterization include laterite, a hard subsurface ironpan, and plinthite, which is a dense, brittle subsurface pan or nodular horizon that hardens irreversibly on repeated wetting and drying. Although there are no Oxisols in the Houston District, there are a number of relict upland soils classified as Ultisols, which are indicative of less intense laterization, and plinthite subsoils are 
Table 7. Generalized relationship between drainage and gleying of soil horizons. Modifed from Batey (1971).

\begin{tabular}{|c|c|c|c|c|c|}
\hline & Freely Drained & $\begin{array}{l}\text { Moderately Well } \\
\text { Drained }\end{array}$ & $\begin{array}{l}\text { Imperfectly } \\
\text { Drained }\end{array}$ & Poorly Drained & $\begin{array}{l}\text { Very Poorly } \\
\text { Drained }\end{array}$ \\
\hline $\begin{array}{c}\text { Epipedon } \\
\text { (O and A horizon) }\end{array}$ & \multirow{3}{*}{ uniform colors } & \multirow[b]{2}{*}{ uniform colors } & uniform colors & $\begin{array}{l}\text { reddish-brown } \\
\text { root traces and } \\
\text { films }\end{array}$ & $\begin{array}{l}\text { dark brown or } \\
\text { black peaty }\end{array}$ \\
\hline $\begin{array}{l}\text { Lower soil } \\
\text { (B horizon) }\end{array}$ & & & \multirow{2}{*}{$\begin{array}{c}\text { Large, prominent } \\
\text { gray or } \\
\text { ochreous mottles }\end{array}$} & \multirow{2}{*}{$\begin{array}{c}\text { or ochreous } \\
\text { mottles and gray, } \\
\text { bluish gray, } \\
\text { or greenish gray } \\
\text { horizons }\end{array}$} & \multirow{2}{*}{$\begin{array}{l}\text { predominantly } \\
\text { gray, greenish } \\
\text { gray, or bluish } \\
\text { gray horizons }\end{array}$} \\
\hline $\begin{array}{l}\text { Subsoil } \\
\text { (C horizon) }\end{array}$ & & $\begin{array}{c}\text { gray or ochreous } \\
\text { mottles }\end{array}$ & & & \\
\hline
\end{tabular}

associated with at least 10 distinct soil series (see Table 2). Although lateritic processes are probably still occurring at some level in the Houston District, significant losses of siliceous components are not apparent in any Holocene-age soils.

Iron and manganese pedofeatures include concretions and other distinctive segregations, and variations in matrix color resulting from redox reactions, which affect both the state and solubility of ferric and manganese compounds (Van Wallenburg 1973; Birkeland 1984). Oxidation-reduction reactions, such as the conversion between ferric iron (e.g., $\mathrm{Fe}^{2} \mathrm{O}^{3}$ ) and ferrous iron (e.g., $\mathrm{FeO}$ ) occur on a regular basis in soils that experience fluctuating moisture conditions brought on by flooding or seasonal changes in the position of the water table. Reducing conditions are initiated as soil microbes exhaust free oxygen in saturating water and initiate anaerobic respiration. Anaerobic respiration results in the sequential reduction of a variety of compounds, the severity of which is measured by the soil's redox potential. In addition to reduction of iron and manganese oxides and hydroxides, reduction results in denitrification, production of organic compounds like ethylene and acetic acid, and conversion of sulfates to sulfide compounds such as hydrogen sulfide gas (which causes the rotten-egg smell commonly noted when marshy sediments are disturbed) and iron sulfide (pyrite) precipitates (Rowell 1994).

Pedogenic iron segregations and masses are common in upland soils in the Houston District, particularly those soils developed on surfaces predating deposition of the Beaumont Formation. Dense, gravel-sized ironstone concretions are common in the bed load of many of the smaller streams draining the Lissie Formation and Willis Formation. These concretions range from a few millimeters to at least several decimeters in diameter and usually show thick concentric banding. Ferric rhizoliths and hardpans are also common in the ancient soils of the District. Some rhizoliths may exceed $5 \mathrm{~cm}$ in diameter and a meter in length. Iron and manganese segregations also occur in Holocene-age soils, but dense iron concretions are relatively rare. Iron in Holocene soils is typically manifest as rusty-colored ped films and filaments; pore linings; small, thin-walled ferric rhizoliths; thin ferric grain coats; and/or prominent redox mottling. Dark brown to black manganese nodules 0.5 to $5 \mathrm{~mm}$ in diameter are also common in many Holocene profiles, particularly in the upper part of the zone of mottling. Greenberg and Wilding (1998) suggest that active redoximorphic features should exhibit indistinct boundaries, and interpret sharply bounded features as relicts. While this argument has merit, sharp boundaries may also indicate features that are subjected to cyclic periods of growth and chemical attack.

In some cases, the arrangement of mottling in the matrix may be indicative of saturation history; peds characterized by oxidized exteriors and gleyed interiors may indicate a shift towards more freely drained conditions, while oxidized interiors and 
gleyed exteriors may indicate a shift towards more restricted drainage. In other cases, the same patterning may reflect soils that are saturated from the bottom up and from the top down, respectively (Veneman et al. 1998). However, such patterns may also result from other factors, such as the formation of coatings on ped faces by infiltrating material (Brammer 1971; Greenburg and Wilding 1998), or maintenance of color inherited from the parent material in the ped interior.Moreover, many redoximorphic features appear remarkably stable long after drainage conditions change, and observed patterns may therefore not reflect extant conditions (Greenburg and Wilding 1998).

Although gley is usually the most obvious consequence of soil saturation, other soil characteristics also arise from seasonally wet conditions. They are mentioned here because they often occur in conjunction with ferric mottling and staining. One consequence of repeated wetting and drying in expansive clay soils is the formation of pressure faces, or slickensides, where the expanding peds come into contact. Another consequence, particularly in alluvial settings, is the development of silty ped coats and caps. As an expansive soil shrinks upon drying, a pattern of subvertical cracks forms in a roughly hexagonal pattern. These cracks are responsible for the formation of both silt coats and slickensides. Silt coats occur when floodwaters containing suspended silts and/or fine sands infiltrate into the open cracks of a dry expansive soil. As the surface is flooded, silt is carried down into the cracks until the soil takes up enough moisture to swell and close them. As the soil expands upon wetting, the faces of opposing peds meet and press into each other, forming slickensides as clays at the ped surfaces are compressed by the expansive pressure.

Anaerobic conditions resulting from continuous saturation typically result in relatively uniform bluish-gray or greenish-gray soil colors. Such conditions can promote spectacular organic preservation, as witnessed by the succession of "bog people" recovered over the past decades in Europe. However, soil moisture conditions that alternate between saturated and freely drained on a regular basis are extremely harsh and tend to degrade organic remains rapidly. Such conditions are common in the Houston District, and are largely responsible for a relative paucity of organic remains and archeological charcoal typical of many Houston area archeological sites.

\section{Clay Formation and Translocation}

The formation of argillic horizons is one of the most commonly cited time-dependent soil processes. Argillic horizons form as clay originally dispersed throughout a deposited sediment is translocated from the A and E horizons into the B horizon. Clay can also be introduced through eolian processes, or created through in situ weathering of silicate minerals over the long term. Infiltrating water carries this clay deeper in the profile, where it accumulates in the $\mathrm{B}$ horizon, forming a characteristic "clay bulge" in the textural profile. Illuvial clay accumulates as coatings on coarser particles, bridges between particles, laminated fillings within voids, and aligned coats on ped faces. These latter features, commonly termed clay films, clay skins, or clay cutans, are probably the most diagnostic macroscopic feature of clay translocation, although care must be taken to avoid confusing them with pressure faces and slickensides resulting from expansion and contraction of clayey materials.

Development of an argillic (Bt) horizon through the action of pedogenesis on a loamy sediment is usually a long-term process. Birkeland (1984) notes that the rate of argillic horizon development varies widely $\left(10^{2}\right.$ to $10^{5}$ years) depending on many factors, including the abundance, character, and timing of precipitation, parent sediment character and texture, rates of eolian influx, and the influence of other soil constituents (such as the dispersive influence of sodium ions). In most cases, incipient argillic horizons will develop within Holocene time scales, although significantly arid conditions may lengthen this process, while high magnitude dust delivery may shorten it considerably. In contrast, argillic horizon development resulting from the neoformation of clay minerals in the profile through weathering of feldspars and other siliceous minerals probably requires considerably longer time spans in most environments.

Although the importance of clay translocation for pedogenesis is almost universally recognized, one recent synthetic work (Paton et al. 1995) argues that the process is not demonstrable and that alternate models such as bioturbation mantles and textural heterogeneity of complex parent materials provide more compelling explanations of the observed morphologies. While the overall argument is not persuasive, Paton et al. (1995) do make the valid point that soil scientists tend to assume that textural 
contrasts between the upper and lower horizons are the result of eluviation/illuviation, and therefore often fail to consider other possibilities. The same is true of another assumption commonly held by soil scientists: that sandy materials occupying the position of an E horizon are in fact the product of pronounced pedogenesis on a single deposit, rather than the result of multiple phases of depositional activity. This assumption has been challenged for soils in the Houston District (Aronow 1992). Indeed, many texture contrast soils are clearly the result of changes in primary texture (due to facies changes or stacked depositional units) or the influence of biological activity (cf. Johnson et al. 1987; Johnson and WatsonStegner 1990). Nevertheless, micromorphological data indicate that considerable clay translocation does take place in most soils over the long term, and dismissing the process is an untenable argument.

Unlike most soil processes, the process of clay translocation has very little direct relevance for archeology because it does not directly affect the context or condition of archeological remains in the matrix (although water infiltration, which drives clay translocation, does affect the chemistry and stability of perishable remains). Clay accumulation in the $\mathrm{B}$ horizon is primarily an indicator of relative soil age, and is often used together with other indicators - such as degree of rubefaction, carbonate morphology, and structural development-as a reliable guide to assess the relative age of deposits as well as to determine when deposits too old to be of cultural relevance are encountered.

\section{DISTURBANCE PROCESSES}

There are many mechanisms capable of disrupting and mixing soils and sediments, and few archeological sites are unaffected by at least one of these processes. This summary addresses turbation mechanisms - those processes that churn and mix soils and sedimentary deposits-typical of the Houston area. It does not address processes of erosion and reburial. Nonetheless, it must be emphasized that erosion and reburial can destroy archeological context just as surely as mixing, with the additional danger that such eroded and reburied deposits can occur in thin, discrete strata that may be very difficult to distinguish from primary archeological remains. In addition, the suite of soil creep processes can affect the entirety of the soil matrix through granular or consolidated movement. While granular creep differs from other processes of erosion and reburial in scale only, deformation of a coherent soil mass may distort the spatial and stratigraphic relationships between artifacts in the matrix.

Five basic pedoturbation processes are relevant to the region around Houston: faunalturbation, floralturbation, argilliturbation, salt growth, and cultural disturbance. There are also several other subsidiary forms of disturbance that may have affected sediment integrity in the region (e.g., seismic disturbance, subsidence faulting, methane gas formation and escape), but they are of minor importance at best and will not be discussed here.

\section{Faunalturbation}

Faunalturbation refers to the mixing of sediments by the action of animals. Faunalturbation occurs primarily through burrowing, although several other processes (e.g., digging by predators, trampling, wallowing) may also contribute to such mixing (Hole 1981; Butler 1995). As described previously, burrowing not only disrupts sediments in the subsurface, but can result in sedimentation on the surface around a burrow entrance as the sediments are ejected and reworked by wash processes and wind. The following discussion outlines the types of disturbance introduced by various classes of organisms.

\section{Insects and Annelids}

Burrowing insects (e.g., ants and termites) and annelids (e.g., night crawlers and other worms) are probably the most ubiquitous agents of faunal disturbance, although they are usually far from the most obvious. While there are thousands of types of burrowing insects, it is the social insects like ants, termites, and bees that have the greatest potential to reorganize sediments and thus significantly modify the surface and subsurface. However, subsurface modifications are also caused by a variety of other insects and arachnids who burrow, albeit singly or in small groups. While the action of such solitary invertebrates is relatively minor when viewed in isolation, in aggregate and over the long term such activity can result in considerable reworking of soil in the subsurface.

Documented rates of surface casting by ants, termites, and earthworms have been summarized 
previously in this chapter. These rates of turnover are impressive, but they become even more so when one considers that much, if not most, of the sediment reworked in the subsurface is not ejected on the surface. Rather, reworked sediment is often rearranged in the subsurface by compaction of burrow walls and backfilling of passages. Over a span of thousands of years, the density of these infilled burrows can approach total reworking of the soil matrix. Moreover, these small krotovina can be extremely difficult to discern unless they are infilled with dissimilar sediment. In West Texas, for example, eolian coppice dunes frequently appear to be featureless masses of fine sand when they are first trenched, but several days of weathering reveal complexes of dense, multigenerational insect krotovina that completely occupy the shallow subsurface (Abbott 1996). Similarly, unpublished observations by the author during mitigation of site 41WB437 in Laredo, Texas, revealed a dense network of small krotovina and open ant and termite burrows extending to more than $1 \mathrm{~m}$ below the surface and infilled with a variety of similarly colored sediments, most prominently laminae of silty clay introduced during flooding. Such dense networks of burrows and krotovina, introduced by many generations of ant and termite activity in the subsurface, may completely rework the fine-grained matrix of a site and significantly alter its chemical composition. However, because of their body size and because the volume of burrows active at any particular point in time is relatively small, ants and termites are unlikely to affect any but the smallest of buried, non-perishable artifacts. Thus, archeological remains like burned rock features and lithic scatters may be maintained with a high degree of subsurface integrity even while the encompassing matrix and incorporated organic remains are gradually reworked to a severe degree.

Earthworms are even more efficient and industrious processors of soil matrix because they actually ingest the soil and excrete it in the form of pellets that often fill the burrow behind them (Stein 1983). While ants initially strive to create a burrow network, the bulk of an ant colony's life cycle is primarily concerned with burrow maintenance while they forage elsewhere for sustenance. Earthworms, in contrast, spend their entire life cycle burrowing because burrowing and eating are essentially the same activity. As a result, they are quite prodigious burrowers. In fact, earthworms appear responsible for the formation of the granular structure typical of many surface horizons, which indicates that the upper 25 to $75 \mathrm{~cm}$ of many soils has been completely and repeatedly processed. As with ants, the body size of earthworms makes it unlikely that large non-perishable artifacts in the subsurface will be substantially affected, while the surrounding matrix may be completely altered.

The effects of solitary burrowing insects are more difficult to assess because they affect significant changes only gradually. As with ants and other burrowing social insects, the most intense modifications occur in the upper part of the soil, decreasing markedly below a depth of 1-1.5 m. However, certain species of insects, such as cicadas, may burrow quite deeply ( $>2 \mathrm{~m}$ ), disrupting the sediment matrix well below the active soil zone. Overall, the impact of burrowing insects and annelids on archeological deposits is a function of (1) the intensity and character of burrowing activity; (2) the age of the deposits (and thus the longevity of burrowing); and (3) the depth of the archeological remains.

\section{Crayfish}

Freshwater crayfish are relatively large (4-10 $\mathrm{cm})$, hard-shelled decapod crustaceans related to, and believed to be descended from, marine lobsters. Although the North American and Australian varieties were once believed to have evolved at two different times, both are now considered to have evolved from a common ancestor in the Permian or Triassic (Hasiotis et al. 1995). In addition to serving as a potential food source for prehistoric populations, crayfish are significant archeologically because of their burrowing behavior, which can profoundly alter archeological sites. Like insects and annelids, crayfish construct complex burrows (Hasiotis and Mitchell 1990) and are capable of considerable mixing of sediments over the long term (Stone 1993).

Crayfish burrows exhibit variable configurations ranging from relatively simple to complex, branching forms. Typically, crayfish burrows consist of a horizontally oriented burrow network concentrated in the upper $0.5 \mathrm{~m}$ of the soil that are connected to one or more vertical "chambers" or "cellars" that penetrate below the depth of the water table and to one or more surface openings termed 
"chimneys" (Hobbs and Hart 1959; Stone 1993, Honey and Hasiotis 1994). However, the development of the horizontal burrow network and the frequency of chimneys appears to vary by species, with some species producing less developed, more vertically oriented burrows than others (Stone 1993). Individual burrows vary in size considerably, but do occupy volumes that are clearly appreciable and can impact archeological strata. Stone (1993) describes burrows of the species Procambarus rogersi as consisting of a system of multiple horizontal burrows typically $>1.5 \mathrm{~m}$ long and up to $8 \mathrm{~cm}$ in diameter, suggesting that, at minimum, a single burrow should occupy a volume of at least 20 liters $\left(0.02 \mathrm{~m}^{3}\right)$, while volumes $2-3$ times this figure would not be unusual. Clearly, penetration of an existing archeological matrix by a succession of crayfish burrows over the long term could have important consequences for the integrity of the assemblage.

Crayfish burrows and krotovina are common features in lowland settings in the Houston District (Larson 1985). Unlike smaller invertebrates, crayfish generally do not homogenize the sediment that they burrow through; crayfish krotovina typically remain clearly visible in section long after they are infilled. In addition to turbation of sites in the subsurface, crayfish have a considerable, and largely unrecognized, potential as an agent of deposition responsible for the burial of archeological sites. The chimneys of crayfish burrows can be quite massive. Hobbs and Whiteman (1991) document chimneys containing up to $40 \mathrm{~kg}$ of sediment, and averaging 11-25 kg. Most chimneys observed by the author in the Houston District were much smaller, and probably contained no more than 1-2 $\mathrm{kg}$ of sediment; nevertheless, over the long term, crayfish chimneys can clearly move a considerable amount of sediment to the surface. As these structures weather, they slake and collapse; some of the sediment will wash back into the burrow, but much of it will spread out over the adjacent ground surface, potentially burying archeological materials resting on the surface around the burrow. The efficiency of this process for burying cultural material is a function of the number of chimneys per unit area, the mass of individual chimneys, the characteristics of the sediment, and the duration of crayfish habitation. Like chimney size, the density of chimneys varies by species. Hobbs and Whiteman (1991) report densities of up to 63,500 mounds/ha in Southeast Texas, while Nials and Gunn (1982) report previously unpublished observations of up to 38 chimneys per $\mathrm{m}^{2}$ (equivalent to a maximum of 380,000 mounds/ha) in southern Oklahoma. While these staggering numbers are clearly not the norm, the implications for surface sedimentation over the long term, even by crayfish populations an order of magnitude smaller, are clearly significant.

\section{Vertebrates}

Vertebrates affect sediment/soil integrity by a variety of mechanisms. The most obvious mechanism is burrowing, which is practiced by a variety of small to medium-sized mammals, a number of reptiles and amphibians, and a few birds. Burrowing is conducted for a variety of reasons, including denning, rearing of young, shelter from predators and the elements, access to below ground resources, caching of food, and protection during hibernation (Butler 1995). Many other animals, including various taxa of reptiles and birds in particular, do not actively burrow but routinely occupy burrows dug by other animals. Burrowing mammals range from relatively small (e.g., shrews, voles) to relatively large (e.g., canids like coyotes and foxes, bears), but the most common are small to moderately sized rodents (e.g., ground squirrels, rabbits, prairie dogs, and pocket gophers) (Bocek 1986). The largest burrowing animals that were present in the Houston District during the culturally relevant past are the black bear and the American alligator. While burrowing by black bears is not common in the southern United States due to the mildness of the winters, alligator burrowing is common on the margins of wetland areas, as is the construction of surficial nests made of earth, vegetation, and debris (Butler 1995).

The size of vertebrate burrows ranges from small, shallow depressions to deep and extensive networks of passages and tunnels. Size is dictated by both the body size of the animal and its behavioral characteristics. In some cases burrows may be quite lengthy but of a diameter only large enough to accommodate the animal's body, while other animals may create burrows that expand into relatively large subterranean living chambers that several animals can inhabit comfortably. Some of the larger documented burrows include prairie dog dens, which average $10-13 \mathrm{~cm}$ in diameter, and may be $30 \mathrm{~m}$ or more long and extend up to $5 \mathrm{~m}$ below the surface, and alligator dens, which may 
be up to $20 \mathrm{~m}$ long with diameters in excess of 75 $\mathrm{cm}$ (Sheets et al. 1971; Butler 1995). The net effect of burrowing on the integrity of the soil matrix is considerably enhanced when the animals involved live in large social groups. A prime example is the prairie dog colony, where hundreds of animals live in close proximity and active burrow entrances can number as high as 300/ha (Whicker and Detling 1988).

The consequences of burrowing behavior include deposition of spoil piles at entrances and changes in the drainage and throughflow characteristics of the soil. Burrow spoil is commonly reworked by wind, water, and gravity on the surface, and by gravity and infiltrating water in the subsurface. Upon abandonment, burrows gradually infill as sediment is washed or blown in and/or the walls and roof collapse. Infilled burrows (krotovina) can vary from distinct to practically imperceptible depending upon the character and contrasts between host and fill sediments. Repeated burrowing over long periods by fossorial rodents has been shown to create subsurface stone lines that represent lag surfaces overlain with exhumed and reworked fine-grained sediment (Johnson 1989).

The archeological consequences of burrowing include disturbance of subsurface remains and introduction of sediment at the surface, which can bury surficial materials as well as archeological materials exhumed as part of the spoil (Bocek 1986). Because of their larger body size, burrowing vertebrates are capable of disrupting much larger artifacts and features than are impacted by insect burrowers, and relatively large burrowers are capable of completely destroying the context of even moderately large subsurface features, such as wall segments and burned rock clusters. Artifacts in matrices impacted by burrowers may be exhumed and reburied in surficial spoil, or they may fall or slide down the burrow and be incorporated deeper in the profile. If individual krotovina are apparent, the interstices between burrows may contain material in primary context, but intense, long-term burrowing by vertebrates can completely destroy the spatial and stratigraphic relationships between elements of an archeological component.

In addition to burrowing, vertebrates can affect archeological sediment matrices in several ways. One common mechanism of disturbance is trampling. The efficacy of trampling as a mixing mechanism is a function of animal mass and foot size, sediment texture, and moisture content. Intense mixing can occur where relatively large animals routinely walk through wet sediments. Ungulates, in particular, are capable of thoroughly mixing the upper half meter of muddy sediments simply by hoof penetration. In contrast, dry sediments (with the exception of eolian sands) are usually not mixed appreciably by trampling. However, they can be significantly compacted and devegetated, resulting in increased susceptibility to reworking by sheet erosion, gullying, and/or eolian deflation (Alderfer and Robinson 1976; York and Dick-Peddie 1969). In addition, trampling on slopes can lead to formation of terracettes and to chipping and calving of banks and slope breaks (Butler 1995).

Wallowing provides another mechanism where soil material can be mixed, compacted, and ultimately mobilized and removed. It represents activity designed to provide protection from heat, insects, or parasites, and can involve either wet (muddy) or dry (dusty) sediments. Wallowing is a common behavior among medium to large mammals, including animals that occurred in the Houston area prehistorically like collared peccary and bison, but is also noted in small rodents (Butler 1995). The degree of mixing caused by wallowing behavior depends on the textural character of the sediments, the size of the animal and the intensity of its behavior, and the moisture content of the sediment. Wallowing also leads to removal of sediments from the wallow, either caked and matted into the fur or on the skin, or through eolian deflation of the devegetated wallow surface.

A final mechanism of disturbance consists of rooting and digging activity by animals in search of food. This activity is performed by fossorial mammals in the process of burrowing, but it is also practiced by larger animals for the sole purpose of obtaining plant or animal food resources. Rooting and digging for food is practiced by herbivores in search of root foods and fungi, carnivores in pursuit of burrowing prey, and omnivores in search of practically everything. Pigs, in particular, have a strong tendency to dig extensively, but the trait is also apparent in raccoons, canids, bears, and porcupines (Butler 1995).

In addition to mechanisms of mixing sediments, devegetation and compaction resulting from overgrazing can render segments of the landscape 
very susceptible to sheet erosion and wind deflation. This tendency is particularly pronounced in domestic livestock, which is often forced by human containment to continue grazing areas that would have otherwise been abandoned in favor of other areas with more luxuriant growth. However, devegetation by wild grazing and browsing vertebrates can also lead to severe sheet and rill erosion (Selby 1993).

\section{Floralturbation}

Floralturbation refers to disruption of sediment through the action of plants. In comparison with the diverse turbation mechanisms attributable to animals, floralturbation is of distinctly secondary importance in most environments. Two basic floristic mechanisms exist that are capable of disrupting sediments to an appreciable degree. The first mechanism is stress imposed by root growth and root movements, and the second mechanism is tree throw.

Root growth exerts slow but incredibly powerful stresses on encasing sediment, as any observation of the cracked and buckled sidewalks typical of many older neighborhoods will demonstrate. The growth of woody roots, in particular, exerts slow but powerful stress that is an effective mechanism for fracturing bedrock. In unconsolidated sediment, increases in the diameter of woody roots results in compaction and displacement of surrounding sediments (and artifacts), and often raises the ground surface surrounding the trunks of large trees into hummocks. If a root penetrates a fragile artifact contained in the matrix, such as a ceramic vessel or a porous sandstone clast, the increase in diameter resulting from subsequent growth can easily shatter the artifact. Elongation of roots during growth also displaces sediment, and provides conduits for water and gases that can accelerate weathering. Even fine, hair-like roots can displace sediment during growth, and are frequently responsible for the destruction of bedding planes in single-grain structured sediments like eolian deposits. When a root dies and decays, it leaves a void that can become filled with loose sediment (and artifacts) from higher in the profile, or it may collapse, displacing overlying strata (Waters 1992).

In addition to growth, roots can exert stresses on the host sediment as the plant is buffeted by the wind. These stresses can result in minor adjustments of unconsolidated sediment surrounding the root network, but the effect on the integrity of archeological materials encased in the matrix is typically negligible. However, the uprooting of trees can result in massive disruption of the subsurface matrix as sediment encased in the root mass is torn from its original location.

\section{Argilliturbation}

Argilliturbation refers to soil mixing resulting from the expansion and contraction of clays in the solum and subsoil with repeated wetting and drying. It is typical of the Vertisol soil order, although soils belonging to other soil orders may also exhibit vertic properties. Clay minerals of the smectite family are able to readily take up and lose water molecules in their crystalline lattice, which causes them to swell when wetted and shrink again upon drying, and all clays (particularly fine clays) tend to expand and contract somewhat during wet-dry cycles due to interparticular phenomena. Wilding and Tessier (1988) identify a number of factors influencing shrink-swell phenomena, including soil fabric, mineralogy, the character of the saturating cation, electrolyte concentration and speciation, clay content, surface area, antecedent soil moisture content, frequency of desiccation/rewetting cycles, confining pressures, soil thickness, macro- and micro-climate, slope, topography, vegetation, cropping patterns, and soil management practices. As a result of these factors, deep soil cracks typically develop as the soil shrinks and the peds separate. These cracks, which can be up to $10 \mathrm{~cm}$ in width and over $1.5 \mathrm{~m}$ deep in extreme cases (Gustavson 1975), provide avenues for fragments of soil material and artifacts to fall deeper into the profile, where they are incorporated in the next phase of wetting. During expansive phases, the margins of adjacent peds exert pressures that result in soil failure and the development of compressed, striated surfaces termed slickensides. Larger, curved slickensides develop at depth as a result of shear forces arising from differential rates of expansion. There is some evidence that these phases of expansion and contraction tend to gradually force large objects such as artifacts to the surface, potentially destroying archeological integrity (Duffield 1970; Limbrey 1975; Schiffer 1987; Johnson et al. 1987).

Vertisols have been referred to as "selfmulching" or "self swallowing" soils (Buol et al. 
1980; Ahmad 1983). Vertic pedoturbation is itself a function of two related processes, upward movement of large objects by incremental heave processes, and infilling of cracks by loose soil material during dry seasons. While these processes clearly operate, development of horizonation and clear trends in physical and chemical parameters with depth in many Vertisols suggest that the role of self-mulching is exaggerated (Wilding and Tessier 1988). Nevertheless, vertical displacement of artifacts, stones, and other large objects contained in vertic clays is a common occurrence (Johnson et al. 1987; Schiffer 1987; Waters 1992), and archeological integrity must always be considered suspect in Vertisols.

Pronounced vertic activity frequently leads to the development of unusual soil features termed gilgai. Gilgai consist of a form of patterned ground associated with, and usually attributed to, the cumulative effect of long-term shrink-swell processes. Where not disturbed by agriculture, gilgai are characterized by a pronounced surface topography of regular, small-scale humps and depressions. Relief between microhighs and microlows is commonly on the order of $10-30 \mathrm{~cm}$, and the depressions are typically 4-6 $\mathrm{m}$ in diameter (Gustavson 1975). On level surfaces, gilgai tend to occur in relatively random patterns that show no preferred orientation, but on low slopes they appear as relatively continuous, subparallel ridges and depressions oriented downslope. In vertical section, gilgai are characterized by highly variable soil profiles. The microhighs are underlain by areas where the lower soil and subsoil rises towards the surface, while the depressions are underlain by thicker $\mathrm{A}$ horizons and one or more B horizons. The elevation of the subsoil commonly varies by a meter or more between the ridges and depressions. Slickensides are commonly well-developed at depth beneath the depressions.

Several explanations have been proposed for the formation of gilgai structures. Paton (1974; Paton et al. 1995) favors an explanation involving plastic deformation of the subsoil due to differential loading. In this model, the subsoil highs represent diapir-type structures formed as plastic subsoil is deformed. There are a number of sedimentary structures on a variety of scales that clearly do represent plastic deformation due to loading (e.g., ball and pillow structures, salt diapirs; Reineck and Singh 1980), but the argument advanced by Paton that such loading also causes gilgai is not convincing for several reasons. First, density differences between the subsoil (which theoretically flows in response to loading) and the soil (which theoretically supplies the load) are not great (Gustavson 1975). Second, the regularity with which most gilgai occur, particularly on slopes, is not consistent with loading structures. Finally, loading of plastic material on slopes would stimulate flow in a downslope direction, resulting in structures oriented perpendicular to the slope, not parallel with it (Wilding and Tessier 1988).

The self-mulching model (Figure 23) attributes formation to forces associated with expansion and contraction of the clays and with redistribution of material through crack filling. Because the deep, wide soil cracks developed during the dry season commonly fill somewhat with dry surface material, when they are rehydrated volume increases in the soil result in lateral pressures that force surrounding sediment, including soil and subsoil, upward and outward. This creates small surface variations that favor the formation and rehydration of cracks in the depressions, accentuating the process. While this model, first proposed nearly a hundred years ago (Hilgard 1906), appears to play a role in gilgai formation, other factors are also involved.

The most comprehensive model to explain the formation of gilgai is the soil dynamics model, proposed by Wilding and Tessier (1988) (see Figure 23). As in the self-mulching model, the formation of, and movement of material in, soil cracks plays a role. However, the role played by cracks in transmitting water rapidly to the subsurface is much more important. The cracks facilitate preferential rewetting, and thus preferential expansion, of the lower soil and subsoil during the early part of the wet season. This results in the formation of cones of force in the sediment that not only force surrounding sediment up and out, but also cause shearing and the formation of large, inclined slickensides that dip toward the center of the depression. As a result of topographic variability at the surface and slickenside inclination in the subsurface, the rate of chemical weathering beneath depressions is accelerated relative to the rate beneath adjacent highs. Variability in the depth of the subsoil is therefore a function of both lateral forces that physically deform the sediment and different rates of weathering beneath the small rises and depressions. Because weathering of the subsoil removes carbonate salts and enhances chemical weathering of clays, readily 


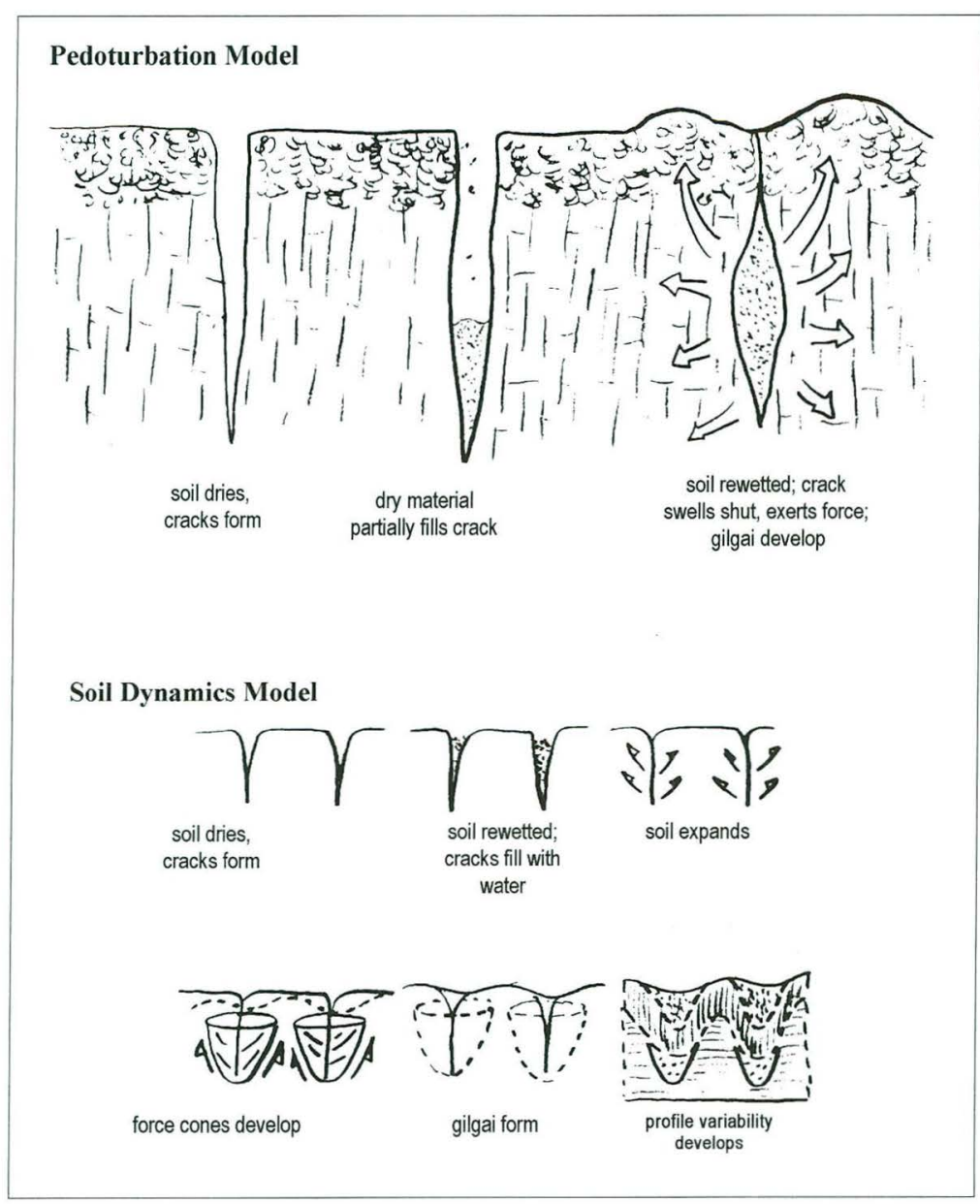

Figure 23. Two different models of soil gilgai formation. The pedoturbation model is adapted from Gustavson (1975) and Buol et al. (1980). The soil dynamics model is adapted from Wilding and Tessier (1988).

expandable clay, moisture, and soil cracks are more common in depressions, resulting in a positive feedback that promotes continued gilgai development. In contrast, topographic variability promotes sheet erosion of surficial sediment from the microhighs and deposition in microlows. This is probably the reason that most gilgai surface expression is on the order of $10-30 \mathrm{~cm}$ of relief, while depth to subsoil commonly varies by a meter or more.

The implications of Vertisols and gilgai for archeology have been touched on previously, but they bear repeating here. Vertisolic expansion and contraction results in the formation of deep soil cracks that can move artifacts deep into the profile, and heave processes can cause artifacts to move upward through the soil to the surface (Johnson et al. 1987; Schiffer 1989). Although sheet erosion from ridges and sheet deposition in depressions is probably common in gilgai terrain, and may sometimes bury artifacts, the self-mulching tendency of the sediments makes the potential for contextual integrity limited.

\section{Salt Growth}

The growth of salt crystals, or crystalturbation (Waters 1992), is another mechanism capable of disrupting sediments. The accumulation of soluble salts in soils, particularly in conjunction with irrigation in semi-arid and arid landscapes, is a major agricultural problem of intense interest to soil scientists (Rowell 1994). However, the disruptive influence of salt growth on soil matrices, and particularly on archeological matrices, has rarely been examined in any detail.

Salt accumulation is typical of areas where salts in solution are concentrated as the water evaporates or is used by plants. In natural settings, salt accumulation is typical of coastlines and of internally drained basins, and salt deposits (evaporites) make up a relatively small but important part of the sedimentary geologic record. However, the widespread practice of irrigation has made the accumulation of soluble salts in the upper horizons of soils, a process termed salinization, a problem of considerable practical interest because it results in drastic reductions in effective fertility and can ultimately make fields unsuitable for crops. Because of the relatively high annual rainfall, crystalturbation is of relatively minor importance in the Houston District except in proximity to saline water bodies and in soils of Pleistocene age, where late Stage II+-Stage III carbonate morphology is common (although its importance justifies separate treatment, calcium carbonate is a salt, and displacive growth of latter-stage carbonate accumulation is a form of salt turbation). However, salt crystals associated with periodic inundation and evaporation of sea water can play a significant role in coastal marshes and on the barrier islands. 
Salt crystallization occurs when dissolved salts are precipitated as water evaporates and becomes supersaturated, and is particularly pronounced at the surface and within the capillary fringe. Common salts include calcite, gypsum, anhydrite, and halite. As evaporation progresses and these salts are concentrated into a brine, the first salt to be precipitated is calcite, followed by gypsum and halite. Salts more soluble than halite (table salt), such as epsomite, sylvite, and bischofite, are extremely ephemeral in open environments, although they do occur in association with halite in evaporation pans. With the exception of calcite, which is relatively insoluble, evaporitic minerals will readily re-enter solution in the opposite order that they are precipitated.

As the brine evaporates, salt crystals begin to form on the soil surface, in the interstices between peds, and ultimately in the sediment matrix. The formation of these crystals exerts tremendous forces on the surrounding sediment and on any fragile or permeable artifacts contained within the matrix. This force causes the sediment to expand and can destroy artifacts by crushing, wedging, and exfoliation. Permeable artifacts like bone and ceramic can literally be pulverized by crystal growth in the artifact and the surrounding matrix. Salt crystals can also form preferentially beneath anomalously large clasts (e.g., artifacts), causing them to be moved. Repeated wetting and drying, and the accompanying expansion and contraction of the soil as salts form and are dissolved, can result in slow heaving of the soil, displacing artifacts vertically and laterally within the sediment matrix.

\section{Cultural Disturbance}

A final category of disturbance processes is cultural activity, which is clearly the most rapid and ubiquitous cause of sediment disruption in the modern era. Although cultural disturbance processes are certainly not limited to the past few hundred years, it is likely that when considered on the basis of sheer volume of disturbed sediments, the amount of cultural disturbance generated in the Houston District during the entire prehistoric period is exceeded on a daily basis in modern Houston. This turbation arises from a wide variety of activities, including building construction; installation and maintenance of utilities and other infrastructure; construction and maintenance of shipping facilities; flood control and shoreline maintenance; waste disposal; mining and other types of mineral extraction; timbering; and agriculture. Given our ability to shape the environment we live in, humans are truly geomorphic agents of a type that the world has never seen before (Nir 1983).

Although a detailed examination of culturally driven disturbance practices is beyond the scope of this study, it is important to briefly address the role of cultural disturbance. Because of their magnitude and ubiquity, modern practices will be addressed first. The section concludes with a brief discussion of prehistoric disturbance.

Four principal classes of modern cultural disturbance can be identified: building construction, infrastructure construction and maintenance, extraction and processing of natural resources, and agriculture. Building construction introduces disturbance through a number of mechanisms, including excavation of foundations, land leveling and blading, cutting, filling, borrowing of fill material, and vegetation clearance. Modern construction practices are such that the potential for preservation of any shallowly buried sites in the area of construction is extremely low. Topsoil is routinely removed from entire lots during construction, and base material is often spread, particularly in areas underlain by expansive materials. With the exception of utility installation, deep disturbance is rare in conjunction with the construction of residences and smaller commercial establishments, but larger buildings frequently involve deep excavations to provide a secure foundation.

Infrastructure construction and maintenance includes activities such as utility construction, road construction, floodwater detention structure construction and stream channelization, dam construction, waste disposal (landfill operation), and the construction and maintenance of air, rail, and shipping facilities. Delivery of electrical, natural gas, water, cable, and telephone services to end users involves complex dendritic delivery systems, many of which require extensive linear excavations. Waste water and storm water systems represent gathering systems, often of considerable size, that collect effluents from a large number of point sources, and also generate considerable subsurface disturbance. Pipelines for the transfer of water, petroleum, natural gas, and a variety of petrochemicals from production areas, ports, and rail heads to processing plants and from plants to distribution sites are extremely common, particularly in the vicinity of 
Galveston Bay and in the Freeport area. Road and highway construction often results in wholesale disruption of near-surface sediments, and may affect deeply buried sediments at bridges and overpasses or in areas where the terrain is modified to accommodate smoother traffic flow or greater speed. Landfill construction impacts areas beneath and around the fill itself, as well as areas used to obtain fill material. Channelization and straightening of stream courses and levee construction has been performed extensively throughout the urbanized part of the district to control flooding, impacting tremendous volumes of Holocene alluvial sediments. Flood control structures such as Barker and Addicks reservoirs, and recreational reservoirs such as Lake Houston and Lake Conroe, have also impacted a great deal of alluvial bottom land through seasonal or permanent inundation. In coastal areas, dredging of the bays and disposal of the dredge spoil have disturbed and buried thousands of acres of bayfront terrain. In coastal areas, the construction of groins and jetties disrupts natural beach processes, and tends to result in localized progradation and erosion of beaches. The cutting of artificial passes through the barrier islands also disrupts barrier processes and existing bay circulation patterns, increasing the need for maintenance of all passes through dredging (Fisher et al. 1972)

Extraction and processing of natural resources is another important source of disturbance. Mining, in particular, results in severe disturbances due to excavation for ore and disposal of waste tailings. However, impacts associated with mining are relatively insignificant in the Houston District because few valuable economic minerals are present. The primary exceptions include sulfur, salt, and gypsum, all of which are typically associated with salt domes and have been produced in high volumes (according to the New Handbook of Texas [Texas State Historical Association 1996] the largest sulfur mine in the world was once situated at Freeport). Other materials extracted on a significant basis are sands and shell deposits mined from open pits and used for construction and road base (Fisher et al. 1972) and clays for brick and tile manufacture. Of greater consequence is the extraction of water and hydrocarbons, which produces disturbance through the preparation of well pads, storage facilities, access roads, and pipelines. In addition to these direct effects, drawdown of the aquifer in the area by intensive, long-term pumping has resulted in regional land subsidence of up to $2 \mathrm{~m}$ or more in parts of the Houston area (Fisher et al. 1972). This subsidence strongly influences the character and magnitude of geomorphic processes in operation, particularly in coastal areas, and may disrupt subsurface infrastructure, such as storm sewers and pipelines.

In addition to mineral resource exploitation, the extraction of timber resources can have severe geomorphic consequences. Although logging currently is a relatively minor industry, the pine forests of East Texas were intensely exploited during the last half of the 19th century and the early 20th century (Maxwell and Baker 1983). As in much of East Texas, most of the relatively dense pine forests in the northern part of the district represent secondary growth. Intensive logging, and especially the clear-cutting style of logging frequently practiced in East Texas, has severe geomorphic consequences, particularly in the deep sandy soils typical of the pine forests. Loss of the protection afforded by the tree canopy and root system, and disruption of the $\mathrm{O}$ horizon and compaction of the ground surface as trees are felled and dragged away for processing, exposes the soil to rill and sheet erosion, and can increase rates of sediment yield dramatically (Nir 1983). As will be elaborated on later, small streams in the northern part of the District frequently exhibit up to $1 \mathrm{~m}$ of very recent sandy fill mantling the floodplains. This material is clearly the result of erosion stimulated by logging and agricultural clearing in the 19th and 20th centuries.

Agriculture, including plant cultivation and stock raising, also results in significant landscape impact. In general, cultivation involves destruction of existing vegetation and disruption of the soil, and can lead to pronounced erosion of the landscape when not controlled (Morgan 1985). Plowing has a number of effects, including the breakdown of soil structure and corresponding loss of aggregate strength and stability in the plow zone; eventual increase in bulk density and decrease in porosity/ permeability as the plow zone settles and compacts; and the formation of a mechanically compacted, impermeable "pan" at the base of the plow zone. The depth of the plow zone differs considerably depending on the equipment used, ranging from a few $\mathrm{cm}$ of disturbance by the animal-drawn plows of the historic period to depths of up to $1 \mathrm{~m}$ by root plows used to prepare forested lands for agriculture. In most cases, modern plows and disks drawn by 
large tractors result in the complete disruption of the upper $25-40 \mathrm{~cm}$ of the soil.

In addition to the gradual auto-compaction of plowed earth, soil compaction also results from the weight of machinery used to cultivate. This load compaction often results in less infiltration and greater erosive runoff. The fertilization and harvesting of crops on a given tract typically results in changes in soil chemistry (particularly increases in nitrates and phosphates) and organic content. While cultivation may lead to organic enrichment if the land is initially poor, more often repeated cropping results in gradual decreases in organic content because the resulting biomass is repeatedly removed during the harvest, rather than allowed to decompose and be reincorporated as soil organic matter (Ross 1989).

Plowing of an archeological site clearly affects integrity. In some cases, plowing results in sheet and rill erosion which can remove the artifacts and the site matrix. Erosion upslope can bury surface artifacts as the eroded sediment is redeposited; frequently, however, the sediments themselves contain artifacts in secondary context. Even where resulting erosion and redeposition are not a factor, plowing causes significant impacts. Artifacts contained within the plow zone are displaced vertically and, with repeated plowing in a consistent direction, tend to migrate laterally across the landscape. Observations also suggest that plowing also tends to bring larger objects to the surface, and is less likely to rebury them, resulting in size-sorting of the assemblage through the plow zone (Lewarch and O'Brien 1981; Schiffer 1987).

Agricultural impacts include not only the direct impacts caused by cultivation, but also those caused by field preparation and maintenance. Activities included in this category are initial clearing, contour terracing, and establishment of drainage or irrigation systems. While many field preparation activities may be beneficial for stemming surface erosion, they can have devastating effects on buried archeological sites, particularly in the shallow subsurface. Rice agriculture, which requires considerable landscape modification to allow flooding and drainage of fields (Agricultural Research Service 1973), is a particularly disruptive form of agriculture practiced in the district.

Although the effects are not as pronounced as cultivation, and the observable effects in the modern Houston District are certainly not great, raising stock also can have marked effects on the condition of the landscape and the rate of soil erosion (Alderfer and Robinson 1974; Warren et al. 1986). Adverse effects are largely the result of overgrazing, or grazing more animals than the landscape can support, although grazing strategies (e.g., pasture rotation frequency) and the characteristics of landscape impacts imparted by different animals (e.g., cattle vs. goats) can also affect the degree of impact. Grazing results in land degradation by two basic mechanisms: (1) removal of vegetative cover, and (2) compaction of the ground surface. Removal of vegetative cover is primarily a result of consumption by the animals, although trampling also has an effect. The degree to which vegetation is cropped varies among different animals, with sheep and goats tending to crop vegetation much shorter (and kill it more frequently) than do cattle and horses. However, when confined to insufficient pasture, cattle and horses are also capable of eating grasses and other plants down to ground level, stunting regrowth and increasing susceptibility to erosion. Trampling results in compaction and vegetation loss, and tends to be localized unless the animals are densely confined (e.g., a corral or pen). Although erosion is strongly stimulated by vegetation loss, significant increases in sediment yield can occur before any change in vegetation density is apparent (Nir 1983). Another potential impact of grazing is the disturbance of sites by mechanisms of faunal disturbance discussed previously: trampling, wallowing, and rooting.

In comparison to modern impacts, the role of prehistoric peoples in shaping the Houston District landscape was clearly of minor importance at best. However, any time people occupy a landscape, some impact is unavoidable. Moreover, because those areas of impact are by definition archeological sites, the impact of such activities on the archeological record is much greater than the overall level of impact on the landscape would suggest. In fact, it can be argued that the formation of an archeological site, no matter how sparse or ephemeral, is by definition an impact on the landscape. Nevertheless, the scale of prehistoric impact was clearly limited by the relatively low number of prehistoric people and their limited technological capabilities (and, some would argue, their cultural predilections).

Prehistoric impacts can be divided into two categories: intentional impacts and unintentional 
impacts. Intentional impacts include excavations (e.g., burials, storage cists, fire pits) and vegetation clearing (by cutting and/or burning). Intentional excavations, while limited in size and number, are notable precisely because they provide opportunity for preservation where it is otherwise lacking. The excavation of a pit provides the potential for preservation in the excavated hollow, whether it is intentionally backfilled or allowed to gradually accumulate sediment, and in areas where the excavation spoil is discarded. Vegetation clearing may be practiced to open areas for habitation or agriculture, although there is little evidence that appreciable agriculture was practiced by the prehistoric peoples of the Houston area (Patterson 1995) or by their successors in the historic era (Newcomb 1961). Elsewhere on the Plains, it has been suggested (although not established archeologically) that grass fires were intentionally set to drive game (Wedel 1961), and such a hunting technique may have been employed on the Coastal Plain. The possibility that intentional fires were also used to kill invading shrubs and improve pasture has also been recognized (e.g., Lintz 1993:334). At least one historical source (Parker 1835) suggests that grassland maintenance was also a stimulus for setting fires in the Houston area. Such grass fires would have a strong potential impact on the landscape by making the soil much more susceptible to erosion by wind and water.

Unintentional impacts by prehistoric people should be concentrated at habitation sites, with the severity of the impact related to the duration of occupation (or successive occupations). These impacts include trampling, organic concentration and depletion, soil chemical alteration, and the creation of anthropic deposits and sediment traps. Trampling by humans does not generally result in the same degree of mixing as is often caused by large, hoofed animals like bovids because the ratio between body mass and foot surface area is lower and because humans tend to avoid soft, saturated areas when possible. Nevertheless, trampling by humans results in ground compaction, vegetation loss, breakage of artifacts, and limited soil mixing, and can stimulate granular creep on slopes and subsequent water and wind erosion. The organic content of soils at an archeological site can be depleted as a result of trampling and degradation of the A horizon, or can be enhanced by the addition and decomposition of organic materials gathered and processed or produced (i.e., excreted) by the inhabitants. Typically, some areas of the site will experience organic depletion, while other areas will exhibit organic enrichment, reflecting the spatial patterning of activities. This patterning results in spatial variations in organic matter content, as well as related chemical constituents like phosphate and calcium (Eidt 1977, 1984). If refuse disposal is intense or prolonged, anthropic deposits such as shell middens may develop. Such deposits often cause significant changes in the chemical composition of surrounding and subjacent soils, and may create micro-topographic features that trap and retain sediments from the surrounding landscape. 


\section{Chapter 4}

\section{Late Quaternary Stratigraphy \\ and Geoarcheology of the Houston District}

\section{INTRODUCTION}

This chapter provides an integration of available stratigraphic and geoarcheological data from the Houston District. The first section addresses geoarcheological issues associated with specific types of landforms. This discussion is followed by an examination of stratigraphic issues and models for a variety of environments in the district.

\section{GEOARCHEOLOGICAL ISSUES ASSOCIATED WITH COMMON SITE SETTINGS}

The following sections present brief discussions of geoarcheological issues associated with some of the most common site settings in the Houston District. The focus of these discussions varies from examination of natural formation processes to age expectations and preservation potential of various depositional micro-environments within given settings.

\section{Pimple Mounds and Floodplain Mounds}

The issue of pimple mounds is one of the most widely discussed, and divergently viewed, geoarcheological issues in the archeological literature from the Houston area. Pimple mounds consist of low, circular to ovate mounds, usually composed of loamy or silty sediment, that typically occur in fields of dozens to hundreds of individual, spatially related features approximately $20-100 \mathrm{~cm}$ high and $3-25 \mathrm{~m}$ in diameter. They often rest on a finer (clayey) substrate, but also often occur on silty to sandy substrates (e.g., relict barrier islands; Pleistocene meander belt ridges) that are not texturally distinct from the mound sediments. Pimple mound fields occur in both upland and lowland (floodplain) settings in the Houston District. Other terms used to describe such features on the Gulf Coastal Plain include sandy mounds, natural mounds, prairie mounds, prairie blisters, and floodplain mounds (Aten and Bollich 1981; O'Brien et al. 1989; White and Wiegand 1989), while similar features on the Washington coast are commonly termed "mima mounds" (Washburn 1988). The term "pimple mound" is used here because it is distinctive and in common use, and because several of the other terms listed above are not universally applicable (e.g., not all pimple mounds are sandy, nor are they all situated on floodplains or in prairie settings) or unnecessarily generalized (e.g., the large salt domes of the coastal plain are also natural mounds, but are of a different scale and formed by an entirely different process). Another argument against the use of the term "prairie mound"- the other commonly used name for these features (e.g., O'Brien et al. 1989; Aten and Bollich 1981) — is that the same term is also used to describe much larger features of clearly different origin on the northern Great Plains (e.g., Bik 1968). While it must be noted that some authors (e.g., Aten and Bollich 1981; Mandel 1987) envision more than one mechanism of mound genesis and prefer to treat upland and lowland mounds separately, there is currently little basis for distinguishing between mounds on the basis of areal distribution, spatial patterning, morphology, or stratigraphic/pedogenic criteria (Heinrich 1993). Accordingly, this summary terms all of these features pimple mounds, but recognizes that a distinction between mound forms in different topographic settings may one day be conclusively documented.

Although pimple mounds are still common in the Houston District, they have suffered from the effects of cultivation and urbanization. Cultivation, 
in particular, makes quick work of the mound structure, although oval patches of dissimilar (and frequently less fertile) soil often persist long after the mound itself is destroyed (Carty et al. 1988). Pimple mounds are of archeological interest because they have frequently proven to be favored locations for prehistoric occupation (McGuff 1973; Aten and Bollich 1981; Ensor 1987). This association is very easy to understand, because the mounds often represent the highest and most freely drained part of the local landscape, and would therefore have been quite attractive to people in the area.

More than 30 models of pimple mound formation have been proposed (Aten and Bollich 1981). The most commonly held theories include: (1) modification of relict fluvial bedforms; (2) products of burrowing disturbance; (3) residual hillocks left following alluvial sheet erosion or eolian deflation; (4) accumulation of eolian material, especially as coppice dunes around clumps of vegetation; (5) combinations of aggradation of the mounds through eolian and/or alluvial processes and degradation of intermound areas through scour or eolian deflation; and (6) formation through cryogenic (periglacial) processes (Ensor 1987; Aronow 1990). Because of the range of landscape settings that pimple mounds occur on, some of these models are clearly not applicable to all mounds in the Houston District, while it is difficult to imagine that cryoprocesses played any role whatsoever on the Texas Coastal Plain. Other less common formation theories (e.g., convergence of seismic shock waves, tree throw mounds, artificial burial or house mounds, methane escape vents, differential sediment compaction, salt migration structures, animal wallows, products of former whirlpools and eddies, fossil fish burrows, or whirlwind deposits; see Holland et al. [1952], Berg [1990], and Reider [1992]) are also not currently accepted by most investigators for the Texas Coastal Plain mounds.

From a geoarcheological perspective, the most important considerations in deciding the archeological potential of pimple mounds are: (1) whether the mounds are dominantly depositional (formed through the accretion of discrete sediment bodies) or erosional (formed through the differential erosion of a sediment body that was previously of quasi-uniform thickness), and (2) if depositional, whether they are composed of sediments of culturally relevant age. Although the accumulated evidence suggests that pimple mounds are, at least in part, depositional and of archeologically relevant age because cultural material is often found in quasistratigraphic order within the mound matrix (McGuff 1973; Ensor 1987), the mechanics of mound genesis and the incorporation of archeological materials are less clear. Examination of size sorting also provides good indications that artifacts tend to migrate vertically in many mounds, although it is not clear whether larger artifacts are moving down or smaller artifacts are moving up (Heinrich 1993).

No pimple mounds were examined in detail in conjunction with this study for the simple reason that no good examples could be located within the extant highway ROW, although a number of locations were noted where pimple mound fields extended up to TxDOT property. This indicates that pimple mounds are routinely destroyed during the process of highway construction and ROW preparation, and that they are therefore of concern primarily for projects involving new locations (either new roads or improvements that include expansion of an existing ROW).

\section{Geoarcheological Consideration of Mound Genesis Hypotheses}

The following paragraphs summarize stratigraphic and geoarcheological expectations for each of the principal models of pimple mound formation. These expectations are contrasted with observations made on the morphology and internal stratigraphy of the mounds by various investigators. As the summary will show, many of the observations are incompatible and contradictory, but taken in total they suggest that the origins of Gulf Coast pimple mounds may be polygenetic, both in aggregate (e.g., a distinction between upland and lowland mounds) and at the level of individual mounds. One thing that many of the proposed aggradational and erosional models share is formation from complex, multi-storied parent sediments. This conclusion, that the mounds are formed from relatively recent sediments resting unconformably on an older substrate, is widely shared, although the source and complexity of the presumed veneer is debated (Heinrich 1993).

\section{Relict Fluvial Bedforms}

The hypothesis that some pimple mounds are relict fluvial bedforms has been advanced by several 
authors, notably Dietz (1945), Krinitzky (1949) and White and Wiegand (1989). The latter authors examined a series of floodplain mounds on the Navasota River and concluded that the cores of these mounds consisted of stratified alluvial sediments related to Late Pleistocene ("Deweyville") fluvial activity overlain by a variable veneer of sands reworked by eolian and bioturbation processes. They argue that the mounds are the dissected remains of fluvial bedforms (primarily longitudinal bars of a braided stream system) deposited during the Late Pleistocene or Early Holocene. As the channel shifted, these bars were stranded as relatively well-drained, elevated features on the floodplain. Because drainage was better beneath the mounds than in the surrounding intermound areas, they then developed relatively luxuriant vegetation that began to preferentially trap eolian sediments, causing the mounds to accrete. At the same time, periodic overbank flooding resulted in the infiltration of silts and clays on the flanks of the mound, while the crests remained relatively clay-free.

In a mound formed by White and Weigand's (1989) model, in situ archeological materials could only be expected in the upper eolian veneer (if present), although reworked materials might occur throughout the upper mound. Even if the parent "Deweyville" sands do prove to be of culturally relevant age, the potential for site integrity in such channel sands is extremely limited. The basal mound should grade into underlying fluvial sands, and should exhibit a well-defined, gently curving truncation surface at the contact between the former bar and the underlying fill (like all models presented below, such a boundary would be subject to blurring and disruption by pedogenic processes and might not be apparent). Detailed, laboratory-based textural examination of the mound profile should be able to discriminate between the fluvial and eolian component on the basis of grain size, sorting, and surface characteristics of individual grains.

In summary, geoarcheological expectations for the fluvial bedform model include:

(1) The mound core should retain vestiges of low to moderate angle crossbedding, and should include sediments in the sand and possibly fine gravel-sized range.

(2) The basal contact should be clear and smooth, and define a fluvial truncation surface.
(3) In situ archeological materials should not be present within the crossbedded core of the mound. All artifacts should be contained in veneer deposits formed by subsequent overbank flooding or eolian activity, or should be intruded into the fluvial matrix by bioturbation.

(4) No definable buried soil should be present beneath the mound.

\section{Burrowing Disturbance}

Burrow spoil produced by insects or rodents has been proposed as a formative mechanism by several investigators (e.g., Hilgard 1873; Branner 1900; Price 1949; Mielke 1977; Cox 1984; Cox and Gakahu 1986). Burrowing insects and rodents are quite capable of making mounds, often of considerable size (Butler 1995). Geoarcheological expectations for mounds formed by burrowing disturbance vary with the type of agent responsible. Insect mounds (e.g., anthills) would likely exhibit little or no discernible internal stratigraphy at the macroscopic level, but filled channels and excretion structures would be apparent in thin section. Open channels apparent at the macro level would also likely be present. Depending on the scale of the colony and the configuration of the mound, the entire basal contact might exhibit a broken, bioturbated boundary, or such a boundary might be limited to the central portion of the mound, with the periphery characterized by a smooth, abrupt contact formed where the mound spoil overrode the preexisting surface. In the case of rodent genesis, the mound matrix should contain a complex series of larger $(2-10 \mathrm{~cm})$, possibly overlapping, krotovina. The margins of the mound might exhibit a smooth, sub-horizontal basal contact (barring pedogenic overprinting) broken periodically by krotovina extending into the substrate, or might be completely disrupted by burrowing. The interior of the mound should be largely disturbed by krotovina, although localized sub-horizontal or dipping strata representing ejected spoil might be preserved (note that several investigators, including Holliday [1987] and Aten and Bollich [1981], have noted a paucity of well-defined krotovina in pimple mound matrices). In most cases, textural and mineralogical characteristics of the mound and the substrate should be similar, although centripedal concentration of sediment might result 
in the superposition of disparate sediments in some geologically variable settings.

Given the character of the mounds reported by the many investigators who have looked at them, it seems unlikely that burrowing behavior is the primary mechanism of mound genesis in the Houston area. The distinct textural difference between most mound sediments and the surrounding and subjacent sediments is a strong argument against the formation of mounds by this mechanism alone. While ants and other burrowing insects do tend to preferentially exhume relatively coarse clasts, suitable source materials are generally absent in the substrate beneath mounds. Moreover, the most ubiquitous coarse "clasts" in the Pleistocene soils of the Houston District are secondary concretions such as carbonate and ferric nodules, and such detrital (rather than neoformed) clasts are rarely noted in mound matrices. Limited documentation of differences in element composition (Carty et al. 1988) also support the idea that the mounds formed from a different parent material than the underlying substrate. Finally, even though centipedal concentration of sediment by rodents can occur (Cox 1984), such a process would be unlikely to selectively concentrate a thin veneer of unconformable sediment into discrete mound features.

For these reasons, in the author's opinion, burrowing behavior by rodents or insects is unlikely to be the primary mechanism of mound genesis in the Houston area. However, it is probable that burrowing was an important secondary mechanism in pimple mound formation and modification, because the elevated and relatively well-drained mounds would provide an attractive habitat for a variety of burrowing organisms. Although a paucity of visible krotovina has been noted several times (Aten and Bollich 1981; Holliday 1987), insect krotovina are often very difficult to distinguish except in thin section. Therefore, while the formation of the mounds is probably largely unrelated to burrowing organisms, bioturbation may indeed play an important role in the character of the mound matrix, and therefore in the integrity of archeological materials they contain.

Geoarcheological expectations for mound formation by burrowing animals vary depending on the body size of the organism. Expectations for mounds formed by small burrowing mammals include:

(1) Mound and substrate sediments should usually be mineralogically and texturally similar, unless there are significant pedological or geological boundaries in the immediate vicinity.

(2) Most incorporated archeological materials should be dispersed through the matrix in secondary context, and there should be archeological materials in the intact matrix beneath the mound. Discrete lenses of occupation debris within the mound are possible, but relatively unlikely because it would require penecontemporaneous occupation by people and burrowing animals. Cultural material could occur anywhere within the matrix.

(3) The mound should exhibit an irregular basal contact broken by krotovina. Occasionally, some parts of the mound periphery might exhibit a smooth, level basal contact where unburrowed ground is overlain by spoil. Although a biconvex, lenticular cross-section has been argued to represent "fluffing up"-reduction in bulk density and a corresponding increase in volume-resulting from rodent bioturbation (Price 1949), this argument is difficult to rectify with the architecture of pocket gopher burrows.

(4) Concretions ( $\mathrm{Fe}, \mathrm{Ca}, \mathrm{Mg}$ ) of any size up to $5-10 \mathrm{~mm}$ present in the underlying substrate should also be dispersed in secondary context through the mound matrix.

Expectations for mounds formed by insect burrowing include:

(1) Mound and substrate sediments should be mineralogically similar; mound sediments should be similar to or slightly coarser than the underlying substrate.

(2) Artifacts larger than approximately $2 \mathrm{~mm}$ should represent materials deposited penecontemporaneously with mound accretion. Such materials could be in either semiprimary or mixed (bioturbated) contexts, but the potential for reasonable integrity to exist is relatively high, particularly for artifacts larger than 3-4 $\mathrm{mm}$ in size.

(3) The mound should exhibit a basal contact broken by sub-vertical burrows. 
(4) If soil concretions are present in the substrate, reworked concretions up to $2-3 \mathrm{~mm}$ in diameter should be present in the mound matrix. Larger concretions should not be present in the matrix, even if they are present in the substrate.

\section{Products of Alluvial Erosion or Eolian Deflation}

Eolian deflation or alluvial stripping has often been proposed as a contributing process in the formation of pimple mounds. Authors such as Melton (1929) and Cain (1974) envision a dominantly erosional process, driven by relatively intense storms during dry climatic intervals when the density of vegetative cover is reduced. During these times, rill and sheet erosion and/or eolian deflation dissected the landscape, leaving remnant hillocks that were modified by gravity and wash processes to form the mounds.

This type of broad, shallow erosional stripping is common in arid areas, particularly in bedded alluvial deposits and in areas where a weathered surface layer lies over a more consolidated substrate. Such areas are characterized by retreating microscarps $2-25 \mathrm{~cm}$ high, and often produce broad, nearly level cut surfaces. Occasionally, such stripping may isolate remnants of the initial surface into small, steep-sided features resembling small-scale mesas. Although such residual hillocks could subsequently develop the rounded morphology of pimple mounds through wash and gravity processes, the frequency and spatial patterning of mounds and the extent of mound fields makes this model relatively unlikely (such mounds would be much more likely to occur in more limited areas and in linear clusters representing dissected interfluves).

Broad-scale eolian deflation is unlikely to affect sediments finer than coarse silts. Deflation of clays can occur where desiccation and salt crystal growth mechanically break clays into sand and siltsized aggregates, but such a process is extremely unlikely to deflate vast expanses while leaving isolated mounds. In fact, eolian deflation alone is unlikely to form mounds except in areas where dense, discrete copses of vegetation anchor specific, localized patches of sediment. In such cases, root traces could be preserved in the mound, while primary sedimentary structures would not be expected. If the parent soil/sediment contained a very distinct textural boundary separating an overlying coarse stratum from an underlying fine stratum (i.e., an albic horizon over an argillic horizon), deflation would likely result in a smooth, level intermound surface. In most sediments, however, the erosional surface would tend to undulate over broad areas, deepening gradually away from the mounds.

In both models, artifactual material could be expected in either primary or secondary context within the mound matrix. However, because such material necessarily would have been deposited prior to the formation of the mounds, artifacts would also be expected to occur as lag deposits in the intermound areas in frequencies equal to the mounds. In other words, the mounds would not be favored areas for occupation.

In summary, the geoarcheological expectations for the erosional models are relatively straight-forward:

(1) Artifacts contained in the mound matrix should pre-date mound formation. In eolian formation, such artifacts should occur in no greater average density than on the surrounding intermound surface. In alluvial stripping settings, smaller artifacts should be reworked or removed from the erosional intermound surface, while large artifacts would probably remain relatively close to their original position. Artifacts with good stratigraphic integrity could be preserved in the matrix.

(2) No erosional surface or other distinct boundary should be apparent at the base of the mounds unless it represents a soil horizon transition grading from a sandy to silty upper horizon to a much finer and more resilient lower horizon. Perched, ground-parallel soil horizons, (e.g., a melanized A horizon) would be likely to occur in the mound matrix.

(3) Depending on the character and origin of the sediment forming the mounds, primary structures could be present in the matrix. Root traces, particularly of relatively large tree or shrub roots, would also be likely to occur.

(4) Downwearing of the intermound surface by overland flow would be likely to preserve flat-lying soil horizons truncated laterally at the margins of the mound. Lateral erosion scarps covered by spoil on the mound slope could also be expected. 
Eolian erosion would be likely to create a rolling intermound surface, exposing a variety of the horizons present in the original soil.

\section{Accumulations of Eolian Material}

This model is probably the most widely accepted single process operating during pimple mound formation. It holds that pimple mounds are essentially coppice dunes formed by the trapping of eolian sediment by vegetation. Sandy coppice dunes are very common in parts of the Southwest, including the El Paso area, where trapping is primarily due to the presence of mesquite scrub. On the Texas Coastal Plain, pimple mounds are frequently interpreted as eolian in origin (e.g., Holliday 1987; Mandel 1987; Aronow 1990).

Geoarcheological implications of the eolian model are also relatively straight-forward:

(1) The mounds must have formed during a period when considerable sediment was available for deflation. In most cases, this implies a relatively arid phase with reduced vegetative cover, because the presence of vegetation and soil moisture severely inhibit eolian movement (see Chapter 3). However, an arid interval is not absolutely necessary as long as there is a source of readily erodable sediment available (e.g., a beach or very active, unvegetated floodplain). Such a source can result from an active depositional regime where the accretion of sediment outpaces colonizing vegetation, or from devegetation due to fire.

(2) The matrix of the mound should be composed of well-sorted material in the fine sand through medium silt size grade. Sedimentary structures might occur, but would probably be absent. Root traces would be more likely to occur in the matrix. Weak, interbedded soils could also occur in the matrix. Such soils should reflect former mound topography and not be planar zones truncated on all mound margins.

(3) Well-developed soils may or may not occur beneath the basal contact, which should be relatively well-defined. If the mounds were accreting on a surface that was also slowly accreting (such as a floodplain), the base should exhibit a gently concave contact, while those formed on a stable surface should be relatively flat-lying. If floodplain aggradation continued after the mound stabilized, the margins should be onlapped and buried by encroaching floodplain sediments.

(4) Cultural occupation should be penecontemporaneous with mound formation, and incorporated artifacts should be in relatively good context. However, such materials could be impacted by post-depositional disturbance mechanisms (e.g., bioturbation) or by impacts due to continuing mound occupation after the objects were discarded.

\section{Polygenetic Models}

Many of the models proposed for the formation of pimple mounds and floodplain mounds, including several outlined above (e.g., Cain 1974; Heinrich 1986a; White and Weigand 1989), are polygenetic, in that they include more than one process either in combination or in succession. The amount and range of debate on the issue alone demonstrates the difficulty of the issue, and lends support to the proposal that the genesis of these features is a complex process. Another characteristic of many models is that they incorporate a stacked, stratified sedimentary body that accounts for the difference in texture between the relatively coarse-grained mounds and the finer-grained adjacent and subjacent sediments. In the author's opinion (which is admittedly based almost entirely on the literature review and informal discussions with various investigators rather than original fieldwork), a multiple process origin at the level of a given mound appears likely. Observations on the character of the internal matrix and the basal and lateral contacts of mounds by such investigators as Holliday (1987), Aten and Bollich (1981), and Frederick (1991), while differing in detail, are indicative of the penecontemporaneous operation of several different processes. Less clear is the idea that completely different suites of processes formed similar landforms in different parts of the landscape; i.e., the distinction drawn between upland pimple mounds and floodplain mounds by 
such authors as Aten and Bollich (1981) and Mandel (1987). Although this idea cannot be confirmed given the currently available data, neither can it be disproven.

As the preceding review indicates, there is as yet no clear consensus on the mechanisms of pimple mound formation. Nevertheless, several important points are clear. First, the archeological record recovered from pimple mounds in the Houston area suggest that many represent Middle Holocene to Late Holocene phenomena, and thus were formed during the culturally relevant period. The existence of older mounds, however, cannot be ruled out. Second, pimple mounds represent distinctive smallscale landforms that offered advantages to prehistoric peoples and were preferentially occupied. Third, pimple mounds often contain interstratified cultural materials that rarely (if ever) rest on discrete, well-defined buried paleosurfaces but often retain reasonable stratigraphic integrity. For this reason, pimple mounds represent small islands of archeological potential that are often contained in expanses of landscape with low potential, and should be investigated whenever they occur in a project area. However, because the process of road construction and ROW preparation typically destroys pimple mounds, they are of concern to TxDOT primarily in areas of new location.

\section{Upland Margins}

The phrase "upland margin" is used here to refer to upland and slope surfaces in proximity to alluvial, deltaic, lagoonal, or estuarine environments. In many cases, upland margins represent ecotones between areas with very different suites of available resources, and were probably attractive for limited settlement because they provided ready access to both environments. This characterization is particularly true for the margins of major inland stream valleys such as the Brazos and the San Jacinto rivers, where extensive suites of riverine resources were available.

Upland margins in the district vary considerably in relief, depending on whether the contact is at the margin of an incised fluvial valley, a completely infilled valley, or at the onlap of advancing lagoonal sediments. In areas where lagoonal and marsh sediments are encroaching on the gently sloping Beaumont plain or where alluvial valleys have been almost completely infilled, the lateral contact between the
Pleistocene and Holocene constructional surfaces is usually very subtle, and little relief is apparent. In contrast, where the boundary is at the margin of inland stream courses, more pronounced relief is typical. The current margin of the incised Brazos River valley in the northwestern part of the district (Waller and Fort Bend counties) provides one of the few localities in the District where a good overview of portions of the surrounding landscape can be obtained, and that relief would only have been more pronounced prior to the Late Holocene when the stream was more deeply entrenched. Research on the Great Plains and in the Rocky Mountains has consistently shown that hunter-gatherers often occupied locations with broad views of the surrounding landscape, presumably to facilitate location and tracking of game. Few such locations are present in the relatively level Houston District landscape, but the margins of the Brazos and San Jacinto valleys may have provided such views if the bottom land was not too densely forested.

As a result of this greater relief and the more common breaks in slope, the potential for site burial and preservation to have occurred is considerably higher than it is on level upland surfaces (Aten 1983). Slopes, particularly those formed in the type of unconsolidated sediments that dominate the Houston District, are the focus of a variety of depositional and erosional processes simply because of the potential energy imparted by their relief (see Chapter 3). The most common are surface wash and gravity processes, which can strip the slope or lay down colluvial sediments. Slopes are also subject to rill and gully processes, which form headward-cutting microvalleys that can form and disappear relatively rapidly, eroding sites or burying archeological materials. Slopes also tend to promote deposition of eolian materials originating in both upland and lowland areas through disruption of wind flow and flow separation.

Slopes that have been stripped by erosion are readily recognized because the thick Pleistocene $B$ horizon will be exposed. Such horizons are typically strongly rubified or gleyed, well-structured, and contain large carbonate and/or ferric concretions. Where such horizons are exposed, the potential for intact sites to exist is negligible (although they may exist downslope). Evidence for colluvial or eolian accumulation on the upland margins includes the presence of a downslope-thickening A horizon; sediments with weak soil development overlying a more 
strongly developed soil; the presence of reworked soil constituents (carbonates, ferric concretions) within the surface soil; extant rills and gullies on the upper slopes; and clear to abrupt stratigraphic contacts, particularly dipping contacts that crosscut horizon boundaries in the substrate. Archeological materials contained within such colluvial or eolian deposits may be in contexts ranging from near-primary to completely reworked, and must be evaluated individually where found. Such evaluation may be accomplished by careful examination of spatial and stratigraphic patterning, artifact orientation and dip, assemblage composition, and chronometric or relative dating of assemblage constituents.

\section{Floodplains and Low Terraces}

Stream floodplains and low terraces in the Houston District provide one of the highest probability areas for prehistoric site preservation with reasonable integrity. However, due to the extreme change in base level caused by the Late Pleistocene sea-level low stand, the potential for site preservation frequently extends far below depths that would be practical to investigate. This is particularly true for larger streams such as the Brazos and San Jacinto rivers, where Holocene deposits can exceed 25-30 $\mathrm{m}$ in thickness. While the archeological potential of such deposits is high, logistical impediments to discovery and investigation of sites buried more than 4-5 $\mathrm{m}$ below the surface are considerable, and the threat to such deposits from most transportation projects is low.

For this reason, vulnerable deposits in the larger stream valleys are generally only a few thousand years old, although in some cases older deposits may be present. Figure 24 illustrates the relationship between age and depth for the alluvial radiocarbon samples analyzed during this project that yielded ages less than $12 \mathrm{ka}$. As the figure indicates, sediments within the upper few meters of the surface typically date to the last $2-3 \mathrm{ka}$, although they may be up to 5-6 ka old. With few exceptions, sediments in excess of $5 \mathrm{ka}$ in the larger stream valleys are buried beneath at least $4 \mathrm{~m}$ of overburden, moving them out of the effective depth of most standard methods of prospection. Consequently, primary Early Archaic and Paleoindian remains are very unlikely to be detected in most alluvial contexts in the larger streams. The few exceptions to this trend are from

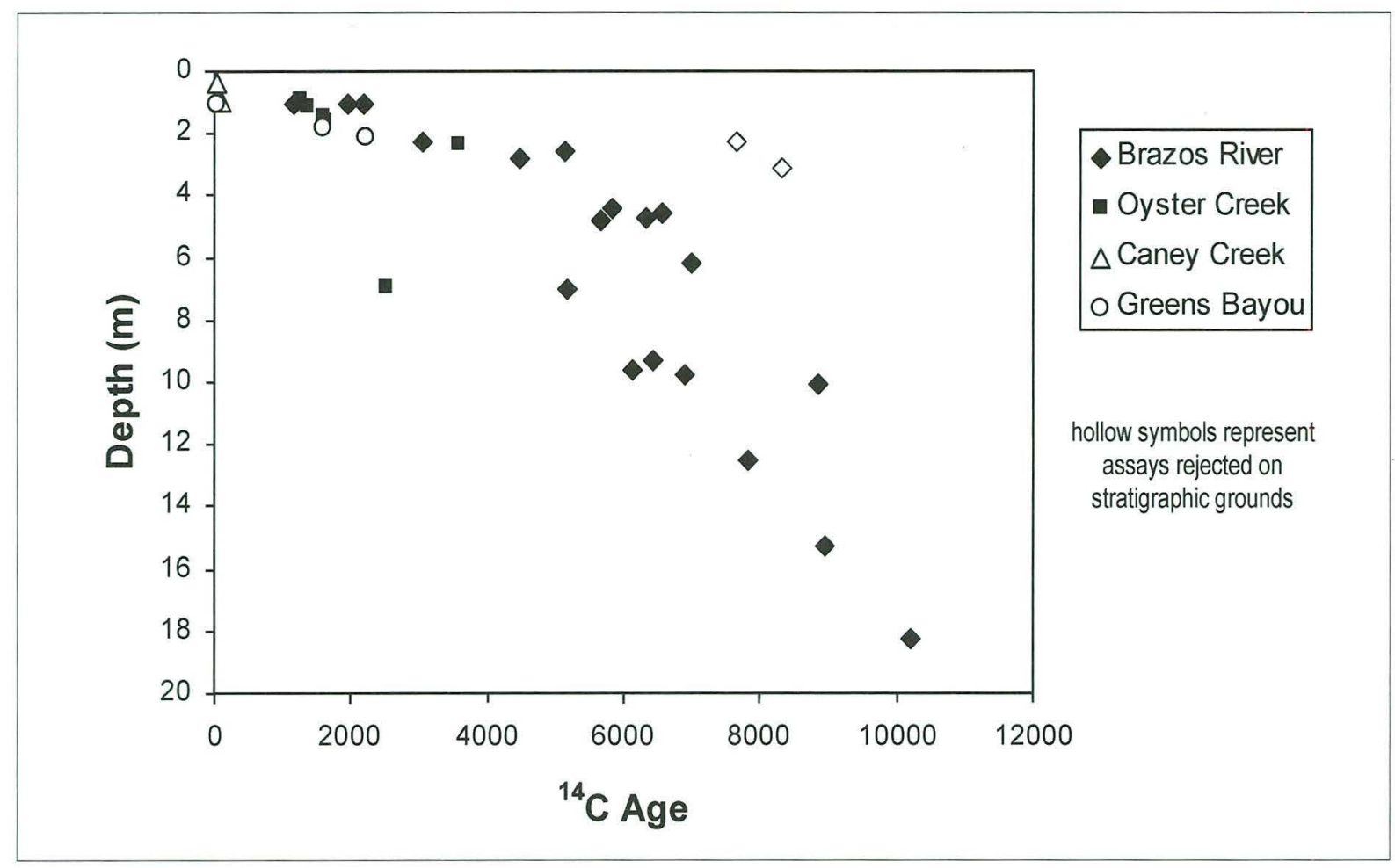

Figure 24. Relationship between age and depth for radiocarbon samples less than 12,000 years old obtained from alluvial contexts during this project. 
the margins of the Brazos River fill, and highlight one of the few landscape elements with the potential to contain accessible, high integrity Early Archaic and Paleoindian remains in the District. On the margins of the filled Brazos valley, arcuate segments of the Pleistocene valley walls document lateral channel migration by much larger, more competent channels during the Late Pleistocene. In the upstream parts of the District, deposits resulting from this former depositional regime are preserved as a series of elevated terraces that are collectively termed the Deweyville terrace (see below). However, as these terraces near the coast they are overlapped and buried by younger alluvial deposits of the Brazos River. In these settings, the potential for buried, accessible archeological components dating to the Late Pleistocene and Early Holocene is relatively high. Although recognizable Deweyville terrace remnants are also well-developed on the margins of the San Jacinto valley, backfilling of the valley is less advanced, and they are not buried by Late Holocene deposits. However, it is possible that remnants of lower terrace fills of Late Pleistocene/Early Holocene age (so-called "low Deweyville") terraces are preserved beneath the Holocene surface in this system also. If present, these buried surfaces could also have high potential for relatively old prehistoric remains with moderate integrity.

In contrast, the broad floodplains and deltas of the Brazos River, San Jacinto River, and lower San Bernard River have high potential to contain archeological deposits of Late Archaic and Late Prehistoric age at depths subject to impact and investigation. The surfaces exhibit a variety of relatively low-relief constructional features, including channels and channel cutoffs, infilled former channels (sloughs), natural levees, flood basins, crevasse splays, freshwater marshes, brackish marshes, saltwater marshes, oxbow lakes, and point bars. Although all of these sediments are of culturally relevant age, the archeological potential of different depositional environments varies considerably as a result of behavioral biases and the relative frequency of historic sediment veneers. Examination of a number of exposures throughout the District has revealed that veneers of recent overbank sediment are very common on the relatively lowlying constructional surfaces, such as sloughs, marshes, and floodbasins. For this reason, and because behavior favored the formation of sites on slightly higher, better-drained environments closer to water, most readily detectable prehistoric sites tend to be situated in proximity to active and former channels on relatively sandy levee and crevasse splay deposits. However, because rapid lateral migration and avulsion are characteristic of these systems, almost all floodplain surfaces have high potential to contain cultural materials at depths below approximately $50-100 \mathrm{~cm}$. An exception in the Brazos system is the active meanderbelt, which is evolving so rapidly that point bar deposits a few hundred years old are often buried beneath many meters of sediment. Here, the potential for buried deposits to be encountered in the upper few meters is moderate at best (although they have been found; see, for example, Aten [1971]); however, when archeological deposits are found in such a context, they are likely to represent a short term, high resolution record of behavior. The age of active point bar deposits in the San Jacinto and lower San Bernard systems is less clear, but is likely to be similar.

Another type of deposit that sometimes overlies floodplain and terrace deposits in the larger stream valleys are eolian sheet sands and silts. Eolian sands are particularly common in the San Jacinto drainage, where they discontinuously mantle the older (Deweyville) terraces. Examination of several construction-related exposures in the vicinity of Crosby, Texas, suggests that sheet sands in the lower San Jacinto valley may be a meter or more thick and overlie an undulating, erosionally truncated Pleistocene soil. Soil development in the sands is moderate; a distinct $\mathrm{A}$ horizon and a rubified $\mathrm{Bw}$ or lamellar $\mathrm{Bw}$ and $\mathrm{Bt}$ horizon is usually present. The age (or ages) of these sands is unclear, but they clearly have the potential to contain archeological material with a reasonable degree of integrity. The distribution and ubiquity of eolian sands in and around the Brazos valley is less clear, although they probably contribute to the character of several relatively sandy localities (e.g., Sandy Point in Brazoria County) on the eastern margins of the valley.

In addition to the primary channel, the Brazos valley is populated with a number of secondary creeks and bayous that occupy former channels of the trunk stream. Examples include Oyster Creek, Bessie's Creek, and Dry Bayou. In a few cases where the area drained is relatively large (e.g., Oyster Creek), these streams have continued to actively modify their course, resulting in the development of a smaller-scale meander pattern superimposed on 
the basic pattern of the former Brazos meanderbelt. In most cases, however, these streams are sluggish and merely represent incomplete infilling of the abandoned Brazos channel. In the former case, a variety of post-avulsion depositional facies can be expected, including point bar, levee, crevasse splay, and floodbasin sediments. In the latter case, postavulsion sediments are likely to be dominated by overbank and channel plug muds, and are less likely to have been selected for occupation.

Besides the large streams such as the Brazos, San Jacinto, and San Bernard, the Houston District is occupied by a number of relatively small, low gradient streams and bayous. These streams can be divided into a few basic types on the basis of channel and valley morphology. The majority of medium to small streams on the Beaumont and Lissie surfaces exhibit low gradient, relatively straight consequent channels in narrow, straight valleys. Examples include Buffalo Bayou, Greens Bayou, Sims Bayou, Halls Bayou, Dickinson Bayou, Cypress Creek, and Clear Creek. Several other similar streams, such as Mustang Bayou and Chocolate Bayou, traverse the Holocene coastal plain as well as the Beaumont surface. The form and character of these streams, coupled with the broader geologic context, suggests that these valleys probably formed through rapid downcutting and/or headward cutting during the period of lowered sea level that ended approximately 5-6 ka. Several of the larger examples (e.g., the lower reaches of Buffalo Bayou and Greens Bayou) exhibit a low-amplitude, entrenched meandering valley, suggesting that they represent meandering streams that entrenched in response to sea level variation during the Late Pleistocene. In contrast, the low sinuosity of many channels and the narrow valley systems suggest that headward cutting may have been very important, particularly in the upper reaches.

In most cases, the valleys of the smaller streams are narrow and show little to no evidence of appreciable valley expansion by lateral cutting. Consequently, the channels occupy a relatively large proportion of the overall valley (channel widths representing $20 \%$ of the entire valley width are not unusual on many of the smaller streams), floodplain deposits are narrow and poorly developed, and extant terraces are practically nonexistent. Frequently, the thalweg meanders back and forth across the constricted valley from valley wall to valley wall, resulting in discrete, alternating segments of preserved floodplain/flood-terrace alternating on either side of the valley.

The depth of deposits in these narrow valleys has not been investigated in detail, although it is likely that they were partially graded to a former base level and therefore deepen considerably as they approach the modern coast. However, some information is available from the work of Saul Aronow, who frequently examined old bore logs to gain insights into the thickness of Holocene fills in the vicinity of individual sites and survey areas he addressed (e.g., Aronow 1989, 1992, 1993, 1994). Aronow $(1992,1994)$ identifies approximately 41 $\mathrm{ft}(12.5 \mathrm{~m})$ of probable Holocene sediments in the valley of Langham Creek at State Highway 6. Langham Creek is a tributary in the Buffalo Bayou drainage in western Harris County, and is incised into the Lissie Formation. This location is relatively far inland, and the degree of incision indicated is relatively great. However, slightly more than three miles upstream, Aronow (1993) interprets the alluvial fill thickness at the FM 529 bridge at $31 \mathrm{ft}(9.4 \mathrm{~m})$, which suggests a steep local gradient. Taking elevational differences into account, Aronow calculates a gradient of $1.6 \mathrm{~m} / \mathrm{km}$, which is very steep for the Gulf Coastal Plain. In contrast, in an examination of bore logs from Spring Creek at Kuykendal Road (a much better-developed system), he determined that Holocene deposits were no more than $8 \mathrm{~m}$ thick, and possibly much thinner (Moore and Aronow 1993).

As in the large valley systems, most sediments encountered in the upper few meters of the small systems appear to date to the last few thousand years. It is unclear whether older sediments are widely preserved at depth, but the narrow valleys increase the likelihood that older deposits were cannibalized as the valleys aggraded. As in the larger systems, it is likely that aggradation was rapid during the Early Holocene and slowed during the Middle-Late Holocene as sea level stabilized. It is also likely that rapid valley formation through headward cutting and downcutting decreased dramatically in the Holocene and effectively ended by at least 4-5 ka, and possibly much earlier.

Prehistoric archeological remains are likely to occur in alluvial and colluvial contexts in the smaller valleys. As decades of research have shown, preservation clearly favors the relatively recent Late Prehistoric sites in these settings. While Late Archaic materials are common (Aten 1983:159), they 
frequently appear disturbed or reworked (Ensor 1987:23). Earlier deposits are relatively rare, although isolates are common and there is the potential for fortuitous preservation. For example, Wheat (1953), Howard et al. (1991), and Patterson (1980; Patterson and Hudgins 1985) have described areas where Paleoindian remains may be preserved in stratigraphic context in the valley fill of such secondary streams. Although subsequent work (e.g., Fields et al. 1983, 1986) has yet to document any intact sites of this age in the district, and some known sites have suffered considerably as a result of channelization (Howard et al. 1991), Patterson and Hudgins (1985) have documented a possibly intact Late Paleoindian occupation with a single corroborating radiocarbon age just west of the district in eastern Wharton County.

In summary, the relatively small, narrow streams draining the Beaumont and Lissie have good potential to preserve cultural material of Late Prehistoric age, and moderate potential to preserve older sites. There is a strong possibility that many older sites in the stream valleys were impacted or destroyed by fluvial processes as the streams evolved; but the possibility that deposits of Late Pleistocene/Early Holocene age are locally and fortuitously preserved clearly exists. If present, accessible older deposits are likely to be limited to the middle and upper reaches of the streams, because old deposits in the lower reaches are likely to be deeply buried by valley backfilling.

A second factor that strongly affects the archeological potential of the moderately sized streams in the Houston District is channelization, which has been performed extensively throughout the urbanized part of the district to control flooding. Channel deepening and straightening represents a major earthmoving activity, and is unlikely to spare archeological sites in the vicinity. However, the process of straightening a channel often isolates and preserves segments of the floodplain and natural channel away from the straightened course. Because the valleys tend to be narrow, channelization often results in the creation of a series of discrete, largely undisturbed remnants of the natural system on the margins of the valley.

A second series of streams on the Beaumont and Lissie, such as Magnolia Creek (Figure 25), occupy the remnants of a high sinuosity channel with relatively large meander amplitudes and wavelengths. These meandering channels are clearly the remnants of high-discharge, Pleistocene-age streams, and many probably represent channels of the ancestral Brazos dating to the last stages of Beaumont aggradation. It is possible (although the lack of entrenchment makes it relatively unlikely) that some of these streams were still active during the latest Pleistocene and Early Holocene, and may therefore include sediments of culturally relevant age. In general, the modern streams that occupy these channels are extremely small and have little potential to appreciably modify the Pleistocene channel pattern.

The archeological potential of this type of stream is unclear. If the high discharge channels were in fact abandoned by the latest Pleistocene (the more likely possibility), then the potential for preserved deposits is limited to relatively recent deposits contained in thin veneer sediments of colluvial or alluvial origin. However, if the Pleistocene streams were still active during the latest Pleistocene and Early Holocene, the potential exists for early archeological manifestations to be preserved with good stratigraphic separation.

A third type of stream is typical of areas in the northern part of the District, where the landscape is older and relief is better developed. Here, streams have excavated broader valleys filled with complex sequences of alluvial and colluvial deposits. Examples include Spring Creek, Lake Creek, Caney Creek (that is, either of the two Caney creeks in Montgomery County), and Mound Creek. In these streams, total relief between the valley bottom and the interfluve is up to $40-50 \mathrm{~m}$, in comparison to relief of 3-10 m on the larger streams draining the Beaumont and Lissie Formations. These streams exhibit relatively complex valley surfaces that usually include a low floodplain and one or more higher terraces that are partially overridden by and merge into colluvial aprons and relatively small alluvial/ colluvial fans. Higher terraces of probable Pleistocene age are also occasionally present. Although the stratigraphy of these settings has only been sporadically investigated (e.g., Mandel 1987), these surfaces overlie sediments with good archeological potential. Floodplains here are often broader and typically show more heterogeneity and relict depositional features than the narrow stream fills closer to the coast. Although most sediments in these settings have geoarcheological potential, it is possible that sediments in excess of $12 \mathrm{ka}$ may be preserved beneath some of the higher terraces and colluvial 


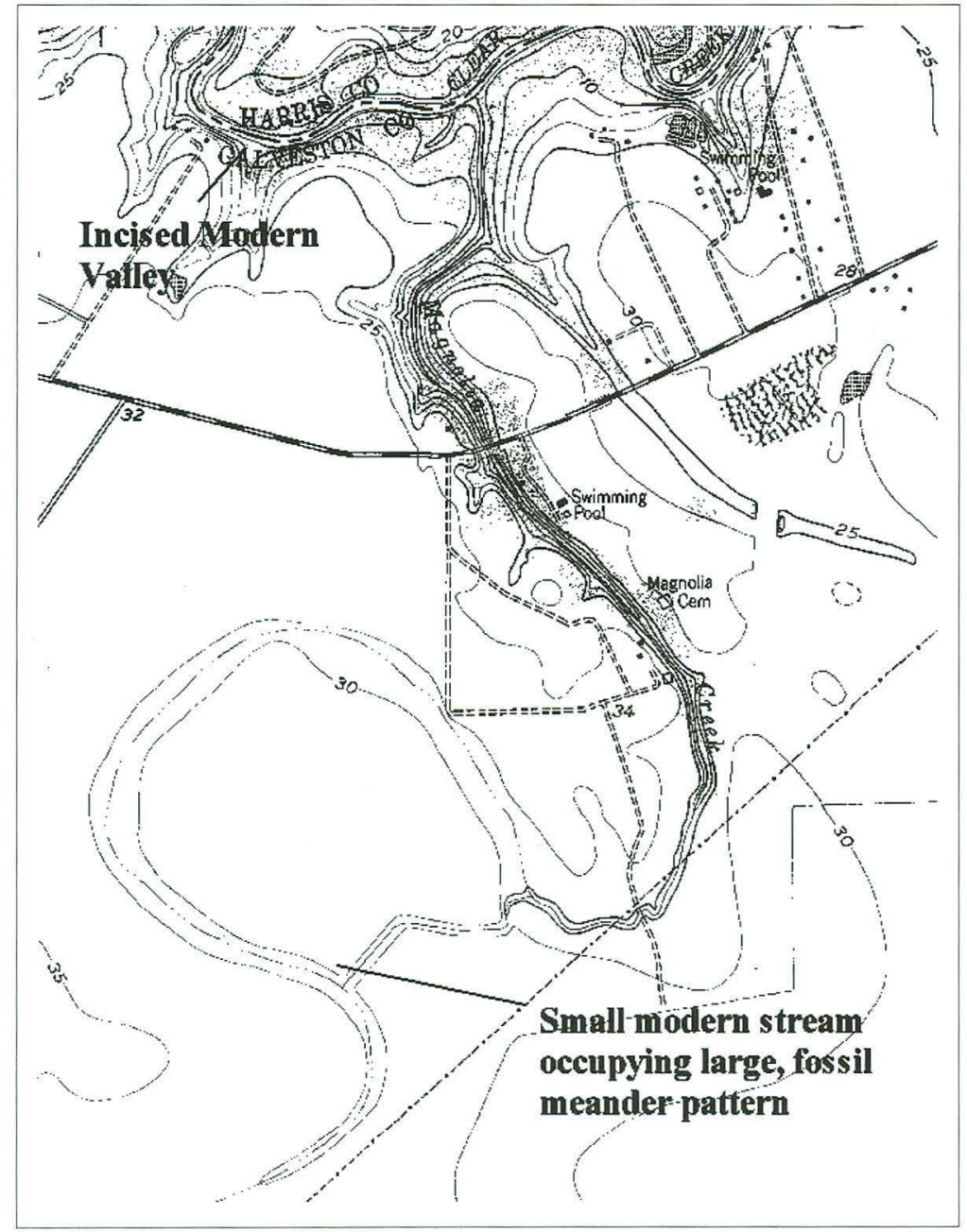

Figure 25. Detail of the Algoa, Texas 7.5' topographic quadrangle, illustrating the occupation of an old, high-discharge relict channel pattern by a small modern stream.

aprons, while the floodplains frequently are mantled with a veneer of sandy sediment up to $1 \mathrm{~m}$ thick dating to the historic period.

In most Houston area streams, flow tends to be perennial due to groundwater discharge, and the sediment load is overwhelmingly dominated by muds and/or very fine sands. However, the finegrained character of the sediment load is more indicative of the nature of the available source materials than limits imposed by flow competence. Although ironstone gravels (reworked ferric soil concretions) up to several centimeters in diameter make up a large component of the bedload in several of the streams draining the Lissie and older formations (e.g., Brookshire Creek), available clasts of this size are absent in the majority of the small to medium-sized Houston area drainages. For this reason, characterization of the depositional energy represented by alluvial deposits (particularly sandy deposits) on the basis of grain size are inadvisable in most alluvial depositional settings.

The architecture of alluvial valley fills varies considerably depending upon the scale of the stream as a whole and the location along its length. In their examination of the MidTex Pipeline Route from Gonzales County to Waller County, Waters and Nordt (1996) examined a number of streams on the central Coastal Plain, and developed a five part classification that is also broadly useful for the Houston District. This basic scheme, modified with the addition of several variants, is presented in Figure 26. The following paragraphs describe the basic characteristics of these different types of streams, all of which have the potential to contain archeological remains in reasonable context.

Group 1 stream architecture is typical of the shallowly incised, first order tributaries that form the upper reaches of most valleys on the outer Coastal Plain. They are typically broadly concave, contain a few centimeters to a few meters of primarily vertically aggraded alluvium, and may or may not be associated with a recognizable channel. Farther inland, first order tributaries may also take this form, although they tend to be more deeply incised, steeper, and shorter, and often lack appreciable alluvium. Archeological materials may be readily preserved in this type of setting, although they are liable to be somewhat compressed in relatively small and shallow drainages, and therefore may have been subject to considerable post-depositional disturbance by various turbation processes.

Group 2 stream architecture is typical of relatively small drainage systems, although it occasionally may occur in the upper reaches of larger systems. These streams are the result of recent, active downcutting. Most alluvium is situated on the margins of the valley, either resting on a gently beveled 


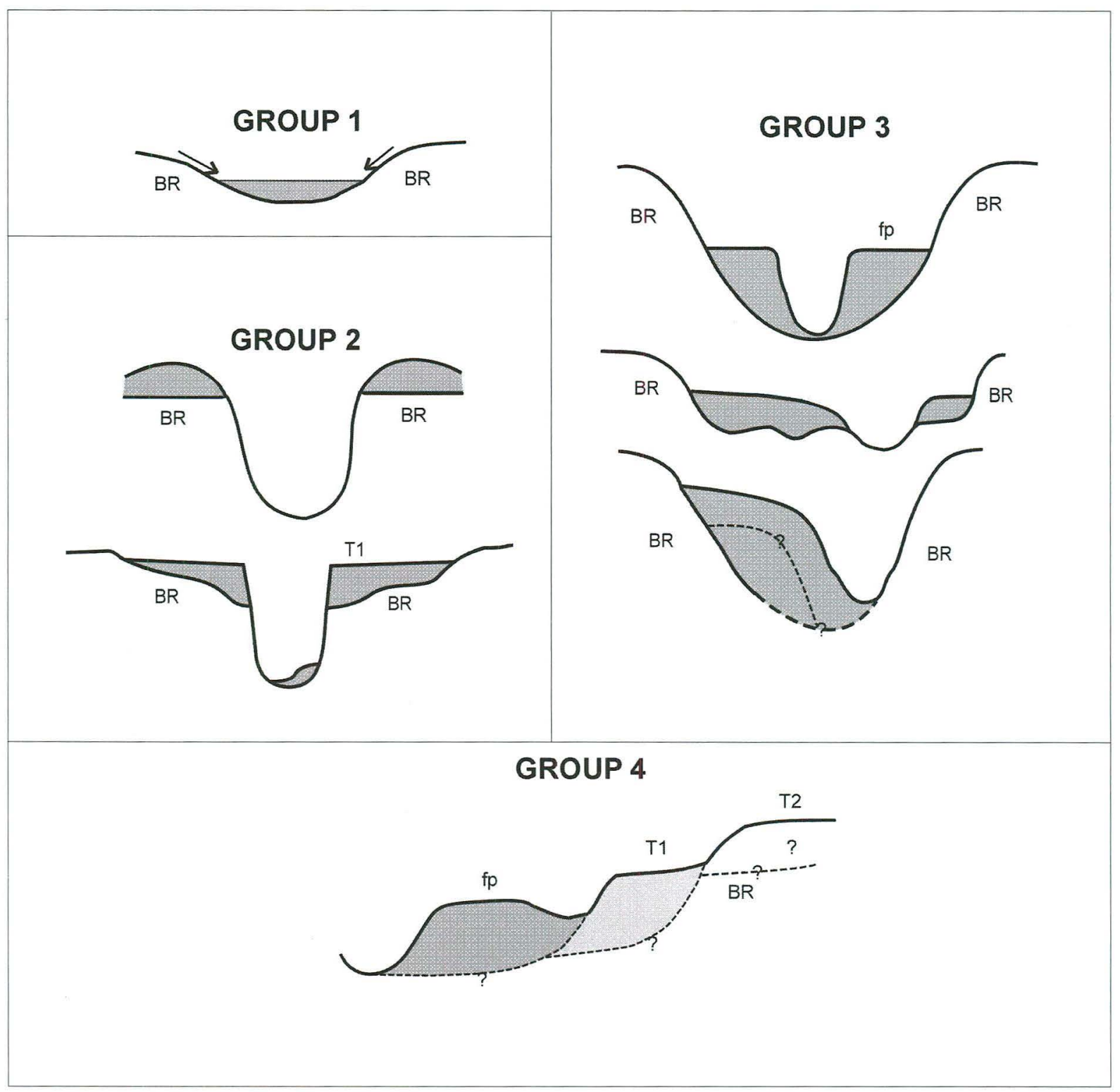

Figure 26. Generalized architecture of small to moderately sized Houston-area streams, expanded and modified from a classification developed by Waters and Nordt (1996) for the central Texas Coastal Plain. Group 5 streams, which represent large streams underlain by complex floodplains (e.g., the Brazos River), are not represented. Key: BR = bedrock; $\mathrm{T} 1=\mathrm{T}_{1}$ terrace; $\mathrm{fp}=$ floodplain .

upland surface (Variant 1) or a more pronounced, broadly concave valley floor (Variant 2). In both cases, the modern channel has incised into the substrate, stranding the deposits as an elevated terrace. The active channel, which is usually ephemeral and steep-walled, is primarily erosional and contains little or no alluvium. Group 2 architecture typically forms as a "Group 1"-style stream valley is entrenched by a headward cutting or downcutting channel. Streams with this type of architecture are relatively common on the flat Beaumont and Lissie surfaces in proximity to the Brazos River. The alluvium stored on the margins of a Group 2 stream usually predates channel entrenchment; contemporary alluvium bypasses in the channel and is not stored in an active floodplain. While such perched terrace deposits may have relatively high archeological potential, there is little to no potential for the system to preserve occupational debris that postdates entrenchment of the channel.

Group 3 stream architecture is typical of the moderately sized streams in the district. These 
streams have a well-defined, albeit often narrow valley and moderate to thick floodplain. Waters and Nordt (1996) identify two Group 3 variants: Variant 1 consists of thick, relatively broad floodplain deposits with an incised channel and a well-developed floodplain, while Variant 2 consists of thinner deposits overlying an irregular, eroded bedrock surface in a relatively broad floodplain. Variant 3, introduced here, consists of thick, laterally discontinuous floodplain deposits in a narrow valley. All three types are typical of relatively small to moderately sized streams on the low-relief outer Coastal Plain, and also sometimes occur in smaller valleys farther inland in the District. In some cases, older alluvial deposits that predate the culturally relevant period may exist at depth within the fill (or, particularly in the case of Variant 2 , beneath the fill), and in other cases considerable volumes of historic-era sediment may mantle the surface. However, the majority of these deposits have relatively high potential to contain cultural remains with moderate to high integrity.

Group 4 architecture is typical of the streams draining the higher relief interior of the district. The alluvial architecture of these streams is quite variable, and no attempt is made in Figure 26 to present the many different configurations it can take in the Houston District. The unifying feature is the presence of more than one alluvial surface, which is the result of several episodes of aggradation punctuated by at least one episode of downcutting. The valley fill may consist of two or more discrete surfaces, each of which is underlain by one or more alluvial fill units. In the Houston District, the most common configuration is a smooth to complex floodplain and a single, elevated ("Deweyville") terrace. This type of architecture is typical of larger tributaries of the San Jacinto River in Montgomery County. Colluvial deposits in the form of fans and aprons are often associated with the margins of these streams, and occasionally override the upper terrace remnants completely.

Group 5 architecture (not illustrated in Figure 26) is characteristic of the largest streams in the district, including the Brazos and the San Jacinto, and is typified by large valleys with broad floodplains. Group 5 differs from Group 4 primarily in scale, and often in the relative complexity and thickness of deposits underlying the floodplain. Although multiple terraces are not a defining characteristic, multiple terraces (including
"Deweyville" terraces and higher stream terrace correlates of the coastwise Beaumont and Lissie terraces) are often present. These deposits may form extant terraces, or they may be overlapped and buried by more recent alluvium.

\section{Barrier Islands}

The barrier formed by Galveston Island and the Bolivar Peninsula forms a unique environment that was exploited from at least the Late Archaic through the Historic period (Newcomb 1961; Ricklis 1994). Although the antiquity of barrier island use is poorly understood, occupation of the barrier island systems (Galveston Island and the Bolivar Peninsula) was clearly constrained by the timing of barrier formation in the Middle to Late Holocene. Because they are in proximity to a variety of marine resources, it is likely that the islands began to be occupied consistently on at least a seasonal basis as soon as they emerged and stabilized around 4-5 ka.

The Gulf Coast barriers are strongly dynamic environments (Morton and McGowen 1980; Suter et al. 1989), limiting the potential for site preservation in many settings. Site burial and preservation on the barrier islands is accomplished primarily by eolian, washover, and marsh sedimentation processes. Site destruction may also occur by these processes or by beach erosion. The action of the surf and the longshore current, which can either cause the beach to aggrade or retreat, is extremely unlikely to bury archeological materials in reasonable context. Therefore, that portion of the barrier island seaward of the storm berm is considered to have negligible archeological potential. Inland of the storm berm, the core of the island represents sands accreted by beach processes and likewise has very low potential. The depositional environments on barrier island that are likely to preserve cultural material form a complex surface veneer that overlies the barrier core. This veneer is composed of a variety of deposits, including eolian sheet sands and dunes, colluvial sands, marsh and bay margin deposits, and storm washover fans. The thickness of these veneer deposits seldom exceeds $2 \mathrm{~m}$, although a few dunes may be thicker. Nevertheless, important prehistoric sites, such as the Mitchell Ridge site (41GV66), are present in the barrier island environment.

Sites on the barriers are highly susceptible to disturbance by modern construction (including transportation improvements) and by natural 
processes. Many barrier veneer sediments are either the product of extreme events such as hurricanes (washover fans) or are highly susceptible to attack by such events (dunes and sand sheets). The most stable deposits are relatively low-energy muds associated with marsh and back-barrier settings, but these are also probably the least likely to be occupied. However, there is potential for other, more conducive barrier facies to lie at shallow depths beneath such lagoonal muds.

\section{Inundated Landscapes}

Although isolated projectile points stylistically linked to the Paleoindian and Early Archaic periods occur in some frequency in the Houston District (Patterson 1996; Turner and Hester 1993), few buried, intact sites dating to the Late Pleistocene/Early Holocene are known. In order to understand the sparse, patchy Paleoindian and Early Archaic record in the Houston area, it is important to realize that much of the relevant Late Pleistocene/Early Holocene archeological landscape has been drowned by sea level rise. Figure 27, which was adapted from a detailed figure presented in Bryant et al. (1992), illustrates the bathymetry of the Texas/Louisiana continental shelf. Although the details vary, reconstructions of sea level rise in the Gulf of Mexico (see Figure 17) agree that the elevation of the Gulf was between 150 and 200 feet $(45-60 \mathrm{~m})$ below modern sea level 10-12,000 years ago. As Figure 27 makes clear, the slope of the Gulf continental shelf is such that a $45-60 \mathrm{~m}$ drop in sea level would result in a 50-

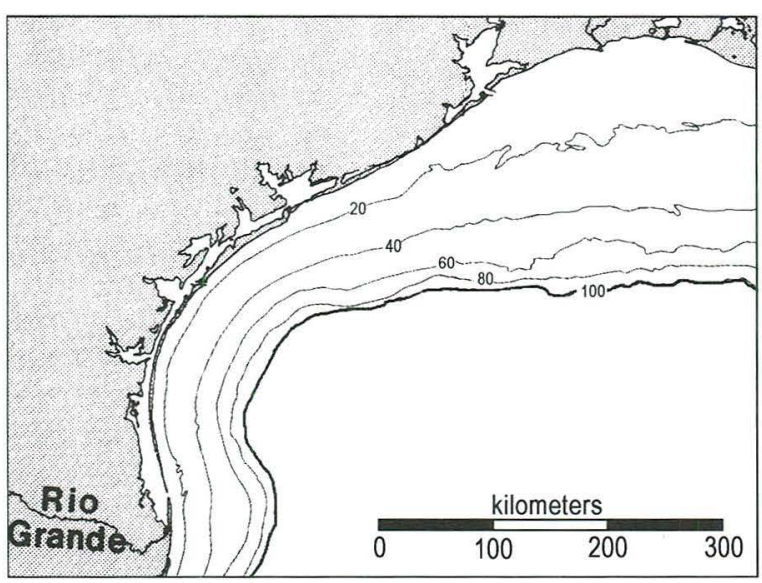

Figure 27. Bathymetry of the Gulf Coast shelf in meters, illustrating the huge expanse of terrain that was drowned by the $100 \mathrm{~m}+$ postglacial sea level rise.
$80 \mathrm{~km}$ seaward migration of the shoreline. In other words, the shoreline during the Late Pleistocene/ Holocene transition was between 50 and $80 \mathrm{~km}$ farther south, and between 4,500 and $7,200 \mathrm{~km}^{2}$ of additional land was exposed on the continental shelf seaward of the modern Brazoria and Galveston County coastline. As a result, it is a virtual certainty that a considerable part of the Late Pleistocene/Early Holocene archeological record lies submerged at distances up to $80 \mathrm{~km}$ off the modern Gulf Coast (Gagliano et al. 1982; Stright 1990, 1995).

While many sites are almost certainly present offshore, the preservation of this record is probably only localized because intense reworking of nearsurface deposits would have occurred in the surf zone as the shoreline slowly advanced. On the basis of offshore cores and seismic data, Abdulah (1995) has been able to define distinct, gently sloping ravinement surfaces cut during marine transgressions as well as more steeply dipping entrenchment surfaces cut by the Brazos and Colorado rivers during low-stands. These smooth, ramped ravinement surfaces represent erosional surfaces, and preservation of open sites was probably not common as they were overridden by the advancing shoreline. A particularly good example of the destructive power of the surf zone is provided by the McFaddin Beach Site (41JF50), which consists of a $30+\mathrm{km}$ stretch of the Gulf coast east of the Bolivar Peninsula where large numbers of reworked Paleoindian and Archaic artifacts (and a variety of Pleistocene fauna) are periodically discovered, presumably after being eroded from deposits a short distance offshore (Turner and Tanner 1994). Although sites attacked by the rapidly (albeit periodically) advancing shoreline would have been subject to much shorter duration attack than sites like McFaddin Beach situated immediately off the modern, quasi-stable shoreline, the "survivability" of open sites was probably low. Along the majority of the coast, subaqueous preservation can be confidently expected only where sites were mantled with a significant overburden due to processes operating in the subaerial environment; in other words, the same types of environments emphasized above. Only in large, drowning river valleys, where high volumes of prodelta sediments were introduced and the potential for wave attack was limited by the embayment, could shallowly buried sites be confidently expected to survive marine transgression. While it is possible that open sites in other settings could survive marine transgression, it is far less likely. 
Although logistical and monetary considerations preclude the location and examination of such submerged sites except under extraordinary circumstances, the implications of this profound change in the landscape for the subaerial archeological record is also important (Gagliano et al. 1982; Aten 1983:137). In particular, it must be realized that almost all evidence of Paleoindian and Early Archaic adaptation to the coastal environment in Texas (and elsewhere) is essentially beyond our reach, and that sites such as McFaddin Beach that currently occupy coastal locations in fact represent exploitation of an inland landscape. Those sites and isolates that are discovered in modern coastal settings, such as McFaddin Beach, represent inland sites that were not situated to exploit the ocean environment. Consequently, our knowledge of Paleoindian and Early Archaic coastal adaptation is negligible, and will likely remain so for the foreseeable future.

\section{Intermediate ("Deweyville") Terraces}

In addition to the gently sloping upland and floodplain surfaces of the Houston District, a series of intermediate surfaces are present along the upstream segments of the Brazos Valley and the trunk stream and tributaries of the San Jacinto watershed. As the discussion in Chapter 2 illustrated, the age of these elevated surfaces is somewhat controversial, with proposals by various investigators varying by several orders of magnitude. Based on their sedimentary character and stratigraphic position, this author is of the opinion that the "Deweyville" terrace complex actually represents several discrete sedimentary bodies laid down during the Late Pleistocene, and therefore has low archeological potential. This opinion is supported by recent work on the Deweyville complex (Blum et al. 1995; Durbin et al. 1997), which suggests that the Deweyville strata accumulated during the falling stage and lowstand of the Wisconsinan stage (approximately 70 to $20 \mathrm{ka}$ ). These authors identify three distinct, consistent fills along the Texas coast which they refer to as the "upper Deweyville," "middle Deweyville," and "lower Deweyville," respectively. In valleys occupied by large rivers with high sediment delivery, such as the Brazos, Rio Grande, and Colorado, these terraces have been overtopped and buried in the lower valleys by Holocene sediment. In smaller streams, such as the Trinity, San Jacinto, Guadalupe, and Nueces rivers, valley infilling is not as advanced and remnants of these older fills are preserved as terraces intermediate between the modern floodplain and the upland surface.

If these estimates are accurate, primary "Deweyville" deposits have little potential to incorporate archeological remains dating to the generally recognized span of human occupation in the Houston area (although "pre-Clovis" remains are a possibility). However, because the age of these features is not well-established, and because substantial reworking of the sandy terrace surfaces and deposition of alluvial and/or eolian veneer deposits during the Holocene is a distinct possibility, extant Deweyville terraces in the district should be routinely investigated with mechanisms to search for shallow and, where the nature of the project merits it, deeply buried archeological remains in advance of projects.

In addition to the Late Pleistocene Deweyville terraces, larger streams in the area are also flanked with relatively large fluvial equivalents to the broad Pleistocene coastwise terraces. Such terraces are common inland of the Beaumont outcrop on the Brazos and San Jacinto valley. While these features may occasionally be mantled with a thin sediment veneer of Holocene age, they have no potential for deeply buried cultural materials.

\section{DISCUSSION AND \\ GEOARCHEOLOGICAL SIGNIFICANCE OF STRATIGRAPHIC MODELS}

This section presents stratigraphic models for a variety of environments in the Houston District using extant and new data. Although only a few streams in the district were examined in any detail during this study, many more were examined at a limited number of locations, and several previous stratigraphic studies are available. Based on these data, a number of generalizations are possible. This section addresses the character and geoarcheological significance of various stratigraphic settings in the Houston District.

\section{The Brazos River}

This discussion encompasses the streams of the Brazos River valley and delta, including the principal system occupying a former Brazos channel (i.e., Oyster Creek). It does not include tributaries to the Brazos that primarily flow across the 
Beaumont and older strata; those systems are discussed below. The portion of the Brazos system in the Houston District is illustrated in Figure 28.

The Brazos River is a large fluvial system that traverses much of Texas and crosses a number of diverse environments. Although it is exceeded in length and drainage area by the Red River and the Rio Grande, the Brazos is the largest fluvial system contained primarily in the state of Texas. The upper basin of the Brazos is divided into three forks, termed the Salt Fork, the Clear Fork, and the Double Mountain Fork. The Salt Fork and the Double Mountain Fork rise on the Llano Estacado (Southern High Plains) and flow across the southern part of the Low Rolling Plains.

The Brazos River proper is considered to begin at the confluence of the Salt Fork and the Double Mountain Fork, in Stonewall County. The length of the Brazos, from the source of the Double Mountain Fork (the longest of the upstream feeder tributaries) to the Gulf of Mexico, is roughly $1350 \mathrm{~km}$ (840 miles), and its drainage basin encompasses approximately $110,850 \mathrm{~km}^{2}\left(42,800 \mathrm{mi}^{2}\right)$. Annual discharge typically exceeds five million acre-feet $\left(6.1\right.$ trillion $\left.\mathrm{m}^{3}\right)$. The modern lower Brazos is a meandering, mixed-load stream that carries a high load of suspended sediment, giving it a characteristic, muddy red-brown color.

The valley of the Brazos is one of the most prominent topographic features of the Houston District, and it forms a corridor where riverine resources attractive to prehistoric peoples were concentrated. The modern stream is a classic underfit meandering stream. It has a width of approximately $50 \mathrm{~m}$ during base flow and $100-500 \mathrm{~m}$ at bankfull stage, and a meander wavelength on the order of $0.5-3 \mathrm{~km}$, but occupies an incised valley that varies from approximately $5-20 \mathrm{~km}$ in width, and averages approximately $10 \mathrm{~km}$. Incised meander "scallops" cut laterally into the valley wall suggest that the meander wavelength of the system during the Late Pleistocene was 3-6 times greater than the modern system. Because the relationship between meander wavelength and channel width is relatively constant (Leopold et al. 1963), this suggests that the width of the Late Pleistocene channel was concomitantly greater. While the relationship between planiform morphology and mean discharge is more variable (depending also upon the crosssectional area of the channel, the slope of the channel, and channel roughness), the large Deweyville meanders clearly indicate that they formed under a substantially higher discharge regime than exists today (see Chapter 2 and below); Epps (1973) has estimated that the Pleistocene stream had a bank full width of 2600 feet and a bank full discharge of a staggering $861,000 \mathrm{cfs}\left(24,366 \mathrm{~m}^{3} / \mathrm{sec}\right.$, or roughly eight times the discharge of peak floods recorded during the historic era).

Although some stratigraphic and geoarcheological studies have been conducted at various places in the upper Brazos drainage (e.g., Blum et al. 1992; Mandel 1992), relatively little stratigraphic work has been performed on the lower Brazos. The closest detailed, chronometrically controlled study of the full Holocene suite is that of Waters and Nordt (1995), who document a $75 \mathrm{~km}$ segment of the Brazos Valley from Hearne to Navasota, in Robertson, Milam, Washington, Brazos, Burleson, and Grimes counties, Texas. This study, which utilized existing exposures and was restricted to deposits underlying the modern floodplain, identified five unconformity-bounded allostratigraphic units (designated I-V), each with preserved channel and floodplain facies (Figure 29). Unit I is up to $9 \mathrm{~m}$ thick, and consists of gravels and sands overlain by a veneer of bedded silt and clay that supports a moderately developed, vertic paleosol termed the A\&M soil. It represents deposition by a competent, laterally migrating stream that laid a thick sequence of gravels and sands down across a broad valley excavated during the Late Pleistocene.

During the waning phases of this unit, the muddy veneer was deposited and a relatively weak A-Bss soil profile developed. Chronometric data from Unit I includes one age of 17,730 $\pm 130 \mathrm{BP}$ and a variety of Pleistocene megafaunal remains from the sandy channel facies, and two ages of $8465 \pm 100 \mathrm{BP}$ and $8390 \pm 330 \mathrm{BP}$ on charcoal and bulk soil humates, respectively, from the A\&M soil. This suggests that discharge waned through the Late-Pleistocene/Holocene transition.

Around $8,400 \mathrm{BP}$, and almost certainly in response to diminishing discharge during the Pleistocene/Holocene transition, the Brazos dramatically changed its depositional style. With this shift, the Brazos became a relatively narrow, deep channel migrating freely in a restricted meander belt, and it no longer cut laterally across the whole floodplain. Consequentially, vertical accretion facies (floodbasin muds, splay and levee sands) became much more volumetrically important than the sandy channel 


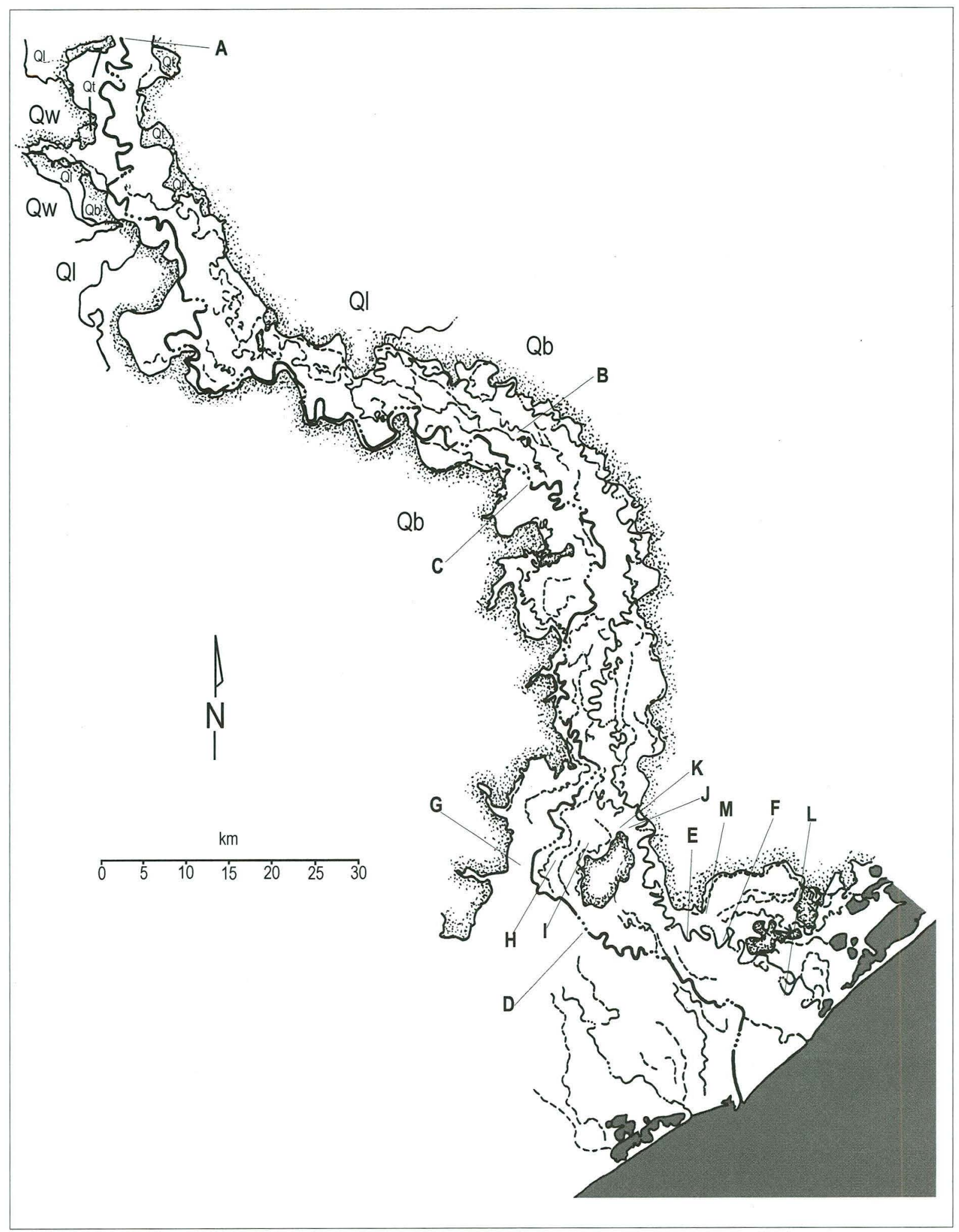

Figure 28. Map of the lower Brazos Valley and Brazos Delta, illustrating the valley form, the position of extant and former channels, and principal study localities. $\mathrm{Qb}=$ Beaumont terrace; $\mathrm{Ql}=\mathrm{Lissie}$ terrace; $\mathrm{Qw}=\mathrm{Willis}$ Fm. Investigated localities: A=Brazos at SH 159; B=Bull Head Slough at US 59; C=Brazos TDCJ Section; D=Brazos at SH 339; $\mathrm{E}=$ Oyster Creek at FM 2004; F=Oyster Creek at SH 288B; G=Core \#1; H=Core \#2; I=Core \#3; J=Core \#4; K=Core \#5; L=Core \#6; M=Core \#7. 


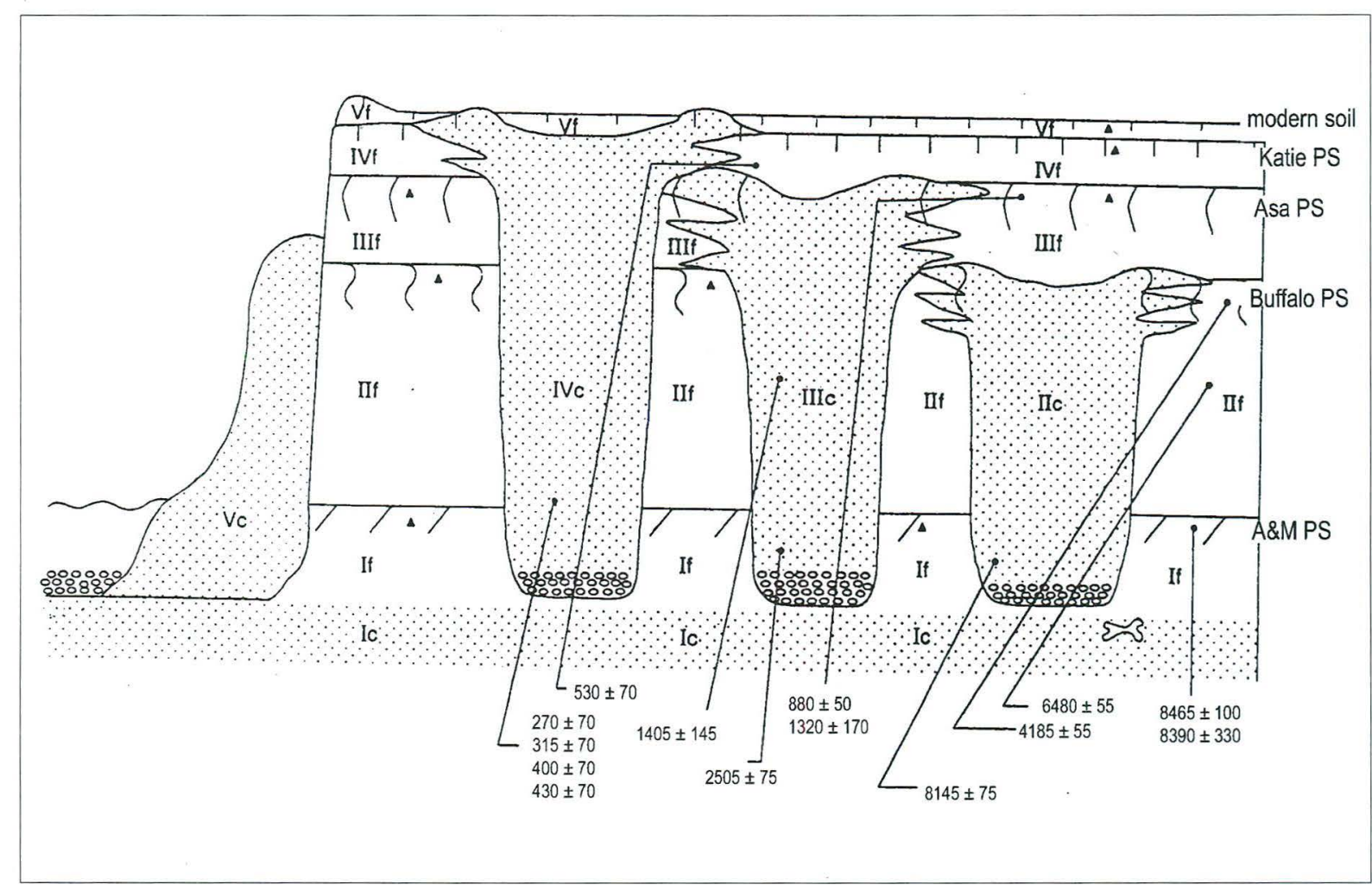

Figure 29. Generalized stratigraphy of the Brazos River between Hearne and Navasota, after Waters and Nordt (1995). The letter $c$ represents channel facies, and $f$ represents floodplain facies. Triangles represent artifact-bearing strata, and the bone symbol represents megafaunal remains.

and point bar facies. Unit II, which consists of a valley-wide overbank sequence with a localized channel/point bar complex, accreted over the next few thousand years. Although Waters and Nordt do not specify the thickness of Unit II, it is the thickest of the Holocene units and spans a presumed period of climatically induced high sediment yield during the Middle Holocene. The period of Unit II aggradation is interpreted as spanning $8,400 \mathrm{BP}$ to at least $4,200 \mathrm{BP}$, when a period of relative quiescence and soil formation was established. This soil, termed the Buffalo paleosol, consists of a relatively thick, reddish Bkss horizon containing common secondary carbonate nodules and filaments and prominent slickensides. Ages from Unit II include $8145 \pm 75 \mathrm{BP}$ on wood from basal channel deposits, $6480 \pm 100 \mathrm{BP}$ on a hearth from the floodplain fill, and $4185 \pm 55$ $\mathrm{BP}$ on a hearth from the Buffalo paleosol.

By approximately 2,500 BP, the Brazos avulsed again and established a new channel, and Unit III began to aggrade. This unit, which is much thinner than Unit II but reflects the same type of depositional style, continued to aggrade episodically until approximately 500 BP. As deposition slowed, a distinct cumulic paleosol with a dark brown to black A horizon and a reddish-brown Bk horizon developed at the top of Unit III. This soil, termed the Asa paleosol, is the most visually distinct paleosol in the sequence and has analogs in a variety of settings across the southern Plains (Hall 1990). Radiocarbon ages on Unit III include an age of $2505 \pm 75$ BP from a log in the lower channel deposits, 1405 $\pm 145 \mathrm{BP}$ on charcoal at the base of a gully fill leading into the Unit III channel, and $1320 \pm 170$ $\mathrm{BP}$ and $880 \pm 50 \mathrm{BP}$ on bulk humates and hearth charcoal, respectively, from the Asa paleosol.

Around 500-600 BP the channel avulsed again and Unit IV began to aggrade. Like Units II and III, it reflects a laterally confined meander belt contained within a broad floodplain. Unlike the older channels, the former course of the Unit IV channel is clearly visible as a swale and associated levees and splays on the modern floodplain surface. A relatively weak vertic soil termed the Katie paleosol is developed at the top of the unit. Chronometric ages from Unit IV include an age of $530 \pm 70 \mathrm{BP}$ 
from a log directly overlying the Asa paleosol in the floodplain facies, and ages of $270 \pm 70 \mathrm{BP}, 315$ $\pm 70 \mathrm{BP}, 400 \pm 70 \mathrm{BP}$, and $430 \pm 70 \mathrm{BP}$ from wood incorporated into the channel fill. Sometime after $300 \mathrm{BP}$, the stream avulsed again, forming the modern channel belt. Deposits laid down outside the meanderbelt since this last avulsion (Unit V) are relatively thin and silty, but contain historic artifacts and clearly have the potential to conceal the prehistoric record.

Although less detailed than the Hearne to Navasota study, the same authors also examined the Brazos floodplain in the Houston District, at the location of the MidTexas pipeline crossing near Brookshire in southern Waller County. This latter study (Waters and Nordt 1996) involved the excavation of over 40 trenches, and thus provided a good window into the upper 3-4 m of Brazos deposits across the valley. However, no chronometric dates were obtained during the study, and dating was inferred from the previous work performed by the authors upstream (Waters and Nordt 1995). Nevertheless, the results show interesting parallels and contrasts with the dated sequence upstream.

Three alluvial stratigraphic units are identified in the Brazos valley along the MidTexas pipeline alignment. Each of these units is correlated with and named after deposits upstream. The oldest exposed unit, Unit II, was detected only at depth on the eastern side of the valley east of Bessie's Creek. It consists of a reddish-brown silty clay that has developed an A-Bk profile which is correlated with the Buffalo soil. Unit III, which forms the principal fill across the majority of the valley, is capped by a prominent soil correlated with the Asa paleosol. Although similar to the upstream equivalent, the Asa soil at the Brookshire crossing bifurcates where capped by levee deposits. The upper, weaker soil developed in these loamy sediments exhibits an A$\mathrm{Bw}$ profile, while the lower soil is developed in floodbasin muds and exhibits an A-Bk profile with a weakly decalcified A horizon and common $\mathrm{CaCO}_{3}$ nodules in the Bk. As the levee deposits thin away from the former channel, these two soils weld into a single paleosol. Finally, Unit IV/V comprises the channel and point bars of the modern meanderbelt, and extends across the floodplain as a thin veneer.

Several differences are apparent between the sequences Waters and Nordt describe upstream of the Houston District and at the Brookshire crossing. First, no equivalent of the Katie paleosol was identified, and Units IV and V are undifferentiated. Second, the Late Pleistocene/Early Holocene unit capped by the A\&M soil in the upstream sequence (Unit I) was not detected; however, it is presumed to exist at depth beneath the floodplain. Finally, the most striking difference between the sequences is the architectural relationship between Unit II and Unit III. While these two units are stacked in the Hearne to Navasota reach, at Brookshire they are at approximately the same elevation, and Unit III is laterally inset into Unit II. If this model is accurate, it implies that a substantial portion of the EarlyMiddle Holocene fill was eroded prior to deposition of the Unit III fill.

Nordt (n.d.b) summarized his observations on the lower Brazos valley, basing his interpretations primarily on his earlier work (Waters and Nordt 1995, 1996), the work reported in Bernard et al. (1970; see below), and available geologic and soils maps. He identifies the Deweyville fill as the product of Late Pleistocene alluvial activity from approximately 35 ka to $10 \mathrm{ka}$, and recognizes deposits related to three episodes of post-Deweyville activity that he attributes to Early Holocene, Late Holocene, and Modern activity. The Early Holocene unit is attributed to the time period between roughly $10 \mathrm{ka}$ and $3 \mathrm{ka}$, with the last thousand years of this time span a period of relative stability and soil formation. Around $3 \mathrm{ka}$, the Brazos avulsed into the Bessie's Creek/Oyster Creek meanderbelt, and the Late Holocene unit began to aggrade. Activity here continued until approximately $500 \mathrm{BP}$, with the last thousand years again characterized by the formation of a cumulic floodplain soil. Around $500 \mathrm{BP}$, the stream avulsed again, forming the modern meander belt.

Another previous study conducted near Richmond in Fort Bend County is reported in Bernard et al. (1970). This study, conducted by members of the Shell Development Company research staff during the 1950s, examined a point bar of the modern Brazos system, and illustrated the dynamism of the active Brazos meander belt. Based on a series of 23 electric core $\operatorname{logs}$ and 10 radiocarbon ages taken across five transverse transects across the Blasdel point bar, Bernard et. al (1970) document the typical fining-upward sequence of the modern point bars (Figure 30). Basal channel deposits consist of massive gravels and coarse sands, and rest on a truncated surface of Early-Middle Holocene alluvium or directly on Pleistocene deposits. These deposits grade up into giant ripple-bedded and trough 


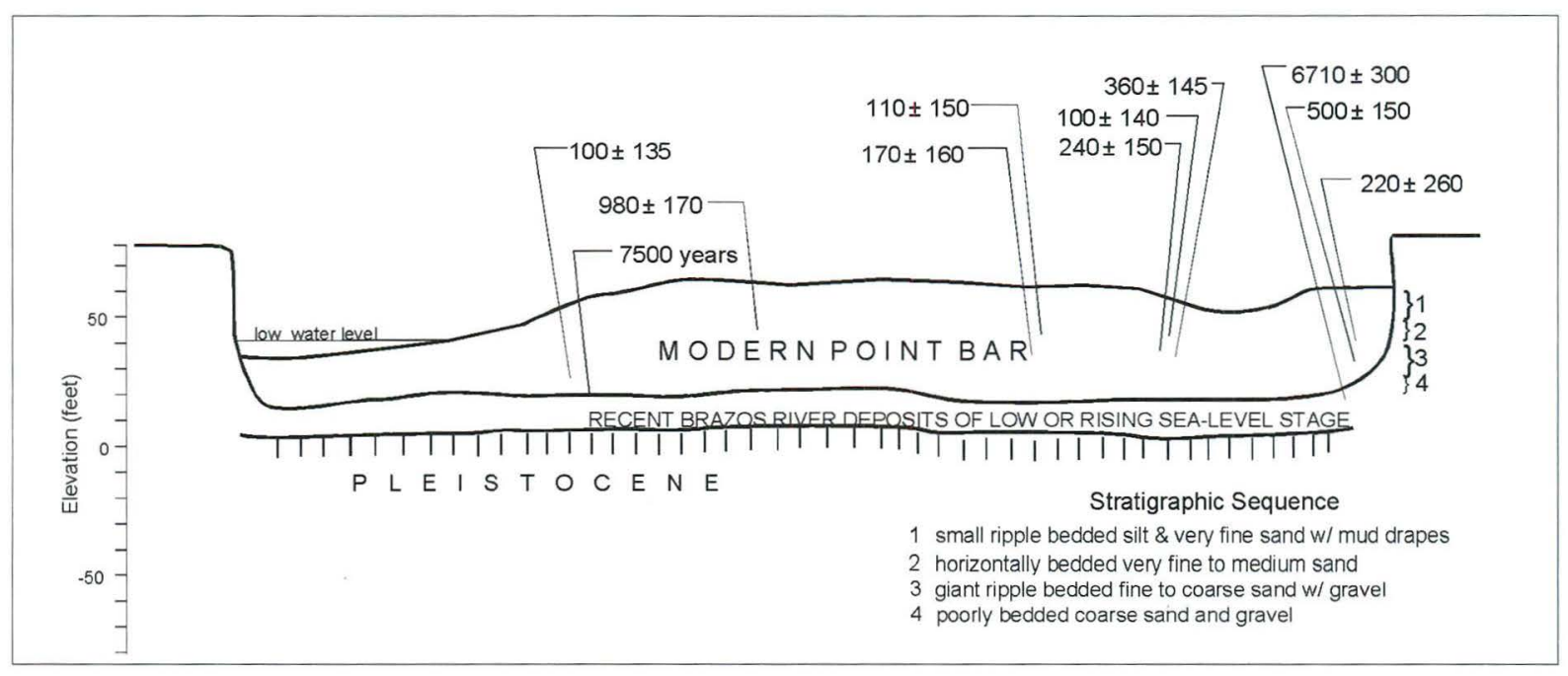

Figure 30. Generalized composite cross-section of the Blasdel point bar, adapted from data presented in Bernard et al. (1970). Radiocarbon ages illustrated are compressed from five discrete sections across the bar. Elevation is expressed in feet relative to mean sea level.

cross-bedded gravelly coarse to fine sand representing the channel and lower point bar. The middle point bar deposits consist of very fine to medium, planar-bedded sand with occasional inclusions of mud drapes, avalanche (spillover) bedding, and contorted bedding. Upper point bar deposits are relatively thick very fine sand and silty sand and exhibit pronounced, small-scale crossbedding. Although a few older ages were obtained, radiocarbon results from the point bar sequence suggests that the entire sequence of point bar deposits accreted in the last few hundred years. Given that the point bar is over 1500 feet wide and attains a thickness of up to 50 feet, this rate of accretion is highly significant, and limits the potential for the discovery of archeological remains in the shallow subsurface. However, any stratified cultural material detected would probably have very good temporal and stratigraphic resolution, and therefore high research potential.

Voellinger (1990) examined the geoarcheological potential of the lower Brazos by extrapolating high probability site locations from existing site file data. The database used included 117 prehistoric sites, which were characterized in terms of distance from the modern coast and from the nearest water source (including infilled paleochannels and other presumed former sources of water). Voellinger found that $98 \%$ of the recorded sites were situated within 250 feet of current or former stream courses within the Brazos Valley and on the uplands, and that the majority (75\%) were Late Prehistoric occupations.
A final previous study is that of Aten (1983), who examined the Brazos as part of his landmark examination of the archeology and geoarcheology of the upper Texas coast. Basing his interpretation on examination of aerial photographs and stratigraphic and chronometric data from Bernard et al. (1970), Aten identified a series of cross-cutting meander belts dating from the Middle to Late Holocene that he terms the Big Slough, Bastrop Bayou, Onion Creek, and Modern Brazos channel stages (Figure 31). Using the dispersed chronometric information in Bernard et al. (1970), these "channel stages" are tentatively dated to approximately 8,000-6,000 BP, 6,000-3,000 BP, 3,000$1,500 \mathrm{BP}$, and 1,500-0 BP, respectively. Citing archeological site location data for support, Aten makes a particularly forceful argument that abandonment of the Oyster Creek meander belt occurred at least 500 years prior to the date suggested by Bernard et al. (1970).

While the arguments concerning the Oyster Creek meander belt are convincing, several aspects of Aten's proposed sequence are somewhat questionable. First, the connections between the older (Bastrop Bayou and Big Slough) channel stages and the radiocarbon ages from Bernard et al. (1970) are tenuous at best; the four ages attributed to the Bastrop Bayou channel stage, for example, are from shell beds in prodelta muds underlying western Galveston Island, while the ages attributed to the Big Slough stage are from muds underlying the modern meander belt (the Blasdel point bar). Also, 


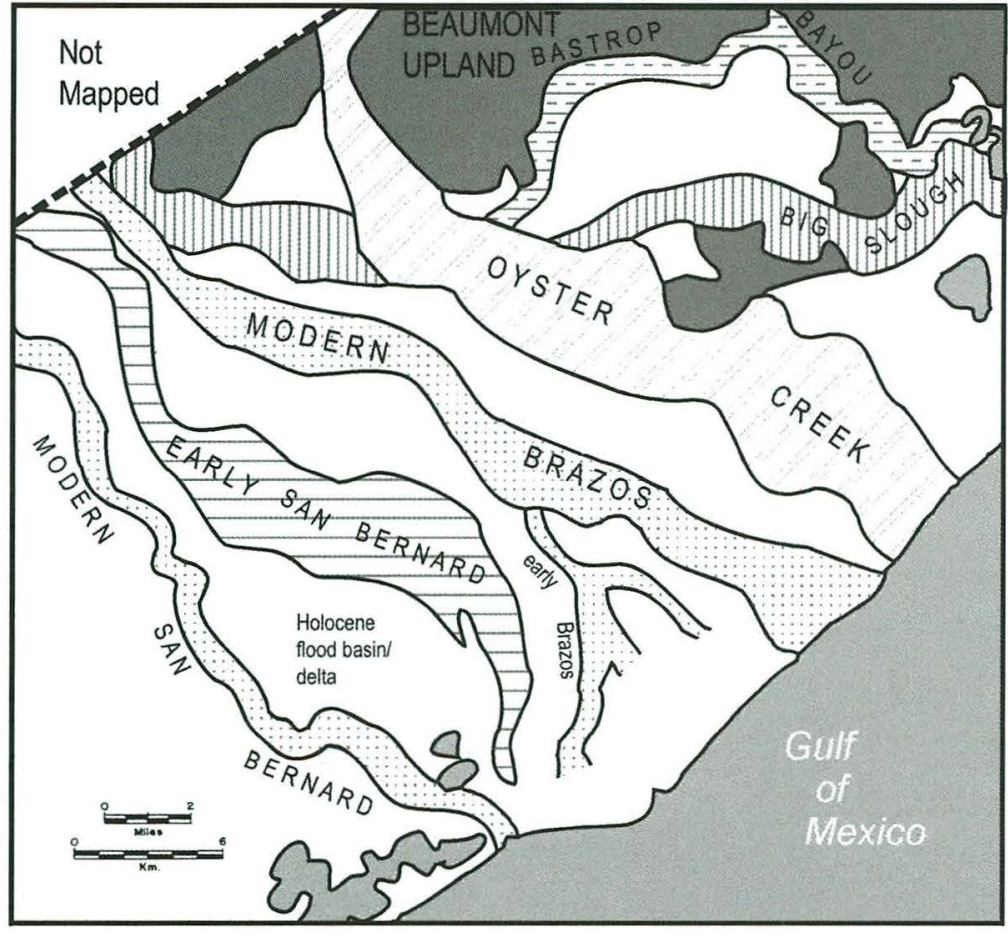

Figure 31. Middle to Late Holocene meanderbelts of the Brazos and San Bernard rivers according to Aten (1983: Figure 8.9).

the attribution of the Bastrop Bayou channel trace to a Holocene Brazos channel seems questionable. Bastrop Bayou occupies a large valley wall meander scar of almost certain Pleistocene age, based on the meander wavelength indicated by scalloping of the valley margin. At the same time, no meandering channel traces with meander wavelengths and amplitudes comparable with the other three "channel stages" are present. In addition, both the Bastrop Bayou and Big Slough channels breach a former ridge of the Beaumont upland (see Figure 31), which would have been extremely unlikely when the stream was entrenched during the Early/Middle Holocene. While such channels could have easily been reoccupied during the Holocene, the width of the mapped Bastrop Bayou meander belt is less than one-quarter the width of the Oyster Creek meander belt, while the time attributed to its occupation is roughly twice that of Oyster Creek $(3,000$ years). Finally, data from the current study (Core 7) indicates that the broad scallop scar occupied by Bastrop Bayou is underlain by a buried Pleistocene ("Deweyville") terrace, which would probably have been eroded if the Brazos had reoccupied the Bastrop Bayou paleochannel for a significant period of time.
Stratigraphic examination of the Brazos River during the current investigation was accomplished through the excavation of backhoe trenches, hollow-tube cores, and cut bank examinations. The location of principal investigated localities is indicated in Figure 28. Backhoe investigations of the Brazos fill were conducted at the crossing of SH 159 in Waller County, at Bullhead Slough near Sugar Land, and at the crossing of SH 332 in Brazoria County. Because of the thickness of the Brazos valley fill and the limitations of backhoe excavation, only the upper few meters of culturally relevant fill were examined at these locations. Nevertheless, these localities illustrate several important characteristics of the upper Brazos valley alluvium.

First, lateral facies variation is often pronounced, particularly given the large scale of the stream and the valley system. At the SH159 crossing, a total of six trenches were excavated within approximately 250 $\mathrm{m}$ of the channel at the location of a planned bridge replacement. Two of these trenches were situated on the streamward margin of the principal $\left(\mathrm{T}_{1}\right)$ terrace surface, and the other four were situated on the inset $\left(\mathrm{T}_{0}\right)$ surface of the modern meander belt. Although all of the trenches were within a few hundred meters of each other, each exhibited a unique profile reflecting pronounced differences in the accumulation and post-depositional alteration of different depositional facies. On the $\mathrm{T}_{0}$ surface, trenches close to the modern channel typically exhibited a weak (AC) epipedon underlain by stratified fine sands, silts, and loams representing thick upper point bar/levee deposits. These deposits ranged from $90 \mathrm{~cm}$ to more than $170 \mathrm{~cm}$ in thickness, and were typically underlain by massive, reddish-brown floodbasin muds that were weakly to strongly gleyed. The thickness of the sands tapered away from the channel; approximately $240 \mathrm{~m}$ from the channel they were absent, and the sequence consisted of more than $4 \mathrm{~m}$ of reddish-brown floodbasin muds supporting a vertic floodplain soil. Although no chronometric ages were obtained from 
the sequence, the topography suggests that these disparate sediments represent roughly coeval sandy and muddy facies of the modern Brazos.

The two trenches in older sediment on the $T_{1}$ terrace also exhibited very different profiles even though they were placed no more than $50 \mathrm{~m}$ apart on the same alluvial surface. Trench 2 exhibited an ABk-Ck-2Bk-2Bkss profile representing $170 \mathrm{~cm}$ of sandy to silty levee deposits over vertic floodplain muds, while Trench 3 exhibited an Ak-ABk-Bk-Bkss profile lacking the coarser overbank material. Once again, these profiles appear to represent disparate, coeval facies in relatively close geographic proximity.

Two trenches excavated at the SH 332 crossing in the town of Brazoria also illustrate lateral variability in the upper Brazos deposits. Here, the trenches are less than $50 \mathrm{~m}$ apart on the principal $\left(\mathrm{T}_{1}\right)$ alluvial surface adjacent to the modern channel. Both trenches exhibit similar surface sequences consisting of vertic soils overlain by a veneer of historic sediment and spoil. The vertic soil exhibits an Ass-Bkss profile, has a strongly undulating A-B contact indicating the former presence of gilgai, and small, hard carbonate concretions and nodules in the B horizon. It is approximately $170 \mathrm{~cm}$ thick at BT1, some $80-100 \mathrm{~m}$ from the modern channel, and $120 \mathrm{~cm}$ thick at BT2, 40-50 m from the channel. In both locations, this muddy sediment with the vertic soil is underlain by a probable levee deposit that consists of dense, massive light grayishbrown silty fine sand. This stratum, which varies from $50 \mathrm{~cm}$ thick in BT1 to $20 \mathrm{~cm}$ thick in BT2, contains common iron-manganese concretions and distinct, sub-vertical krotovina that appear to represent crayfish burrows.

In contrast to the upper sequence, which differs primarily in the thickness of the strata, the lower profiles of the trenches are very dissimilar. In BT2, situated closer to the channel, the levee deposit is underlain by at least $50 \mathrm{~cm}$ of weak sub-angular blocky, sandy to silty clay loam. This unit is predominantly gray with prominent dark reddish redox mottles at the top, and grades down to strong brown with prominent reddish mottles by the base of the trench. No appreciable secondary carbonate is present in the unit. In contrast, the basal unit in BT1 is suffused with secondary carbonate, primarily in the form of hard and chalky nodules, roughly equant concretions, and elongate rhizoconcretions. Many of these masses are quite large; the nodules and rounded concretions are up to $2 \mathrm{~cm}$ in diameter, and the rhizoconcretions are of a similar diameter and up to $8-10 \mathrm{~cm}$ long. In the upper part (3Btkgb horizon), the host sediment consists of a light gray clay loam containing abundant prominent brown, yellowish-brown, orange, and red redox mottles; fine brown iron-manganese concretions; and abundant secondary carbonate masses. In addition to the rhizoliths, many of the equant nodules were arranged in linear sub-vertical "chains" that clearly also reflect former root systems. With depth, the number and size of carbonate masses declined somewhat, the clay loam became light yellowishred with subtle coarse orange mottles and distinct, fine dark brown mottles.

Because no chronometric data are available, the stark contrast between the basal units in the two trenches at the Brazoria bridge locality is difficult to explain. While it is possible that the secondary carbonate-suffused unit exposed in BT1 represents a buried surface that is substantially older than the gleyed unit in BT2, this is considered very unlikely given the location of the trenches. Core data from the lower Brazos (see below) suggests that any substantially older unit in the middle of the valley should be deeply buried beneath Middle to Late Holocene sediments. Therefore, despite the very distinct differences in carbonate development, these two trenches are also interpreted as the result of marked facies variability within a limited geographic area.

The second important observation from the trenching is the widespread presence of a recent veneer overlying floodbasin muds on the Brazos floodplain. Veneer deposits exhibiting very weak soil development were observed at a number of different localities in the Brazos valley, including Bullhead Slough at US 59, SH 159 at the Brazos River, FM 2004 and SH 288B at Oyster Creek (see below), and several undocumented localities in Fort Bend and Brazoria counties. Although no supporting chronometric ages were obtained during this study, these thin (typically $20-30 \mathrm{~cm}$ ) veneers of sediment exhibit weak soil development at best and occasionally contain historic artifacts (particularly glass). Nordt (n.d.b) also alludes to the presence of a recent veneer over much of the flood basin, and cites an age of $40 \pm 35$ BP obtained by Kuehn (1996) from a depth of $30 \mathrm{~cm}$ in the Brazos floodplain in Washington County. The deposition of floodbasin veneer sediments occurred as aggradation along the margin of the channel, the channelproximal environments, creating a sediment sink 


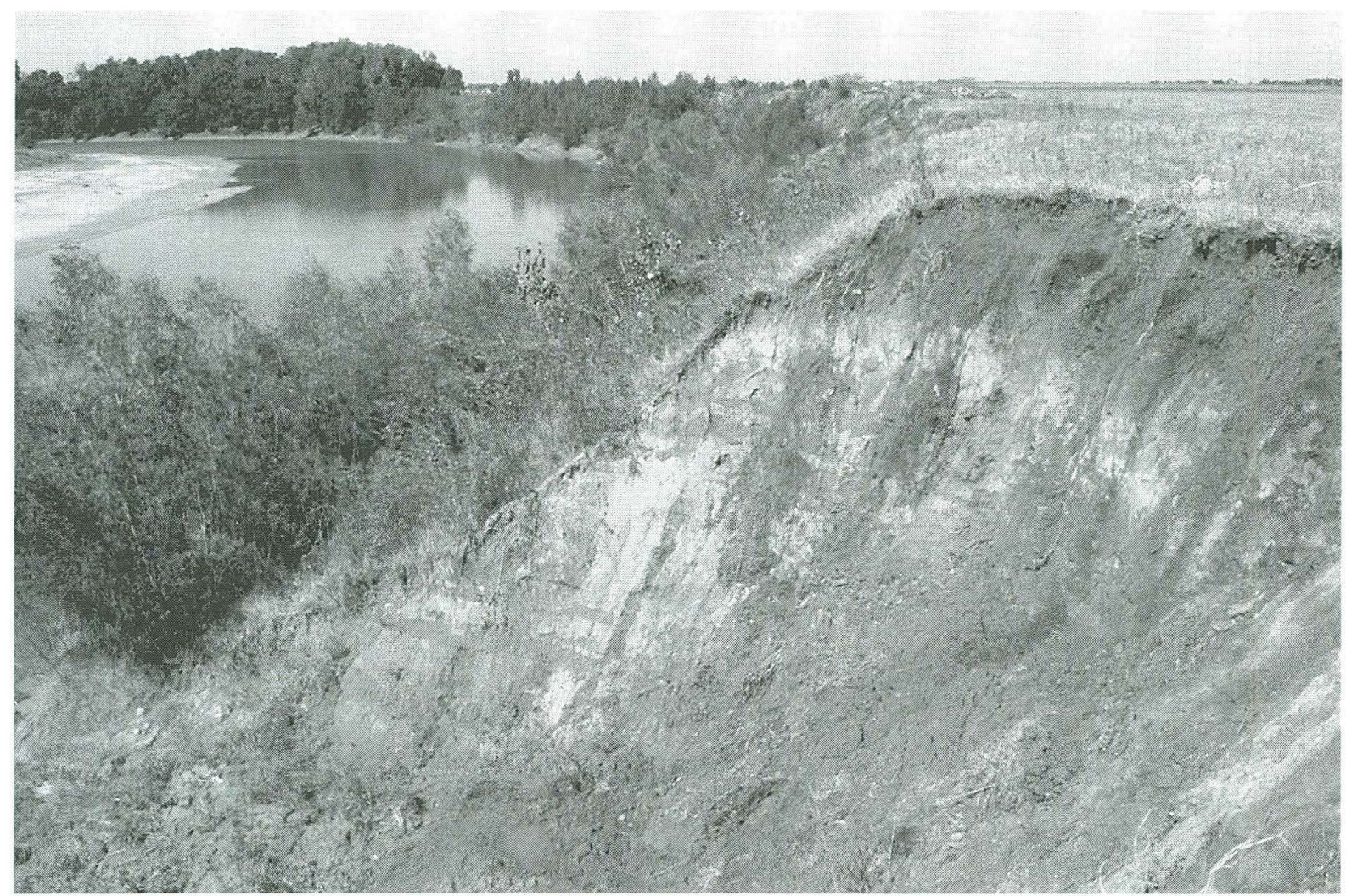

Figure 32. Photograph of the Brazos TDCJ Section, Fort Bend County.

that traps clays during flood events. While this historic veneer is not ubiquitous across the floodbasin, the fact that it is frequently present, coupled with the high incidence of long-term cultivation and the low incidence of surface sites (Voellinger 1990), suggests that routine surface survey of the Brazos floodbasin away from extant and former watercourses is not warranted. However, because other, higher potential facies can exist at depth, deep prospection is warranted in such environments when appropriate for the character of individual projects.

In addition to the backhoe excavations, a number of cutbank exposures were briefly examined. However, only one was recorded and sampled in detail. This exposure is situated near Sugar Land in Fort Bend County on property owned by the Texas Department of Criminal Justice. This cutbank exposed a $10 \mathrm{~m}$ section through the upper Brazos valley fill, consisting of stacked alluvial muds and splay/levee sands with four intercalated paleosols (Figure 32). This profile, termed the Brazos TDCJ section, was described in detail and dated with soil/ sediment humates. The profile is illustrated in Figure 33. Paleosol 1, which lies between approximately 8.75 and $9.75 \mathrm{~m} \mathrm{bgs}$, consists of a structured clay loam exhibiting a Bt-Btg-Bg profile. It is interpreted as a relatively well-developed floodplain soil formed under the influence of a high water table. A radiocarbon age of $6120 \pm 80 \mathrm{BP}$ was obtained from the Btg horizon. Although this age may be somewhat too old due to the influx of allogenic organic matter from the basin, it provides a good estimate for the maximum age of the deposit.

Paleosol 1 is overlain by approximately $2 \mathrm{~m}$ of weakly stratified, brown sandy to clayey loam with a very weak superimposed sub-angular blocky structure. A weak cumulic paleosol (Paleosol 2) representing a minor interruption in sedimentation separates these otherwise similar deposits. A radiocarbon age of $5170 \pm 90 \mathrm{BP}$ was obtained from the weak soil at a depth of approximately $7 \mathrm{~m}$ bgs.

Five meters bgs, the brown sediment is unconformably overlain by a $60 \mathrm{~cm}$-thick packet of strongly structured, dark reddish-brown clay. Slickensides and faint gray mottles are common through the clay horizon, which is interpreted as the lower part of a truncated, multi-story (and possibly welded) soil developed through several disparate, stacked alluvial deposits. A radiocarbon age of $6560 \pm 40$ $\mathrm{BP}$ was obtained from this stratum. Given the other 


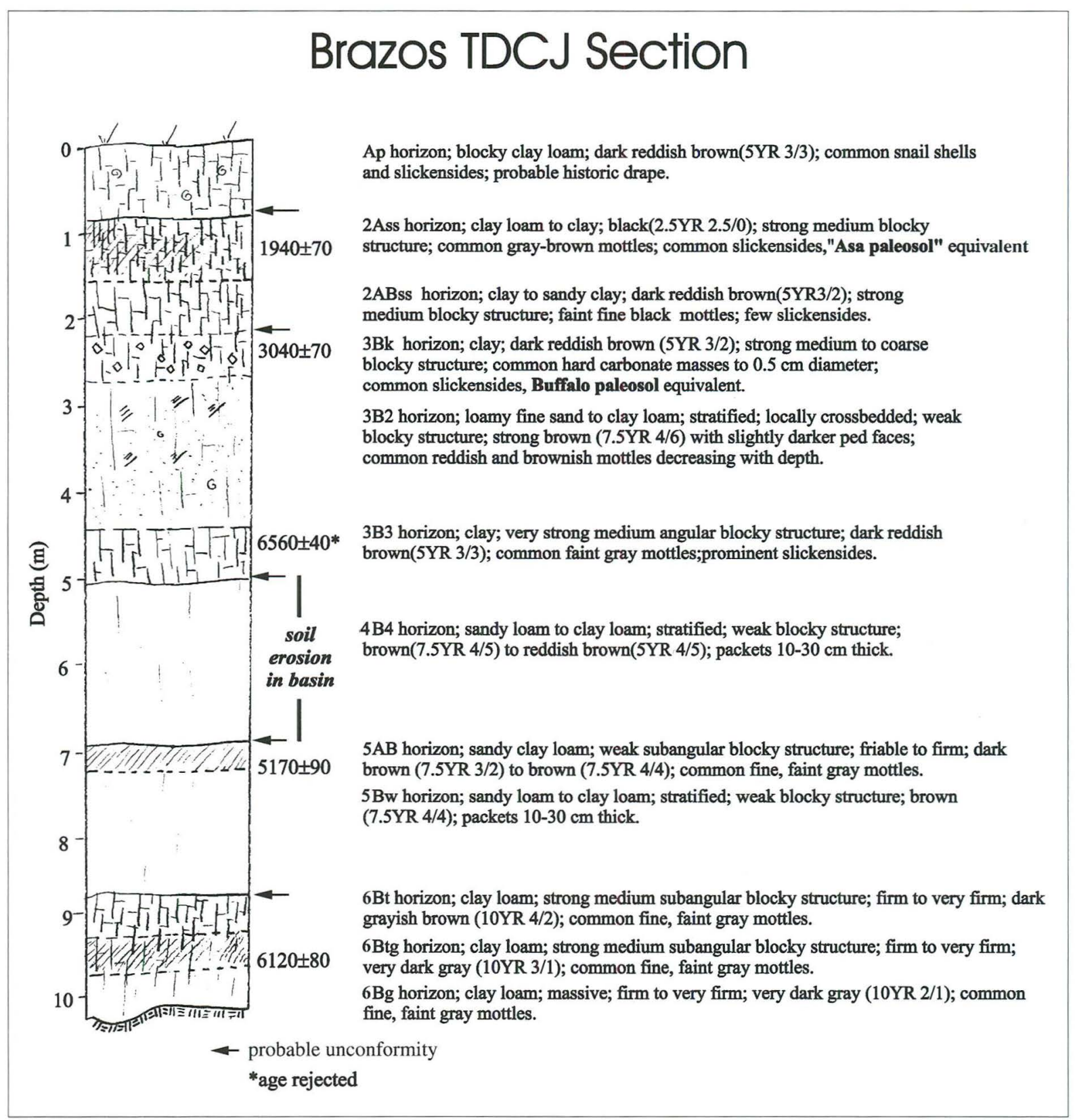

Figure 33. Profile of the Brazos TDCJ Section.

ages in the sequence, this age is clearly too old to represent the age of deposition, and the horizon therefore appears to be dominated by allogenic organics derived from soil erosion in the catchment. Other anomalous ages were obtained from similar stratigraphic locations in cores taken downstream; the significance of these ages is addressed below.

Approximately $4.4 \mathrm{~m}$ bgs, the dense clay grades into an overlying sediment composed of stratified, strong brown loamy fine sand and clay loam. This series of deposits is almost two meters thick, and appears conformable with the disparate sediments above and beneath it. Although subtle color banding representing residual depositional stratigraphy is readily observable, and remnants of preserved ripple bedding and cross bedding are occasionally apparent in the sands, soil development is also apparent in the stratum. The most notable alterations include a relatively weak but pervasive sub-angular blocky structure, pronounced redox mottling in the upper part of the unit, and a noticeable darkening of the ped faces that may reflect reduction and/or 
emplacement of silty clay by water flowing preferentially through the voids between peds. This unit grades upward into the remnant of a relatively strongly developed, truncated Bk horizon composed of dark reddish-brown clay exhibiting a strong angular blocky structure and common slickensides. Large, crystalline carbonate nodules are common throughout the $50 \mathrm{~cm}$-thick horizon. A radiocarbon age of $3040 \pm 70 \mathrm{BP}$ was obtained from this horizon. The sequence of deposits extending from this horizon (2.25 m bgs) down to approximately $5 \mathrm{~m} \mathrm{bgs}$ is interpreted as a single soil developed through a series of disparate sediment packets. Because the overlying sediments appear unconformable, the A horizon appears to have erosionally truncated. Although the most recent date from this soil is roughly a thousand years younger than stratigraphically comparable dates from the Buffalo Paleosol (Waters and Nordt 1995), it is tentatively correlated with the Buffalo Paleosol on the basis of character, stratigraphic position, and bracketing ages.

Overlying this soil is a $1.5 \mathrm{~m}$ thick unit that supports a dark Ass-ABss soil profile. It rests on a relatively clear contact that probably represents an erosional unconformity, although soil development through the unit has partially welded it to the underlying soil. A radiocarbon age of $1940 \pm 70 \mathrm{BP}$ was obtained from the A horizon. The upper $80 \mathrm{~cm}$ of the section consists of dark reddish-brown muds that represent relatively recent deposition. Soil development is limited (although a moderate blocky structure with weak slickensides is present), and the deposit is believed to date to the last few hundred years.

Finally and most informatively, a series of seven hollow tube cores were extracted from localities in the lower Brazos valley and Brazos Delta. Five of these cores were collected from a crossvalley transect along the ROW of SH 35 between Angleton and West Columbia, one was collected from between Oyster Creek and Bastrop Bayou in the vicinity of the large valley wall scallop north of Clute/Lake Jackson, and one was collected near the community of Oyster Creek on the Brazos delta (see Figure 28). These cores, which penetrated up to $100 \mathrm{ft}(30 \mathrm{~m})$ into the Brazos fill, are curated at the Bureau of Economic Geology (BEG), The University of Texas at Austin. However, few of the cores are continuous because the rig was unable to recover thick $(>5 \mathrm{ft})$ saturated fine sands. Despite the use of a catcher sleeve in the core barrel, these wet, heavy sands simply flowed back out the base as the core barrel was withdrawn. Moreover, when the hollow core barrel was withdrawn, hydrostatic pressure would often force the saturated sands up the inside of the hollow auger, which required the whole assembly to be backed out of the section until the core barrel and auger could be aligned. When such sands were encountered, the core was continued without extraction until a finer-grained stratum was reached.

All cores were described at the BEG and sampled for radiocarbon dating (see Appendix IV). In addition, two cores (Core 2 and Core 6) were bulk sampled at roughly $50 \mathrm{~cm}$ intervals and analyzed for texture, carbonate content, organic matter content, and magnetic susceptibility. Because recovery was incomplete, the thickness of channel/point bar sands is frequently inferred, and gaps exist in the quantitative data from Core 2 and Core 6.

Figure 34 illustrates the stratigraphy of the cross-valley transect. The first five cores represent an actual transect across the valley, while Core 7 represents a landscape feature situated several kilometers downstream. An important characteristic of the cross-section is that it captures the Beaumont outlier underlying Bailey's Prairie, which lies between the Oyster Creek meander belt and the remainder of the Brazos valley (see Figure 28). Although the spacing of the cores (approximately 2 $\mathrm{km}$ ) makes correlation between individual cores difficult and assures that many architectural details are missing (for example, the entire modern meander belt lies between Core 1 and Core 2), the sequence is quite informative. However, it also raises a number of stratigraphic questions that cannot be resolved without further work.

The sequence of deposits recovered from the individual cores ranges from a relatively simple Middle-Late Holocene fining-upward point bar sequence in the Oyster Creek meander belt (Core 4) to thick, complex series of Late Pleistocene to Late Holocene deposits in cores in the western part of the valley (Cores 1-3) and veneers of Middle/ Late Holocene material over thick Late Pleistocene alluvium (Core 7) and Beaumont Formation muds (Core 5) elsewhere. Four generalized phases of deposition are identified: Middle/Late Holocene deposits, which occupy the Oyster Creek and modern meanderbelts and form a thick $(2-5 \mathrm{~m})$ veneer over the remainder of the floodplain; complex Late Pleistocene/Early Holocene deposits, which are up to $20 \mathrm{~m}$ thick and limited to the 


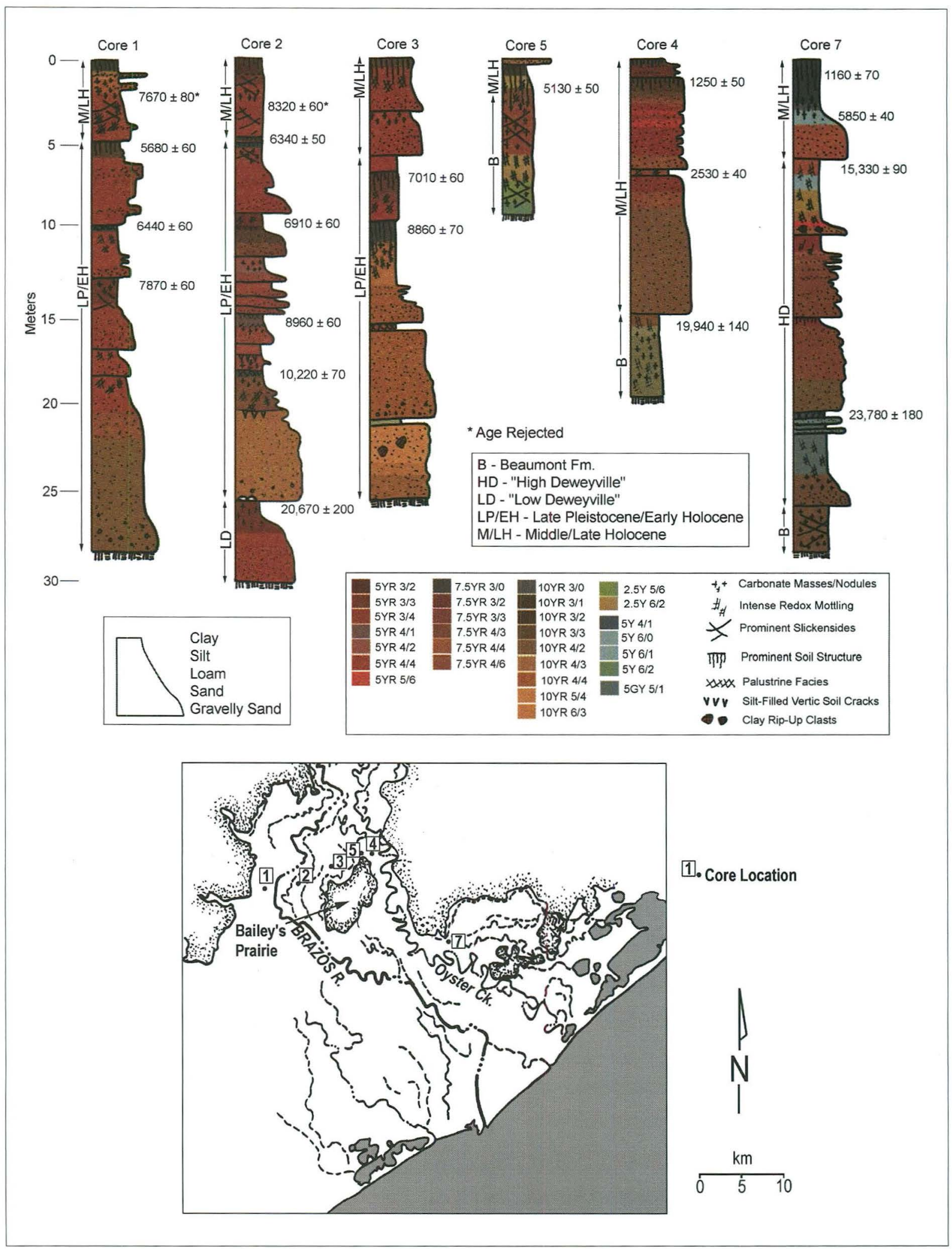

Figure 34. Schematic stratigraphy of the Brazos Valley cores, with radiocarbon ages and fill age interpretations. See Figure 28 for core locations. Modern sea level is between $8.5 \mathrm{~m}$ and $10 \mathrm{~m}$ below the top of cores $1-5$ and approximately 4.5 below the top of core 7 . 
broader and deeper part of the valley west of Bailey's Prairie; deeply buried Late Pleistocene alluvial deposits in the valley axis; and thick, relatively shallowly buried Late Pleistocene alluvium on the valley margin. For purposes of discussion, these latter deposits are termed the "low Deweyville" and "high Deweyville," respectively, following terminology developed by Blum and his colleagues (Blum et al. 1995; Aslan and Blum 1999). The Low and High Deweyville fills are defined by bounding surfaces and thus comprise allostratigraphic units, but the division between the Early/Middle Holocene and Late Holocene deposits is poorly defined and reflects an arbitrary judgement based on extant radiocarbon ages.

Several characteristics of the Brazos valley cores are quite striking. First, the thickness and timing of the valley fill agrees quite well with the reconstructions of sea level variations in the Gulf during the Late Pleistocene and Holocene. The principal valley excavated during the Late Pleistocene sea-level low stand is situated west of the Bailey's Prairie Beaumont outlier. It is infilled with a thick $(20 \mathrm{m+})$, complex sequence that aggraded between approximately $12 \mathrm{ka}$ and $5 \mathrm{ka}$ as sea level was rapidly rising (see Figure 17). The Middle/Late Holocene, in contrast, is characterized by thinner $(2-5 \mathrm{~m})$ deposits except in areas occupied by a thick, Middle/Late Holocene meanderbelt (i.e., the Oyster Creek and modern meanderbelts). Because the Middle/Late Holocene radiocarbon ages from the floodbasin are problematic (see below), aggradation rates are difficult to quantify with confidence. However, it is instructive to note that the deposits in Core 2 aggraded an average of $0.348 \mathrm{~cm} / \mathrm{yr}$ from approximately $10 \mathrm{ka}$ to $6 \mathrm{ka}$, then slowed dramatically to $0.071 \mathrm{~cm} / \mathrm{yr}$ from $6 \mathrm{ka}$ to the present. This clearly reflects the important role of eustatic control on the incision and backfilling of the lower Brazos valley.

Second, significant estuarine deposits are not apparent in the sequence. The general character of estuarine deposits varies considerably depending on the rate and character of alluvial sediment delivery, the configuration of the drowned valley, and the degree to which the estuary is isolated from the open sea by bars or spits (Bernard et al. 1970; Reineck and Singh 1980). Although they are typically sandier than the muddy lagoonal facies, estuarine deposits are characterized by (1) the presence of intense bioturbation structures, (2) diverse sedimentary structures, including lenticular and flaser bedded sands, symmetrical ripples, and massive to laminated, reduced muds, and (3) the inclusion of marine or brackish fauna, peats, and rounded clay pebbles. In stratigraphic terms, estuarine deposits should underlie the deltaic sequence and overlie the cut valley bottom in an infilled estuary. If infilling is accompanied by continued sea-level rise, or if the rate of fluvial sediment supplied to the delta is exceeded by the rate of erosion or subsidence, estuarine deposits could also interfinger with deltaic and prodeltaic sediments.

McGowen et al. (1976:17) proposed that backflooding of the lower Brazos and Colorado valleys formed a large estuary that persisted through the majority of the Holocene. Basing this conclusion on expectations derived from the sea level curve, they hypothesized that this estuary continued to infill until approximately $1.8 \mathrm{ka}$. In contrast, Aten (1983:122) suggested that valley filling by the Brazos may have kept pace with sealevel rise during the Middle-Late Holocene, preventing the formation of a large estuary. Aten's hypothesis is supported by the current core data, which show no evidence that appreciable estuarine deposition penetrated inland as far as the $\mathrm{SH}$ 35 crossing. However, a number of relatively thin, reduced muds that represent paludal (marsh) environments are dispersed throughout the sequence. Several of these muds exhibit a very distinct "coffee ground" or "cottage cheese" texture that probably represents rapid flocculation in response to increasing salinity. Although the salinity of the deposits has clearly not remained constant, once formed such floccules can be stabilized by mucous produced by fungus, bacteria, and algae (Reineck and Singh 1980:316). Thus, while a large estuary apparently did not invade the incised Brazos valley as far up as the current position of SH 35, it is considered likely that brackish to saline conditions did occasionally develop on the delta through the Early Holocene.

Third, radiocarbon ages on sediments dating from roughly $5.5 \mathrm{ka}$ to $3.5 \mathrm{ka}$ exhibit very intense biases due to the incorporation of old organics. This bias, which appears to range up to $3-4 \mathrm{ka}$, is apparent in the ages from Cores 1 and 2 and from the Brazos TDCJ section. Radiocarbon ages on sediments and soils are often criticized precisely because they often produce demonstrably old measured ages (e.g., Nordt 1992; Johnson and Goode 1994), but Abbott (1997b) has demonstrated 
that this same tendency can be extremely informative regarding landscape dynamics, and particularly the timing of episodes of regional soil erosion and stability. In this case, the age bias is probably a result of widespread soil erosion. Regional soil loss during the Middle Holocene has been noted previously (Nordt 1992; Toomey 1993; Toomey et al. 1993; Collins 1995), and is usually attributed to a regional episode of Middle/Late Holocene aridity commonly termed the Altithermal or Hypsithermal (Antevs 1948; see also Hall 1988; Holliday 1989; Nordt et al. 1994; Humphrey and Ferring 1994). While the timing of this episode inferred by various authors varies by several thousand years (cf. Nordt 1992; Toomey et al. 1993; Nordt et al. 1994; Johnson and Goode 1994), the current study suggests that sediment derived from this episode was accumulating in the lower Brazos valley between approximately $5.5 \mathrm{ka}$ and $3.5 \mathrm{ka}$. Although some lag time is probably represented in the transport of these eroded soils to the lower basin, this interval probably closely follows the most intensive phase of Holocene soil erosion in the Brazos basin.

Fourth, the ages obtained from the buried "Deweyville" fills are problematic. As outlined previously (see Chapter 2), there is no clear consensus in the literature on which deposits are properly termed "Deweyville," or on the time span that these deposits represent (Bernard 1950; Delcourt and Delcourt 1977; Otvos 1980; Aten 1983; Alford et al. 1985; DuBar et al. 1991; Blum et al. 1995; Aslan and Blum 1999). Until recently, most authors have tended to view the Deweyville sequence in relation to a presumed age of approximately $30 \mathrm{ka}$ for abandonment of the Beaumont surface; consequently, the Deweyville has commonly been interpreted as deposits formed in response to oscillations in sea level and/or discharge during the rising sea level stage of the latest Pleistocene and Early Holocene (e.g., Bernard 1950; Aten 1983). However, the gradual abandonment of Fisk's classic four-fold division of the Pleistocene, coupled with data derived from new dating methods like optically stimulated luminescence, has led some investigators to revise these ideas. In the author's opinion, the most reasonable recent treatment is by Blum et al. (1995), who employ the term "Deweyville" to describe unconformity-bounded (allostratigraphic), coarsegrained deposits laid down during Oxygen Isotope Stage 4, 3, and 2. Blum et al. (1995) recognize that the Deweyville sequence is complex; at least three distinct cut and fill cycles are encompassed in the Colorado valley. While Oxygen Isotope Stage 2 ended around $11 \mathrm{ka}$, Aslan and Blum (1999) place the end of Deweyville deposition at approximately $20 \mathrm{ka}$. Given that the stratigraphic architecture of the coastal reach of streams like the Brazos and Colorado was strongly controlled by eustatic sea level fluctuations, and sea-level low-stand occurred sometime around $18 \mathrm{ka}$, this usage makes intuitive sense. If no significant reversals in sea level trend occurred during the rising sea-level stage, all deposits laid down since that time should represent the modern valley fill and thus lack major bounding unconformities. However, if major reversals like those indicated in the sea-level curve by Curray (1960; see Figure 17) did occur, then they could have led to re-entrenchment and the development of additional bounding unconformities (i.e., additional "Deweyville" terraces formed during the rising sea-level stage).

Because the allostratigraphic definition of the "Deweyville" unit is not based on the textural and hydrologic characteristics that have previously been used to define and describe the sequence (i.e., relatively coarse-grained deposits preserving large, sinuous channel traces), it is likely that some deposits that have previously been considered components of the Deweyville should be excluded. Given the apparent character of climate from $18 \mathrm{ka}$ to $10 \mathrm{ka}$, the texture and facies architecture of Late Pleistocene deposits laid down during the rising sea level stage should be similar to the relatively coarsegrained Deweyville sequence, and distinct from the fine-grained, overbank-dominated Late Holocene sequence. However, unless a clear bounding surface can be identified, such deposits should not be considered part of the Deweyville sequence. Thus, if the allostratigraphy argument of Blum et al. (1995) is accepted, the crucial factor separating the Pleistocene "Deweyville" deposits from the "postDeweyville" Pleistocene deposits is the presence of three-dimensional cut-and-fill architecture and a well-developed soil at the upper contact.

Although formal, published stratigraphic work on the Deweyville sequence in the lower Brazos valley is lacking (Blum et al. 1995), Deweyville units are clearly present, and ongoing dissertation research by Dennis Sylvia, University of Texas Department of Geology, will clarify the picture considerably (Silvia, personal communication, 2000). 
Elevated Quaternary terraces are mapped in positions between the floodplain and the inset Beaumont alluvial terraces inland of the Lissie outcrop, but are absent coastward (Barnes 1974a, 1982), suggesting that the Deweyville surfaces were overlapped and buried by Holocene alluvium. Upstream, Waters and Nordt (1995) avoid the term "Deweyville," but describe a basal unit (Unit I) that conforms to its general characteristics: a coarse-grained, channeldominated sequence with a paucity of vertical accretion facies. However, at least part of this unit is clearly attributable to the period of rising sea-level following $18 \mathrm{ka}$, and its relationship to the Deweyville assemblage as defined by Blum et al. (1995) is therefore questionable. Because it is unlikely that stratigraphic architecture this far upstream was influenced by base level changes, episodes of aggradation and channel trenching would have been a function of changing environmental characteristics in the basin, tempered by systemic response times and complex adjustments. Thus, it is unlikely that Deweyville deposition in this area would have terminated at the same time as in the eustatically controlled coastal reach.

The Brazos core sequence obtained during this study includes two Late Pleistocene fill sequences that are informally termed "High Deweyville" and "Low Deweyville," respectively. The contact between the "Low Deweyville" and more recent deposits is defined by a well-developed soil that occurs in Core 2 at a depth of $26 \mathrm{~m}$ bgs (roughly $18 \mathrm{~m}$ below mean sea level), and dates to $20,670 \pm 200$ BP. This position and age is consistent with expectations for an inset fill dating to the final stages of valley incision prior to the low-stand. According to the model advanced by Blum et al. (1995), the successive Deweyville fills represent a series of inset alluvial units formed after abandonment of the Beaumont as the stream alternately incised and filled, and the younger units should therefore be encountered at greater depths in the valleys' systems. Although this model makes intuitive sense and is supported by OSL ages from Colorado and Nueces river systems, the ages from the "High Deweyville" fill in the Brazos sequence are problematic. Here, a coarse-grained fill capped by a thick clay with a strong paleosol is dated to between $23,780 \pm 180 \mathrm{BP}$ and $15,330 \pm 90 \mathrm{BP}$. This fill was encountered at an elevation of approximately $5.5 \mathrm{~m}$ below the top of the core ( $1 \mathrm{~m}$ below modern sea level). Therefore, despite the fact that they differ by at least $10 \mathrm{~m}$ in elevation, the extant data indicate that the "high" and "low" Deweyville fills in the lower Brazos valley were apparently accumulating contemporaneously. Even if accumulation of the Brazos Valley "High Deweyville" was not influenced by eustatic base level and the depositional loci was separated from the deep Late Pleistocene valley by a now buried interfluve, it is difficult to envision a scenario where deposits of this thickness could accumulate at such drastically different elevations in such close proximity. Therefore, despite the fact that the ages from the "Upper Deweyville" fill are internally consistent, they are problematic when viewed from a broader perspective. One possibility is that the lower (23 ka) age from the "high" Deweyville fill is erroneous, while the upper $(15 \mathrm{ka})$ age represents a mean residence time soil age. However, while it would make the data fit the broad model, this scenario is far from certain. It is particularly unclear how contamination of the deeply buried deposits would have occurred far beneath the active soil zone, although the possibility definitely exists. Clearly, more work is needed to understand the Late Pleistocene sequence in the lower Brazos valley. Fortunately, this ambiguity has relatively little relevance for geoarcheological planning in CRM, because although the relationship between these two stratigraphic units remains in question, both units clearly pre-date the Clovis period.

Figure 35 illustrates the quantitative character of Core 2, which penetrates through the majority of the Late Pleistocene/Holocene fill sequence. The sequence clearly illustrates the complexity of the Brazos valley fill. Rather than a sequence dominated by relatively unaltered sediments in which a few soils are intercalated, chemical and geomagnetic analysis suggests that the majority of fine-grained sediments making up the section are moderately to intensely altered by pedogenesis and subsequent groundwater diagenesis. The pervasive pedogenic influence on the sequence is supported by visual observations, including the systematic presence of redox mottling, carbonate accumulation, iron and manganese concretions, and well-developed slickensides and soil structure. At the same time, the character and intensity of pedogenic alteration is far from uniform throughout the section. Variation in carbonate content, organic matter content, and the state of iron compounds clearly indicates horizons where either leaching and eluviation or illuvial accumulation have dominated (i.e., relatively well 


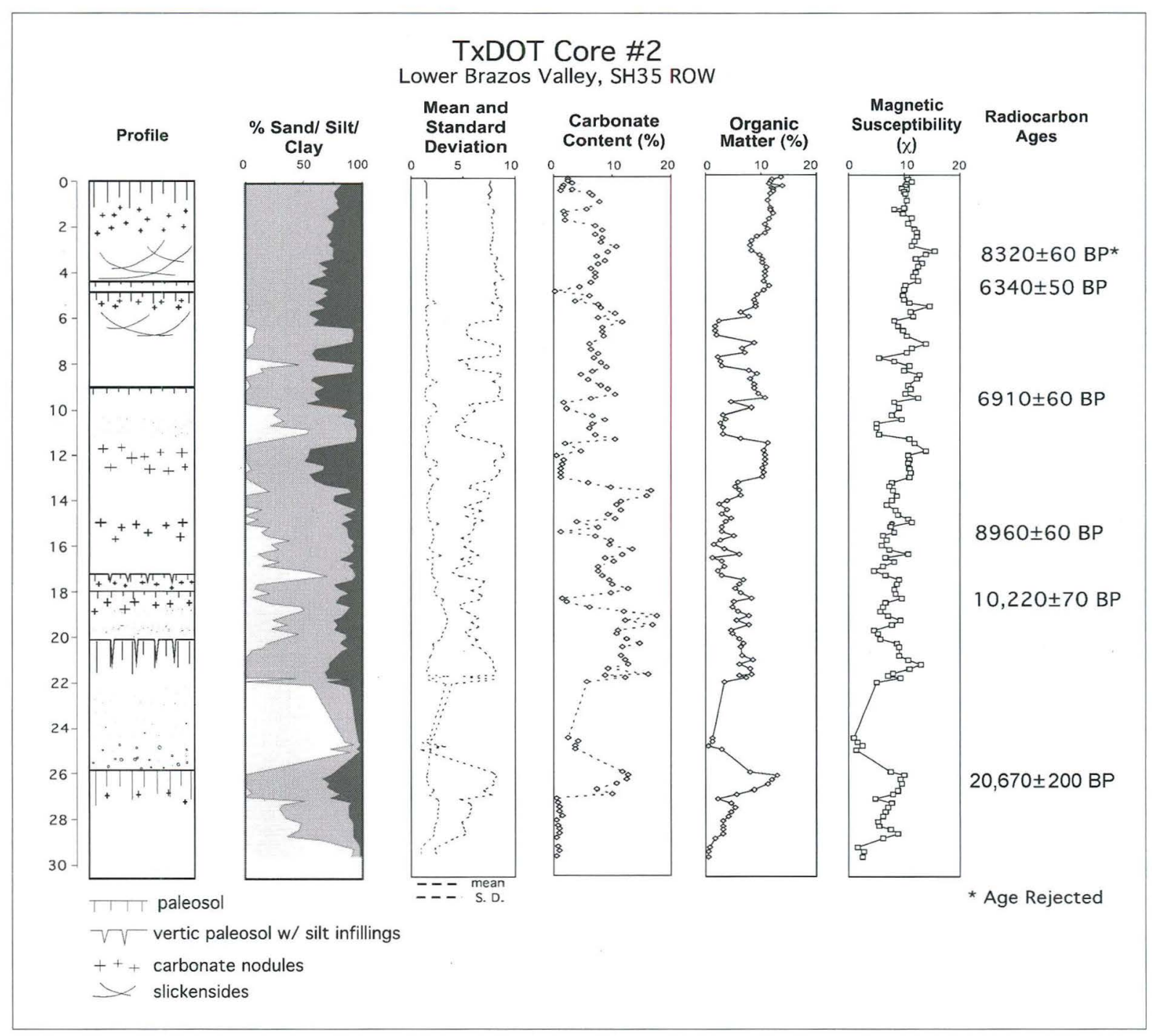

Figure 35. Illustration of textural, chemical, and magnetic trends in Core 2 from the lower Brazos valley.

developed soils). For example, horizons where secondary calcite nodules are particularly prominent tend to coincide with zones where the matrix is relatively decalcified, and the trend in organic matter is clearly related to variations in magnetic susceptibility. Although not reflected in Figure 35, there are also complex, systematic trends apparent in the character of redox mottling, including the size and intensity of mottles, the overall degree of reduction, and the relative frequency of fine manganese nodules. Another observation not indicated in the figure is the presence of small gypsum crystals at intervals in the relatively clayey facies. The position and concentration of these gypsum accumulations does not suggest that arid, evaporitic environments are represented; rather, they appear to be the result of diagenetic precipitation from briny groundwater. This suggests that some of the carbonate nodules apparent in the sequence may also be the result of post-burial diagenesis, but the position and habit of most carbonate zones is consistent with pedogenic formation (see Appendix II).

Core 5 was situated between the Oyster Creek meander belt and the large western valley on the Bailey's Prairie interfluve. It revealed a veneer of Middle/Late Holocene floodbasin alluvium overlying a strong upland soil developed in Beaumont Formation clays. A mean residence radiocarbon age of $5130 \mathrm{BP}$ was obtained from the upper part of the Beaumont Formation soil, suggesting that the Beaumont surface was buried and sealed approximately 3-4 ka. 


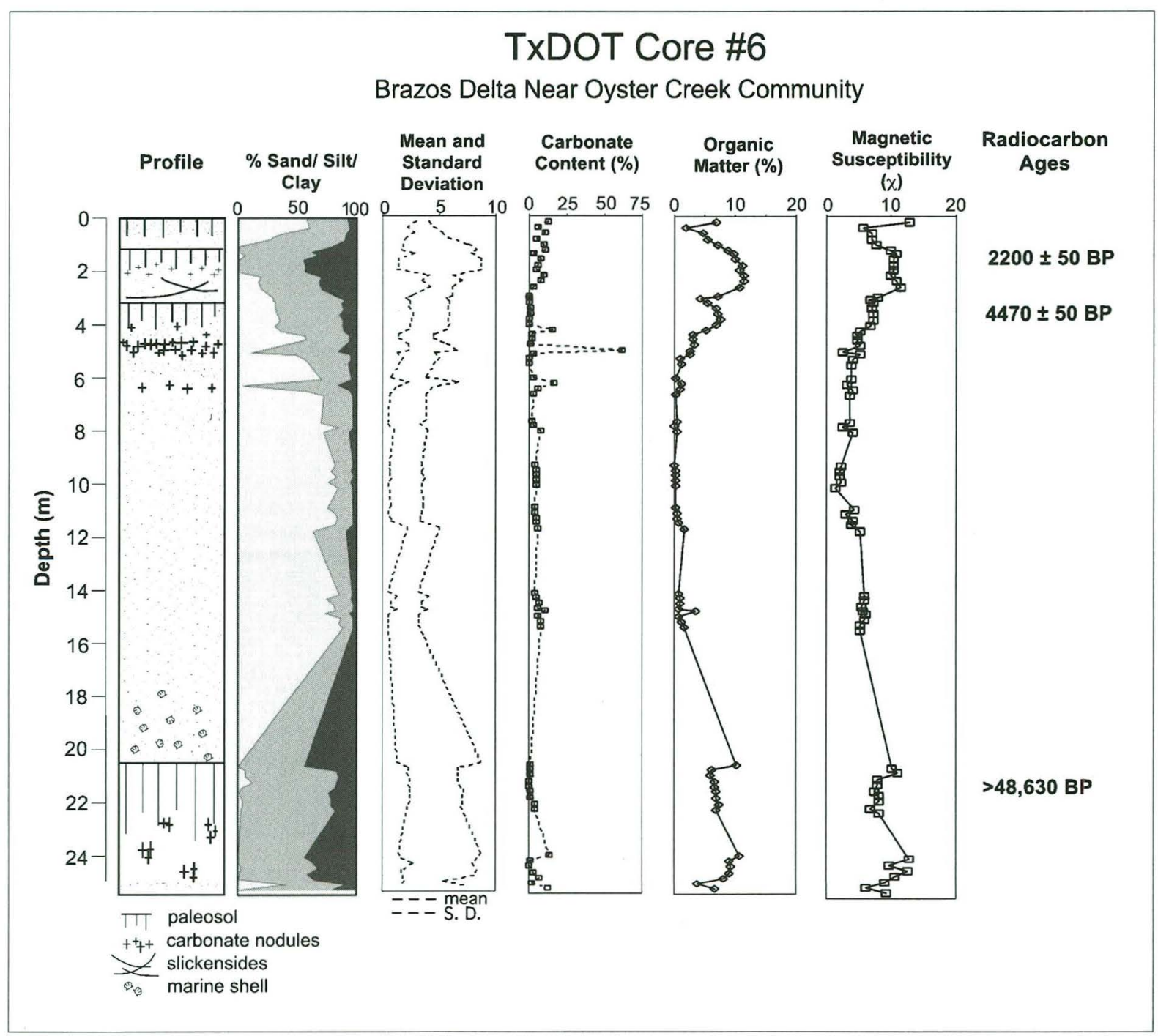

Figure 36. Illustration of textural, chemical, and magnetic trends in Core 6 from the Brazos delta.

Three cores in the Brazos delta plain are described by Bernard et al. (1970). These cores vary from laminated and cross-bedded fine sands, silts, and muds in an Oyster Creek point bar sequence to massive, mud-dominated floodplain and marsh deposits on the delta flat. In contrast, the single core recovered from an unconfined deltaic setting during this study (Figure 36) exhibits a relatively simple, coarse-grained sequence that is interpreted as a Brazos River channel/point bar sequence. This core was recovered from the east-central part of the delta, within the Oyster Creek meander belt, at an elevation of approximately $5 \mathrm{ft}(1.6 \mathrm{~m})$ above modern sea level (see Figures 28 and 31). The upper few meters of the sequence consist of floodbasin silts and muds containing two distinct, buried paleosols dated to $2200 \mathrm{BP}(1.6 \mathrm{~m} \mathrm{bgs})$ and 4470 BP (3 m bgs), respectively. The upper soil exhibits an Ak-Bk-Bss profile and is moderately altered by redox processes in its lower part. The lower soil is heavily redox-mottled throughout and exhibits an A-Bk-K profile. The $\mathrm{K}$ horizon is approximately $30 \mathrm{~cm}$ thick and consists of white $(5 \mathrm{Y} 8 / 0)$ clay containing approximately $50 \%$ crystalline carbonate nodules by volume. It is interpreted as a capillary zone carbonate formed in a relatively brief period of time $(<2 \mathrm{ka})$. Below the soil, the sequence consists of a thick accumulation of fine to medium loamy sands. Unfortunately, this material proved extremely difficult to recover and there are many gaps in the sequence (see Figure 36), but it clearly represents a sequence of fluvial channel/ 
point bar sands. This material continued to a depth of $18-19 \mathrm{~m} \mathrm{bgs}$, where it graded into a well-sorted beach sand containing abundant marine shell. Unfortunately, the character of the contact between fluvial and coastal facies could not be determined because of incomplete recovery, and it is unclear if the contact was erosional or gradational. The beach sand was at least $3 \mathrm{~m}$ thick, and rested on a dense clay with a strong soil developed in it. This stratum is interpreted as an upland soil formed in the Beaumont Formation. A dead radiocarbon age was obtained from one of a number of coarse grass roots (cf. Spartina roots) in growth position in the upper part of this soil. Although this age supports the Beaumont interpretation, it was surprising because the roots were expected to represent vegetation colonizing the surface shortly before it was overridden and buried by the Late Pleistocene/Holocene delta. It is unclear how such roots were preserved in what was probably a relatively freely drained soil for more than $30 \mathrm{ka}$.

\section{Oyster Creek}

Oyster Creek is a moderately sized, highly sinuous stream that occupies the eastern side of the Brazos valley for most of its length. It represents a former channel of the Brazos abandoned during a major avulsion that occurred between 500 and 1,500 years ago (Bernard et al. 1970; McGowen et al. 1976; Nordt n.d.b). Oyster Creek extends inland from its mouth on the eastern side of the Brazos/ Colorado delta to central Fort Bend County, occupying the eastern side of the Brazos Valley for its entire length. Oyster Creek proper ends in central Fort Bend County, where the channel intersects the modern Brazos meanderbelt. Upstream of Oyster Creek's nominal origin, the same paleochannel is successively occupied by modern streams named Jones Creek and Bessie's Creek, the latter of which continues upstream into Waller County. According to data published on the World Wide Web by the Environmental Protection Agency (www.epa.gov/ surf2/hucs/), Oyster Creek drains a basin of more than $630 \mathrm{mi}^{2}\left(1630 \mathrm{~km}^{2}\right)$, including the eastern side of the Brazos valley and the adjacent Beaumont upland for several kilometers inland.

Because it occupies a cutoff paleochannel of the Brazos, the upper reaches of Oyster Creek have little in the way of a catchment, and flow tends to be intermittent. By the time the channel reaches the vicinity of Sugar Land, however, groundwater discharge is sufficient to sustain relatively permanent flow. A 35 year record of discharge from a discontinued gauging station near Angleton reveals that base flow varies from approximately 50$100 \mathrm{cfs}\left(1.4-2.8 \mathrm{~m}^{3} / \mathrm{sec}\right)$ with periodic floods of 2,500$4,000 \mathrm{cfs}\left(70-114 \mathrm{~m}^{3} / \mathrm{sec}\right)$. The channel geometry of Oyster Creek suggests that the stream continued to actively meander following abandonment of the meander belt by the Brazos, which is unsurprising given the magnitude of modern discharge

Limited investigations of the stratigraphy of relatively recent Oyster Creek deposits were conducted at two localities in the cities of Clute/ Richwood Village and Lake Jackson, Texas. Both of these study areas spanned Oyster Creek, and captured very similar point bar/levee/floodbasin assemblages. Point bar sediments were primarily subhorizontal to steeply dipping silty to loamy fine sands, and are capped by weak (A-C profile) soils (Figure 37a). The sediments on the outside of the meander bends consisted of 1-1.6 $\mathrm{m}$ of sub-horizontally bedded, interstratified packets of silty loam, clay loam, and silts. Although discernible levee relief was not noted in either of the two relatively urbanized localities, these deposits are interpreted as a natural levee sequence associated with the modern Oyster Creek channel. The silts retain a degree of primary stratification, and contain interstratified vegetation and post-depositional tree roots. In both localities, these levee deposits are underlain by dark, organic-rich floodbasin muds supporting a moderately well-developed cumulic paleosol (Figure 37b). The paleosol exhibits moderate slickenside development and common fine, hard carbonate nodules and rhizoliths. Radiocarbon ages of $1580 \pm 50 \mathrm{BP}$ and $3590 \pm 60 \mathrm{BP}$ were obtained from the upper and lower part of the soil, respectively, at the Clute locality, while radiocarbon samples on interstratified vegetation from the lower part of the levee sequence and on bulk humates in the upper part of the flood basin soil yielded ages of $1350 \pm 50 \mathrm{BP}$ and $1480 \pm 70 \mathrm{BP}$, respectively, at the Lake Jackson locality. The soil grades down into a dark reddish-brown clay loam that represents flood basin alluvium.

Figure 38 illustrates a simplified reconstruction of the geometry of deposits at the Clute locality, but the same basic relationships are applicable to both of the Oyster Creek localities. The sequence of deposits and planiform morphology of Oyster Creek suggests that the dark paleosol and flood basin muds were in place for at least a short period 
a

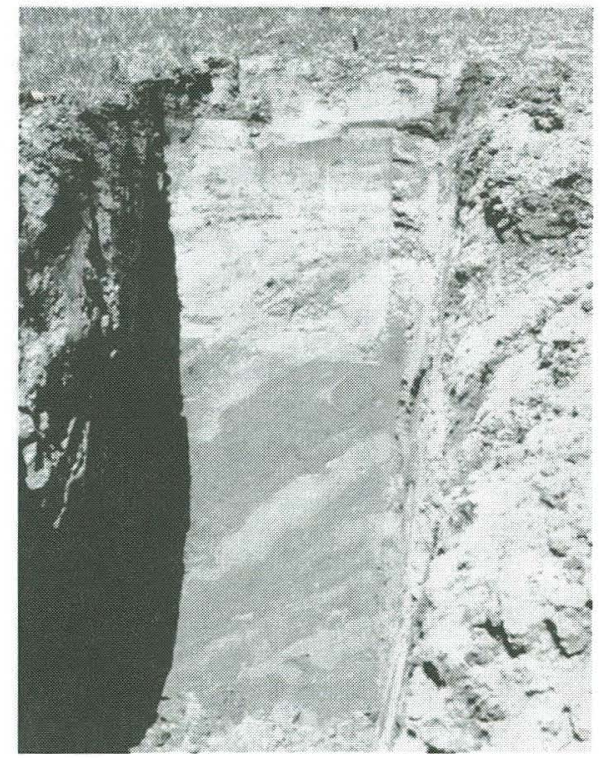

b

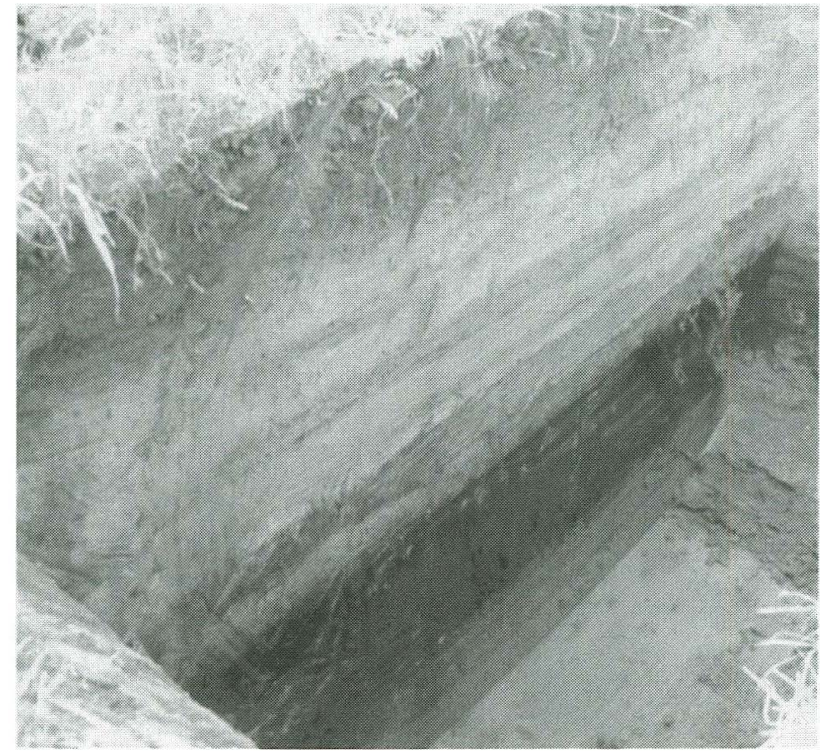

Figure 37. Typical Oyster Creek profiles: a, steeply dipping avalanche deposits associated with modern Oyster Creek point bar; b, thick, subhorizontal levee silts and fine sands over floodbasin muds.

before the stream meanders migrated south, constructing the point bar sequences, and burying the flood basin surface with coarser natural levee sediments. Given the ages inferred for occupation of the Oyster Creek meander belt by the Brazos (see above), it is likely the point bar deposits represent activity by Oyster Creek since the avulsion, while the flood basin facies represent pre-avulsion sediments deposited by the ancestral Brazos.

One deep core (Core 4) was placed through deposits of the Oyster Creek meander belt at the SH 35 crossing west of Angleton (see Figure 34). This locality is situated on the lateral margin of an Oyster Creek point bar near the former interfluve formed by Bailey's Prairie. The core reveals a subtle fining upward sequence approximately $15 \mathrm{~m}$ thick overlying Beaumont clay. The lower $8 \mathrm{~m}$ of the point bar sequence consists of fine brown sands that grade upward into reddish-brown loamy sands. The sequence is broken by a thin, mottled sandy clay at approximately $7 \mathrm{~m}$ bgs. This thin mud yielded a helical snail shell that was dated to 2530 $\pm 40 \mathrm{BP}$. From approximately 3 to $7 \mathrm{~m} \mathrm{bgs}$, the sequence consisted of thin beds of reddish-brown sandy loam and loamy sand, which is interpreted as intermediate point bar deposits. A dark brown paleosol with an A-Bw-Bk profile capped the sequence at approximately $1 \mathrm{~m}$ bgs. A bulk soil organic sample age of $1250 \mathrm{BP}$ was obtained from the A horizon of the paleosol. This sequence is interpreted as a point bar deposit laid down by the Brazos River prior to its avulsion into the modern meander belt. The upper meter of the sequence consisted of muds with thin, interbedded stringers of sand, and is interpreted as post-avulsion deposits laid down by the periodic flooding of Oyster Creek.

\section{Summary of the Stratigraphy and Geoarcheology of the Lower Brazos River}

Given the available information, a generalized, preliminary history of Late Pleistocene/Holocene activity in the Brazos/Oyster Creek system can be reconstructed. In response to lowered sea level during the Late Wisconsinan Stage, the ancestral Brazos incised a deep $\left(30^{+} \mathrm{m}\right)$ valley across the outer Coastal Plain and the exposed shelf that merged with the Trinity/Sabine valley before entering the Gulf of Mexico. During this time period, the Brazos was a much larger stream than it is now, and meandered freely across its valley, transporting a relatively coarse, sandy load and cutting laterally into the confining valley walls. As the stream gradually incised, a series of at least two distinct terrace levels were created by floodplain abandonment, forming the Deweyville terraces. Around 18,000 BP, sea level was at its lowest point (approximately $130 \mathrm{~m}$ below the modern level), and the modern coastal reach of the 


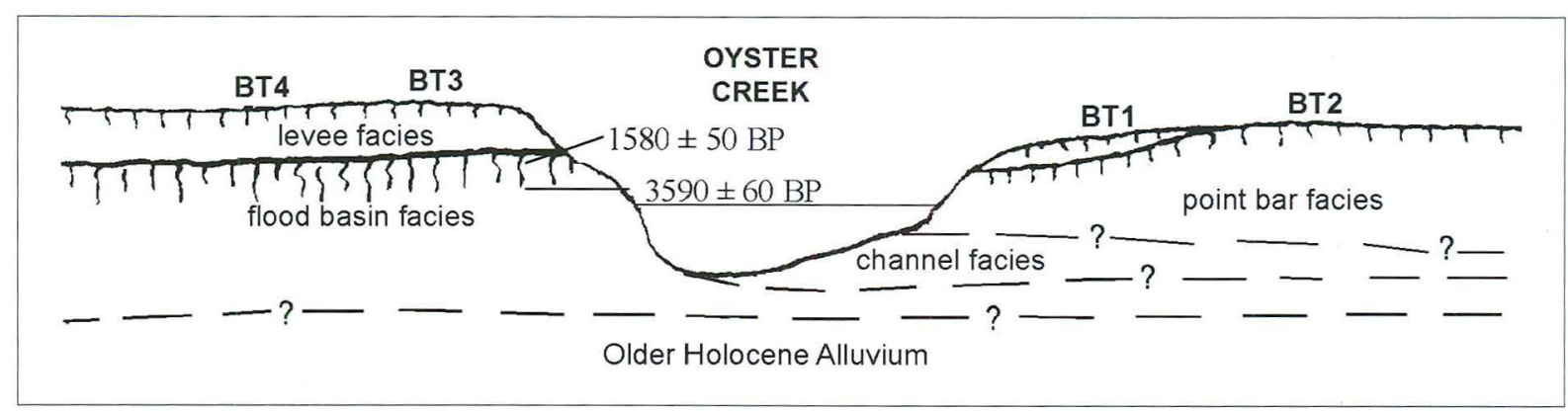

Figure 38. Inferred geometry and facies associations at the crossing of State Highway 288B and Oyster Creek.

Brazos was situated well inland in a deep, incised valley. From $18 \mathrm{ka}$ to approximately $5-6 \mathrm{ka}$, sea level rose rapidly, and the modern lower Brazos valley infilled with a thick sequence of sandy and muddy sediments in response to the rise in base level. Because the stream was able to deliver high volumes of sediment during this period, the valley did not develop a large embayment during the Early-Middle Holocene.

Few of the prominent soil zones exposed in Cores 1-3, which document the sequence infilling the deeply incised Late Pleistocene valley, can be traced across the buried valley. Rather, the sequence appears to represent a rapidly aggrading floodplain occupied by an unstable, frequently avulsing channel. Core 2 , in particular, exhibits a sequence characteristic of repeated channel avulsion during the Early Holocene (10 and $18 \mathrm{~m} \mathrm{bgs}$ ). This sequence is characterized by multiple, thin splay sands interbedded with flood basin muds and floodplain pond deposits. There is little evidence of significant erosional unconformities, although scour surfaces are common in the coarser-grained facies. This suggests that the sequence aggraded through the Early-Middle Holocene without prolonged depositional hiatuses. As this sequence was accumulating, pedogenic modification of the deposits was also occurring, particularly on the more slowly aggrading parts of the floodplain away from the active channel. However, because the channel was frequently shifting as a result of lateral cutting and periodic avulsion, the loci of intense pedogenesis also shifted on a regular basis, creating the complex soil-stratigraphic record exposed by Cores 1-3. A broadly similar scenario has been proposed for the lower Mississippi River (Aslan and Autin 1998). By the Middle-Late Holocene, the channel became relatively more stable as the rate of eustatic sea level rise slowed, allowing the stream to establish and maintain the relatively stable Oyster Creek and modern meander belts. With this shift, the volume occupied by channel and point bar sediments declined at the expense of floodbasin deposits.

During the low stand and subsequent rising sea level stage, small drainages cut headward into the Beaumont upland from the margins of the river valleys. As the Brazos floodplain aggraded to within a few meters of its modern elevation, one of these small headward-cutting streams captured the Brazos channel, diverting it through the divide between Bailey's Prairie and the extensive Beaumont surface to the east. While this event is not well-dated, the extant suite of ages suggest that it probably occurred somewhere between $5 \mathrm{ka}$ and $3.5 \mathrm{ka}$. This implies that the Brazos already occupied the approximate position of the Oyster Creek meanderbelt above Bailey's Prairie by this time, and that the abandoned Bastrop Bayou/Big Slough meander belt indicated by Aten (1983; see Figure 31) in fact represents this older phase. It is unlikely that either the Big Slough or Bastrop Bayou meander belts defined by Aten represent Late Pleistocene/Early Holocene Brazos channels because they would not have been able to breach the (now buried) Beaumont ridge southeast of Lake Jackson when the valley was deeply incised. Moreover, visibility of any meanderbelts dating to this period should be extremely limited by up to $20 \mathrm{~m}$ of overburden. Because the geometry of the Big Slough paleochannels clearly indicate Brazosscale discharge, Aten's Big Slough meanderbelt is tentatively interpreted as a Brazos channel dating to sometime between approximately $5.5 \mathrm{ka}$ and $3.5 \mathrm{ka}$. Bastrop Bayou, in contrast, is interpreted as a small Holocene stream that occupies the trace of a buried Deweyville meander.

The geoarcheological potential of Brazos River deposits is a function of facies distribution and 
sedimentation rate. Because they are so deeply buried, the accessibility of archeological sites with integrity dating to the Late Pleistocene and Early Holocene is extremely limited. The highest potential for encountering such sites is in association with buried Deweyville terrace surfaces on the margin of the valley. Middle Holocene and later sites should be concentrated in the upper 4-5 $\mathrm{m}$ of the valley fill, although some sites associated with active, incised channel belts could be preserved at greater depths. Although all of the depositional facies except channel assemblages have the potential to preserve sites, behavioral factors probably favor relatively sandy, channel-proximal localities over floodbasin muds.

\section{The San Bernard River}

The Holocene Brazos delta merges laterally with the equally extensive delta of the Colorado River to the southwest. A considerable area in the southwestern part of the district is occupied by deposits associated with the Colorado system, particularly those centered around the modern San Bernard River. No subsurface investigation of the San Bernard/Colorado system was conducted during this study, and the following summary is based primarily on extant geologic maps and the work of McGowen et al. (1976) and Blum and his colleagues (1990, 1992, 1995; Blum and Valastro 1994; Blum et al. 1995; Aslan and Blum 1999).

The Colorado River is a large extra-basinal stream that drains a vast area extending northwest to the southern High Plains. Like the Brazos, it carved a broad, deep valley during the Late Pleistocene low-stand, then aggraded its lower valley to roughly the elevation of the surrounding uplands in the Late Holocene. Because it drains the Edwards Plateau and the Llano Uplift, and crosses the Balcones fault system near its closest approach to the modern coast, the lower Colorado has a somewhat steeper gradient and a noticeably coarser-grained sediment load than the Brazos. Still, the two systems share many similarities, including a complex valley fill subsuming multiple meander belts that document a series of avulsions during the Middle to Late Holocene, and a series of older ("Deweyville") terraces that are subaerial inland but become buried within $50-100 \mathrm{~km}$ of the coast. Both systems also exhibit evidence for stream piracy. The Brazos event is a relatively small-scale diversion that routed the Oyster Creek meanderbelt around the eastern side of Bailey's Prairie, then re-entered the existing valley. In the case of the Colorado, the entire Late Pleistocene/ Holocene valley below the city of Wharton was abandoned when the Colorado was diverted into a new valley to the west. This event occurred as recently as 300 years ago (Aslan and Blum 1999), and was either the result of stream piracy by a headward-eroding coastal stream (McGowen et al. 1976) or simple diversion into a relict coarsegrained meander belt associated with the Beaumont deltaic system (Aslan and Blum 1999). The well-developed meander belt occupied by the Colorado River immediately prior to this capture is now occupied by an underfit channel termed Caney Creek. Other streams in the lower valley and delta that probably represent former Colorado channel axes include Linnville Bayou, Live Oak Bayou, and the San Bernard River.

Although the association between the San Bernard River and the ancestral Colorado seems clear, geologic mapping of the southwestern part of the district is inconsistent (Figure 39), and several maps show the distribution of Holocene sediments as much more restricted. For example, the Geologic Atlas of Texas, Houston Sheet (Barnes 1968a, 1982; see Figure 8) maps the lower portion of the San Bernard River above the Holocene delta as a narrow, erosional stream confined within a trench cut through the Pleistocene Beaumont Formation. According to this interpretation, the inland reach of the channel occupies the large alluvial valley of the former Colorado River. However, approximately $44 \mathrm{~km}$ inland, the channel exits this valley system and flows across the mapped extent of the Pleistocene Beaumont formation before crossing onto the Holocene delta $32 \mathrm{~km}$ from the modern coast. No Holocene alluvium is mapped in this $12 \mathrm{~km}$ segment of the stream. This interpretation makes little sense unless the stream was captured by a local, headward-cutting channel, which appears unlikely. A far different picture is presented by McGowen et al. (1976), who mapped the same area in conjunction with environmental geologic mapping of the Texas coastal zone, and Blum (1992; Aslan and Blum 1999), who mapped it in conjunction with his continuing research on the Colorado River system. Both of these sources recognize more extensive Holocene deposits, and relate them to the Colorado River system. 


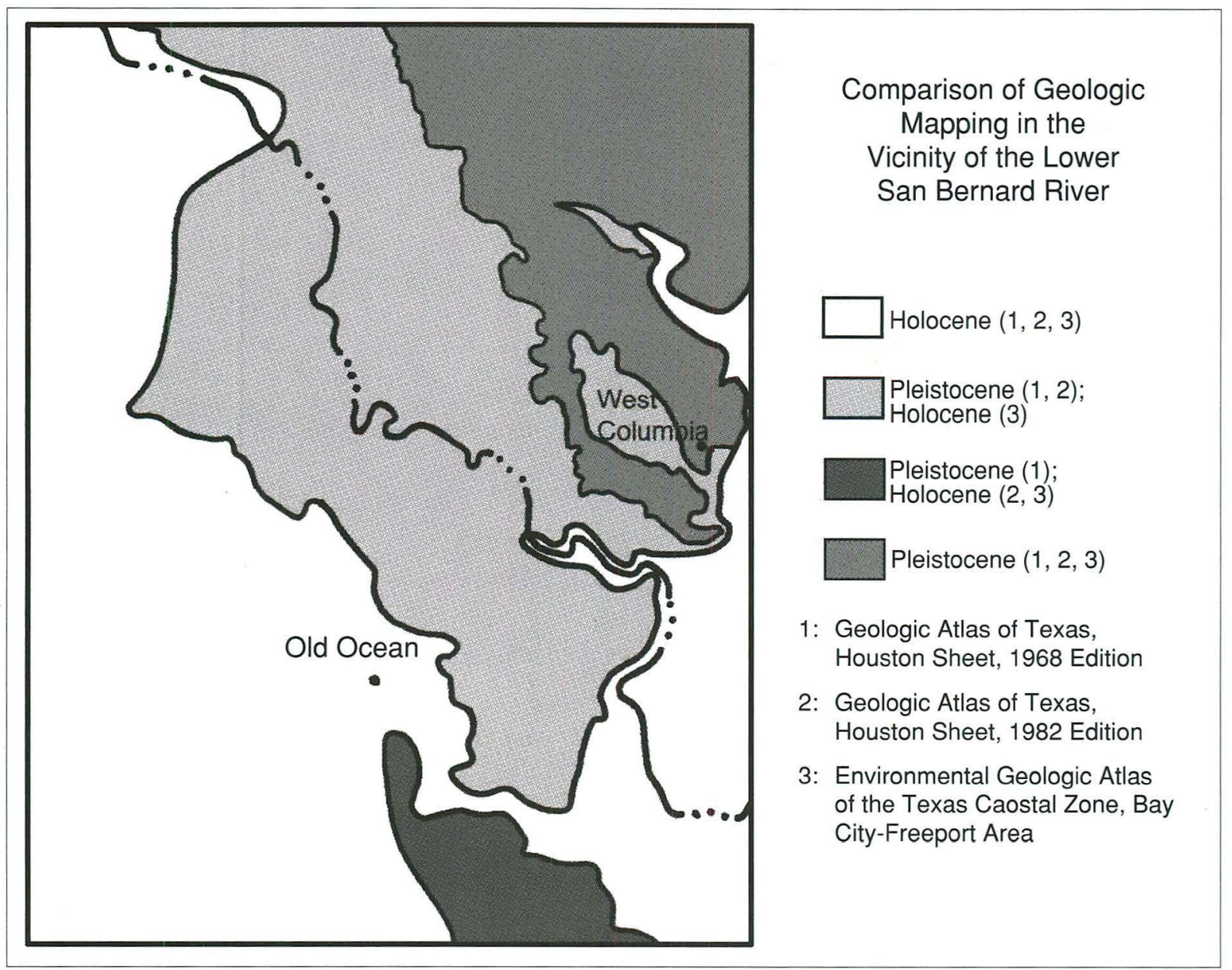

Figure 39. Illustration of the different mapping interpretations of the vicinity of the lower San Bernard River by the Bureau of Economic Geology, The University of Texas at Austin.

As with most extensive geological mapping, the conflicting maps illustrated in Figure 39 and those prepared by Blum are based primarily on aerial photographs, coupled with some independent field checking. Identification of the boundary between Pleistocene and Holocene alluvium in this area from remote imagery is complicated by several factors. First, the area is heavily wooded, which McGowen et al. (1976:46) admit prevented differentiation between coarse-grained (meander belt) and fine-grained (flood basin) facies. Second, soils mapped in the area (Crenwelge et al. 1981) are dominated by clayey Vertisols (e.g., Lake Charles clay), which are consistent with but by no means exclusive to the Beaumont surface. Third and most significantly, the Holocene floodplain is nearly at the same elevation as the adjacent Pleistocene "upland," and no prominent bounding scarp is present to define the contact. For these reasons, the extent of Holocene deposits has been interpreted in very different ways, as illustrated in Figure 39.

Although no independent field work was performed on this question during the current study, examination of maps, aerial photographs, and satellite imagery supports the interpretation that the San Bernard occupies the eastern part of the filled Colorado valley. Blum (1992; Blum and Valastro 1994) identifies two principal allostratographic units in the lower Colorado River valley. The first is termed the Eagle Lake Allofomation, which equates to the Deweyville sequence (Blum et al. 1995), and is dated to the Late Pleistocene (Blum and Valastro 1994; Blum et al. 1995). The second, termed the Columbus Bend Alloformation, is subdivided into three members that date to approximately $13-5 \mathrm{ka}$, 5-1 ka, and <1 ka, respectively (Blum 1992; Blum and Valastro 1994). According to Blum, each successive unit is inset into and overlaps the 


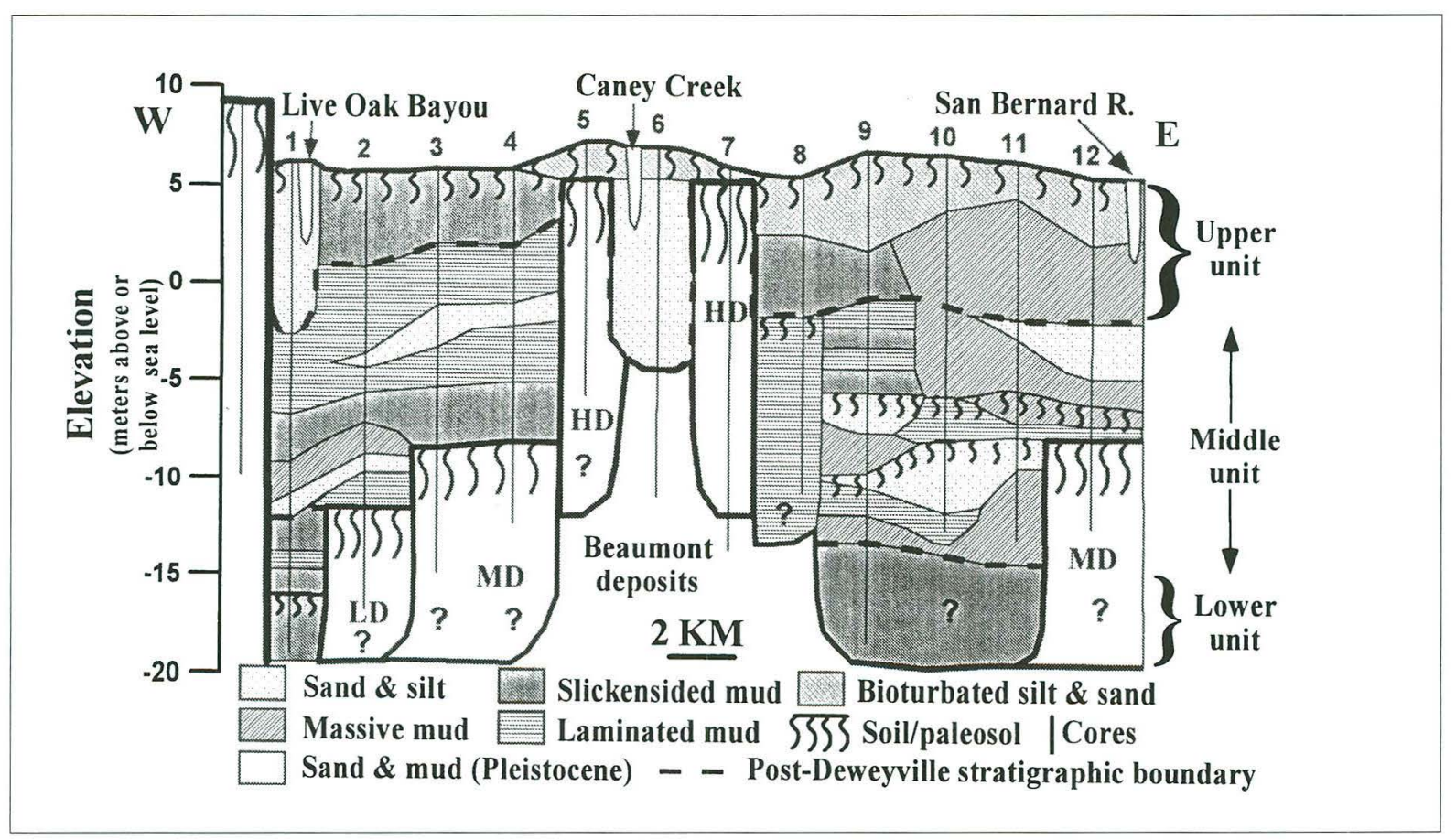

Figure 40. Cross-section of the former lower Colorado valley based on a series of 12 cores along FM 521, west of Brazoria, Texas, by Aslan and Blum (1999). Note the presence of a now-buried interfluve defining what are apparently two different Late Pleistocene valleys. The Colorado River proper no longer occupies the valley due to a stream piracy event in the last millennium.

preceding unit in the lower valley, and relatively recent deposits (Columbus Bend Member 3) make up a significant component of the fill.

However, recent work by Aslan and Blum (1999) further complicates the situation. A series of 12 deep cores taken along FM 521 east of Brazoria (Figure 40) clearly indicates two Late Pleistocene valleys separated by a now-buried interfluve. It is unclear how these two valleys developed, but it is unlikely that both were excavated by the same stream during the Pleistocene low-stand. It is also difficult to relate the stacked stratigraphy illustrated in Figure 40 to the overlapped, inset stratigraphy previously documented a short distance upstream (Blum 1992; Blum and Valastro 1994). Although this shoreward shift in the basic architecture of the Late Pleistocene/Holocene fill is clearly related to the increasing influence of base level, more work needs to be done to fully understand the architecture of the coastal reach of the Colorado valley.

From a geoarcheological perspective, the lower Colorado system appears very similar to the neighboring Brazos valley. Post-Beaumont alluvium is preserved as a series of buried fill terraces dating to the period prior to the Late Pleistocene low stand, and a sequence of stacked and/or inset deposits dating to the rising and standing sea level stages. Although the Deweyville (Eagle Lake) fills predate $12 \mathrm{ka}$, and therefore have limited archeological potential, they formed a series of intermediate terraces from the Paleoindian period to as late as the Middle Archaic, and the now-buried surfaces of these terrace treads have good potential to contain associated cultural material. The Late Pleistocene-Holocene fill on the Colorado is comparable to the Brazos in scale and character, and shares its potential. Middle to Late Holocene sites should be concentrated in the upper few meters of the fill. The lower part of the Colorado fill probably accumulated rapidly under the influence of a frequently shifting/avulsing channel, while the upper fill accumulated more slowly in association with a more stable meandering channel. This difference should be reflected in the frequency and preservation potential of archeological sites. As in the Brazos system, behavioral biases should make sites more common in sandy depositional environments (e.g., levee, upper point bar, crevasse splay). 


\section{San Jacinto River}

Although questions remain about the stratigraphy of the Brazos and Colorado River systems, the deposits of the San Jacinto River are almost completely unstudied and therefore very poorly understood. Direct examination of the stratigraphy of the San Jacinto during this study was limited to a few localities where surficial deposits on the higher, better-drained terraces were exposed by construction activities. No field examinations of the Holocene alluvial stratigraphy of the San Jacinto were made, and no previous detailed investigations are known. Consequently, the conclusions that can be drawn about the San Jacinto system are somewhat limited. However, Saul Aranow (1989) did examine geotechnical core data from the lower San Jacinto near Lake Houston, and this study includes similar examinations of core data from the East and West Forks farther upstream. Although the interpretations based on these remote examinations must be considered extremely tentative, they do provide valuable "windows" into the stratigraphy of the San Jacinto.

In contrast to the Brazos and Colorado, the San Jacinto is a relatively low sediment-yield system and has not effectively backfilled its valley (Fisher et al. 1972). According to Aslan and Blum (1999), fluvial behavior in the similar Trinity and Nueces river valleys has been dominated by periodic avulsions where the active channel reoccupies segments of Pleistocene channel traces buried by relatively thin veneers of Holocene sediments. Because sediment yield is low, this style of activity results primarily in the reworking of the existing "Deweyville" deposits. Post-avulsion deposits are predominantly steeply dipping, interbedded fine sands and muds (lateral accretion deposits) inset into Deweyville channels and point bars, overlain by a few meters of flatlying, vertical accretion muds and fine sands. Overall, the valleys are dominated by primary and reworked Deweville deposits overlain by a relatively thin Holocene mud veneer. Avulsion occurs as the migrating channel intersects remnant channels or is diverted into former channel swales during floods.

Although no direct field examinations were conducted during this study, compilation of existing geotechnical data from two different study areas suggests that the Pleistocene fill is more deeply buried and has been reworked less intensely than Aslan and Blum's model implies. Figure 41 illustrates the character of the valley fill of the West Fork San
Jacinto at the crossing of State Highway 242 in Montgomery County, as recorded in geotechnical bore logs. The SH 242 crossing of the San Jacinto is situated on the Lissie coastal terrace, but the western side of the valley is flanked by a broad alluvial inset of Beaumont age (Barnes 1982). Because the cores were not archived, no chronometric information is available from this section. Moreover, the core descriptions were made for geotechnical purposes, and many observations that would have been useful for stratigraphic interpretation were not made or were made inconsistently. Nevertheless, some tentative stratigraphic conclusions are possible, particularly when the redox character of the different sediment bodies is considered.

First, there is a clear tendency for the higher, more recent deposits in the cores to exhibit distinct mottling or gleying, while deeper deposits retain an oxidized, reddish-brown color. It is tentatively concluded that this oxidation is indicative of older deposits laid down prior to or in association with the Pleistocene sea level low-stand, when the water table was lower and the deposits were more freely drained. The upper, reduced sediments are tentatively interpreted as Holocene deposits laid down under the influence of a seasonally to permanently high water table. Second, in addition to these two suites of deposits, a thick sequence of overbank muds is preserved in an intermediate stratigraphic position in the eastern part of the crosssection (see Figure 41). These muds, which are up to $7 \mathrm{~m}$ thick, mantle the most highly oxidized basal sands and are only moderately altered by redox processes. They appear to represent a flood basin sequence deposited while the stream was occupying a relatively stable channel on the western side of the valley, but their age is unclear. Based on the architectural reconstruction (Figure 41, lower part), the most likely interpretation is that these muds were laid down during the rising sea-level stage, and are temporally related to the sandy channel and point bar facies at the base of the western side of the valley (i.e., the deposits labeled "Deweyville?" in Figure 41). Regardless of whether this model is correct, Holocene sediments at least $5 \mathrm{~m}$ thick are present in the San Jacinto valley, while several probable Holocene channels are incised deeply into the underlying oxidized sands and muds.

Additional information is available from a second suite of geotechnical cores taken on the East Fork San Jacinto at the US 159 crossing near 


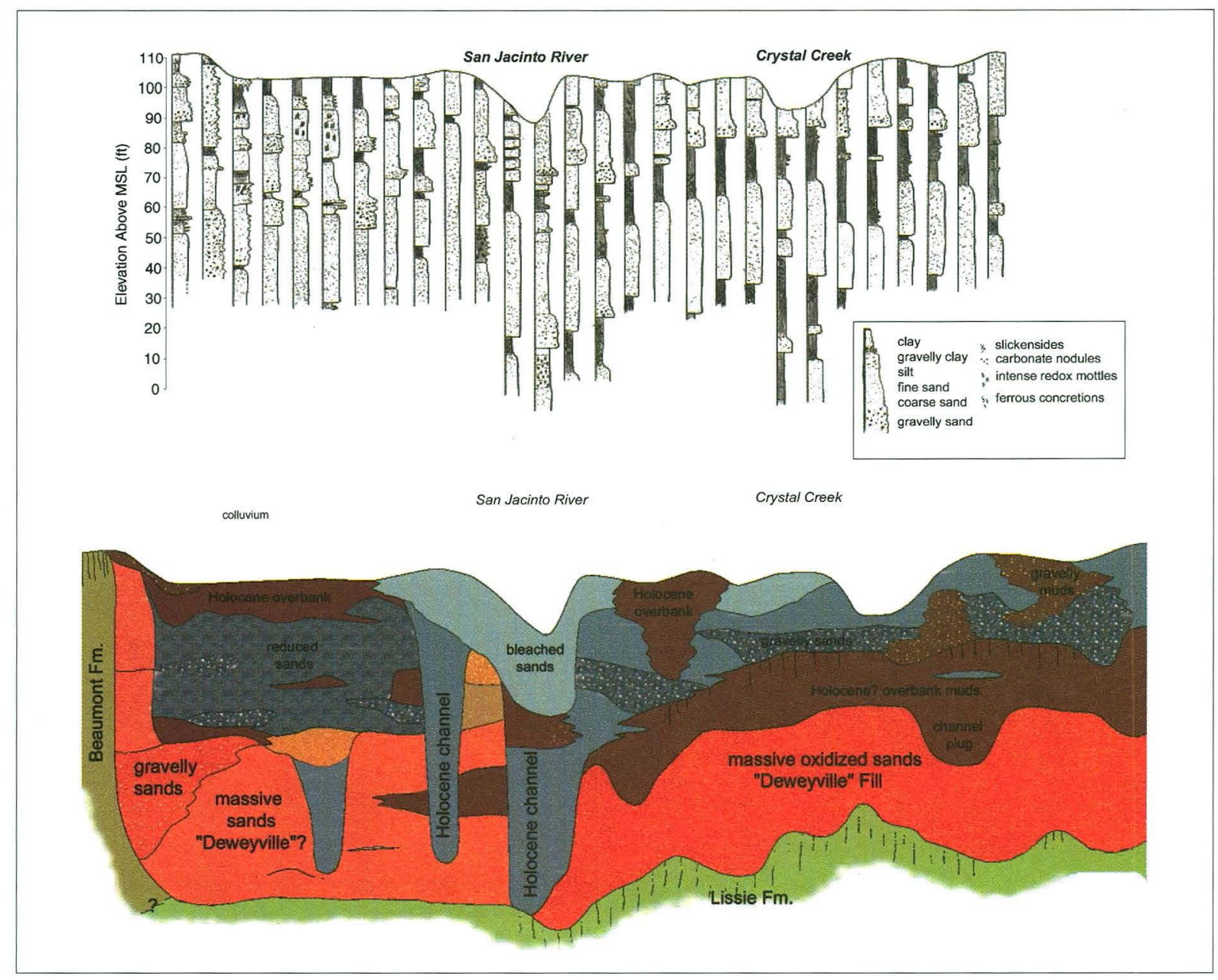

Figure 41. Illustration of core logs from the SH 242 crossing of the West Fork of the San Jacinto River at Crystal Creek (top) and tentative stratigraphic interpretation (bottom).

Cleveland. This locality is in the extreme western part of the Beaumont District, but is probably also representative of this branch of the stream in the Houston District. The Holocene stream valley at the cored locality is relatively narrow (approximately $500 \mathrm{~m}$ ) and is flanked by high "Deweyville" terraces of Late Pleistocene age inset into the coastal Lissie terrace. Although the available detail is not comparable with the SH 242 cross-section, the US 59 section (Figure 42) does exhibit striking similarities. The upper 5-6 m of the recent valley fill consists primarily of sands and silts, and the basal deposits consist of sands and gravels. However, as in the West Fork cross-section, there is a thick sequence of vertical accretion muds that mantles the coarse "Deweyville" sands and gravels and is in turn overlain by the sands, silts, and loams of the modern system. While much more work is needed to understand the character and implications of the San Jacinto stratigraphic sequence, the presence of thick, extensive floodbasin muds in the same stratigraphic position in both cross-sections seems potentially significant.

Aronow (1989) conducted a similar examination of geotechnical core logs from the lower San Jacinto, and arrived at two different possible scenarios (Figure 43). In the first alternative (Interpretation " $\mathrm{A}$ "), the majority of the sediments are Deweyville, and Holocene deposits make up a minor component of the fill. In the second alternative (Interpretation "B"), which Aronow favors, the majority of the valley fill is of Beaumont age, while Deweyville sediments occupy a relatively narrow, deep trench and mantle the remainder of the surface as a thick veneer. However, examination of the cores reveals a third possibility. Like the two 


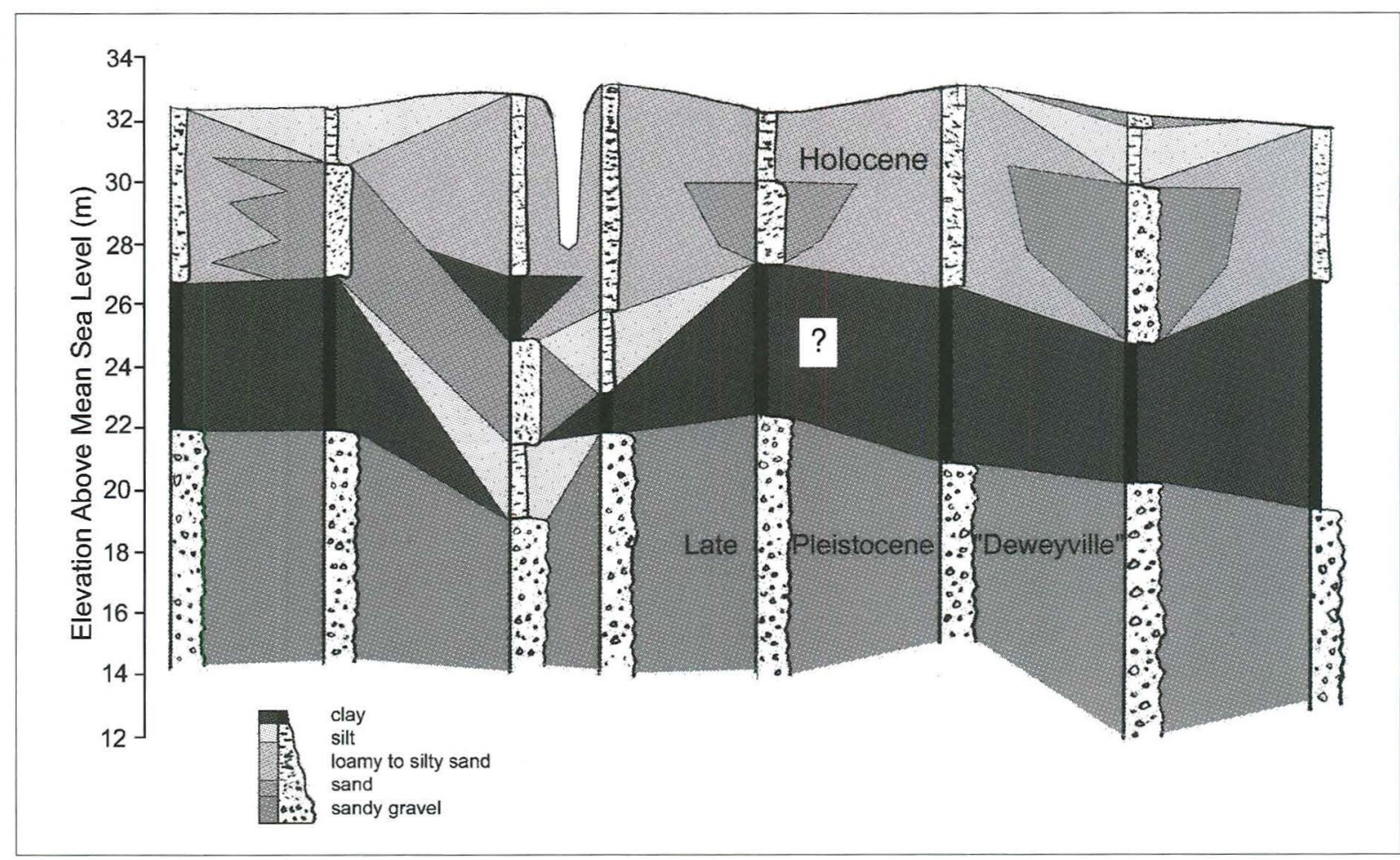

Figure 42. Schematic illustration of core logs from US 59 crossing of the East Fork of the San Jacinto River in Liberty County, Texas, with tentative interpretation. The entire cross-section represents approximately $500 \mathrm{~m}$ of floodplain.

cross-sections from upstream, there is a thick, laterally continuous mud that extends across much of the valley at a depth of approximately 6-9 m below the surface. Although Aronow's data does not incorporate description of sediment color, it is considered likely that this mud is equivalent to the muds upstream that separate the upper, relatively reduced Holocene sediments from the lower, oxidized Deweyville sequence. However, as stressed above, these conclusions must be considered highly tentative until at least one sequence can be examined and dated by radiometric means.

While no detailed work was conducted on the San Jacinto during this study, reconnaissance was conducted in a variety of accessible locations. No deep exposures of alluvium were found in this process, but veneer deposits of probable eolian origin were noted in several locations. Typical of these is a locality situated on a mapped Deweyville surface near the upstream end of Lake Houston. A construction site excavation examined on this surface (Figure 44) revealed a profile of approximately 1$1.5 \mathrm{~m}$ of fine, slightly loamy sands over an irregularly bounded substrate of reddish-brown sandy clay. The abrupt, strongly undulating contact with the red sandy clays suggests that the fine sands are resting unconformably on an erosional surface. The sandy veneer is predominantly massive, but exhibits occasional rodent-sized krotovina, roots and root traces, and faint vestiges of relatively steeply dipping $\left(>10^{\circ}\right)$ bedding planes. The age of the sandy veneer and the underlying argillic horizon is unknown, but the degree of soil development in the sands (a relatively strong A-Bw profile) suggests that they have been in place for at least several hundred years.

In summary, the stratigraphy of the San Jacinto system, and therefore its geoarcheological potential, remains relatively poorly understood. Like the more intensively studied lower Trinity (Aten 1983), the San Jacinto is situated in an unfilled valley that empties into Galveston Bay. Surficial sediments consist of sandy (Voss series; Hatliff series) to clayey (Nahatche series) deposits exhibiting weak to moderate soil development. It is likely that the San Jacinto channel, like the neighboring Trinity, has been actively migrating and periodically avulsing during the last few thousand years. Consequently, many parts of the floodplain have almost certainly been reworked, damaging or destroying any sites that were present. Nevertheless, the core 


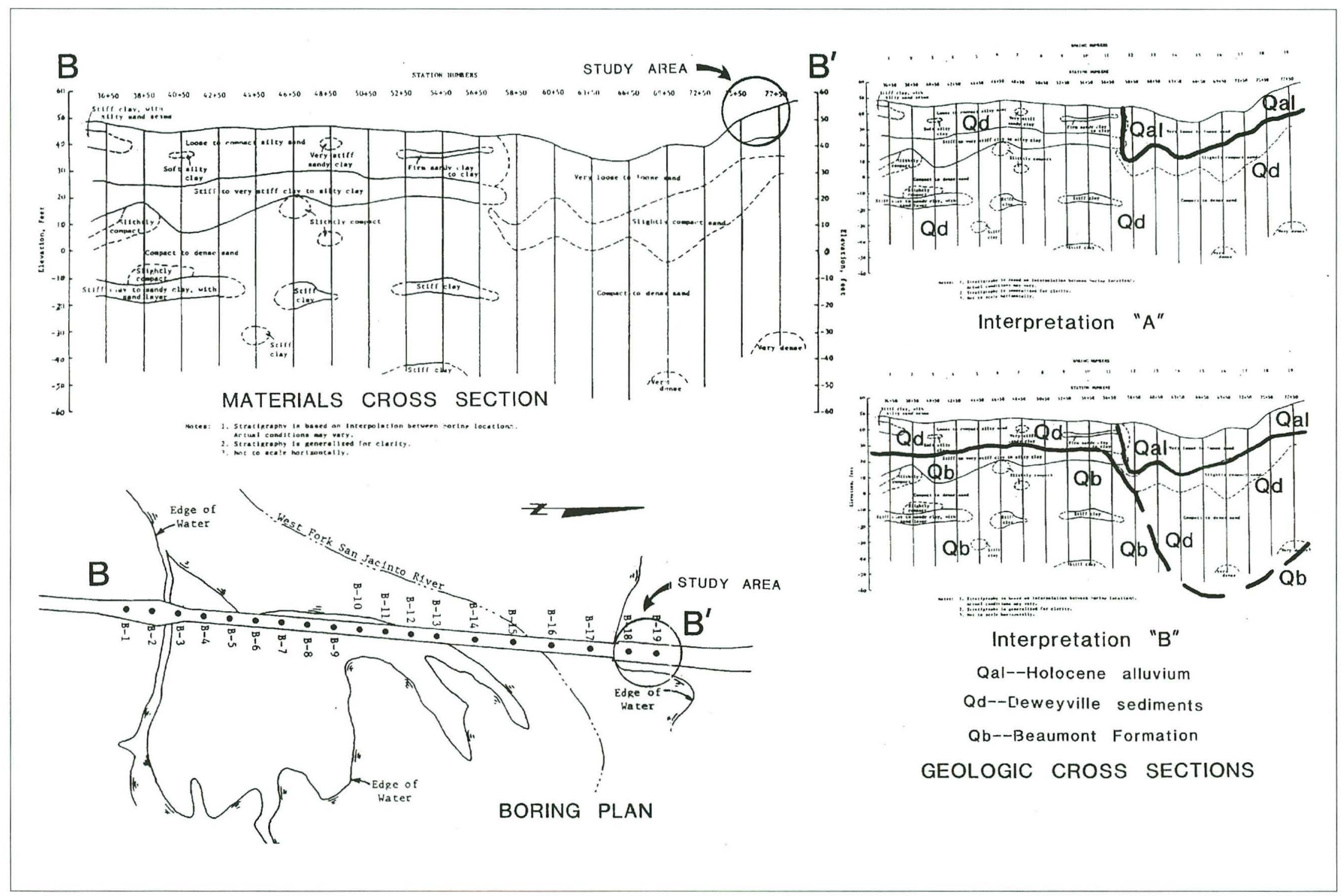




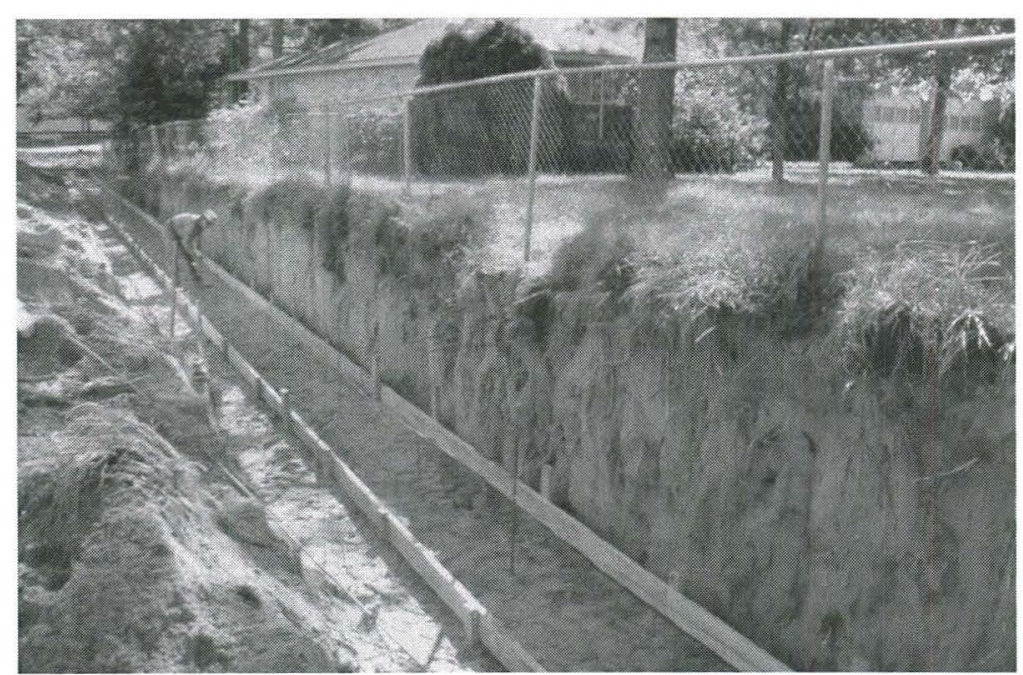

Figure 44. Artificial exposure of thick, slightly loamy fine sands with moderate soil development on a mapped Deweyville terrace of the San Jacinto River near Humble, Texas. Although it is not possible to rule out an alluvial original with the extant field data, the texture and vestiges of relict bedding exposed in this cut suggest that these sands are Holocene deposits of eolian origin.

records from the SH 242 crossing of the West Fork San Jacinto and the US 59 crossing of the East Fork San Jacinto both indicate that up to $10 \mathrm{~m}$ of culturally relevant fill is preserved in the respective valleys, and the potential for reasonably intact sites to be preserved is therefore high. In addition, eolian deposits $1 \mathrm{~m}$ or more thick are preserved in many locations adjacent to the valley, particularly capping the low Deweyville terraces. While the temporal context of these deposits is not known, they appear to predate Anglo-American settlement of the region, and therefore have good potential to contain cultural material in good context.

\section{Smaller Streams}

Unlike the Brazos, Colorado, and San Jacinto rivers, the many small streams of the Houston area did not carve large valleys by lateral planation during the Pleistocene low-stand. As previously mentioned, smaller streams in the Houston District can be divided into several types: (1) those that occupy narrow, relatively straight valleys that were probably formed by rapid headward-cutting during the period of dramatically lowered sea level prior to 5 $\mathrm{ka}$; (2) older, more inland systems that occupy welldeveloped valleys and clearly pre-date the Holocene; and (3) small unentrenched streams occupying large, high-amplitude Pleistocene paleochannels (primarily on the Beaumont surface). The majority of Houston area streams were not examined during the current investigation, and the discussion of medium-to-small stream stratigraphy is therefore highly generalized. Streams that were examined through cutbank examination and/or mechanical trenching include segments of Greens Bayou, Caney Creek, Goose Creek, Brookshire Creek, Gum Gully, Clear Creek, and Spring Creek. Because trenching was limited to existing ROW, several investigated localities proved uninformative due to very extensive modification during road construction. The following discussion focuses on those streams where reliable (albeit frequently limited) stratigraphic information is available from either the current investigation or previous investigations.

\section{Greens Bayou}

Greens Bayou is a narrow, south-flowing tributary of Buffalo Bayou that is incised into the Pleistocene Beaumont Formation (Barnes 1982). It represents one of the narrow, incised streams that developed by headward-cutting or meander entrenchment during the period of lowered sea level. At present, Greens Bayou is a low gradient perennial stream that drains a moderately-sized basin. Like many of the streams in the Houston metropolitan area, it has been channelized and straightened along much of its length (Aronow 1990), concealing or destroying several previously known sites in the process (Howard et al. 1991). However, relatively intact segments of the original stream remain along the channelized course and as artificial "oxbows" where meanders were cut off during channelization. Prior to its modification, the stream occupied a narrow, entrenched valley with little preserved floodplain and a few discontinuous terrace remnants.

The first examined locality on Greens Bayou is at the crossing of FM 526 in northeastern Harris County. At the closest gauging station (Greens Bayou at Ley Road, situated approximately $5 \mathrm{~km}$ upstream from the examined locality), the 
contributing basin is $182 \mathrm{mi}^{2}$ (471 $\mathrm{km}^{2}$ ) in size, and base flow is approximately $2200 \mathrm{cfs}$ (62 cubic meters/sec). United States Geological Survey hydrologic records dating back to the early 1970 s indicate peak flood discharges up to $38,500 \mathrm{cfs}$ ( 1090 cubic meters/ sec) and flood crests up to $8 \mathrm{~m}$ ( 25 feet) above base flow (Figure 45). These data suggest that the inset surface is flooded on a regular basis, but overtopping of the low valley wall is rare. Mapped soils at the locality consist of Aldine very fine sandy loam on the south side of the stream and Beaumont clay on the north side (Wheeler 1976). Both series are highly horizonated and altered soils typical of the Beau mont upland.

The uplands surrounding the

FM 526 locality are level and lie at approximately $10-11 \mathrm{~m}(35 \mathrm{ft})$ above mean sea level. There is one discontinuous, inset alluvial surface associated with the stream that lies at an elevation of approximately 7-8 m (21-25 ft) above sea level. One segment of this lower surface is preserved as a point bar on the south side of the stream at the study locality. Two trenches were excavated on this small flood terrace. BT 4 (Figure 46) was excavated in the proximal part of the terrace about $15 \mathrm{~m}$ from the modern channel, and BT 5 was excavated on the distal flood terrace near the artificially steepened riser to the upland. Both trenches revealed thick accumulations $(110 \mathrm{~cm}$ and $75 \mathrm{~cm}$, respectively) of sandy sediments of probable historic age (Unit II) resting on loamy alluvial sediments of probable Late Holocene age (Unit I). The historic age of the sandy deposits was supported by a radiocarbon age on partially decomposed organic remains from just above the basal contact with the underlying loamy alluvium. This sample, from $110 \mathrm{~cm}$ bgs, yielded an age of $20 \pm 70 \mathrm{BP}$ ( 2 sigma calibration age ranges of $\mathrm{AD}$ 1680 to 1745 and $\mathrm{AD} 1805$ to 1935 ). A weak cumulic alluvial paleosol was present in both historic sections, suggesting that the floodplain stabilized for a short period between an initial episode of landscape disturbance (Unit II-a) and a second, more recent episode (Unit II-b). No cultural material or chronometric data was recovered from the underlying loamy alluvium, which exhibited an $\mathrm{A}-\mathrm{AB}-\mathrm{Bw}-\mathrm{Bg}$ profile.

More detailed stratigraphic data was obtained by Nordt (n.d.a) from site 41HR751, situated adjacent to an unnamed tributary at its confluence with Greens Bayou. This locality is situated on Greens Bayou approximately $2 \mathrm{~km}$ south of the FM 526 crossing. Here, Nordt identified three Holocene stratigraphic units (Units I-III) resting unconformably on a strath cut into the Pleistocene Beaumont Formation (Figure 47). Unit I, which is subdivided into Units $\mathrm{Ia}$ and $\mathrm{Ib}$, comprises the principal fill at the site, and is capped by a buried soil with an A-E/Bt profile. It is assumed to represent a single sequence of point bar deposits laid down by the tributary as it migrated laterally across the Beaumont strath, although Nordt does allow for the possibility that the transition between Unit Ia and Ib represents a bounding unconformity rather than a shift in depositional facies. Unit Ia consists of friable, redox-mottled loamy sands and is $100-130 \mathrm{~cm}$ thick. Ceramics and Late Archaic artifacts were recovered from the upper part of the unit, while Middle Archaic artifacts are present in the lower part. Chronometric information from Unit Ia includes dates of $1510 \pm 50 \mathrm{BP}$ on charcoal and 


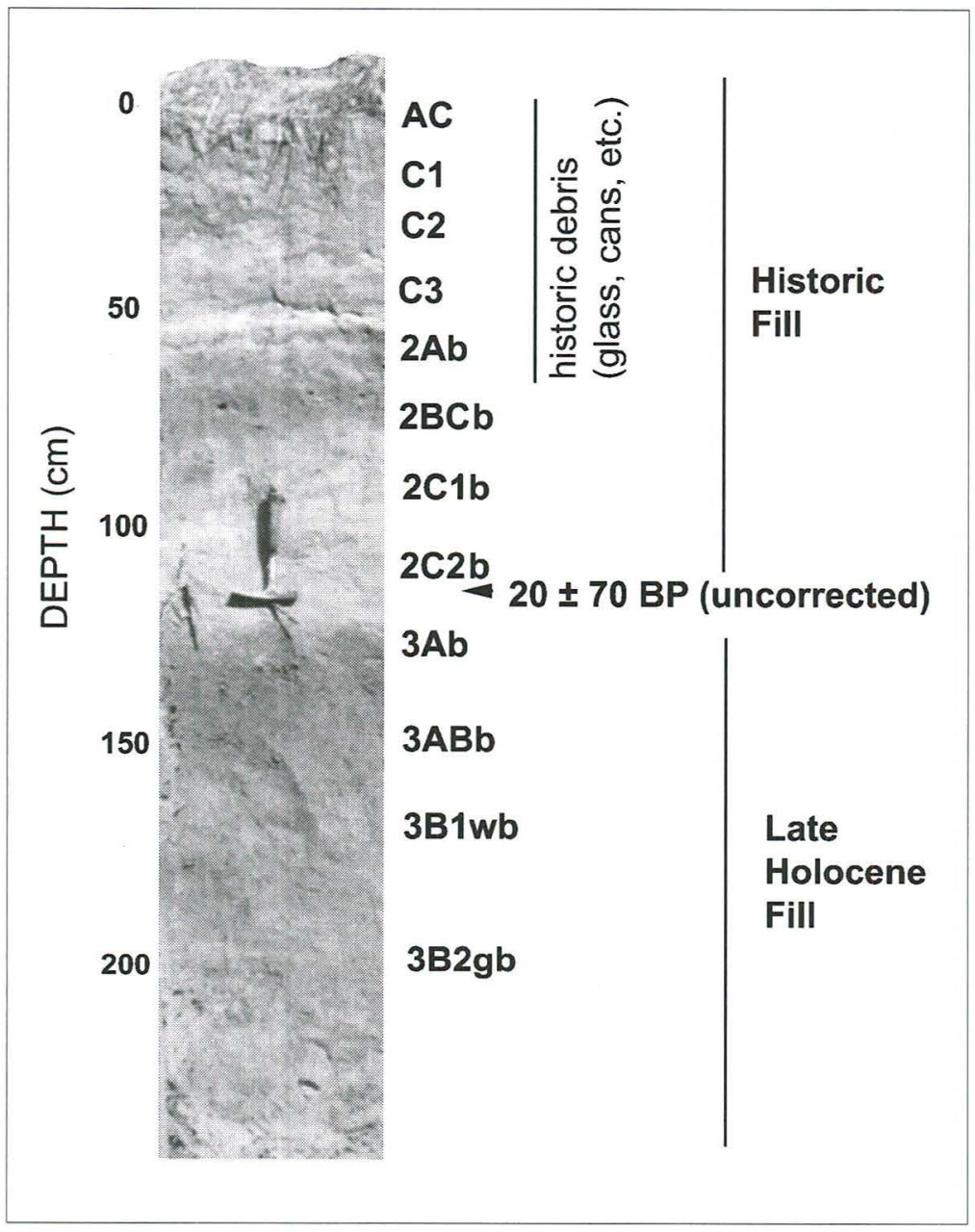

Figure 46. Profile of BT4 at Greens Bayou and FM 526, illustrating thick historic-age sediments capping the terrace.

$1590 \pm 50 \mathrm{BP}$ on humates from the upper part of the fill and $2200 \pm 50 \mathrm{BP}$ on humates from the lower part. Although Nordt uses the deeply buried Middle Archaic material to postulate an age of up to $5 \mathrm{ka}$ for the beginning of Unit Ia sedimentation, the chronometric data (which were funded by TxDOT after Nordt's analysis was completed) suggests that the unit may only be half that old. However, more data is needed before the question can be adequately resolved.

Unit Ia is overlain by Unit Ib, which consists of 90 to $130 \mathrm{~cm}$ of loamy sands supporting an A-E/Bt profile. The unit consists of brown to grayish-brown sands in the buried A horizon, and pale brown to light grayish-brown sands with superimposed dark yellowish-brown clay lamellae in the E/Bt horizon. Chronometric data from the unit include arrow points and radiocarbon ages of $1510 \pm 50 \mathrm{BP}, 1130 \pm 50$
$\mathrm{BP}, 850 \pm 50 \mathrm{BP}$, and $270 \pm 50 \mathrm{BP}$. Only the latter of these four ages was available when Nordt wrote his initial evaluation, but his estimate based on the available information appears broadly accurate. The unit appears to have started to accumulate sometime around 1500 $\mathrm{BP}$, and was apparently abandoned during a brief phase of stream incision in the last few hundred years.

Unit II consists of up to 0.5 $\mathrm{m}$ of grayish-brown loamy sand that unconformably mantles the terrace surface and supports a weak A-Bw profile. Faint traces of primary bedding are preserved throughout the unit, which represents no more than the last few hundred years. Three radiocarbon ages of $300 \pm 40 \mathrm{BP}, 180 \pm 40$ $\mathrm{BP}$, and $150 \pm 50 \mathrm{BP}$ were obtained from Unit 2, and historic cultural debris was detected in the upper $10 \mathrm{~cm}$ of the deposit.

Comparison of the FM 526 sequence with Nordt's 41HR751 sequence suggests that the deposits designated Unit II at each locality may represent the same depositional unit. Both are relatively recent sandy veneers that preserve vestiges of primary bedding overprinted with a weak soil, and occupy the same stratigraphic position. Two of the three calibrated ages from 41HR751 (180 $\pm 40 \mathrm{BP}$, cal. AD 16481710, 1717-1886, 1912-1950; and $150 \pm 50 \mathrm{BP}$, cal. AD 1663-1898, 1900-1942) substantially overlap the calibrated age from FM $526(20 \pm 70$ BP; cal. AD 1680-1745, 1805-1935). The third age from 41HR751 (300 \pm 40 BP; cal. AD 1478-1662) substantially overlaps the most recent age from Unit Ib (270 \pm 50 BP, cal. AD 1484-1676, 1764-1771, 17751802 , 1939-1946), but barely overlaps the other two ages from Nordt's Unit II, suggesting that it may have been reworked. While the other ages are all consistent with landscape disturbance during the historic period, the radiocarbon results are not sufficient to distinguish between a historic and a protohistoric age for these sandy deposits, and more work is needed. 


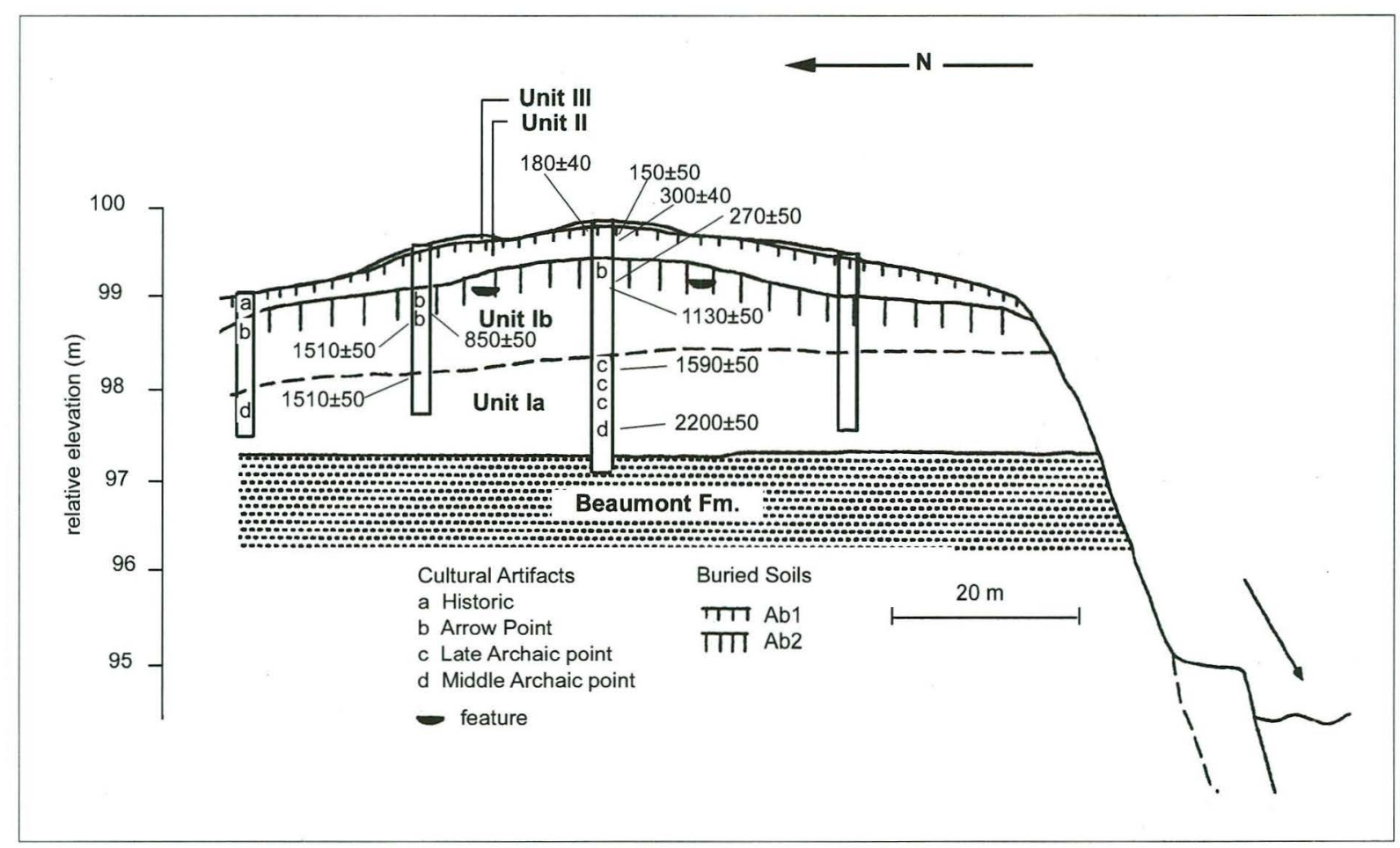

Figure 47. Stratigraphic interpretation of site 41HR751 by Nordt (1995), with supplemental chronometric information, including ages obtained by Moore Archeological Consulting and ages funded by TxDOT. Figure modified from Nordt (1995).

The final unit identified at 41HR751 (Unit III) consists of a very thin, discontinuous deposit of sand containing historic artifacts. Nordt notes that it may represent recent flood deposits or historic cultural activity (e.g., tree and brush clearing). It has little volumetric or geoarcheological relevance.

The geoacheological potential of deposits examined at the two localities on Greens Bayou is relatively high, but appears limited to Late Archaic, Late Prehistoric, and Historic components. Although the study locality is situated in the lower portion of Greens Bayou, the deposits at 41 HR751 are situated on a cut (strath) terrace that lies several meters above the modern Greens Bayou channel. Presumably, there is a deeper valley that was excavated prior to $3 \mathrm{ka}$, but any such valley is very narrow, and its depth and the character and age of any infilling deposits must await further work.

\section{Little Caney Creek}

One locality on Little Caney Creek was examined in northeastern Montgomery County during this study. A series of trenches were excavated on the margin of the floodplain to examine the stratigraphy associated with the confluence of a small, unnamed upland drainage. The Little Caney Creek valley is inset into rocks of the Miocene Fleming Formation just inland of the onlap of the Early Quaternary Willis Formation (Barnes 1982). Mapped soils in the floodplain are dominated by the Kosse series (McClintock et al. 1972), which consist of very dark grayish-brown (10YR 3/2) clayey to loamy alluvium that is heavily alterated by redox processes and typically exhibits an A-B-Cg profile approximately 48 inches $(122 \mathrm{~cm})$ thick. The representative profile of the Kosse series exhibits weakly developed ferric concretions and relatively intense redox mottling in the $\mathrm{B}$ and $\mathrm{C}$ horizons.

Three trenches were excavated into the terrace fill surrounding the channel of the tributary. Exposure was limited to the upper $2 \mathrm{~m}$ of the terrace fill. The same two natural stratigraphic units were present in each trench. Unit I is buried at depths between 100 and $160 \mathrm{~cm}$ below the surface. It consists of massive clay loam, and grades down from a reddish mottled, very dark grayish-brown (10YR3/2) A horizon to a heavily mottled, dark gray $\mathrm{Cg}$ horizon. In broad terms, it resembles the described profile of Kosse soils. No 
cultural material was noted in association with this unit, but it is almost certainly of Holocene age.

Unit II represents a very different suite of deposits, consisting of a fining-upward sequence of stratified sandy loams, sands, and occasional gravels up to $1.2 \mathrm{~m}$ thick. It is subdivided into Unit II-a and II-b on the basis of a weak, gleyed cumulic paleosol that occurs from $30-45 \mathrm{~cm}$ bgs, and is capped by a weak, cumulic sandy clay soil. The contact between Unit I and Unit II is markedly erosional, but the contact between Unit II-a and II-b appears to represent a relatively short term reduction in the frequency of large floods. The presence of clay rip-up clasts at the base of BT 2, and the scoured appearance of the contact in all three trenches, demonstrate that initial flow conditions were quite energetic. Two radiocarbon ages were obtained on partially decomposed organic matter from Unit II. The first age, $40 \pm 40 \mathrm{BP}$ (cal. AD 1675-1955+) was associated with the weak buried soil in BT 1 (30 $\mathrm{cm}$ bs). The second age, $100 \pm 40 \mathrm{BP}$ (cal. AD 1678-1759, 1804-1936, and 1939-1949) was recovered from organic debris situated a few $\mathrm{cm}$ above the erosional contact with Unit I.

The transition from Unit I to Unit II represents a very pronounced change in the dynamics of floodplain sedimentation, and suggests that this change was stimulated by penecontemporaneous changes in sediment availability due to extensive disturbance of the surrounding watershed. This finding is quite similar to the results of investigations in Greens Bayou (see above). While a protohistoric age cannot be ruled out on the basis of radiocarbon data, the coincidence between this shift in sediment yield and historic settlement of the region suggests a causal relationship. In particular, the advent of large-scale timbering in the late 19th century (Maxwell and Baker 1983) seems more than coincidental. Although no studies of the geomorphic and edaphic consequences of this industry are known in Texas, clear cutting has been shown to drastically increase erosion and sediment yield elsewhere, particularly in sandy soils (Goudie 1986). It is considered likely that Unit II accumulated in a few decades as a result of clear-cut timbering following Anglo-American settlement. However, as at Greens Bayou, this hypothesis must be considered preliminary due to the imprecision of recent radiocarbon ages and the paucity of corroborating data.
Coupled with the results from Greens Bayou, the results of the Little Caney Creek study have very strong implications for the visibility of prehistoric archeological sites in the interior part of the Houston District. Put simply, it appears that many of the floodplains in the northern and eastern part of the district are mantled with $1 \mathrm{~m}$ or more of sandy sediment dating to the last few hundred years. These sediments mantle the pre-existing alluvial topography, and are probably quite variable in thickness. While relatively high-relief alluvial features such as natural levees are less likely to be deeply buried, the demonstrated thickness of these deposits suggests that shovel testing alone should be applied judiciously, because many settings will require mechanical means of site prospection.

\section{Lake Creek}

While very few substantive stratigraphic studies of the smaller Houston area streams exist, a notable exception is Mandel's (1987) investigation at the location of the planned Lake Creek Reservoir in southern Montgomery County. This study, associated with a moderately sized reservoir that was never built, provided a relatively comprehensive and thoughtful geomorphic/geoarcheological examination of the landscape that is applicable to much of the northern part of the district.

Figure 48 illustrates Mandel's generalized cross-sections of Lake Creek (a relatively large tributary of the West Fork of the San Jacinto), Mound Creek (a relatively high-order Lake Creek tributary), and a typical first-order to second-order tributary. The large Lake Creek valley is incised into the Willis Formation, but contains a large terrace remnant correlated with the coastal Lissie terrace. A sandy "Deweyville" fill is inset against this ancient terrace, and a clayey Holocene fill is inset against and on top of the Deweyville. Eolian and colluvial sediments, floodplain mounds, and natural levees complete the assemblage. The somewhat smaller Mound Creek valley exhibits roughly the same sequence, except that the ancient Lissieequivalent alluvial terrace is absent. Low order tributaries, in contrast, are lacking Deweyville deposits, suggesting that they were either incised or flushed since the Latest Pleistocene/Early Holocene.

The archeological potential of the different units varies. The ancient Lissie-equivalent terrace and the Willis Formation uplands are characterized by 


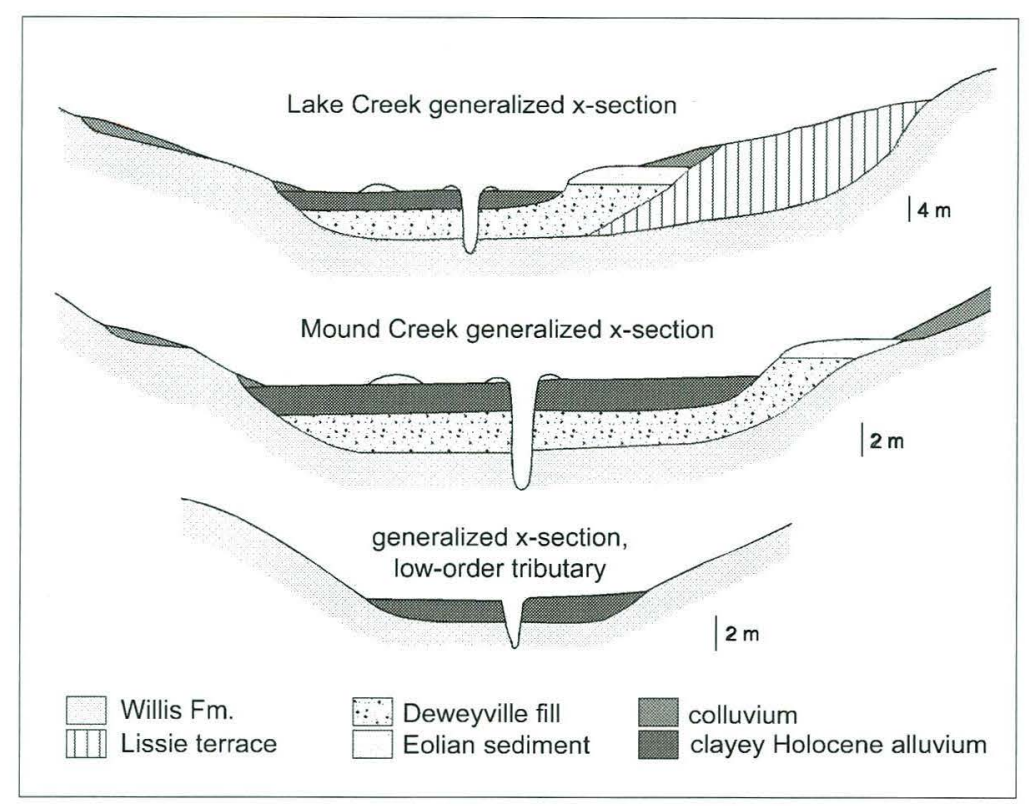

Figure 48. Generalized, schematic stratigraphy of Lake Creek and tributary streams, after Mandel (1987).

siliceous sands and gravels with lenses of silt and clay, and support deeply weathered soils with thick argillic horizons. They have negligible potential to contain primary archeological materials in reasonable context, but both landforms may host eolian and/or colluvial veneers with archeological potential.

The Deweyville sequence forms a low (2-5 $\mathrm{m})$, discontinuous terrace in the Lake Creek and Mound Creek valleys. It exhibits the same type of relict topography characteristic of many Deweyville surfaces, including remnants of outsized channel geometry. The fill consists of a sequence of coarse to fine sands that fine upward into silty clays and clays, and supports a well-developed soil with a thick argillic horizon. This soil is capped in turn by a sequence of sandy deposits that are interpreted as eolian in origin. While the age of these deposits is unknown, their stratigraphic position indicates that these sands have the potential to contain prehistoric sites in good context. Sands of presumed Deweyville age are also present at depth beneath the Holocene floodplain. Mandel interprets the age of the Deweyville fill at between $30 \mathrm{ka}$ and $9 \mathrm{ka}$. Although the archeological potential of these deposits is not demonstrated, there is a good possibility that Paleoindian or Early Archaic remains could be preserved high in the sequence.
The floodplain of all three streams are dominated by clayey sediments, but contain sandy facies representing natural levees, colluvial aprons, and floodplain mounds. The floodplain deposits as a whole have the potential to contain cultural material dating back at least as far as the Early Archaic, although the floodplain mounds and levees are unlikely to predate the Late Holocene.

The general character of Mandel's Lake Creek model is probably applicable to other streams in the northern part of the district. Observations made during reconnaissance associated with this project suggest that prominent low terraces are rare, but low rises on the margin of floodplains that may represent terrace remnants overridden with colluvial and/or eolian sediments are common in the larger valleys. In most valleys, prominent colluvial aprons are present on the valley margins, while the Holocene valley floors are often broadly concave rather than level, suggesting that colluvium and slopewash probably overrides and interfingers with the fine-grained valley fill for a considerable distance from the valley margin.

\section{Spring Creek}

Spring Creek is another of the larger secondary streams occupying a relatively well-developed valley in the northern part of the district. Aronow examined the Spring Creek valley in conjunction with an archeological assessment of the proposed Spring Lake (Moore and Aronow 1993). This work consisted of literature review, examination of geotechnical borehole data, and limited backhoe trenching, but is unconstrained by chronometric data. On this basis, Aronow proposed two different possible interpretations for the sequence (Figure 49).

Basing his interpretations on the seven geotechnical boreholes placed across the Holocene floodplain, Aronow interprets the Spring Creek fill to be approximately 6 to $8 \mathrm{~m}$ thick. This fill consists of a lower zone of 3-5 m of sand, silty sand, and gravelly sand, as well as a more variable upper 


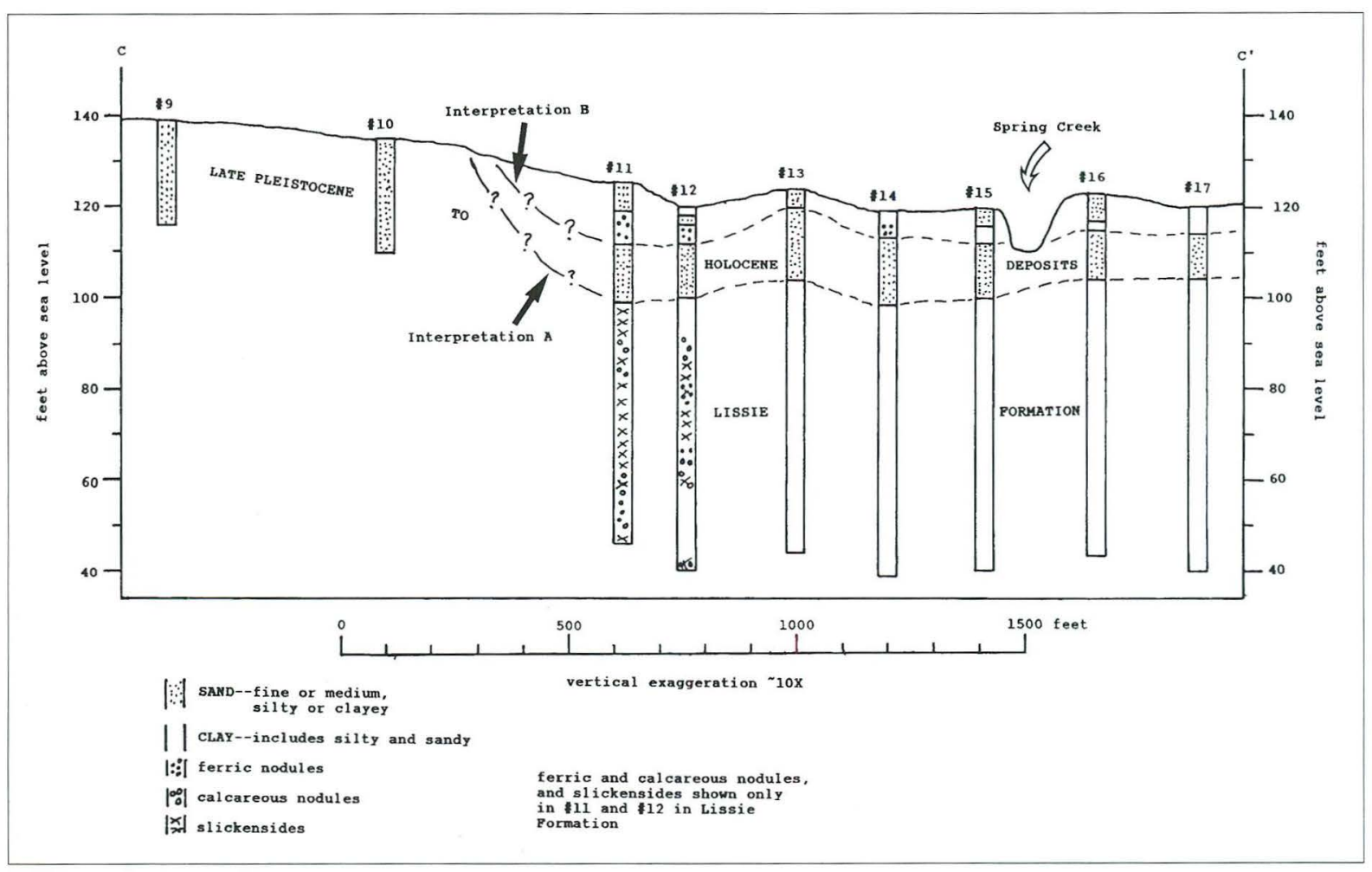

Figure 49. Generalized, schematic cross-section of Spring Creek at Kuykendahl Road, Harris and Montgomery counties, with interpretations by Aronow (Moore and Aronow 1993).

zone 2-4 m thick consisting of silty to clayey fine sands and stiff sandy clays. Ferric concretions were noted in some of the finer sediments in the upper part of the sequence, particularly on the margin of the valley away from the stream (see Figure 49). Maximum thickness of the Holocene valley fill is variously interpreted as approximately $9 \mathrm{~m}$ (Aronow's Interpretation A) or approximately $4 \mathrm{~m}$ (Aronow's Interpretation B). In this author's opinion, the former is far more likely. There is also an indicated contact inferred between the "Late Pleistocene" (i.e., Deweyville) sediments underlying the higher terrace and the Lissie sediments underlying the excavated valley.

The geoacheological potential of Aronow's Spring Creek sequence is unclear. Given the paucity of information, there is little basis to confidently interpret either the age of the sediments or the depositional energies involved in their deposition except in the broadest possible terms. However, the entire sequence of floodplain deposits has the potential to contain cultural material dating back at least as far as the Early Archaic, although the majority of accessible deposits probably date to the Late Holocene.

\section{Marsh and Bay Margin Settings}

Only one locality in the marsh and bay margin environments was examined in detail (i.e., using mechanical means of investigation) during this investigation. Previous investigations with a geoarcheological focus are also rare in these environments. Consequently, conclusions regarding the character and archeological potential of such sediments must be considered tentative. Nevertheless, the trenches excavated in the single bay margin locality examined demonstrate that marked changes in the character of the sediments and superimposed soils can occur in small and superficially similar settings.

\section{Coastal Marsh}

One trench-based investigation was undertaken in the coastal marsh environment fronting the backbarrier lagoonal part of Galveston Bay. This investigation was undertaken on SH 6 about $0.8 \mathrm{~km}$ to 2 $\mathrm{km}$ west of its junction with $\mathrm{IH} 45$. This portion of SH 6 traverses the margins of a coastal marsh developed on the low, flat terrain surrounding the mouth 
of Highland Bayou. The elevation of the entire study area is less than 5 feet above sea level. Standing water and stands of salt-tolerant marsh vegetation are present on both sides of the road, and saturated sediments were encountered immediately below the surface in all trenches. Because of the marshy conditions, the backhoe was restricted to the elevated, artificial berm occupied by $\mathrm{SH}$ 6. The trenches were excavated either by extending the backhoe boom out into the natural marsh, or by excavating through artificial sediments forming the road bed to the natural sediments beneath. A wide range of sediments and diagenetic alterations were noted in the series of trenches, all of which exposed marsh, alluvial overbank, and storm deposits that, while undated, are probably no more than a few thousand years old.

The relatively high ground at the western end of the study area exhibited profiles consisting of pale brown to light gray turbated sandy clay overprinted with prominent orange, gray, and brown redox mottles. Several thin, highly bioturbated sandy lenses representing probable storm deposits were noted, but recognizable A horizons were absent. The marsh flat exposed more complex profiles. One trench exposed a well-developed A-B1g-B2kg profile beneath approximately $35 \mathrm{~cm}$ of artificial fill. The A horizon was approximately $25 \mathrm{~cm}$ thick and consisted of very dark grayish-brown (2.5Y $3 / 2$ ), moderately calcareous, massive clayey fine sand. A few exotic chert gravels were noted in the horizon, probably indicating bioturbation after the overlying road fill was emplaced. This weakly melanized A horizon graded down into an olive gray (5Y 5/2), weakly calcareous sandy clay loam B1g horizon characterized by small, prominent manganese concretions 1-2 $\mathrm{mm}$ in diameter and common oxidized (brown) root traces. This $20 \mathrm{~cm}$ thick horizon was underlain by a gray (5Y 6/1), mottled clay loam $\mathrm{B} 2 \mathrm{~kg}$ horizon containing abundant small, hard carbonate nodules. These irregular nodules were 2-6 $\mathrm{mm}$ in diameter and the same color as the matrix. While the other trench was similar, the Bk horizon was noticeably more oxidized (prominent yellow-brown mottles), and many of the carbonate nodules were distinctly larger (up to $1 \mathrm{~cm}$ in diameter) and contrasted with the surrounding matrix.

The most prominent marsh sequence was exposed mid-way between Highland Bayou and the western end of the study area. Below $35 \mathrm{~cm}$ of artificial fill, the surface horizon consisted of a 30 $\mathrm{cm}$ thick, highly organic $\mathrm{A} / \mathrm{O}$ horizon composed of black (5YR 2.5/1) sandy clay loam with interbedded shell fragments and mats of partially decomposed organic matter. It graded into a very dark gray (10YR 3/1), strongly calcareous Bg horizon containing occasional marine shell fragments, occasional large prominent iron-stained krotovina that probably represent infilled crayfish burrows, and a few irregular carbonate rhizoliths to approximately $2 \mathrm{~cm}$ long and $0.5 \mathrm{~cm}$ in diameter. Less prominent orange and brown redox mottles were also present from approximately $1 \mathrm{~m}$ bgs.

Approximately $75 \mathrm{~m}$ farther east, another trench (Figure 50) revealed two thin (approximately 5-10 $\mathrm{cm}$ ), organic-rich marsh deposits separated by a thick $(15 \mathrm{~cm})$ packet of light brownish-gray $(2.5 \mathrm{Y}$ $6 / 2$ ) sandy clay mottled with faint orange, gray, and brown redox mottles. It is likely that this thick, intervening packet represents storm deposits laid down over a relatively brief period of time, perhaps even a single large storm. Below the lower marsh stratum, the sediments consisted of light gray $(2.5 \mathrm{Y}$

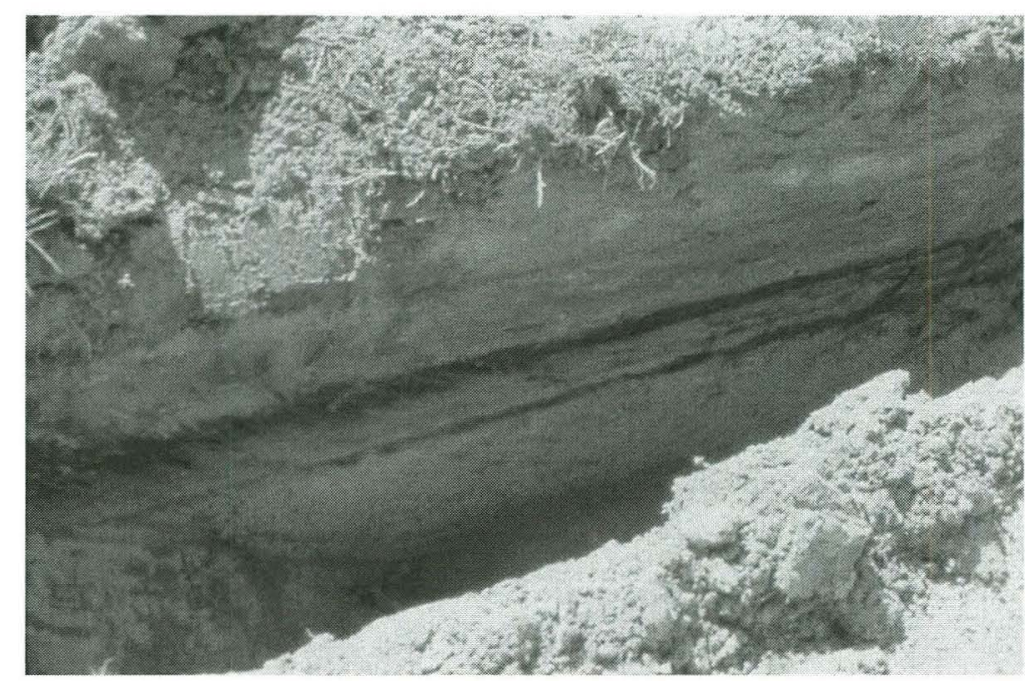

Figure 50. Oblique photograph of the profile of Trench 7 at SH 6 and Highland Bayou, illustrating organic marsh strata separated by probable storm deposits. Material above the higher black stratum is artificial fill brought in to raise the grade of SH 6. 
7/3) massive clay loam containing abundant small $(<0.5 \mathrm{~cm}$ diameter), irregular hard carbonate nodules. Although they made up approximately $50 \%$ of the matrix through most of the exposed subsoil, the frequency of these nodules decreased considerably below approximately $135 \mathrm{~cm}$. Another nearby trench revealed a very similar profile, but contained only one clear marsh stratum. Once again, pockets and thin beds of undecomposed organic matter was common in the black sandy clay of the marsh horizon, and the development of small, hard carbonate nodules was pronounced in the subsoil.

A weak organic marsh deposit was also present above a gray sandy clay next to a narrow slough that parallels Highland Bayou. Small, hard carbonate nodules were abundant here below approximately $1 \mathrm{~m}$. In contrast, visible secondary carbonate was absent approximately $100 \mathrm{~m}$ farther west at the footing of the bridge over Highland Bayou. This trench revealed a moderately dark mineral A horizon overlying an olive gray sandy clay with common faint brownish mottles.

The most striking aspect of the series of trenches excavated along SH 6 is the very strong differences apparent in the soil profiles of what appears to be relatively uniform, marshy ground. Although no chronometric ages were obtained, the landscape position of the exposed sediments clearly suggests that they are no older than a few thousand years, and may be less than 1,000 years old. Nevertheless, a number of the profiles exhibit very strong carbonate development, occupying up to $50 \%$ of the matrix with small to moderately large nodules, while other profiles exhibit either very sparse rhizoliths or no observable secondary carbonate. It is likely that this variability reflects zones of subsurface water movement dictated by relatively minor differences in texture and the configuration of surface water in the surrounding marsh, but it clearly demonstrates that considerable carbonate accumulation can occur in the phreatic/capillary zone in a short period of time. The presence of clear storm lenses in some trenches only suggests that deposition from individual storms can be significant and yet relatively localized depending on the configuration of the marsh. Similarly, the variation in the presence and thickness of organic-rich mats demonstrates that organic accumulation also varies considerably in relatively limited distances. In short, the configuration of a marsh in terms of the spatial distribu- tion of vegetative islands and surface water, and relatively minor differences in the textural character of mineral sediments, appear to strongly influence pedogenic and diagenetic alteration of marsh sediments fronting on Galveston Bay.

The archeological potential of such settings is unclear. No prehistoric archeological materials were noted in the nine trenches excavated around Highland Bayou. In addition, no buried soils indicating overridden terrestrial surfaces were noted, but they are likely to occur in other settings. Depending on the rate of sea level rise in the bay and the rate of marsh progradation along the shore, such environments could lie directly beneath marsh deposits or beneath a thin intermediate deposit of estuarine/bay muds. Because the level of biological activity in estuarine and marsh environments is high, strong potential exists for the integrity of archeological sites in the setting to be impacted by intense bioturbation.

\section{Upland and Colluvial Settings}

The extensive upland surfaces of the district are underlain by Cenozoic rocks, including the Beaumont, Lissie, Willis, and Fleming Formations. These surfaces can be subdivided into the more recent Lissie and Beaumont terraces, which are relatively level, clayey to fine sandy, and exhibit primarily constructional relief (i.e., broad, slightly elevated meander belts and lower, associated flood basins), and the more dissected Willis and Fleming Formations, which are characterized by erosionally sculpted relief and generally coarser parent material. Because of this difference in relief and differences in the parent material weathered from the underlying rocks, the geoarcheological potential of the landscapes underlying the Willis and Fleming is quite different than those underlying the Lissie and the Beaumont, and this will be addressed separately in the following discussion.

\section{The Beaumont and Lissie Terraces}

The Beaumont and Lissie outcrops are smooth, nearly level to slightly irregular surfaces that have existed in approximately their modern form since at least the last Full Glacial (approximately $18 \mathrm{ka}$ ), and thus the deposits that underlie the surfaces have negligible potential to contain artifacts dating from demonstrated, culturally relevant periods. However, several researchers have suggested that an 
unconformable veneer of eolian material may have developed on many of these surfaces during the terminal Pleistocene and/or Holocene, and served as the parent material for pimple mounds (Heinrich 1986a, 1993; Frederick 1991). Observations made across the Beaumont coastal terrace during this study suggest that no discrete, widespread eolian veneer is currently present on these surfaces except possibly in the form of residual pimple mounds. In contrast, observations on various parts of the Lissie surface indicates that the substrate is frequently sandy, and thus subject to eolian reworking during relatively dry phases.

If a widespread eolian veneer developed on the Beaumont and Lissie surfaces at some point during the prehistoric period, it is logical to assume that some of this eolian material would have been incorporated into the underlying soil by turbative processes. Because eolian deposits are by na-

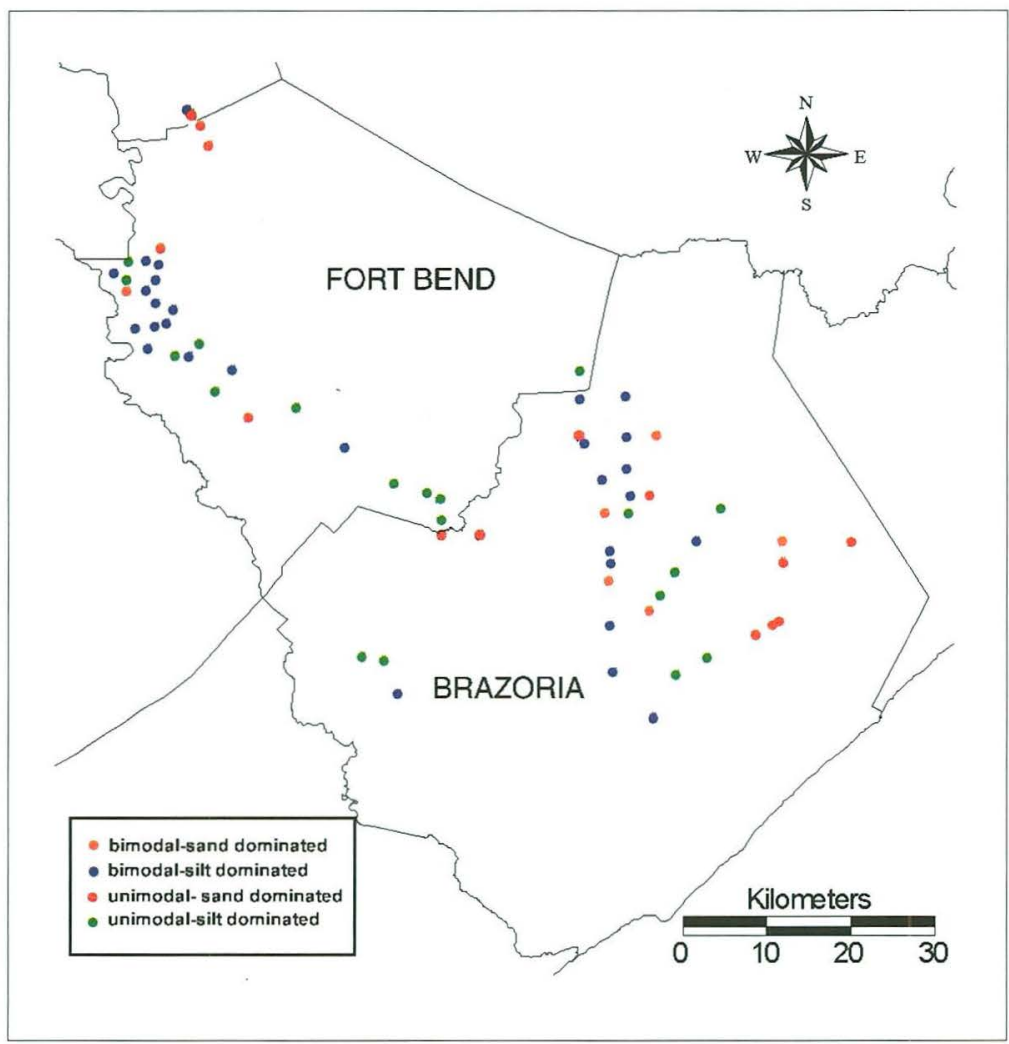

Figure 51. Distribution and character of analyzed upland samples. With the exception of the four samples near the Fort Bend/Waller county line (upper left), all samples are from uplands underlain by the Beaumont Formation.

ture well-sorted, it was reasoned that the presence of a well-defined, subsidiary peak of fine sand to coarse silt size in the texture of the silty to clayey surface horizon would support the hypothesis that such a veneer was once present. Moreover, if the source of any such sediments was the coast or the Brazos River valley, then the mean size of any such sediments should decrease to the northeast. To investigate this possibility, a series of 65 samples were collected from the epipedon of soils developed on the Beaumont surface in the southwestern part of the district (Figure 51). To provide for some comparison, four additional samples were collected from the Lissie outcrop near the Waller/ Fort Bend county line. The locations of all samples were recorded using a low-cost GPS receiver with $\pm 100 \mathrm{~m}$ accuracy. The samples were analyzed for texture using a laser particle size analyzer. In this analysis, the samples were dried in a $40^{\circ} \mathrm{C}$ oven for 24 hours. No coarse fragments were present in the upland samples, so the entire textural determination was made with the laser analyzer. An undisturbed fragment that was judged to be

representative of the overall samples was removed and boiled in $30 \%$ hydrogen peroxide for $20 \mathrm{~min}$ utes to remove organic matter. The samples were then analyzed in aqueous mode on a Cilas 1064 laser particle size analyzer.

Overall, the laser analysis indicates somewhat coarser-grained texture than the field characterization, with textures dominated by medium to fine silt. The textural mean of the 69 samples ranged from $4.07 \phi$ (coarse silt) to $7.88 \phi$ (very fine silt), with an average of $6.34 \phi$ (medium silt). This may indicate incomplete disaggregation of the clays during analysis, but is not believed to appreciably affect either the accuracy of the coarse tail $(<4 \phi)$ or the modality of the distribution. Thirty four of the 69 samples exhibited a clearly bimodal distribution, while 15 exhibited a unimodal distribution with a peak in the very fine sand to coarse silt range, and 20 exhibited a unimodal peak in the medium to fine silt range. Thirty of the bimodally distributed samples exhibited primary peaks in the medium to fine silt range, with secondary peaks in the coarse silt to fine sand 
range. Only five of the bimodal samples had a dominant peak that was coarser than the secondary peak. Table 8 summarizes the results of the analysis, and Figure 52 illustrates examples of each of the characteristic frequency distributions.

Roughly half of the analyzed soil samples from the level Pleistocene uplands exhibited bimodal distributions indicative of eolian input. Rather than a discrete, readily visible veneer, this material is incorporated into the soil developed on the surfaces. Comparison of the distribution of these bimodal samples with the distribution of distributary and interdistributaries facies of the Beaumont suggests that this material is locally reworked, and not transported long distances from the coast or the major stream valleys.

From a geoarcheological perspective, the Beaumont and Lissie uplands represent long-term stable surfaces. Where the epipedon is clayey to loamy, they have little to no potential to host sites with contextual integrity except where pimple mounds are present. However, there is some potential for shallow burial by eolian and/or colluvial processes in areas with a sandy epipedon, and shovel testing should be conducted in such settings except where historic activity has compromised the integrity of surficial deposits.

\section{Older Uplands}

Older uplands in the northern part of the district exhibit more varied relief than the relatively undissected Beaumont and Lissie surfaces. Although a number of road cuts were briefly examined, none of these settings were examined in detail with mechanical trenches during this project. Although more common in the Eocene outcrops to the north and west, the northern Houston District includes settings that conform to the broad definition of the East Texas sand sheet. This broad area is characterized by the occurrence of widespread, relatively featureless sands that occur on slope and upland settings. These sands, which can be two meters or more thick on slopes and uplands alike, are typically underlain by an abruptly bounded argillic horizon, and often contain cultural material. Although a number of authors (e.g., Heinrich 1986b; Perttula et al. 1986; Davis et al. 1987; Mandel 1987, 1994; Ensor and Carlson 1988; Bousman 1990; Nordt et al. 1992; Thoms 1993; Thoms and Olive 1993; Fields et al. 1995; Gadus et al. 1997) have explored processes and/or examined the geomorphology and stratigraphy of sites in the sandy mantle, there is no consensus on the mechanisms of natural site formation or the generalized context and integrity of cultural remains within the mantle. In his review of the site formation issues associated with the sandy mantle, Thoms (1993) identifies four basic classes of models that have been advanced: (1) colluvial models; (2) eolian models; (3) colluvial/eolian models; and (4) pedogenesis/bioturbation models. In a subsequent chapter of the same volume, Thoms and Olive (1993) advance a fifth class of model that they term graviturbation/sheetwash/gullying/ pedogenesis. While the principal theories that have been advanced to explain the sandy mantle are briefly reviewed below, no attempt is made in this study to resolve the question.

The colluvial model has been advanced in various forms by several authors, notably Heinrich (1986b) and Bousman (1990), who both reported investigations at Jewett Mine in Leon and Freestone counties. Slow, protracted colluvial/slopewash processes are consistently cited as the preferred model in subsequent Jewett Mine reports produced by Prewitt and Associates (e.g., Fields et al. 1995; Gadus et al. 1997), and is widely cited by other investigators in the sandy mantle (e.g., Tate and Rogers 1998). The colluvial model holds that the sandy mantle has formed primarily through the downwasting of sandy bedrock outcrops and the redistribution of sands by incremental mass wasting and unconfined sheet flow. The primary objection to this model is the development of thick sands on ridge and hilltops, where erosion would be expected (Perttula et al. 1986; Thoms 1993).

Variations of the eolian model have also been advanced several times (e.g., Ensor and Carlson 1988; Largent 1991; Rogers 1992). Although eolian processes are an attractive mechanism for explaining the accumulation of substantial sands on topographic highs, two significant objections can be raised. First, pebble-sized clasts too large to be transported by wind are commonly distributed through these sands, indicating that eolian processes alone cannot account for their development. More importantly, substantial eolian accumulation on a regional basis requires dry conditions and limited vegetation, and is difficult to rectify with reconstructions of regional climate and vegetation in East Texas during the Holocene (Perttula et al. 1986). On the other hand, localized eolian reworking of fluvial and colluvial deposits and sandy soils undoubtedly occurred, and models that combine 


\section{Houston Area Geoarcheology}

Table 8. Location and character of upland soil samples.

\begin{tabular}{|c|c|c|c|c|c|c|c|c|}
\hline Sample & Location & Latitude & Longitude & mean & skewness & modality & primary & secondary \\
\hline UP 1 & Albert Marek Rd & $29^{\circ} 33^{\prime} 30^{\prime \prime}$ & $96^{\circ} \quad 0^{\prime} \quad 3^{\prime \prime}$ & 7.83 & 0.12 & bimodal & fine silt & $\mathrm{v}$. fine silt \\
\hline UP 2 & B. J.Ducek Rd@Macha Rd & $29^{\circ} 35^{\prime} 21^{\prime \prime}$ & $96^{\circ} \quad 0^{\prime} \quad 3{ }^{\prime \prime}$ & 6.26 & -0.01 & bimodal & fine silt & v. fine sand \\
\hline UP 3 & B. J. Dusek Rd & $29^{\circ} 35^{\prime} 22^{\prime \prime}$ & $96^{\circ} 1^{\prime} 19^{\prime \prime}$ & 7.57 & 0.10 & unimodal & v. fine silt & na \\
\hline UP 4 & Beard Rd & $29^{\circ} 20^{\prime} 31^{\prime \prime}$ & $95^{\circ} 42^{\prime} 30^{\prime \prime}$ & 6.50 & 0.11 & unimodal & v. fine silt & na \\
\hline UP 5 & Blase Rd & $29^{\circ} 28^{\prime} \quad 7^{\prime \prime}$ & $95^{\circ} 53^{\prime} 58^{\prime \prime}$ & 5.79 & 0.10 & bimodal & med. silt & v. fine sand \\
\hline UP 6 & Bohacek Rd & $29^{\circ} 29^{\prime} 13^{\prime \prime}$ & $95^{\circ} 58^{\prime} \quad 9^{\prime \prime}$ & 6.39 & 0.17 & unimodal & med. silt & na \\
\hline UP 7 & Braz CR 17 & $29^{\circ} 17^{\prime} \quad 3 "$ & $95^{\circ} 39^{\prime} 12 "$ & 4.50 & 0.31 & unimodal & $\mathrm{v}$. fine sand & na \\
\hline UP 8 & Braz CR 203 & $29^{\circ} 14^{\prime} 26^{\prime \prime}$ & $95^{\circ} 14^{\prime} 26^{\prime \prime}$ & 5.84 & 0.19 & unimodal & v. fine sand & na \\
\hline UP $=9$ & Braz CR 203 & $29^{\circ} 15^{\prime} 38^{\prime \prime}$ & $95^{\circ} 14^{\prime} 26^{\prime \prime}$ & 5.29 & 0.27 & bimodal & v. fine sand & v. fine silt \\
\hline UP 10 & Braz CR 25 (intermound) & $29^{\circ} 16^{\prime} 56^{\prime \prime}$ & $95^{\circ} 36^{\prime} 22 "$ & 4.45 & 0.38 & unimodal & v. fine sand & na \\
\hline UP 11 & Braz CR 25 (mound) & $29^{\circ} 16^{\prime} 56^{\prime \prime}$ & $95^{\circ} 36^{\prime} 22 "$ & 4.23 & 0.47 & unimodal & v. fine sand & na \\
\hline UP 12 & Braz CR 51 & $29^{\circ} 19^{\prime} \quad 4^{\prime \prime}$ & $95^{\circ} 23^{\prime} 50^{\prime \prime}$ & 5.85 & 0.19 & unimodal & coarse silt & na \\
\hline UP 13 & Braz CR 60 & $29^{\circ} 22^{\prime} 53^{\prime \prime}$ & $95^{\circ} 23^{\prime} 9^{\prime \prime}$ & 5.81 & 0.07 & bimodal & v. fine sand & med. silt \\
\hline UP 14 & FM 1301 & $29^{\circ} \quad 9^{\prime} 28^{\prime \prime}$ & $95^{\circ} 45^{\prime} 15^{\prime \prime}$ & 7.24 & 0.20 & unimodal & fine silt & na \\
\hline UP 15 & FM 1301 & $29^{\circ} \quad 9^{\prime} \quad 9^{\prime \prime}$ & $95^{\circ} 43^{\prime} 41 "$ & 7.53 & 0.14 & unimodal & fine silt & na \\
\hline UP 16 & FM 1459 & $29^{\circ} \quad 7^{\prime} \quad 2^{\prime \prime}$ & $95^{\circ} 42^{\prime} 47^{\prime \prime}$ & 6.43 & 0.12 & bimodal & med. silt & v. coarse silt \\
\hline UP 17 & FM 1489 & $29^{\circ} 35^{\prime} \quad 3 "$ & $95^{\circ} 59^{\prime} \quad 9^{\prime \prime}$ & 6.16 & -0.13 & bimodal & fine silt & fine sand \\
\hline UP 18 & FM 1489 & $29^{\circ} 36^{\prime} 6^{\prime \prime}$ & $95^{\circ} 58^{\prime} 54 "$ & 3.63 & 0.28 & unimodal & fine sand & na \\
\hline UP 19 & FM1875@Lehmann Rd & $29^{\circ} 30^{\prime} \quad 1^{\prime \prime}$ & $95^{\circ} 56^{\prime} 24 "$ & 7.40 & 0.16 & unimodal & fine silt & na \\
\hline UP 20 & FM1875@Lehmann Rd & $29^{\circ} 32^{\prime} 10^{\prime \prime}$ & $95^{\circ} 58^{\prime} \quad 8^{\prime \prime}$ & 6.45 & -0.01 & bimodal & fine silt & v. fine sand \\
\hline UP 21 & FM 1952@FH 90A & $29^{\circ} 32^{\prime} 35^{\prime \prime}$ & $95^{\circ} 59^{\prime} 21^{\prime \prime}$ & 6.28 & -0.05 & bimodal & fine silt & v. fine sand \\
\hline UP 22 & FM 1952@FH 90A & $29^{\circ} 34^{\prime} 35^{\prime \prime}$ & $96^{\circ} \quad 2,22 "$ & 6.32 & -0.09 & bimodal & fine silt & v. fine silt \\
\hline UP 23 & FM1952@FH 90A & $29^{\circ} 34^{\prime} \quad 1^{\prime \prime}$ & $95^{\circ} 59^{\prime} 23 "$ & 7.49 & 0.17 & bimodal & fine silt & v. fine silt \\
\hline UP 24 & FM 2004 & $29^{\circ} 44^{\prime} 54^{\prime \prime}$ & $95^{\circ} 24^{\prime} 14 "$ & 7.62 & 0.11 & bimodal & fine silt & v. fine silt \\
\hline UP 25 & FM 2004 & $29^{\circ} 10^{\prime} 35^{\prime \prime}$ & $95^{\circ} 14^{\prime} 52 "$ & 4.39 & 0.36 & unimodal & v. fine sand & na \\
\hline UP 26 & FM 2004 & $29^{\circ} 10^{\prime} 27^{\prime \prime}$ & $95^{\circ} 15^{\prime} 12 "$ & 4.62 & 0.35 & unimodal & v. fine sand & na \\
\hline UP 27 & FM 2004 & $29^{\circ} \quad 7^{\prime} 29^{\prime \prime}$ & $95^{\circ} 222^{\prime} 25^{\prime \prime}$ & 7.37 & 0.15 & unimodal & fine silt & na \\
\hline UP 28 & FM 2004 & $29^{\circ} \quad 8^{\prime} 31^{\prime \prime}$ & $95^{\circ} 20^{\prime} 13 "$ & 7.51 & 0.16 & unimodal & fine silt & na \\
\hline UP 29 & FM 2004 & $29^{\circ} 15^{\prime} 27^{\prime \prime}$ & $95^{\circ} \quad 9^{\prime} 27^{\prime \prime}$ & 5.80 & 0.11 & unimodal & v. fine sand & na \\
\hline UP 30 & FM 2004 & $29^{\circ} \quad 9^{\prime} 50^{\prime \prime}$ & $95^{\circ} 16^{\prime} 38^{\prime \prime}$ & 4.15 & 0.43 & unimodal & v. fine sand & na \\
\hline UP 31 & FM 359 & $29^{\circ} 42^{\prime} 38^{\prime \prime}$ & $95^{\circ} 55^{\prime} 6^{\prime \prime}$ & 3.54 & 0.42 & unimodal & fine sand & na \\
\hline UP 32 & FM 359 & $29^{\circ} 43^{\prime} 51^{\prime \prime}$ & $95^{\circ} 55^{\prime} 46^{\prime \prime}$ & 3.41 & 0.41 & unimodal & fine sand & na \\
\hline UP 33 & FM 359 & $29^{\circ} 44^{\prime} 40^{\prime \prime}$ & $95^{\circ} 56^{\prime} 20^{\prime \prime}$ & 3.30 & 0.44 & unimodal & fine sand & na \\
\hline UP 34 & FM 359 & $29^{\circ} 44^{\prime} 59^{\prime \prime}$ & $95^{\circ} 56^{\prime} 35^{\prime \prime}$ & 5.90 & -0.03 & bimodal & fine silt & v. fine sand \\
\hline UP 35 & FM 521 & $29^{\circ} 20^{\prime} \quad 9^{\prime \prime}$ & $95^{\circ} 27^{\prime} 20^{\prime \prime}$ & 6.45 & 0.19 & bimodal & med. silt & $\mathrm{v}$ fine sand \\
\hline UP 36 & FM 521 & $29^{\circ} 22^{\prime} 30^{\prime \prime}$ & $95^{\circ} 28^{\prime} 30^{\prime \prime}$ & 6.72 & 0.20 & bimodal & med. silt & v. fine sand \\
\hline UP 37 & FM 521 & $29^{\circ} 25^{\prime} 20^{\prime \prime}$ & $95^{\circ} 28^{\prime} 40^{\prime \prime}$ & 6.81 & 0.13 & bimodal & med. silt & v. fine sand \\
\hline UP 38 & FM 521 & $29^{\circ} 27^{\prime} \quad 8^{\prime \prime}$ & $95^{\circ} 28^{\prime} 31^{\prime \prime}$ & 7.71 & 0.13 & unimodal & fine silt & na \\
\hline UP 39 & FM 521 & $29^{\circ} 23^{\prime} \quad 1^{\prime \prime}$ & $95^{\circ} 28^{\prime} 50^{\prime \prime}$ & 4.73 & 0.52 & unimodal & fine sand & na \\
\hline UP 40 & FM521 & $29^{\circ} 18^{\prime} \quad 1^{\prime \prime}$ & $95^{\circ} 27^{\prime} \quad 7 "$ & 6.92 & -0.02 & bimodal & fine silt & v. fine sand \\
\hline UP 41 & Foster School Rd & $29^{\circ} 25^{\prime} 36^{\prime \prime}$ & $95^{\circ} 49^{\prime} 22{ }^{\prime \prime}$ & 7.71 & 0.17 & unimodal & med. silt & na \\
\hline UP 42 & Grunewald Rd & $29^{\circ} 29^{\prime} \quad 9^{\prime \prime}$ & $95^{\circ} 57^{\prime} \quad 7 "$ & 6.18 & 0.01 & bimodal & fine silt & v. fine sand \\
\hline UP 43 & Hopkins Rd & $29^{\circ} 31^{\prime} 15^{\prime \prime}$ & $95^{\circ} 58^{\prime} 44^{\prime \prime}$ & 7.03 & 0.18 & bimodal & med. silt & v. fine sand \\
\hline UP 44 & Hopkins Rd & $29^{\circ} 31^{\prime} 8^{\prime \prime}$ & $95^{\circ} 59^{\prime} 28^{\prime \prime}$ & 6.15 & -0.03 & bimodal & med. silt & v. fine sand \\
\hline UP 45 & Jeske Rd & $29^{\circ} 22^{\prime} 51^{\prime \prime}$ & $95^{\circ} 46^{\prime} \quad 4^{\prime \prime}$ & 7.74 & 0.14 & bimodal & med. silt & v. fine silt \\
\hline UP 46 & Meyer Rd & $29^{\circ} 25^{\prime} \quad 1^{\prime \prime}$ & $95^{\circ} 53^{\prime} \quad 0^{\prime \prime}$ & 5.32 & 0.40 & unimodal & v. fine sand & na \\
\hline UP 47 & Meyer Rd & $29^{\circ} 26^{\prime} 51^{\prime \prime}$ & $95^{\circ} 55^{\prime} 14 "$ & 7.62 & 0.17 & unimodal & fine silt & na \\
\hline UP 48 & Pilcek Rd@Albert Marek Rd & $29^{\circ} 33^{\prime} 29^{\prime \prime}$ & $96^{\circ} 10^{\prime} 30^{\prime \prime}$ & 6.18 & 0.40 & bimodal & coarse silt & v. fine silt \\
\hline UP 49 & Pilcik Rd & $29^{\circ} 34^{\prime} \quad 5^{\prime \prime}$ & $96^{\circ} 11^{\prime} 32 "$ & 7.69 & 0.18 & unimodal & fine silt & na \\
\hline UP 50 & Rycade School Rd & $29^{\circ} 18^{\prime} 6^{\prime \prime}$ & $95^{\circ} 39^{\prime} 13 "$ & 7.61 & 0.20 & unimodal & fine silt & na \\
\hline UP 51 & Rycade School Rd & $29^{\circ} 19^{\prime} 18^{\prime \prime}$ & $95^{\circ} 39^{\prime} 13 "$ & 7.83 & 0.10 & unimodal & fine silt & na \\
\hline UP 52 & Schultz Rd & $29^{\circ} 19^{\prime} 50^{\prime \prime}$ & $95^{\circ} 40^{\prime} 11 "$ & 7.88 & 0.09 & unimodal & fine silt & na \\
\hline UP 53 & SH 288 & $29^{\circ} 20^{\prime} 47^{\prime \prime}$ & $95^{\circ} 25^{\prime} 31^{\prime \prime}$ & 6.43 & -0.12 & bimodal & fine silt & v. fine sand \\
\hline UP 54 & SH 288 & $29^{\circ} 13^{\prime} 40^{\prime \prime}$ & $95^{\circ} 27^{\prime} 10^{\prime \prime}$ & 6.13 & 0.20 & bimodal & v. fine sand & $\mathrm{v}$. fine silt \\
\hline UP 55 & SH 288 & $29^{\circ} 15^{\prime} 35^{\prime \prime}$ & $95^{\circ} 26^{\prime} 51^{\prime \prime}$ & 6.45 & 0.08 & bimodal & med. silt & v. coarse silt \\
\hline UP 56 & SH 288 & $29^{\circ} 7^{\prime} 47^{\prime \prime}$ & $95^{\circ} 27^{\prime} \quad 3 "$ & 6.91 & 0.00 & bimodal & fine silt & v. fine sand \\
\hline UP 57 & SH 288 & $29^{\circ} 19^{\prime} \quad 2^{\prime \prime}$ & $95^{\circ} 25^{\prime} 19^{\prime \prime}$ & 6.36 & -0.10 & & fine silt & $\mathrm{v}$ fine sand \\
\hline UP 58 & SH 288 & $29^{\circ} 10^{\prime} 45^{\prime \prime}$ & $95^{\circ} 27^{\prime} \quad 9 "$ & 6.03 & -0.11 & bimodal & fine silt & v. fine sand \\
\hline UP 59 & SH 288 & $29^{\circ} 17^{\prime} 58^{\prime \prime}$ & $95^{\circ} 25^{\prime} 33^{\prime \prime}$ & 7.78 & 0.16 & unimodal & fine silt & na \\
\hline UP 60 & SH 288@ Braz CR 60 & $29^{\circ} 22^{\prime} 51^{\prime \prime}$ & $95^{\circ} 25^{\prime} 24 "$ & 6.85 & 0.10 & bimodal & med. silt & v. fine sand \\
\hline UP 61 & SH 288@Braz CR 64 & $29^{\circ} 25^{\prime} 28^{\prime \prime}$ & $95^{\circ} 25^{\prime} 25^{\prime \prime}$ & 6.56 & 0.18 & bimodal & med. silt & v. coarse silt \\
\hline UP 62 & SH 35 & $29^{\circ} 16^{\prime} \quad 4^{\prime \prime}$ & $95^{\circ} 20^{\prime} 36^{\prime \prime}$ & 6.34 & -0.03 & bimodal & fine silt & coarse silt \\
\hline UP 63 & SH 35 & $29^{\circ} 18^{\prime} \quad 2^{\prime \prime}$ & $95^{\circ} 18^{\prime} 46^{\prime \prime}$ & 7.84 & 0.18 & unimodal & fine silt & na \\
\hline UP 64 & SH 35 & $29^{\circ} 14^{\prime} \quad 0^{\prime \prime}$ & $95^{\circ} 22^{\prime} 14 "$ & 7.96 & 0.11 & unimodal & v. fine silt & na \\
\hline UP 65 & SH 35 & $29^{\circ} 12^{\prime} 33^{\prime \prime}$ & $95^{\circ} 233^{\prime} 23 "$ & 7.55 & 0.21 & unimodal & fine silt & na \\
\hline UP 66 & SH 35 Angleton & $29^{\circ} 11^{\prime} 33^{\prime \prime}$ & $95^{\circ} 24^{\prime} 16^{\prime \prime}$ & 5.81 & 0.22 & bimodal & v. fine sand & fine silt \\
\hline UP 67 & SH B-288 & $29^{\circ} 14^{\prime} 45^{\prime \prime}$ & $95^{\circ} 26^{\prime} 47^{\prime \prime}$ & 6.30 & 0.04 & bimodal & fine silt & med. silt \\
\hline UP 68 & West Tavener Rd & $29^{\circ} 31^{\prime}, 1 "$ & $96^{\circ} \quad 0^{\prime} 58^{\prime \prime}$ & 6.17 & 0.02 & bimodal & med. silt & v. fine sand \\
\hline UP 69 & West Tavener Rd & $29^{\circ} 29^{\prime} 45^{\prime \prime}$ & $96^{\circ} 0^{\prime} 6^{\prime \prime}$ & 6.77 & 0.16 & unimodal & med. silt & na \\
\hline
\end{tabular}




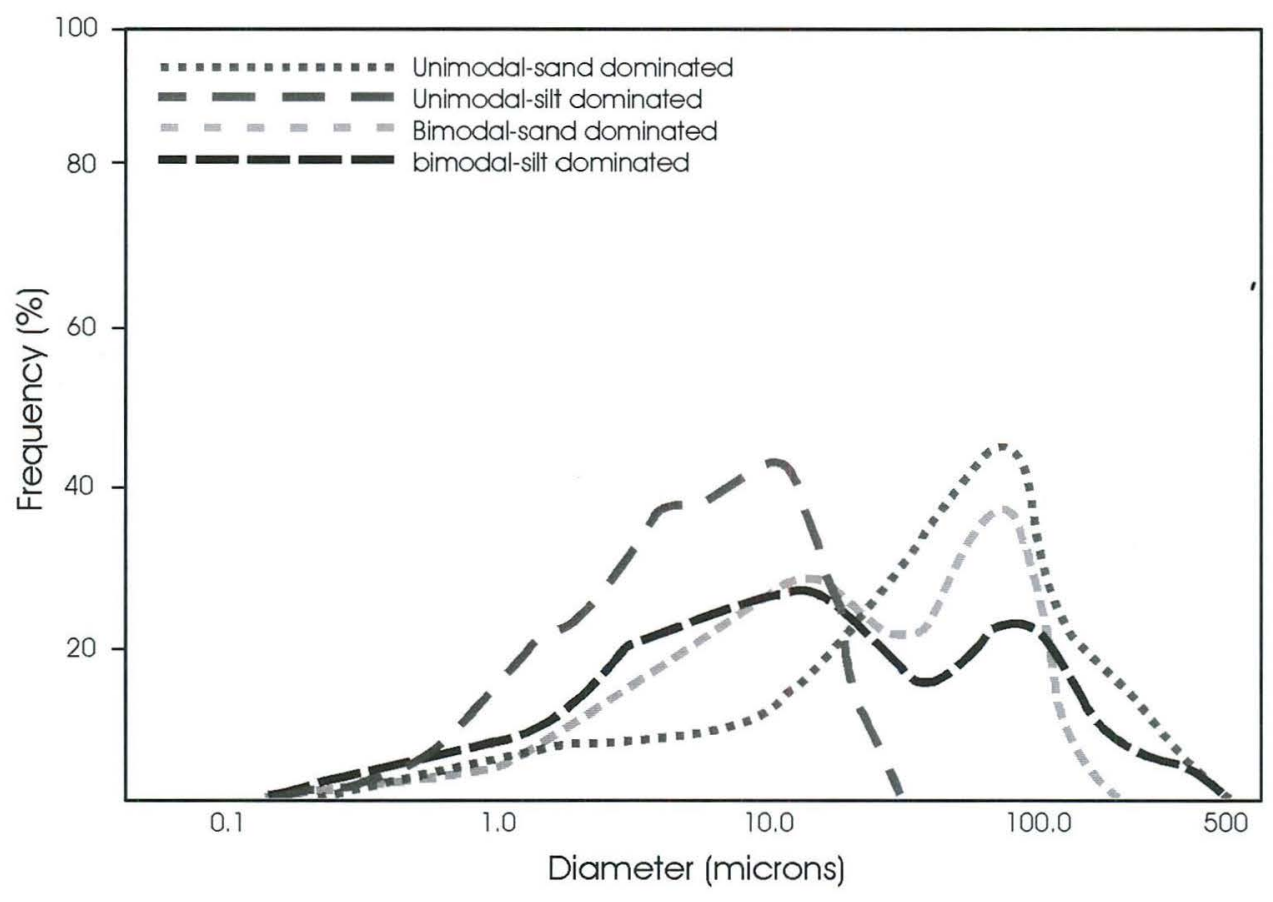

Figure 52. Typical textural frequency curves for unimodal and bimodal distributions dominated by sand and silt.

elements of colluvial and eolian sedimentation (e.g., Mandel 1987) are somewhat more persuasive.

In contrast to the various mechanisms of deposition, bioturbation and other forms of pedoturbation have been proposed as explanations for the burial of artifacts within a non-aggrading setting. In an oft-cited presentation, Brown (1975) proposed that incremental disturbance processes can serve to intrude artifacts into soils, and that the depth of intrusion reflects both artifact size and the duration of pedoturbation; thus, a false cultural stratigraphy can develop because older artifacts are worked more deeply into the soil than more recent artifacts. Variations of this model have been invoked by several authors, including Bruseth and Perttula (1981) and Perttula et al. (1986). Importantly, most bioturbation arguments focus on disturbance of the matrix, and pay scant attention to exhumation of sediments by burrowing animals as a mechanism of surface burial (see Chapter 3). The model proposed by Thoms and Olive (1993) combines colluvial activity and pedoturbation processes with other types of soil processes to explain the development of the sandy mantle. Although this model also has many persuasive components, it includes a concept of progressive, downward attrition of the argillic horizon (that is, downward migration of the Bt horizon through time) that is extremely difficult to accept.

The extent of the sandy mantle in the Houston District is not well established, although the work at Lake Creek Reservoir (Mandel 1987) clearly establishes its presence. Readily identifiable, albeit thin, sands of probable mixed eolian/slopewash origin were noted at several road cuts in the district. An example is a road cut on the frontage of Interstate 45 in the Woodlands, Texas (Figure 53). Here, a thin (approximately $50 \mathrm{~cm}$ ) wedge of fine sand was preserved on the north side of a low $(60-70 \mathrm{~cm})$ bedrock mound or ridge. The bedrock at this locality is mapped as the Lissie Formation (Barnes 1992), and consists of interbedded sandy muds and muddy sands overprinted with an intensely mottled argillic horizon. A few ironstone concretions and remnants of marine bivalve shells were incorporated into the 


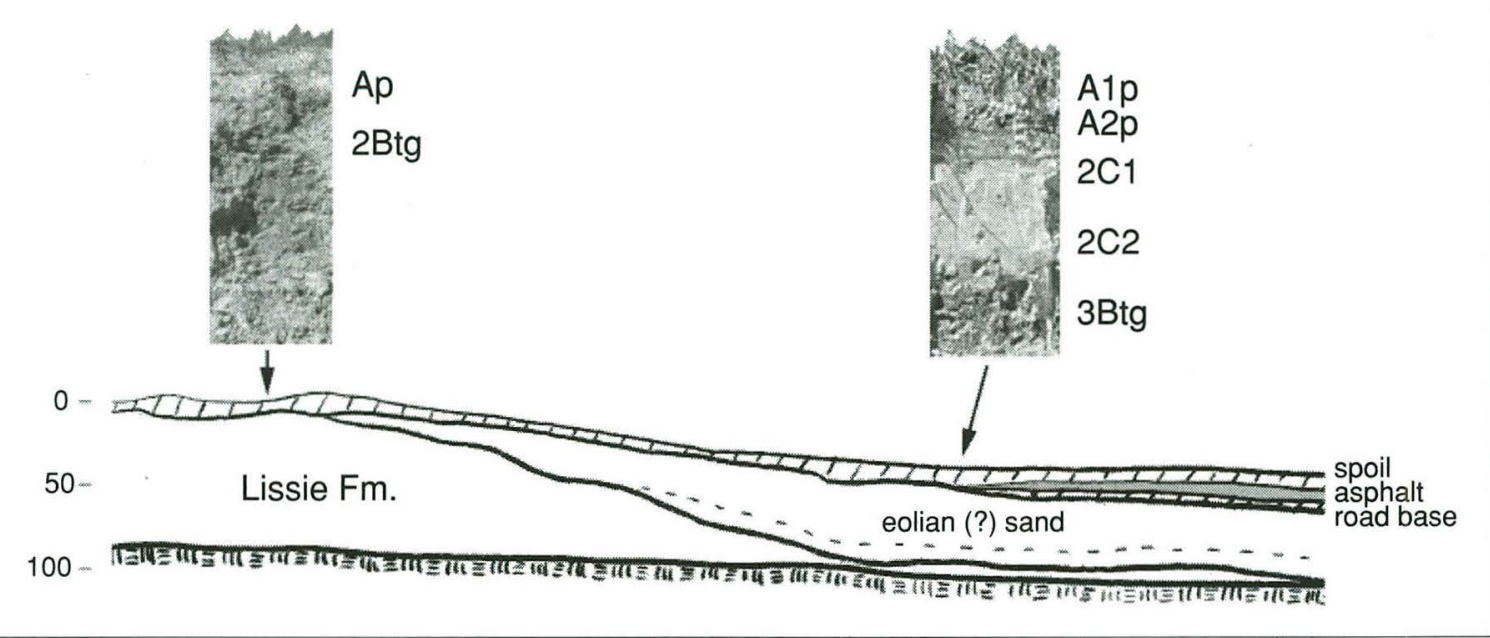

Figure 53. Schematic illustration of the Woodlands 1 exposure, illustrating a thin, discontinuous mantle of eolian sand in the uplands.

bedrock. The probable eolian unit was up to $60 \mathrm{~cm}$ thick and consisted of massive, pale brown, slightly loamy very fine sand. Occasional ironstone pebbles (reworked concretions) occurred in the unit, indicating that colluvial processes must have played a role in its accumulation. However, the wedge exhibited a high degree of sorting relative to the sands in the underlying bedrock, strongly suggesting an eolian origin. Although the age of these deposits is unknown, the almost total lack of pedogenic alteration in the sands suggests that they were either deposited or severely truncated relatively recently.

Although substantially thicker upland sands were not documented during this study, such deposits have been documented previously in the district (e.g., Mandel 1987), and are probably common on lower slopes and toeslopes in Montgomery County. Clearly, more work is needed to adequately explain site formation processes in these settings. However, from a geoarcheological perspective, the overarching question is not the mechanism(s) of site formation per se, but rather whether sites in such settings have sufficient integrity to justify eligibility for inclusion in the National Register. Here, recent OSL dating of the quartz sands making up the sand sheet by Robert Rogers, Charles Frederick, and Mark Bateman (e.g., Bateman 1998; Frederick and Bateman 1998; Tate and Rogers 1998) suggests that these deposits can often yield Holocene ages that occur in the correct stratigraphic order. Therefore, while the integrity of upland prehistoric sites in this type of setting requires careful and thorough documentation, it seems clear that there is insufficient information to justify excluding sand sheet settings from survey or located sites from intensive and thoughtful eligibility testing.

Finally, there is a strong possibility that many of these upland and slope environments experienced significant historic disturbance that may have adversely affected the archeological record. As mentioned above, the northern Houston District was extensively deforested for timbering and agricultural clearance during the historic period (Maxwell and Baker 1983). Although much of the tree cover has since regenerated (Figure 54), the widespread stripping of anchoring vegetation can have dramatic effects on sandy soils (Nir 1983; Goudie 1986), and there is strong evidence of at least two significant episodes of sand influx into several of the smaller stream systems in the northern part of the district during the latter 19 th or early 20 th century. Archeologists working in the area should be alert to the possibility that increased soil erosion, colluvial/ slopewash transport, and toeslope deposition prior to WWII may have adversely affected sites in the sandy mantle settings.

\section{Colluvial Settings}

No detailed investigations of colluvial environments were conducted during this study, and very few examinations have been conducted previously. A variety of colluvial settings exist in the 

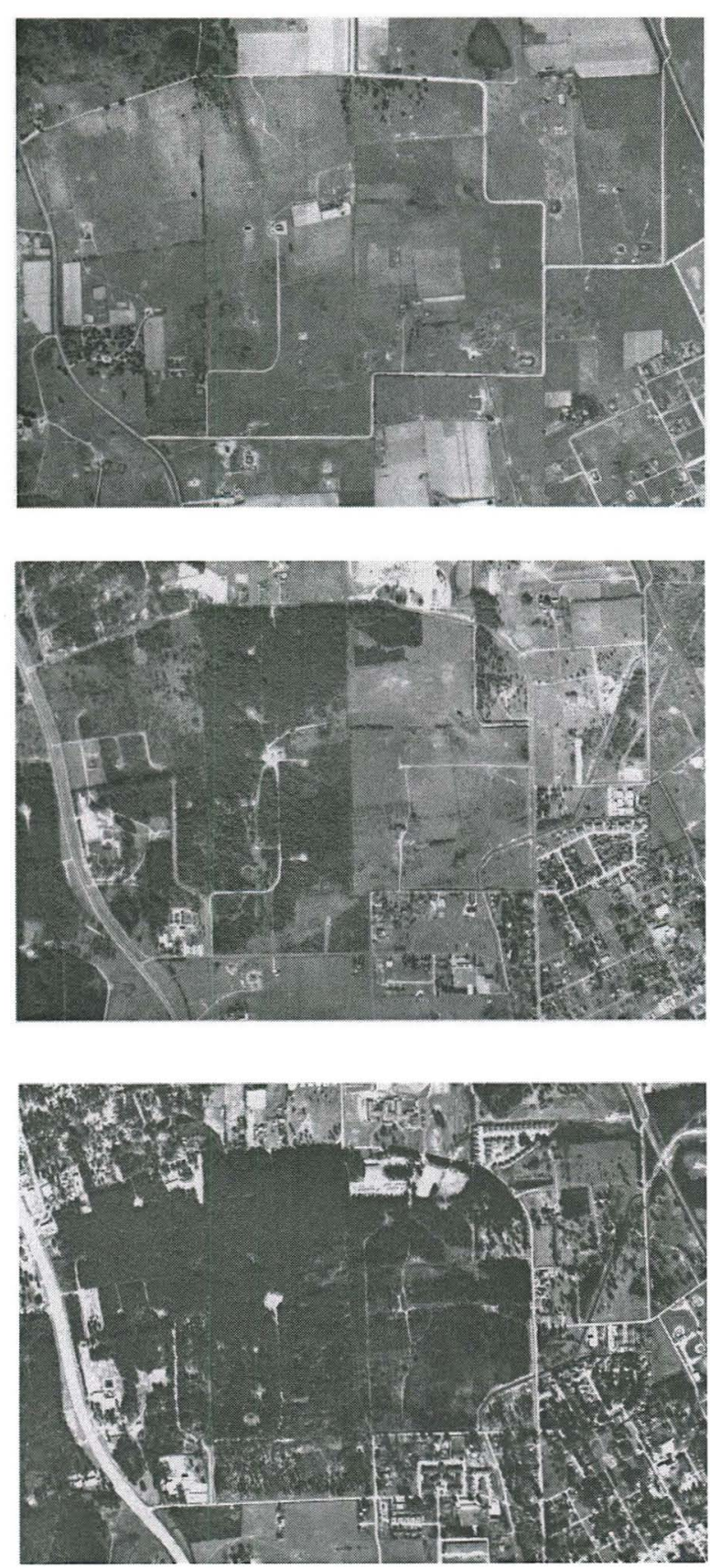

Figure 54. Time series of aerial photographs illustrating forest regeneration in the vicinity of Tomball during the last half century.

district, but in general they grade between two basic end-members: relatively low-gradient, clayey colluvial slopes on the margins of the Beaumont surface, and relatively steep, sandy to silty slopes farther inland.

A good example of the archeological potential of upland margin settings in the Houston District is documented by Paine (1987a, 1990) at Peggy Lake, on the margin of the San Jacinto River valley a few miles from Galveston Bay. Here, the upland margins are mantled with a moderately thick, relatively uniform deposit of colluvium that contains archeological materials in relatively discrete context (Gadus and Howard 1990). On the basis of a program of intensive backhoe trenching, sediment analysis, and dating, Paine proposed a model for the development of the Peggy Lake slopes that is illustrated in Figure 55. He found that the Beaumont upland was capped by a thick Late Pleistocene soil that he characterized as an $\mathrm{A}-\mathrm{AC}-2 \mathrm{C}-3 \mathrm{C}$ profile (the area is mapped as Lake Charles clay-a thick vertisol-by the USDA-SCS). Trenching revealed that this soil was laterally truncated by the stream valley wall, which Paine argued was an indication that the valley was shallowly incised during its formation. He inferred that the soil formed primarily during the last Full Glacial following presumed Beaumont deposition during the previous highstand. During the Late Glacial and Early/Middle Holocene, eustatic lowering of the base level led to incision and lateral expansion of the valley, truncating the soil. During this phase, lateral erosion of the valley walls stimulated gullying and limited colluvial accretion. With inundation of the local valley by sea level rise about $4 \mathrm{ka}$, valley wall erosion ceased and colluvium began to accrete, incorporating archeological sites (primarily shell middens resulting from exploitation of the estuarine environment).

Several aspects of Paine's model are debatable. For example, available evidence now suggests that Beaumont deposition in this area substantially predated the last Glacial, and that the thick upland soil probably formed well before $18 \mathrm{ka}$. The degree of lateral valley cutting during the late phases of sea level rise (Early/Middle Holocene) also seems questionable; the lack of older colluvial deposits could instead indicate climate-driven sheet stripping and gullying of the valley walls, and could therefore affect much more extensive areas of the district. Nevertheless, the principal conclusion, that colluvial deposits predating approximately $4 \mathrm{ka}$ appear absent and the potential for preservation of archeological components older than the Late Archaic is therefore limited, appears valid in the Peggy Lake area. It is likely that similar deposits occur in many other localities in the Houston District. In particular, the relatively sandy substrates and more pronounced relief typical of the northern part of the district are 


\section{Full Glacial-Late Glacial}

Thick soil forms on Beaumont Surface

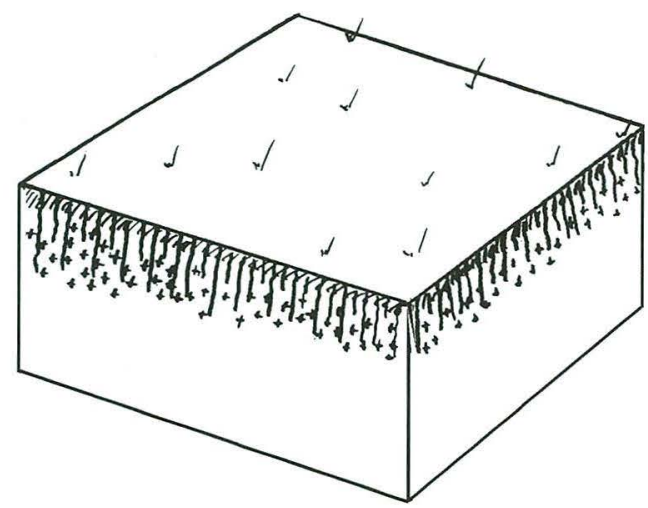

\section{Late Holocene}

rising sea level eliminates lateral cutting; slopes begin to develop colluvial mantle that incorporates archeological sites

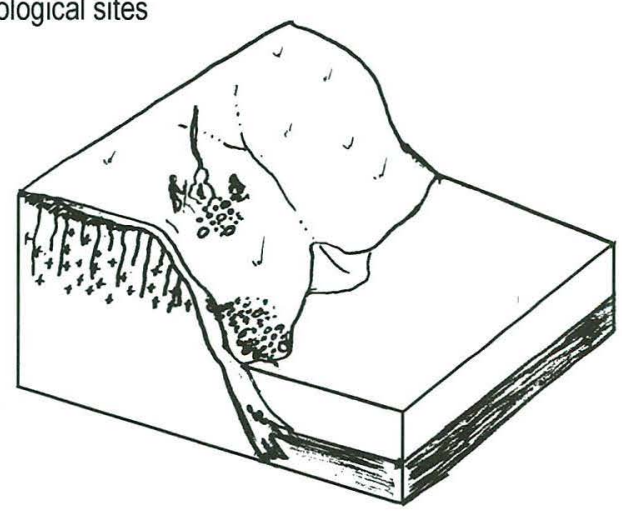

\section{Late Glacial-Middle Holocene}

San Jacinto incises and cuts laterally; soil continues to form on uplands; gullying

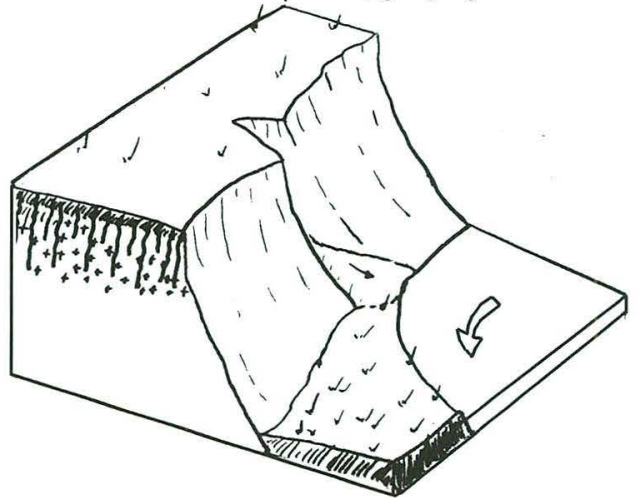

Modern

archeological sites contained in colluvial mantle overlying laterally truncated Pleistocene soil

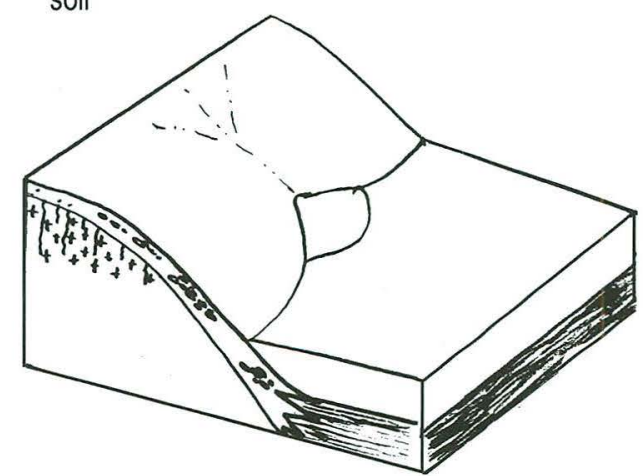

Figure 55. Model of landscape development and site burial proposed by Paine (1987a, 1990) at Peggy Lake in the lower San Jacinto Valley. Original figure based on model developed by Paine.

extremely likely to result in colluvial mantles on footslopes and toeslopes.

Archeological materials in the upland margin environment should be relatively shallowly buried in most cases, although depths of greater than $1 \mathrm{~m}$ may occur in some colluvial toeslope environments. Colluvial deposits should be particularly common in sandy to silty settings, but Paine's (1987a, 1990) work demonstrates that clayey sediments may also form colluvial mantles with archeological potential. Many colluvial deposits should be discrete and clearly unconformable with underlying sediments. However, subsequent soil development could mask such contacts, making differentiation of colluvium and substrate difficult. Eolian deposits, including fine-grained loess and coarser sandy sediments, may also be present on the slopes and upland margins, particularly adjacent to the larger drainages and the coast. Like colluvial deposits, such eolian deposits may be either distinct from or gradational with the underlying substrate.

\section{THE HOUSTON DISTRICT AS AN EVOLVING ARCHEOLOGICAL LANDSCAPE}

From the perspective of cultural ecology, any given landscape represents a spatio-temporal matrix of resources and constraints (Butzer 1982). These 
resources, whether biological (plants and animals) or abiotic (e.g., building materials, lithic raw material, water), are patterned on the landscape in specific, albeit complex and interrelated, ways. Human adaptation to a given landscape is accomplished through a complex network of shared knowledge, principles, and traditions that are collectively termed culture. Any given cultural system reflects myriad choices made and agreed upon by its members, both past and present, and thus is a dynamic entity that will (and must) evolve through time. Although the range of possible choices available to a given culture group is extremely varied, it is constrained by three limiting factors. The first of these is extant technology. Although the technological framework is subject to change through innovation or diffusion, no culture can surmount the limitations imposed by a lack of technological knowledge. The second constraint is imposed by the beliefs and values of the culture, which often exclude potential adaptive strategies that could otherwise be adopted. For example, although insects represent a tremendous, renewable protein resource, few modern Americans would consider taking advantage of them to satisfy their nutritional needs. Finally and most obviously, adaptation is limited by the suite of resources available to a given population. In the Houston District, the density and distribution of resources through time, and the constraints imposed by these patterns of resource availability, provided the canvas upon which the hunter-gatherers of the Houston District fashioned their subsistence, settlement, and organizational strategies.

One of the more striking lessons imparted by study of the geomorphic and paleoenvironmental data is the realization that landscapes are not static entities, even within relatively short-term frameworks. As the character of a landscape and its associated suite of resources evolves, cultural systems adapted to the landscape must also evolve. Thus, understanding of cultural adaptation and change requires a complementary understanding of the evolution of the host landscape. Unfortunately, it is impossible to know the details of past resource distributions (particularly biological resources) in any detail, because the diverse information needed to reconstruct such a complex spatial mosaic is either not available or is not practical to pursue due to the very intensive costs and time demands involved. For example, while it is relatively easy to determine and map the modern distribution and density of any particular biological resource (e.g., pecan trees, oyster reefs) within a given area, determining the distribution and density of those same resources, even at a much simpler level of detail, for any given time in the past varies from extremely difficult and costly to impossible. Nevertheless, it is frequently possible to infer broad resource availability and landscape patterns from available evidence. In particular, it is possible to characterize the evolution of the physical landscape through detailed examination of the geomorphologic, stratigraphic, and pedologic evidence. The more elusive biotic landscape can be approximated using indirect evidence and inference based on modern distributions. This final section of Chapter 4 examines the Houston District from the perspective of landscape change and its effect on the archeological record. Because many aspects of the discussion are not well-grounded, it should be considered a preliminary statement only.

The six counties making up the Houston Highway District were characterized by landscapes very different from the present during the latest Pleistocene and Early Holocene (for purposes of this discussion, roughly $14,000-8,000 \mathrm{BP}$ ). As detailed previously in this chapter, sea level was approximately $150-200$ feet lower than present 10,000 years ago, and the shoreline was shifted $60-80 \mathrm{~km}$ seaward. The larger streams in the district, such as the Brazos and the San Jacinto, were deeply incised (up to $30 \mathrm{~m}$ below the modern floodplain) in response to the drop in sea level, and had pronounced multi-tiered alluvial fill terraces that differed in elevation by up to 15-25 $\mathrm{m}$. The degree of incision of the smaller streams probably varied considerably, but average gradient was much steeper than in the modern systems and many were actively cutting headward across the smooth Late Pleistocene alluvial-deltaic surfaces.

Reconstructions of paleotopography currently offshore (Abdulah 1995) suggest that, during the last sea-level low stand, the ancestral Brazos and Trinity systems merged on the Coastal Plain before entering the Gulf (Figure 56). Based on the isotopic signature of alluvial deposits from this period, the broad, smooth landscape near the coast was probably dominated by open prairie that included a significant population of $\mathrm{C}_{4}$ grasses. While it is likely that the streams had associated riparian corridors, the outer Coastal Plain appears to have been a refugium for "tropical" $\mathrm{C}_{4}$ species that were practically non-existent in the interior (see Appendix III). This grassland would 


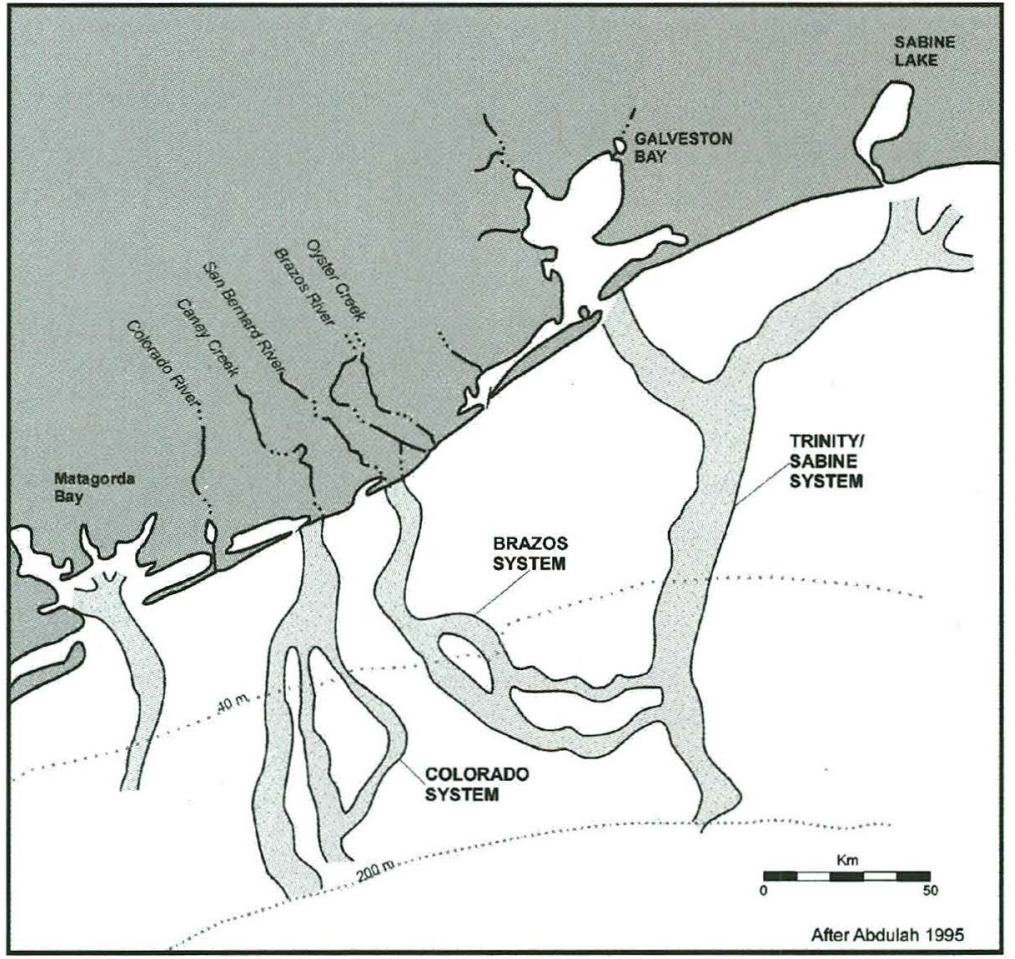

Figure 56. Map of Late Pleistocene (Oxygen Isotope Stage 2) incised valleys on the upper Texas paleocoastline, after Abdulah (1995).

have probably hosted a diverse suite of plants and animals, including a variety of Pleistocene megafauna, and would therefore have been an attractive landscape for food procurement and habitation.

Away from the coast in the interior parts of the District, the widespread occurrence of Alfisols and Ultisols (many with albic horizons) suggests that pine/hardwood forests and/or closed woodlands were probably present, both in their current range and in adjacent areas now occupied primarily by grasslands and open woodlands. The alluvial record indicates that discharge from the major rivers was substantially greater than at present, and the systems were sand-dominated and rapidly reworked by migrating channels. However, large flood events were also probably uncommon, and overbank environments were consequently less pervasive than today in larger systems like the Brazos and San Jacinto. Smaller systems on the Beaumont and Lissie surfaces were narrow and relatively straight, and probably also quickly reworked alluvium deposited in their valleys, while inland valleys were sand and gravel-dominated. The character of the shoreline is unknown, although it is unlikely that extensive barrier systems were developed.
Nevertheless, the high rate of discharge was clearly matched by significant sediment delivery to the coast, and consequent deltaic sedimentation in areas that are now far offshore.

Although sparse sites and isolates clearly demonstrate that Paleoindian and Early Archaic people lived in the Houston District, there is little archeological evidence for the character of adaptation, because the extant record is strongly skewed towards relatively recent archeological sites. Although this bias could be partially remedied by a program focused on the identification and examination of deposits dating to this period (Aten 1983:141), preservation of sites from this time period is clearly limited. Understanding of coastal adaptations, in particular, is hampered by inundation of the paleo-coastline during sea level rise. Therefore, while the understanding of Paleoindian and Early Archaic adaptation could probably be improved considerably by targeted prospection for sites with reasonable integrity, the range of environments from this period that are preserved is limited, and the spectrum of adaptation is therefore largely inaccessible.

During the Early to Middle Holocene, climate was warming and possibly drying, and the shoreline rapidly regressed as global sea level rose, overriding and eroding former terrestrial environments on the shorefront. At the same time, salt water rapidly invaded inland up the lower river valleys, creating open estuarine environments. In the case of the Brazos (and possibly the Colorado), estuarine formation appears to have been limited because the river delivered enough sediment to maintain a near-coastal delta as sea level rose. The Trinity/San Jacinto valley, in contrast, was flooded extensively as the Gulf invaded inland, and remains so to this day. Although evidence is sparse, the forests and woodlands may have contracted north and east during this period in response to the encroaching salt water, compensating somewhat for the loss of coastal grasslands as sea level rose. 
The Early to Middle Holocene also appears to have witnessed a fundamental change in the depositional style of the larger streams in the district, which shifted from sandy, broad channels with little floodplain development to narrower, deeper alluvial channels with localized meanderbelts and (in the larger systems) broad clayey floodplains. At the same time, many floodplains in the district began to rapidly aggrade in response to rising sea level, isolating and burying a succession of potential short-term occupation surfaces. Because the channels and floodplains were aggrading rapidly, the frequency of channel avulsion events was probably high, particularly in larger systems like the Brazos and Colorado. In the latter part of the Middle Holocene, the trend towards warming and drying reached its peak, and sea level approached and possibly exceeded its current elevation (Paine 1987b; Aronow et al. 1994; Michael Blum, personal communication, 1999). Simultaneously, the rate of floodplain aggradation slowed dramatically, and it is likely that the frequency of large-scale avulsion events also decreased as meander belts became more stable. The character of smaller streams is more poorly known. Few alluvial deposits dating to the Early-Middle Holocene have been identified in the district. The presence and accessibility of older deposits is questionable in the small, narrow streams that flow across the Beaumont and Lissie surfaces, but they are more likely to be preserved in the more mature valleys in the northern part of the district.

The suite of biotic resources available during the Middle Holocene was probably substantially similar to those present at the time of European contact, although the relative abundance of grassland and woodland species may have fluctuated in response to climatic shifts. For example, the availability of bison was probably periodic at best during the Holocene on the Coastal Plain (Dillehay 1974), while the grassland would probably have flourished in comparison to the forest during the warm "Altithermal" phase(s). Marine resource availability probably also fluctuated under the influence of periodic minor changes in sea level (Ricklis 1993; Ricklis and Blum 1997). Other factors, such as the severity and recurrence of hurricanes, autocyclic variations in coastal processes, and the rate of clastic delivery by major streams may also have affected the abundance and character of marine resources. There is good evidence that production of clastic sediments in the Brazos and Colorado drainages (and probably the Trinity also) was elevated by significant erosion of thick Pleistocene soils in the basins during the Middle Holocene (Nordt 1992; Toomey et al. 1993). Because this increase is reflected in the carbon signature of sediments dating to the period but not in the volume of sediment stored in the valleys, it is likely that this increased production was accompanied by increased discharge of clastic effluent from the river mouths. Such increases in suspended sediment can dramatically affect marine organisms in the coastal environment (Stickney 1984).

By the Late Holocene (roughly $4 \mathrm{ka}$ ), the Houston District landscape was beginning to approximate its modern configuration. The ocean had achieved an elevation within a few meters of modern sea level, and the barrier islands were emerging and stabilizing. As this occurred, open ocean influences on the estuarine and bay systems declined, and a rich and varied suite of marine resources developed in the protected waters. The terrestrial environment exhibited a biotic mosaic that varied between open prairie to the south and closed pine forest to the northeast. At many locations across the district, vast fields of pimple mounds were developing on the uplands, and floodplain mounds were forming in the drainage systems. By at least 1-2 ka, and possibly earlier, the environment appears to have achieved the same basic character that the Europeans first encountered.

Although Middle Archaic remains are known, the archeological record is dominated by Late Holocene sites, including the pre-ceramic Late Archaic sites and a wealth of Late Prehistoric sites. Although geomorphic bias clearly plays a role in the higher frequency of these more recent sites relative to Middle Archaic and older sites, a dramatic increase in population across the region probably occurred also (Patterson 1995). There are clear material culture differences apparent between the coastal occupations, which focused on exploitation of marine resources, and inland occupations focused on terrestrial resources. Despite these differences, which may represent seasonal scheduling by groups exploiting both environments and/or groups practicing completely different subsistence strategies, all represent variations on a broad-based, mobile hunting and gathering adaptation. No evidence that horticulture was practiced in the area has been advanced, and there 
has consequently been no suggestion that people had a significant impact on the environment prior to European contact. However, the recently analyzed pollen column from Kinglet Bog exhibits several interesting characteristics that may indicate that the prehistoric people did play a significant role in shaping the environment. The oldest levels in the core, which predate $1 \mathrm{ka}$, are dominated by grasses, Ambrosia (ragweed), and Asteroideae (aster and related compound herbs), and not by the pines and hardwoods that would be expected in this part of northern Harris County during this period. While this may reflect a climatic signal, the high incidence of ragweed and aster are suggestive of an early succession assemblage that accompanies deforestation (Webb 1973; Bradley 1985). While the frequency of oak increases in the following interval, the most notable increase is in the frequency of finely divided charcoal, which occurs in abundance for more than $50 \mathrm{~cm}$ of the column. Although the sampling interval is not particularly tight, the fact that this charcoal is relatively continuous rather than spiky suggests that intentional, repeated burns rather than occasional natural fires may have been responsible. While far from conclusive, these data suggest that the prehistoric peoples of the Houston District may have played a more active role in shaping their environment than previously believed. 


\section{Chapter 5}

\section{Potential Archeological Liability Mapping of the Houston District}

\section{INTRODUCTION}

TxDOT routinely affords consideration to cultural resources affected by road construction and maintenance. In cases where projects involve federal funds or federal oversight, this consideration is mandated by the National Historic Preservation Act of 1966 (as amended) and is afforded in accordance with a Programmatic Agreement (PA) among TxDOT, the Federal Highway Administration (FHWA), the Texas State Historic Preservation Officer (SHPO), and the Advisory Council on Historic Preservation. In cases where federal funds or oversight are not involved, consideration is mandated by the Antiquities Code of Texas, and administered under a Memorandum of Understanding (MOU) between TxDOT and the Texas Historical Commission (THC). These agreements strongly encourage development programs to identify and mitigate significant cultural resources by means that are scientific, timely, and cost-effective. Such programs may be used to augment, or in some cases replace, traditional archeological and historical methodologies. TxDOT, recognizing the benefits of a proactive stance to the agency and the historic preservation community, has implemented several programs of proactive research. Examples include a protocol for archeological monitoring, a statewide inventory and evaluation of historic truss bridges, an inventory of depression-era properties, and an inventory of historic roadside parks. Each of these programs was developed to meet TxDOT's compliance responsibilities and its ethical responsibility to design and conduct such studies in a manner that contributes to the state of knowledge about the cultural resources in Texas. This part of the report describes the rationale and methodology for design and implementation of another resource to further these goals, the Houston District Potential Archeological Liability Map (Houston-PALM).
The Houston-PALM is a geoarcheological model designed as a decision-support tool for use by TxDOT in the compliance process. The model represents a relatively simple, spatially oriented classification of the landscape in the Houston District developed using the concepts and data outlined in Chapters 2-4 of this document. It allows confident a priori assessment of geoarcheological potential and the potential impact on archeological resources by transportation activities without requiring a field visit. Properly utilized, HoustonPALM can increase the efficiency of cultural resource management (CRM) operations by: (1) identifying areas where the character or age of deposits is not consistent with preservation of archeological sites in good context, thus limiting the area where archeological survey and testing is recommended; and (2) identifying areas where depositional processes have been active during the Late Pleistocene/Holocene, requiring deep mechanical prospection to locate buried archeological sites.

Because the ultimate goal of the compliance process is to identify significant archeological sites (e.g., potential National Register properties or State Archeological Landmarks), and because archeological compliance is expensive and timeconsuming, it follows that the presence of a mechanism for early identification of areas where significant sites are not likely to occur or are likely to be deeply buried can yield considerable savings in manpower and expenditures. Although significance varies based on the extant suite of research questions that drive evaluation, few questions can be adequately addressed from sites lacking reasonable contextual integrity. Thus, a landscape model such as Houston PALM is a powerful tool for maximizing information return, and minimizing expenditures incurred locating and testing sites lacking legal significance. 
The Houston-PALM is explicitly a tool to facilitate management of archeological resources in the district under a contextual paradigm (Butzer 1980), and was developed under consultation with the Texas SHPO and outside reviewers. Given that reasonable archeological integrity is requisite for a site to be judged significant under current standards, the Houston-PALM provides an efficient mechanism to concentrate agency resources where they will be most beneficial. Although CRM is often equated with "conservation archeology" (Schiffer and Gumerman 1977; Kerber 1994), there is an important distinction between the two. Conservation archeology is essentially a paradigm for study that recognizes that archeological excavation is an inherently destructive process that should be carried out only if "the destruction of the resource is beyond the archaeologist's control, or if the information contained in that resource is believed to be potentially of great immediate research value" (McGimsey and Davis 1984:120). It advocates conservation of representative sites for future generations when improved techniques will allow extraction of more comprehensive or higher quality data (Fowler 1982; Kerber 1994). In contrast, CRM archeology is not a paradigm, but rather a process by which adverse impacts on cultural resources are addressed and minimized under existing federal and state laws. The Section 106 process does not allow significance determination on the basis of undemonstrable potential future research value. The Secretary of the Interior's Standards and Guidelines for Evaluation state that "evaluation of the significance of historic properties uses established criteria" and "a statement of the minimum information necessary to evaluate properties against criteria should be provided to direct information gathering activities." In other words, the significance of a historic property (i.e., an archeological site eligible for inclusion in, or listed on, the National Register of Historic Places) is dependent upon the ability of the property to further extant research goals using extant methodology. Although the significance of a historic property may change as research questions evolve or methods improve (see 36 CFR 800.4(c)), the potential future research value of a historic property is not relevant to significance decisions made in connection with scheduled undertakings affecting a given site.

Although Houston-PALM can be considered a predictive model, it differs from other models in archeology in that the emphasis here is predicated on the preservation potential of the environment rather than on behavior. The distinction between these two different, yet equally valid approaches is illustrated by comparing the Houston-PALM to a different Houston area predictive model that was developed by Roger Moore and is currently used by the Texas Water Development Board (TWDB) (Moore 1995a, 1995b). Moore's model generates certain predictions for site locations in Harris County based on cultural preferences deduced from the archeological record (e.g., sites are more common in forested areas than grasslands, near potable water, and on sandy to loamy rather than clayey substrates); in other words, it predicts the location of sites based on the reconstruction and interpretation of behavior-what the prehistoric population did or did not do-rather than the processes of site formation. The Houston-PALM, in contrast, is predicated on the potential for archeological preservation and integrity. Although there are a few instances where behavioral inferences are incorporated-for example, the coastal salt marshes are not considered to have particularly high potential because they have been wet since their formation, even though they clearly represent significant deposition in the culturally relevant time frame-the model is directed towards identifying where on the landscape sites are likely to be preserved with reasonable integrity, rather than where they are likely to exist.

\section{MAP DESIGN AND IMPLEMENTATION}

This section describes the design and development of the Houston-PALM. The project was conceived as a planning tool that would provide decision support for TxDOT planners and archeologists, regulatory agencies, and the broader archeological community. In order to be an effective tool, it was determined that the Houston-PALM should be:

(1) Accurate

The primary attribute of a successful model is reasonable accuracy and reliability, which is necessary to justify management decisions made on the basis of the model;

(2) Explicit

The criteria for mapping and methods used 
should be reasonable, scientifically grounded, and clearly stated;

(3) Readily Interpretable

In order to be a useful tool for a broad range of users, the map units should be as few and as conceptually simple as possible to effectively communicate the necessary information;

(4) Appropriately Detailed

The scale of mapping should be adjusted to provide a sufficient level of resolution for the proposed use without a surfeit of distracting detail;

(5) Accessible

The finished map should be delivered in a form readily accessible to the primary users; and

(6) Developed in a Timely Manner

The map should be delivered in a reasonable amount of time under a reasonable budget.

The Houston-PALM methodology was developed to provide a degree of accuracy and detail appropriate for the types of long, linear impacts created by transportation projects. While this level of detail is also applicable to other linear impacts (e.g., pipelines, transmission routes), it is less appropriate for impacts affecting large contiguous areas (e.g., subdivisions, landfills) which, due to their coverage, are more likely to contain significant internal variability. Therefore, while the mapped units should provide a good indication of overall preservation potential in a given tract, survey decisions should balance the Houston-PALM information against the extent and intensity of impact. In many of these cases, prudent consideration of the archeological record may require more conservative survey decisions (i.e., more work) than indicated for the locality by Houston-PALM. Therefore, TxDOT does not endorse the use of this tool for any purpose other than its intended function.

\section{Methodology}

The methodology of mapping was designed to satisfy the criteria presented above, and was integrated into the project as a whole. Based upon literature review and field reconnaissance, an initial matrix was constructed that identified basic landscape unit classes in the district and their geoarcheological potential. Because this determination could often not be confidently made, the matrix was used as a heuristic device to identify a series of extant data gaps. Where possible, these data gaps were addressed with directed field research (see Chapter 4).

Principal data gaps identified include:

(1) The stratigraphic characteristics (e.g., age, facies relationships, and architecture) of small and intermediate streams and bayous in the district;

(2) The stratigraphic characteristics (e.g., age, facies relationships, and architecture) of the lower Brazos River and Brazos River delta;

(3) The presence and, if proven to exist, the age, extent, and origin of Holocene-age veneers on upland and Late Pleistocene ("Deweyville") age alluvial terrace surfaces in the district;

(4) The age and extent of Holocene colluvial deposits in the district;

(5) The character and geoarcheological potential of coastal marsh environments; and

(6) The morphology and temporal implications of soil profiles developed on landforms of different ages in the Houston area.

These data gaps represent an extremely diverse set of questions, and could not be satisfactorily resolved by a single person working within a restricted time frame and a limited budget. Given these realities, primary fieldwork conducted during this study was never intended to fully resolve the gaps identified in the extant database. However, it was felt that a limited amount of directed fieldwork could contribute substantially to clarifying many of the identified issues, and thus improve the accuracy and reliability of the map. Because mapping was conducted conservatively to afford maximum protection to the archeological resource, and because most extant geological information from the Houston District does not have a geoarcheological focus, the additional information gained from primary fieldwork was very important in identifying landscape elements with poor geoarcheological potential. The results of fieldwork conducted during this study are integrated into Chapter 4 of this document. 
Based on the results of this work, the initial matrix was revised (Table 9) and used to construct a set of explicit mapping criteria in consultation with the Texas SHPO and independent reviewers (see next section). These criteria were then used to map geoarcheological potential in the district. Mapping was conducted using aerial stereopair photographs, in conjunction with field checking and reference to available soils and geologic data, on a base provided by USGS 7.5 minute quadrangles. Six basic map units were defined:

Map Unit 1: Surface Survey Recommended, Deep Reconnaissance Recommended if Deep Impacts are Anticipated.

This map unit is characteristic of areas underlain by deep Holocene deposits that exhibit low to moderate surficial disturbance. The phrase "surface survey" includes shovel testing, which is necessary in all Houston area settings to identify sites.

Map Unit 2: Surface Survey Recommended, No Deep Reconnaissance Recommended.

This map unit is characteristic of Holoceneage, alluvial, eolian, or colluvial veneer deposits that exhibit low to moderate evidence of disturbance and rest on Pleistocene landforms. As in Map Unit 1, the phrase "surface survey" includes shovel testing.

Map Unit 2a: Surface Survey of Mounds Only; No Deep Reconnaissance Recommended.

This unit is used to map areas where pimple mounds appear to be preserved on the uplands. The map unit was created because such features have archeological potential and are impractical to map individually. Survey should be limited to mounds.

Map Unit 3: No Surface Survey Recommended, Deep Reconnaissance Recommended if Deep Impacts are Anticipated.

This map unit is characteristic of Holocene landforms exhibiting recent veneer sediments, thick recent deposits, or Holocene deposits with moderate surface disturbance, particularly within intensively farmed areas. It is characteristic of rural settings on the Brazos delta, in the modern Brazos meanderbelt, and in flood basins.
Map Unit 3a: No Surface Survey Recommended, Deep Reconnaissance Recommended only if Severe Deep Impacts are Anticipated.

This map unit is similar to Map Unit 3. It is reserved for areas where trenching is logistically complicated, such as urbanized areas and marshes. While the term "severe deep impacts" is intentionally vague to allow archeological review staff maximum flexibility in evaluating individual projects, it is intended to address projects such as storm sewers, detention ponds, and new location of roads where large volumes of material will be affected.

\section{Map Unit 4: No Survey Recommended.}

This unit is characteristic of stable or erosional Pleistocene landforms lacking Holocene veneers, Pleistocene landforms in urban contexts, areas underlain by deposits of recent (historic) age, and made land (e.g., dredge spoil).

In addition to these six units, a seventh unit (Map Unit 0, water bodies, no survey required) was employed. All of the surface area of the district was assigned to one of the units.

\section{MAPPING CRITERIA}

As described above, development of the final mapping criteria used in constructing the HoustonPALM was a multi-stage process. Three primary criteria were used in making mapping decisions: (1) landform type; (2) soil type; and (3) evidence of historic/recent land use. The protocol used in mapping the Houston-PALM is illustrated in Figure 57. The following paragraphs describe the application of that protocol.

The first decision required in mapping was determination of the broad environmental setting, of which there are four possibilities: upland, coastal, riverine, and water. Upland environments are those underlain at shallow depth by deposits pre-dating the Holocene. In most cases, this determination was made with the appropriate Geologic Atlas of Texas sheet (Barnes 1974a, 1974b, 1975, 1982, 1992). In a few localities, primarily in the southwestern part of the district, more geoarcheologically conservative mapping in the Environmental Geologic Atlas of 
Table 9. Evaluation of geoarcheological potential of Houston District landforms.

\begin{tabular}{|c|c|c|c|c|c|c|c|c|c|c|c|c|}
\hline \multirow[b]{2}{*}{ Landform Class } & \multirow[b]{2}{*}{ Landform } & \multirow[b]{2}{*}{ Landform Element } & \multicolumn{2}{|c|}{ Paleoindian } & \multicolumn{2}{|c|}{ Early Archaic } & \multicolumn{2}{|c|}{ Middle Archaic } & \multicolumn{2}{|c|}{ Late Archaic } & \multicolumn{2}{|c|}{$\begin{array}{c}\text { Late Prehistoric/ } \\
\text { Protohistoric }\end{array}$} \\
\hline & & & $\begin{array}{c}\text { Surface } \\
\text { Potential }\end{array}$ & $\begin{array}{c}\text { Deep } \\
\text { Potential }\end{array}$ & \begin{tabular}{l|l} 
urface \\
tential \\
\end{tabular} & $\begin{array}{c}\text { Deep } \\
\text { Potential } \\
\end{array}$ & $\begin{array}{c}\text { Surface } \\
\text { Potential }\end{array}$ & $\begin{array}{c}\text { Deep } \\
\text { Potential }\end{array}$ & $\begin{array}{c}\text { Surface } \\
\text { Potential }\end{array}$ & $\begin{array}{c}\text { Deep } \\
\text { Potential }\end{array}$ & $\begin{array}{c}\text { Surface } \\
\text { Potential }\end{array}$ & $\begin{array}{c}\text { Deep } \\
\text { Potential }\end{array}$ \\
\hline Coastal Landforms & $\begin{array}{l}\text { Delta } \\
\text { Estuary } \\
\text { Lagoon }\end{array}$ & $\begin{array}{l}\text { Beach } \\
\text { Barrier crest } \\
\text { Washover Fan } \\
\text { Saltwater/Brackish Marsh } \\
\text { Lagoon Margin } \\
\text { Delta Front } \\
\text { Delta Plain } \\
\text { Historic Delta } \\
\text { Estuary Margin Slope } \\
\text { Tidal Flat } \\
\text { Lagoon Margin Slope } \\
\text { Tidal Flat } \\
\text { Saltwater/Brackish Marsh } \\
\text { Freshwater Marsh } \\
\end{array}$ & $\begin{array}{c}\text { none } \\
\text { none } \\
\text { none } \\
\text { none } \\
\text { none } \\
\text { none } \\
\text { none } \\
\text { none } \\
\text { moderate } \\
\text { none } \\
\text { slight } \\
\text { none } \\
\text { none } \\
\text { none }\end{array}$ & $\begin{array}{l}\text { none } \\
\text { none } \\
\text { none } \\
\text { none } \\
\text { none } \\
\text { none } \\
\text { none } \\
\text { none } \\
\text { slight } \\
\text { none } \\
\text { slight } \\
\text { none } \\
\text { none } \\
\text { none }\end{array}$ & $\begin{array}{c}\text { none } \\
\text { none } \\
\text { none } \\
\text { none } \\
\text { none } \\
\text { none } \\
\text { none } \\
\text { none } \\
\text { moderate } \\
\text { none } \\
\text { moderate } \\
\text { none } \\
\text { none } \\
\text { none }\end{array}$ & $\begin{array}{l}\text { none } \\
\text { none } \\
\text { none } \\
\text { none } \\
\text { none } \\
\text { none } \\
\text { slight } \\
\text { none } \\
\text { slight } \\
\text { none } \\
\text { slight } \\
\text { none } \\
\text { none } \\
\text { none }\end{array}$ & $\begin{array}{l}\text { none } \\
\text { none } \\
\text { none } \\
\text { none } \\
\text { none } \\
\text { none } \\
\text { none } \\
\text { none } \\
\text { good } \\
\text { none } \\
\text { good } \\
\text { none } \\
\text { none } \\
\text { none }\end{array}$ & $\begin{array}{l}\text { none } \\
\text { none } \\
\text { slight } \\
\text { none } \\
\text { none } \\
\text { none } \\
\text { slight } \\
\text { none } \\
\text { slight } \\
\text { none } \\
\text { slight } \\
\text { slight } \\
\text { none } \\
\text { none }\end{array}$ & $\begin{array}{l}\text { none } \\
\text { good } \\
\text { none } \\
\text { none } \\
\text { slight } \\
\text { none } \\
\text { none } \\
\text { none } \\
\text { good } \\
\text { none } \\
\text { good } \\
\text { none } \\
\text { none } \\
\text { none }\end{array}$ & $\begin{array}{l}\text { none } \\
\text { good } \\
\text { moderate } \\
\text { none } \\
\text { slight } \\
\text { slight } \\
\text { slight } \\
\text { none } \\
\text { slight } \\
\text { none } \\
\text { slight } \\
\text { slight } \\
\text { none } \\
\text { none }\end{array}$ & $\begin{array}{l}\text { none } \\
\text { good } \\
\text { none } \\
\text { none } \\
\text { slight } \\
\text { none } \\
\text { none } \\
\text { none } \\
\text { good } \\
\text { none } \\
\text { good } \\
\text { none } \\
\text { none } \\
\text { none }\end{array}$ & $\begin{array}{c}\text { none } \\
\text { good } \\
\text { moderate } \\
\text { none } \\
\text { slight } \\
\text { slight } \\
\text { slight } \\
\text { none } \\
\text { slight } \\
\text { none } \\
\text { slight } \\
\text { slight } \\
\text { none } \\
\text { none }\end{array}$ \\
\hline Riverine Landforms & $\begin{array}{l}\text { Channel } \\
\text { Floodplain/Active } \\
\text { Meander Belt } \\
\text { Holocene Terrace } \\
\text { Pleistocene Terrace }\end{array}$ & $\begin{array}{l}\text { Active Channel } \\
\text { Floodbasin } \\
\text { Oxbow Lake } \\
\text { Oxbow Margin } \\
\text { Levee } \\
\text { Crevasse Splay } \\
\text { Point Bar } \\
\text { Chute Channel } \\
\text { "floodplain mound" } \\
\text { Floodbasin } \\
\text { Meander Scar } \\
\text { Levee } \\
\text { Crevasse Splay } \\
\text { with Holocene veneer } \\
\text { without Holocene veneer }\end{array}$ & $\begin{array}{l}\text { none } \\
\text { none } \\
\text { none } \\
\text { none } \\
\text { none } \\
\text { none } \\
\text { none } \\
\text { none } \\
\text { none } \\
\text { none } \\
\text { none } \\
\text { none } \\
\text { none } \\
\text { slight } \\
\text { slight }\end{array}$ & $\begin{array}{l}\text { none } \\
\text { slight } \\
\text { none } \\
\text { slight } \\
\text { slight } \\
\text { slight } \\
\text { none } \\
\text { slight } \\
\text { none } \\
\text { slight } \\
\text { slight } \\
\text { slight } \\
\text { slight } \\
\text { slight } \\
\text { slight }\end{array}$ & $\begin{array}{l}\text { none } \\
\text { none } \\
\text { none } \\
\text { none } \\
\text { none } \\
\text { none } \\
\text { none } \\
\text { none } \\
\text { none } \\
\text { none } \\
\text { slight } \\
\text { slight } \\
\text { slight } \\
\text { slight } \\
\text { slight }\end{array}$ & $\begin{array}{c}\text { none } \\
\text { moderate } \\
\text { none } \\
\text { slight } \\
\text { slight } \\
\text { slight } \\
\text { slight } \\
\text { slight } \\
\text { slight } \\
\text { slight } \\
\text { slight } \\
\text { moderate } \\
\text { slight } \\
\text { slight } \\
\text { none }\end{array}$ & $\begin{array}{l}\text { none } \\
\text { slight } \\
\text { none } \\
\text { slight } \\
\text { slight } \\
\text { slight } \\
\text { none } \\
\text { slight } \\
\text { slight } \\
\text { slight } \\
\text { slight } \\
\text { moderate } \\
\text { slight } \\
\text { slight } \\
\text { none }\end{array}$ & $\begin{array}{c}\text { none } \\
\text { moderate } \\
\text { none } \\
\text { moderate } \\
\text { moderate } \\
\text { moderate } \\
\text { moderate } \\
\text { slight } \\
\text { slight } \\
\text { moderate } \\
\text { slight } \\
\text { moderate } \\
\text { slight } \\
\text { slight } \\
\text { none }\end{array}$ & $\begin{array}{l}\text { none } \\
\text { slight } \\
\text { none } \\
\text { moderate } \\
\text { moderate } \\
\text { moderate } \\
\text { slight } \\
\text { slight } \\
\text { moderate } \\
\text { slight } \\
\text { slight } \\
\text { moderate } \\
\text { slight } \\
\text { slight } \\
\text { none }\end{array}$ & $\begin{array}{c}\text { none } \\
\text { good } \\
\text { none } \\
\text { good } \\
\text { good } \\
\text { good } \\
\text { moderate } \\
\text { slight } \\
\text { slight } \\
\text { moderate } \\
\text { slight } \\
\text { good } \\
\text { slight } \\
\text { slight } \\
\text { none }\end{array}$ & $\begin{array}{c}\text { none } \\
\text { slight } \\
\text { none } \\
\text { moderate } \\
\text { moderate } \\
\text { moderate } \\
\text { slight } \\
\text { slight } \\
\text { moderate } \\
\text { moderate } \\
\text { slight } \\
\text { moderate } \\
\text { slight } \\
\text { slight } \\
\text { none }\end{array}$ & $\begin{array}{l}\text { none } \\
\text { good } \\
\text { none } \\
\text { good } \\
\text { good } \\
\text { good } \\
\text { good } \\
\text { slight } \\
\text { slight } \\
\text { good } \\
\text { slight } \\
\text { good } \\
\text { slight } \\
\text { slight } \\
\text { none }\end{array}$ \\
\hline Upland Landforms & $\begin{array}{l}\text { Beaumont Surface } \\
\text { Lissie Surface } \\
\text { Pre-Lissie Surface }\end{array}$ & $\begin{array}{l}\text { Distributary Sands } \\
\text { Interdistributary Muds } \\
\text { Pimple Mounds } \\
\text { without Holocene veneer } \\
\text { with Holocene veneer } \\
\text { Pimple Mounds } \\
\text { Upland } \\
\text { Convex Slope } \\
\text { Concave Slope }\end{array}$ & $\begin{array}{l}\text { moderate } \\
\text { none } \\
\text { none } \\
\text { none } \\
\text { slight } \\
\text { none } \\
\text { none } \\
\text { none } \\
\text { slight } \\
\end{array}$ & $\begin{array}{c}\text { none } \\
\text { none } \\
\text { none } \\
\text { none } \\
\text { none } \\
\text { none } \\
\text { none } \\
\text { none } \\
\text { slight }\end{array}$ & $\begin{array}{l}\text { moderate } \\
\text { none } \\
\text { none } \\
\text { none } \\
\text { slight } \\
\text { none } \\
\text { none } \\
\text { none } \\
\text { slight } \\
\end{array}$ & $\begin{array}{l}\text { none } \\
\text { none } \\
\text { none } \\
\text { none } \\
\text { none } \\
\text { none } \\
\text { none } \\
\text { none } \\
\text { slight } \\
\end{array}$ & $\begin{array}{l}\text { moderate } \\
\text { none } \\
\text { slight } \\
\text { none } \\
\text { slight } \\
\text { slight } \\
\text { slight } \\
\text { slight } \\
\text { slight } \\
\end{array}$ & $\begin{array}{l}\text { none } \\
\text { none } \\
\text { none } \\
\text { none } \\
\text { none } \\
\text { slight } \\
\text { none } \\
\text { none } \\
\text { slight } \\
\end{array}$ & $\begin{array}{l}\text { moderate } \\
\text { none } \\
\text { moderate } \\
\text { none } \\
\text { slight } \\
\text { moderate } \\
\text { slight } \\
\text { slight } \\
\text { slight } \\
\end{array}$ & $\begin{array}{l}\text { none } \\
\text { none } \\
\text { slight } \\
\text { none } \\
\text { none } \\
\text { slight } \\
\text { none } \\
\text { none } \\
\text { slight } \\
\end{array}$ & $\begin{array}{l}\text { moderate } \\
\text { none } \\
\text { moderate } \\
\text { none } \\
\text { slight } \\
\text { moderate } \\
\text { slight } \\
\text { slight } \\
\text { slight } \\
\end{array}$ & $\begin{array}{l}\text { none } \\
\text { none } \\
\text { slight } \\
\text { none } \\
\text { none } \\
\text { slight } \\
\text { none } \\
\text { none } \\
\text { slight } \\
\end{array}$ \\
\hline
\end{tabular}




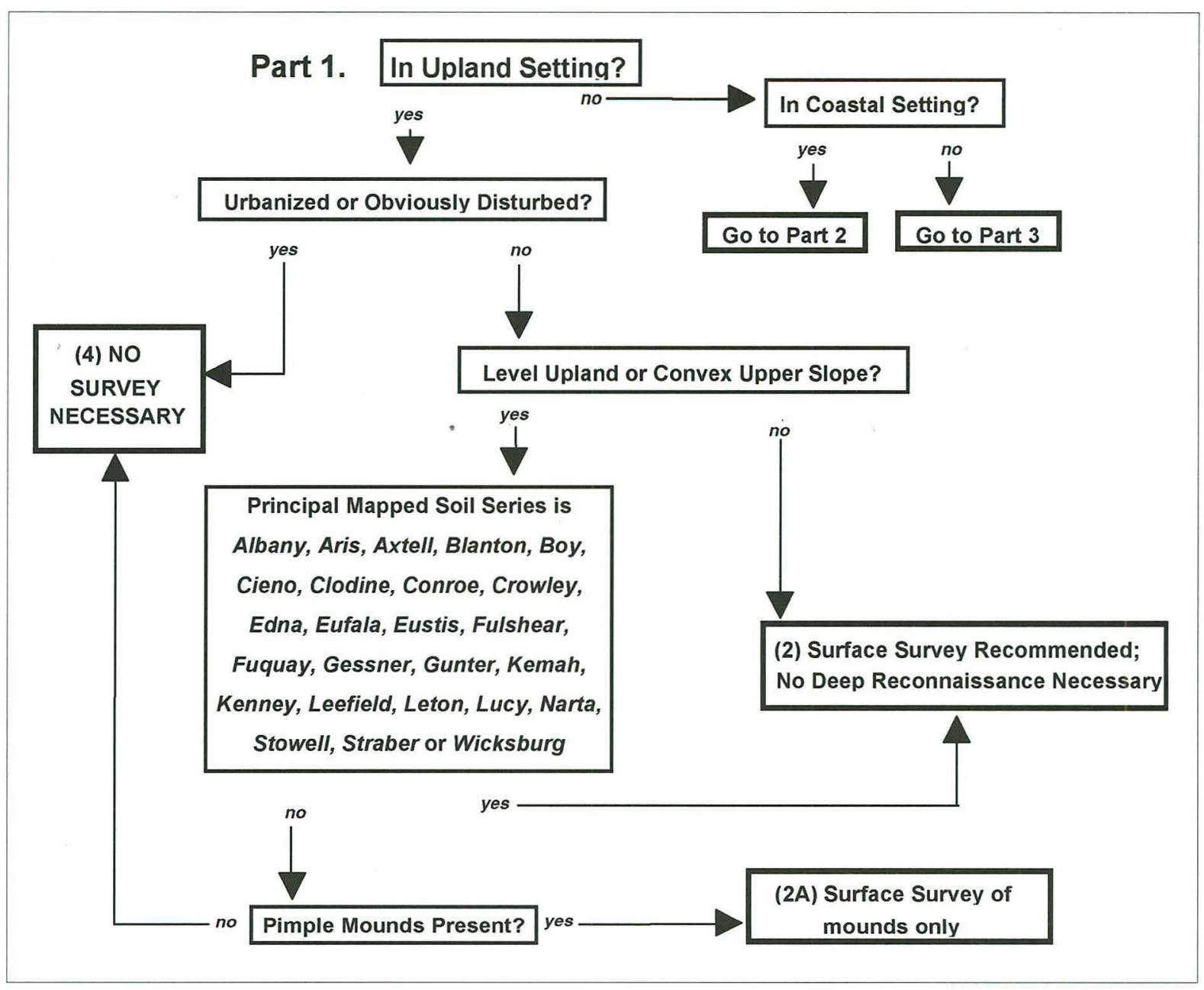

Figure 57. Flowchart illustrating the mapping protocol for the Houston-PALM.

the Texas Coastal Zone (McGowen et al. 1976; Fisher et al. 1972) was used (see Figure 39). Riverine and coastal settings are defined to subsume both Holocene deposits and dominantly erosional landforms associated with Holocene environments incised into Pleistocene (or older) deposits, including the slopes of incised estuaries and river valleys. To capture sites situated adjacent to the depositional settings, upland areas within approximately $1-2 \mathrm{~km}$ of the coast and $0.25-1.0 \mathrm{~km}$ of river valleys (excluding very small streams and bayous) were arbitrarily included in the coastal and riverine environments.

If a given tract is in an upland setting, the next decision involved a determination of whether the tract was urbanized or obviously disturbed. As used in this protocol, urbanization refers to the construction of relatively closely spaced buildings in an urban, suburban, or industrial setting, together with the installation of asphalt and concrete roadways, landscaping, and buried utilities. Obvious disturbance subsumes a number of phenomena indicative of wholesale disturbance of the shallow subsurface, including the presence of borrow pits, artificial channels, landfills, artificial levees and other earthworks, and spoil deposits. Both characteristics are considered to contraindicate survey, because the potential for preservation of near-surface archeological remains in such situations is low. Evidence of plow agriculture alone was not considered to constitute obvious disturbance, but evidence of large-scale terrain modification, such as the land leveling and berming necessary to create rice paddies, was considered to contraindicate survey.

If the tract in question was not urbanized or obviously disturbed, then a determination was made whether or not the tract represents a concave lower slope. Because appreciable upland relief in the 


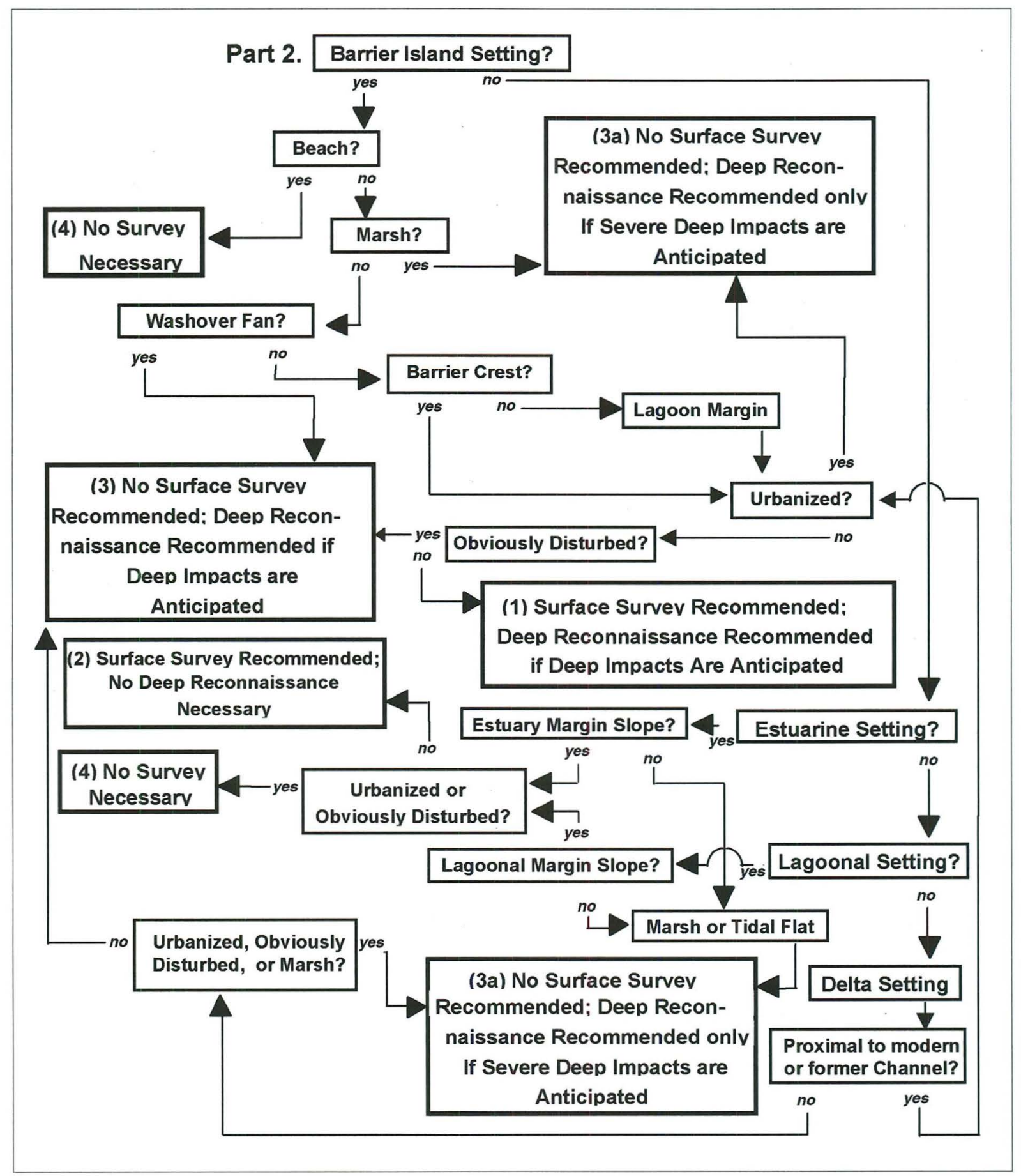

Figure 57. (Continued).

district is largely limited to the northern part (e.g., northern Harris, Montgomery, and Waller counties), where relatively sandy soils are also common, the presence of an identifiable footslope/toeslope assemblage was considered likely to be associated with sandy colluvial deposits. Even though many of these deposits are probably of very recent (i.e., historic) age, they do have the potential to contain archeological materials with reasonable integrity. Because the depth of such colluvial mantles is probably rarely more than one meter, only surface survey is recommended in such situations (Map 


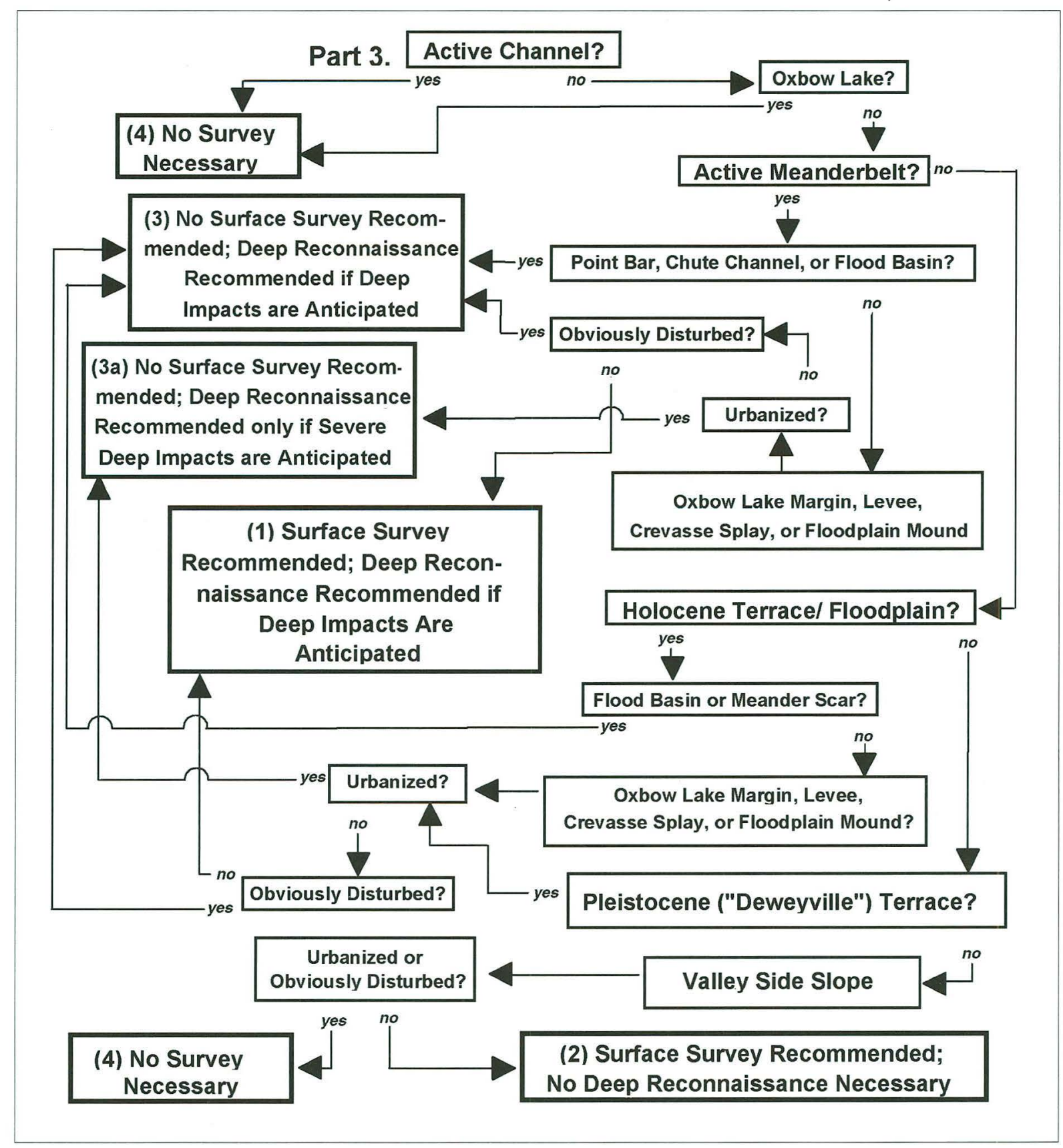

Figure 57. (Continued).

Unit 2). However, because deep testing may be required in a few of these settings where colluvial deposits are overthickened, field judgments may supersede this general recommendation.

If the upland setting is level or a convex upper slope, then a determination of the principal mapped soil series was made from the appropriate USDA County Soil Survey. Twenty-seven soil series are identified that could potentially include an eolian, colluvial, or biomantle cap of Holocene age based either on their published description or on an indication of high sand content in their USDA Soil Taxonomy classification (i.e., arenic and grossarenic soils). If one of these series (the Albany, Aris, Axtell, Blanton, Boy, Cieno, Clodine, Conroe, Crowley, Edna, Eufala, Eustis, Fulshear, Fuquay, Gessner, Gunter, Kemah, Kenney, Leefield, Leton, Lucy, Narta, Stowell, Straber, Styx, Waller, and 
Wicksburg series; see Table 2) is predominant in the tract (as mapped in the individual county soil surveys), then the tract was classified as Map Unit 2 (surface survey only). If not, the next determination was whether possible pimple mounds were apparent on the aerial photographs. If pimple mounds were observed on the aerial photographs, then the tract was classified as Map Unit 2a. Note that because mounds often have a distinctive associated subsoil, many of the mound fields identified in aerial photographs may have been destroyed by cultivation. If no pimple mounds are observed or suspected, the tract was classified as Map Unit 4 (no survey).

Where the tract in question is in a coastal setting, the first decision involved determination of the general environment, of which there are four possibilities: barrier island setting, delta setting, estuary setting, or lagoonal setting. If the setting was a barrier island, the determination was then made if the tract represents a beach, marsh, washover fan, barrier crest, or lagoonal margin environment. Beaches were classified as Map Unit 4 (no survey necessary), because there is little to no potential for buried prehistoric deposits in this dynamic environment. Marsh environments were classified as Map Unit 3a (no surface survey necessary; deep reconnaissance recommended only if severe deep impacts are anticipated) because, while there is potential for buried prehistoric sites (potentially with very good organic preservation), the high logistical difficulties involved in trenching in marsh environments makes routine application problematic. The use of this classification allows the project reviewer the flexibility to make decisions on a case by case basis. Washover fan identification was limited to recent (historic or modern) fans that can be clearly and confidently identified. For this reason, if the tract can be identified as a clear washover fan, it was classified as Map Unit 3 (no surface survey recommended; deep reconnaissance recommended if deep impacts are anticipated). If the tract occupied the crest (i.e., the area inland of the highest beach berm, including any dune that might be present) or lagoonal side of the barrier, and could not be identified as a clear washover fan, then a determination of urbanization/disturbance was made using the criteria outlined above. Urbanized areas were classified as Map Unit 3a (no surface survey necessary; deep reconnaissance recommended only if severe deep impacts are anticipated), disturbed rural areas were classified as Map Unit 3 (no surface survey recommended; deep reconnaissance recommended if deep impacts are anticipated), and undisturbed rural areas were classified as Map Unit 1 (surface survey recommended; deep reconnaissance recommended if deep impacts are anticipated).

Because the transition between riverine and deltaic environments is gradational, deltaic settings were arbitrarily defined as those areas within approximately $10 \mathrm{~km}$ of the coast on the large, wave-modified Brazos-Colorado delta (encompassing the Brazos River, San Bernard River, and Oyster Creek), and within $2 \mathrm{~km}$ of the coast on the smaller estuarine delta of the San Jacinto/Buffalo Bayou. If the tract was situated in a deltaic setting, then a determination was made whether or not the area is proximal to an extant or identifiable former channel. If so, a determination was then made if the area is urbanized or disturbed. If so, then the area was classified as Map Unit 3a (no surface survey necessary; deep reconnaissance recommended only if severe deep impacts are anticipated), otherwise, it was classified as Map Unit 1 (surface survey recommended; deep reconnaissance recommended if deep impacts are anticipated). If the area was not channel proximal, a determination was then made if the tract is urbanized, obviously disturbed, or a marsh. If so, then the area was classified as Map Unit 3a (no surface survey necessary; deep reconnaissance recommended only if severe deep impacts are anticipated); if not, the area was classified as Map Unit 3 (no surface survey necessary; deep reconnaissance recommended if deep impacts are anticipated).

In estuarine and lagoonal settings, locations that are occupied by freshwater or saltwater marshes (permanently wet), or wetted by the low tidal range (wetted on a daily basis), were mapped as Map Unit 3a (surface survey recommended; deep reconnaissance recommended only if severe deep impacts are anticipated). Once again, this classification allows the decision maker to weigh the potential for buried deposits to exist against the logistical difficulties of reconnaissance within the context of individual projects. All other locations were considered the estuarine/lagoonal margin slope. If urbanized or obviously disturbed (according to criteria outlined above), then the tract was classified as Map Unit 4 (no survey necessary); otherwise, it was classified as Map Unit 2 (surface survey only). 
If the tract occupies a riverine setting, then the mechanics of classification vary depending on the size of the stream. In the case of the Brazos River, the lower San Bernard River, and the San Jacinto River, a distinction was drawn between the active meanderbelt and the broader alluvial bottom. Landforms occupying the active meanderbelt are dominated by recent point bars, but may also include smaller features like oxbow lakes, chute channels, flood basins, oxbow lake margins (defined as flood basin areas within approximately $150 \mathrm{~m}$ of an oxbow lake), natural levees, crevasse splays, and floodplain mounds. Current and previous research (see Chapter 4) suggests that the active meanderbelts of these large streams are occupied by thick sediments laid down entirely within the last millennium, with near-surface sediments only a few hundred years old. For this reason, surface survey is contraindicated except in sandy environments that are highly attractive for occupation. Therefore, point bar, chute channel, and flood basin environments within the active meander belt were mapped as Map Unit 3 (no surface survey recommended; deep reconnaissance recommended if deep impacts are anticipated), while oxbow lake margin, levee, crevasse splay, and floodplain mound environments were mapped as Map Unit 1 (surface survey recommended; deep reconnaissance recommended if deep impacts are anticipated). Channel and oxbow lakes were excluded from survey (Map Unit 4), although exposed cutbanks should be examined in conjunction with survey of adjacent map units.

In areas outside of the active meanderbelt on larger streams, and on all medium to small streams, flood basin and meander scar (swale) deposits were not recommended for surface survey, but require deep reconnaissance when appropriate (Map Unit 3 ). In both cases, the high frequency of historic age deposits typical of these environments, coupled with a commonly presumed cultural bias against the dense, sticky muds they contain, contraindicates routine survey. However, in any case where the depth of disturbance will exceed approximately $75 \mathrm{~cm}$, mechanical trenching should be performed because other, more conducive, depositional environments may lie at depth. In contrast, oxbow lake margin, natural levee, crevasse splay, and floodplain mound deposits were recommended for routine surficial and appropriate deep survey (Map Unit 1) except in cases where they are urbanized or obviously disturbed (per above criteria). If disturbed, they were recommended only for deep reconnaissance when appropriate (Map Unit 3), while urbanized areas were recommended for deep reconnaissance only if severe deep impacts are anticipated (Map Unit 3a). Deeply channelized streams, which are common in the Houston metropolitan area, were not recommended for survey except where relatively undisturbed remnants of the original system can be identified. As in other environments, stream systems where the suite of sub-environments could not be confidently distinguished on available imagery were mapped conservatively (Map Unit 1).

The classification of areas occupying inset elevated (Deweyville) river terraces is also dependent on the extent of urbanization and surface disturbance. Urbanized areas are classified as Map Unit 3a, obviously disturbed areas are classified as Map Unit 3, and other areas are classified as Map Unit 1. Valley side slopes (and uplands within 0.25 to $1.0 \mathrm{~km}$ of the valley break) were mapped as Unit 2 (surface survey only), except where they are urbanized or disturbed (Map Unit 4; no survey).

The preceding methodology represents an explicit approach to mapping geoarcheological potential in the Houston District. However, several aspects of the application of this methodology require comment. The first issue that arises in applying the above methodology is the question of scale. As has been pointed out previously, some elements of the landscape have a fractal quality, in that variation is apparent at any level of detail. Because one of the goals of the Houston-PALM was an appropriate level of detail for use in planning, the decision was made to avoid mapping discrete areas smaller than approximately 5 acres. In most cases where smaller areas of differing potential were recognized, they were not mapped separately. The error introduced by this decision is acknowledged, but is not considered to have substantially impacted the accuracy of the map for its intended purpose.

The second issue involves the practical impediments to following the mapping protocol. In short, some of the depositional environments used to subdivide the landscape into areas of differing potential proved to be extremely difficult to recognize from aerial photographs and existing maps. This was particularly true in riverine settings and in densely forested areas. Every attempt was made to map the environments accurately, but 
intensive field mapping/checking of the more than $15,000 \mathrm{~km}^{2}$ of the Houston District was simply not practical. To compensate, mapping decisions were consciously conservative; whenever classification of a landform was questionable, the choice requiring more work was selected. A second problem involved mapping of the upland areas on the basis of soil association. In practice, the extant USDANRCS mapping of these soil associations in some parts of the district proved to be too detailed for this technique to be practical. In these instances, upland mapping was accomplished using generalized criteria; in other words, the presence of potentially suitable soils was noted, but map unit boundaries were constructed using geomorphic criteria. Subsequently, soil series identified as exhibiting the potential for upland preservation (the Albany, Aris, Axtell, Blanton, Boy, Cieno, Clodine, Conroe, Crowley, Edna, Eufala, Eustis, Fulshear, Fuquay, Gessner, Gunter, Kemah, Kenney, Leefield, Leton, Lucy, Narta, Stowell, Straber, Styx, Waller and Wicksburg series) were isolated using the USDA GIS coverages of the detailed soil maps for each county (the SSURGO data sets, which are the electronic equivalent of the detailed maps published in the respective county soil surveys) and combined with the PALM map in the GIS system. As a consequence, areas originally excluded on the basis of urbanization were lost (particularly in the northern part of the district). While far from ideal, this solution represents an archeologically conservative appraisal of areas where survey is not required.

The most difficult mapping decisions clearly involve the fluvial environments. In addition to the commonly heavy tree cover in alluvial bottoms, the distinction between landform elements differentiated largely on the grounds of sediment texture (e.g., muddy flood basin deposits vs. sandy levee and crevasse splay deposits) is particularly difficult to distinguish in many cases. For this reason, the distribution of these environments was sometimes inferred from the planiform shape, using generalized models for meandering streams (see Chapter 3). In the case of many of the smaller streams, including the floodplain and valley slopes, differentiation was not possible or practical at the scale of mapping, and entire valley systems were mapped as Map Unit 1 (surface survey recommended; deep reconnaissance recommended if deep impacts are anticipated).

\section{PRELIMINARY EVALUATION OF THE HOUSTON-PALM MODEL}

In order to evaluate the model, the HoustonPALM was compared to the extant site inventory from the Texas Historical Commission's Historic Sites Atlas database. Site locations in the six county district were extracted from the Historic Sites Atlas and added as a layer to the ArcView GIS system, where they were overlain on the Houston-PALM. The results of this exercise are summarized in Table 10. Only site centroids were used in the comparison, so each site was assigned to only one map unit. Although 1264 sites within the boundaries of the six county area were downloaded from the Atlas, eight of these sites bore trinomial designations indicating that they are located in other counties (and thus misplotted). These sites were excluded from the analysis.

The highest number of identified sites $(n=420)$ is associated with Map Unit 2, which occupies approximately $27 \%$ of the total area. Map Unit 1 , which has the best potential for both shallow and deeply buried sites, occupies less than half the area of Map Unit 2 (11.5\%), yet captures almost as many identified sites $(n=358)$. Map Units $3 a$ and 4 also capture relatively high frequencies of sites ( $n=142$ and $n=209$, respectively), while Map Units $2 \mathrm{a}$ and 3 capture considerably fewer $(\mathrm{n}=35$ and $\mathrm{n}=50$, respectively). Finally, 42 sites are mapped in the 0 (water) map unit. The majority of the "water" sites $(n=25)$ were situated in the basin of Lake Conroe, while the remainder were associated with other reservoirs, oxbow lakes in the Brazos drainage, Buffalo Bayou cutbanks, other artificial lakes, or the Galveston Bay shoreline. Most of these "water" sites are situated adjacent to terrain subject to survey, and thus probably would have been identified under a survey dictated by the Houston-PALM.

Another way to examine the comparison is to normalize the distribution by dividing site frequency by the area occupied by each map unit. Viewed in this manner, the frequency of sites is greatest in Map Units 3a and 1 (0.54 and 0.51 sites $\left./ \mathrm{mi}^{2}\right)$, intermediate in Map Units 0 and 2 (0.29 and 0.25 sites $/ \mathrm{mi}^{2}$, respectively), and lowest in Map Units 3, 4 , and $2 \mathrm{a}\left(0.10,0.09\right.$, and 0.08 sites $/ \mathrm{mi}^{2}$, respectively). The high frequency of sites captured by Units $3 \mathrm{a}$ is not surprising, since much of this map unit represents areas that would have been classified as Map Unit 1 except that they are urbanized, and thus more likely to have been surveyed. The same is 
Table 10. Comparison of Houston-PALM map units and identified archeological sites.

\begin{tabular}{|l|c|c|c|c|c|}
\hline Map Unit & $\begin{array}{c}\text { Site } \\
\text { Count }\end{array}$ & $\begin{array}{c}\text { Percentage of } \\
\text { Total Sites }\end{array}$ & Acreage & $\begin{array}{c}\text { Square } \\
\text { Miles }\end{array}$ & $\begin{array}{c}\text { Percentage of } \\
\text { Total Area }\end{array}$ \\
\hline Water & 42 & 3.3 & 89,545 & 143 & 2.3 \\
\hline Map Unit 1 & 358 & 28.5 & 442,670 & 708 & 11.5 \\
\hline Map Unit 2 & 420 & 33.4 & $1,038,080$ & 1,661 & 26.9 \\
\hline Map Unit 2a & 35 & 2.8 & 283,259 & 453 & 7.4 \\
\hline Map Unit 3 & 50 & 4.0 & 303,803 & 486 & 7.9 \\
\hline Map Unit 3a & 142 & 11.3 & 164,750 & 264 & 4.3 \\
\hline Map Unit 4 & 209 & 16.6 & $1,531,393$ & 2,450 & 39.7 \\
\hline \hline Grand Total & 1256 & 100 & $3,853,500$ & 6,166 & 100 \\
\hline
\end{tabular}

largely true for the now-drowned landscapes represented by much of Map Unit 0 . Map Unit 2, in contrast, captures a much more extensive area with only moderate potential for integrity. However, because these areas are characteristic of settings where the potential for deep burial is limited, visibility is consequently high. Similarly, the low frequency of identified sites in Map Unit 3 is probably a function of low visibility as much as a true indication of site density. The low number of sites in Map Unit 2a, in contrast, is somewhat surprising, and may indicate that many of the pimple mounds identified on the aerial photographs are in fact remnant soil signatures of former mounds destroyed by cultivation.

The sites of greatest interest are the 209 sites that occur in Map Unit 4, because these are the sites that would not have been captured by the Houston-PALM. While these sites make up a little less than $17 \%$ of the total inventory, they represent both the largest mapping unit (almost $40 \%$ of the total acreage) and the terrain where site visibility should be greatest. To examine the character of these sites more thoroughly, their distribution was plotted in ArcView, and the computerized site form for each site was examined on the Texas Historic Sites Atlas. This review suggested several trends. First, it appears that urbanization was probably responsible for the classification of the majority of the sites into Map Unit 4. Examination of the database on a county-by-county basis indicated that the number of sites classified as Map Unit 4 varied from a low of 2 (of $141 ; 1.4 \%$ ) in largely rural Brazoria County to a high of 173 (of $682 ; 25 \%$ ) in highly urbanized Harris County. In fact, the number of Harris County sites classed in Map Unit 4 was approximately five times that of the other five counties combined, which had a collective total of 35 Map Unit 4 sites.

The number of "missed" sites is also inflated by two factors: the list includes sites of historic age, which the Houston-PALM is not designed to address, and it includes recorded sites that are highly disturbed or destroyed, and thus appropriately mapped in Map Unit 4. While the frequency of historic sites assigned to Map Unit 4 in Harris County is not particularly high (30 of the 173 sites are historic), the majority (6 of 9) of Map Unit 4 sites in Fort Bend County are historic in age. Moreover, the number of historic sites in Harris County may be slightly higher-an additional 31 Map Unit 4 sites either have no associated electronic form or the form is so abbreviated that it is impossible to determine if they are historic or prehistoric. Because the Historic Sites Atlas merely transcribes original site forms that include highly variable levels of detail, the frequency of sites that are now either heavily disturbed or destroyed is impossible to ascertain; however, 36 of the sites are described as such in the Atlas.

Despite these factors, there are clearly some formerly eligible prehistoric sites that would have been excluded from survey by the Houston-PALM. A good example is the Alabonson Road Site (41HR273), excavated by Texas A\&M University in the late 1980s (Ensor and Carlson 1991). In almost every case, these sites were excluded on the basis of urbanization. Examination of the distribution of these sites (Figure 58) reveals that most are clustered in a few areas, including the upland margins of Buffalo Bayou, Greens Bayou, Cypress Creek, the vicinity of Clear Lake, and the lower 
reaches of White Oak Bayou. All of these areas are excluded primarily on the basis of intense development and channelization. However, these areas have also been surveyed relatively intensively, and TxDOT will continue to address previously identified sites regardless of their classification in the Houston-PALM. Moreover, the Houston-PALM is not intended to be a decision maker, but a decision-support tool. Survey decisions will continue to be made by TxDOT staff archeologists, who will take into account the Houston-PALM recommendation, the characteristics and potential impacts of the project, and their knowledge of the Houston area archeological record.

In summary, despite the fact that $39.7 \%$ of the total area is excluded from survey, the HoustonPALM model would capture $83.4 \%$ of the identified site inventory in the six county Houston District. This is somewhat surprising, because the excluded area represents primarily long-term stable settings where the potential for site visibility should be highest. This strongly supports Moore's (1995a) contention that sites are primarily situated in proximity to water or on sandy substrates, characteristics that dovetail nicely with Map Units 1 and 2. It also suggests that the Houston-PALM is a relatively robust and reliable model for focusing archeological work in the Houston District. However, it does not mean that the model is perfect. The final section weighs the pros and cons of such an approach to cultural resource management.

\section{ADVANTAGES AND \\ DISADVANTAGES OF AN INTEGRITY-DRIVEN ARCHEOLOGICAL LIABILITY MODEL}

There are several advantages as well as potential disadvantages in the application of a landscape model like Houston-PALM to cultural resource management. This section outlines many of these strengths and weaknesses, and argues that the former far outweigh the latter. Each recognized disadvantage is listed and explained, and a rebuttal argument is made that illustrates why the disadvantage is outweighed. In several cases, it is pointed out that design and implementation of complementary planning tools would compensate for deficiencies in the approach. This discussion is followed by a list of the advantages of the approach for efficient and effective compliance with cultural resource laws, and for the advancement of scientific knowledge about Houston area prehistory.

\section{Recognized Disadvantages and Potential Disadvantages of the Houston-PALM}

Disadvantage: Houston-PALM may fail to correctly map areas with good contextual potential.

Amplification and Rebuttal: No landscape model is perfect. As mentioned earlier, landscapes have a 
fractal quality in many respects, in that significant variability is typically observable at all scales. It is unrealistic to assume that examination of geo-archeological potential in a regional framework can produce a map that is sufficiently detailed that all areas of high potential are captured and all areas of low potential are excluded. Thus, it is virtually assured that some sites with reasonable integrity will be missed (i.e., mapped as low potential). In some cases, there may have been insufficient evidence to identify high potential areas, particularly where the potential is provided by a thin veneer of more recent sediment on an older landform.

Moreover, from a practical standpoint, it is undesirable to produce a map that is so detailed that it will not be used for the intended purpose. For this reason, some very small areas that were recognized to have relatively high potential were mapped as low potential, and vice-versa.

Disadvantage: Houston-PALM may fail to correctly map areas with poor contextual potential.

Amplification and Rebuttal: For the same reasons outlined above, some low potential areas may well have been unintentionally and/or intentionally included in high potential mapping areas. In fact, in situations where the context was ambiguous and could not be resolved, this was the preferred solution. In other words, mapping was conducted conservatively to assure that most errors were not detrimental to the archeological resource.

Disadvantage: Houston-PALM has no mechanism for identifying sites in low potential parts of the landscape.

Amplification and Rebuttal: As stated above, the geoarcheological model adopted here is directed towards identifying where sites are likely to be preserved in reasonable context, rather than where they are likely to exist. This distinction is crucial. The distribution of sites obtained through application of this model will exhibit bias against activities that may have been regularly conducted in stable or erosional parts of the landscape. Thus, viewed in isolation, the data set produced is not well suited to broad-scale issues such as settlement patterning and certain aspects of resource procurement. While TxDOT recognizes this failure, extant cultural resource laws are not concerned with every archeological site, but rather with sites that contain enough meaningful data to qualify as historic properties. In almost all cases, reasonable archeological integrity is required for a site to satisfy these criteria. Moreover, the extant site inventory contains many sites that $d o$ relate to settings with poor potential for integrity because they tend to be more highly visible, while deeply buried and stratified sites are almost certainly underrepresented because appropriate steps to identify and locate them have seldom been taken. By directing future research toward areas where such sites are likely to occur, the potential for advancing the state of knowledge about Texas archeology is enhanced.

Disadvantage: Houston-PALM is unsuited to identify intentionally buried prehistoric resources.

Amplification and Rebuttal: Because the Houston-PALM is focused on identifying areas where natural processes have the potential to bury and preserve archeological sites, it is poorly suited to address sites characterized by intentional prehistoric excavation in parts of the landscape that otherwise have low potential. Although other site/ feature types created in this manner (e.g., caches, storage cists, deep basin hearths) have the potential to occur in such an environment, the most common example of this type of site on the coastal plain is the prehistoric cemetery (e.g., the Loma Sandia site, the Ernest Witte site, the Harris County Boy's School site), where dozens, or sometimes hundreds, of interments have been found (Story 1985; Hall 1995; Taylor 1995). Although many, if not most, of the known prehistoric cemeteries on the coastal plain are apparently situated in lowland settings (Hall 1995) and would therefore be encompassed in high potential areas, the potential clearly exists for such sites to occur in stable, upland settings judged to have poor geoarcheological potential using the criteria in the current model. One possible solution is the development of a behaviorally based model of topographic setting for these sites, to be used in conjunction with the Houston-PALM to identify the need for archeological assessment.

Disadvantage: Houston-PALM is unsuited to identify historic archeological resources.

Amplification and Rebuttal: The model employed in this study is predicated on prehistoric remains; the assumption is that sites formed on stable upland surfaces have been exposed for so long that disturbance and cultural overprinting will typically render any contextual data recovered 
suspect. However, the same is not true of historic sites, where the diversity of time-diagnostic materials and limited time depth render spatial/ stratigraphic disturbance and cultural overprinting much less problematic than it is for prehistoric sites. Thus, the map units in the Houston-PALM do not apply to historic resources. On the other hand, the location of historic resources can use a broader set of data sources (e.g., historic maps, land records, aerial photographs) than are useful in locating prehistoric resources, and it would be relatively easy to establish a distinct protocol for evaluating the need to determine whether areas exempted from prehistoric survey on contextual grounds might require survey focused on historic remains. TxDOT is currently funding research to implement such a protocol, which will be used in conjunction with the Houston-PALM in making management decisions.

\section{Advantages of the Houston-PALM}

In TxDOT's opinion, the advantages of Houston-PALM far outweigh the disadvantages. These advantages include:

(1) Houston-PALM allows for more rapid and consistent evaluation of archeological potential for proposed projects, and more rapid coordination with regulatory agencies.

Amplification: All CRM archeologists, including those working for TxDOT as employees and contractors, must make frequent decisions about whether a survey is necessary to satisfy legal antiquities protection requirements for planned undertakings falling under federal and/or state jurisdiction. Such decisions are based on a variety of information, including the landscape setting, soils, distribution of previously identified sites on the surrounding landscape, and the character and extent of planned impacts. Such decisions are also filtered through the conscious or subconscious preferences and experience of the person making the decision. Needless to say, because each archeologist has unique experiences and perspectives, the recommendation that different archeologists would make on any given project may differ. Houston-PALM provides a straightforward evaluative framework that is reasonable, consistent, and scientifically grounded.

Moreover, because the decisions currently made by archeologists about whether to survey and test are by nature individualistic, the process of review by archeologists in regulatory positions (THC) requires considerable thought and effort, which is itself time consuming. Houston-PALM provides a mechanism for TxDOT and THC to reach broad consensus on the patterning of areas possessing or lacking archeological potential on a regional basis, thus eliminating much of the effort, and the time, involved in this aspect of compliance review.

(2) Houston-PALM eliminates the need for archeological survey in existing and proposed right of way in a considerable portion of the Houston Highway District.

Amplification: Archeological survey is an expensive and time-consuming process. TxDOT's legal and ethical responsibility to account for archeological resources in the process of fulfilling its mandate is balanced by its fiduciary responsibility to the taxpaying public. It follows that it is incumbent on TxDOT to develop mechanisms to accomplish compliance with existing antiquities laws in ways that are as scientifically effective and as fiscally efficient as possible. As Chapter 3 of this volume demonstrates, there are many factors that contribute to the preservation or degradation of an archeological site, and the distribution of environments conducive to preservation is patterned and predictable on the landscape. Because reasonable archeological integrity is a necessary attribute of a significant site within the current operational framework, it is possible to predict where preservation is unlikely, and where the need for survey can therefore be eliminated.

It is important to stress that archeological integrity is not a binary concept, but a relative measure that spans the continuum between absolute behavioral integrity (the pompeii premise) and utter entropy. Few sites occupy either end of the continuum; most reflect the combined influence of behavior and the filters imposed by subsequent physical and biological processes. The phrase "reasonable integrity" refers to a position on that continuum where it is still reasonable to expect that aspects of the behavioral context can be teased out with a degree of confidence. Because people tend to reoccupy certain places on the landscape, and because the majority of materials recovered from prehistoric archeological sites in Texas are not themselves time-diagnostic, an important component of reasonable integrity is the potential for the occurrence of stratigraphically isolable 
components or component elements. For this reason, Houston-PALM emphasizes loci where depositional processes have been active in the culturally relevant period.

(3) Houston-PALM allows District Transportation Planners to better anticipate compliance needs in evaluating routing alternatives.

Amplification: Transportation planners must make many decisions in planning and evaluating the evolution of transportation networks. This process involves evaluation of need, and development of alternatives to meet that need. Such decisions are made on the basis of a wide variety of information, including the physical and engineering characteristics of alternative sites, the location of existing buildings and infrastructure, forecasts of future demands on the system, cost-benefit analyses of proposed improvements, and costs associated with environmental compliance. At present, the impact of archeological compliance on a given project is a "black box" to the transportation planner; in almost every case, they have no idea how or whether archeology will impact any given project. HoustonPALM provides a tool that supplies the transportation planner with another line of information to use in designing a system that maximizes efficiency and minimizes cost to the taxpayer.

(4) Houston-PALM limits tax dollars spent identifying and testing sites that ultimately will be judged ineligible due to lack of archeological integrity.

Amplification: As discussed above (point 2), the process of archeological survey is expensive and time consuming. However, this statement is even more true for the process of significance testing, which usually involves the excavation of a number of formal test pits, frequently supplemented by the excavation of backhoe trenches, surface collections, and additional shovel tests. The costs for field labor are compounded by the extensive time and expense of analysis, report preparation, and curation. For this reason, site testing investigations in Texas often take weeks and cost tens, or sometimes hundreds, of thousands of dollars when many sites warrant testing. Under standard archeological practice (i.e., the traditional application of the Section 106 process), determinations of ineligibility on the basis of insufficient integrity are typically only made after significance testing has been performed (although there are exceptions; see Trierweiler [1994]). While evaluation of data content can usually only be made following significance testing, it is possible to predict the likelihood that many sites will not satisfy required integrity criteria on the basis of the site's setting. Houston-PALM is such a predictive model. Because the existing cultural resource laws are concerned not with sites per se, but with potential historic properties, Houston-PALM provides a mechanism to save tax dollars that would have otherwise been spent locating and testing nonsignificant sites.

(5) Houston-PALM focuses survey investigations on areas with moderate to strong potential to contain sites with stratigraphic integrity, and thus contributes to our understanding of the prehistoric record.

Amplification: Houston-PALM provides an important benefit to the scientific discipline of archeology, in that it directs the focus of investigations to settings that are likely to yield highquality, focused data. Because the processes that promote site preservation also tend to limit site visibility, there is a relatively consistent inverse relationship between the quality of data integrity at a site and the odds that it will be found with traditional pedestrian survey techniques. For this reason, and because of the long-term emphasis on phase-building and material culture characterization, traditional Texas archeology has tended to focus on sites that are relatively visible and contain relatively large quantities of cultural material. Unfortunately, these are exactly the wrong kind of sites to capture discrete behavioral episodes, and therefore to characterize adaptive behaviors in anything but a broadly generalized way (Ferring 1986; Collins 1995). At the same time, those sites that do contain such assemblages have been largely ignored because they have poor visibility and low material density, and were thus rarely looked for, and often dismissed when they were found because of low artifact frequency. Houston-PALM is predicated on the tenet that buried, isolated components representing discrete behavioral episodes represent the highest quality data source to address cultural questions, and it is designed to focus resources on environments likely to yield these types of data. 


\section{References Cited}

Abbott, J. T.

1990 Geomorphic and Geoarchaeological Investigations. In Phase II Investigations at Prehistoric and Rock Art Sites, Justiceburg Reservoir, Garza and Kent Counties, Texas, by D. K. Boyd, J. T. Abbott, W. A. Bryan, C. M. Garvey, J. M. Quigg, and R. C. Fields. Report of Investigations 71. Prewitt and Associates, Inc., Austin.

1994 Geomorphic Context of the Barton Site (41HY202) and the Mustang Branch Site (41HY209). In Archaic and Late Prehistoric Human Ecology in the Middle Onion Creek Valley, Hays County Texas, Volume 2: Topical Studies, by R. A. Ricklis and M. B. Collins, pp. 353-379. Studies in Archeology 19. Texas Archeological Research Laboratory, The University of Texas at Austin.

1996 Geomorphic investigations in the lowlands. In $\mathrm{Cul}$ tural Resource Survey of Area $F$ of the Jewett Mine, Freestone County, Texas, by J. Peck, J. T. Abbott, C. D. Frederick, P. L. O'Neill, and A. C. Treece, pp.131-160. TRC Mariah Associates, Inc., Austin.

1997a Mechanical Survey of Farm to Market Road 616 between Lolita and Vanderbilt in Jackson County, Texas. Letter report on file, Environmental Affairs Division, Texas Department of Transportation, Austin.

1997b Late Quaternary Alluviation and Soil Erosion in Southern Italy. Ph.D. Dissertation, The University of Texas at Austin.

1998 Backhoe prospection at Oyster Creek in Clute. Letter Report on file, Environmental Affairs Division, Texas Department of Transportation, Austin.

Abbott, J. T. and R. P. Mauldin

1996 Chronometrics research domain. In Significance Standards for Prehistoric Archeological Sites at Fort Bliss: A Design for Further Research and the Management of Cultural Resources, by J. T. Abbott, R. Mauldin, P. E. Patterson, W. N. Trierweiler, R. J. Hard, C. R. Lintz, and C. L. Tennis, pp. 57-81. TRC Mariah Associates, Inc., Austin.
Abdulah, K. C.

1995 The Evolution of the Brazos and Colorado Fluvial/ Deltaic Systems During the Late Quaternary: An Integrated Study, Offshore Texas. Ph.D. Dissertation, Rice University, Houston.

Agricultural Research Service, U.S. Department of Agriculture 1973 Rice in the United States: Varieties and Production. Agricultural Handbook No. 289. U. S. Government Printing Office, Washington, D.C.

Ahmad, N.

1983 Vertisols. In Pedogenesis and Soil Taxonomy, II: The Soil Orders, edited by L. P. Wilding, N. E. Smeck, and G. F. Hall, pp. 91-123. Developments in Soil Science IIB. Elsevier Publishing Company, Amsterdam

Alderfer, R. B. and R. R. Robinson

1974 Runoff from pastures in relation to grazing intensity and soil compaction. Journal of the American Society of Agronomists 39:948-958.

Alford, J. J. and J. C. Holmes

1985 Meander scars as evidence of major climate changes in southeast Louisiana. Annals of the Association of American Geographers 75:395-403.

Alford, J. J., C. R. Kolb, and J. C. Holmes

1985 Terrace stratigraphy along the lower Red River, Louisiana. Southeastern Geology 26:47-51.

Amundson, R. G., O. A. Chadwick, J. M. Sowers, and H. E. Donner

1988 Relationship Between Climate and Vegetation and the Stable Carbon Isotope Chemistry of Soils in the Eastern Mojave Desert, Nevada. Quaternary Research 29:245-254.

Andrews, P. B.

1970 Facies and Genesis of a Hurricane Washover Fan, St. Joseph Island, Central Texas Coast. Report 67. Bureau of Economic Geology, The University of Texas at Austin. 
Antevs, E.

1948 Climatic Changes and Pre-White Man in the Great Basin, with Emphasis on Glacial and Postglacial Times. University of Utah Bulletin 38:168-191.

Aronow, S.

1988 Surface Geology. In Soil Survey of Galveston County, Texas, by G. W. Crenwelge., E. L. Griffin, and J. K. Baker, pp. 101-104. United States Department of Agriculture, Soil Conservation Service, Washington, D.C.

1989 Geology, geomorphology, and soils. In Significance Testing at Site 41HR616, West Lake Houston Parkway Project, Harris County, Texas, by R. G. Moore, pp. 6-37. Report of Investigations No. 26. Moore Archeological Consulting, Houston.

1990 Geomorphology of the Project Area. In An Archaeological Survey of the Proposed Greens Bayou Regional Stormwater Detention Facility, Greens Bayou, Harris County, Texas, by B. Ensor, S. Aronow, M. D. Freeman, and J. M. Sanchez, pp. 21-44. Archaeological Surveys No. 7. Texas A\&M University, Archeological Research Laboratory. College Station.

1991 Geology and Geomorphology of the Cypress Creek study area. In Archeological Survey of Cypress Creek from Spring Branch to Kuykendahl Road, Harris County, Texas, edited by H. B. Ensor, pp. 33-42. Archeological Surveys No. 8. Archeological Research Laboratory, Texas A\&M University, College Station.

1992 Geomorphic soils indicators of former dry climates in the Houston area, Harris County, Southeastern Texas. Geological Society of America Abstracts with Programs 24:2.

1994 Geologic background. In National Register Testing at Site 41HR729, Langham Creek, Harris County, Texas, by R. G. Moore. Report of Investigations No. 93. Moore Archeological Consulting, Houston.

Aronow, S. A., C. E. Pearson, and R. A. Weinstein

1994 Natural Setting. In Archaeological Investigations Along the Lower Lavaca River, Jackson County, Texas: The Channel to Red Bluff Project, by R. A. Weinstein, pp. 7-20. Coastal Environments, Inc., Baton Rouge.

Aslan A. and W. J. Autin

1998 Holocene flood-plain soil formation in the southern lower Mississippi Valley: Implications for interpreting alluvial paleosols. Geological Society of America Bulletin 110:433-449.

Aslan A. and M. D. Blum

1999 Contrasting Styles of Holocene Avulsion, Texas Gulf Coastal Plain, U.S.A. In Proceedings of the $6^{\text {th }}$ International Conference on Fluvial Sedimentology, edited by N. D. Smith and J. J. Rogers. International Association of Sedimentologists, Special Publication. Blackwell Scientific, London.
Aten, L. E.

1971 Archaeological Excavations at the Dow-Cleaver Site, Brazoria County, Texas. Texas Archeological Salvage Project, Technical Bulletin No. 1. The University of Texas at Austin.

1983 Indians of the Upper Texas Coast. Academic Press, New York.

Aten, L. E. and C. N. Bollich

1981 Archeological evidence for pimple (prairie) mound genesis. Science 213 (4514):1375-1376.

Attendorn, H.-G. and R. N. C. Bowen

1997 Radioactive and Stable Isotope Geology. Chapman \& Hall, London.

Bachman, G. O. and M. N. Machette

1977 Calcic Soils and Calcretes in the Southwestern United States. Open File Report 77-794. U.S. Geological Survey, Washington, D.C.

Bagnold, R. A.

1941 The Physics of Blown Sand and Desert Dunes. Chapman \& Hall, London.

Baker, V. R. and M. M. Penteado-Orellana

1977 Adjustment to Quaternary climate change by the Colorado River in Central Texas. Journal of Geology 85: 395-422.

Barnes, V. E.

1968a Geologic Atlas of Texas, Houston Sheet. Bureau of Economic Geology, The University of Texas at Austin.

1968b Geologic Atlas of Texas, Beaumont Sheet. Bureau of Economic Geology, The University of Texas at Austin.

1974a Geologic Atlas of Texas, Austin Sheet. Bureau of Economic Geology, The University of Texas at Austin.

1974b Geologic Atlas of Texas, Seguin Sheet. Bureau of Economic Geology, The University of Texas at Austin.

1975 Geologic Atlas of Texas, Beeville-Bay City Sheet. Bureau of Economic Geology, The University of Texas at Austin.

1982 Geologic Atlas of Texas, Houston Sheet, revised. Bureau of Economic Geology, The University of Texas at Austin.

1992 Geologic Atlas of Texas, Beaumont Sheet, revised. Bureau of Economic Geology, The University of Texas at Austin.

Barton, D. C.

1930 Deltaic coastal plain of southeastern Texas. Geological Society of America Bulletin 41:359-382. 
Bateman, M.D.

1998 Appendix C: Quartz Optical Dating Report. In A Cultural Resources Survey of the 1,557-Acre AX Area at the Sandow Surface Mine, Milam County, Texas, by M. Tate and R. Rogers. Espey, Huston \& Associates, Inc., Austin.

Bates, R. L. and J. A. Jackson

1984 Dictionary of Geological Terms. 3rd Edition. Anchor/Doubleday, Garden City, New York

Batey, T.

1971 Soil Field Handbook. ADAS Advisory Papers No. 9. Ministry of Agriculture, Fisheries and Food, London.

Baxter, F. P. and F. D. Hole

1967 Ant (Formica cinerea) pedoturbation in a prairie soil. Soil Science Society of America Proceedings 31: 425-428.

Berg, A. W.

1990 Formation of mima mounds: A seismic hypothesis. Geology 18:281-284.

Bernard, H. A.

1950 Quaternary Geology of Southeast Texas. Ph.D. Dissertation, Louisiana State University, Baton Rouge.

Bernard, H. A. and R. J. LeBlanc

1965 Resume of the Quaternary geology of the northwestern Gulf of Mexico Province. In The Quaternary of the United States, edited by H. E. Wright, pp. 137-185. Princeton University Press, Princeton, New Jersey

Bernard, H. A., R. J. LeBlanc, and C. F. Majors

1962 Recent and Pleistocene geology of southeast Texas. In Geology of the Gulf Coast and Central Texas, edited by E. H. Rainwater and R. P. Zingula, pp. 175-224. Houston Geological Society, Houston.

Bernard, H. A., C. F. Major, Jr., B. F. Parrot, and R. J. LeBlanc, Sr.

1970 Recent Sediments of Southeast Texas. Guidebook 11. Bureau of Economic Geology, The University of Texas at Austin.

Berner, R. A.

1971 Bacterial processes effecting the precipitation of calcium carbonate in sediments. In Carbonate Cements, edited by O. P. Bricker, pp. 247-251. Johns Hopkins University Press, Baltimore.

Bik, M. J. J.

1968 Morphoclimatic observations on prairie mounds. Zeitschrift für Geomorphologie 12(4):409-469.

Bird, M. and P. Pousai

1997 Carbon isotope variations in the surface soil organic carbon pool. Global Biogeochemical Cycles 11: 313.
Birkeland, P. W.

1984 Soils and Geomorphology. 2nd Edition. Oxford University Press, New York.

Blair, W. F.

1950 The biotic provinces of Texas. Texas Journal of Science 2(1): 93-117.

Blum, M. D.

1989 Quaternary Stratigraphy of the Pedernales River. In Geomorphology, Quaternary Stratigraphy, and Paleoecology of Central Texas, by M. D. Blum, J. F. Petersen, and R. S. Toomey III. Guidebook to the 7th Annual Field Trip of the South-Central Cell of the Friends of the Pleistocene, April 7-9, 1989.

1990 Climatic and eustatic controls on Gulf Coastal Plain fluvial sedimentation: An example from the Late Quaternary of the Colorado River, Texas. In Sequence Stratigraphy as and Exploration Tool: Concepts and Practices in the Gulf Coast, edited by J. M. Armentrout and B. S. Perkins, pp. 71-83. Proceedings of the 11th Annual Research Conference, Gulf Coast Section of the Society of Economic Paleontologists and Mineralogists.

1992 Modern Depositional Environments and Recent Alluvial History of the Lower Colorado River, Gulf Coastal Plain of Texas. Ph.D. Dissertation, The University of Texas at Austin.

1995 Fluvial Systems of the Texas Gulf Coastal Plain: Geologic and Climatic Controls, Depositional Styles, and Alluvial Successions. Geological Society of America, Abstracts with Programs 27(6):215.

Blum, M. D., J. T. Abbott, and S. A. Valastro

1992 Evolution of landscapes on the Double Mountain Fork of the Brazos River, West Texas: Implications for preservation and visibility of the archaeological record. Geoarchaeology 7:339-370.

Blum, M. D., R. A. Morton, and J. M. Durbin

1995 "Deweyville" terraces and depostits (sic) of the Texas Gulf coastal plain. Transactions of the Gulf Coast Association of Geological Societies 45:53-60.

Blum, M. D. and D. M. Price

1994 Glacio-eustatic and climatic controls on Quaternary alluvial plain deposition, Texas coastal plain. Transactions of the Gulf Coast Association of Geological Societies 44:85-92.

Blum, M. D. and S. Valastro, Jr.

1989 Response of the Pedernales River of Central Texas to Late Holocene Climatic Change. Annals of the Association of American Geographers 79:435-456.

1992 Quaternary stratigraphy and geoarchaeology of the Colorado and Concho Rivers of west Texas. Geoarchaeology 7:419-448. 
1994 Late Quaternary sedimentation, lower Colorado River, Gulf Coastal Plain of Texas. Geological Society of America Bulletin 106:1002-1016.

Bocek, B.

1986 Rodent ecology and burrowing behavior: Predicted effects on archaeological site formation. American Antiquity 51(3):589-603.

Bomar, G.

1995 Climate of the Texas Hill Country and East Texas. In The Changing Climate of Texas: Predictability and Implications for the Future, edited by $\mathrm{J}$. Norwine, J. R. Giardino, G. R. North, and J. B. Valdes, pp. 76-91. GeoBooks, College Station.

Bousman, C. B.

1990 Geomorphic Investigations, 41LN29A and 41LN106. In Excavations at the Charles Cox, Lambs Creek Knoll, and Buffalo Branch Sites, Jewett Mine Project, Leon and Freestone Counties, Texas, edited by R. C. Fields, pp. 65-93. 2 Vols. Reports of Investigations No. 70. Prewitt and Associates, Inc., Austin.

1991 Paleoenvironments. In Excavations at the Bottoms, Rena Branch, and Moccasin Springs Sites, Jewett Mine Project, Freestone and Leon Counties, Texas, by R. C. Fields et al., pp. 21-35. Reports of Investigations No. 82. Prewitt \& Associates, Inc., Austin.

Boutton, T. W., S. R. Archer, A. J. Midwood, S. F. Zitzer, and R. Bol

1998 Delta ${ }^{13} \mathrm{C}$ values of soil organic carbon and their use in documenting vegetation change in a subtropical savanna ecosystem. Geoderma 82:5-41.

Bradley, R. S.

1985 Quaternary Paleoclimatology: Methods of Paleoclimatic Reconstruction. Allen \& Unwin, Boston.

Brammer, $\mathrm{H}$.

1971 Coatings in seasonally flooded soils. Geoderma 6:5-16.

Branner, J. C.

1900 Ants as geologic agents in the tropics. Journal of Geology 8:151-153.

Bretz, J. H. and Horberg, L. H.

1949 Caliche in southeastern New Mexico. Journal of Geology 57:491-511.

Broeker, W. S., J. P. Kennett, B. P. Flower, J. T. Teller, S. Trumbore, G. Bonani, and W. Wolfi

1989 Routing of meltwater from the Laurentide ice sheet during the Younger Dryas cold episode. Nature 341:318-321.
Brown, A. G.

1997 Alluvial Geoarchaeology: Floodplain Archaeology and Environmental Change. Cambridge University Press, Cambridge.

Brown, A. G. and M. Keough

1992 Paleochannels, paleoland-surfaces and the three-dimensional reconstruction of floodplain environmental change. In Lowland Floodplain Rivers: Geomorphological Perspectives, edited by P. A. Carling and G. E. Petts, pp. 185-202. John Wiley \& Sons, New York.

Brown, C. N.

1956 The origin of caliche on the northeastern Llano Estacado, Texas. Journal of Geology 64:1-15.

Brown, D. A.

1984 Prospects and limits for a phytolith key for grasses in the central United States. Journal of Archaeological Science 11:345-368.

Brown, K. M.

1975 Time's Arrow and Postdepositional Disturbance. Paper presented at the 17th Annual Caddo Conference, College Station, Texas.

Bruseth, J. E. and T. K. Perttula

1981 Prehistoric Settlement Patterns at Lake Fork Reservoir. Texas Antiquities Permit Series, Report 2. Southern Methodist University and Texas Antiquities Committee, Dallas and Austin.

Bryan, K. and C.C. Albritton

1943 Soil phenomena as evidence for climatic changes. American Journal of Science 241:469-490.

Bryant, W. R., J. Lugo, C. Cordova, and A. Salvador

1992 Physiography and bathymetry. In The Geology of North America, Volume J, The Gulf of Mexico Basin, edited by A. Salvador pp. 13-30. Geological Society of America, Boulder.

Bryant, V. M. and R. G. Holloway

1985 The Late Quaternary paleoenvironmental record of Texas. In Pollen Records of Late Quaternary North American Sediments, edited by V. M. Bryant and R. G. Holloway, pp. 39-70. American Association of Stratigraphic Palynologists, Dallas.

Bryant, V. M. and H. J. Shafer

1977 The Late Quaternary paleoenvironment of Texas: A model for the archeologist. Bulletin of the Texas Archeological Society 48:1-25.

Buchmann, N., J. R. Brooks, K. D. Rapp, and J. R. Ehleringer

1996 Carbon isotope composition of $\mathrm{C}_{4}$ grasses is influenced by light and water supply. Plant Cell Environments 9:392-402. 
Buechner, H. K.

1942 Interrelationships between pocket gopher and land use. Journal of Mammalogy 23:346-348.

Buol, S. W., F. D. Hole, and R. J. McCracken

1980 Soil Genesis and Classification. 2nd Edition. Iowa State University Press, Ames.

Butler, D. R.

1995 Zoogeomorphology: Animals as Geomorphic Agents. Cambridge University Press, Cambridge.

Butzer, K. W.

1971 Environment and Archeology. 2nd Edition. Aldine, Chicago.

1975 The ecological approach to archeology: Are we really trying? American Antiquity 40(1): 106-111.

1980 Context in archaeology: An alternative perspective. Journal of Field Archaeology 7: 417-422.

1982 Archeology as Human Ecology. Cambridge University Press, Cambridge.

Cain, R. H.

1974 Pimple mounds: A new viewpoint. Ecology 55:178182.

Caran, S. C.

1998 Quaternary paleoenvironmental and paleoclimatic reconstruction: A discussion and critique, with examples from the southern High Plains. Plains Anthopologist 43:111-124.

Carr, C.

1982 Handbook on Soil Resistivity Surveying: Interpretation of Data from Earthen Archeological Sites. Center for American Archeology Press, Evanston, Illinois.

Carty, D. J., J. B. Dixon, L. P. Wilding, and F. T. Turner

1988 Characterization of a pimple mound-intermound soil complex in the Gulf Coast Prairie region of Texas. Soil Science Society of America Journal 52:17151721.

Cerling, T. E.

1984 The stable isotopic composition of modern soil carbonate and its relationship to climate. Earth and Planetary Science Letters 71:229-240.

Cerling, T. E., J. Quade, Y. Wang, and J. R. Bowman

1989 Carbon isotopes in soils and paleosols as ecology and paleoecology indicators. Nature 341:138-139.

Chervenka, G. and W. Daniel

1983 Montgomery County, Texas, Soil Survey Supplement. United States Department of Agriculture, Soil Conservation Service, Washington, D.C.
Chorley, R. J. (editor)

1969 Introduction to Fluvial Processes. Methuen \& Co. Ltd., London.

Chorley, R. J., S. A. Schumm, and D. E. Sugden

1984 Geomorphology. Methuen, London.

CLIMAP Project Members

1981 Seasonal reconstructions of the earth's surface at the last glacial maximum. Geological Society of America Map and Chart Series MC-36.

Coch, N. K.

1994 Geologic effects of hurricanes. Geomorphology 10:37-63.

COHMAP Members

1988 Climatic changes of the last 18,000 years: Observations and model simulations. Science 241:10431052 .

Collins, L. M., J. N. Collins, and L. B. Leopold

1987 Geomorphic processes of an estuarine marsh: Preliminary results and hypotheses. In International Geomorphology 1986, edited by V. Gardiner, pp. 1049-1072. John Wiley \& Sons, New York.

Collins, M. B.

1995 Forty years of archeology in Central Texas. Bulletin of the Texas Archeological Society 66:361-400.

Collins, M. B. and C. B. Bousman

1993 Quaternary Environments and Archeology in Northeast Texas. In Archeology in the Eastern Planning Region, edited by N. A. Kenmotsu and T. K. Perttula, pp. 49-67. Cultural Resource Management Report 3. Department of Antiquities Protection, Texas Historical Commission, Austin.

Cowan, J. A., G. S. Humphries, P. B. Mitchell, and C. L. Murphy

1985 An assessment of pedoturbation by two species of mound-building ants, Camponotus interpidus (Kirby) and Iridomymex purpureus (F. Smith). Australian Journal of Soil Research 22:98-108.

Cox, G. W.

1984 Mounds of mystery. Natural History 6:36-45.

Cox, G. W. and C. G. Gakahu

1986 A latitudinal test of the fossorial rodent hypothesis of Mima mound origin. Zeitschrift für Geomorphologie 30:485-501.

Cox, G. W., B. G. Lovegrove, and W. R. Siegfried

1987 The small stone content of mima-like mounds in the South African Cape region: Implications for mound origin. Catena 14:165-176. 
Crenwelge., G. W., J. D. Crout, E. L. Griffin, M. L. Golden, and J. K. Baker

1981 Soil Survey of Brazoria County, Texas. United States Department of Agriculture, Soil Conservation Service, Washington, D.C.

Crenwelge., G. W., E. L. Griffin, and J. K. Baker

1988 Soil Survey of Galveston County, Texas. United States Department of Agriculture, Soil Conservation Service, Washington, D.C.

Darwin, C.

1881 The Formation of Vegetable Mould Through the Action of Worms, With Observations on Their Habits. John Murray, London.

Davis, M. W., D. K. Utley, S. A. Tomka, and S. A. Turpin

1987 Continuing Cultural Resources Investigations in the Calvert Prospect: 1986 Season, Robertson County, Texas. Research Report 95. Texas Archeological Survey, The University of Texas at Austin.

Delcourt, P. A. and H. R. Delcourt

1977 The Tunica Hills, Louisiana-Mississippi: Late Glacial locality for spruce and deciduous forest species. Quaternary Research 7:218-237.

DeNiro, M. J.

1987 Stable Isotopy and Archaeology. American Scientist 75:183-191.

Deussen, A.

1924 Geology of the Texas Coastal Plain west of the Brazos River. United States Geological Survey Professional Paper 126. U.S. Government Printing Office, Washington, D.C.

Dietz, R. S.

1945 The small mounds of the Gulf Coastal Plain. Science 102:596-597.

Dillehay, T.

1974 Late Quaternary bison population changes on the southern Plains. Plains Anthropologist 19:180-196.

1997 Monte Verde: A Late Pleistocene Settlement in Chile: The Archeological Context, Vol. II. Smithsonian Institution Press, Washington, D.C.

Dixon, J. C.

1994 Duricrusts. In Geomorphology of Desert Environments, edited by A. D. Abrahams and A. J. Parsons, pp. 82-105. Chapman \& Hall, Ltd., London.

Doering, J. A.

1935 Post-Fleming surface formations of southeast Texas and south Louisiana. Bulletin of the American Association of Petroleum Geologists 19:651-688.
1956 Review of Quaternary surface formations of the Gulf Coast region. Bulletin of the American Association of Petroleum Geologists 40(8):1816-1862.

DuBar, J. R., T. E. Ewing, E. L. Lundelius, E. G. Otvos, and C. D. Winkler

1991 Quaternary Geology of the Gulf of Mexico Coastal Plain. In The Geology of North America, Volume K2: Quaternary Non-Glacial Geomorphology, Conterminous United States, edited by R. B. Morrison, pp. 583-610. Geological Society of America, Boulder.

Duffield, L. F.

1970 Vertisols and their implications for archaeological research. American Anthropologist 72:1055-1062.

Durbin, J. M., M. D. Blum, and D. M. Price

1997 Late Pleistocene stratigraphy of the Nueces River, Corpus Christi, Texas: Climatic and eustatic control on valley fill architecture. Transactions of the Gulf Coast Association of Geological Societies 47:119130.

Eidt, R. C.

1977 Detection and examination of anthrosols by phosphate analysis. Science 197(4311):1327-1333.

1984 Advances in Abandoned Settlement Analysis: Application to Prehistoric Anthrosols in Colombia, South America. University of Wisconsin Press, Milwaukee.

Elias, S. A., and T. R. Van Devender

1990 Fossil insect evidence for Late Quaternary climatic change in the Big Bend region, Chihuahuan Desert, Texas. Quaternary Research 34:249-261.

Ellis, L. W., G. L. Ellis, and C. D. Frederick

1995 Implications of environmental diversity in the Central Texas archeological region. Bulletin of the Texas Archeological Society 66:401-426.

Ensor, H. B.

1987 The Cinco Ranch Sites, Barker Reservoir, Fort Bend County, Texas. Reports of Investigations No. 3. Archeological Research Laboratory, Texas A\&M University, College Station.

Ensor, H. B. and D. L. Carlson

1988 The Crawford Site, 41PK69, Central Trinity River Uplands, Polk County, Texas. Contract Reports in Archaeology 4. Texas State Department of Highways and Public Transportation, Highway Division, Austin.

1991 Alabonson Road: Early Ceramic Period Adaptation to the Inland Coastal Prairie Zone, Harris County, Southeast Texas. Report of Investigations No. 8. Archeological Research Laboratory, Texas A\&M University, College Station. 
Epps, L. W.

1973 Geologic History of the Brazos River. Baylor Geological Studies Bulletin 24. Baylor University Press, Waco.

Fenwick, I.

1985 Paleosols: Problems of recognition and interpretation. In Soils and Quaternary Landscape Evolution, edited by J. Boardman, pp. 3-43. John Wiley \& Sons, New York.

Ferring, C. R.

1986 Rates of fluvial sedimentation: Implications for archaeological variability. Geoarchaeology 1(3): 259274.

1994 Late Quaternary Geology of the Upper Trinity River Basin, Texas. Ph.D. Dissertation, University of Texas at Dallas.

1995 Middle Holocene environments, geology, and archaeology in the Southern Plains. In Archaeological Geology of the Archaic Period in North America, edited by E. A. Bettis, III, pp. 21-35. Special Paper 297. Geological Society of America, Boulder.

2000 The Late Quaternary Geology and Prehistoric Archaeology of the Grand Prairie and Cross Timbers Portions of North Central Texas. Guidebook to the 13th Annual Field Trip of the South-Central Cell of the Friends of the Pleistocene. Department of Geography and Center for Environmental Archaeology at the University of North Texas, Denton.

Fields, R. C., E. F. Gadus, A. C. Earls, K. M. Gardner, L. W.

Klement, and J. K. Wagner

1995 National Register Assessments of Prehistoric \& Historic Sites in Area E at the Jewett Mine, Freestone County, Texas. Reports of Investigations No. 100. Prewitt and Associates, Inc., Austin.

Fields, R. C., M. F. Godwin, M. D. Freeman, and S. V. Lisk 1986 Inventory and Assessment of Cultural Resources at Barker Reservoir, Fort Bend and Harris Counties, Texas. Reports of Investigations No. 40. Prewitt and Associates, Inc., Austin.

Fields, R. C., M. D. Freeman, and S. M. Kotter

1983 Inventory and Assessment of Cultural Resources at Addicks Reservoir, Harris County, Texas. Reports of Investigations No. 22. Prewitt and Associates, Inc., Austin.

Finlayson, B. L.

1985 Soil creep: a formidable fossil of misconception. In Geomorphology and Soils, edited by K. S. Richards, R. R. Arnett, and S. Ellis, pp. 141-158. Allen \& Unwin, London.
Fisher, W. L., J. H. McGowen, and C. G. Groat

1972 Environmental Geologic Atlas of the Texas coastal zone-Galveston-Houston area. Bureau of Economic Geology, The University of Texas at Austin.

Fisk, H. N.

1938 Geology of Grant and LaSalle Parishes. Geological Bulletin No. 10. Louisiana Department of Conservation, Baton Rouge.

1940 Geology of Avoyelles and Rapides Parishes. Geological Bulletin No. 18. Louisiana Department of Conservation, Baton Rouge.

Fowler, D. D.

1982 Cultural resource management. In Advances in Archaeological Method and Theory, Vol. 5, edited by M. B. Schiffer pp.1-50. Academic Press, New York.

Frederick, C. D.

1991 Mima-like mounds of the Texas and Louisiana Gulf Coastal Plain: An overview of their composition, morphology, age, and hypothesized origins. Program and Abstracts, 1991 Annual Meeting of the Association of American Geographers, Miami.

1993 Geomorphology. In Historic and Prehistoric Data Recovery at Palo Duro Reservoir, Hansford County, Texas, J. M. Quigg, C. Lintz, F. M. Oglesby, A. C. Earls, C. D. Frederick, W. N. Trierweiler, D. Owlsley, and K. W. Kibler. Technical Report No. 485. Mariah Associates, Austin.

1996 Geoarcheological results. In Archeology and Native American Religion at the Leon River Medicine Wheel, by M. J. Quigg, C. D. Frederick, and D. Lippert, pp. 88-109. Archeological Resource Management Series, Research Report No. 33. United States Army, Fort Hood.

Frederick, C. D. and M. D. Bateman

1998 The potential applications of optical dating to the sandy uplands of East Texas and Northwest Louisiana. Journal of Northeast Texas Archaeology 11:133-147.

Fredlund, G.

1998 Phytolith Analysis. In Wilson-Leonard: An 11,000year Archeolgical Record of Hunter-Gatherers in Central Texas, assembled by M. B. Collins, pp. 1637-1651. Studies in Archeology 31, Texas Archeological Research Laboratory, The University of Texas at Austin, and Report 10, Archeology Studies Program, Texas Department of Transportation, Austin. 
Fredlund, G. G. and L. L. Tieszen

1997 Phytolith and carbon isotope evidence for Late Quaternary vegetation and climate change in the Southern Black Hills, South Dakota. Quaternary Research 47: 206-217.

1998 Stable carbon isotope analysis of soil organic matter. In Wilson-Leonard: An 11,000-year Archeolgical Record of Hunter-Gatherers in Central Texas, assembled by M. B. Collins, pp. 1653-1656. Studies in Archeology 31, Texas Archeological Research Laboratory, The University of Texas at Austin, and Report 10, Archeology Studies Program, Texas Department of Transportation, Austin.

Freytet, P. and J.-C. Plaziat

1978 Les redistributions carbonatées pédogénétiques (nodules, croûtes, "calcrete"): les deux types principaux d'environments favorables à leur développment. Compte Rendue des Séances de l"Academie des Sciences de Paris 286:1775-1778.

1982 Continental Carbonate Sedimentation and Pedogenesis-Late Cretaceous and Early Tertiary of Southern France. Contributions to Sedimentology 12 E. Schweizerbart'sche Verlagbuchhandlung, Stuttgart.

Fullerton, D. S.

1986 Stratigraphy and correlation of glacial deposits from Indiana to New York and New Jersey. In Quaternary Glaciations in the Northern Hemisphere, edited by V. Sibrava, D. Q. Bowen, and G. M. Richmond, pp. 23-37. Pergamon Press, Oxford.

Gabrysch, R. K.

1984 Ground-water withdrawals and land surface subsidence in the Houston-Galveston region, Texas, 1906-1980. Report 287. Texas Department of Water Resources, Austin.

Gadus, E. F., R. C. Fields, D. E. Williams, K. W. Kibler and S. R. Sauer

1997 National Register Assessments of Prehistoric and Historic Sites in Area DX at the Jewett Mine, Freestone and Leon Counties, Texas. Reports of Investigations No 112. Prewitt and Associates, Inc., Austin.

Gadus, E. F. and M. A. Howard

1990 Hunter-Fisher-Gatherers on the Upper Texas Coast: Archeological Investigations at the Peggy Lake Disposal Area, Harris County, Texas. Reports of Investigations No. 74. Prewitt \& Associates, Inc., Austin.

Gagliano, S. M., C. E. Pearson, R. A Weinstein, D. E. Wiseman and C. M. McClendon

1982 Sedimentary Studies of Prehistoric Archaeological Sites: Criteria for the Identification of Submerged Archaeological Sites of the Northern Gulf of Mexico. U.S. Department of the Interior, National Park Service,
Division of State Plans and Grants, Preservation Planning Series. Prepared by Coastal Environments, Inc., Baton Rouge, Louisiana.

Gagliano, S. M. and B. G. Thom

1967 Deweyville terrace, Gulf and Atlantic coasts. Coastal Studies Bulletin No. 1:23-41, Louisiana State University, Baton Rouge.

Gile, L. H., J.W. Hawley, and R. B. Grossman

1970 Distribution and Genesis of Soils and Geomorphic Surfaces in a Desert Region of Southern New Mexico. Soil Science Society of America Guidebook, Soil-Geomorphology Field Conference, August 21-22 and 29-30, 1970.

1981 Soils and geomorphology in the Basin and Range area of southern New Mexico Guidebook to the Desert Project. Memoir 39. New Mexico Bureau of Mines and Mineral Resources, Socorro.

Gile, L. H., F. F. Peterson, and R. B. Grossman

1965 The K horizon: A master soil horizon of carbonate accumulation. Soil Science 99:74-82.

1966 Morphological and genetic sequences of carbonate accumulation in desert soils. Soil Science 101:347360.

Gilet-Blein, N., G. Marien and J. Evin

1980 The unreliability of ${ }^{14} \mathrm{C}$ dates from organic matter of soils. Radiocarbon 22:919-929.

Gladfelter, B. G.

1977 Geoarchaeology: The geomorphologist and archaeology. American Antiquity 42(4):519-538.

1981 Developments and directions in geoarchaeology. In Advances in Archaeological Method and Theory, Vol. 4, edited by M. B. Schiffer, pp. 343-364. Academic Press, New York.

Goh, K. M. and B. P. J. Molloy

1978 Radiocarbon dating of paleosols using soil organic matter components. Journal of Soil Science 29:567573.

Goodfriend, G. A. and G. L. Ellis

2000 Stable carbon isotope record of Middle to Late Holocene climate changes from land snail shells at Hinds Cave, Texas. Quaternary International 67:47-60.

Goudie, A.

1973 Duricrusts in tropical and subtropical landscapes. Clarendon Press, Oxford.

1983 Calcrete. In Chemical Sediments and Geomorphology: Precipitates and Residua in the Near Surface Environment, edited by A. S. Goudie and K. Pye, pp. 93-131. Academic Press, New York. 
1986 The Human Impact on the Natural Environment. 2nd Edition. MIT Press, Cambridge.

Graham, R. W.

1987 Late Quaternary mammalian faunas and paleoenvironments of the southwestern Plains of the United States. In Late Quaternary Mammalian Biogeography and Environments of the Great Plains and Prairies, edited by R. W. Graham, H. A. Semken, and M. A. Graham pp. 24-86. Scientific Papers 22. Illinois State Museum, Springfield.

Greely, A. W.

1900 Hurricanes on the coast of Texas. National Geographic 11(11):442-445.

Green, C. P. and D. F. M. McGregor

1987 River terraces: A stratigraphic record of environmental change. In International Geomorphology 1986, edited by V. Gardiner, pp. 977-987. John Wiley \& Sons, New York.

Greenberg, W. A. and L. P. Wilding

1998 Evidence for contemporary and relict redoximorphic features of an Alfisol in east-central Texas. In Quantifying Soil Hydromorphology, edited by M. C. Rabenhorst, J. C. Bell, and P. A. McDaniel, pp. 227-246. Soil Science Society of America Special Publication No. 54.

Greenwade, J. M.

1984 Soil Survey of Austin and Waller Counties, Texas. United States Department of Agriculture, Soil Conservation Service, Washington, D.C.

Gustavson, T. C.

1975 Microrelief (gilgai) structures on expansive clays of the Texas Coastal Plain-Their recognition and significance in engineering construction. Geological Circular 75-7. Bureau of Economic Geology, The University of Texas at Austin.

Hall, G. D.

1995 A perspective on some prehistoric cemeteries in Texas: Loma Sandia in the regional setting. In $\mathrm{Ar}$ cheological Excavations at the Loma Sandia Site (41LK28): A Prehistoric Cemetery and Campsite in Live Oak County, Texas, Volume 1, by A. J. Taylor and C. L. Highly, pp. 47-57. 2 Vols. Studies in Archeology 20. Texas Archeological Research Laboratory, The University of Texas at Austin.

Hall, S. A.

1988 Environment and archaeology of the central Osage Plains. Plains Anthropologist 33 (120):203-218.

1990 Channel trenching and climate change in the southern U.S. Great Plains. Geology 18:342-345.
1995 Grassland vegetation in the southern Great Plains during the last glacial maximum. Quaternary Research 44:237-245.

Harden, J. W., E. M. Taylor, M.C. Reheis, and L. D. McFadden 1991 Calcic, gypsic, and siliceous soil chronosequences in arid and semiarid environments. In Occurrence, Characteristics, and Genesis of Carbonate, Gypsum, and Silica Accumulations in Soils, edited by W. D. Nettleton, pp. 1-35. Soil Science Society of America Special Publication No. 26.

Harms, J. C., D. B. MacKensie, and D. G. McCubbin

1963 Stratification in modern sands of the Red River, Louisiana. Journal of Geology 71:566-580.

Hasiotis, S. T., M. C. Geddes, and R. J. Musgrove

1995 Crayfish Jambalaya: Burrowing experiments with Australian and North American crayfish, comparison of burrowing signatures, and implications for the evolutionary and fossil history of freshwater crayfish. Geological Society of America, Abstracts with Programs 27(6):165.

Hasiotis, S. T. and C. E. Michell

1990 Preliminary report on the comparison of Triassic and Holocene crayfish burrow morphologies. Geological Society of America, Abstracts with Programs 22(1):22.

Hayes, C. W. and W. Kennedy

1903 Oil Fields of the Texas Louisiana Coastal Plain. Bulletin 212. United States Geological Survey, Washington, D.C.

Hayes, M. O.

1967 Hurricanes as geologial agents, south Texas coast. Bulletin of the American Association of Petroleum Geologists 51:937-942.

Haynes, C. V., Jr.

1991 Geoarchaeological and paleohydrologic evidence for a Clovis-age drought in North America and its bearing on extinction. Quaternary Research 35:438-450.

Heinrich, P. V.

1986a Geomorphology of the Barker Reservoir area. In Inventory and Assessment of Cultural Resources at Barker Reservoir, Fort Bend and Harris Counties, Texas, by R. C. Fields, M. F. Godwin, M. D. Freeman, and S. V. Lisk, pp. 147-176. Reports of Investigations No. 40. Prewitt and Associates, Inc., Austin.

1986b Geomorphology of seven sites at the Jewett Mine project. In National Register Assessments of Archeological and Historical Resources at the Jewett Mine, Leon County, Texas, by R. C. Fields, S. V. Lisk, J. M. Jackson, M. D. Freeman, and G. L. Bailey, pp. 191-223. Reports of Investigations No. 48. Prewitt and Associates, Inc., Austin. 
1993 Natural Setting. In National Register Eligibility Testing at Sites 41 HR632 and 41HR633, Clear Creek Flood Control Project, Harris County, Texas, by C. Kuttruff, pp. 5-22. Coastal Environments, Inc., Baton Rouge.

Henry, M. J., M. Kontrovitz, and J. M. Slack

1998 Analysis of ostracode remains. In Wilson-Leonard: An 11,000-year Archeolgical Record of HunterGatherers in Central Texas, assembled and edited by M. B. Collins, pp. 1605-1608. Studies in Archeology 31, Texas Archeological Research Laboratory, The University of Texas at Austin, and Report 10, Archeology Studies Program, Texas Department of Transportation, Austin.

Hertz, N.

1990 Stable isotope geochemistry applied to archaeology. In Archaeological Geology of North America, edited by N. P. Lasca and J. Donahue, pp. 585-595. Centennial Special Volume 4. Geological Society of America, Boulder.

Hilgard, E. W.

1873 Supplementary and Final Report of a Geological Reconnaissance of the State of Louisiana. New Orleans Academy of Science and the Bureau of Immigration, New Orleans.

1906 Soils. MacMillan Co., New York.

Hobbs, H. H., Jr. and C. W. Hart, Jr.

1959 The freshwater decapod crustaceans of the Apalachicola drainage system in Florida, southern Alabama, and Georgia. Bulletin of Florida State Museum 4(5):145-191.

Hobbs, H. H., Jr. and M. Whiteman

1991 Notes on the burrows, behavior, and color of the crayfish Fallicambarus (F.) devastator(Decapoda: Cambaridae). Southwestern Naturalist 36:127-135.

Hole, F. D.

1981 The effects of animals in soil. Geoderma 25:75-112.

Holland, W. C., L. W. Hough, and G. E. Murray

1952 Geology of the Beauregard and Allen Parishes. Geological Bulletin 27. Department of Conservation, Louisiana Geological Survey, Baton Rouge.

Holliday, V. T.

1987 Observations on the Cinco Ranch Pimple Mounds. In Cinco Ranch Sites, Barker Reservoir, Fort Bend County, Texas, by H. B. Ensor, pp. 275-280. Reports of Investigations No. 3. Archeological Research Laboratory, Texas A\&M University, College Station.

1989 Middle Holocene drought on the Southern High Plains. Quaternary Research 31:74-82.
1990 Pedology in archaeology. In Archaeological Geology of North America, edited by N. P. Lasca and J. Donahue, pp. 525-540. Centennial Special Volume 4. Geological Society of America, Boulder.

1994 The "state factor" approach in geoarchaeology. In Factors of Soil Formation: A Fiftieth Anniversary Retrospective, edited by R. Amundson, J. Harden, and M. Singer, pp. 65-86. Soil Science Society of America Special Publication No. 33.

2000 Folsom drought and episodic drying on the Southern High Plains from 10,900-10,200 ${ }^{14} \mathrm{C}$ yr B.P. Quaternary Research 53:1-12.

Holliday, V. T. and P. Goldberg

1992 Glossary of selected soil science terms. In Soils in Archaeology, edited by V. T. Holliday, pp. 247-254. Smithsonian Institution Press, Washington, D.C.

Honey, J. G. and S T. Hasiotis

1994 Occurrence and distribution of crayfish burrows, Paleocene of Wyoming and Colorado: Their utility in paleohydrologiv interpretations of alluvial sediments. Geological Society of America, Abstracts with Programs 26(6):18.

Howard, A. D.

1992 Modeling channel migration and floodplain sedimentation in meandering streams. In Lowland Floodplain Rivers: Geomorphological Perspectives, edited by P. A. Carling and G. E. Petts, pp. 1-41. Wiley \& Sons, New York.

Howard, M. A., M. D. Freeman, and C. B. Bousman

1991 Archaeological Reconnaissance on Upper Greens Bayou, Harris County, Texas. Reports of Investigations No. 83. Prewitt \& Associates, Inc., Austin.

1992 Archeological Reconnaissance in the Third Reach of the Clear Creek Flood Control Project, Galveston and Harris Counties, Texas. Reports of Investigations No. 85. Prewitt \& Associates, Inc., Austin.

Huebner, J. A.

1991 Cactus for dinner again! An isotopic analysis of Late Archaic diet in the Lower Pecos Region of Texas. In Papers on Lower Pecos Prehistory, edited by S. A. Turpin, pp. 175-190. Studies in Archeology 8. Texas Archeological Research Laboratory, The University of Texas at Austin.

Huebner, J. A. and T. W. Boutton

1990 The isotopic ecology of bison in Texas. Paper presented at the 48th Plains Anthropological Conference, Oklahoma City, Oklahoma. 
Huebner, J. A. and A. G. Commuzzie

1992 Appendix F: An isotopic analysis of dietary patterns at Blue Bayou. In The Archeology and Bioarcheology of Blue Bayou: A Late Archaic and Late Prehistoric Mortuary Located in Victoria County, Texas, by J. A. Huebner and A. G. Comuzzie, pp. 193-200. Studies in Archeology 9. Texas Archeological Research Laboratory, The University of Texas at Austin.

Humphrey, J. D. and C. R. Ferring

1994 Stable isotopic evidence for latest Pleistocene and Holocene climatic change in North-Central Texas. Quaternary Research 41:200-213.

Isphording, W. C.

1994 Erosion and deposition in northern Gulf of Mexico estuaries. Transactions of the Gulf Coast Association of Geological Societies 44:305-314.

Isphording, W. C., F. D. Imsand, and L. C. Flowers

1984 Storm-related rejuvenation of a northern Gulf of Mexico estuary. Transactions of the Gulf Coast Association of Geological Societies 37:357-370.

Isphording, W. C. and G. W. Isphording

1991 Identification of ancient storm events in buried Gulf Coast sediments. Transactions of the Gulf Coast Association of Geological Societies 41:339-347.

Jenny, $\mathrm{H}$.

1941 Factors of Soil Formation. McGraw Hill, New York.

Jochim, M. A.

1981 Strategies for Survival: Cultural Behavior in an Ecological Context. Academic Press, New York.

Johnson, D. L.

1989 Subsurface stone lines, stone zones, artifactmanuport layers, and biomantles produced by bioturbation via pocket gophers (Thomomys bottae). American Antiquity 54(2):370-389.

1990 Biomantle evolution and the redistribution of earth materials and artifacts. Soil Science 149:84-102.

Johnson, D. L. and F. D. Hole

1994 Soil formation theory: A summary of its principal impacts on geography, geomorphology, soil-geomorphology, Quaternary geology and paleopedology. In Factors of Soil Formation: A Fiftieth Anniversary Retrospective, edited by R. Amundson, J. Harden, and M. Singer, pp. 111-126. Soil Science Society of America Special Publication No. 33.

Johnson, D. L., D. Watson-Stegner, D. N. Johnson, and R. J. Schaetzl

1987 Proisotropic and proanisotropic processes of pedoturbation. Soil Science 143:278-292.
Johnson D. L. and D. Watson-Stegner

1990 The soil evolution model as a framework for evaluating pedoturbation in archaeological site formation. In Archaeological Geology of North America, edited by N. P. Lasca and J. Donahue, pp. 541-560. Centennial Special Volume 4. Geological Society of America, Boulder.

Johnson, L. Jr. and G. T. Goode

1994 A new try at dating and characterizing Holocene climates, as well as archeological periods, on the eastern Edwards Plateau. Bulletin of the Texas Archeological Society 65:1-51.

Kerber, J. E.

1994 Introduction. In Cultural Resource Management: Archaeological Research, Preservation Planning, and Public Education in the Northeastern United States, edited by J. E. Kerber, pp. 1-17. Bergin \& Garvey, Westport, Connecticut.

Kibler, K. W., M. D. Freeman, L. E. Aten, S. D. Hoyt, and K. M. Gardner

1996 Comprehensive Historic Preservation Plan for the Houston-Galveston Navigation Channels, Chambers, Galveston, and Harris Counties, Texas. Prewitt and Associates, Inc., Austin.

Kingston, M.

1986 Texas Almanac, Sesquicentennial Edition. Dallas Morning News, Dallas.

Kirk, D. R.

1970 Wild Edible Plants of the Western United States. Naturegraph Publishers, Healdsburg, California.

Kocurek, G.

1981 Significance of interdune deposits and bounding surfaces in aeolian dune sands. Sedimentology 28: 753780.

Krinitzky, E. L.

1949 Origin of pimple mounds. American Journal of Science 247(10):706-714.

Kuehn, D. D.

1996 Results of geoarcheological investigations. In Report on the 1995 Archeological and Historical Investigations at Washington-on-the-Brazos State Park (41WT5), Washington County, Texas, edited by D. D. Kuehn. pp. 33-46. Technical Report 2. Center for Environmental Archaeology, Texas A\&M University, College Station.

Lancaster, N.

1995 Geomorphology of Desert Dunes. Routledge, London. 
Lankford, R. R. and L. J. Rehkemper

1969 The Galveston Bay complex: A summary of characteristics. In Holocene Geology of the Galveston Bay Area, edited by R. R. Lankford and J. J. W. Rogers, pp. 1-11. Houston Geological Society, Houston.

Lankford, R. R. and J. J. W. Rodgers

1969 Summary. In Holocene Geology of the Galveston Bay Area, edited by R. R. Lankford and J. J. W. Rogers, pp. i-xi. Houston Geological Society, Houston.

Largent, F. B., Jr.

1991 The Prehistory of the Little Pin Oak Site (41FY53), Fayette County, Texas. Master's Thesis, Texas A\&M University, College Station.

Larkin, T. J. and G. W. Bomar

1983 Climatic Atlas of Texas. Publication LP-192. Texas Department of Water Resources, Austin.

Larson, P.

1985 Horror of prairie crayfish no joke to East Texas Farmers. Houston Chronicle, 19 May.

Leatherman, S. P.

1979 Barrier Islands. Academic Press, New York.

1981 Overwash Processes. Benchmark Papers in Geology 58. Hutchinson Ross Publishing Co., Stroudsberg, Pennsylvania.

LeBlanc, R. J. and W. D. Hodgeson

1959 Origin and development of the Texas shoreline. Transactions of the Gulf Coast Association of Geological Societies 9:197-220.

Leopold, L. B., M. G. Wolman, and J. P. Miller

1963 Fluvial Processes in Geomorphology. W. H. Freeman Co., San Francisco.

Lewarch, D. E. and M. J. O'Brien (editors)

1981 Plowzone Archaeology: Contributions to Theory and Technique. Publications in Anthropology 27. Vanderbilt University, Nashville.

Limbrey, S.

1975 Soil Science and Archaeology. Academic Press, New York.

Lintz, C. R.

1993 Early historical period environmental descriptions. In Cultural Resource Investigations in the O. H. Ivie Reservoir, Concho, Coleman, and Runnels Counties, Texas, Volume I: Project Introduction, Setting, and Methods, by C. L. Lintz, W. N. Trierweiler, A. C. Earls, F. M. Oglesby, M. Blum, P. L. O’Neill, J. Kuhl, R. Holloway, L Scott-Cummings, and D. Scurlock, pp. 333-341. Technical Report No. 346-I. Mariah Associates, Inc., Austin.
Lintz, C. R., C. D. Frederick, and J. T. Abbott

1992 Discrete occupations, fluvial processes, and site structure: A cautionary study. Paper presented at the 50th Plains Anthropological Conference, Lincoln, Nebraska.

Looney, R. M. and V. R. Baker

1977 Late Quaternary geomorphic evolution of the Colorado River, inner Texas Coastal Plain. Transactions of the Gulf Coast Association of Geological Societies 27:323-333.

Lowe, J. J. and M. J. C. Walker

1984 Reconstructing Quaternary Environments. Longman, London.

Lundelius, E. L.

1967 Late Pleistocene and Holocene faunal history of central Texas. In Pleistocene Extinctions: A Search for a Cause, edited by P. S. Martin and H. E. Wright, Jr., pp. 287-319. Yale University Press, New Haven.

Lutz, H. J. and F. S. Griswold

1939 The influence of the tree roots on soil morphology. American Journal of Science 237:389-400.

Machette, M. N.

1985 Calcic soils of the southwestem United States. In Soils and Quatemary geology of the Southwestern United States, edited by D.L. Weide, pp. 1-21. Special Paper 203. Geological Society of America, Boulder.

Mandel, R. D.

1987 Geomorphological Investigations. In Buried in the Bottoms: The Archeology of Lake Creek Reservoir, Montgomery County, Texas, by L. C. Bement, R. D. Mandel, J. F. De la Teja, D. K. Utley, and S. A. Turpin, pp. 4-1 to 4-41. Research Report 97. Texas Archeological Survey, The University of Texas at Austin.

1992 Geomorphology. In An Archeological Survey of the Proposed South Bend Reservir Area: Young, Stephens, and Throckmorton Counties, Texas, edited by J. W. Saunders, C. S. Mueller-Wille, and D. L. Carlson, pp. 53-83. Archeological Surveys No. 6. Archeological Research Laboratory, Texas A\&M University, College Station.

1994 Geomorphology and Soil-Stratigraphy of Site 41MU55. In The Valley Branch Archaeological Project: Excavations at an Archaic Site (41MU55) in the Cross Timbers Uplands, North-Central Texas, edited by A. V. Thoms, pp. 41-50. Reports of Investigations 15. Archaeological Research Laboratory, Texas A\&M University, College Station. 
Mandel R. D. and C. J. Sorenson

1982 The role of the western harvester ant (Pogonomyrmex occidentails) in soil formation. Soil Science Society of America Journal 46:785-788.

Mann, A. W. and R. C. Horwitz

1979 Groundwater calcrete deposits in Australia: Some observations from Western Australia. Journal of the Geological Society of Australia 26:293-303.

Matthews, J.A.

1985 Radiocarbon dating of surface and buried soils: principals, problems, and prospects. In Geomorphology and Soils, edited by K. S. Richards, R. R. Arnett, and S. Ellis, pp. 269-288. Allen \& Unwin, London.

Maxwell, R. S. and R. D. Baker

1983 Sawdust Empire: The Texas Lumber Industry 18301940. Texas A\&M University Press, College Station.

McClintock, W. R., Jr., T. L. Galloway, B. R. Stringer, and L. E. Andrew

1972 Soil Survey of Montgomery County, Texas. United States Department of Agriculture, Soil Conservation Service, Washington D.C.

McFadden, L. D.

1982 The impacts of temporal and spatial climatic changes on alluvial soils genesis in Southern California. Ph.D. Dissertation, University of Arizona, Tucson.

McFadden, L. J. and J. C. Tinsley

1985 Rate and depth of pedogenic carbonate accumulation in soils: Formulation and testing of a compartment model. In Soils and Quaternary geology of the southwestern United States, edited by D. L. Weide, pp. 23-41. Special Paper 203. Geological Society of America, Boulder.

McGimsey, C. R., III and H. A. Davis

1984 United States of America. In Approaches to Archaeological Heritage Management: A Comparative Study of World Cultural Resource Management Systems, edited by H. Cleere, pp. 116-124. Cambridge University Press, Cambridge.

McGowen, J. H., L. F. Brown, Jr., T. J. Evans, W. L. Fisher, and C. G. Groat

1976 Environmental Geologic Atlas of the Texas Coastal Zone-Galveston-Houston area. Bureau of Economic Geology, The University of Texas at Austin.

McGowan, J. and L. E. Garner

1970 Physiographic features and stratification types of coarse-grained point bars: modern and ancient examples. Sedimentology 14:77-112.
McGuff, P. R.

1973 Association of archeological material with pimple mounds. In A Survey of Archeological and Historical Resources of Areas to be Affected by the Clear Creek Flood Control Project, Texas by P. R. McGuff and W. N. Cox, pp. 62-72. Report 28. Texas Archeological Survey, The University of Texas at Austin.

McMahan C. A., R. G. Frye, and K. L. Brown

1984 The Vegetation Types of Texas, including Cropland. Map and accompanying Illustrated Synopsis, Texas Parks and Wildlife Department, Austin.

Melton, F. A.

1929 Natural mounds of northeastern Texas, southern Arkansas, and northern Louisiana. Oklahoma Academy of Science Proceedings 19:110-130. University Bulletin No. 456.

Meltzer, D. J., D. K. Grayson, G. Ardila, A. W. Barker, D. F. Dincauze, C. V. Haynes, F. Mena, L. Núñez, and D. J. Stanford

1997 On the Pleistocene antiquity of Monte Verde, Southern Chile. American Antiquity 62:659-663.

Menking, K. M., J. L. Bischoff, J. A. Fitzpatrick, J. W. Burdette, and R. O. Rye

1997 Climatic/hydrologic oscillations since $155,000 \mathrm{yr}$ B.P. at Owens Lake, California, reflected in abundance and stable isotope composition of sediment carbonate. Quaternary Research 48:58-68.

Mielke, H. W.

1977 Mound building by pocket gophers (Geomyidae): Their impact on soils and vegetation of North America. Journal of Biogeography 4:171-180.

Monger, H. C.

1993 Radiocarbon and stable isotopes in the basin floor soils on Fort Bliss. In Soil-Geomorphic and Paleoclimatic Characteristics of the Fort Bliss Maneuver Areas, Southern New Mexico and Western Texas, edited by H. C. Monger, pp. 89-92. Historic and Natural Resources Report 10. Cultural Resources Management Program, Directorate of the Environment, United States Army Air Defense Artillery Center, Ft. Bliss, Texas.

Monger, H. C., D. R. Cole, J. W. Gish, and T. H. Giordano

1998 Stable carbon and oxygen isotopes in Quaternary soil carbonates as indicators of ecogeomorphic changes in the northern Chihuahuan Desert, USA. Geoderma 82:137-172.

Moore, R. G.

1995a An Empirical Analysis of Elements of Prehistoric Site Location and Formation in Harris County, Texas. Report of Investigations No. 149. Moore Archeological Consulting, Houston. 
1995b The Mossy Grove Model of Long-Term ForagerCollector Adaptations in Inland Southeast Texas. Ph.D. Dissertation, Rice University, Houston.

Moore, R. G. and S. Aronow

1993 A Geomorphological and Archeological Assessment of the Proposed Spring Lake, The Woodlands, Harris and Montgomery Counties, Texas. Report of Investigations No. 98. Moore Archeological Consulting, Houston.

Morgan, R. P. C.

1985 Soil degradation and erosion as a result of agricultural practice. In Geomorphology and Soils, edited K. S. Richards, R. R. Arnett, and S. Ellis, pp. 379395. Allen \& Unwin, London.

Morrison, R. B.

1967 Principles of Quaternary soil stratigraphy. In Quaternary Soils, R. B. Morrison and H. E. Wright, Jr., pp. 1-69. Desert Research Institute, University of Nevada at Reno.

Morton, R. A.

1988 Late Quaternary geology of the Texas coastal plain. In Geological Society of America Centennial Field Guide, South-Central Section, 1988. pp. 445-458.

1994 Texas barriers. In Geology of Holocene Barrier Island Systems, edited by R. A. Davis, Jr., pp. 75-114. Springer Verlag, New York.

Morton, R. A. and J. H. McGowen

1980 Modern Depositional Environments of the Texas Coast. Guidebook 20. Bureau of Economic Geology, The University of Texas at Austin.

Morton, R. A. and D. Nummendal

1982 Regional Geology of the N. W. Gulf Coastal Plain. In Sedimentary Processes and Environments Along the Louisiana-Texas Coast, edited by D. Nummendal, pp. 3-25. Field Trip Guidebook, 1982 Meeting, Geological Society of America.

Mosley, M. P.

1973 Rainsplash and the convexity of badland divides. Zeitschrift für Geomorphologie, Supplement 18, pp. 10-25.

Mossa, J, W. J. Autin, and B. J. Miller

1989 Pleistocene terrace overview. In Quaternary Geomorphology and Stratigraphy of the Florida Parishes, Southeastern Louisiana: A Field Trip, edited by J. Mossa and W. J. Autin, pp. 73-81. Guidebook Series No. 5, Louisiana Geological Survey, Baton Rouge.

Mowery, I. C., G. S. McKee, F. Matanzo, and E. Francis 1960 Soil Survey of Fort Bend County, Texas. United States Department of Agriculture, Soil Conservation Service, Washington, D.C.
Netterberg, F.

1978 Dating and correlation of calcretes and other pedocretes. Transactions of the Geological Society of South Africa 81:379-391.

Newcomb, W. W.

1961 The Indians of Texas: From Prehistoric to Modern Times. University of Texas Press, Austin.

Nials, F. and J. Gunn

1982 Geomorphology and soils. In Eagle Hill: A Late Quaternary Upland Site in Western Louisiana, edited by J. Gunn and D. O. Brown, pp. 126-143. Special Report No. 12. Center for Archaeological Research, University of Texas at San Antonio.

Nir, D.

1983 Man, A Geomorphological Agent. Keter Publishing House, Jerusalem.

Nordt, L. C.

1992 Archaeological Geology of the Fort Hood Military Reservation, Fort Hood, Texas. Archeological Resource Management Series, Research Report No. 25. U.S. Army Fort Hood, Texas.

1994 Additional Geoarchaeological Investigations at the Fort Hood Military Reservation, Ft. Hood, Texas. Archeological Resource Management Series, Research Report No. 28. U.S. Army Fort Hood, Texas.

n.d.a Geomorphology. In Data Recovery Excavations at Site 41HR751, Woodforest Road, Harris County, Texas, by N. Hubbard. Report of Investigations No. 178. Moore Archeological Consulting, Houston. Unpublished ms.

n.d.b. Geoarchaeology of the South Texas Project Area: An Overview for Cultural Resource Planning. In Archaeology of the Rio Grande and Central Coastal Plains, Texas: A Planning Document, edited by S. A. Tomka, T. K. Perttula, and R. J. Hard. Archaeological Survey Report No. 266. Center for Archaeological Research, University of Texas at San Antonio. Unpublished ms.

Nordt, L. C., T. W. Boutton, C. T. Hallmark, and M. R. Waters 1994 Late Quaternary Vegetation and Climate Changes in Central Texas Based on the Isotopic Composition of Organic Carbon. Quaternary Research 41(1):109-120.

Nordt, L. C., C. T. Hall, L. P. Wilding, and W. G. Chervenka 1992 Soils and Geomorphology Tour of Brazos and Eastern Burleson Counties, Texas. Report on file at the Soil and Crop Science Department, Texas A\&M University, College Station.

North American Commission on Stratigraphic Nomenclature 1983 North American Stratigraphic Code. Bulletin of the American Association of Petroleum Geologists 67: 841-875. 
Nummendal, D.

1982 Hurricane landfalls along the N. W. Gulf Coast. In Sedimentary Processes and Environments Along the Louisiana-Texas Coast, edited by D. Nummendal, pp. 63-78. Field Trip Guidebook, 1982 Meeting, Geological Society of America.

Nyman, J. A., C. R. Crozier, and R. D. Delaune

1993 Roles and patterns of hurricane sedimentation in a coastal marsh. Abstracts with Programs, American Society of Agronomy, 1993 National Meeting. American Society of Agronomy, Madison, Wisconsin.

O'Brien, M. J., R. L. Lyman, and T. D. Holland

1989 Geoarchaeological evidence for prairie-mound formation in the Mississippi alluvial valley, Southeastern Missouri. Quaternary Research 31:83-93.

Otvos, E. G.

1972 Mississippi Gulf Coast Pleistocene beach barriers and the age problem of the Atlantic-Gulf Coast "Pamlico"-"Ingleside" beach ridge system. Southeastern Geology 14:241-250.

1980 Age of the Tunica Hills (Louisiana-Mississppi) Quaternary fossiliferous creek deposits: Problems of radiocarbon dates and intermediate valley terraces in coastal plains. Quaternary Research 13:80-92.

1991 Houston Ridge, SW Louisiana-End link of the Pleistocene Ingleside barrier chain? Prairie Formation newly defined. Southeastern Geology 31:235-249.

Overpeck, J. T., L. C. Peterson, N. Kipp, J. Imbrie, and D. Rind

1989 Climate change in the circum-North Atlantic region during the last deglaciation. Nature 338:553-557.

Paine, J. G.

1987a Late Quaternary development of the San Jacinto River Valley Margin at Peggy Lake, upper Texas Coast. Transactions of the Gulf Coast Association of Geological Societies 37:433-441.

1987b The Swan Lake Site (41AS16) and the Holocene highstand hypothesis. In National Register Assessments of the Swan Lake Site, 4IAS16, on Copano Bay, Aransas County, Texas, by E. R. Prewitt, S. V. Lisk, and M. A. Howard, pp 241-253. Reports of Investigations No. 56. Prewitt \& Associates, Inc., Austin.

1990 Late Quaternary Geology of the Peggy Lake Area. In Hunter-Fisher-Gatherers on the Upper Texas Coast Archeological Investigations at the Peggy Lake Disposal Area, Harris County, Texas, by E. Gadus and M. A. Howard, pp. 373-400. Reports of Investigations No. 74. Prewitt \& Associates, Inc., Austin.

Parker, A. A.

1835 Trips to the West and Texas. White and Fisher, Concord, New Hampshire.
Paton, T. R.

1974 Origin and terminology for gilgai in Australia. Geoderma 11:221-242.

Paton, T. R., G. S. Humphreys, and P. B. Michell

1995 Soils: A New Global View. Yale University Press, New Haven, Connecticut.

Patterson, L. W.

1980 The Owen Site 41HR315: A long occupation sequence in Harris County, Texas. Houston Archeological Society Report 3.

1995 The Archeology of Southeast Texas. Bulletin of the Texas Archeological Society 66:239-264.

1996 The Clovis projectile point in Southeast Texas. Journal of the Houston Archeological Society 116:17-21.

Patterson, L. W. and J. D. Hudgins

1985 Paleo-Indian occupations in Wharton County, Texas. Bulletin of the Texas Archeological Society 56:155170.

Perttula, T. K., B. D. Skiles, M. B. Collins, M. C. Trachte, and F. Valdez, Jr.

1986 "This Everlasting Sand Bed": Cultural Resources Investigations at the Texas Big Sandy Project, Wood and Upshur Counties, Texas. Reports of Investigations No. 52. Prewitt \& Associates, Inc., Austin.

Piperno, D. R.

1988 Phytolith Analysis: An Archaeological and Geographic Perspective. Academic Press, New York.

Plummer, F. B.

1932 Cenozoic Systems in Texas. In The Geology of Texas, Volume 1: Stratigraphy, edited by E. H. Sellards, W. S. Adkins, and F. B. Plummer, pp. 519-818. Bulletin No. 3232. Bureau of Economic Geology, The University of Texas At Austin.

Price, W. A.

1933 Role of diastrophism in topography of Corpus Christi area, south Texas. Bulletin of the Association of American Petroleum Geologists 17:907-962.

1949 Pocket gophers as architects of mima (pimple) mounds of the western United States. Texas Journal of Science 1:1-17.

1955 Environment and formation of the chenier plain. Quaternaria 2:75-86.

1958 Sedimentary and Quaternary geology of South Texas. Transactions of the Gulf Coast Association of Geological Societies 8:41-75.

Pye, K.

1987 Aeolian Dust and Dust Deposits. Academic Press, New York 
Rapp, G., R. Bullard, and C. Albritton

1974 Geoarchaeology? The Geologist 9:1.

Reeves, C. C., Jr.

1970 Origin, classification, and geologic history of caliche on the southern High Plains, Texas and eastern New Mexico. Journal of Geology 78:352-362.

Reider R. G.

1992 Mima-like mounds as salt-movement structures, Laramie Basin, Wyoming, USA. Program and Abstracts of the 12th Biennial Meeting of the American Quaternary Association, p. 74.

Reineck, H. E. and I. B. Singh

1980 Depositional Sedimentary Environments: With Reference to Terrigenous Clastics. 2nd Edition. Springer-Verlag, New York.

Renfrew, C.

1976 Archeology and the earth sciences. In Geo-Archaeology, edited by D. A. Davidson and M. L. Shackley, pp. 1-5. Duckworth, London.

Ricklis, R. A.

1993 A Model of Holocene Environmental and Human Adaptive Change on the Central Texas Coast: Geoarchaeological Investigations at White's Point, Nueces Bay, and Surrounding Area. Coastal Archaeological Research, Inc., Corpus Christi.

1994 Aboriginal Life and Culture on the Upper Texas Coast: Archaeology at the Mitchell Ridge Site, 41GV66, Galveston Island. Coastal Archaeological Research, Inc., Corpus Christi.

1995 Prehistoric occupation of the central and lower Texas coast: A regional overview. Bulletin of the Texas Archeological Society 66:265-300.

1996 Hunter-gatherer economic strategies and mobility patterns in the southern coastal corridor. In Archeology in the Central and Southern Planning Region, Texas: A Planning Document, edited by P. A. Mercado-Allinger, N. A. Kenmotsu, and T. K. Perttula, pp. 85-166. Office of the State Archeologist, Special Report 35, and the Department of Antiquities Protection, Cultural Resources Management Report 7, Texas Historical Commission, Austin.

Ricklis, R. A. and M. D. Blum

1997 The geoarchaeological record of Holocene sea level change and human occupation on the Texas Gulf Coast. Geoarchaeology 12(4):287-314.

Rightmire, C. T.

1967 A radiocarbon study of the age and origin of caliche deposits. Master's Thesis, The University of Texas at Austin.
Ritter, D. F.

1978. Process Geomorphology. Wm. C. Brown Company, Dubuque, Iowa.

Robinson, R. L.

1982 Biosilica analysis of three prehistoric archaeological sites in the Choke Canyon Reservoir, Live Oak County, Texas: Preliminary summary of climatic implications. In Archaeological Investigations at Choke Canyon Reservoir, South Texas: Phase I Findings, by G. D. Hall, S. L. Black, and C. Graves, pp. 597-610. Choke Canyon Series, Volume 5. Center for Archaeological Research, University of Texas at San Antonio.

Rogers, R.

1992 Data Recovery at Three Prehistoric Sites at the Gibbons Creek Third Five-Year Mine Permit Area, Grimes County, Texas. Espey, Huston and Associates, Inc., Austin.

Ross, S.

1989 Soil Processes: An Integrated Approach. Routledge, London.

Rowell, D. L.

1994 Soil Science: Methods and Applications. Longman Scientific, Harlow, Essex.

Ruhe, R. V.

1965 Quaternary paleopedology. In The Quaternary of the United States, edited by H. E. Wright and D. G. Frey, pp. 755-764. Princeton University Press, Princeton, New Jersey.

Ruhe, R. V. and R. B. Daniels

1958 Soils, paleosols, and soil-horizon nomenclature. Soil Science Society America Proceedings 22:66-69.

Russ, D. P

1975 The Quaternary Geomorphology of the lower Red River Valley, Louisiana. Ph.D. Dissertation, Louisiana State University, Baton Rouge.

Scharpenseel, H. W.

1971 Radiocarbon dating of soils: problems, troubles, hopes. In Paleopedology: Origin, Nature, and Dating of Paleosols, edited by D. Yaalon, pp. 77-88. Israel University Press, New York.

Schiffer, M. B.

1987 Formation Processes of the Archaeological Record. University of New Mexico Press, Albuquerque.

Schiffer, M. B. and G. J. Gumerman (editors)

1977 Conservation Archaeology: A Guide for Cultural Resource Management Studies. Academic Press, New York. 
Schumm, S. A.

1977 The Fluvial System. John Wiley and Sons, New York.

Schwartz, D., A. Mariotti, R. Lanfranchi, and B. Guillet

$1986{ }^{13} \mathrm{C} /{ }^{12} \mathrm{C}$ ratios of soil organic matter as indicators of vegetation changes in the Congo. Geoderma 39:97103.

Scott, A. J. and W. L. Fisher

1969 Delta systems and deltaic deposition. In Delta Systems in the Exploration for Oil and Gas: A Research Colloquium, edited by W. L. Fisher and others, pp. 10-29. Bureau of Economic Geology, The University of Texas at Austin.

Scott, A. J., R. A. Hoover, and J. H. McGowen

1969 Effects of Hurricane "Beulah," 1967, on Texas Coastal Lagoons and Barriers. In Lagunas Costeras, Un Simposio, Mem. Simp. Intern. Lagunas Costeras, November 28, 1967, Mexico. UNAM-UNESCO. Reprinted in Overwash Processes, edited by S. P. Leatherman, pp. 215-224. Benchmark Papers in Geology 58 (1981). Hutchinson Ross Publishers, Stroudsburg, Pennsylvania.

Selby, M. J.

1993 Hillslope Materials and Processes. 2nd Edition. Oxford University Press, Oxford.

Sellards, E.H., W.S. Akins, and F.B. Plummer

1932 The Geology of Texas, Volume I: Stratigraphy. Bulletin No. 3232. Bureau of Economic Geology, The University of Texas at Austin.

Sellés-Martínez, J.

1996 Concretion morphology, classification and genesis. Earth Science Reviews 41:177-210.

Shackleton, N. J. and N. D. Opdyke

1973 Oxygen isotope and paleomagnetic stratigraphy of equatorial Pacific core V28-238: oxygen isotope temperatures and ice volumes on a $10^{5}$ and $10^{6}$ year scale. Quaternary Research 3:39-55.

Sharpe, C. F. S.

1938 Landslides and Related Phenomena. Columbia University Press, New York.

Sheets, R. G., R. L. Linder, and R. B. Dahlgren

1971 Burrow systems of prairie dogs in South Dakota. Journal of Mammalogy 52:451-452.

Smiley, T. L., R. A Bryson, J. E King, G. J. Kukla, and G. I. Smith

1991 Quaternary Paleoclimates. In The Geology of North America, Volume K2: Quaternary Non-Glacial Geomorphology, Conterminous United States, edited by R. B. Morrison, pp. 13-44. Geological Society of America, Boulder.
Smith, F. L. and D. P. Russ

1974 Geologic investigation of the lower Red RiverAtchafalaya Basin area. Technical Report No. S74-5. U. S. Army Corps of Engineers, Waterway Experiment Station, Vicksburg.

Soil Survey Staff

1975 Soil Taxonomy: A Basic System for Making and Interpreting Soil Surveys. United States Department of Agriculture Handbook 436. U.S. Government Printing Office, Washington, D.C.

1990 Keys to Soil Taxonomy (fourth printing). SMSS Technical Monograph 19. Soil Management Support Services, Virginia Polytechnic Institute and State University, Blacksburg, Virginia.

1999 Soil Taxonomy: A Basic System for Making and Interpreting Soil Surveys. 2nd edition. United States Department of Agriculture Handbook 436. U.S. Government Printing Office, Washington, D.C.

Sorenson, C. J., R. D. Mandel, and J. C. Wallis

1976 Changes in bioclimate inferred from paleosols and paleohydrologic evidence in east central Texas. Journal of Biogeography 3:141-149.

Stahl, C.

1995 Appendix II: Plant Economies. In The Mossy Grove Model of Long-Term Forager-Collector Adaptations in Inland Southeast Texas, by R. G. Moore. Ph.D. Dissertation, Rice University, Houston.

Stein, J. K.

1983 Earthworm activity: A source of potential disturbance of archaeological sediments. American Antiquity 48:277-289.

1992 Organic matter in archaeological contexts. In Soils in Archaeology: Landscape Evolution and Human Occupation, edited by V. T. Holliday, pp. 193-216. Smithsonian Institution Press, Washington, D.C.

Stickney, R. R.

1984 Estuarine Ecology of the Southeastern United States and Gulf of Mexico. Texas A\&M University Press, College Station.

Stone, E. L.

1993 Soil burrowing and mixing by crayfish. Soil Science Society of America Journal 57:1096-1099.

Story, D. A.

1985 Adaptive strateges of Archaic cultures of the West Gulf Coastal Plain. In Prehistoric Food Production in North America, edited by R. I. Ford, pp. 19-56. Anthropological Papers No. 75. Museum of Anthropology, University of Michigan, Ann Arbor. 
Strahler, A. H. and A. N. Strahler

1992 Modern Physical Geography. John Wiley \& Sons, New York.

Stright, M. J.

1990 Archaeological sites on the North American continental shelf. In Archaeological Geology of North America, edited by N. P. Lasca and J. Donohue, pp. 439-465. Centennial Special Volume 4. Geological Society of America, Boulder.

1995 Archaic period sites on the continental shelf of North America: The effects of relative sea-level changes on archaeological site locations and preservation. In Archaeological Geology of the Archaic Period in North America, edited by E. A. Bettis, III, pp. 131-147. Special Paper 297. Geological Society of America, Boulder.

Suhm, D.A. and E. B. Jelks (editors)

1962 Handbook of Texas Archeology: Type Descriptions. Texas Archeological Society, Special Publications No. 1, and Texas Memorial Museum, Bulletin No. 4 , Austin.

Suter, J. R. and R. A. Morton, with S. Penland

1989 Coastal Depositional Systems, Northwest Gulf of Mexico. In Coastal and Marine Geology of the United States. American Geophysical Union, Washington, D.C.

Tate, M. and R. Rogers

1998 A Cultural Resources Survey of the 1557-Acre AX Area at the Sandow Surface Mine, Milam County, Texas. Espey, Huston and Associates, Inc., Austin.

Taylor, A. J.

1995 An overview of mortuary traits at Loma Sandia and certain other Texas sites. In Archeological Excavations at the Loma Sandia Site (41LK28): A Prehistoric Cemetery and Campsite in Live Oak County, Texas, by A. J. Taylor and C. L. Highly, pp. 663699. 2 Vols. Studies in Archeology 20. Texas Archeological Research Laboratory, The University of Texas at Austin.

Texas State Historical Association

1996 The New Handbook of Texas, in Six Volumes. Texas State Historical Association, Austin.

Thoms, A. V.

1993 Buried in the sandy mantle: Site formation in the Post Oak Savannah. In The Brazos Valley Slopes Archeological Project: Cultural Resources Survey and Assesment for the Texas A\&M University Animal Science Teaching and Research Complex, Brazos County, Texas, edited by A. V. Thoms, pp. 51-60. Reports of Investigations 14. Archaeological Research Laboratory, Texas A\&M University, College Station.
Thoms, A. V. and R. D. Mandel

1992 The Richard Beene site: A deeply stratified Paleoindian to Late Prehistoric occupation in southcentral Texas. Current Research in the Pleistocene 9:42-44.

Thoms, A. V. and B. W. Olive

1993 The ASTRC landscape and natural site formation processes: Sandy mantle sediments and reconstituted cultural stratigraphy. In The Brazos Valley Slopes Archeological Project: Cultural Resources Survey and Assesment for the Texas A\&M University Animal Science Teaching and Research Complex, Brazos County, Texas, edited A. V. Thoms, pp. 61-80. Reports of Investigations 14 . Archaeological Research Laboratory, Texas A\&M University, College Station.

Thorn, C. E.

1978 A preliminary assessment of the geomorphic role of pocket gophers in the alpine zone of the Colorado Front Range. Geografiska Annaler 60A:181-188.

Thorp, J.

1949 Interrelations of Pleistocene geology and soil science. Geological Society of America Bulletin 60:1517-1526.

Tomka, S. A., T. K. Perttula, and R. J. Hard (editors)

n.d. Archaeology of the Rio Grande and Central Coastal Plains, Texas: A Planning Document. Archaeological Survey Report No. 266. Center for Archaeological Research, University of Texas at San Antonio, 1997 Review Draft.

Toomey, R. S., III

1993 Late Pleistocene and Holocene Faunal and Environmental Changes at Hall's Cave, Kerr County, Texas. Ph.D. Dissertation, The University of Texas at Austin.

Toomey, R. S., III, M. D. Blum, and S. Valastro, Jr.

1993 Late Quaternary climates and environments of the Edwards Plateau, Texas. Global and Planetary Change 7:299-320.

Trierweiler, W. N. (editor)

1994 Archeological Investigations on 571 Prehistoric Sites at Fort Hood, Bell and Coryell Counties, Texas. Archeological Resource Management Series, Research Report No. 31. United States Army Fort Hood, Texas.

Turner, E. S. and T. R. Hester

1993 A Field Guide to Stone Artifacts of Texas Indians, 2nd Edition. Texas Monthly Field Guide Series. Gulf Publishing Co., Houston. 
Turner, E. S. and P. Tanner

1994 The McFaddin Beach Site on the Upper Texas Coast. Bulletin of the Texas Archeological Society 65: 319 335 .

United States Army Corps of Engineers

1961 Report on Hurricane Carla, 9-12 September, 1961. Galveston District, U.S. Army Corps of Engineers. U. S. Government Printing Office, Washington, D.C.

n.d. Common Wetland Plants of Southeast Texas. Galveston District, U. S. Army Corps of Engineers.

van der Merwe, M. J.

1982 Carbon Isotopes, Photosynthesis, and Archaeology. American Scientist 70:596-606.

Van Devender, T. R.,

1990 Late Quaternary climate and vegetation of the Chihuahuan desert, United States and Mexico. In Packrat Middens: The Last 40,000 Years of Biotic Change, edited by J. L. Betancourt, T. R. Van Devender, and P. S. Martin, pp. 104-133. University of Arizona Press, Tucson.

Van Donk, J.

$1976 \mathrm{An}{ }^{18} \mathrm{O}$ record of the Atlantic Ocean for the entire Pleistocene. In Investigation of Late Quaternary Paleooceanography and Paleoclimatology, edited by R. M. Cline and J. D. Hays, pp. 145-163. Memoir 145. Geological Society of America, Boulder.

Van Nest, J.

1988 The good earthworm: How natural processes preserve upland Archaic sites in the Midwest. Paper presented at the 63rd Annual Meeting of the Society for American Archaeology, Seattle, Washington, D.C.

Van Siclen, D. C.

1972 Correspondence of coastal terraces with inland surfaces in Texas, Lower Brazos and Colorado River valleys. Texas Journal of Science 24:569-571.

1985 Pleistocene meander-belt ridge patterns in the vicinity of Houston, Texas. Transactions of the Gulf Coast Association of Geological Societies. 35:525-532.

1991 Surficial geology of the Houston area: An offlapping series of Pleistocene (\& Pliocene?) highest sea level fluviodeltaic sequences. Transactions of the Gulf Coast Association of Geological Societies 41:651-666.

Van Wallenburg, C.

1973 Hydromorphic soil characteristics in alluvial soils in connection with soil drainage. In 5th and 6th Commission, International Soil Science Society Transactions, pp. 393-403.
Veneman, P. L. M., L. A. Spokas, and D. L. Lindbo

1998 Soil moisture and redoximorphic features: A historical perspective. In Quantifying Soil Hydromorphology, edited by M. C. Rabenhorst, J. C. Bell, and P. A. McDaniel, pp. 1-23. Soil Science Society of America Special Publication No. 54.

Voellinger, L. R.

1990 The Geomorphological Analysis of the Lower Brazos River Basin, Texas, Applied to the Management of Its Cultural Resources. Master's Thesis, Southwest Texas State University, San Marcos.

Walker, H. J. and J. M. Coleman

1987 Atlantic and Gulf Coastal Province. In Geomorphic Systems of North America, edited by W. L. Graf, pp. 51-110. Centennial Special Volume 2. Geological Society of America, Boulder.

Walker, R. G. and D. J. Cant

1980 Sandy Fluvial Systems. In Facies Models, edited by R. G. Walker, pp. 23-31. Reprint Series 1, 2nd Printing, Geoscience Canada.

Wang, Y., R. Amundson, and S. Trumbatore

1996 Radiocarbon dating of soil organic matter. Quaternary Research 45:282-288.

Warren, R. D., T. L. Thurow, W. H. Blackburn, and N. E. Garza

1986 The influence of livestock trampling under intensive rotation grazing on soil hydrologic characteristics. Journal of Range Management 39:491-495.

Washburn, A. L.

1988 Mima Mounds, and Evaluation of Proposed Origins with Special Reference to the Puget Lowland. Report of Investigations No. 29. Washington Division of Geology and Earth Resources, Department of Natural Resources, Olympia.

Wasson, R. J. and P. M. Nanninga

1986 Estimating wind transport of sand on vegetated surfaces. Earth Surface Processes and Landforms 11: 505-514.

Waters, M. R.

1992 Principals of Geoarchaeology: A North American Perspective. University of Arizona Press, Tucson.

Waters, M. R. and L. C. Nordt

1995 Late Quaternary Floodplain History of the Brazos River in east-central Texas. Quaternary Research 43: 311-319.

1996 Geomorphic reconnaissance of selected segments of the MidTexas pipeline. In Archaeological Survey of the Proposed 130-Mile MidTexas Pipeline, Gonzales, DeWitt, Lavaca, Austin, and Waller Counties, Texas, edited by K. A. Miller, pp. 39-67. SWCA Environmental Consultants, Inc., Austin. 
Webb, T., III

1973 A comparison of modern and pre-settlement pollen from S. Michigan (USA). Review of Paleobotany and Palynology 16:137-156.

Wedel, W. R.

1961 Prehistoric Man on the Great Plains. University of Oklahoma Press, Norman.

West, L. T., L. R. Drees, L. P. Wilding, and M. C. Rabenhorst 1988 Differentiation of pedogenic and lithogenic carbonate forms in Texas. Geoderma 43:271-287.

Wheat, J. B.

1953 An Archeological Survey of Addicks Basin, Southeast Texas. Bulletin 154, pp. 143-252. Bureau of American Ethnology, Washington, D.C.

Wheeler, F. F.

1976 Soil Survey of Harris County, Texas. United States Department of Agriculture, Soil Conservation Service.

Whicker, A. D. and J. K. Detling

1988 Ecological consequences of prairie dog disturbances. Bioscience 38:778-784.

White, K. L. and K. C. Wiegand

1989 Geomorphic analysis of floodplain sand mounds, Navasota River, Texas. Bulletin of the Association of Engineering Geologists 26(4):477-499.

Wilding, L. P. and D. Tessier

1988 Genesis of Vertisols: Shrink-swell phenomena. In Vertisols: Their Distribution, Properties, Classification and Management, edited by L. P. Wilding and R. Puentes, pp 55-81. Technical Monograph No. 18. Soil Management Support Services, Soil Conservation Service, United States Department of Agriculture. Texas A\&M University Printing Center, College Station.
Wilkinson, B. H. and R. A. Basse

1978 Late Holocene history of the central Texas coast from Galveston Island to Passo Cavallo. Geological Society of America Bulletin 89:1592-1600.

Wilkinson, B. H., J. H. McGowen, and C. R. Lewis

1975 Ingleside strandplain sand of central Texas coast. Bulletin of the American Association of Petroleum Geologists 59:347-352.

Winker, C.

1979 Late Pleistocene Fluvial-Deltaic Deposition, Texas Coastal Plain and Shelf. Master's Thesis, The University of Texas at Austin.

Winsborough, B. M.

1995 Diatom-based paleoecological analysis of the Late Quaternary valley fill. In Stratigraphy and Paleoenvironments of Late Quaternary Valley Fills on the Southern High Plains, by V. T. Holliday, pp. 67-82. Memoir 186. Geological Society of America, Boulder.

1998 Diatom analysis. In Wilson-Leonard: An 11,000-year Archeological Record of Hunter-Gatherers in Central Texas, assembled and edited by M. B. Collins, pp. 1601-1604. Studies in Archeology 31, Texas Archeological Research Laboratory, The University of Texas at Austin, and Report 10, Archeology Studies Program, Texas Department of Transportation, Austin.

Wright, L. D.

1977 Sediment transport and deposition at river mouths: A synthesis. Geological Society of America Bulletin 88:857-868.

Yaalon, D. H. and E. Ganor

1973 The influence of dust on soils during the Quaternary. Soil Science 116:146-155.

York, J. C. and W. A. Dick-Peddie.

1969 Vegetation changes in southern New Mexico during the past hundred years. In Arid lands in perspective, edited by W. G. McGinnies and B. J. Goldman, pp. 155-166. University of Arizona Press, Tuscon. 


\section{A pPENDix I}

\section{Glossary of Terms}

\begin{abstract}
A Horizon: The surface horizon of a natural soil. An A horizon is a mineral soil horizon characterized by an accumulation of partially decomposed to decomposed organic matter and eluvial loss of constituents such as clays and carbonates, which tend to accumulate in the B horizon. It represents the upper solum of a soil. Common subordinate descriptors include lowercase $\mathrm{p}$ (Ap horizon), which designates an anthropically modified or disturbed A such as a plow zone; lowercase $\mathrm{b}(\mathrm{Ab})$ which indicates burial; and lowercase ss (Ass), which indicates the presence of slickensides.
\end{abstract}

Albic Horizon: A light colored soil horizon characterized by a significant loss of clay and free-iron oxides, a lack of organic accumulation, and a concentration of residual silica. It is synonymous with E horizon.

Allogenic: Refers to a material formed elsewhere and transported to its current location. Antonym: Authigenic.

Alluvium: Clastic (detrital) material deposited by a channelized, flowing stream, including material deposited outside of the channel during overbank flooding. The term is occasionally used to denote any sediment deposited by flowing water.

Angular Unconformity: Boundary between two different stratigraphic units that exhibit differing internal strikes and dips, usually as a result of tectonic deformation of the older unit.

Architecture: In a stratigraphic sense, refers to the three-dimensional arrangement of, and relationships between, sedimentary units within any given landscape setting.

Argillic Horizon: A soil horizon (Bt horizon) that exhibits significant enrichment in illuvial clay minerals or clay-size particles. Such clays typically form grain coats, grain bridges, and ped-face coats of oriented clay that are visible in thin section, and usually can be identified with a hand lens. Such minerals may have either formed by silicate weathering higher in the profile or been deposited as clay minerals in the first place, but must exhibit significant illuvial accumulation of clays translocated from overlying horizons to qualify as argillic; clay-rich primary deposits do not qualify.

Argilliturbation: Mixing of soil or sediment, and materials contained therein, due to the expansion and contraction of clay minerals with wetting and drying.

Authigenic: Formed in place. Antonym: Allogenic.

Autocompaction: Compaction of a sediment, particularly in a deltaic setting, under its own weight. Deltaic autocompaction is largely a function of gradual dewatering.

Avulsion: Process where a river abandons its channel and establishes a new channel. Avulsion is particularly common in a rapidly aggrading system where the natural levees aggrade and the water surface builds up to an elevation at or above the surrounding floodplain.

B Horizon: The lower solum of a natural soil. A B horizon is a mineral soil horizon characterized by an accumulation of constituents such as clays, carbonates or salts, or organic complexes that have been translocated from the A horizon. Common subordinate descriptors include lowercase $\mathrm{t}(\mathrm{Bt})$, which indicates accumulation of illuvial clays; lowercase $\mathrm{k}(\mathrm{Bk})$, which indicates accumulation of carbonate; lowercase $\mathrm{g}(\mathrm{Bg})$, which indicates pronounced gleying; lowercase $\mathrm{s}(\mathrm{Bs})$, which indicates illuvial accumulation of sesquioxides ( $\mathrm{Fe}$ and $\mathrm{Al}$ ), and lowercase w $(\mathrm{Bw})$, which indicates structural or color changes with no significant accumulations of alluvial material. Incipient soils frequently lack a B horizon.

Bed Load: Clastic sediment moved by rolling or sliding along the bed of a stream or at the air/ground interface. 
Benthic: Pertaining to the ocean floor and the organisms that live there.

Bioturbation: Mixing of soil or sediment by the action of plants or animals. Subsumes both faunalturbation and floralturbation.

C Horizon: Weathered, but relatively little altered parent material at the base of a soil profile. Roughly synonymous with subsoil, although the latter term is often used to encompass the lower B horizons.

Calcic Horizon: In general usage, a soil horizon characterized by the accumulation of pedogenic carbonate. In the USDA Soil Taxonomy system, a calcic horizon must meet specific criteria (thickness, $\mathrm{CaCO}_{3}$ content). Depending on the degree of development, a calcic horizon can either be designated as a $\mathrm{Bk}$ horizon or as a $\mathrm{K}$ (or $\mathrm{Bm}$ ) horizon.

Calcification: A soil-forming pathway typical of semiarid to arid climates and characterized by incomplete leaching of carbonate, resulting in the development of a calcic horizon. Organic matter content is primarily controlled by the rate of organic production, which typically exceeds the rate of microbial destruction of organic matter.

\section{Calcrete: See $K$ horizon.}

Cambic Horizon: A B horizon exhibiting color change and/or structural development relative to the parent material, but lacking clear evidence of illuvial accumulation of material. It is synonymous with the Bw horizon in general usage. In the strict usage of Soil Taxonomy, a cambic horizon must satisfy a number of specific criteria.

Capacity: A measure of the total clastic load carried by a stream under a given set of conditions, including the traction load and suspended load. While competence relates to the largest clast that can be moved, and is a function primarily of velocity, capacity relates to the total volume of sediment moved and is dependent primarily on discharge.

Capillary Fringe: Zone immediately above the water table where water is drawn upward and held in pore spaces by surface tension.

Catena: A soil catena represents an assemblage of soils whose differences primarily reflect the influence of their position on a slope. It is a type of toposequence.

Chronosequence: A spatially related assemblage of soils whose differences primarily reflect the influence of time as a soil forming factor, or systematic spatial variation in soil properties or soil development attributable to the influence of the duration of pedogenesis.
Clast: Any detrital particle (sediment) created by the weathering and disintegration of a larger rock mass and transported by, or subject to physical transport by, water, wind, or ice. Clast also includes discrete particulates created and deposited by volcanic action (pyroclastics).

Clastic: Describes a system dominated by the physical transport of sediment clasts, or a body of rock derived from such a system.

Clay: Used in two senses. In a mineralogical sense, refers to one of a class of very fine, siliceous minerals formed by layering of silicon, aluminum, oxygen, iron, and other atoms. Some clay minerals can take on water and expand in volume, while some do not, but all are platy and exhibit an electrostatic (colloidal) charge that causes them to attract ions. Texturally, the term refers to clay minerals and other similarly sized particles $(<0.002 \mathrm{~mm})$, such as sesquioxides and amorphous minerals in association with humus, that share these colloid properties.

Competence: A measure of the ability for a stream to transport a sediment clast of a particular size or mass in the traction load or short-term suspension (cf. capacity). Competence is largely a function of the velocity of the stream.

Concretion: A product of localized mineral precipitation, commonly in the soil zone or in marine sediments. Concretions exhibit a concentric laminar structure due to the addition of successive layers from the exterior or interior, and may be subspherical or elongate. Many concretions contain cracks and/or internal voids, and are more properly termed pedodes or septaria.

Cumulic Soil: A soil formed in a setting experiencing relatively slow deposition, so that freshly introduced sediment is incorporated into the A horizon, leading to overthickening of the surface horizon. Cumulic soils are common in alluvial overbank and colluvial settings.

Deflation: Removal of fine-grained surface material by eolian processes, often resulting in a lag of coarse clasts. The use of this term to denote downwearing of the surface of a site by any process (e.g., sheet erosion, rainsplash) is common in the archeological literature, but is imprecise and should be discouraged.

Deformation: Plastic reorganization of sediment due to any one of a number of factors including pressure, consolidated mass movement, loss of support, dewatering, subsidence, etc. Deformation can result in characteristic sedimentary structures such as contorted bedding or microfaulting. 
Deltaic: Related to deposits formed where a stream enters a standing body of water, such as a sea or a lake, and loses its ability to transport sediment. A delta is a landform composed of deltaic sediments.

Diapir: A dome/mushroom-shaped geologic structure formed by the extrusion of relatively plastic material in a stratum through a rupture in overlying strata. Salt domes on the Gulf Coast are diapirs formed by the extrusion of salts from deep evaporite beds through overlying strata.

Dip: The angle between the sloping surface of an inclined, tabular body of rock and a level plane, as measured at right angles to the strike.

Discharge: The amount of water moving through a given cross-section of a stream in a given amount of time (e.g., cubic feet/sec or cubic meters/sec). Discharge $(\mathrm{Q})$ is equal to the cross-sectional area (A) times the mean velocity (V).

Disconformity: Unconformity that separates two sediment or rock units that exhibit a similar strike and dip of internal bedding. Such a boundary may be either roughly parallel to the internal bedding or inclined at a different angle.

E Horizon: A light colored soil horizon characterized by a significant loss of clay and free-iron oxides, a lack of organic accumulation, and a concentration of residual silica. When present, an E horizon is situated between the A and B horizons in a soil profile; it is synonymous with albic horizon.

Edaphic: A term referring to the soil environment, particularly in reference to its influence on organisms.

Eluviation: Removal of material (e.g., organic matter, clay, calcium carbonate) from a soil horizon by percolating water. This material is moved (translocated) through the profile (typically downward), where it may either be deposited or precipitated (illuviated) in another horizon or removed (leached) in groundwater.

Eolian: Refers to sedimentary processes and deposits resulting from the action of wind.

Erosional Unconformity: Unconformity indicative of erosion of the older unit prior to renewed deposition.

Eustacy; Eustatic Sea Level Change: Change in the elevation of global sea level due to changes in water volume in the ocean basins or changes in the overall volume of the basins due to sea floor spreading. At the Quaternary scale, the former is much more important. Changes in global ocean water volume occurred cyclically as water was bound and released from continen- tal glaciers. At any given location, sea level history represents the net result of eustatic sea level change, isostatic adjustment, and coastal developmental factors such as subsidence and tectonic movement.

Exhumed Soil: Typically, a formerly buried soil that has been exposed by erosion of overlying sediments. Like many soil terms (e.g., paleosol, relict soil), the connotations of the term have varied somewhat (see Chapter 3).

Facies: A definable (and frequently mappable) subdivision of a formal or informal stratigraphic unit. The term facies is used in many different contexts, including lithofacies, biofacies, stratigraphic facies, and sedimentary facies. One particularly useful application is the relation of facies designations to rocks or sediments representing distinct depositional environments; thus a unit representing a meandering stream deposit may be subdivided into channel, point bar, levee, crevasse splay, flood basin, and abandoned channel fill facies.

Faunalturbation: Disturbance or mixing of soil or sediment by the action of animals, and particularly burrowing animals.

Floralturbation: Disturbance or mixing of soil or sediment by the action of plants.

Fluvial, Fluviatile: Of, or pertaining to, rivers or streams. Fluvial is a rough synonym of alluvial, although the latter term is often used to describe any deposits laid down by running water, whether or not they are confined to stream channels. The term fluvial is often reserved for processes, while resultant deposits are denoted as fluviatile.

Fluviodeltaic: Refers to the complex processes and deposits of a river delta. Typically, fluviodeltaic deposits represent a mix of material deposited due to energy dissipation as the stream flows into the standing body of water and higher energy alluvial deposits laid down as the delta progrades seaward.

Geoarcheology: A subdiscipline of archeology that uses concepts and methods of the geosciences to address archeological issues.

Gley: Alteration of a soil horizon or sediment by prolonged saturation in an anoxic environment; a gleyed soil horizon is characterized by greenish-gray to bluish-gray colors with low chroma produced by reduction of iron compounds.

Gravel: In a textural sense, refers to particles $>2.0$ $\mathrm{mm}$ in size. Gravel is commonly divided into boulders, cobbles, and pebbles. The term stones is also sometimes used as a textural synonym. In general 
usage, the term gravel generally denotes material rounded by transport, as in a stream.

Hardpan: A hard, impervious soil horizon formed by the accumulation and cementation of minerals such as iron, silica, or calcite.

Holocene: Geological period spanning roughly the last 10,000 years. The Holocene is roughly equivalent to the Post-Glacial period, and often referred to as the "Recent" period in geology. Many investigators consider the Holocene to be an interstadial in the ongoing Pleistocene epoch.

Horizon: A discrete, relatively uniform layer in a soil profile that is typically subparallel with the surface and formed as the result of pedogenic processes.

Illuviation: Accumulation of material (e.g., organic matter, clay, calcium carbonate) introduced into a soil horizon (typically a B horizon), usually by percolating water. This material may be introduced as either finely divided solids or through precipitation from solution.

Inset: In terms of alluvial stratigraphic architecture, refers to two laterally opposed units separated by a sloping to vertical disconformity. An inset is formed by a cycle of incision, which creates the disconformity, and subsequent aggradation of the second unit as the inset body.

Interdigitate: Lateral contact between two different bodies of sediment characterized by vertically alternating "fingers" overlapping in the contact zone, much as is formed by the interlaced fingers of two hands. This is typical of the contact between sedimentary facies (e.g., levee sands and floodbasin muds) where the boundary between the two environments oscillates over time.

Interstadial: A warmer subphase of a glacial period, marked by temporary retreat of continental ice.

Isostacy, Isostatic Sea Level Change: Localized changes in the elevation of the earth's crust due to changes in loading pressure. The continental crust is lighter than the underlying mantle and essentially floats on it. If weight is added to certain parts of the crust (through deposition of thick bodies of sediment or overriding by continental glaciers), the crust will be slowly depressed (timespans of $10^{4}$ to $10^{5}$ years are typical) locally until the buoyancy of that portion reaches equilibrium with the mass. If, on the other hand, weight is removed through erosion or glacial retreat, the crust will slowly rebound until equilibrium is again achieved. Such changes can cause local shifts in the position of the shoreline and changes in the available accommodation space for deposition.
Isotope: One of two or more species of a chemical element, differentiated by the number of neutrons contained in the nucleus. See radioisotope and stable isotope.

K horizon: A mineral soil horizon where accumulation of pedogenic carbonate has advanced to the stage that it is plugged and/or indurated by secondary calcite (Stage III or above). Approximate synonyms include calcrete (although this term is sometimes reserved for a $\mathrm{K}$ horizon developed in gravelly parent material), caliche (although this term is also often applied to Stage I or II Bk horizons), and petrocalcic horizon (the USDA Soil Taxonomy term, which must meet specific criteria). The $\mathrm{K}$ horizon designation is not used by the USDA-NRCS (equivalent horizons are termed $\mathrm{Bkm}$ ).

Krotovina: A discrete, anomalous area visible in plan or profile in a soil resulting from the infilling of a void (e.g., a burrow or root trace) with dissimilar sediment. Some investigators prefer to limit the term to animal burrows, preferring the term "root trace" for infillings related to decayed roots. Some krotovina are obvious, while others are tiny and may only be identified in thin section.

Lag: A deposit of relatively coarse material-possibly including artifacts-resulting from the erosion of what was formerly a fine-grained encasing matrix. Note that if more than one cultural stratum was present in the former matrix, the lag will represent a mixed or palimpsest assemblage. Lag deposits may be buried by subsequent deposition.

Leaching: Removal of soluble components from a soil due to percolating water. Such components enter the saturated zone and are transported elsewhere by groundwater movement.

Lithosequence: A spatially related assemblage of soils whose differences primarily reflect the influence of parent material as a soil forming factor, or systematic spatial variation in soil properties, or soil development attributable to the influence of different parent materials.

Lithostratigraphic Unit: A stratigraphic subdivision based on lithologic characteristics of a body of rock, including textural and/or mineralogical attributes, and its stratigraphic position. Definition does not require homogeneity, only the presence of specific unifying lithologic characteristics. Lithostratigraphic units are typically tabular and conform to the law of superposition. Lithodemic units are defined similarly, but describe irregular rock bodies composed of intrusive, highly 
deformed, or highly metamorphosed rock that do not conform to the law of superposition.

Littoral: Refers to near-shore and shoreline processes and deposits; littoral may sometimes be used in a more restricted sense to refer to the intertidal zone (i.e., the elevation between high tide and low tide) only.

Matrix: In geoarcheological usage, refers to the sediments in which the artifacts at an archeological site are encased.

Morphostratigraphic Unit: A stratigraphic subdivision based on morphologic characteristics of outcrops, including topographic expression and soil development. A morphostratigraphic unit is not recognized by the 1983 North American Commission on Stratigraphic Nomenclature.

Mottling: Irregular color variation in a soil profile or sediment body. Mottling is typically due to either the action of redox processes, carbonate segregation, or patterns of krotovina and root traces. Many prefer to limit the term to redox features (i.e., iron/manganese concentrations, depletions, and phase changes).

Mud: In geological usage, a fine-grained sediment dominated by silt and clay, often containing considerable water.

Nodules: A product of localized mineral precipitation, commonly in the soil zone or in marine sediments. True nodules have no particular internal fabric, although the term is often used in general terms to include features better classified as concretions. Common nodules formed in the soil zone include materials made of carbonate compounds, ferric compounds, manganese compounds, and (in locations where weathering is intense) siliceous compounds. All may capture and engulf other soil constituents. Nodules may be either elementary or complex, where the latter represent fusion of smaller nodules.

O horizon: A dominantly organic horizon composed of undecomposed and/or partially decomposed organics, and possibly some mineral components, at the surface.

Offlap: An arrangement of related, conformable sediment bodies in which the updip margin of each successive unit lies farther basinward, leaving the inland part of the preceding unit exposed. They are characteristic of regressive marine deposits (cf. onlap). In a more colloquial sense, the term is sometimes used to refer to beds that exhibit a similar pattern, such as lateral accretion deposits making up a point bar.

Onlap: In specific usage, refers to an arrangement of related conformable rock or sediment bodies in a transgressive marine sequence, where the updip margin of each successive unit lies farther shoreward, burying the preceding unit (cf. offlap). In a more colloquial sense, the term is sometimes used to refer to any two inset units where the successive unit has aggraded sufficiently to overlap and bury a portion of the older unit.

Paleosol: Although the term has been used in a number of different contexts (see Chapter 3), the term paleosol typically equates to "buried soil" in geoarcheological usage. Others prefer a broader usage, basing the definition on a relationship between morphology and previous environments, and encompass relict and exhumed soils within the term.

Palimpsest: Archeologically, refers to a mixed assemblage of cultural material of different ages. Palimpsest deposits are commonly found resting on surfaces that were relatively stable for a long period, allowing for repeated occupation by a succession of groups, or in loci where materials of different ages are conflated due to erosion (lag palimpsest). Note that not all palimpsest assemblages are currently exposed, as they may be buried by additional sediments after their formation.

Pedode: A type of soil nodule or concretion containing one or more internal voids. Void forms include brecciated voids, characterized by fracturing of the interior, and delamination voids, characterized by often curvate voids formed by separation along laminar lines in a concretion.

Pedoturbation: General term for processes resulting in the mixing of soil.

Pelagic: Pertaining to the ocean water column and the organisms that live there, whether planktonic (passively drifting) or nektonic (actively swimming).

Penecontemporaneous: Formed at approximately the same time.

Perched Ground Water: Zone of saturated, unconfined ground water separated from the main body of ground water by an unsaturated (and relatively impermeable) zone.

Phreatic Water: Water that occurs in the saturated zone of a soil, sediment or rock; phreatic water is synonymous with ground water.

Pleistocene: The first epoch of the Quaternary period, spanning the time between approximately 2.0 to 1.65 million years ago and 10,000 years ago. Characterized by repeated continental glaciations, the Pleistocene witnessed the evolution of modern humans. 
Polygenetic Soil: A soil that exhibits characteristics that suggest formation under a succession of different climatic regimes. A classic example is a soil that contains both iron concretions (presumably formed during wet phases) and carbonate concretions (presumably formed during dry phases), although this conclusion is considered questionable.

Polypedon: A spatially discrete area mapped as a single soil mapping unit., such as are used in USDASCS soil surveys.

Profile: A sequence of horizons making up a soil, or a description or depiction of the same.

Progradation: A seaward shift in the coastline that occurs when sediments are delivered to the coast more rapidly than they can be eroded. Progradation represents a type of regression.

Quaternary: The second period of the Cenozoic Era, encompassing the Pleistocene and Holocene epochs; roughly the last 1.65 million years.

Radioisotope: An isotope subject to radioactive decay, such as ${ }^{14} \mathrm{C}$ or ${ }^{238} \mathrm{U}$. The decay of such isotopes is the basis of radiometric dating. Compare with stable isotope.

Ravinement Surface: A large-scale erosional surface, often nearly planar in form, formed by coastal erosion during periods of sea level rise (transgression).

Redox reaction: Term encompassing the suite of biochemical reactions where oxygen is lost (reduction) or gained (oxidation) from a molecule, such as the common conversion between ferric iron $\left(\mathrm{Fe}^{2} \mathrm{O}^{3}\right)$ and ferrous iron $(\mathrm{FeO})$ when sediments are saturated or drained. Reduction is caused by anaerobic respiration of soil microbes, and its severity is measured by the redox potential of the soil.

Regression: A seaward shift in a coastline. Regression may result from a fall in eustatic sea level, coastal progradation (sedimentation), or tectonic uplift.

Relict Soil: In general, an extant soil that has not been buried and reflects the influence of former environmental conditions in its morphology. Like the term paleosol, usage has varied, and the threshold at which a soil merits relict status is poorly defined (see Chapter 3).

Rhizoconcretion: A concretion formed in the soil zone, usually elongate and subvertically oriented, that represents laminar precipitation of mineral matter as an irregular tubule surrounding a root. Rhizoconcretions commonly form from the precipitation of carbonates or ferric minerals, although occasionally siliceous or gypsic precipitation may contribute.
Rip-up clast: Informal term for gravel-sized clasts of mud or clay that have been eroded from a finegrained bed by flood scour and deposited as clasts in coarser flood or channel deposits. They appear as rounded or angular pockets of mud contained within sands. Original bedding laminations may be preserved in the interior of such features; when present, the tend to be randomly oriented. They are also sometimes termed mud balls or clay balls.

Saltation: Mode of sediment transport by a low-viscosity fluid (air or water), where clasts are lifted off the bed in a near vertical trajectory and settle quickly back in a parabolic trajectory, striking the bed and imparting energy that can stimulate other particles to saltate. Saltating particles essentially bounce along within a short distance of the bed.

Sand: In a textural sense, refers to particles in the size range from $2.0 \mathrm{~mm}$ to $0.06 \mathrm{~mm}$.

Sediment Load: Measure of the amount of sediment carried by a stream.

Sedimentary Structure: A structure resulting from bedding features, surface features, and physical or organic modifications preserved in sediments and sedimentary rocks. Sedimentary structures may be either primary or secondary, although usage of these terms varies. In sedimentary geology, the term "primary" is typically used for all structures formed prior to lithification. When addressing unconsolidated Late Quaternary rocks, it is more useful to limit the scope of "primary" structures to those features (typically bedding structures) formed at the time of deposition, and use the term "secondary structure" to features formed after deposition (e.g., bioturbation structures, deformation structures, etc.). However, because it deviates from standard geological usage, this distinction needs to be explicitly stated to avoid confusion on the part of the reader.

Septode: A type of soil nodule characterized by radial cracks and fissures, often exhibiting a polygonal pattern on the nodular surface.

Sheetwash: Unconfined flow of water across a surface; erosion or deposition of sheet sediments by such flow; or deposits formed by such a process. In general usage, sheetwash typically subsumes true unconfined flow and channelized flow in small rills.

Silt: In a textural sense, refers to particles in the size range from $0.06 \mathrm{~mm}$ to $0.002 \mathrm{~mm}$.

Slickensides: Grooved, polished faces between peds in an expansive clay soil formed by friction as the peds swell and press together during wetting cycles. 
Smectitic clays: A family of clay minerals, including smectite and montmorillonite, that exhibit strong shrink-swell properties on wetting and drying.

Sorting: A measure of the range of clast sizes in a deposit; sediments made up of clasts of approximately the same size (e.g., a sand dune composed of medium sand) are said to be well sorted, while sediments composed of a wide range of textural size grades (e.g., a landslide deposit composed of bouldery clay) are said to be poorly sorted.

Stable isotope: An isotope not subject to radioactive decay, such as ${ }^{13} \mathrm{C}$ or ${ }^{18} \mathrm{O}$. Compare with radioisotope.

Stream Piracy: Diversion of a stream into a new valley system at any given location along its length, usually by intersection of a headward-cutting valley, but sometimes as a result of an intersection resulting from lateral migration of either channel. This is also termed stream capture.

Strike: Direction defined by a horizontal line on the surface of any inclined, tabular body of rock or sediment. Strike occurs at right angles to the dip.

Suspended Load: Clastic particles transported by suspension in a turbulent fluid (air, water).

Taphonomy: The study of the post-mortem fate of organic remains (and, in the case of archeological materials, associated inorganic remains) and the transformations that they undergo before, during, and after incorporation into geological deposits.
Toposequence: A spatially related assemblage of soils whose differences primarily reflect the influence of relief as a soil forming factor, or systematic spatial variation in soil properties or soil development attributable to the influence of landscape position. A catena is a type of toposequence.

Traction Load: Component of sediment transported as bedload and saltating load.

Transgression: A landward shift in a coastline. Transgression is typically due to sea level rise, coastal subsidence, or coastal erosion. This often results in the erosion of the former subaerial surface as the coastline invades inland, forming a ravinement surface.

Tree Throw: A bioturbation phenomenon resulting from the uprooting of a tree. Earth trapped in the root system is displaced vertically and laterally as the roots rotate up and out, and is then gradually released as the root system dries out and decomposes. In large trees, tree throw can result in the movement of a considerable volume of sediment.

Unconformity: Stratigraphic term for a boundary created by a depositional hiatus.

Vadose Water: Water in the aerated portion of a sediment, soil, or rock, that is capable of moving freely downward under the influence of gravity; cf. phreatic water.

Water Table: Surface defined by the top of the saturated zone. 


\section{ApPENDIX II \\ Character of Soil Carbonate Morphology and Implications of Soil Carbonate Accumulation in the Houston District}

\section{INTRODUCTION}

The accumulation of soil carbonate is one of the most commonly used indicators of soil age in Quaternary geomorphology and geoarcheology. Carbonate accumulation and the morphology and distribution of secondary carbonates is an important component of constructing and utilizing a soil chronosequence to estimate the age of soils in the field (Harden et al. 1991; Vincent et al. 1994). In practice, the sequence of carbonate accumulation is grounded in a model of sequential carbonate morphological stages developed in conjunction with the Desert Project, a long-term USDA soil research project in southern New Mexico (Gile et al. 1965, $1966,1970,1981)$. This model, and its embellishments (e.g., Machette 1985), provide the theoretical framework used in interpretation of soil carbonate chronosequences and resulting estimates of soil age, particularly in western North America.

Observations made during the course of this study on the outer Texas Coastal Plain suggest that the Desert Project model of carbonate accumulation, used explicitly or implicitly by virtually all geoarcheologists working in western North America, may not be adequate to explain the morphology and development of secondary carbonates observed in the soils of the Houston District. Rather, many carbonates in Houston District soils, and particularly those in Holocene sediments, appear to reflect a different, more poorly understood suite of hydromorphic soil processes. This appendix examines carbonates recovered from various locations on the outer Coastal Plain from the perspective of morphology, genesis, and environmental and temporal implications. It is based on field observations made in the Houston District and elsewhere on the Coastal Plain of Texas, supplemented by a limited number of thin section analyses of soil carbonate masses. These data were collected opportunistically during the stratigraphic investigations, and are not intended to represent an exhaustive examination of the topic. Rather, the purpose of this appendix is to illustrate characteristics that challenge the standard wisdom, and thereby hopefully stimulate more involved research.

\section{STAGES OF SECONDARY CARBONATE ACCUMULATION AND THEIR TEMPORAL IMPLICATIONS}

The theory of carbonate salt accumulation in soils is outlined in relative detail in Chapter 3, and will be addressed only briefly here. In desert and grassland (arid to subhumid) soils, secondary carbonate morphology has been shown to develop in a series of stages that is temporally related to the carbonate content of the parent material, the rate of aerosolic/rainwater influx of calcium ions, and the degree of soil development (Gile et al 1966; Machette 1985; Dixon 1994). In fine-grained soils, the first stage of secondary carbonate development is the formation of fine threads and films of calcite, while gravelly soils typically begin to develop thin coats on the underside of coarse clasts. In Stage II soils, nodules and concretions are developed in finegrained parent material, while gravelly soils develop thick and continuous pendants and grain coats. Stage III and above is characterized by sufficient impregnation of the matrix to impede drainage, formation of a laminar cap, brecciation, and recementation (see Chapter 3). Typically, the upper horizons of a soil undergo progressive decalcification, and late-stage (III+) carbonate development 
is typified by a decalcified A and upper B (often an argillic $\mathrm{Bt}$ ) except where the surface is eroding or substantial amounts of non-local carbonate are being introduced.

The accumulation of soil carbonates under the Desert Project model has associated temporal implications. Although the time required varies with climate, the character of the parent material, and the rate of carbonate dust influx, Stage I morphology typically develops within a span of approximately $10^{2}-10^{3}$ years, while Stage II represents $10^{3}-10^{4}$ years of development, and usually requires at least 4-5 ka to form (Machette 1985; Harden et al. 1991; Birkeland 1999). For this reason, the morphology of the calcareous horizons, and the degree of decalcification apparent in overlying horizons, is often used as a proxy for soil age in soil-geomorphic studies (Gile et al. 1981; Hardin 1982; Birkeland 1999). Stage III or greater development is typically limited to soils of Pleistocene age or older, and is usually considered a contraindication for archeological relevance in North America. Soil carbonate is also often used to infer the character of the prevailing climate during formation: calcareous pedofeatures in ancient paleosols are typically interpreted as the product of a dry climate (e.g., Aten 1983; Dixon 1994).

The character of groundwater carbonates, in contrast, bears little relation to the length of the soil forming interval, and few Quaternary scientists consider them to be products of pedogenesis per se (Birkeland 1984, 1999). Groundwater (or phreatic) carbonates form as calcium ions react with bicarbonate ions and precipitate from solution. They may take many different forms, including platy or massive indurated zones, nodular zones, and poorly cemented "chalky" zones (Kraus and Aslan 1993; Birkeland 1999). Because vadose soil carbonates have clear temporal and environmental implications, while the implications of phreatic carbonates and inherited carbonate parent material are more limited, a number of papers have addressed criteria for distinguishing between vadose and phreatic cements (e.g., Müller 1971; Dunham 1971; Thorstenson et al. 1972; Salomons and Mook 1976; Magaritz and Amiel 1980; Rabenhorst et al. 1984; West et al. 1988; Sellwood 1994; Nordt et al. 1998). At a macro-morphological level, vadose-zone carbonates are characterized by pendantic (bottom-thickened) and/or meniscus cements and the development of distinct ped films and filaments, while phreatic carbonates are characterized by isopachous and diffuse matrix cements. Other distinctions include chemical and isotopic differences, the habit of individual crystals and crystalline groups in microscopic analysis (the distinction between isopachous and meniscus cements is also characteristic at the microscopic level), and the occurrence of vadose-zone carbonates in predictable positions in a soil profile.

While the soil-geomorphic literature has tended to focus on a dichotomy between pedogenic carbonate formed in the vadose zone under a relatively arid climate and other forms of carbonate (e.g., lithorelicts, groundwater carbonates, see West et al. [1988] and Birkeland [1999]), a few investigators have recognized that some saturation-zone carbonate precipitates are associated with hydromorphic soil development (e.g., Freytet and Plausiat 1978, 1982; Kraus and Aslan 1993). However, this work is far less comprehensive than the large body of extant research on dryland soil carbonates, and much of it is associated with studies of ancient soils in the geological record. Consequently, the morphologic pathways and temporal implications of such wet soil carbonates are poorly understood; in fact, their relevance as pedogenic features is not widely accepted (e.g., West et al. 1988; Nordt et al. 1998; Birkeland 1999).

\section{MORPHOLOGY OF SECONDARY CARBONATES IN LATE QUATERNARY SOILS OF THE HOUSTON DISTRICT}

Secondary carbonates were observed in a number of settings investigated during the course of this project. In fact, with the exception of very recent (i.e., historic) and very sandy deposits, some type of secondary carbonate was present in almost every profile examined. These carbonates varied considerably in appearance, color, and habit, but most shared an apparent association with a fluctuating to high water table. Because of this association, some soil scientists and Quaternary scientists would probably argue that such features are phreatic/capillary phenomena unrelated to soil formation (Salomons and Mook 1976; Magaritz and Amiel 1980; Birkeland 1999), or are relict features formed during a more arid climatic phase (Aten 1983). However, the restriction of the term "pedogenic" to 
vadose zone carbonate makes little sense in the Houston area, because many soils are saturated by a high water table on at least a seasonal basis. The presence of this groundwater does not take such soils out of the pedogenic realm; rather, it only changes the types of processes affecting them. An arid paleoclimatic origin can also be ruled out for many of the soils because they date to the last few thousand years; it is likewise unnecessary to invoke this explanation for older soils because humid climates can also produce such features.

With the exception of filament and ped film carbonates, most of the calcareous features observed in Houston area soils appear to have formed in the phreatic/capillary environment in association with other pedogenic features (e.g., ferrous concretions, reduction mottling, slickensides). In addition, many of these features have obviously formed in association with active plant roots in the near-surface environment, occur in predictable positions in the profile, and resemble undisputed pedogenic morphologies that occur in drier environments. For these reasons, it is argued that such features are products of the pedogenic processes affecting environments with relatively poor drainage. Although this argument is not widely accepted in North America, a similar argument has been advanced in Europe by Freytet and Plauziat (1982), and calcareous pedofeatures have been recognized in other hydromorphic alluvial soils (e.g., Aslan and Autin 1998). This argument is not meant to imply that translocation and reprecipitation of carbonate by vadose waters does not occur under such conditions; it clearly does, and at substantially higher rates than in more arid areas. However, it does imply that precipitation is not a wetting-front phenomenon, and that the depth to secondary carbonate is therefore not climate dependent as it is in drier climates (Dormaar 1976; Birkeland 1984).

The following summary is based on incidental observations made in conjunction with stratigraphic investigations in the Houston District, rather than a systematic program of investigation. Observations of carbonate habit and occurrence were made as part of the soil descriptions routinely recorded for cores, trenches, and natural exposures addressed in this study and in other, concurrent examinations on the Texas Coastal Plain. To more thoroughly address the question, thin sections were prepared from samples of secondary soil carbonate from the Texas Coastal Plain. These thin sections were examined microscopically, and the polished, impregnated blocks that they were prepared from were examined at the macroscopic level. Macroscopic examination of the cut face of the impregnation block proved very informative about the generalized structure and fabric arrangement, while microscopic examination provided details about the arrangement of components.

\section{Carbonate Morphology}

This section describes the character and morphology of secondary carbonates observed in Houston District soils. The terminology used in the following discussion is modified and expanded from Freytet and Plauziat (1982) to address the observed range of morphology. Examples of representative features are illustrated at macroscale and microscale in Figures 59 and 60, respectively.

\section{Filaments and Films}

Carbonate films and filaments were observed in a number of profiles in the Houston District. Carbonate filaments (often termed mycellial or pseudo-mycellial carbonates) consist of thin, linear accumulations of carbonate, usually in the form of fine needles of sparry calcite. They are commonly oriented subvertically and may vary in color from white to yellowish-brown or bluish-gray. They appear to be restricted to soil horizons that are typically aerated for much of the year, and are particularly common in finer-grained sediments or stratified, texturally diverse deposits where drainage is retarded. Filaments can occur on ped boundaries and/or in their interior, but in soils with well-developed structure the former are typically more prominent. In thin section, filaments occupying ped interiors consist of microspar calcite filling soil cracks or as calcite-lined tubules (see Figure $60 \mathrm{~A})$. In some cases, these filaments are associated with extant fine roots, but more often the organic root structure has decayed.

Films (calcans) are also composed of fine crystalline to microcrystalline calcite, and occur on the faces of well-developed soil peds. In the field, they resemble whitish or yellowish coatings of varying opacity on the faces of peds. They sometimes are found in association with crystals of more soluble salts, including gypsum and halite, suggesting that they may represent seasonal precipitates that form 


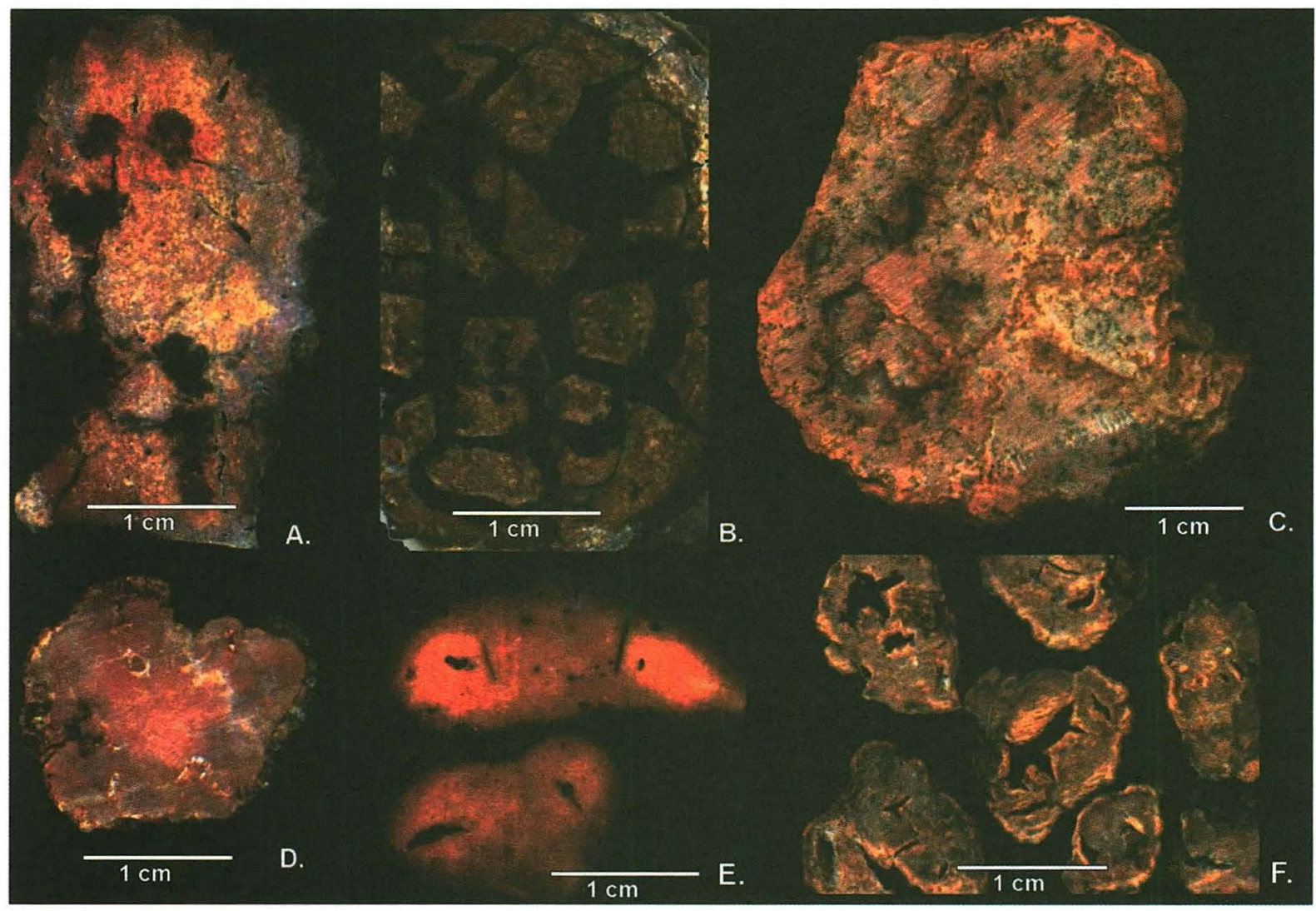

Figure 59. Examples of macroscopic morphological variability in cut faces of impregnated thin section blocks. No stain has been applied. A: Large compound nodules from Brazos River alluvium at SH 332 crossing in Brazoria, Texas (depth approx. 2 m; Late Holocene); B: Large brecciated pedode from shallow Beaumont Fm. roadcut, SH 228, Brazoria County (depth <1 m; Pleistocene); C: Large compound nodule from Late Pleistocene alluvium, DeWitt County, inner Coastal Plain(depth approx. $1.5 \mathrm{~m}$; Late Pleistocene); D: Irregular, etched compound nodule from probable Late Pleistocene soil, Brazoria \#2 core (depth $26.4 \mathrm{~m}$ ); E: moderately large, smooth compound nodules/incipient pedodes from Brazos River alluvium at SH 332 crossing in Brazoria, Texas (depth=approx. $1.2 \mathrm{~m}$; Late Holocene); F: Moderately sized pedodes exhibiting brecciation and delamination from Oyster Creek at Clute (depth=approx $1.5 \mathrm{~m}$; Late Holocene).

and dissolve with changes in soil moisture, probably as a result of salt migration to the ped boundaries during soil drying. Like filaments, films appear largely restricted to the vadose zone. While the longevity and permanence of such films is not wellestablished, they can clearly form relatively rapidly, and therefore have little significance for interpreting the age of associated soils. No carbonate films were thin-sectioned during the current investigation.

\section{Matrix Carbonates}

Another class of diffuse carbonate accumulation may be termed matrix (or disseminated) carbonates. These features consist of the accumulation of dispersed micrite within the soil groundmass.
They can be identified in the field by an increase in reactivity with dilute hydrochloric acid and a lightening of chroma and/or value relative to other parts of the soil matrix. In some cases, matrix carbonates are restricted to specific horizons, particularly when textural stratification is apparent. However, in other cases matrix enrichments occur as diffuse "clouds" in the sediment, sometimes in conjunction with redox mottling or iron/manganese accumulation. In addition, some profiles exhibit diffuse "halos" of matrix carbonate around nodules or other dense carbonate masses, which probably are indicative of chemical attack and dispersion of the nodule's calcite by saturating water. There are also probably many instances when microcrystalline calcite enrichment of the matrix is not visible at a macroscopic scale. Although the origin of matrix 

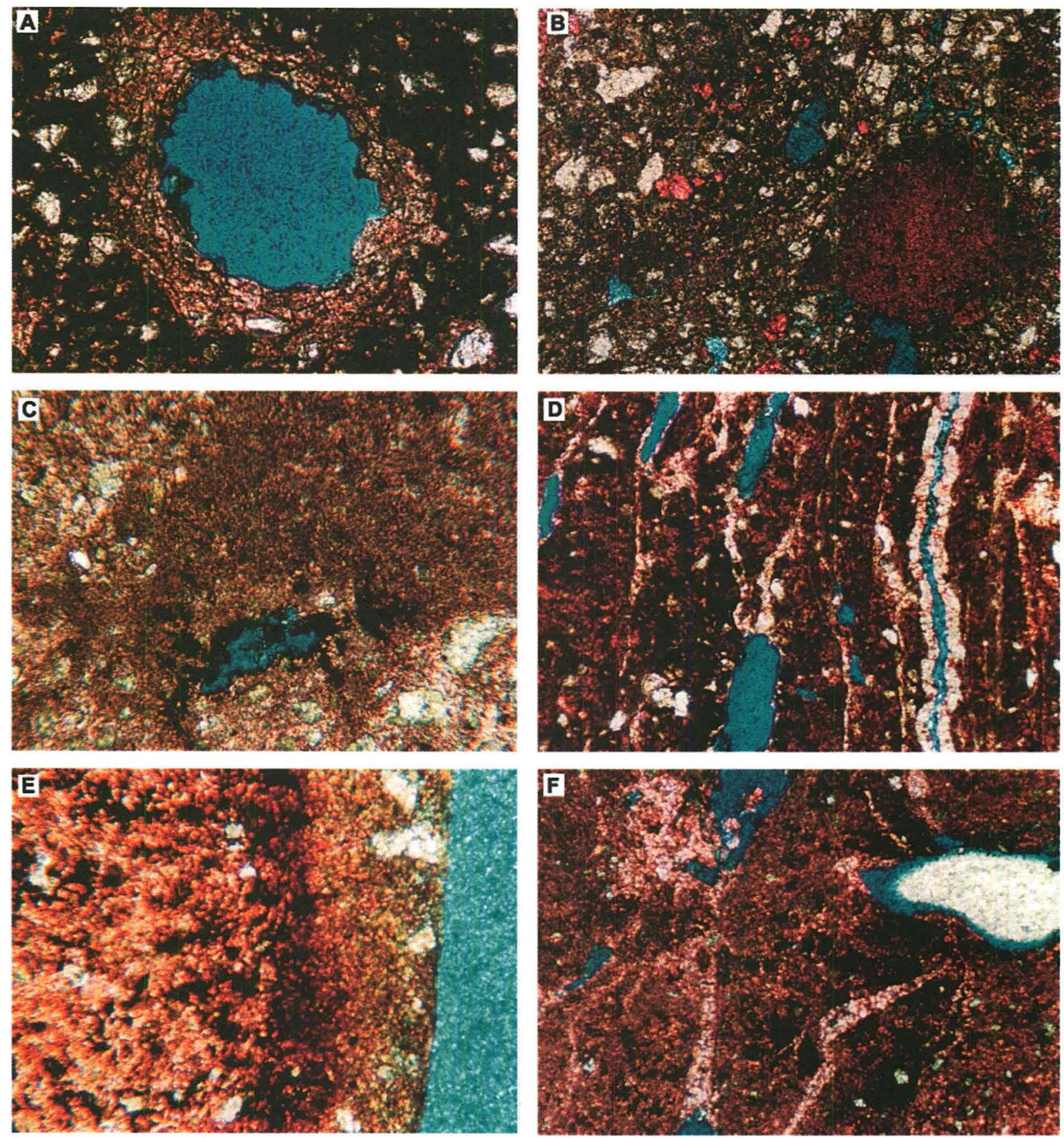

Figure 60. Photomicrographs of thin sections illustrating some of the characteristics and variability of calcite pedofeatures in Pleistocene and Holocene soils on the outer Gulf Coastal Plain. The pink to dark red color of carbonate minerals is due to staining with Alizarin red, while the blue color represents the epoxy resin. A: Relatively coarse calcite crystals surrounding channel through Late Holocene carbonate nodule. Dark groundmass surrounding the void is micritic calcite; B: Incipient secondary nodule and primary carbonate rock fragments from Late Holocene Brazos Valley alluvium; C: Variable matrix impregnation with fine crystalline to micritic calcite from Holocene compound nodule. Note void infilling with dark amorphous matter (probably manganese or organics); D: Delamination cracks with secondary infilling by crystalline carbonate on the outer laminae of Pleistocene brecciated pedode; E: Depletion/iron enrichment rind on the margin of smooth nodule from Holocene Brazos alluvium. Note iron/manganese infilling of fine internal voids; F: Fractured, carbonate-dominated groundmass with a variety of carbonate and iron/manganese impregnations and void fills. 
accumulations is not clear, they are probably related to periodic saturation with, and subsequent evaporation of, carbonate-enriched water.

\section{Simple Nodules}

Simple nodules consist of localized, amorphous concentrations of carbonate in a soil (see Figure 60B). Occasional simple nodules were noted in the Houston District soils, including very small (medium sand-sized) nodules from floodbasin muds in the deep Brazos cores, and larger (1-2 mm) nodules from a number of different alluvial soils. With the exception of occasional crystalline inclusions and color variations, simple nodules lack identifiable internal structures. In almost all cases, these nodules are associated with fine-grained (sandy clay, silty clay, and clay) sediments, and all but those noted in the deep Brazos cores were in recent $(<3$ ka) stratigraphic contexts. Nodule color varied between white, pinkish-white, light yellowish-brown, and bluish-white. The white nodules tend to be microcrystalline, irregularly shaped, diffuse bounded, and somewhat porous, giving them a "powdery" texture. They are typically readily broken by squeezing between the thumb and forefinger; however, harder, macrocrystalline inclusions are often associated. White nodules are frequently associated with ped boundaries in relatively welldrained soils, and tend to co-occur with carbonate films and threads. Pinkish nodules tend to be slightly harder and more sharply bounded, but otherwise occur in similar contexts. Their pink color probably represents the inclusion of oxidized iron, and may signify chemical attack by iron-enriched water without significant reduction, as the pink color tends to be less pronounced in the interior. The yellowishbrown and bluish nodules, in contrast, tend to occur in more poorly drained soils, and are typically sharply bounded, microcrystalline (micritic) to coarse crystalline, and hard (they can rarely be broken by squeezing between the thumb and forefinger). The bluish nodules tend to be relatively round, but the yellowish-brown nodules can be either equant or thin (often $<2 \mathrm{~mm}$ ) and elongate. The elongate nodules almost certainly represent precipitation along root channels, and are often hollow. The bluish nodules probably result from the inclusion of reduced iron and/or manganese compounds, while the yellow color may represent inclusion of a number of different constituents, including limo- nitic iron compounds and/or muddy siliceous parent material. In some cases, yellowish-brown nodules are so similar in color to the host sediment that they are not visible in a profile, but are readily identified by tactile examination or by the grating sound made by a metal digging implement.

In other types of soil concretions, the distinction between sharp and diffuse boundaries has been cited as a criterion to distinguish between active and relict nodules (Greenberg and Wilding 1998), and it is easy to presume the same thing about carbonate nodules. However, while sharp boundaries are almost certainly diagnostic of chemical attack, short-term (i.e., seasonal) chemical variations in the soil environment are common during nodule growth. Therefore, such boundaries are not necessarily diagnostic of nodules formed under a previous soil environment.

\section{Compound Nodules}

Compound nodules (see Figure 59A, C-E) represent the fusion of two or more simple nodules. Well-defined internal growth structures (e.g., concentric laminae) are not generally present, but the size and organization of crystals making up the carbonate matrix is usually variable, and crack fills and pore fills are often prominent (see Figure 60F). Siliceous grains representing the engulfed soil fabric are also present, sometimes in large numbers. Examples of compound nodules were noted in both Holocene and Pleistocene soils of the Houston District, and were far more common than simple nodules. Although Holocene compound nodules up to $1 \mathrm{~cm}$ in diameter are common, most of the large compound nodules are associated with Pleistocene soils. In these soils, large irregular compound nodules with diameters of several centimeters occur frequently, often in association with an underlying or overlying zone of platy or massive carbonate. Most soil nodules larger than 2-3 mm exhibit a "bumpy" surface texture that almost certainly represents the fusion of smaller nodules. Surface texture is sometimes powdery, but more often these nodules are hard and sharply bounded. In some cases, the outer surface of the nodules has a distinct "weathering" rind $1 \mathrm{~mm}$ or more thick where minerals have been lost to solution. Typically, these rinds have a pinkish or yellowish color that contrasts with the interior, suggesting that iron may be precipitating as carbonate is lost (see Figure 60E) 
Inclusions of various types are common in compound nodules, and may also occur in simple nodules. The most common inclusions noted consist of engulfed primary fabric grains and dark amorphous coatings and pore fillings that represent organic matter and/or precipitated iron and manganese (see Figure 60C, E-F). In a few cases, these concentrations may have been engulfed by the growing nodule, but most clearly represent material deposited in pores and chambers within the nodule after it formed.

\section{Concretions}

Concretions of various types make up a very common class of soil carbonate masses in the Houston area. Concretions differ from nodules in that they have a macroscopically visible, concentric laminar structure representing "growth rings." Although simple concretions were noted, they are relatively rare in comparison with various types of pedodes and rhizoconcretions. Pedodes and septodes are two specific classes of soil concretions. Pedodes are concretions that contain large internal voids, while septodes are characterized by prominent networks of large cracks oriented perpendicular to the nodule surface (radial relative to the nodular core). Both pedodes and septodes may exhibit relatively equant dimensions, or they may be elongate or irregular masses, including masses of rhizolitic origin.

Several different types of equant pedodes were noted in Houston area soils, and examples were noted in soils of Pleistocene (see Figure 59B) to Late Holocene (see Figure 59F) age. Two basic types were noted in the Houston District. The first type, which may be termed a brecciated pedode, is characterized by one or more transverse, lenticular voids in early stages of development (see Figure $59 \mathrm{E}$ ) and by a large, irregular internal void bounded by an angular wall during latter stages (see Figure 59B). Occasionally, remnants of a distorted concretion fabric are apparent in the brecciated interior. A second type, which may be termed delaminating pedodes, exhibits arcuate voids formed by separation along the boundaries between concentric laminae (see Figure 60D). Sometimes, both types of voids occur in the same nodule (see Figure 59F).

The formative mechanism of geodes, of which pedodes form a specific type, is not well understood (Sellés-Martínez 1996). Most geodes are believed to form in rocks that have been buried and are under pressure, and both "implosive" and "explosive" textures have been identified (Hayes 1963; SellésMartínez 1996). Many models involve an initial void or replacement of a fossil or other pre-existing component of the rock, and expansive growth is often discounted (Sellés-Martínez 1996). However, given their morphology, expansive growth appears to represent the best explanation for Houston area pedodes. The pedodes observed during this project appear to form "explosively" through a complex process of crystalline growth in the outer, active laminae of a concretion. Under normal conditions, carbonate is added as a sequence of thin laminar coats. However, as concretions grow, they sometimes appear to develop networks of fine cracks on the exterior surface, possibly as a function of wetting and drying processes in the nodule and/or the surrounding matrix. These cracks serve as sites for new crystals to form and grow, exerting lateral pressures in the outer laminae and causing them to expand like an inflating balloon. Because the forces imposed by crystal growth are considerable (Birkeland 1984; Sellés-Martínez 1996), the inner portion of the concretion is exposed to tremendous stresses. Gradually, it is torn apart along transverse planes of weakness and/or laminar boundaries. Figure 61 illustrates the interior of a Pleistocene pedode

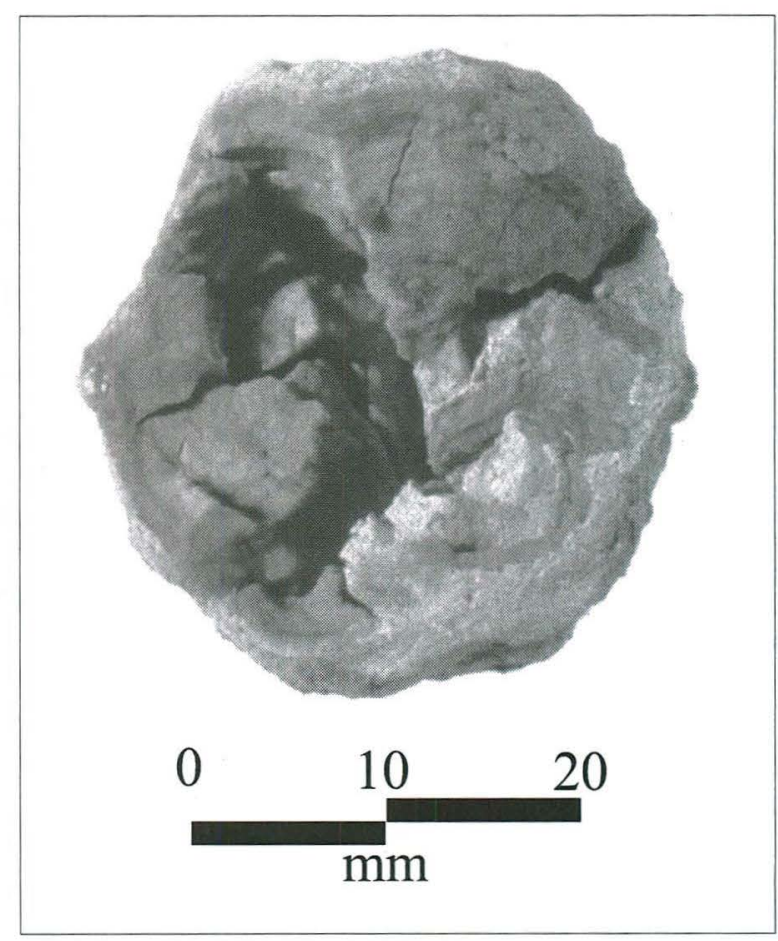

Figure 61. Photograph of broken Pleistocene brecciated pedode, illustrating "explosive" internal morphology. 
from the Beaumont Formation that has grown explosively, tearing apart the interior into a series of blocky fragments.

Septodes were observed less frequently in the district, and they occupied soils of Pleistocene age. They appear to represent contraction (shrinkage) of the outer part of the nodule, and often exhibit a polygonal series of intersecting surface cracks of varying depths. This cracking is typically somewhat regular, and should not be confused with surface etching that affects many of the calcareous masses. Some authors (e.g., SellésMartínez 1996) also use the term to denote radial cracking of a nodule from the core outward, but these features are better considered incipient brecciated pedodes under this classification. All septodes observed were associated with Pleistocene soils, but, like pedodes, the rate of their formation is probably dependent more on the occurrence of conducive chemical conditions in the soil than on extended periods of time.

\section{Rhizoliths}

Rhizoliths, or rhizoconcretions, are elongate calcareous concretions that vary from a few millimeters to several centimeters in diameter and a few centimeters to as much as $1 \mathrm{~m}$ in length. They are usually oriented subvertically and often split into a dendritic pattern with depth. Most appear to be formed in association with plant roots. Frequently, they contain a prominent central void. While this void is occasionally sealed, more often it is lined with smooth, microcrystalline calcite that resembles travertine, suggesting that water has continued to move through the pore, dissolving and reprecipitating bounding material. Most rhizoliths larger than a few millimeters in diameter exhibit a concentric structure in cross-section.

The formation of rhizoliths probably requires soils that are saturated on a periodic basis. In freely drained soils, respiration by plant roots tends to increase the partial pressure of $\mathrm{CO}_{2}$, and thus increase the solubility of calcium carbonate in their vicinity (see Chapter 3 ). However, as the development of mycellial filaments suggests, this tendency can be counterbalanced by the release of carbonate ions during water uptake. Under saturated conditions, the uptake of water appears to stimulate carbonate precipitation, resulting in the formation of rhizoliths. Although the mechanism of growth is not well established, it is possible that rhizoliths grow from the inside out, adding laminae to the interior near the root and forcing the exterior to expand.

In addition to rhizoliths, complex features here termed rhizolitic nodule chains were noted at a number of localities. These features consist of subvertically oriented, bifurcating-downward alignments of calcareous nodules. Such features were noted at several localities within Holocene alluvial soils, and always occurred in nodular (Stage II) horizons with associated dispersed nodules. The appearance of these features clearly resemble dendritic roots, and they are believed to represent the same basic types of processes responsible for rhizolith development.

\section{CONCLUSIONS}

Despite the fact that the Houston District lies east of the generalized boundary between calcic soils (pedocals) and non-calcic soils (pedalfers) (Marbut 1935; Jenny 1941), secondary calcite pedofeatures of many different forms are present in both Pleistocene and Holocene soils of the Houston District. The investigation reported here is not an exhaustive examination of these common features; much more work is needed to understand the conditions, processes, and rates of their formation. Nevertheless, a number of preliminary conclusions are possible:

(1) The formation of soil carbonates does not necessarily imply an arid climate. Such a conclusion is often drawn from studies of soils and paleosols. For example, Aten (1983) concluded that the prominent soil carbonates in the Pleistocene soils around Houston were the result of an arid phase during the Early to Middle Holocene. Given the character of carbonate development in many Late Holocene alluvial settings in the district, this conclusion does not seem warranted. Rather, the suite of extant pedogenic processes typical of many poorly drained soils in the district appears responsible for the development of a variety of soil carbonate forms. This does not mean that progressive decalcification and top-down translocation of carbonate (and other soil constituents) is not occurring in Houston area soils, only that this carbonate is not necessarily being removed by leaching. 
(2) Formation of well-developed Stage II carbonate morphology does not necessarily imply a very long period of soil development, because calcareous masses can apparently form rapidly in a hydromorphic soil environment. The presence of abundant, large nodules/concretions in growth position was noted in a number of Late Holocene soils on the Coastal Plain, including pedode concretions in excess of 1 $\mathrm{cm}$ in diameter that occur in Brazos floodbasin soils reliably dated to less than $2 \mathrm{ka}$. These features indicate that large carbonate masses can develop rapidly in wet soils if the conditions are conducive.

(3) Many carbonate masses exhibit a variety of fabrics and inclusions that suggest a complex history of development. Most nodules, concretions, and other large masses appear to be the result of fluctuating conditions where growth was facilitated at times and chemical attack was prevalent at others. In particular, the incorporation of ferromanganese and amorphous organic compounds as both pre-existing masses and subsequent void infillings implies that the chemical environment was often far from stable. Whether these fluctuations were the result of seasonal variations or longer term changes in the edaphic environment is difficult to determine, but it is likely that both played a significant role in the development of many soil carbonates in the district.

(4) The hydromorphic model has implications that may affect many of the assumptions employed in isotopic and mass-balance characterization of carbonate accumulation. In particular, the delivery of solute calcium and bicarbonate ions in stream water may create mass-balance discrepancies in a large system like the Brazos. Thus, mechanisms such as the incremental aerosolic delivery of carbonate dust (Birkeland 1999) or intensive decalcification of upper soil horizons, is not necessary to explain the accumulation of large volumes of soil carbonate. Moreover, because the calcium and bicarbonate ions may be introduced in solution from elsewhere, the assumption that the $\mathrm{CO}_{2}$ is in equilibrium with local vegetation may not be satisfied, and the isotopic signature may not be representative of local climate.

\section{REFERENCES CITED}

Abbott, J. T.

1997 Mechanical Survey of Farm to Market Road 616 between Lolita and Vanderbilt in Jackson County, Texas. Letter report on file, Environmental Affairs Division, Texas Department of Transportation.

Aslan, A. and W. J. Autin

1998 Holocene flood-plain soil formation in the southern lower Mississippi Valley: Implications for interpreting alluvial paleosols. Geological Society of America Bulletin 110:433-449.

Aten, L. E.

1983 Indians of the Upper Texas Coast. Academic Press, New York.

Birkeland, P. W.

1984 Soils and Geomorphology. 2nd Edition. Oxford University Press, New York.

1999 Soils and Geomorphology. 3rd Edition. Oxford University Press, New York.

Dixon, J. C.

1994 Duricrusts. In Geomorphology of Desert Environments, edited by A.D. Abrahms and A. J. Parsons, pp. 82-105. Chapman \& Hall, Ltd., London.

Dormaar, J. F.

1976 Effects of boulderflow on soil transformation under tipi rings. Plains Anthropologist 21:115-118.

Dunham, R. J.

1971 Meniscus cement. In Carbonate Cements, edited by O. P. Bricker, pp. 297-300. Johns Hopkins University Press, Baltimore.

Freytet, P. and J.-C. Plaziat

1978 Les redistributions carbonatées pédogénétiques (nodules, croûtes, "calcrete"): les deux types principaux d'environments favorables à leur développment. Compte Rendue des Séances de l"Academie des Sciences de Paris 286:1775-1778.

1982 Continental Carbonate Sedimentation and Pedogenesis-Late Cretaceous and Early Tertiary of Southern France. Contributions to Sedimentology 12 E. Schweizerbart'sche Verlagbuchhandlung, Stuttgart. 
Gile, L. H., J. W. Hawley, and R. B. Grossman

1970 Distribution and Genesis of Soils and Geomorphic Surfaces in a Desert Region of Southern New Mexico. Soil Science Society of America Guidebook, Soil-Geomorphology Field Conference, August 21-22 and 29-30, 1970.

1981 Soils and geomorphology in the Basin and Range area of southern New Mexico Guidebook to the Desert Project. Memoir 39. New Mexico Bureau of Mines and Mineral Resources, Socorro.

Gile, L. H., F. F. Peterson, and R. B. Grossman

1965 The K horizon: A master soil horizon of carbonate accumulation. Soil Science 99:74-82.

1966 Morphological and genetic sequences of carbonate accumulation in desert soils. Soil Science 101:347-360.

Greenberg, W. A. and L. P. Wilding

1998 Evidence for contemporary and relict redoximorphic features of an Alfisol in East-Central Texas. In Quantifying Soil Hydromorphology, edited by M. C. Rabenhorst, J. C. Bell, and P. A. McDaniel, pp. 227-246. Soil Science Society of America Special Publication No. 54.

Harden, J. W.

1982 A quantitative index of soil development from field descriptions: Examples from a chronosequence in central California. Geoderma 28:1-28.

Harden, J. W., E. M. Taylor, M. C. Reheis, and L. D. McFadden 1991 Calcic, gypsic, and siliceous soil chronosequences in arid and semiarid environments. In Occurrence, Characteristics, and Genesis of Carbonate, Gypsum, and Silica Accumulations in Soils, edited by W. D. Nettleton, pp. 1-35. Soil Science Society of America Special Publication No. 26.

Hayes, J. B.

1963 Geodes and concretions of the Mississippian Warsaw Formation. Journal of Sedimentary Petrology 34:123-132.

Jenny, $\mathrm{H}$.

1941 Factors of Soil Formation: A System of Quantitative Pedology. McGraw Hill, New York.

Kraus, M. J. and A. Aslan

1993 Eocene hydromorphic paleosols: Significance for interpreting ancient floodplain processes. Journal of Sedimentary Petrology 63:453-463.

Machette, M. N.

1985 Calcic soils of the southwestern United States. In Soils and Quaternary Geology of the Southwestern United States, edited by D. L. Weide, pp. 1-21. Special Paper 203. Geological Society of America, Boulder.
Magaritz, M. and A. J. Amiel

1980 Calcium carbonate in a calcareous soil from the Jordan Valley, Israel: Its origin as revealed by the stable carbon isotope method. Soil Science Society of America Journal 44:1059-1062.

Marbut, C. F.

1935 Soils of the United States. United States Department of Agriculture, Atlas of American Agriculture, Part III. Washington, D.C.

Müller, G.

1971 "Gravitational" cement: An indicator for the vadose zone of the subaerial diagenetic environment. In Carbonate Cements, edited by O. P. Bricker, pp. 301-302. Johns Hopkins University Press, Baltimore.

Nordt, L. C., C. T. Hallmark, L. P. Wilding, and T. W. Boutton 1998 Quantifying pedogenic carbonate accumulations using stable carbon isotopes. Geoderma 82:115-136.

Rabenhorst, M. C., L. P. Wilding, and L. T. West

1984 Identification of pedogenic carbonates using stable carbon isotopes and microfabric analysis. Soil Science Society of America Journal 48:125-132.

Salomons, W., and W. G. Mook

1976 Isotope geochemistry of carbonate dissolution and reprecipitation in soils. Soil Science 122:15-24.

Sellés-Martínez, J.

1996 Concretion morphology, classification, and genesis. Earth Science Reviews 41:177-210.

Sellwood, B. W.

1994 Principles of carbonate diagenesis. In Quantitative Diagenesis: Recent Developments and Applications to Reservoir Geology, edited by A. Parker and B. W. Sellwood, pp. 1-32. Kluwer Academic Publishers, Dordrecht.

Thorstenson, D. C., F. T. MacKenzie, and B. L. Ristvet

1972 Experimental vadose and phreatic cementation of skeletal carbonate sand. Journal of Sedimentary Petrology 42:162-167.

Vincent, K. R., W. B. Bull, and O. A. Chadwick

1994 Construction of a soil chronosequence using the thickness of pedogenic carbonate coatings. Journal of Geological Education 42:316-324.

West, L. T., L. R. Drees, L. P. Wilding, and M. C. Rabenhorst 1988 Differentiation of pedogenic and lithogenic carbonate forms in Texas. Geoderma 43:271-287. 


\section{Appendix III}

\section{Stable Isotopic Evidence for Late Quaternary Environmental Change in the Houston District}

\section{INTRODUCTION}

Stable carbon isotopes contained in soil organic matter and soil carbonates have been used by a number of researchers to infer previous biotic conditions, and by extension, the character of previous climates (e.g., Schwartz et al. 1986; Amundson et al. 1988; Humphrey and Ferring 1994; Nordt et al. 1994; Fredlund and Tieszen 1997; Menking et al. 1997; Buck and Monger 1999). This appendix examines trends in the stable carbon isotope values of the organic matter in soils and sediments of the Houston District to infer the timing and character of environmental change. The basic theory behind the application of stable carbon isotope analysis to paleoenvironmental questions has been presented previously in Chapter 2 and will not be repeated here. Rather, the discussion will focus on the methodology of this analysis, potential problems and possible erroneous assumptions in stable carbon isotope studies in general, and the implications of the stable carbon isotope record for vegetation and climate history in the District.

\section{METHODOLOGY}

Measurement of the ${ }^{13} \mathrm{C} /{ }^{12} \mathrm{C}$ ratio $\left(\delta^{13} \mathrm{C}\right)$ was accomplished by two different mechanisms. The first suite of determinations were made by Beta Analytic, Inc.; with two exceptions, these determinations were made in conjunction with radiocarbon dating of bulk sediments. As was pointedly noted by one of the reviewers of the draft, such determinations are not performed as rigorously as those processed by an environmental laboratory, and therefore have a greater potential error. To partially compensate for this problem, and to provide additional data for interpretation, a series of samples were obtained from soil horizons in Brazos Core 2 (see Chapter 4) and submitted for analysis at Coastal Science Laboratories, Inc., an environmental isotope laboratory in Austin, Texas.

Once the $\delta^{13} \mathrm{C}$ value was obtained, the relative contribution of organic matter from $\mathrm{C}_{3}$ and $\mathrm{C}_{4}$ plants was estimated for each sample using the method employed by Nordt et al. (1994). This method assumes a mean $\delta^{13} \mathrm{C}$ value of $-27 \%$ and $-13 \%$ o for $\mathrm{C}_{3}$ plants and $\mathrm{C}_{4}$ plants, respectively, and is determined by the following mass balance equation:

$$
\delta^{13} \mathrm{C} \text { soil }=\left(\delta^{13} \mathrm{C}_{4}\right)(\mathrm{x})+\left(\delta^{13} \mathrm{C}_{3}\right)(1-\mathrm{x})
$$

Although it appears relatively complex at first glance, this equation represents a straightforward ratio between $\mathrm{C}_{3}$ and $\mathrm{C}_{4}$ contributions; a value of $27 \%$ o equates to $100 \% \mathrm{C}_{3},-23.5 \%$ o equates to $75 \%$ $\mathrm{C}_{3},-20 \%$ o equates to $50 \% \mathrm{C}_{3}$, and so on.

A total of 42 radiocarbon samples from alluvial contexts in the Houston District were analyzed during the current project. Of these, 10 were excluded from the stable carbon isotope analysis because the materials dated were the remains of individual organisms (e.g., wood charcoal, snail shell, undecomposed organic matter), and four were excluded because the ages were stratigraphically inconsistent, indicating a predominance of non-local organic matter. The corrected radiocarbon age and measured $\delta^{13} \mathrm{C}$ value of the remaining 28 samples are presented in Figure 62. With four exceptions, all of these samples are from the lower Brazos valley (including Oyster Creek) and the Brazos delta. The exceptions consist of two Late Holocene samples each from Greens Bayou and Kinglet Bog, both of which are located near the modern boundary between the Upland Prairies and Woods Natural Region and the Mixed Pine-Hardwood Natural Region in northeast Harris County. 


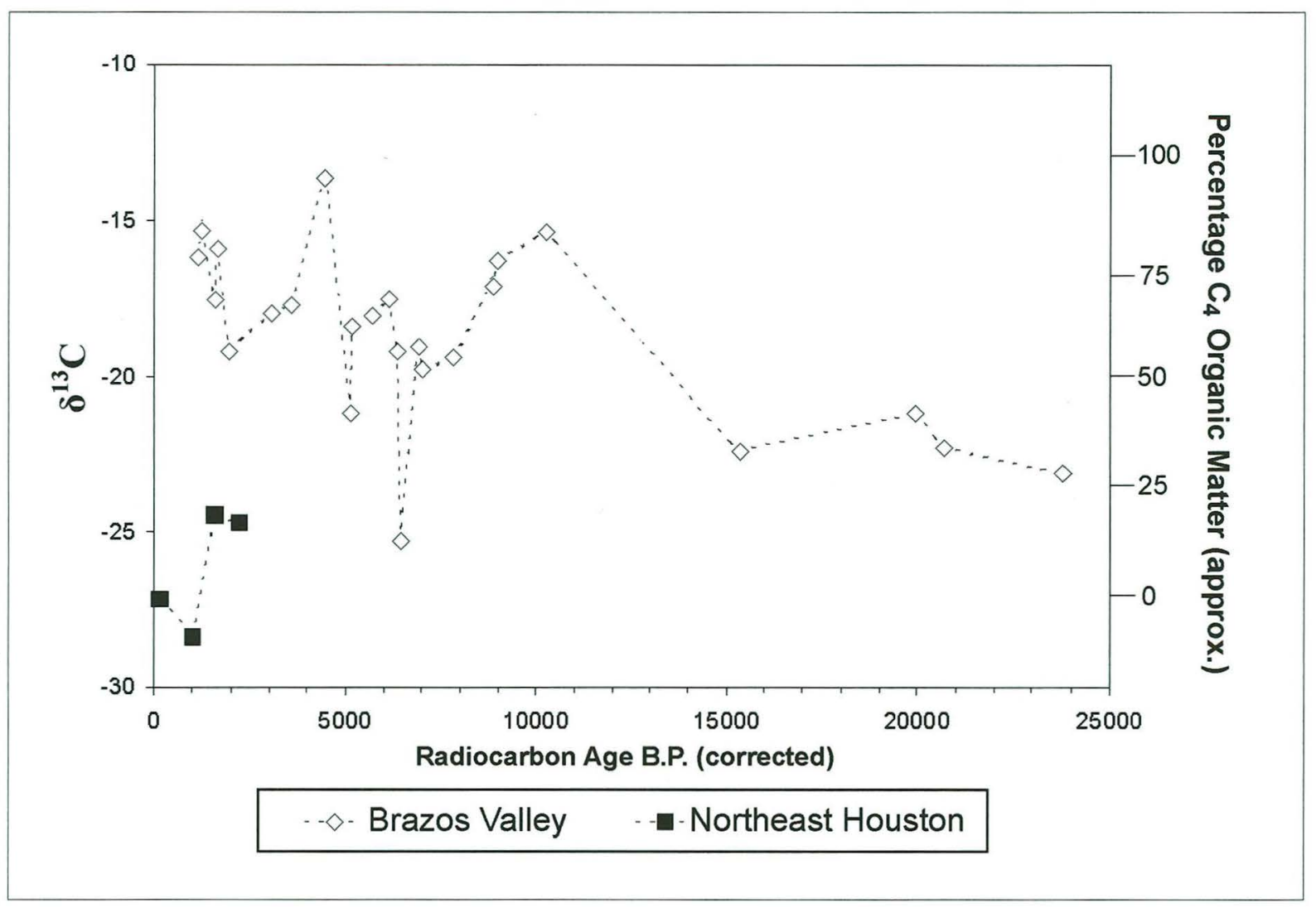

Figure 62. Results of $\delta^{13} \mathrm{C}$ assays on bulk humate radiocarbon samples vs. radiocarbon age for samples from the Houston District.

An additional 36 samples were obtained from Brazos Core 2 to provide more data for interpretation. Clusters of stacked samples were taken from a series of fine-grained facies/alluvial soils throughout the column. These soils and facies were sampled at intervals of approximately $20 \mathrm{~cm}$. The results of these assays and the original, radiocarbon-related assays from the core are presented in Figure 63.

Four of the 36 isotope samples from Brazos Core 2 were taken from positions just above and contiguous to the previously extracted radiocarbon samples. This strategy provided an approximation of paired samples to allow for an initial, tentative, assessment of the magnitude of potential error in the stable carbon assays performed by the radiocarbon laboratory.

\section{RESULTS AND DISCUSSION}

Carbon isotope-based climatic reconstructions in Texas have been conducted using bulk soil organics (e.g., Bousman 1991; Nordt et al. 1994; Abbott 1996) and soil carbonates (e.g., Monger 1993; Humphrey and Ferring 1994). Both methods have yielded valuable data, but both are also subject to a number of potential problems. Although some of these problems have been outlined previously (see Chapter 2), it is appropriate to address them again here in the context of the results from this project.

Soil carbonate-based reconstructions are based on the assumption that the carbonates are precipitated in the vadose (aerated) zone of the soil and reflect the isotopic composition of soil $\mathrm{CO}_{2}$, which in turn reflects the isotopic composition of vegetation colonizing the soil. As outlined in Appendix II, it is likely that many of the soil carbonates in Houston area soils were precipitated under saturated (phreatic) conditions, and therefore it cannot be assumed that the isotopic character of the resulting carbonates is exclusively a function of the isotopic composition of soil organic matter. Even if this argument is rejected, soil carbonates remain problematic because they may be precipitated at any time after the deposition of a given sediment; therefore, even if the carbonates do represent the isotopic composition of soil $\mathrm{CO}_{2}$ at the time of their formation, they may 


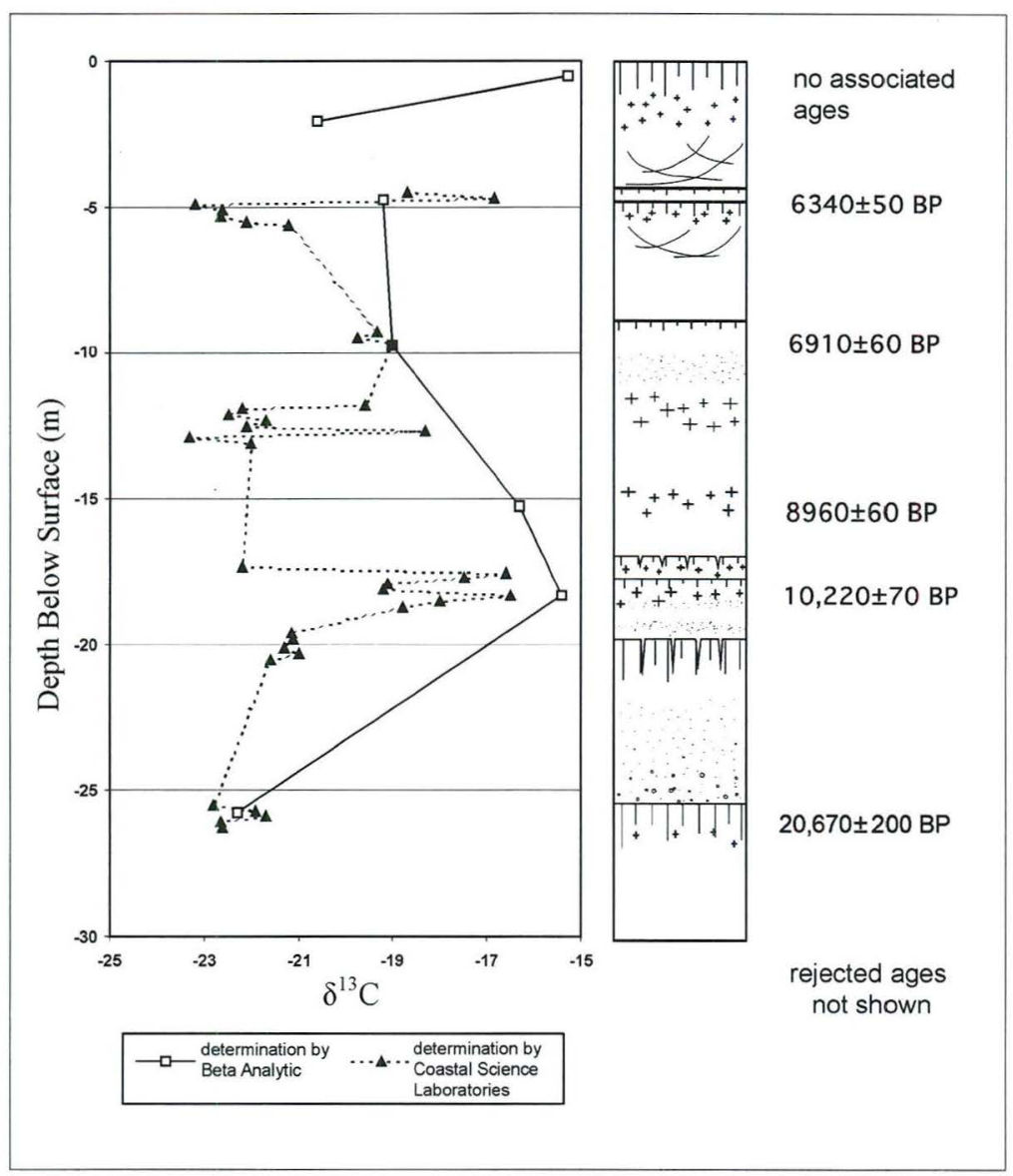

Figure 63. Results of $\delta^{13} \mathrm{C}$ assays by Beta Analytic and Coastal Science Laboratories on samples from Brazos Core 2.

have formed (or reformed through dissolution and reprecipitation) hundreds or thousands of years after the sedimentary body that contains them was deposited (Gile et al. 1970). Therefore, dates from the encompassing matrix may substantially predate the age actually represented by the stable isotope signal, while ages on the carbonate material itself are often unreliable due to the incorporation of "dead" carbon, particularly in carbonate terrains (Williams and Polach 1969, 1971; Goudie 1983; Birkeland 1984). Moreover, because partial dissolution and reprecipitation of soil carbonates is common, particularly in soils with a fluctuating water table, carbonate samples will typically include material of many different ages, and bulk stable isotope results may represent a meaningless average of a number of different isotopic signatures. Although this problem can be partially overcome by careful micro-sampling of specific, spatially-related crystalline structures within carbonate masses (Prezbindowski 1980), there is still little basis for assigning the results to a specific time period in most cases.

Isotopic reconstructions based on bulk humates have their own potential problems. Many of these problems follow from difficulties identified in the voluminous literature on the radiocarbon dating of soils and sediments (e.g., Scharpenseel 1971; Goh and Molloy 1978; Gilet-Blein et al. 1980; Matthews 1985; Abbott and Mauldin 1996). Briefly, the organic material contained in a stable soil represents the sum total of organics added to the system through the in situ death and decay of organisms and sedimentary additions, minus the organics lost by advanced decay and leaching. Because fresh organic matter is continuously accreting while old organics are continuously being removed from an active soil system, eventually each soil will reach a quasi-equilibrium between organic additions and losses. When this happens, the apparent age of the soil, as indicated by radiocarbon dating, will stabilize even as the true age increases. For this reason, radiocarbon ages on stable soil horizons have come to be termed apparent mean residence time (AMRT) ages, and are properly interpreted as minimum ages only.

In the case of sediments, organic matter is typically derived from a combination of contemporary and older (i.e., eroded soil) organics in the sediment source. If the organic matter is predominantly contemporary with the sediment, then radiocarbon dating will yield a relatively precise age of deposition, but if it is dominated by old organics, the apparent age may be hundreds or thousands of years too old (Nordt 1992; Abbott and Mauldin 1996; Abbott 1997). Thus, sediment assays represent maximum ages only, and are difficult to assess in isolation. However, when multiple ages from stratigraphically related contexts are run and compared, and the results are considered in light of expectations derived from stratigraphic position and soil morphology, 
erroneous dates (and, thus, unreliable isotopic signatures) can usually be identified.

Alluvial paleosols, which typically represent cumulic floodplain soils, may be affected by both of these biases: they may incorporate older detrital organic matter introduced from the catchment and thus date too old, or, if stable for a long time, may date too young due to organic turnover. In most well-developed alluvial soils, however, the rate of in situ organic production overwhelms the detrital organic component, while the length of the soil forming interval in buried Holocene paleosols is usually to short to introduce significant bias through organic turnover. For this reason, many bulk humate dates from melanized, sealed alluvial paleosols are quite good. Aside from the potential for older, detrital carbon to be incorporated, the most significant problem for the accuracy of cumulic soil dates is posed by root penetration and translocation of younger organic solids and organic acids due to leaching of overlying units. However, the bias imposed by translocated organic acids can also be minimized by aggressive sample pre-treatment.

Given the relationship between the radioactive isotope ${ }^{14} \mathrm{C}$ and the stable isotope ${ }^{13} \mathrm{C}$, it follows that a bulk sediment sample that yields an unreliable radiocarbon age is also unsuitable for stable isotope interpretation. The same is true for soil carbonates, because the factors that tend to make such dates unreliable (e.g., the hard water error, addition of old air-fall carbonate, etc.) will also bias the stable isotope signature. By the same token, those samples yielding reliable radiocarbon ages will also yield stable isotope signatures that provide a meaningful indication of the relative contribution of $\mathrm{C}_{3}$ and $\mathrm{C}_{4}$ plants to the local organic pool at that particular point in time.

However, two additional uncertainties still remain in using these types of data to reconstruct the character of regional vegetation. The first question involves the reliability of the percentage estimate arrived at by using the relatively simple mass balance equation of Nordt et al. (1994) (Equation 1). While this equation provides a reasonable estimate of the relative percentage of $\mathrm{C}_{3}$ and $\mathrm{C}_{4}$-derived organic matter in a given sample (even here, minor environmental differences in the isotopic values of $\mathrm{C}_{3}$ and $\mathrm{C}_{4}$ plants, the variable contribution of CAM plants, and possible changes in global atmospheric ${ }^{13} \mathrm{C}$ introduce uncertainty), it is an oversimplification to equate this ratio to the relative abundance of $\mathrm{C}_{3}$ and $\mathrm{C}_{4}$ plants on the landscape, because the organic productivity of different plant taxa varies considerably. For this reason, it is inadvisable to use estimates of relative $\mathrm{C}_{3} / \mathrm{C}_{4}$ contributions for anything more rigorous than obtaining a heuristic picture of the past landscape.

The second important question involves the extent to which a given isotopic signature from an alluvial setting represent a regional or localized signal. Although previous researchers in Texas (e.g., Nordt et al. 1994; Humphrey and Ferring 1994; Buck and Monger 1999) have emphasized regional patterns on the basis of a few analyzed sections, there are good reasons to believe that the isotopic signature may sometimes represent only the immediate surroundings. For example, at Jewett Mine in east central Texas, Bousman (1991; Collins and Bousman 1993) found strong (approximately 6\%o) differences in the isotopic signature of roughly timeequivalent samples from upland and lowland settings. Although the trends of these sample sets are broadly in phase, indicating that they probably do reflect climatic influences, the strong contrast between upland and lowland signatures suggests that local vegetation is the overriding determinant of the isotopic signature. In the same area, Abbott (1996) found even stronger variability (up to 8\%o) in floodplain soils, suggesting that a spatial mosaic of $\mathrm{C}_{3} / \mathrm{C}_{4}$ vegetation can significantly affect data from a relatively consistent depositional environment. This conclusion is supported by research in Australia, where Bird and Pousai (1997) have documented variations in soil $\delta^{13} \mathrm{C}$ of approximately $6 \%$ in the span of a few meters on the $\mathrm{C}_{4}$-dominated savanna.

Clearly, the potential problems inherent in stable carbon isotope analysis merit interpretive caution. Nevertheless, the discussion of potential problems above is not intended as a critique leveled at any particular study or group of studies. Indeed, the stable isotope method provides a powerful tool to examine the character of past environments, and the existing investigations in Texas have made very significant contributions to understanding the character of Texas paleoenvironments. However, confident interpretation of the spatial character of environments in Texas through the culturally relevant period will require much more data than currently exists in the literature. This appendix represents another incremental step toward that eventual goal. 
As pointed out by a peer reviewer, the potential error of the radiocarbon-related isotopic assays presented in Figure 62 may be relatively large. To address this question, an approximation of paired samples was obtained by sampling the core immediately above and contiguous to the previously obtained radiocarbon sample. The adjacent sample was necessary because the radiocarbon samples removed the entire core between specified depths (most were 4-6 cm thick). Clearly, the four pseudopairs obtained in this manner do not represent a statistically valid sample, but they do give some indication of the magnitude of the potential error. Of the four "paired" samples, one pair returned identical values, one pair differed by $0.4 \%$, one pair differed by $1.1 \%$, and one pair differed by $2.35 \%$, for an average discrepancy of approximately $0.96 \%$. Factors that may have contributed to the discrepancy between pairs, other than analytical error by Beta Analytic, include analytical error by Coastal Science Labs (the nominal error of these assays is $0.2 \%$ ), and real differences between the isotopic ratio of the two members of the "pair." This latter consideration is not trivial, as adjacent samples differed by more than $6 \%$ in the data produced by Coastal Science Labs (see Figure 63). Nevertheless, it appears that the radiocarbon-related stable isotope assays may sometimes be off by at least 2-3\%o. This implies that rigorous interpretation of such data is unjustified, but that generalized trends are probably informative.

The results of radiocarbon-associated stable carbon isotopes from bulk soils analyzed during this project (see Figure 62) show several notable trends. One of the most striking is exhibited by the three samples dating to between $8.8 \mathrm{ka}$ and $10.2 \mathrm{ka}$. All three of these samples, which were recovered from deep cores in the Brazos alluvial valley, exhibit $\mathrm{d}^{13} \mathrm{C}$ values between $-15.4 \%$ and $-17.1 \%$, which nominally equate to between $70 \%$ and $84 \% \mathrm{C}_{4}$ vegetation. This finding contrasts with most other isotopic results from Texas, which usually indicate a predominantly $\mathrm{C}_{3}$ assemblage during the Late Pleistocene/Early Holocene transition (Nordt et al. 1994; Humphrey and Ferring 1994), as well as with general expectations for the character of the Late Pleistocene/Early Holocene biota derived from other paleoenvironmental methods (e.g., Lundelius 1967; Bryant and Holloway 1985; Toomey et al. 1993). Although some form of groundwater contamination cannot be ruled out, the radiocarbon ages are stratigraphically consistent and broadly conform with expectations derived from extant sea-level curves for the Gulf. For these reasons, the radiocarbon ages are believed to be relatively accurate (i.e., within a few hundred years). In addition, the accompanying stable carbon isotopes are considered relatively likely to reflect the general character of the local vegetation, even though analytical imprecision may have introduced errors of up to $2-3 \%$.

More detailed data from Brazos Core 2 (see Figure 63) does not exhibit quite as marked a shift at the Pleistocene-Holocene transition, but does support the same general trend. There is a distinct shift from a fairly consistent $\mathrm{C}_{3}$-dominated assemblage during the Late Pleistocene to a more variable, $\mathrm{C}_{4}$-dominated assemblage around $10 \mathrm{ka}$. This suggests that the vegetation in the lower Brazos Valley may have been quite different from most other parts of Texas during the Late Pleistocene/ Holocene transition. Perhaps the climate of the outer Texas Coastal Plain, particularly the portion seaward of the modern shoreline, was moderated enough by proximity to the Gulf to allow $\mathrm{C}_{4}$ grasses to flourish as the cool Pleistocene climate slowly warmed. The earlier samples collected from the deep Brazos cores, which date between approximately $12 \mathrm{ka}$ and $24 \mathrm{ka}$, exhibit signatures indicating $50-75 \% \mathrm{C}_{3}$ vegetation, suggesting that $\mathrm{C}_{4}$ grasses were somewhat suppressed but far from eliminated during the last Full Glacial and Late Glacial periods. As the climate warmed and sealevel rise began to stimulate backfilling of the lower valleys, these grasses appear to have flourished for a short period in the relatively protected, rapidly aggrading Brazos valley. Notably, one other study from Texas also indicates a $\mathrm{C}_{4}$-dominated assemblage during the Late Pleistocene/Early Holocene. This study (Bousman et al. 1990) is from the Rio Grande delta plain, and supports the proposition that portions of the outer Coastal Plain may have been dominated by $\mathrm{C}_{4}$ grasses and/or CAM plants during the Pleistocene-Holocene transition. Interestingly, both of the current isotopic data sets suggest that the Early Holocene assemblage quickly returned to a more balanced $\mathrm{C}_{3} / \mathrm{C}_{4}$ ratio in the lower Brazos area.

Another characteristic of interest in the data from Brazos Core 2 is an apparent change in the internal variability of sample "clusters" at the Pleistocene-Holocene transition. The two clusters below the 10.2 ka date both show relatively minor 
internal ranges $(0.6 \%$ from 19.6 to $20.5 \mathrm{~m}$, and $1.1 \%$ from 25.5 to $26.3 \mathrm{~m}$ ), but most of the subsequent clusters show considerably more pronounced variability $(5.7 \%$ o from 17.3 to $18.7 \mathrm{~m}$, $5 \%$ from 11.8 to $13.1 \mathrm{~m}$, and $6.35 \%$ from 4.5 to $5.6 \mathrm{~m}$ ). The sole exception to this trend is the threepoint cluster from 9.3 to $9.7 \mathrm{~m}$, which had a total variability of $0.75 \%$. There are several possibilities to explain the relatively high variability of the clusters of closely spaced samples dating from 6.4 $\mathrm{ka}$ to $10.2 \mathrm{ka}$. Given the thick deposit and the tight sampling interval, the least likely possibility is that the shifts reflect real, abrupt changes in the character of regional vegetation. More plausibly, the shifts may reflect the influx of sediments reworked from a variety of sources of different age and with a differing isotopic character. However, such variation should also affect the apparent radiocarbon ages of the samples, and the ages from Brazos Core 2 are not consistent with the addition of a high percentage of allogenic organic matter. A third possibility, considered most likely by the author, is that the sudden shifts reflect the influence of changing local assemblages superimposed on the broad pattern of more incremental regional climate change.

The Middle to Late Holocene record is not present in Brazos Core 2, and the available data are limited to stable carbon isotope assays measured in conjunction with radiocarbon dating. According to this data, $\mathrm{C}_{4}$ grasses again decrease somewhat at the expense of $\mathrm{C}_{3}$ vegetation by the early Middle Holocene, but remain a dominant component of the assemblage, comprising $50-60 \%$ of the organic carbon pool. Between approximately $8 \mathrm{ka}$ and $1 \mathrm{ka}$, this percentage gradually increases in the Brazos valley until the remains of $\mathrm{C}_{4}$ grasses again comprise approximately $75-80 \%$ of the total soil carbon pool. This long trend is indicative of gradual warming and/or drying, with no strong signal attributable to a Middle Holocene "Altithermal" event (see Antevs 1948; Holliday 1989; Humphrey and Ferring 1994; Nordt et al. 1994). Although the trend is clear, the data also contain a good deal of noise, including a few isolated samples that shift radically to almost total $\mathrm{C}_{3}$ or $\mathrm{C}_{4}$ dominance. Once again, it is considered relatively unlikely that such shifts represent rapid, short-term changes in the regional assemblage; instead, the majority of these anomalous samples are interpreted as localized concentrations of $\mathrm{C}_{3}$ or $\mathrm{C}_{4}$ plants within a broader mixed assemblage. However, the four samples from Northeast
Houston produced $\mathrm{C}_{3}$-dominated signatures that may indicate that the boundary between the mixed $\mathrm{C}_{3} / \mathrm{C}_{4}$ coastal grassland and the $\mathrm{C}_{3}$-dominated pine-hardwood forest has been in approximately the same location for at least the last $2 \mathrm{ka}$.

\section{CONCLUSION}

The stable carbon isotope data from this study provide a fascinating glimpse into the character of Holocene paleoenvironments in the study area, and bear relatively little relation to most isotopic studies conducted elsewhere in Texas (e.g., Bousman 1991; Monger 1993; Nordt et al. 1994; Humphrey and Ferring 1994; Abbott 1996). Particularly noteworthy are (1) an apparent expansion of warm/arid-adapted $\mathrm{C}_{4}$ vegetation in the lower Brazos valley during the Pleistocene/Holocene transition, which contrasts with data from other areas except the Rio Grande delta; and (2) the lack of a strongly defined $\mathrm{C}_{4}$ peak in the Middle Holocene period, which also differs from most inland proxy records in Texas (excluding the frequently discussed bog pollen records, which also do not indicate an "Altithermal"). Although the present data suggest that conditions on the outer Coastal Plain may have been quite different than elsewhere in Texas, this conclusion is tentative at best and requires further study.

\section{REFERENCES CITED}

Abbott, J. T.

1996 Geomorphic investigations in the lowlands. In Cultural Resource Survey of Area $F$ of the Jewett Mine, Freestone County, Texas, by J. Peck, J. T. Abbott, C. D. Frederick, P. L. O'Neill, and A. C. Treece, pp.131-160. TRC Mariah Associates, Inc., Austin.

1997 Late Quaternary Alluviation and Soil Erosion in Southern Italy. Ph.D. Dissertation, The University of Texas at Austin.

Abbott, J. T. and R. P. Mauldin

1996 Chronometrics research domain. In Significance Standards for Prehistoric Archeological Sites at Fort Bliss: A Design for Further Research and the Management of Cultural Resources, by J. T. Abbott, R. Mauldin, P. E. Patterson, W. N. Trierweiler, R. J. Hard, C. R. Lintz, and C. L. Tennis, pp. 57-81. TRC Mariah Associates, Inc., Austin. 
Amundson, R. G., O. A. Chadwick, J. M. Sowers, and H. E. Donner

1988 Relationship Between Climate and Vegetation and the Stable Carbon Isotope Chemistry of Soils in the Eastern Mojave Desert, Nevada. Quaternary Research 29:245-254.

Antevs, E.

1948 Climatic Changes and Pre-White Man in the Great Basin, with Emphasis on Glacial and Postglacial Times. University of Utah Bulletin 38:168-191.

Bird, M. and P. Pousai

1997 Carbon isotope variations in the surface soil organic carbon pool. Global Biogeochemical Cycles 11:313.

Birkeland, P. W.

1984 Soils and Geomorphology. Oxford University Press, New York.

Bousman, C. B.

1991 Paleoenvironments. In Excavations at the Bottoms, Rena Branch, and Moccasin Springs Sites, Jewett Mine Project, Freestone and Leon Counties, Texas, edited by R. C. Fields, pp. 65-93. Reports of Investigations No. 70. Prewitt \& Associates, Inc., Austin.

Bousman, C. B., S. A. Tomka, and G. L. Bailey

1990 Prehistoric Archeology and Paleoenvironments in Hidalgo and Willacy Counties, South Texas: Results of Phase II Test Excavations. Report of Investigations No. 76. Prewitt and Associates, Inc., Austin.

Bradley, R. S.

1985 Quaternary Paleoclimatology: Methods of Paleoclimatic Reconstruction. Allen \& Unwin, Boston.

Bryant, V. M. and R. G. Holloway

1985 The Late Quaternary paleoenvironmental record of Texas. In Pollen Records of Late Quaternary North American Sediments, edited by V. M. Bryant and R. G. Holloway, pp. 39-70. American Association of Stratigraphic Palynologists, Dallas

Buck B. J. and H. C. Monger

1999 Stable isotopes and soil-geomorphology as indicators of Holocene climate change, northern Chihuahuan Desert. Journal of Arid Environments 43:357-373.

Collins, M. B. and C. B. Bousman

1993 Quaternary Environments and Archeology in Northeast Texas. In Archeology in the Eastern Planning Region, edited by N. A. Kenmotsu and T. K. Perttula, pp. 49-67. Cultural Resource Management Report 3. Department of Antiquities Protection, Texas Historical Commission, Austin.
Decker, S., S. L. Black, and T. Gustavson

in press The Woodrow Heard Site, 41UV88, A Holocene Terrace Site in the Western Balcones Canyonlands of Southwest Texas. Studies in Archeology 33, Texas Archeological Research Laboratory, The University of Texas at Austin, and Report 14, Archeological Studies Program, Environmental Affairs Division, Texas Department of Transportation, Austin.

Fredlund, G. G. and L. L. Tieszen

1997 Phytolith and carbon isotope evidence for Late Quaternary vegetation and climate change in the Southern Black Hills, South Dakota. Quaternary Research 47:206-217.

Gile, L. H., J. W. Hawley, and R. B. Grossman

1970 Distribution and Genesis of Soils and Geomorphic Surfaces in a Desert Region of Southern New Mexico. Soil Science Society of America Guidebook, Soil-Geomorphology Field Conference, August 21-22 and 29-30, 1970.

Gilet-Blein, N., G. Marien, and J. Evin

1980 The unreliability of ${ }^{14} \mathrm{C}$ dates from organic matter of soils. Radiocarbon 22:919-929.

Goh, K. M. and B. P. J. Molloy

1978 Radiocarbon dating of paleosols using soil organic matter components. Journal of Soil Science 29:567-573.

Goudie, A.

1983 Calcrete. In Chemical Sediments and Geomorphology: Precipitates and Residua in the Near Surface Environment, edited by A. S. Goudie and K. Pye, pp. 93-131. Academic Press, New York.

Holliday, V. T.

1989 Middle Holocene drought on the southern Great Plains. Quaternary Research 31:74-82.

Humphrey, J. D. and C. R. Ferring

1994 Stable isotopic evidence for latest Pleistocene and Holocene climatic change in North-Central Texas. Quaternary Research 41:200-213.

Lundelius, E. L.

1967 Late Pleistocene and Holocene faunal history of central Texas. In Pleistocene Extinctions: A Search for a Cause, edited by P. S. Martin and H. E. Wright, Jr., pp. 287-319. Yale University Press, New Haven.

Matthews, J. A.

1985 Radiocarbon dating of surface and buried soils: principals, problems, and prospects. In Geomorphology and Soils, edited K. S. Richards, R. R. Arnett, and S. Ellis, pp. 269-288. Allen \& Unwin, London. 
Menking, K. M., J. L. Bischoff, J. A. Fitzpatrick, J. W. Burdette, and R. O. Rye

1997 Climatic/hydrologic oscillations since 155,000 yr B.P. at Owens Lake, California, reflected in abundance and stable isotope composition of sediment carbonate. Quaternary Research 48:58-68.

Monger, H. C.

1993 Radiocarbon and stable isotopes in the basin floor soils on Fort Bliss. In Soil-Geomorphic and Paleoclimatic Characteristics of the Fort Bliss Maneuver Areas, Southern New Mexico and Western Texas, edited by H. C. Monger, pp. 89-92. Historic and Natural Resources Report 10. Cultural Resources Management Program, Directorate of the Environment, United States Army Air Defense Artillery Center, Ft. Bliss, Texas.

Nordt, L. C.

1992 Archaeological Geology of the Fort Hood Military Reservation, Fort Hood, Texas. Archaeological Resource Management Series, Research Report No. 25. U.S. Army Fort Hood, Texas.

Nordt, L. C., T. W. Boutton, C. T. Hallmark, and M. R. Waters 1994 Late Quaternary Vegetation and Climate Changes in Central Texas Based on the Isotopic Composition of Organic Carbon. Quaternary Research 41(1):109-120.
Presbindowski, D.

1980 Microsampling technique for stable isotopic analyses of carbonates. Journal of Sedimentary Petrology 50: 643-645.

Scharpenseel, H. W.

1971 Radiocarbon dating of soils: problems, troubles, hopes. In Paleopedology: Origin, Nature, and Dating of Paleosols, edited by D. Yaalon, pp. 77-88. Israel University Press, New York.

Schwartz, D., A. Mariotti, R. Lanfranchi, and B. Guillet

$1986{ }^{13} \mathrm{C} /{ }^{12} \mathrm{C}$ ratios of soil organic matter as indicators of vegetation changes in the Congo. Geoderma 39:97-103.

Toomey, R. S., III, M. D. Blum, and S. Valastro, Jr.

1993 Late Quaternary climates and environments of the Edwards Plateau, Texas. Global and Planetary Change 7:299-320.

Williams, G. E. and H. A. Polach

1969 The evaluation of C-14 ages for soil carbonate from the arid zone. Earth and Planetary Science Letters 7:240-242.

1971 Radiocarbon dating of arid zone calcareous paleosols. Geological Society of America Bulletin 82:3069-3086. 


\section{Appendix IV}

\section{Results of Radiocarbon Dating}

\section{INTRODUCTION}

This appendix presents the results of radiocarbon analyses conducted during the course of this project. The context and implications of the results are discussed in Chapter 4 of the report. Calibrated ages are as reported by Beta Analytic except for three pre-Holocene samples (Beta-120667, Beta20669, and Beta-120673) reported prior to the publication of the 1998 calibration curve revision. Those three samples were calibrated by the author using Calib 4.1 and the 1998 Atmospheric decadal dataset. 


\begin{tabular}{|c|c|c|c|c|c|c|c|}
\hline \begin{tabular}{|l} 
Sample \\
Designation
\end{tabular} & $\begin{array}{c}\text { Sample } \\
\text { Description }\end{array}$ & Material & $\begin{array}{c}\text { Measured } \\
\text { Age }\end{array}$ & $\begin{array}{c}\text { Corrected } \\
\text { Age }\end{array}$ & $\delta^{13} \mathrm{C}$ & $\begin{array}{c}\text { Calibrated Age } \\
\text { (2 sigma) }\end{array}$ & Method \\
\hline Beta-108142 & \begin{tabular}{|l|} 
Little Caney \\
Creek @ Waverly \\
Road, unnamed \\
tributary con- \\
fluence, BT1, \\
depth = $30 \mathrm{~cm}$ \\
\end{tabular} & $\begin{array}{l}\text { uncarb. } \\
\text { macro- } \\
\text { fossil } \\
\text { frags }\end{array}$ & $60 \pm 40$ & $40 \pm 40$ & -26.6 & AD 1675-1955* & AMS \\
\hline Beta-108143 & \begin{tabular}{|l|} 
Little Caney \\
Creek @ Waverly \\
Road, unnamed \\
tributary con- \\
fluence, BT1, \\
depth = 95 cm \\
\end{tabular} & $\begin{array}{l}\text { uncarb. } \\
\text { macro- } \\
\text { fossil } \\
\text { frags }\end{array}$ & $100 \pm 40$ & $100 \pm 40$ & -25.1 & $\begin{array}{l}\text { AD } 1678-1759,1804- \\
1936, \text { and } 1939-1949\end{array}$ & AMS \\
\hline Beta-117795 & $\begin{array}{l}\text { FM526@Greens } \\
\text { Bayou, BT4, Zone } \\
7,110 \mathrm{~cm}\end{array}$ & $\begin{array}{c}\text { uncarb. } \\
\text { macro- } \\
\text { fossil } \\
\text { frags }\end{array}$ & $20 \pm 70$ & $20 \pm 70$ & $-25^{*}$ & $\begin{array}{l}\text { AD } 1680 \text { to } 1745 \text { and } \\
\text { AD } 1805 \text { to } 1935\end{array}$ & radiometric \\
\hline Beta-117796 & $\begin{array}{l}\text { Brazos TDCJ\#1 } \\
2 \mathrm{~A} \text { horizon } 105 \\
\mathrm{~cm}\end{array}$ & sediment & $1840 \pm 70$ & $1940 \pm 70$ & -19.2 & BC 60 to AD 240 & radiometric \\
\hline Beta-117797 & $\begin{array}{l}\text { Brazos TDCJ\#1 } \\
\text { 2Btk horizon } 230 \\
\mathrm{~cm}\end{array}$ & sediment & $2920 \pm 70$ & $3040 \pm 70$ & -18 & BC 1430 to 1045 & radiometric \\
\hline Beta-117798 & $\begin{array}{l}\text { Brazos TDCJ\#1 } \\
\text { 3B3 horizon } 460 \\
\mathrm{~cm}\end{array}$ & sediment & $6480 \pm 40$ & $6560 \pm 40$ & -19.7 & BC 5530 to 5425 & AMS \\
\hline Beta-117799 & $\begin{array}{l}\text { Brazos TDCJ\#1 } \\
4 \mathrm{ABw} \text { horizon } \\
700 \mathrm{~cm}\end{array}$ & sediment & $5070 \pm 90$ & $5170 \pm 90$ & -18.4 & BC 4225 to 3775 & radiometric \\
\hline Beta-117800 & \begin{tabular}{|l|} 
Brazos TDCJ\#1 \\
5Btg horizon 960 \\
$\mathrm{~cm}$
\end{tabular} & sediment & $6000 \pm 80$ & $6120 \pm 80$ & -17.5 & BC 5245 to 4830 & radiometric \\
\hline Beta-117801 & \begin{tabular}{|l|} 
Clute Oyster \\
Creek BT3, Zone \\
$5,148 \mathrm{~cm}$
\end{tabular} & sediment & $1460 \pm 50$ & $1580 \pm 50$ & -17.5 & AD 395 to 605 & radiometric \\
\hline Beta-117802 & $\begin{array}{l}\text { Clute Oyster } \\
\text { Creek BT3 Zone } \\
6,240 \mathrm{~cm} \\
\end{array}$ & sediment & $3470 \pm 60$ & $3590 \pm 60$ & -17.7 & $\begin{array}{l}\text { BC } 2120 \text { to } 2080 \text { and } \\
\text { BC } 2050 \text { to } 1755\end{array}$ & radiometric \\
\hline Beta-118666 & $\begin{array}{l}\text { 41HR751, top of } \\
\text { Stratum 7,182 } \\
\text { cmbd }\end{array}$ & sediment & $1580 \pm 50$ & $1590 \pm 50$ & -24.5 & AD 390 to AD 600 & AMS \\
\hline Beta-118667 & $\begin{array}{l}\text { 41HR751, bottom } \\
\text { of Stratum 7, } 215 \\
\text { cmbd }\end{array}$ & sediment & $2220 \pm 50$ & $2220 \pm 50$ & -24.7 & BC 390 to 150 & AMS \\
\hline Beta-120653 & BRA\#6, $22.0 \mathrm{~m}$ & $\begin{array}{l}\text { woody } \\
\text { mat'I }\end{array}$ & $>48630$ & $>48560$ & -29.5 & not applicable & AMS \\
\hline Beta-120654 & BRA\#6, $7.25 \mathrm{~m}$ & grass frag & $1.103 \pm 5 \%$ & $108.3 \pm 5 \%$ & -15.7 & not applicable & AMS \\
\hline Beta-120655 & BRA\#6, $18.2 \mathrm{~m}$ & plant frag & $1.059 \pm 5 \%$ & $1.068 \pm 5 \%$ & -29.2 & not applicable & AMS \\
\hline Beta-120656 & BRA\#3, $23.1 \mathrm{~m}$ & grass frag & $1.05 \pm 6 \%$ & $1.064 \pm 6 \%$ & -32 & not applicable & AMS \\
\hline Beta-120657 & BRA\#4, $6.94 \mathrm{~m}$ & snail shell & $2250 \pm 40$ & $2530 \pm 40$ & -7.4 & BC 800 to 515 & AMS \\
\hline Beta-120658 & BRA\#3, $10.05 \mathrm{~m}$ & sediment & $8730 \pm 70$ & $8860 \pm 70$ & -17.1 & BC 8030 to 7700 & AMS \\
\hline Beta-120659 & BRA\#3, $6.17 \mathrm{~m}$ & sediment & $6920 \pm 60$ & $7010 \pm 60$ & -19.8 & BC 5970 to 5710 & AMS \\
\hline
\end{tabular}




\begin{tabular}{|c|c|c|c|c|c|c|c|}
\hline Beta-120660 & BRA\#6, $2.85 \mathrm{~m}$ & sediment & $4280 \pm 50$ & $4470 \pm 50$ & -13.6 & BC 3345 to 2925 & AMS \\
\hline Beta-120661 & BRA\#5, $2.6 \mathrm{~m}$ & sediment & $5070 \pm 50$ & $5130 \pm 50$ & -21.2 & BC 4000 to 3975 & AMS \\
\hline Beta-120662 & BRA\#7, $1.06 \mathrm{~m}$ & sediment & $1020 \pm 50$ & $1160 \pm 50$ & -16.2 & AD 775 to 995 & AMS \\
\hline Beta-120663 & BRA\#2, $9.75 \mathrm{~m}$ & sediment & $6810 \pm 60$ & $6910 \pm 60$ & -19 & BC 5860 to 5625 & AMS \\
\hline Beta-120664 & BRA\#7, $4.41 \mathrm{~m}$ & $\begin{array}{l}\text { uncarb. } \\
\text { macro- } \\
\text { fossil } \\
\text { frags }\end{array}$ & $5740 \pm 40$ & $5850 \pm 40$ & -18.2 & BC 4805 to 4605 & AMS \\
\hline Beta-120665 & BRA\#6, 1.09m & sediment & $2070 \pm 50$ & $2200 \pm 50$ & -17.2 & BC 380 to 100 & AMS \\
\hline Beta-120666 & BRA\#2, $3.12 \mathrm{~m}$ & sediment & $8220 \pm 60$ & $8320 \pm 60$ & -19.2 & $\begin{array}{l}\text { BC } 7940 \text { to } 7235 \text { and } \\
\text { BC } 7160 \text { to } 7140\end{array}$ & AMS \\
\hline Beta-120667 & BRA\#7, 6.15m & sediment & $15290 \pm 90$ & $15330 \pm 90$ & -22.4 & BC 16881 to 16146 & AMS \\
\hline Beta -120668 & BRA\#2, 15.24 m & sediment & $8820 \pm 60$ & $8960 \pm 60$ & -16.3 & BC 8070 to 7940 & AMS \\
\hline Beta-120669 & BRA\#4 $14.9 \mathrm{~m}$ & sediment & $19880 \pm 140$ & $19940 \pm 140$ & -21.2 & BC 22478 to 21196 & AMS \\
\hline Beta-120670 & BRA\#1, $12.49 \mathrm{~m}$ & sediment & $7730 \pm 60$ & $7820 \pm 60$ & -19.4 & BC 6735 to 6470 & AMS \\
\hline Beta-120671 & BRA\#2, $4.75 \mathrm{~m}$ & sediment & $6240 \pm 50$ & $6340 \pm 50$ & -19.2 & BC 5345 to 5225 & AMS \\
\hline Beta-120672 & BRA\#4, $0.91 \mathrm{~m}$ & sediment & $1090 \pm 50$ & $1250 \pm 50$ & -15.3 & AD 670 to 890 & AMS \\
\hline Beta-120673 & BRA\#2, $18.28 \mathrm{~m}$ & sediment & $10060 \pm 70$ & $10220 \pm 70$ & -15.4 & BC 10385 to 9681 & AMS \\
\hline Beta-120674 & BRA\#7, $20.97 \mathrm{~m}$ & sediment & $23750 \pm 180$ & $23780 \pm 180$ & -23.1 & not applicable & AMS \\
\hline Beta-120675 & BRA\#1, $9.31 \mathrm{~m}$ & sediment & $6440 \pm 60$ & $6440 \pm 60$ & -25.3 & BC 5450 to 5260 & AMS \\
\hline Beta-120676 & BRA\#2, $25.78 \mathrm{~m}$ & sediment & $20630 \pm 200$ & $20670 \pm 200$ & -22.3 & not applicable & AMS \\
\hline Beta-120677 & BRA\#1, $2.28 \mathrm{~m}$ & sediment & $7610 \pm 80$ & $7670 \pm 80$ & -21.3 & BC 6600 to 6370 & AMS \\
\hline Beta-120678 & BRA\#1, $4.78 \mathrm{~m}$ & sediment & $5570 \pm 60$ & $5680 \pm 60$ & -18.1 & BC 4690 to 4370 & AMS \\
\hline Beta-120679 & $\begin{array}{l}\text { FM2004 @ } \\
\text { Oyster Creek, BT } \\
4,1.15 \mathrm{~m}\end{array}$ & $\begin{array}{l}\text { uncarb. } \\
\text { macro- } \\
\text { fossil } \\
\text { frags }\end{array}$ & $1350 \pm 50$ & $1350 \pm 50$ & -25.1 & $A D 630$ to 780 & AMS \\
\hline Beta-120680 & $\begin{array}{l}\text { FM2004@ } \\
\text { Oyster Creek, BT } \\
4,1.5-1.6 \mathrm{~m}\end{array}$ & sediment & $1480 \pm 70$ & $1620 \pm 70$ & -15.9 & AD 260 to 605 & radiometric \\
\hline Beta-137387 & $\begin{array}{l}\text { Kinglet Bog pollen } \\
\text { column, 40-45 } \\
\text { cmbs }\end{array}$ & sediment & $200 \pm 60$ & $170+60$ & -27.2 & AD 1640 to 1955 & AMS \\
\hline Beta-135113 & $\begin{array}{l}\text { Kinglet Bog pollen } \\
\text { column, } 80-85 \\
\text { cmbs. }\end{array}$ & sediment & $1070 \pm 40$ & $1010 \pm 40$ & -28.4 & $\begin{array}{l}\text { AD } 980 \text { to } 1050 \text { and } \\
\text { AD } 1095 \text { to } 1140\end{array}$ & AMS \\
\hline
\end{tabular}




\section{Appendix V}

\section{Reviewer Comments}

\section{INTRODUCTION}

The scope of the Houston Area Geoarcheology document is considerably broader and more detailed than most geoarcheological works published in CRM. As outlined in Chapter 5, TxDOT adopted a detailed review process to guide its development. We identified a suite of reviewers that included both geoarcheologists familiar with Texas, and regulatory and consulting archeologists familiar with the Houston area, and submitted manuscripts for review at three different stages of the project. The first round of review addressed the mapping protocol, and was conducted prior to mapping. The second stage involved review of the draft, and was used as a basis for revision of the document. The third stage involved review of the revised document, and resulted in the reviews published here.

There is little doubt that the Houston Area Geoarcheology manuscript posed a more daunting task than usual for the peer reviewers. As might be expected in a document of this scope, several aspects of the manuscript proved somewhat controversial, while others found broad agreement. Because there were several areas of less than universal agreement, and because we believe that it is important to air all valid viewpoints, we decided to offer each of the reviewers an opportunity to comment formally in print. The following comments are by the reviewers who chose to take this opportunity (one reviewer of the draft chose not to prepare comments for publication). These comments are followed by TxDOT's response to the issues raised. 


\title{
THE HOUSTON POTENTIAL ARCHEOLOGICAL LIABILITY MAP: A CRITICAL REVIEW
}

\author{
C. Britt Bousman \\ Center for Archaeological Studies \\ Southwest Texas State University \\ San Marcos, Texas
}

\begin{abstract}
Abbott has undertaken a monumental task with the construction of the Houston Potential Archeological Liability Map (Houston PALM). This study presents the first truly comprehensive account of Late Quaternary geology and soils in the Houston area. It also provides a detailed accounting of depositional and formational processes. While I think the general approach, that of using geological principals to help assess archeological context and significance, is a valid one, the specific approach used by the Houston PALM is designed to eliminate sites from consideration before the potential of these sites has been assessed. Personally, I do not think that we understand the archeological or geological records well enough to use this approach. I doubt if context can be predicted from the generalized mapped data to the degree necessary for eliminating areas from survey. Abbott (this volume) divided the region into environmentally homogeneous areas (mapping units) and assessed each mapping unit for its average ability to preserve prehistoric archeological sites. Many sites would never be assessed because the mapping unit would not be surveyed, and these sites would be left unrecorded. Abbott (p. 180) discusses the inability for this scheme to work for historic sites, and it is likely to be equally problematic for protohistoric Native American sites. Furthermore, other unique and significant sites that do not fall into the average pattern could easily be overlooked.

Many arguments can be offered contesting the strategy of this specific plan, but a serious issue is that posed by its approach to integrity and site significance. Over the last 20 years in Texas archeology, there has been a decided move toward the systematic use of geological methods for prospecting for archeological sites, and for determining if sites are significant in terms of National Register criteria. This represents a dramatic move away from assessing site significance based on archeological and historical criteria alone. In most cases the use of geological techniques has improved the quality of investigations and led to a more robust, rigorous, and informative archeological record (Collins 1995).
\end{abstract}

However, using a site's geological context as the first and often the sole criterion for judging $\mathrm{Na}$ tional Register significance is inadequate.

Application of the Houston PALM, in many cases, would completely eliminate our ability to engage any criteria other than gross estimates of presumed geological context, and only these estimates of geological context would be used to determine if areas should be surveyed or investigated. I believe it is a mistake to give this much weight to geological context, especially so when archeologi$\mathrm{cal} /$ historic significance is ignored. Both geological and archeological contexts of sites should be assessed and weighed on a case by case basis. The most obvious problems that will be encountered with the application of the Houston PALM will be with historic and protohistoric sites. Many of these sites will be missed.

Additionally, the way that the Houston PALM uses context is severely restricted. Only sites in intact buried contexts would be judged significant. Recently, in a testing project at Lackland Air Force Base in San Antonio, the Center for Archaeological Research, University of Texas at San Antonio developed a scheme for classifying the geological contexts of archeological sites (Houk and Nickels 1997; Bousman et al. in press). We designed this scheme solely for hunter-gatherer sites where the processes of deposition are primarily geological in nature. Sites with significant cultural deposits, such as most historic, some Late Prehistoric, and protohistoric sites, are not adequately covered by this scheme. Our scheme shares this deficiency with the Houston PALM. A slightly altered version of this scheme is presented below. The recent literature on archeological site formation processes usually identifies and characterizes the processes that create and disturb materials and sediments in archeological sites (Schiffer 1972, 1987). Discussions in Waters (1992) and Goldberg et al. (1993) identify these primary and secondary processes. However, end products can also be identified and used for assessing site significance. 
Table 11. Primary and Secondary Contexts.

\section{Primary Contexts}

Intact Buried Context

Archeological materials are discarded in a geological context that covers the materials by low energy deposits which do not move artifacts or materials in any appreciable manner. In some settings archeological occupations/ components are separated by sterile deposits.

\section{Intact Surface Context}

Archeological materials (artifacts and features) from a single occupation or component are discarded on a stable surface. These materials undergo little horizontal or vertical movement.

\section{Surface Palimpsest}

Artifacts and/or features from multiple occupations are deposited on stable surfaces, usually bedrock, where the artifacts from different occupations or components are intermingled.

Compressed Stratigraphy

Archeological materials are discarded in very slowly accumulating deposits but in correct stratigraphic order. The physical separation is noticeably less than occurs in other sites with intact buried components.

\section{Secondary Contexts}

Turbated Palimpsest

Archeological materials are discarded on a stable surface; however, pedo-geological processes and biological activity below and on that surface move artifacts at various rates in multiple vertical and horizontal directions.

\section{Lag Palimpsest}

Archeological materials are discarded in an accumulating depositional environment, but later, usually either by wind or water erosion, the fine-grained sediments are removed, artifacts drop in elevation, and become intermingled on this erosional surface.

Mixed Deposit

Archeological materials are discarded in an accumulating depositional environment, but later through rodent burrowing, tree falls, or other forms of bioturbation or soil processes, materials are vertically mixed.

\section{Redeposited Context}

Archeological materials are discarded in an accumulating depositional environment or on stable surfaces but later, either by wind or water erosion, artifacts are redeposited in another sedimentary unit.

\section{Reversed Stratigraphy}

Archeological materials discarded in an accumulating depositional environment but later, either by wind or water erosion, artifacts are redeposited in another sedimentary unit and in reversed chronological order.

Reversed stratigraphy is a subset of materials in Redeposted Contexts.

If context is viewed in terms of primary and secondary deposits, then a number of different contexts can be identified (Figure 64 and Table 11). In this approach, primary and secondary context refer to the geological setting of cultural materials. In a primary context, artifacts retain their original associations and discard locations regardless of the nature of the cultural process(es) which created them. In a secondary context, these artifacts have lost their original association(s) or discard locations through one or more process. The various endproducts, grouped by Primary Contexts and Secondary Contexts and created by a variety of geologic, pedogenic, and biologic processes, are illustrated in Figure 64 and discussed in Table 11.

In the Lackland Air Force Base case, one site, 41BX1103, occurred in a gravel bar and was judged to be in a Secondary Redeposited Context (Houk 


\section{Primary Geological Context}

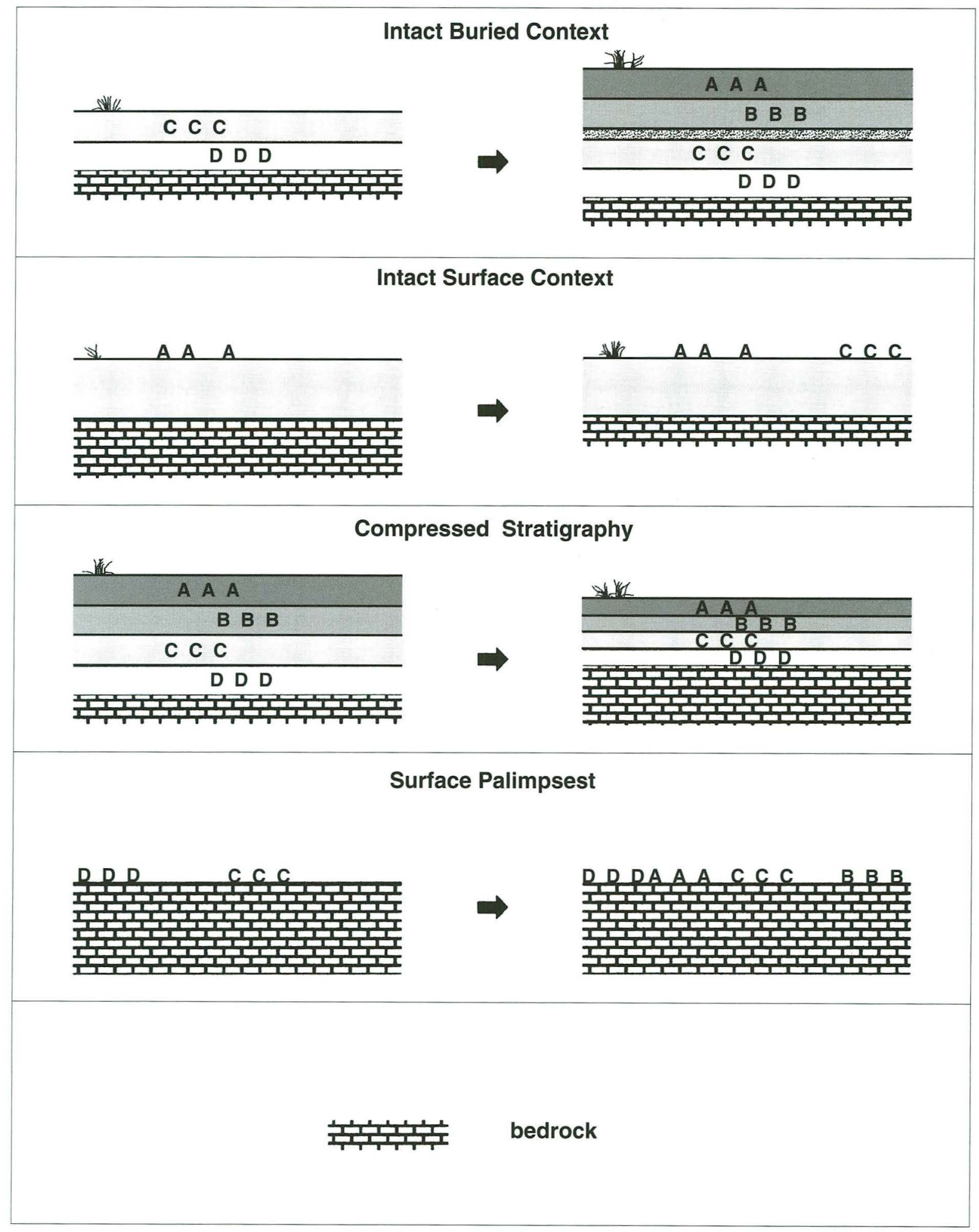

Figure 64. Geological contexts. 


\section{Secondary Geological Context}

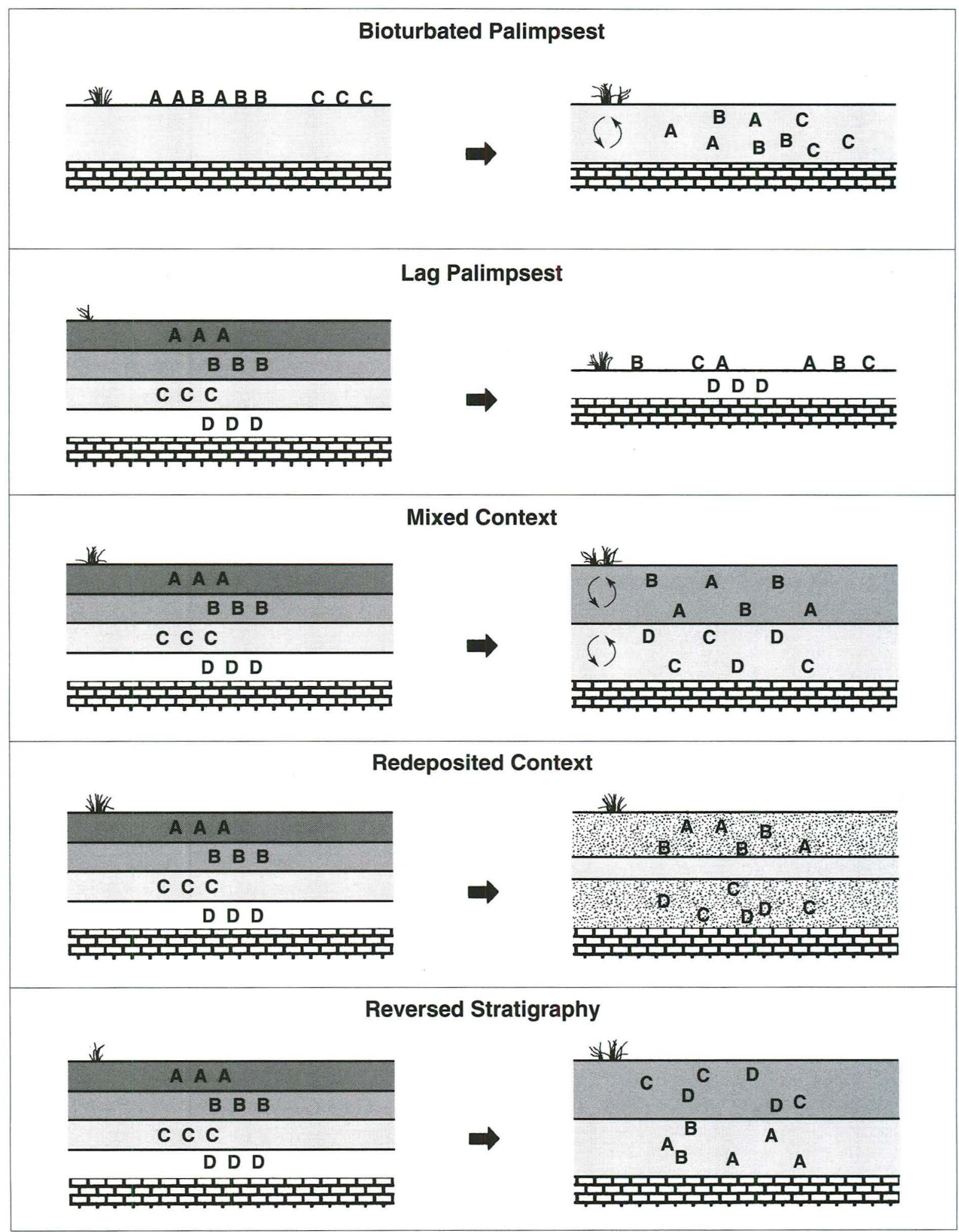

Figure 64. (Continued) 
and Nickels 1997). Deposition of the gravel bar ensued shortly after $3600 \mathrm{BP}$ and terminated in the Late Holocene. The gravel bar was apparently used as a prehistoric campsite from around $3600 \mathrm{BP}$ until approximately $1250 \mathrm{BP}$ based on artifacts diagnostic of the Late Archaic (ca. 4000-1250 BP) period found on the surface and during excavations (Houk and Nickels 1997). Occupational components were scoured by flood events, and matrixsupported pebbles in the upper part of the gravel bar indicate that with each initial flood surge, coarse fragments were deposited and the voids were subsequently infilled by fine-grained sediments during flood recession (Nordt 1997).

Given this formation history, the cultural materials at the site are classified as in a Redeposited Context. To determine the extent to which the cultural material had been stream transported, each lithic artifact recovered from the site was examined for evidence of battering, rounding, or smoothing on flake scar ridges (not edges which are typically modified through cultural processes). Of the 839 artifacts examined, only 15 (less than two percent) showed conclusive evidence of stream damage.

The lack of stream damage and the fact that faunal material was recovered during the excavations imply that the materials have not been transported any great distance during the various flood episodes. Therefore, even though the materials are in a Redeposited Context, they approximate an Intact Buried Context. Furthermore, the deposits appear to be stratified chronologically based on the distribution of diagnostic projectile points within the excavation units (Houk and Nickels 1997). Because the site has the potential to address the poorly defined Late Archaic chronology of South Texas (see Hester 1995), 41BX1103 is a significant site despite its Secondary Context. Houk and Nickels (1997) suggested that the site should be excavated if further impacts were to occur. The Texas Historical Commission accepted this recommendation.

This example demonstrates that we cannot simply place sites in gross contextual categories, and thoughtlessly use context to judge site-significance without considering a variety of detailed information. It would be a mistake to exclude all sites in Secondary Contexts or only investigate sites that fall within the category of Intact Buried Contexts. This logic is too simple and does not fully take advantage of the full wealth of data in the archeological record, and its lacunae. Additionally, it is easy to visualize situations where sites in Primary Contexts should not be investigated. For example, Surface Palimpsests would often be excluded from detailed study because of the difficulty of unraveling the sequence of occupations. Context is but one aspect on which to judge site significance. Other aspects include our knowledge of the regional archeological record as well as the ability of a site to answer specific research questions defined in the literature or research designs.

When viewed in this light, the use of context by the Houston PALM would eliminate potentially significant sites by failing to record those sites. Recording and assessing the significance of sites in the field by archeologists is not a foolproof process, but it is the first, and in many cases, the only time that site significance will be assessed before a site is destroyed. Systematically eliminating this step will bias the archeological record and ignore any site that does not fit a simplistic average pattern. Furthermore, the Houston PALM does not provide a strategy for assessing historic and protohistoric sites. However, the Houston PALM does provide an excellent review of depositional and turbation process and a set of easily recognizable characters or attributes that can be used by a variety of investigators to more quickly assess site context in the field. It should be viewed as providing a very important tool, but not the only tool, for archeologists working in the Houston area who are concerned with systematically and efficiently assessing site context in terms of National Register criteria.

\section{REFERENCES CITED}

Bousman, C. Britt, Brett A. Houk, Lee Nordt, and Paul Goldberg

in press A Systematic Classification of Geological Contexts in Archaeological Sites. Houston Archaeological Society Journal.

Collins, Michael B.

1995 Forty years of Archeology in Central Texas. Bulletin of the Texas Archeological Society 66:361-400.

Goldberg, Paul, M. Nash, and D. T. Petragelia

1993 Formation Processes in Context. Monograph in World Archaeology, Number 17. Prehistory Press, Madison, Wisconsin. 
Hester, Thomas R.

1995 The Prehistory of South Texas. Bulletin of the Texas Archeological Society 66:427-459.

Houk, Brett and David L. Nickels (assemblers)

1997 Phase II Archaeological Investigations at Lackland Air Force Base, San Antonio, Texas. Archaeological Survey Report No. 264. Center for Archaeological Research, The University of Texas at San Antonio.

Nordt, L.

1997 Geoarchaeology. In Phase II Archaeological Investigations at Lackland Air Force Base, San Antonio, Texas, assembled by B. Houk and D. L. Nickels, pp. 28-38. Archaeological Survey Report No. 264. Center for Archaeological Research, The University of Texas at San Antonio.
Schiffer, M B.

1972 Archaeological Context and Systemic Context. American Antiquity 37:156-165.

1987 Formation Processes of the Archaeological Record. University of New Mexico Press, Albuquerque.

Waters, M. R.

1992 Principles of Geoarchaeology, a North American Perspective. University of Arizona Press, Tucson. 


\title{
COMMENT ON HOUSTON AREA GEOARCHEOLOGY
}

\author{
Charles D. Frederick \\ Department of Archaeology and Prehistory \\ University of Sheffield \\ Sheffield, UK
}

I am pleased to have an opportunity to review and comment on this document. I believe that it represents a significant step in the integration and implementation of geoarcheology within Texas archeology. The volume, although divided into four parts, has basically two functional components: (1) a masterful summary of the state of geoarcheological knowledge for the Houston region that covers basic physical geography, Quaternary geology, and archeological formation processes, and (2) a predictive model (or PALM, Potential Archeological Liability Map) that is intended to use geoarcheology to identify where the greatest archeological (and therefore financial) liability lies within the Houston region. The first part summarizes theoretical and regionally specific information to produce a very comprehensive image of the region and its geoarcheological problems. The PALM, on the other hand, is an applied management tool that implements geoarcheological information in order to focus archeological efforts where they are most productive, namely dynamic geologic environments. Although the first part is not unique in the Texas literature, Abbott's approach is distinctly different. The PALM, on the other hand, is an entirely new venture.

Before getting into the details it is worth commenting on Abbott's approach to this project. It is obvious that there are many ways one could tackle a project such as this. The approach taken here is comprehensive and regionally focused. Abbott takes the opportunity to craft an explicit position statement on the state of knowledge, the existing gaps, and what problems need to be considered when working in the region. This was, in my opinion, a critical step because the implementation of the PALM will only be acceptable if it is based upon sound, regionally tailored information. This is a challenging remit given the patchiness of the Quaternary record in the upper Texas Coastal Plain, or in Texas in general for that matter.

This volume shares attributes with previous regional plans in that it reviews major research themes pertinent to the region, and then makes recommendations on the types of work needed for us to progress. However, in Houston Area Geoarcheology, Abbott pushes the scope out to include a comprehensive regional summary of formation processes and stratigraphy, and then uses this as a model for targeting site settings where a geoarcheological approach may enhance our archeological recovery. This is geoarcheology in action, and it is very impressive.

The approach, although perhaps a bit too general for geoarcheologists who have worked in the field for years, transcends this by tailoring the basic issues with regional specifics. I have never seen this done before and it is an impressive and clearly very useful exercise. Like Abbott, I have worked as a geoarcheologist for more than a decade, and have experience in many parts of the state. And with every new project I have had to do a lot of the work that is articulated here myself. If I had the time. Which I often didn't. Despite growing up in Houston, I have had only one opportunity to work in this region before, and my knowledge of the specific geological details is best described as patchy. I feel certain that I am not unique in this regard. The benefit of this document (and hopefully others of its kind for other parts of the state) is that it is state of the art and allows anyone to immediately read for themselves what has been done, where the gaps lie, and where their work will make a solid contribution. Also, by starting at the ground level and working up, Abbott levels the field, making it approachable by more than just the geoarcheological crowd, and directly available to everybody working in the region.

The PALM stands to be a very useful planning tool. Technically it identifies the geographic location of the major financial liabilities associated with the archeological compliance process. Conceptually it focuses work on the environments that provide the best archeological detail. Illustrations of this are widely available in the Texas archeological literature of the last decade, and some of the best examples are studies funded by TxDOT. By identifying and targeting these areas in advance, we may 
expect to find and excavate more better context sites in the coming years. Hence this approach makes sense from both planning and an archeological perspectives. It will be interesting to see how well it works in practice.

Although I like this volume a lot, it is possible to quibble with some of its content and intent. The PALM is geared toward identifying where there is a high probability of encountering significant sites in dynamic environments, mostly occupation sites, and the benefits and problems are clearly discussed in the text. However, I am concerned that site types that do not fit this model well will be missed. The most explicit example are cemeteries and the built environments. Cemetery sites are often not situated in dynamic environments and often have very low visibility. Likewise, where prehistoric occupation involved construction of settlements with significant built environments, the zones of significant archeological liability may expand beyond the limits of the dynamic environments. In the Houston area this is probably negligible, but this problem will intensify into the Caddo areas (East Texas in general) or in the far west part of the state. If this approach is to be applied elsewhere, there must be some provision for catching such sites if the implementation of the PALM is to be successful. This point is addressed in Chapter 5, but I would feel better if the development of a "behaviorally based model of topographic settings" was identified as a priority and implemented as suggested. To suggest it and to do it are two fundamentally different things. The PALM may be in line for strong criticism if some provision is not made to take this into account.

Overall, I think this is an brilliant document and I think it deserves a wide circulation. I actually think it is one of the best geoarcheology tomes I have yet read and it is a sterling example of what we should be aiming for overall. Geoarcheology can be used as a predictive tool that will enhance our archeological knowledge; that has been demonstrated repeatedly in the last decade. However, this volume provides a rationale for using it in the proper sequence and context and that is refreshing. The success of the PALM will be demonstrated in its implementation, but given the quality of the work in the text, I feel that it will meet or exceed TxDOT's expectations. 


\title{
PEER REVIEW OF HOUSTON AREA GEOARCHEOLOGY
}

\author{
Roger G. Moore \\ Moore Archeological Consulting, Inc. \\ Houston, Texas
}

I must note at the outset of these remarks that I am not a geoarcheologist. Therefore, my remarks will be confined to informal citations of Dr. Saul Aronow's work and my own rather idiosyncratic and anecdotal observations based on my intimate familiarity with the study area.

James Abbott's Houston Area Geoarcheology is an innovative and ground-breaking study. TxDOT is to be commended for funding proactive approaches like this document to streamline its consideration of cultural resources. The report, furthermore, will doubtlessly be cited countless times for its lucid and exhaustive synthesis of regional soils, geomorphic processes, and explication of specific Houston District landform elements.

\section{Page- or Section-Specific Comments}

p. 49-53: Saul Aronow attributed minor eolian deposition on high terraces of the San Jacinto River to materials (sands) picked up from nearby, unvegetated sand bar/point bar deposits along the active channel of the river. These sands were dropped onto the terraces due to velocity changes as the winds climbed the terrace slopes (see Aronow 1989). Continuous deposition at site 41HR616 during its ca. 1000 year period of occupancy supports a local and continuous origin for these sands rather than some past extensive devegetation event which was geographically broader in scope but limited in duration. The potential for continuous deposition in these high terrace or upland margin contexts has important implications for site integrity and significance. Continuous or semi-continuous deposition of eolian soils will permit the formation of archeological sites that retain an informative degree of cultural stratigraphy even in sites continuously or repeatedly occupied over a long period. The considerable vertical separation of components resulting from this steady or repetitive deposition further acts to reduce the stratigraphicallydestructive effects of normal degrees of bioturbation within sandy soils. p. 99: I emphatically agree with the assessment of pimple mounds as "small islands of archeological potential that are contained in expanses of landscape with low potential, and should be investigated wherever they occur within a project area." Our field results over the years have repeatedly supported this observation and we routinely test every pimple mound we encounter on survey. We further, at the pre-field documentary archeological assessment stage, routinely identify mound-forming soils as areas of higher archeological probability.

p. 124: Archeological data from our excavations on Oyster Creek in Cullinan Park (41FB199, 41FB200; Moore 1996, Moore et al. 1996) seem to support Aten's date for the Oyster Creek [Brazos] channel abandonment.

p. 147: We have completed countless shovel tests within the sandy mantle which contain pebblesized clasts, supporting Abbott's argument against exclusively eolian origins for the hilltop sandy mantle in the northern portion of the Houston District.

Biotic Sedimentation Processes: Abbott's proposition of biologic exhumation of sediments as an agent of site burial (yielding buried cultural materials with relatively high degrees of archeological integrity) is an important insight. This thesis forms a useful counterpoint to the proposed downward migration of artifacts via biologic processes resulting in the incorporation/intrusion of artifacts into sandy soils, yielding buried sites with low integrity. While site integrity within sandy soil matrices in general is of course highly variable I am less inclined than some others to routinely dismiss the research potential of sandy soil sites. Some sites are clearly bioturbated to a highly destructive extent (see for example our excavation results at 41FB200, Cullinan Park; Moore et al. 1996), while others retain a degree of cultural stratigraphy that at least renders them somewhat informative (our 41HR616 and 41HR751 excavations as cited in this volume, for example). Both my earlier predictive study for the Texas Water Development Board and Abbott's current work have demonstrated that inland sites 
within the Houston District are very frequently found within sandy soils. While sandy soil sites will always have their interpretive limitations, to dismiss their potential significance out of hand is to in effect dismiss a priori the significance of the great majority of inland prehistoric sites in major portions of the Houston District.

Barrier Islands: In a truly unique and anecdotal circumstance, archeological potential assessments within the portion of Galveston Island behind the sea wall must consider the effects of the massive graderaising program which was carried out simultaneously with sea wall construction early in the last (20th) century. This program placed a mantle of up to 18 feet of fill to raise the island surface behind the sea wall, converting the surface from its natural, roughly convex cross-section to that of an inclined plane. This inclined plane tilts gradually downward toward the bay side of the island from its crest immediately behind the sea wall. The variable depth of this fill is illustrated in our Galveston Trolley Project report (Moore 1999:Figure 4), and the archeological implications of its placement are discussed extensively in the various articles and reports by Texas Anderson and myself on excavations at the Ashton Villa house museum on Broadway. One effect of this fill event at Ashton Villa and elsewhere was to freeze and seal the ca. 1900 occupational surface, thus preserving from later modifications landscaping elements that were often of mid-19th century origin. The fill also serves as a buffer zone protecting archeological deposits to a greater or lesser extent from the effects of modern development (as well as storm activity) on the island. The extent of this protection depends, of course, upon the depth of the fill at the locality in question.

The generally positive preservation implications of the placement of the grade-raising fill mantle are probably most important and certainly most dramatic for early 19 th century historic remains. The same fill, however, has undoubtedly likewise mantled and preserved prehistoric sites at some localities on the island. Several bayous and natural ponds or lagoons appear on early maps of the city. Prehistoric sites associated with these water bodies may have been preserved by the fill placement. Projects within the City of Galveston should be reviewed against the locations of these water bodies and the local depths of fill in order to identify and test locations where buried (or even deeplyburied) archeological deposits may be preserved.

\section{Chapter 5: Potential Archeological Liability Mapping of the Houston District}

p. 156: Abbott correctly notes that my site location model for TWDB focused upon prehistoric behaviors and did not incorporate consideration of issues of site preservation, integrity, and hence potential regulatory significance. The immediate aim of the model was successful site prospection. It sought to (1) provide criteria to differentiate areas of higher site occurrence probability from those at which the probability of site occurrence would be low, (2) assist in the development of appropriate survey designs for specific project areas, and (3) provide quantitative justifications for the elements of those survey designs.

I believe that the Houston District PALM mapping effort is generally quite successful and will be an invaluable management tool. I further applaud Abbott's decision to take a conservative approach to the PALM mapping in areas where determination is difficult. The objectives the map was designed to satisfy and the methodology of its development are clearly and explicitly stated. The single area of concern I have regarding the mapping is derived inevitably from Abbott's attempt to integrate consideration of site integrity and significance into the mapping model. This area of concern is in regard to the decision points on the mapping protocol flowchart regarding the consequences of "urbanization," especially as expressed in Abbott's Mapping Units 3a and 4. I believe that the model may overstate the destructive effects of recent development within this highly urbanized district. My bias in this regard is the result of our long experience within these areas of extensive, but not always absolute, disturbance. I am convinced by this experience that in many cases pockets of preservation of various sizes and depths may survive within otherwise disturbed terrains.

Part of my bias with regard to the extent of recent cultural disturbance due to urbanization results from our intensive historical archeology work within the Houston Central Business District. This work has included subsurface survey (mechanical stripping) and excavations encompassing 20 or more downtown blocks. These blocks all had 100-150 year histories of successive stages of construction and demolition, but in many cases we were able to locate significant historic period archeological deposits and features which had, by chance, eluded 
destruction. I realize that the subject of the Abbott inquiry is prehistoric sites but I think some of the lessons learned in the most intensely urbanized section of Harris County apply as well to the consideration of the prospects for survival of prehistoric sites and features.

My bias, however, is not exclusively the result of historic period investigations. To cite a brief example, two linear detention basin surveys encompassing approximately $4 \mathrm{~km}$ of the fully (sub)urbanized and channelized portion of Buffalo Bayou between IH 610 and Kirkwood Road yielded three previously unknown prehistoric sites. Two of these sites (41HR802 and 41HR826) were deemed eligible for designation as State Archeological Landmarks based on their yield and state of preservation (Prikryl 1997, 1998).

p. 165: "The high frequency of sites in Map Unit $3 \mathrm{a}$ is not surprising, since much of this map represents areas that would have been classified as Map Unit 1 except that they are urbanized, and thus more likely to have been surveyed." There is danger in pre-supposing that all of the previously identified sites within Unit 3a were located by survey that took place prior to or during urbanization. I suspect that a considerable percentage of these sites were identified after the areas surrounding them were developed.

p. 166: In regard to the high number of sites $(n=173)$ within the highly urbanized Harris County portion of Mapping Unit 4, Abbott is correct in discounting the historic sites and in his assertion that many of the remaining prehistoric sites are heavily disturbed or destroyed. However, many of these sites, as he notes, "are clustered in a few areas, including the upland margins of Buffalo Bayou, Greens Bayou, and Cypress Creek, the vicinity of Clear Lake, and the lower reaches of White Oak Bayou. All of these areas are excluded primarily on the basis of intense development and channelization. However, all these areas have also been surveyed relatively intensively, and TxDOT will continue to address previously identified sites regardless of their classification on the Houston PALM."

I believe that one cannot disregard the potential for at least partially intact, unrecorded sites in the above geographical contexts regardless of channelization and intensive development. TxDOT and other agencies should do more than simply "continue to address previously identified sites" within these intensively occupied contexts which are crucial to our understanding of prehistory in this portion of the District. This is a case where prehistoric behavior intrudes forcefully into the PALM model. The potential for fortuitous preservation is much higher along these stream simply because the prehistoric people liked them so much and left a lot of sites along their banks. The more sites you have in a discontinuously disturbed area, the more probable it is that some of them will survive. There is also some inescapable behavioral element to the popularity of these streams: if the streams were more intensively occupied then they were loosely more "important" culturally to the inhabitants and we should make an effort to determine why this was so.

There are a couple of specific reasons why I consider it inadequate for TxDOT to deal only with previously identified sites in these contexts. First, an examination of Moore Archeological Consulting's exhaustive and unique compilation of previously surveyed areas within Harris County indicates that there are substantial unsurveyed areas adjacent to each of these streams or water bodies. One simply cannot assume that all the potentially significant sites in these contexts have already been identified.

Secondly, urbanization and channelization do not spell absolute and certain doom for potentially significant archeological deposits within areas mapped as Unit 4. Abbott cites the Alabonson Road site (41HR273) as an example of a "formerly eligible site that would have been excluded from survey by the Houston PALM." This site is indeed a fine example of the new information potential remaining even after a stream has been channelized and its surroundings urbanized since such was the condition in which the site was originally recorded and ultimately excavated. I am convinced that other perhaps equally disturbed and obscured but likewise equally informative unrecorded sites remain to be discovered on the upland margins of Buffalo Bayou, Greens Bayou, and Cypress Creek, the vicinity of Clear Lake, and the lower reaches of White Oak Bayou.

While I have emphasized the potential for preservation of significant archeological deposits within these disturbed contexts I do acknowledge that the collective impacts of urbanization are severe. I do not suggest, therefore, that the upland margins of Buffalo Bayou, Greens Bayou, and Cypress Creek, the vicinity of Clear Lake, and the lower reaches of White Oak Bayou be re-mapped into one of the 
other five existing PALM categories. I rather suggest that TxDOT should not cease to identify areas where assessments of archeological potential and liability must be made at a finer, project-specific scale than is permissible or intended under the proposed PALM mapping.

Our difference in viewpoint regarding such landscape entities as Buffalo and White Oak bayous is not the result of a conflict between an archeological integrity-based model and a behavior-based model. It is rather that my perception of potential for contextual integrity is observed from a different (closer) viewpoint and thus at a different degree of resolution. It is worthwhile to keep in mind that the "fractal quality" of landscapes cited by Abbott (p. 168) applies to the distribution of cultural disturbances across the landscape as well as its geomorphic aspects. Abbott states that "the geoarcheological model adopted here is directed towards identifying where sites are likely to be preserved in reasonable context rather than where they are likely to exist." Scale becomes a dividing issue between our viewpoints when one reaches the fine resolution at which cultural disturbances are resolved into discrete, discontinuous areas distributed across the landscape rather than broad, continuous regions (i.e., Mapping Units 3a and 4). Archeological sites, at approximately the same level of resolution, begin to be depicted as two-dimensional (albeit, typically small) areas rather than points. This roughly concurrent threshold change from broad regions and dimensionless points to, in both cases, discrete and discontinuous areas defines the appropriate scale of analysis for projects which take place within zones of low preservation potential due to human disturbance but within zones of high behavioral potential.

Readers of these comments should keep in mind that I am not at all condemning the results or intended function of the Houston PALM liability mapping. As Abbott states in regard to the urbanized margins of Buffalo Bayou, Greens Bayou, and Cypress Creek as well as the vicinity of Clear Lake, "the Houston PALM is not intended to be a decision-maker, but a decision support tool. Survey decisions will continue to be made by TxDOT staff archeologists, who will take into account the Houston PALM recommendations, the characteristics and potential impacts of the project, and their knowledge of the Houston-area archeological record."

Taking into account the Houston-area archeological record is a process that can be carried out at a less formal level (through review of the existing site records). Or this process may be conducted in a more formal manner through a comparison of the proposed project to a behavioral model identifying those areas where sites are more likely to exist independent of their preservation potential in reference to the Houston PALM model. It is only when Mapping Units 3a and 4 overlap with areas of high recorded site density or areas of high potential for site existence that project-specific analysis should "zoom in" to the threshold of resolution at which the discontinuous nature of cultural disturbances becomes evident. I am confident that, formally or informally, TxDOT will continue to provide adequate consideration of project impacts within these urbanized areas.

I will conclude this review by reiterating that I believe that the publication of Houston Area Geoarcheology will provide planners with an invaluable tool and likewise stimulate interesting and valuable inquiries among archeologists working in the District. I would like, finally, to acknowledge TxDOT and Dr. Abbott for their support of Moore Archeological Consulting investigations by funding radiocarbon dating at 41HR751 and for Ms. Beck's pollen research at Aronow Bog.

\section{REFERENCES CITED}

Aronow, Saul

1989 Geology, geomorphology and soils. In Significance Testing at Site 41HR616, West Lake Houston Parkway Project, Harris County, Texas, by R. G. Moore, pp. 6-37. Report of Investigations No. 26. Moore Archeological Consulting, Houston.

Moore, Roger G.

1996 Test Excavations at Sites 41FB199, 41FB200 and $41 F B 202$ in Cullinan Park, Fort Bend County, Texas. Report of Investigations No. 92. Moore Archeological Consulting, Houston.

1999 An Archeological Assessment and Monitoring Program of the Galveston Trolley Project, Galveston, Texas. Report of Investigations No. 242. Moore Archeological Consulting, Houston.

Moore, Roger G., Linda W. Ellis, Laurie S. Zimmerman, William L. McClure, and Saul Aronow

1996 Data Recovery Excavations at Sites $41 F B 199$ and $41 F B 200$ in Joseph S. and Lucie H. Cullinan Park, Fort Bend County, Texas. Report of Investigations No. 153. Moore Archeological Consulting, Houston. 
Prikryl, Daniel J.

1997 An Archeological Survey of the Proposed Buffalo Bayou Detention Basin Project, Southwestern Harris County, Texas. Report of Investigations No. 198. Moore Archeological Consulting, Houston.
1998 An Archeological Survey of the Harris County Flood Control District's Proposed Buffalo Bayou Linear Detention Kirkwood Road to Wilcrest Drive Project, Harris County, Texas (Project Identification Number W100-00-00-Y009). Report of Investigations No. 220. Moore Archeological Consulting, Houston. 


\section{TXDOT'S RESPONSE TO COMMENTS}

The preceding peer reviews present thoughtful opinions about a variety of issues related to the Houston Area Geoarcheology document. The comments generated during the draft stage were carefully considered by the author and the professional archeological staff of TxDOT's Archeological Studies Program, and were also submitted to the SHPO (THC) for their consideration. A number of revisions were made to the document following these reviews, and the document is clearly stronger as a result of the input. However, many comments by the peer reviewers reflect more substantive differences in our approaches. In these cases, we respectfully disagree with the positions taken by the reviewers, and present our response below.

Because few of the published comments address deficiencies in the discussions of relevant processes and stratigraphy, the majority of this response addresses the discussion of the Houston PALM model. However, in addition to the three reviewers who contributed the written comments presented here, a fourth (unnamed) reviewer made several pointed comments in his review of the draft, but declined for reasons of time to prepare comments for publication. These comments included some strenuous objections to specific pedological and stable isotope issues raised in the discussion. While we continue to stand by the interpretation of these issues, we feel that it is important to emphasize again that there are some aspects of the process treatment (in particular the carbonate discussion) that are both decidedly different than the mainstream view and as yet very preliminary. In revising the draft for publication, Abbott attempted to make the tentative and personal character of these interpretations as clear as possible by reorganizing the discussion. However, the reader should be on notice that other researchers may disagree with the interpretations in some cases, and use his or her own critical faculties to evaluate the presentation.

The peer reviewer's comments on the Houston PALM model vary from mild concern about possible misapplication (Frederick) through disagreement with a few specific mapping decisions (Moore) to strong objection to the entire concept of integrity modeling (Bousman). While we will attempt to address all of the comments, the focus will clearly be on Bousman's critique. Comparison of Bousman's arguments with those advanced in Chapter 5 reveals fundamental differences in our respective viewpoints, and many of Bousman's arguments are addressed there. Bousman's criticisms can be summarized as follows: (1) use of the Houston PALM model will restrict survey to certain environments, and sites in untargeted areas will not be recorded and assessed; (2) the Houston PALM uses a site's geological context as the first and often sole criterion for judging National Register significance, which eliminates proper consideration of archeological or historical significance; and (3) the way that the Houston PALM uses the term context is very reductive, distorting real-world complexity. With a few minor caveats, we agree with each of these basic points. Use of the Houston PALM will restrict the areal extent of archeological survey. It will result in the failure to record some sites, and a few of these may have otherwise proven to be National Register eligible. It does elevate context—or, more properly, integrity potential-to first cut status in making eligibility determinations, and it does have a reductive effect on the complex universe of potential archeological contexts. Where we differ is in the value judgements that Bousman draws-the notion that these effects are necessarily a bad thing. We argue that these are desirable goals from an efficient management perspective, and are less deleterious to the overall resource base than the alternative.

Bousman's first argument-that the Houston PALM will cause sites to be missed-applies equally to any survey strategy, and particularly to those that call for anything less than "100\%" pedestrian survey. All forms of archeological survey, no matter how intensive, represent only a sample of the landscape, and only the most naive archeologist truly believes that they can find all of the sites in an area of any appreciable size. Federal regulations (36 CFR 800.4(b)) acknowledge this fact, mandating only that the Agency Official make a "reasonable and good faith effort" to identify historic properties. Decisions about where and how intensively to search for archeological sites are made every day by CRM archeologists, including those employed by TxDOT. Significantly, the implementation of the Houston PALM does not 
change this fact; the ultimate decision about whether or not to survey (and if so how) still lies with the TxDOT district archeologist operating in consultation with the Texas SHPO. The difference is that now that archeologist is armed with additional information derived consistently and in a reasoned, explicit manner, and that more resources are available for examination of the areas likely to yield historic properties.

Bousman's second point is that elevating geological context to the fore effectively eliminates consideration of the "archeological/historic significance" of a site. Here, the implementing regulations that TxDOT and other sponsoring agencies are required to follow are specific:

The quality of significance in...archeology...is present in...sites...that possess integrity of location, design, setting, materials, workmanship, feeling, and association and (emphasis added)

(a) that are associated with events that have made a significant contribution to the broad patterns of our history; or

(b) that are associated with the lives of persons significant in our past; or

(c) that embody the distinctive characteristics of a type, period, or method of construction, or that represent the work of a master, or that possess high artistic values, or that represent a significant and distiguishable entity whose components may lack individual distinction; or

(d) that have yielded, or may be likely to yield, information important in history or prehistory (36 CFR 60.4).

In contrast to Bousman's implication, the regulations make it clear that prehistoric sites-and particularly the vast majority considered significant primarily for their information content (Criterion (d) sites)—-may not possess significance entirely independent of their geological context, because integrity of association is necessary for significance to exist. This is not to say that all eligible sites must be pristine to possess the "quality of significance"no site is pristine, and the level of integrity required for significance is a function of the questions one asks of the data. However, an eligible site must exhibit reasonable integrity, so that the data extracted and the conclusions advanced are relatively trustworthy. Without consideration of geological context, reliable assessment of integrity is not possible unless one is interested in extremely general questions applicable to the whole of prehistory. At TxDOT, we believe that such general questions can be addressed by examining the many extant archeological collections, and do not merit the expenditure of public monies for field research.

The universe of primary and secondary geological contexts that Bousman presents in Table 11 represent a clear and effective classification of possible settings for discarded cultural materials. The problem lies in the difficulty in discriminating between many of these contexts in the archeological record, and thus interpreting them appropriately. This is particularly true of the various contexts characteristic of stable or erosional surfaces (e.g., intact surface context, surface palimpsest, turbated palimpsest, lag palimpsest). In a scatter of historic artifacts, it is relatively easy to cull and ignore modern artifacts like beer bottle glass and pull-tabs commingled with artifacts from a 19th century farmstead; a depositional setting is therefore not particularly critical. Accomplishing such a basic sorting procedure is a much more difficult—and inherently less trustworthy-task with a prehistoric site; indeed, because the frequency of diagnostic artifacts in a prehistoric assemblage is so low, recognition of palimpsest status itself is sometimes inherently difficult. Moreover, while it is often possible to conclude that a site on a stable surface is a surface palimpsest, it is practically impossible given the current state of analytical technology to confidently draw the opposite conclusion. Even if one could confidently rule out palimpsest status, we are skeptical that the data content of such sites would be sufficient to merit a determination of eligible status in most cases. In other words, although we agree with Bousman that the contexts he lists exist, we do not believe that many can be reliably distinguished from each other. If they cannot be distinguished in a reliable way, it follows that the reliability of any analysis arising from such data is commensurately reduced to the extent that it relies on artifact associations. For these reasons, TxDOT has made a programmatic decision to focus inquiry in the Houston District on aggradational settings where sites with reasonable integrity are more likely to occur (Kenmotsu et al. 1998). 
In a previous presentation of the contextual hierarchy he outlines above, Bousman has argued that while the quality of information varies, we can learn something about prehistory from every archeological site (Bousman et al. 1997). While we agree with this statement at a broad theoretical level, we strongly question whether we should commit the time and resources necessary to attempt this difficult goal within the context of CRM archeology. As urbanization and infrastructure development proceeds apace, spending limited archeological resources to wring the last drops of information from severely disturbed sites does not seem the best approach to us. We simply cannot focus this type of attention on every site; it is neither efficient nor cost effective, and would represent an abrogation of TxDOT's fiduciary responsibility to the public. Instead, we argue that the better approach is to put our efforts into identifying and studying (or protecting) sites that have reasonable potential to inform on prehistory in a meaningful way.

Basing his review on an intimate knowledge of the Houston archeology, Moore raises a more specific objection to one specific, related series of mapping decisions surrounding several of the urbanized streams in Houston itself. Moore quite correctly points out that one's judgement of integrity potential is dependent on scale, and argues that a finer scale examination of the areas surrounding these streams would yield many areas worthy of examination. We agree with this assessment. In his review of the draft document, Moore recommended that the map be revised to create an area subject to more detailed scrutiny. While we sympathize with this recommendation, we feel that such a change would be inappropriate. Many other parts of the Houston District would also fare differently if examined at a finer resolution. Thus, changing only part of the map would introduce an unacceptable inconsistency, while remapping the entire district at a finer degree of resolution would be both very expensive and detrimental to its use as a tool suitable for regional planning. As both Moore and Frederick point out, because the Houston PALM is simply a tool, it is the manner in which it is applied that will ultimately dictate its worth. Thus, we reiterate that the party responsible for making the final decision on whether or not to survey any particular project will continue to be a professional archeologist employed by TxDOT's Environmental Affairs Division and meeting the Secretary of Interior's Standards for training and experience.
Finally, Bousman's argument that the Houston PALM reduces a very complex continuum of contextual settings to a binary decision reflects its design for use as an effective planning tool. We grant that the world is a very complex place, and that the mapping units used in the Houston PALM represent a simplification of reality. Nevertheless, the fundamental decision of whether or not to survey is ultimately a binary decision. In an ideal world, the Houston PALM would not be necessary. TxDOT archeologists would have a unlimited amount of time and a limitless budget to intensively survey for, locate, and investigate or avoid every site subject to disturbance by agency activities. Unfortunately, we do not live in an ideal world. The Houston PALM represents one of a series of tools TXDOT is developing to maximize the scientific return on its compliance investments. Bousman acknowledges that a profound shift towards a geoarcheological approach has occurred in Texas during the last 20 years. We also recognize this paradigm shift (attributable almost entirely to the insistence of the SHPO's office), and we would cite two corollary developments: (1) the adoption of subsurface mechanical prospection as a relatively routine technique to locate buried sites in depositional environments, and (2) the realization that the measure of a site's worth lies not in the sheer number and variety of artifacts that it yields, but in its ability to inform on prehistoric behavior in a meaningful way. Considered together with the use of geoarcheological principles for site evaluation and interpretation, these changes provide avenues that allow CRM archeology to truly make a difference in our cumulative knowledge of prehistory.

\section{REFERENCES CITED}

Bousman, C. B., B. Houk, L. Nordt, P. Goldberg, J. Leach, T. Stafford, and B. Baker

1997 Identifying Context. Paper presented in the symposium Finding and Interpreting Gisements in Texas. 68th Annual Meeting of the Texas Archeological Society, Midland.

Kenmotsu, N., A. Irwin, G. L. Ellis, and J. T. Abbott

1998 Targeting Future Highway Research Dollars: What to Do When We Can't Do Everything. Paper presented in the symposium Pots to Potholes: Paving New Roads to the Past through Transportation Corridor Studies. 63rd Annual Meeting of The Society for American Archaeology, Seattle. 


\section{Appendix VI}

\section{Houston-PALM Maps}




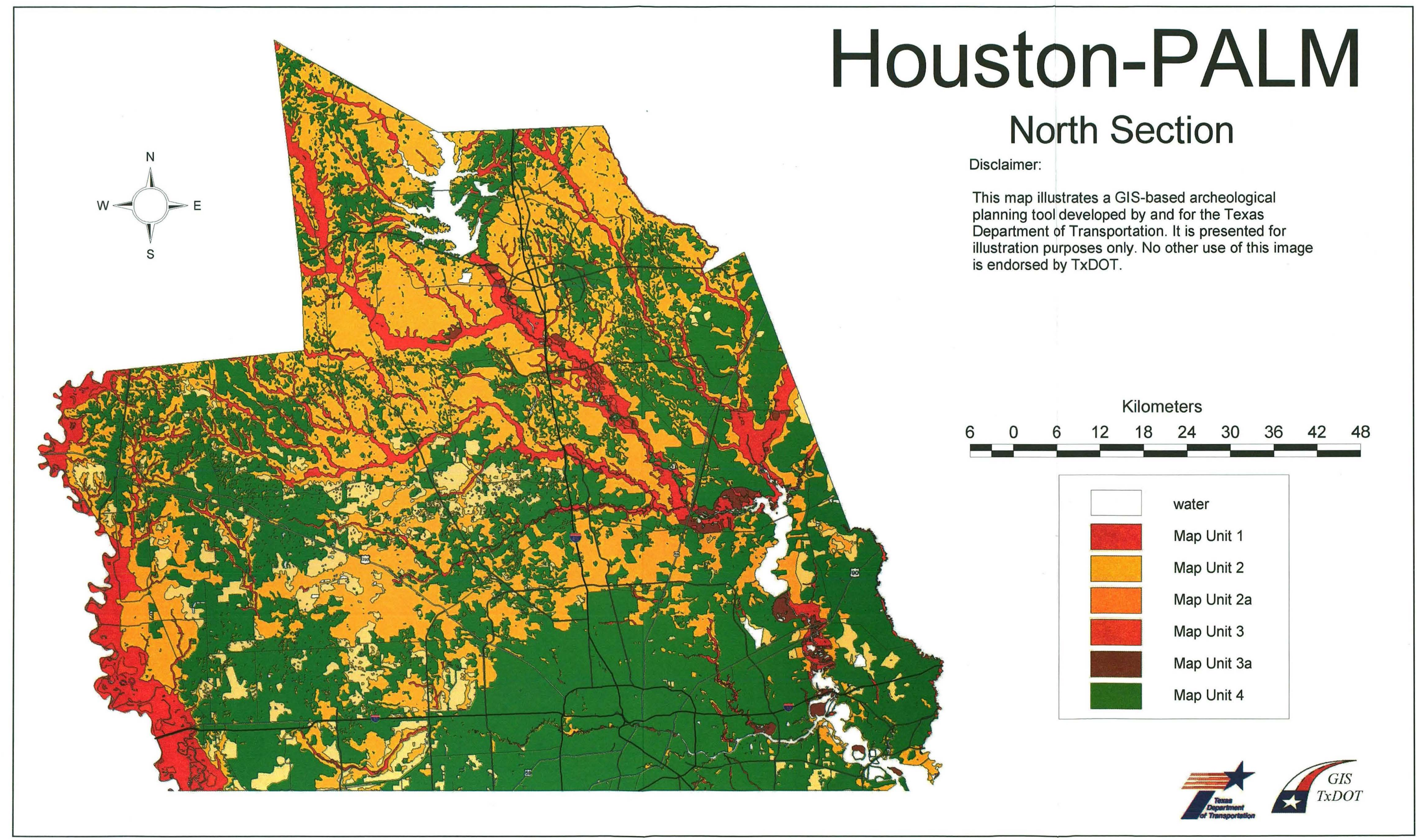

Figure 65. Houston-PALM map, north section. 


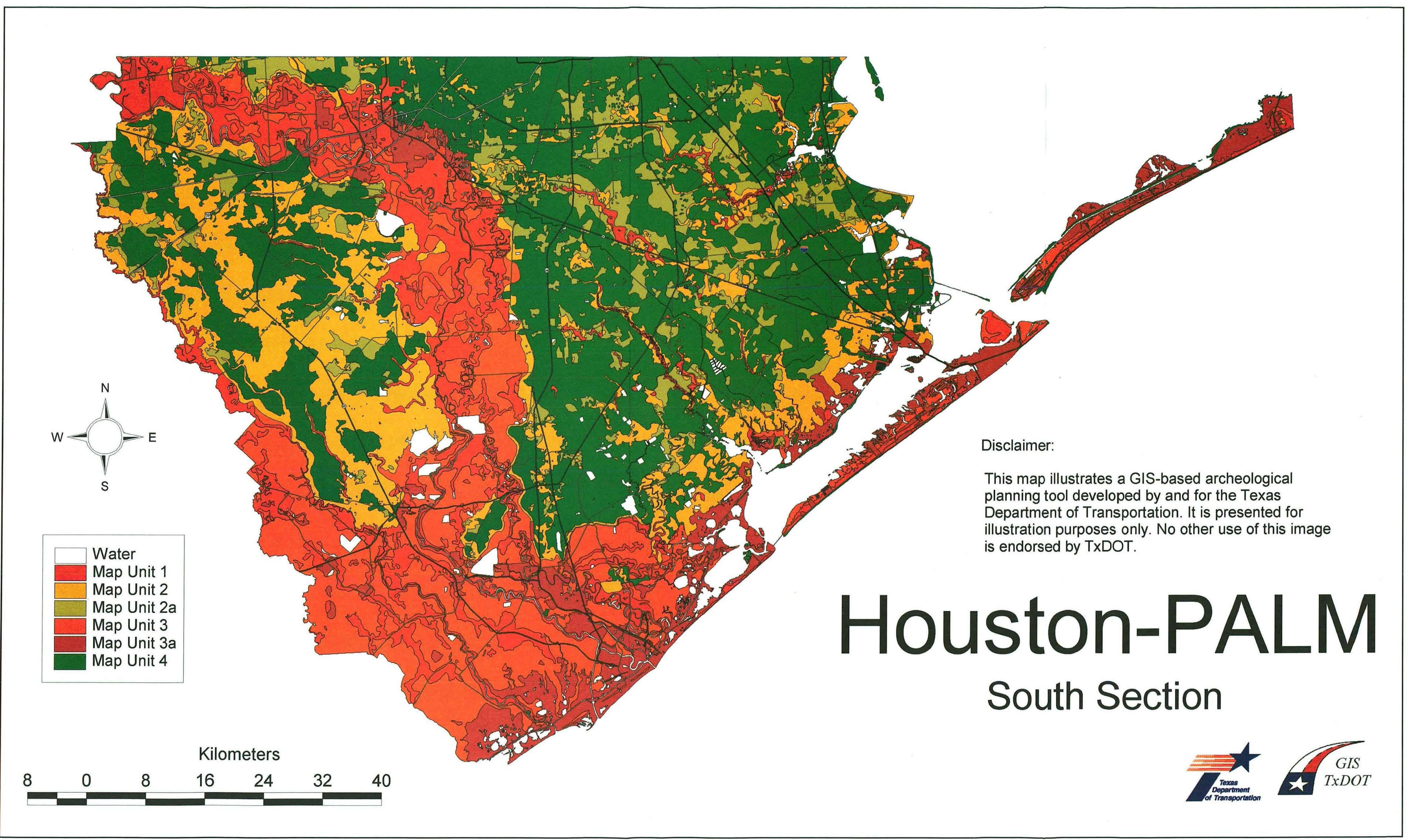

Figure 66. Houston-PALM map, south section. 
